
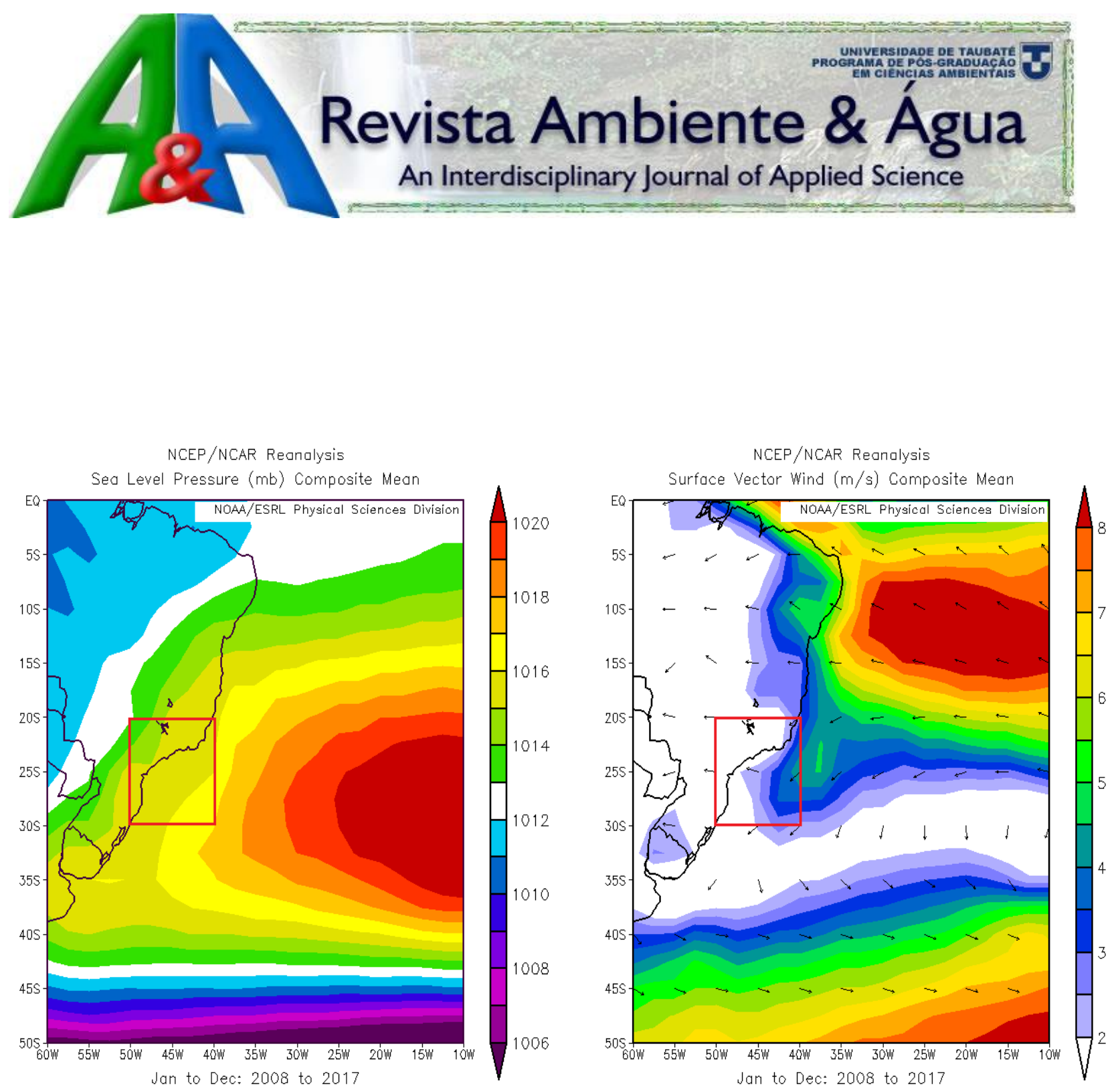

ISSN = 1980-993X (Online)

$5^{\text {th }}$ Edition of Revista Ambiente \& Água - An Interdisciplinary Journal of Applied Science, Taubaté, V. 15, N. 5, p. 1-20 Sep/Oct. 2020. (doi:10.4136/ambi-agua.v15.n5) 


\section{EDITORIAL BOARD}

\section{Editors}

Getulio Teixeira Batista (Emeritus Editor) Universidade de Taubaté - UNITAU, BR

Nelson Wellausen Dias (Editor-in-Chief), Fundação Instituto Brasileiro de Geografia e Estatística - IBGE, BR

Ana Aparecida da Silva Almeida

Marcelo dos Santos Targa

Andrea Giuseppe Capodaglio

Arianna Callegari

Antonio Teixeira de Matos

Apostol Tiberiu

Claudia M. dos S. Cordovil

Dar Roberts

Giordano Urbini

Gustaf Olsson

Hélio Nobile Diniz

Ignacio Morell Evangelista

János Fehér

Julio Cesar Pascale Palhares

Luis Antonio Merino

Maria Cristina Collivignarelli

Massimo Raboni

Petr Hlavínek

Richarde Marques da Silva

Stefan Stanko

Teresa Maria Reyna

Yosio Edemir Shimabukuro

Zhongliang Liu Beijing

Text Editor

Reference Editor

Peer-Reviewing Process

System Analyst

Secretary and Communication

\section{Associate Editors}

Universidade de Taubaté (UNITAU), BR

Universidade de Taubaté (UNITAU), BR

\section{Editorial Commission}

University of Pavia, ITALY

Università degli Studi di Pavia, ITALY

Universidade Federal de Minas Gerais (UFMG), BR

University Politechnica of Bucharest, Romênia

Centro de estudos de Engenharia Rural (CEER), Lisboa, Portugal

University of California, Santa Barbara, United States

University of Insubria, Varese, Italy

Lund University, Lund, Sweden

Inst. Geológico, Sec. do Meio Amb. do Est. de SP (IG/SMA), BR

University Jaume I- Pesticides and Water Research Institute, Spain

Debrecen University, Hungary

Embrapa Pecuária Sudeste, CPPSE, São Carlos, SP, BR

Institute of Regional Medicine, National University of the Northeast, Corrientes, Argentina

University of Pavia, Depart. of Civil Engineering and Architecture, Italy

LIUC - University "Cattaneo", School of Industrial Engineering, Italy

Brno University of Technology República Tcheca

Universidade Federal da Paraíba (UFPB), BR

Slovak Technical University in Bratislava Slovak, Eslováquia

Universidad Nacional de Córdoba, Argentina

Instituto Nacional de Pesquisas Espaciais (INPE), BR

University of Technology, China

Theodore D`Alessio, FL, USA, Maria Cristina Bean, FL, USA

Liliane Castro, Bibliotecária - CRB/8-6748, Taubaté, BR

Marcelo Siqueira Targa, UNITAU, BR

Tiago dos Santos Agostinho, UNITAU, BR

Luciana Gomes de Oliveira, UNITAU, BR

\section{Library catalog entry by Liliane Castro CRB/8-6748}

Revista Ambiente \& Água - An Interdisciplinary Journal of Applied Science / Instituto de Pesquisas Ambientais em Bacias Hidrográficas. Taubaté. v. 15, n.5 (2006) - Taubaté: IPABHi, 2020.

Quadrimestral (2006 - 2013), Trimestral (2014 - 2016), Bimestral (2017), Publicação Contínua a partir de Janeiro de 2018.

Resumo em português e inglês.

ISSN 1980-993X

1. Ciências ambientais. 2. Recursos hídricos. I. Instituto de Pesquisas Ambientais em Bacias Hidrográficas.

CDD - 333.705

CDU - (03)556.18 


\section{TABLE OF CONTENTS}

\section{COVER:}

This figure shows the reduced pressure at sea level and surface wind climatology data (10-year mean) in the Brazilian coast as a component of a research that aims at showing the semi-systematic methodology to analyze aspects usually present in oil spill modeling and environmental impact assessment. The semisystematic approach seeks to identify and understand all potentially relevant research traditions that have implications for the studied topic, in this case, preventing the impacts of oil spill from offshore exploration in the Brazilian coast. Source: ZACHARIAS, D.C. et al. Brazilian offshore oil exploration areas: an overview of hydrocarbon pollution. Rev. Ambient. Água, Taubaté, vol. 15 n. 5, p. 1-20, 2020. doi:10.4136/ambi-agua.2569

\section{EDITORIAL}

Water resources, public policies and the COVID-19 pandemic

doi:10.4136/ambi-agua. 2540

$1-14$

Diego Antonio França de Freitas; Julio Issao Kuwajima; Gesmar Rosa dos Santos

\section{ARTICLES}

Effect of the inoculum/substrate ratio on the biochemical methane potential (BMP) of grape marc

01 doi:10.4136/ambi-agua.2541

Kessia Caroline Dantas da Silva; Miriam Cleide Cavalcante de Amorim; Renan Santana Galvão; Yandra Beatriz de Oliveira Gonçalves; Paula Tereza de Souza e Silva; Eduardo Souza Costa Barros

Technical and scientific aspects of dams in Brazil: a theoretical approach

02 doi:10.4136/ambi-agua.2552

Admilson da Penha Pacheco; Renato Filipe Faria Henriques; Paulo Marcelo Vieira Ribeiro

DOF/DAF comparison for the treatment of milk industry wastewater

03 doi:10.4136/ambi-agua.2553

Magno dos Santos Pereira; Alisson Carraro Borges; Gustavo Lopes Muniz; Fernanda Fernandes Heleno; Lêda Rita D'Antonino Faroni

Sub-daily hydrological-hydrodynamic simulation in flash flood basins: Una river (Pernambuco/Brazil)

04

doi:10.4136/ambi-agua.2556

Otacílio Correia Lima Neto; Alfredo Ribeiro Neto; Fellipe Henrique Borba Alves; José Almir Cirilo

Photochemical efficiency in pineapple plants under saline water irrigation

doi:10.4136/ambi-agua.2564

Cleiton Fernando Barbosa Brito; Varley Andrade Fonseca; Marcelo Rocha dos Santos;

Sérgio Luiz Rodrigues Donato; Alessandro de Magalhães Arantes; Aloísio José dos Santos

Assessment of community-managed water systems in rural areas of Espírito Santo, Brazil, using the SIASAR tool

Anna Virginia Muniz Machado; Marina Thurler Nogueira; Lucas Magalhães Carneiro Alves; Norbertho Quindeler da Silveira; Juliana da Costa Dias Silva; Pedro Antonio de Paiva Aranha; Ricardo Pereira Gonçalves; Natália Lascas Soares de Siqueira

An Artemia franciscana bioassay for the monitoring of lipophilic phycotoxins in marine bivalve mollusc cultures: An alternative to screening testing?

Alailton dos Reis Guaralde; Daniela Almeida de Souza; Celso Luiz Possas Guimarães Júnior; Rafael Soares Guimarães; Victor Barbosa Saraiva; José Augusto Ferreira da Silva;

Marcos Massao Murata; Renato Matos Lopes; Rachel Ann Hauser-Davis; Manildo Marcião de Oliveira 
Quality of surface water and generation of sludge at water treatment plants

08 doi:10.4136/ambi-agua.2565

Fabiana Alves Fiore; Suzelei Rodgher; Cristiane Yumi Koga Ito; Vivian Silveira dos Santos Bardini; Luis Miguel Gutiérrez Klinsky

Estimate and evaluation of reservoir metrics in Serra da Mesa dam (GO) using the Google Earth Engine platform

Gabrielle de Oliveira Xavier; Tati de Almeida; Carlos Magno Moreira de Oliveira;

Petronio Diego Silva de Oliveira; Victor Hugo Barros Costa; Larissa Moreira Alves Granado

Evaluation of physicochemical water parameters in watersheds of southern Brazil

Marta Sória; Vitor Emanuel Quevedo Tavares; Marília Alves Brito Pinto; Lizete Stumpf; Daiane Zarnott; Jéssica Bubolz; Bernardo Gomes Nörenberg

Metal phytosorption potential of Hydrocotyle ranunculoides for mitigation of water pollution in high Andean wetlands of Peru

11 doi:10.4136/ambi-agua.2535

Walter Javier Cuadrado Campó; María Custodio; Carmela Emperatriz Vicuña Orihuela; Richard Pavel Peñaloza Fernández

Variations in soil water replacement levels promote changes in forage cactus mineral composition and biomass productivity

12 doi:10.4136/ambi-agua.2537

Rener Luciano de Souza Ferraz; José Dantas Neto; Patrícia da Silva Costa; Antônio Suassuna de Lima; Patrícia Ferreira da Silva; Rigoberto Moreira de Matos; Alberto Soares de Melo

Influence of parent material on organic phosphorus fractions in vineyard soils in Santa Catarina, Brazil

Shirlei Almeida Assunção; Marcos Gervasio Pereira; Denilson Dortzbach; Eduardo Carvalho da Silva Neto

Brazilian offshore oil exploration areas: an overview of hydrocarbon pollution

14 doi:10.4136/ambi-agua.2569

Daniel Constantino Zacharias; Adalgiza Fornaro

Multivariate statistical analysis applied to assess the dispersion of contaminants in a mining tailings basin in the semiarid region of Bahia - Brazil

15 doi:10.4136/ambi-agua.2572

Nelize Lima Santos; Maria da Conceição Rabelo Gomes; José Ângelo Sebastião Araújo dos Anjos; Fernanda Gonçalves Cunha

Use of organic fertilization with irrigation in coffee production in brazilian cerrado

André Luís Teixeira Fernandes; Eusímio Felisbino Fraga Júnior; Márcio José de Santana; Reginaldo de Oliveira Silva; Marcelo Moreira Dias

New Water and Biotic Quality Assessment Indices for a tropical reservoir based on fuzzy logic

Andres Paladines Andrade; Marley Vellasco; Karla Figueiredo; Francisco Gerson Araújo;

Christina Wyss Castelo Branco 


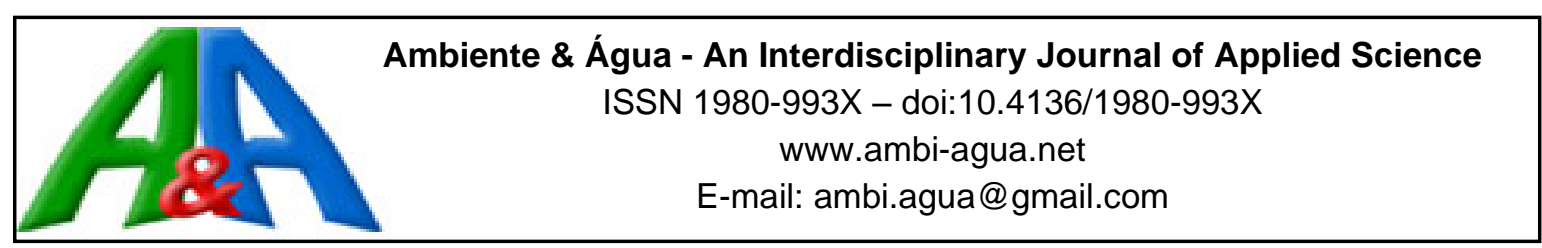

\title{
Water resources, public policies and the COVID-19 pandemic
}

\author{
EDITORIAL doi:10.4136/ambi-agua.2540
}

Received: 05 Aug. 2020; Accepted: 07 Aug. 2020

\author{
Diego Antonio França de Freitas ${ }^{1 * i D}$; Julio Issao Kuwajima ${ }^{2}$ iD; \\ Gesmar Rosa dos Santos 3 \\ ${ }^{1}$ Instituto de Ciências Agrárias. Universidade Federal de Viçosa (UFV), Campus UFV Florestal, \\ CEP: 35690-000, Viçosa, MG, Brazil. \\ ${ }^{2}$ Consultor Independente, Alameda dos Jurupis, n 410, CEP: 04088-001, São Paulo, SP, Brazil. \\ E-mail: jkuwajima@gmail.com \\ ${ }^{3}$ Diretoria de Estudos e Políticas Regionais, Urbanas e Ambientais (DIRUR). Instituto de Pesquisa Econômica \\ Aplicada (IPEA), Setor Bancário sul, Qd 1, Bloco J, CEP-70076-900, Brasília, DF, Brazil. \\ E-mail: gesmar.santos@ipea.gov.br \\ *Corresponding author. E-mail: diegofranca@ufv.br
}

\begin{abstract}
The novel coronavirus pandemic has resulted in global socioeconomic impacts; however, there is still a need to improve understanding and data about its form and patterns of propagation. Therefore, studies on the role of water resources and sanitation should be prioritized, given the potential to serve as a means of dispersing the SARS-CoV-2 virus, which causes COVID-19 disease. So far, the RNA of the transmitting virus has been detected in domestic sewage in several countries, but there is, so far, no evidence of contamination by direct contact with these effluents. Even so, poor regions without adequate treatment of water and sewage, as occur in Brazil, must act in order to develop efficient policies to improve water quality aimed at public health. One of the options is the formation of a Hub that aggregates the various interrelated aspects of water and sanitation into a cohesive and actionable whole. It is essential to combine investment, research, and monitoring of water and effluent quality to improve sanitary security, water quality and human health, with an emphasis on the poorest sectors. The Hub would also serve as a means of controlling and monitoring the dispersion of pathogens such as the SARS-CoV-2 virus, thus mitigating economic and societal impacts.
\end{abstract}

Keywords: integrating Hub, public health, wastewater treatment.

\section{Recursos hídricos, políticas públicas e a pandemia de COVID-19}

\section{RESUMO}

A nova pandemia do coronavírus resultou em impactos socioeconômicos globais; no entanto, ainda há necessidade de melhorar o entendimento e os dados sobre sua forma e padrões de propagação. Portanto, estudos sobre o papel dos recursos hídricos e do saneamento devem ser priorizados, dado o potencial de servir como meio de dispersão do vírus SARS-CoV-2, causador da doença COVID-19. Até o momento, o RNA do vírus transmissor já foi detectado em esgoto doméstico de vários países, mas não há, no entanto, evidências de contaminação pelo contato direto com esses efluentes. Mesmo assim, regiões pobres e sem tratamento adequado de água e esgoto, como ocorre no Brasil, devem atuar no sentido de desenvolver políticas

This is an Open Access article distributed under the terms of the Creative Commons Attribution License, which permits unrestricted use, distribution, and reproduction in any medium, provided the original work is properly cited. 
eficientes de melhoria da qualidade da água voltadas para a saúde pública. Uma das opções é a formação de um $H u b$ que agregue os vários aspectos inter-relacionados de água e saneamento em um contexto coeso e ágil. É essencial combinar investimento, pesquisa e monitoramento da qualidade da água e dos efluentes para melhorar a segurança sanitária, a qualidade da água e a saúde humana, com ênfase nas áreas mais pobres. O Hub também serviria como meio de controlar e monitorar a dispersão de patógenos como o vírus SARS-CoV-2, mitigando assim impactos econômicos e sociais.

Palavras-chave: Hub integrador, saúde pública, tratamento de esgoto.

\section{INTRODUCTION}

The year 2020 was marked by the COVID-19 pandemic, which directly affected the economy, with travel restrictions, closure of cities and borders and the suspension of social and cultural economic activities. These actions resulted almost immediately in an economic recession in several countries, especially those that failed to contain the internal spread of the disease.

COVID-19 is a disease caused by SARS-CoV-2, which belongs to the family of Coronaviridae viruses, which is also composed of SARS-CoV, which caused the SARS outbreak in 2003, and the MERS-CoV which causeding the outbreak of MERS in 2012. As the most recent strain of this family, SARS-CoV-2 became known as the Novel Coronavirus, capable of causing asymptomatic infections as well as severe respiratory conditions, with consequent death in severe cases. According to Decaro (2011), the main form of transmission of viruses in this family occurs through droplets of saliva, direct contact with contaminated objects or people, contact with aerosols and via the fecal-oral route. Particularly for SARSCoV-2, Chen et al. (2020) state that there is the possibility of transmission occurring through feces, with its spread being increased by contaminated water.

The risks and cases of the transmission of pathogens by water is a well-known topic, and precisely for this reason it is extensively investigated and debated by researchers and public managers from different areas. However, it is worth noting that there is evidence that sewage and water treatment are effective in inactivating coronaviruses (USEPA, 2020a).

According to Cunliffe (2008), since the 70's there has been the emergence and reappearance of water-borne diseases, caused by several vectors, which represents a growing challenge to predict and minimize the impacts for public health and sanitation authorities. Thus, it is vital to monitor the quality of water resources, especially in relation to effluents, which can be a source of contamination for COVID-19. Hart and Halden (2020) highlight the epidemiological monitoring of SARS-CoV-2 in sewers as a tool of great potential due to its cost-benefit and robustness; however, this resource should not be used to replace clinical tests in infected individuals and/or suspected to be contaminated.

In this sense, the World Bank (2020) considers it essential that water, sanitation and hygiene (WaSH) services are managed safely, as a way of preventing and protecting human health during outbreaks of infectious diseases, including the current pandemic of Covid-19. Nevertheless, according to Lavezzo et al. (2020), even regions with a low level of hospitalizations due to COVID-19 must remain alert, since approximately $40 \%$ of the population is asymptomatic and have the same viral load and potential for infection as those with symptoms.

Based on this information, the objective of this text is to survey the potential contamination of SARS-CoV-2 in water resources and to analyze support systems for research and innovation, highlighting possible mitigations and public policies to be implemented in Brazil. 


\section{DISCUSSION}

\subsection{Risk of transmission and contagion of SARS-CoV-2 by water and sewage}

While the main form of transmission of coronaviruses is not by water or contact with feces, during the SARS outbreak in 2003, aerosols from domestic effluents were considered as probable means of transmission (Jack, 2006). Yeo et al. (2020) and CDC (2020) infer that, despite the low risk, the similarities between SARS-CoV-2 and the SARS and MERS viruses do not rule out transmission and contamination through contact with excreta.

Some studies show the possibility of SARS-CoV-2 survival in feces. According to Wu et al. (2020), who analyzed 98 symptomatic hospital patients, on average, the feces incorporated shed virus cells for 27.9 days. However, Duan et al. (2003) identified that the SARS virus remains infectious in feces for 4 to 5 days at temperatures of $20^{\circ} \mathrm{C}$, which corroborates the findings of Lai et al. (2005), who observed that this type of virus survives for 4 days at room temperature in diarrheal stools with alkaline $\mathrm{pH}$.

In domestic sewage, the survival of these pathogens depends on several factors, according to Wang et al. (2005), who found that with favorable environmental conditions such as temperature and biofilms, viruses can remain active for up to 14 days. However, Gundy et al. (2009) observed that the presence of solvents and detergents in these effluents can damage the viral envelope, inactivating them quickly in between 2 to 4 days.

There is also evidence that sewage treatment technologies are effective in inactivating corona-type viruses. According to Casanova et al. (2009), after three weeks, rates above $99.99 \%$ are observed in the removal of these pathogens in sludge at room temperature $\left(25^{\circ} \mathrm{C}\right)$. The authors pre-pasteurized the sludge, interrupting biological fermentation activity; when there was no pasteurization between $30-38^{\circ} \mathrm{C}$, inactivation occurred more quickly. Kampf et al. (2020), studying the persistence on inanimate surfaces and the inactivation of the virus by biological agents, observed that high temperatures (between $30^{\circ} \mathrm{C}$ and $40^{\circ} \mathrm{C}$ ) accelerate the inactivation of coronaviruses.

Studies have pointed out, according to WHO and Unicef (2020), that there is no risk of SARS-CoV-2 remaining in treated water and in groundwater, which supports the claim that there is a low risk of contagion in this way. Studies on the level of presence of Covid-19 in raw and treated sewage are ongoing, as mentioned above, with no evidence of transmission through this medium (WHO and UNICEF, 2020).

Thus, based on the available knowledge, the evidence is quite clear that sewage and water treatment techniques are efficient in inactivating coronaviruses, which provides a safety margin to infer that if the SARS-CoV-2 virus is present in sewage, the sewage treatment process, in particular sludge fermentation, can inactivate it almost completely. This possibly validates the recognition of several respected organizations, that until now there is no evidence or evidence of the presence of the virus in the drinking water supply (CDC, 2020; USEPA, 2020a; GLOBAL WATER RESEARCH COALITION, 2020; WHO and UNICEF, 2020).

Despite this, there is potential for contamination by direct contact with excreta, according to Xing et al. (2020), who found that SARS-CoV-2 may exist in the infant gastrointestinal tract for a longer period than the respiratory system, justifying greater attention in the management of solid and liquid waste from children's schools. In addition, Nghiem et al. (2020), Quilliam et al. (2020), University of Stirling (2020) and Yeo et al. (2020) warn that despite the low risk and probability of transmission, contamination by contact with faeces and poor sanitation conditions should not be ruled out, mainly due to the difficulty of obtaining this type of data and the lack of studies in this regard.

Most studies with consolidated data on fecal contamination of SARS-CoV-2 address hospitalized patients Ling et al. (2020), Xu et al. (2020), Wu et al. (2020), Wölfel et al. (2020) and Wan et al. (2020). Another point to be raised is the lack of data on the behavior of the virus 
in asymptomatic people. Thus, Tang et al. (2020) studied the presence of the virus in the stool of only one asymptomatic child for 17 days, during 9 days of which the virus was detected. However, there are no data available to state what viral quantity of contaminated excreta would be needed to transmit the disease to other individuals (CDC, 2020). This corroborates concerns that water resources may act as potential sources of contamination.

Nghiem et al. (2020), highlights that the long half-life of the virus in materials such as garbage cans and sewage increases the risk of contamination and the potential for aerosol transmission from sewage treatment plants. Meng et al. (2020) parallels what happened in the SARS outbreak in Hong Kong, warning of the potential for SARS-CoV-2 contamination by discharge aerosols, specially in rural regions, which use inadequate toilet facilities and lacking of hygienic conditions.

Due to the risk of infection through exposure to domestic sewage, there are safety recommendations and standards for the protective equipment of professionals who work in these environments or who come into contact with domestic effluents or contaminated solid waste. Thus, manuals were prepared with recommendations for preventive and safety measures to be taken by Sewage Treatment Plant operators (Babiano, 2020; Nolasco, 2020).

\subsection{Monitoring of viral levels in domestic effluents}

Continuous and systematic research and monitoring of viral presence in domestic effluents make it possible to quantify the risk of contagion by direct contact or aerosols and to monitor the behavior and pattern of contamination of the population by SARS-CoV-2. Since testing across the population is a complex and expensive task, the epidemiological methodology for domestic effluents has been very successful in monitoring the hepatitis A virus, polio, Norovirus, and Rotavirus (Asghar et al., 2014; Hellmér et al., 2014; Santiso-Bellón et al., 2020).

According to Lodder and Husman (2020) and Quilliam et al. (2020), the epidemiological monitoring of COVID-19 can be performed by monitoring enteric pathogens in domestic effluents. This is a fundamental action to assess the potential risk to public health, as well as a source of valuable data to assess and understand the circulation, behavior and contamination pattern of the virus, as this way it is possible to assess the general population and not only those who are hospitalized.

Daughton (2020) states that it is imperative to develop methods of sewage epidemiology as a form of mass surveillance and early warning, both for the current and future epidemics. Thus, governments should be aware of the vital role of this tool in controlling the dissemination of COVID-19 and therefore national agencies should encourage and allocate resources to enable this monitoring.

However, according to Mallapaty (2020), in order to be able to quantify the scale of infection in a population from domestic effluent samples, it is necessary to find out the amount of viral RNA excreted in the feces in order to extrapolate the number of people infected from viral RNA concentrations in wastewater samples for a given population. As we have seen before, although there are data on hospitalized contaminants, there are still no consolidated data on the viral amount excreted by asymptomatic people or those infected with mild symptoms.

Despite these limitations, there are interesting results of this monitoring in the current epidemic. In the Netherlands, Medema et al. (2020) found viral RNA in the city of Amersfoort before infections were reported in the community; and Mallapaty (2020) reports that traces of SARS-CoV-2 were detected in wastewater at Schiphol airport in Tilburg, just four days after the Netherlands confirmed its first case of COVID-19.

Randazzo et al. (2020) monitored epidemiological data on domestic sewage in the region of Murcia, Spain, and were able to detect the SARS-CoV-2 RNA from 12 to 16 days before 
having confirmed cases in the municipalities of Lorca, Cieza and Totana. Würtzer et al. (2020) conducted the monitoring during the implementation of the lockdown in Paris and observed an increase in the RNA concentration of the virus approximately 8 days in advance of the contaminated peak; but despite the contaminated curve having decreased significantly, the viral RNA concentration had slightly decreased and remained stable, which can be explained by asymptomatic contaminants.

Studies involving the identification and potential of contamination can be improved with the development of computational models to improve the monitoring and detection of virus particles per unit in sewers (Casanova, 2009; Casanova and Weaver, 2015). Hart and Halden (2020) highlight the need and difficulty of obtaining information about the potential for contamination of the virus in sewers, due to the current temporary limitations of operation of the research laboratories and biosafety requirements above Level 2 to perform this type of test; they also emphasize that the virus inactivation and detection due to temperature should be better understood.

\subsection{Monitoring and risks of contamination by water resources in Brazil}

In Brazil, there are projects in progress to monitor the presence of the virus in domestic sewage. A pilot project is conducting "indirect testing" by inferring the number of infected people regionally, identifying symptomatic and asymptomatic hosts and reducing underreporting in the Belo Horizonte and Contagem region in Minas Gerais, three in the sub Ribeirão Arrudas Basin and five in the Ribeirão do Onça Sub-basin (COPASA et al., 2020a; 2020b). Unlike some foreign experiences, the results so far have not made it possible to provide early warning of contamination peaks, due to the low number of clinical tests. Even so, after 9 weeks of monitoring, the project was able to detect a significant increase in the viral RNA load, after easing the social distance measures in which the estimated number of contaminated people jumped from 20,000 people to 50,000 (COPASA et al., 2020a; 2020c).

Although samples were not taken systematically as in Minas Gerais, the sewers of Florianópolis were also analyzed to detect the presence of the virus. According to Fongaro et al. (2020), from a total of 6 samples from the end of October 2019 until the beginning of March 2020, the SARS-CoV-2 virus was detected in a sample of 11/27/2019, 60 days before the first known case of the continent and 90 days before the first known case of the country.

The most recent initiative in Brazil is the SARS-CoV-2 Environmental Surveillance Project in the state of Rio Grande do Sul, which aims to analyze viral circulation and dynamics based on the occurrence and quantification of viral RNA in raw water and wastewater. In the second Monitoring Bulletin (CEVS-RS, 2020) virus was detected in 13 of the 42 samples collected $(30.95 \%)$ in sewage treatment plants, hospital effluents, raw water collection points and highly impacted water bodies in the cities of Porto Alegre, Novo Hamburgo and São Leopoldo.

However, in Brazil, water and sewage services are not universalized, with large deficits in the collection and treatment of sewage, mainly in the North and Northeast regions and in rural areas (Santos and Kuwajima, 2018), which limits the effectiveness of these methodologies and epidemiological monitoring of domestic effluents. Another implication of the lack of sanitation is the increased risk of contagion and dissemination of pathogens that cause COVID-19, as the treatment of sewage helps in the prevention of disease and in the neutralization of the virus. According to Brasil (2019), in 2018 about 54.2\% of the Brazilian population had sewage collection and only $46.3 \%$ of the generated sewage was treated (Table 1 ).

Where there is no regular supply of safe drinking water, there is an increased risk of contagion with COVID-19 and greater risk of death, where the most vulnerable populations live, with less financial resources and reduced access to adequate medical treatment. Sabastiani and Costa (2020) highlight that poorer populations tend to have a higher risk of malnutrition, 
which can increase the contagion of infectious diseases in general, including COVID-19. Thus, collection, treatment and training is necessary for the effectiveness of sanitation and public health actions.

Table 1. Indexes of water and sewage services in municipalities participating in SNIS in 2018 - urban areas.

\begin{tabular}{cccc}
\hline \multirow{2}{*}{ Macroregion } & \multicolumn{2}{c}{ Network service index (\%) } & Treatment index of generated sewage (\%) \\
\cline { 2 - 3 } & Water Supply & Sewage collection (Total) & (IN046) \\
\cline { 2 - 3 } & (IN055) & (IN056) & 21.7 \\
North & 57.1 & 10.5 & 36.2 \\
North-east & 74.2 & 28.0 & 50.1 \\
South-east & 91.0 & 79.2 & 45.4 \\
South & 90.2 & 45.2 & 53.9 \\
Centre-west & 89.0 & 52.9 & $\mathbf{4 6 . 3}$ \\
Brazil & $\mathbf{8 3 . 6}$ & $\mathbf{5 4 . 2}$ &
\end{tabular}

Source: Prepared by the authors with data from the SNIS Historical Series 2018, from Brazil (2019).

Finally, it is alarming that the federal government, despite all the contrary evidence, does not consider water, sewage collection, treatment and distribution as essential activities during the pandemic. Despite being included in the original list of Decree No. 10,282 / 2020 issued on 3/20/2020 (Brasil, 2020a), these activities were revoked about 1 month later by Decree No. 10,329 / 2020, issued on 4/28/2020 (Brasil, 2020b). This condition of a minor role for these provided services, combined with operational risks and contamination of operators and with the increase in default, imposes a risk of interruption of services to the most vulnerable part of the population, which may aggravate the contamination scenario.

With all that is known, the need to monitor water resources in Brazil must be highlighted, in order to contribute information on the level of infection of the population by the SARS-CoV2 virus and other pathogens. In this way, the country will be able to develop appropriate public policies in the area of sanitation and health, capable of reducing inequalities and social injustices.

\subsection{Public policies, Covid-19 and water resources: the research path}

The protection of water resources, the treatment and adequate storage of water at all stages and the non-contact with sewage are the essential factors for protection against pathogens. However, in view of the series of other risks of water contamination making it unsuitable for its various uses, it is worth debating the financing of research on this topic as a central point within continental countries such as Brazil. Among the risks already investigated are, in addition to the set of pathogens, chemical substances and elements harmful to human health, life in water and food, including pesticides, hormones and various chemical residues. The Covid-19 pandemic demands attention and calls for new efforts from all. In this sense, the role of the State is essential in financing research and monitoring water resources, sewage and risk prevention.

The unfeasibility of financial returns from basic research and even links in the research and innovation chain in this area make public financing a priority. European Union countries and the United States have support systems for research and innovation in water resources that can indicate paths for the poorest nations, such as Brazil, in order to face and reduce risks. 
Therefore, the challenge for governments is to allocate scarce resources with necessary management, planning and coordination, so that the search for answers is focused on priorities and makes use of knowledge networks and integrated research systems.

\subsection{Support systems for research and innovation in water resources in the United States of America}

The United States (USA) has about 20 federal agencies that fund research on water resources in several subthemes (NRC, 2004), with emphasis on the National Science Foundation (NSF), the United States Geological Survey (USGS) and Environmental Protection Agency (EPA). The water resources research structure was set up in the 1960s and 1970s, with changes and an increase in the budget since then. Still, the answers to questions such as those brought up with Covid-19 are not easy to obtain, requiring joint efforts and subsidies for research and measures that serve vulnerable communities (USEPA, 2020b).

Although there is a system to promote research and management of water in the United States, in several situations, support for research is fused with protection measures and environmental rules for access to water; it is a complex and robust system. This structure has allowed the set of federal programs to have a history of allocations in research with a regional focus, decentralized, and aimed at all states. At the time of the pandemic, new contributions are offered in both directions, as is the case with the promotion of care with Covid-19 for tribal populations (USEPA, 2020c).

In the USA, the traditional water research support system is structured in the states, in addition to the aforementioned federal agencies that finance the studies. There are 50 state research institutions (reaching the four districts), as provided for in The State Water Resources Research Act Program, that at the time of the pandemic are eligible for new research resources (USEPA, 2020c; NRC, 2004). The system was instituted in 1984 in the Water Resources Research Act, which structures the model based on cooperation between federal agencies and state water resources research institutes or centers for planning, promoting and transferring technologies, training, competitiveness in use water supply and subsidies, among others. Regional research coordination is the responsibility of the institutes or centers, with annual subsidies, in addition to contributions for specific topics. There is also the possibility of forming a Hub involving several development agencies, research institutes, universities and the private sector, when there is a technological bottleneck to be overcome.

\subsection{Support systems for research and innovation in water resources in the European Union}

The European Union (EU) has shown considerable advances in the standardization of uses, protection and support for research on water resources. In addition to the laws of the countries, the European Union, through the 2012 European Commission Communication nr. 673 to the European Parliament, deals with "point and diffuse sources of chemical or other pollution of the aquatic environment through various legislative instruments" (EC, 2012). Among the indicative measures are the Directives for: Urban Wastewater Treatment (DTARU), Nitrates (DN), Plant Protection Products (DPF), Industrial Emissions (IPPC-DEI), Floods. Together, they aim to protect health, human life and water resources from pollution by nutrients and / or other chemicals in agriculture, housing and industry. The EU document indicates progress and limitations, such as non-compliance with part of the norms or ignorance of the chemical status of $40 \%$ of its waters and risks of eutrophication in $30 \%$ of the freshwater body in 17 countries in the bloc, due to the increase in nutrient load.

In the EU, actions such as sustainable infrastructure (green) in sanitation works, fighting drought and water reuse in cities are indicated. The focus on post-Covid-19 pathogens has evolved, to include restructuring support for research and drawing attention to the water-healthlife focus in the first place, as does the Institut Pasteur (Paris) and the Institut Pasteur 
International Network ${ }^{1}$.

Legislation on chemicals, plant protection products and biocides tends to be more restrictive from marketing authorization to the way of use, disposal and monitoring, in line with the Sustainable Development Goals.

European experience in management and research initiatives, for example the Knowledge Hub and Research Hub, can be avenues to support studies on ecosystems, demand water pollution, governance and integrated uses, as well as monitoring Covid-19 in sewers and in water. In addition to large independent national institutes, the platform for the dissemination of initiatives, lines of research, consultancy, and the dissemination of standards, among other actions, is facilitated in the European system by the Joint Research Center (JRC), an initiative linked to the European Commission that fosters science in several areas. The theme of water is very prominent, as noted on the JRC website ${ }^{2}$.

\subsection{Support systems for research and innovation in water resources in Brazil}

Brazil has faced difficulties in carrying out research, as well as in providing water and sewage services. Santos (2012) analyzed contributions from the Sectorial Fund for Technological Innovation in Water Resources (CT-Hidro), the main source of public funds from the federal government for scientific research on water in Brazil, pointing to discontinuity of supported lines, the low rate of disbursement of resources contractors and an incipient chain generating knowledge and innovations. As one of the components of the National Fund for Scientific and Technological Development (FNDCT), the main source of funds for CT-Hidro is the collection for Financial Compensation for the use of Water Resources (CFUR), paid by the hydroelectric sector (Law 9.648 / 1998, amended by Law 1.3661 / 2018), which has generated annual revenue close to R \$ 100 million.

Managers and members of the CT Hidro Sectorial Fund, of the then Ministry of Science and Technology (MCT) interviewed by Santos (2012) have already indicated the need to increase the research capacity on persistent organic pollutants (POPs) and viruses in water. Budget execution data from CT-Hidro show that in 2015 the approved budget was only R \$ 17.7 million, with execution below R \$ 4 million, the same amount budgeted for the following year. Thereafter, the CT-Hidro Fund ran out of new projects, the last public call for MCTI / FINEP CT-Hidro taking place in 2013.

Specifically, for sanitation, the resources for research are currently restricted to applied and decentralized themes (such as losses and energy efficiency, from the Ministry of Regional Development), sporadic initiatives by the National Water Agency and allocations from the productive sector (water supply and sanitation services utilities). The Basic Sanitation Research Program (Prosab), a joint initiative by government agencies and universities that had calls from 1983 to 2010, this being the last major initiative in this area in Brazil. Operated by Caixa Econômica, Finep and CNPq, in addition to BNDES, Abes, association of municipalities and CT-Hidro in different years, the studies of Prosab covered important contributions in water and sanitation, including on pathogens and types of waterborne disease transmission.

Currently, initiatives of this nature and new financing are again essential, mainly due to the lack of sanitation in some regions of Brazil. This is justified, because research on sewage indicates an incidence of the new coronavirus in between $72 \%$ and $100 \%$ of the samples collected (COPASA et al., 2020a), requiring greater monitoring in places of greater social vulnerability. Further studies are necessary in order to cover the analysis of open sewers, with possible ways of transmitting pathogens such as Coronavirus, including in water systems

\footnotetext{
${ }^{1}$ List of themes and projects available at: https://www.pasteur.fr/en/all-covid-19-institut-pasteur/researchprojects/coronavirus-covid-19-research-projects

${ }^{2}$ More information and publications available at: https://ec.europa.eu/jrc/en/research-topic/water.
}

Rev. Ambient. Água vol. 15 n. 5, e2540 - Taubaté 2020 
without the necessary treatment processes and without necessary chemical products.

Therefore, the participation of the State to guarantee the financing and continuity of research actions is essential, in order to include studies on unresolved issues such as impacts of the discharge of sewage by the productive sector (mining, diverse industries and agriculture), in addition to human action and domestic sewage. The certainty of water-use best practices and integrated and participative management are the way to reduce future expenses of liabilities that continue to be generated daily.

\section{FINAL REMARKS}

The full extent of the impact of COVID-19 is as yet immeasurable, but the need to move forward with research involving water resources and better water treatment and distribution is already clear. Even though mass contamination by SARS-CoV-2 through water has not yet been confirmed, there must be an efficient effluent treatment policy that allows for the monitoring of effluents and the quality of water bodies to prevent and reduce the spread of both new and existing pathogens.

COVID-19 showed that there is a great need to improve the management of water resources and access to clean water in regions with vulnerable populations that do not have access to water supply and sewage collection services, as is common in many areas of Brazil. These populations are exposed to various pathogens and can be more easily contaminated due to the lack of infrastructure that guarantees basic hygienic conditions.

As these are the poorest regions, their inhabitants often do not have private health plans; they have more health problems due to an unbalanced diet and they may have more risk factors due to the lack of periodic monitoring by doctors. Thus, prioritizing resources to solve water and sewage problems is to invest directly in the quality of life and health of this population.

All aspects covered in this text are premised on the existence of research and data production on a continuous basis, which, in turn, is only possible with adequate, predictable financing. Thus, a public policy option for Brazil, which encompasses this moment when Covid-19 generates uncertainty, causes hundred thousand deaths in the country and impacts on the economy, is the formation of a Hub that aggregates the various interrelated aspects of water and sanitation into a cohesive and actionable whole.

Thus, we consider that the idea, though not necessarily the models of Science Hub and Water Hub of the European Union and the United States, can be replicated with adaptations for countries like Brazil. In fact, there are clear possibilities for this to be done through partnerships between governments, academia and companies, in order to make financing for studies feasible. To this end, it is important to adopt the understanding that actions cannot be promoted only on specific issues, such as Covid-19, but as a robust management, governance and research model that has guaranteed budget and independent agenda.

The focus should be on reaching those lacking assistance from sanitation systems, as these are the most vulnerable, and therefore lives and financial resources are spared with such a focus. This may arise from an initiative of the Ministry of Science, Technology and Innovation (MCTI) and the Ministry of Health (MS), under the execution of CT-Hidro and CT-Saúde, supported by CNPq and Finep.

In the future, the support of the Technical Chambers of the National Water Resources Council (CNRH) and its leadership will be essential to coordinate actions in the states and the Federal District. This configuration enables long-term actions, aligning planning with research, integrated management and a robust cooperative system. Legislation allows for such a design and the resources already exist, and should be allocated as established and complemented through partnerships and cooperative agreements. 


\section{REFERENCES}

ASGHAR, H.; DIOP, O. M.; WELDEGEBRIEL, G.; MALIK, F. et al. Environmental Surveillance for Polioviruses in the Global Polio Eradication Initiative. The Journal of Infectious Diseases, v. 210, suppl_1, p. S294-S303, 2014. https://doi.org/10.1093/infdis/jiu384

BABIANO, L. (ed.). COVID-19 Manual Urgente para Operadores de Gestión Urbana de Agua. IWA Publishing, 2020. https://doi.org/10.2166/9781789061710

BRASIL. Ministério do Desenvolvimento Regional. Secretaria Nacional de Saneamento. Sistema Nacional de Informações sobre Esgoto: $24^{\circ}$ Diagnóstico dos Serviços de Água e Esgotos - 2018. Brasília, DF, 2019. p. 180.

BRASIL. Presidência da República. Decreto ${ }^{\circ}$ 10.282, de 20 de março de 2020. Regulamenta a Lei $\mathrm{n}^{\circ} 13.979$, de 6 de fevereiro de 2020, para definir os serviços públicos e as atividades essenciais. Diário Oficial [da] União: seção 1, Brasília, DF, ed. extra, 21 mar. 2020a.

BRASIL. Presidência da República. Decreto ${ }^{\circ} 10.329$, de 28 de abril de 2020. Altera o Decreto $\mathrm{n}^{\circ} 10.282$, de 20 de março de 2020, que regulamenta a Lei $\mathrm{n}^{\circ} 13.979$, de 6 de fevereiro de 2020, para definir os serviços públicos e as atividades essenciais. Diário Oficial [da] União: seção 1, Brasília, DF, 29 abr. 2020b.

CASANOVA, L.; RUTALA, W. A.; WEBER, D. J.; SOBSEY, M. D. Survival of surrogate coronaviruses in water. Water Research, v. 43, n. 7, p. 1893-1898, 2009. https://doi.org/10.1016/j.watres.2009.02.002

CASANOVA, L. M.; WEAVER, S. R. Inactivation of an enveloped surrogate virus in human sewage. Environmental Science and Technology Letters, n. 3, p. 76-78, 2015.

CENTERS FOR DISEASE CONTROL AND PREVENTION (U.S.). Coronavirus Disease 2019 (COVID-19): Water \& COVID Facts - Information about Drinking Water, Treated Recreational Water, and Wastewater. 2020. Available at: https://www.cdc.gov/coronavirus/2019-ncov/php/water.html. Access: 10 May 2020.

CEVS-RS. Monitoramento ambiental de SARS-CoV-2: Boletim de acompanhamento $\mathrm{n}^{\circ} 2$. 17 July 2020. 12 p.

CHEN, Y.; CHEN, L.; DENG, Q.; ZHANG, G. et al. The presence of SARS-CoV-2 RNA in the feces of COVID-19 patients. Journal of Medical Virology, v. 20, n. 7, 2020. https://doi.org/10.1002/jmv.25825

COPASA; INCT; UFMG; IGAM et al. Boletim de Acompanhamento No 6. Belo Horizonte, 19 June 2020a. p. 9.

COPASA; INCT; UFMG; IGAM et al. Boletim de Acompanhamento: Monitoramento COVID Esgotos. Belo Horizonte: 04 May 2020b. p. 7.

COPASA; INCT; UFMG; IGAM et al. Boletim Temático No. 1 - Estimativa da população infectada pelo novo coronavírus baseada no monitoramento do esgoto: Evolução temporal e espacial em Belo Horizonte. Belo Horizonte: 26 June 2020c.

CUNLIFFE, D. A. Emerging Enteric and Potentially Waterborne Pathogens. Water Practice and Technology, v. 3, n. 4, 2008. https://doi.org/10.2166/wpt.2008.092 
DAUGHTON, C. The international imperative to rapidly and inexpensively monitor community-wide Covid-19 infection status and trends. Science of The Total Environment, v. 726, 2020. https://dx.doi.org/10.1016\%2Fj.scitotenv.2020.138149

DECARO, N. Alphacoronavirus + . In: TIDONA, C.; DARAI, G. (ed.). The Springer Index of Viruses. New York: Springer New York, 2011. p. 371-383.

DUAN, S.-M.; ZHAO, X.-S.; WEN, R.-F.; HUANG, J.-J. et al. Stability of SARS coronavirus in human specimens and environment and its sensitivity to heating and UV irradiation. Biomedical and Environmental Sciences: BES, v. 16, n. 3, p. 246-255, 2003.

EC. A Blueprint to Safeguard Europe's Water Resources. Brussels, 2012. 24 p.

FONGARO, G.; HERMES STOCO, P.; SOBRAL MARQUES SOUZA, D.; GRISARD, E. C. et al. SARS-CoV-2 in human sewage in Santa Catalina, Brazil, November 2019. MedRxiv, n. 2020.06.26.20140731, 2020. https://doi.org/10.1101/2020.06.26.20140731

GLOBAL WATER RESEARCH COALITION. Factsheet: COVID-19 Virus: Water, Sanitation and Wastewater Management. London, 2020. 2 p.

GUNDY, P. M.; GERBA, C. P.; PEPPER, I. L. Survival of Coronaviruses in Water and Wastewater. Food and Environmental Virology, v. 10, n. 1, 2009. https://doi.org/10.1007/s12560-008-9001-6

HART, O. E.; HALDEN, R. U. Computational analysis of SARS-CoV-2/COVID-19 surveillance by wastewater-based epidemiology locally and globally: Feasibility, economy, opportunities and challenges. Science of Total Environment, v. 730, n. 15, 2020. https://doi.org/10.1016/j.scitotenv.2020.138875

HELLMÉR, M.; PAXÉUS, N.; MAGNIUS, L.; ENACHE, L. et al. Detection of Pathogenic Viruses in Sewage Provided Early Warnings of Hepatitis A Virus and Norovirus Outbreaks. Applied and Environmental Microbiology, v. 80, n. 21, p. 6771-6781, 2014. https://dx.doi.org/10.1128/AEM.01981-14

JACK, L. Drainage design: factors contributing to Sars transmission. Proceedings of the Institution of Civil Engineers - Municipal Engineer, v. 159, n. 1, p. 43-48, 2006. https://doi.org/10.1680/muen.2006.159.1.43

KAMPF, G.; TODT, D.; PFAENDER, S.; STEINMANN, E. Persistence of coronaviruses on inanimate surfaces and their inactivation with biocidal agents. Journal of Hospital Infection, v. 104, n. 3, p. 246-251, 2020. https://doi.org/10.1016/j.jhin.2020.01.022

LAI, M. Y. Y.; CHENG, P. K. C.; LIM, W. W. L. Survival of Severe Acute Respiratory Syndrome Coronavirus. Clinical Infectious Diseases, v. 41, n. 7, p. e67-e71, 2005. https://doi.org/10.1086/433186

LAVEZZO, E.; FRANCHIN, E.; CIAVARELLA, C.; CUOMO-DANNENBURG, G. et al. Suppression of a SARS-CoV-2 outbreak in the Italian municipality of Vo'. Nature, $n$. 584, p. 425-429, 2020. https://doi.org/10.1038/s41586-020-2488-1

LING, Y.; XU, S.-B.; LIN, Y.-X.; TIAN, D. et al. Persistence and clearance of viral RNA in 2019 novel coronavirus disease rehabilitation patients. Chinese Medical Journal, v. 133, n. 9, p. 1039-1043, 2020. https://dx.doi.org/10.1097\%2FCM9.0000000000000774

LODDER, W.; HUSMAN, A. M. D. R. SARS-CoV-2 in wastewater: potential health risk, but also data source. The Lancet Gastroenterology \& Hepatology, v. 5, p. 533 - 534, 2020. 
MALLAPATY, S. How sewage could reveal true scale of coronavirus outbreak. Nature, p. 176-177, 2020.

MEDEMA, G.; HEIJNEN, L.; ELSINGA, G.; ITALIAANDER, R. et al. Presence of SARSCoronavirus-2 in sewage. MedRxiv, n. 2020.03.29.20045880, 2020. https://doi.org/10.1101/2020.03.29.20045880

MENG, X.; HUANG, X.; ZHOU, P.; LI, C. et al. Alert for SARS-CoV-2 infection caused by fecal aerosols in rural areas in China. Infection Control \& Hospital Epidemiology, v. 41, n. 8, p. 987, 2020. https://doi.org/10.1017/ice.2020.114

NGHIEM, L. D.; MORGAN, B.; DONNER, E.; SHORT, M. D. The COVID-19 pandemic: considerations for the waste and wastewater services sectorTT. Case Studies in Chemical and Environmental Engineering, v. 1, n. 100006, 2020. https://doi.org/10.1016/j.cscee.2020.100006

NOLASCO, D. A. COVID-19 Guia para reduzir riscos à saúde de operadores de estações de tratamento de esgoto e redes de esgoto. 2020. 5 p. Available at: https://iwanetwork.org/wp-content/uploads/2020/03/Coronav\%C3\%ADrus-Guia-para-reduzirriscos-\%C3\%A0-sa\%C3\%BAde-de-operadores-de-ETEs-NOLASCO-25mar2020v.2.pdf. Access: Sep. 2020.

NRC. Confronting the Nation's Water Problems: The Role of Research. Washington, DC: The National Academies Press, 2004. 324 p.

QUILLIAM, R. S.; WEIDMANN, M.; MORESCO, V.; PURSHOUSE, H. et al. COVID-19: The environmental implications of shedding SARS-CoV-2 in human faeces. $\begin{array}{lllll}\text { Environmental } & \text { International, } & \text { v. } & 140, & 2020 .\end{array}$ https://dx.doi.org/10.1016\%2Fj.envint.2020.105790

RANDAZZO, W.; TRUCHADO, P.; FERRANDO, E. C.; SIMON, P. et al. SARS-CoV-2 RNA titers in wastewater anticipated COVID-19 occurrence in a low prevalence area. $\begin{array}{llll}\text { MedRxiv, } & \text { n. 2020.04.22.20075200, } & 2020 .\end{array}$ http://dx.doi.org/10.1016/j.watres.2020.115942

SABASTIANI, R.; COSTA, É. P. Degradação ambiental e doenças infecciosas: quais novidades em relação à COVID-19? In: VALENCIO, N.; OLIVEIRA, C. M. (Ed.). COVID-19: crises entremeadas no contexto de pandemia (antecedentes, cenários e recomendações). São Carlos: UFSCar/CPOI, 2020. cap. 12. p. 185-200.

SANTISO-BELLÓN, C.; RANDAZZO, W.; PÉREZ-CATALUÑA, A.; VILA-VICENT, S. et al. Epidemiological Surveillance of Norovirus and Rotavirus in Sewage (2016-2017) in Valencia (Spain). Microorganisms, v. 8, n. 3, p. 21, 2020. https://www.mdpi.com/20762607/8/3/458\#

SANTOS, G. R. Financiamento público da pesquisa em recursos hídricos no Brasil: o Fundo Setorial CT-Hidro. Texto para Discussão, n. 1742, p. 54, 2012.

SANTOS, G. R.; KUWAJIMA, J. I. Saneamento e Segurança À Saúde: Caminhos para Ampliação de Infraestruturas e Melhoria dos Serviços. In: LOZARDO, E.; YWATA, A. X. D. C. et al. (Ed.). Desafios da Nação - Volume 2. Brasília, DF: IPEA; MPDG, 2018. p. 91-102. 
TANG, A.; TONG, Z.-D.; WANG, H.-L.; DAI, Y.-X. et al. Detection of Novel Coronavirus by RT-PCR in Stool Specimen from Asymptomatic Child, China. Emerging infectious Diseases, v. 25, n. 2020, 2020.

UNITED STATES. Environmental Protection Agency. Coronavirus and Drinking Water and Wastewater. 2020a. Available at: https://www.epa.gov/coronavirus/coronavirusand-drinking-water-and-wastewater. Access: May 15th 2020.

UNITED STATES. Environmental Protection Agency. EPA Provides Grant Funding to Support Environmental Justice Communities Impacted by COVID-19. Washington, D.C.: 2020b. Available at: https://www.epa.gov/newsreleases/epa-provides-grantfunding-support-environmental-justice-communities-impacted-covid-19. Access: July 25 th 2020.

UNITED STATES. Environmental Protection Agency. Tribal Water Utility Resources for the COVID-19 Pandemic. 2020c. Available at: https://www.epa.gov/coronavirus/tribalwater-utility-resources-covid-19-pandemic\#funding-financing. Access: July 25th 2020.

UNIVERSITY OF STIRLING. Sewage poses potential COVID-19 transmission risk, experts warn. 2020.2 Available at: https://www.sciencedaily.com/releases/2020/05/200506133603.htm. Access: 10 May 2020.

WAN, Y.; LI, J.; SHEN, L.; ZOU, Y. et al. Enteric involvement in hospitalised patients with COVID-19 outside Wuhan. The Lancet Gastroenterology \& Hepatology, v. 5, p. 534535, 2020. https://doi.org/10.1016/S2468-1253(20)30118-7

WANG, X. W.; LI, J.; GUO, T.; ZHEN, B. et al. Concentration and detection of SARS coronavirus in sewage from Xiao Tang Shan hospital and the 309th Hospital of the Chinese People's Liberation Army. Water Science and Technology, v. 52, n. 8, p. 213 221, 2005. https://doi.org/10.2166/wst.2005.0266

WHO; UNICEF. Water, sanitation, hygiene, and waste management for the COVID-19 virus: interim guidance. WHO Global: 2020.9 p.

WORLD BANK. Water, Sanitation and Hygiene: The First Line of Defense in the Battle Against COVID-19 (English). Washington, D.C.: 2020. 4 p.

WU, Y.; GUO, C.; TANG, L.; HONG, Z. et al. Prolonged presence of SARS-CoV-2 viral RNA in faecal sample. The Lancet Gastroenterology \& Hepatology, v. 5, n. 5, p. 434-435, 2020. https://doi.org/10.1016/S2468-1253(20)30083-2

WÜRTZER, S.; MARECHAL, V.; MOUCHEL, J.-M.; MADAY, Y. et al. Evaluation of lockdown impact on SARS-CoV-2 dynamics through viral genome quantification in Paris $\begin{array}{llll}\text { wastewaters. MedRxiv, } & \text { n. } & \text { 2020.2004.2012.20062679, }\end{array}$ https://doi.org/10.1101/2020.04.12.20062679

WÖLFEL, R.; CORMAN, V. M.; GUGGEMOS, W.; SEILMAIER, M. et al. Virological assessment of hospitalized patients with COVID-2019. Nature, v. 581, p. 465-469, 2020. https://doi.org/10.1038/s41586-020-2196-X

XING, Y. H.; NI, W.; WU, Q.; LI, W. J. et al. Prolonged viral shedding in feces of pediatric patients with coronavirus disease 2019. Journal of microbiology, immunology, and infection, 53, n. 3, p. 473-480, 2020. https://doi.org/10.1016/j.jmii.2020.03.021 
XU, Y.; LI, X.; ZHU, B.; LIANG, H. et al. Characteristics of pediatric SARS-CoV-2 infection and potential evidence for persistent fecal viral shedding. Nature Medicine, 26, p. 502506, 2020. https://doi.org/10.1038/s41591-020-0817-4

YEO, C.; KAUSHAL, S.; YEO, D. Enteric involvement of coronaviruses: is faecal-oral transmission of SARS-CoV-2 possible? The Lancet Gastroenterology \& Hepatology, London, UK, 5, n. 4, p. 335-337, 2020. https://doi.org/10.1016/S2468-1253(20)30048-0 


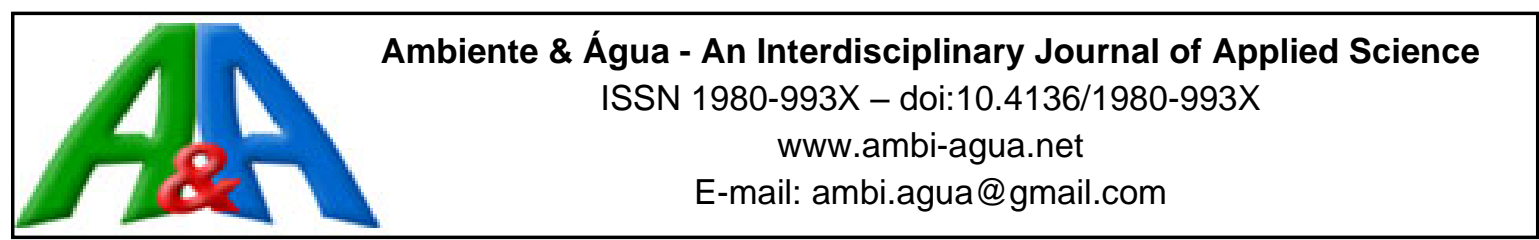

\title{
Effect of the inoculum/substrate ratio on the biochemical methane potential (BMP) of grape marc
}

\author{
ARTICLES doi:10.4136/ambi-agua.2541
}

Received: 07 Mar. 2020; Accepted: 07 Jul. 2020

\author{
Kessia Caroline Dantas da Silva ${ }^{1 *}$; Miriam Cleide Cavalcante de Amorim ${ }^{1}$;D; \\ Renan Santana Galvão ${ }^{1}$; Yandra Beatriz de Oliveira Gonçalves ${ }^{2}{ }^{D}$; \\ Paula Tereza de Souza e Silva ${ }^{3}$; Eduardo Souza Costa Barros ${ }^{4}$ \\ ${ }^{1}$ Colegiado de Engenharia Agrícola e Ambiental. Universidade Federal do Vale do São Francisco (UNIVASF), \\ Avenida Antônio Carlos Magalhães, n 510, CEP: 48902-300, Juazeiro, BA, Brazil. \\ E-mail: miriamcleidea@gmail.com, renan81097@hotmail.com \\ ${ }^{2}$ Colegiado de Engenharia Civil. Universidade Federal do Vale do São Francisco (UNIVASF), Avenida Antônio \\ Carlos Magalhães, n 510, CEP: 48902-300, Juazeiro, BA, Brazil. E-mail: yandra_oliveira@ @otmail.com \\ ${ }^{3}$ Embrapa Semiárido (EMBRAPA), Rodovia BR-428, Km 152, Caixa Postal 23, CEP: 56302-970, Petrolina, \\ PE, Brazil. E-mail: paula.silva@embrapa.br \\ ${ }^{4}$ Colegiado de Pós-Graduação em Engenharia Agrícola. Universidade Federal do Vale do São Francisco \\ (UNIVASF), Avenida Antônio Carlos Magalhães, nº 510, CEP: 48902-300, Juazeiro, BA, Brazil. \\ E-mail: barros-eduardo2005@hotmail.com \\ *Corresponding author. E-mail: kessia155@hotmail.com
}

\begin{abstract}
The grape industrialization process produces large volumes of solid organic waste, with the grape bagasse being the main waste generated in the winemaking process. Anaerobic digestion can be used to treat and dispose of agro-industrial biomass waste. The objective of this study was to evaluate the effect of the inoculum/substrate ratio on the Biochemical Methane Potential (BMP) of grape marc. The experiment was performed in laboratory scale through a system of reactor bottles in batches, removing a set of triplicate flasks for sampling and analysis every 48 hours, with the test lasting 12 days. The reactors contained residue, inoculum and $20 \%$ of nutritive solution, maintaining $20 \%$ of headspace. The reactors were incubated in an incubator at a mesophilic temperature $\left(35 \pm 2{ }^{\circ} \mathrm{C}\right)$ and shaken manually every 24 hours. Three different inoculum/substrate (I/S) ratios of $0.75,1.5$ and 3 were used to evaluate the methane yield, organic removals and at the end of degradation the morphology of the bacterial community was evaluated by means of scanning electron microscopy. The I/S 3 ratio provided the best results for loading anaerobic systems, indicating that grape marc presents potential for biological treatment through anaerobic digestion.
\end{abstract}

Keywords: agroindustrial waste, anaerobic digestion, biogas, biomethane.

\section{Efeito da relação inóculo/substrato no potencial bioquímico de metano (PBM) no bagaço de uva}

\section{RESUMO}

O processo de industrialização da uva produz grandes volumes de resíduos sólidos orgânicos, sendo o bagaço de uva o principal resíduo gerado no processo de vinificação. A digestão anaeróbica pode ser utilizada para o tratamento e disposição dos resíduos de biomassa 
agro-industrial. O objetivo deste estudo foi avaliar o efeito da relação inóculo/substrato no Potencial Bioquímico de Metano (PBM) do bagaço de uva. O experimento foi realizado em escala laboratorial através de um sistema de frascos reatores em lotes, retirando um conjunto de triplicatas dos frascos para amostragem e análise a cada 48 horas, com a duração do teste de 12 dias. Os reatores continham resíduo, inóculo e $20 \%$ de solução nutritiva, mantendo $20 \%$ de headspace. Os reatores foram incubados em uma incubadora à temperatura mesófila $\left(35 \pm 2{ }^{\circ} \mathrm{C}\right)$ e agitados manualmente a cada 24 horas. Três diferentes razões inóculo/substrato (I/S) de 0,75, 1,5 e 3 foram utilizadas para avaliar a produção de metano, as remoções orgânicas e no final da degradação a morfologia da comunidade bacteriana por meio de microscopia eletrônica de varredura. A relação I/S 3 forneceu os melhores resultados para carregamento de sistemas anaeróbicos, indicando que o bagaço de uva apresenta potencial para tratamento biológico através da digestão anaeróbica.

Palavras-chave: biogás, biometano, digestão anaeróbica, resíduos agroindustriais.

\section{INTRODUCTION}

Wine production is an activity that stands out all over the world (Devesa-rey et al., 2011), producing large volumes of organic solid waste. According to Mello (2018), the production of grapes in Brazil for processing (wine, juice and derivatives) was 818,783 million $\mathrm{kg}$ in 2017, $48.74 \%$ of the total production of grapes, with the rest $(51.26 \%)$ for consumption in natura.

For Zhang et al. (2017), solid organic by-products of wine production include grape marc, stalk, wine lees and sludge. The main one is grape marc, composed mainly of seeds and peelings (Christ and Burrit, 2013; Duba et al., 2015).

Although potentially polluting, for Avaci et al. (2013), biogas can be recovered through anaerobic digestion (AD), which is seen as an ideal form of biomass waste treatment. It is a promising technology in the management of organic materials and renewable energy production, nutrient recycling and reduction of waste streams (Li et al., 2018).

The $\mathrm{AD}$ process is regulated by environmental factors, some of the main ones being temperature (mesophilic or thermophilic regime) and $\mathrm{pH}$, waste composition, physical state and substrate structure and the inoculum/substrate ratio (I/S) (Angelidaki et al., 2009; Zarkadas et al., 2016; Córdoba et al., 2018).

The ratio between substrate and inoculum is an important parameter in anaerobic digestion and is one of the most important factors for the initiation of a balanced microbial population in the anaerobic system (Haider et al., 2015; Zhu et al., 2014). In a study by Latifi et al. (2019), the results showed that the decrease in the I/S ratio led to the accumulation of fatty acids and high ammonia concentrations in the reactor, resulting in lower methane yields. In this sense, the relationship between inoculum/substrate, which is incubated in the reactors, influences the specific production of methane, taking into account that different residues require different proportions due to intrinsic characteristics of their generating processes.

Given the diversity of factors that affect anaerobic digestion, anaerobic biodegradation tests are used to establish the potential for biodegradation and determine the methane production potential of waste (Angelidaki et al., 2009), and tests of Biochemical Methane Potential (BMP) can be used for such purposes (Holliger et al., 2016). Also, the BMP of the I/S ratios can be used to design installation parameters of a full-scale reactor operation, and according to Filer et al. (2019), even the size of the digesters and possibilities of biogas exploitation. For example, Holliger et al. (2017) found that the weekly methane production rates of BMP were similar and followed the same pattern compared to the full-scale reactor installation.

Thus, faced with the generation of waste that is part of the grape industrialization process,

Rev. Ambient. Água vol. 15 n. 5, e2541 - Taubaté 2020 
anaerobic digestion becomes a viable alternative for treatment and disposal of such waste, and may also be reverted into benefits for the production system of the winemaking itself. Therefore, the objective of this study was to compare the influence of the inoculum/substrate ratio on the biochemical methane potential of grape marc, evaluating at the end of the degradation the morphology of the bacterial community by means of scanning electron microscopy.

\section{MATERIALS AND METHODS}

\subsection{Substrate and Inoculum}

For the BMP assays, the bagasse of the pressed grape (hybrid cultivars Isabel and BRS Violeta) was used as substrate, reminiscent of the winemaking process, composed of peelings, seeds and moisture, without stalks. The residue was collected at Vitivinícola Quintas São Braz, located in the rural area of the city of Petrolina-PE, Brazil.

The waste collection process was performed according to the procedures of the German Guideline VDI 4630 (VDI, 2016) and ABNT NBR 10007, where simple samples were collected, taking four sub-samples of three sections (top, middle and bottom of the waste pile) to integrate the composite sample, which was packed, identified and transported under refrigeration. Physical-chemical characterizations of the substrate were performed in triplicate, analysis of total solids and total volatile solids, $\mathrm{pH}$, humidity, phosphorus, total nitrogen and chemical oxygen demand (COD), according to APHA et al. (2012), and organic matter (OM). The metals nickel, iron, potassium, sodium, calcium, copper, manganese, zinc and lead were determined by means of nitric acid digestion and subsequent analysis in atomic absorption spectrophotometer with atomization by air-acetylene flame in the specific wavelength for each chemical element analyzed according to APHA et al. (2012).

The origin, quality criteria and preparation of the inoculum met the recommendations of VDI 4630 (VDI, 2016), using anaerobic sludge from the discharge of a UASB (Upflow Anaerobic Sludge Blanket) reactor treating domestic sewage in a treatment station of the Companhia Pernambucana de Saneamento, located in Petrolina - PE, Brazil. The specific methanogenic activity (SMA) of the sludge for propionate, butyrate and acetate substrates is $0.125 \mathrm{~L} \mathrm{CH}_{4} \mathrm{~kg} \mathrm{STV} \mathrm{d}^{-1}$, considered a good activity for anaerobic sludge (Angelidaki et al., 2009).

\subsection{Experimental Configuration of the BMP Assay}

By adapting VDI 4630 (2016) to the sacrifice bottle methodology adopted by Amorim et al. (2013), the experiment was conducted in a system of 66 reactor bottles in batches, each with a total volume of $115 \mathrm{~mL}$ (Holliger et al., 2016). The reactors contained residue, inoculum and $20 \%$ nutrient solution, filling a working volume of $92 \mathrm{~mL}$, to maintain $20 \%$ of headspace (Angelidaki et al., 2009). The assay lasted 12 days, in order to make the identification of the potential faster, considering that normally most of the biogas forms in the first week of the trial. A set of triplicates was removed every 48 hours for sampling and analysis.

Prior to that, 24 hours before the installation of the experiment, the microbial biomass was acclimatized in the reactors, placing only the anaerobic sludge and the nutritive solution, enriching them to later receive the grape marc. After mixing and homogenization of the inoculum and bagasse, the $\mathrm{pH}$ of the contents of the bottles was checked using sodium bicarbonate, leaving them close to neutrality. Subsequently, the bottles were sealed with nitrile rubber caps and aluminum seals, with crimping pliers. The biogas was measured every 24 hours, a $10 \mathrm{~mL}$ syringe was inverted into the lid of the reactor, through to the nitrile rubber cap and aluminum seal. The pressure inside the reactor pushes the piston of the syringe, allowing the measurement of biogas. The reactor bottles were incubated in an incubator at a mesophilic 
temperature $\left(35 \pm 2{ }^{\circ} \mathrm{C}\right)$ and shaken manually every 24 hours. Methane production due to the possible presence of residual substrate in the inoculum was subtracted by performing blank controls.

\subsection{Inoculum/substrate Ratios Used in BMP}

Three inoculum/substrate ratios (I/S) of $0.75,1.5$ and 3.0 were tested and achieved by maintaining a fixed inoculum concentration $\left(15 \mathrm{~g} \mathrm{VS} \mathrm{L}^{-1}\right)$ and varying the substrate concentration from 5 to $20 \mathrm{~g} \mathrm{VS} \mathrm{L}^{-1}$ (Table 1).

Table 1. Experimental conditions used for the different BMP tests performed.

\begin{tabular}{ccccc}
\hline \multirow{2}{*}{ Ratios $(\mathbf{I} / \mathbf{S})$} & \multicolumn{2}{c}{ Inoculum } & \multicolumn{2}{c}{ Substrate } \\
\cline { 2 - 5 } & Volume $(\mathbf{L})$ & Concentration $\left(\mathrm{g} \mathrm{VS} \mathrm{L} \mathrm{L}^{-1}\right)$ & Volume $(\mathbf{L})$ & Concentration $\left(\mathrm{g} \mathrm{VS} \mathrm{L}^{-1}\right)$ \\
\hline $\mathbf{0 . 7 5}$ & 0.015 & 15 & 0.007 & 20 \\
$\mathbf{1 . 5 0}$ & 0.015 & 15 & 0.004 & 10 \\
$\mathbf{3 . 0 0}$ & 0.015 & 15 & 0.002 & 5 \\
\hline
\end{tabular}

The evaluation of the effect of the I/S ratio on BMP was determined by the percentage of removal of volatile solids and COD, and by the methane yield per mass of volatile solids added ( $\left.\mathrm{L} \mathrm{CH}_{4} \mathrm{~kg}^{-1} \mathrm{VS}_{\text {Aditioned }}\right)$. The methane yield $(\% \mathrm{R})$ was calculated in relation to the theoretical volume of methane $\left(\mathrm{TV}_{\mathrm{CH} 4}\right)$ obtained according to Chernicharo (2007) (Table 2). The characteristics of the substrate, the anaerobic inoculum and the I/S ratios are shown in Table 2.

Table 2. Physical-chemical characterization of inoculum, substrate and I/S ratios.

\begin{tabular}{|c|c|c|c|c|c|c|}
\hline \multirow{2}{*}{ Parameters } & \multirow{2}{*}{ Units } & \multirow{2}{*}{ Inoculum } & \multirow{2}{*}{ Grape marc } & \multicolumn{3}{|c|}{$\mathbf{I} / \mathbf{S}$} \\
\hline & & & & 0.75 & 1.5 & 3.0 \\
\hline pH & - & 8.15 & 3.72 & 7.23 & 7.40 & 7.53 \\
\hline Humidity & $\%$ & 51.75 & 68.37 & - & - & - \\
\hline TS & $\%$ & 9.07 & 47.33 & 217.25 & 125.78 & 172.29 \\
\hline VS & $\%$ & 4.40 & 40.92 & 197.54 & 107.72 & 148.97 \\
\hline COD & $\mathrm{g} \mathrm{L}^{-1}$ & - & 36.30 & 4.88 & 3.39 & 2.71 \\
\hline OM & $\%$ & - & 98 & & & \\
\hline NT & $\%$ & 0.89 & 1.31 & - & - & - \\
\hline $\mathrm{NH}_{3}$ & $\mathrm{~g} \mathrm{~kg}^{-1}$ & 1.82 & 0.02 & - & - & - \\
\hline $\mathbf{P}$ & $\mathrm{mg} \mathrm{L}^{-1}$ & 90.14 & 542.98 & - & - & - \\
\hline $\mathbf{K}$ & $\mathrm{g} \mathrm{kg}^{-1}$ & 5.80 & 0.14 & - & - & - \\
\hline $\mathrm{Na}$ & $\mathrm{g} \mathrm{kg}^{-1}$ & 6.50 & 0.0022 & - & - & - \\
\hline Mg & $\mathrm{g} \mathrm{kg}^{-1}$ & 1.50 & 0.0167 & - & - & - \\
\hline $\mathrm{Ca}$ & $\mathrm{g} \mathrm{kg}^{-1}$ & 1.60 & 0.0024 & - & - & - \\
\hline Nitrate & $\mathrm{g} \mathrm{kg}^{-1}$ & 0.11 & 0.062 & - & - & - \\
\hline $\mathbf{Z n}$ & $\mathrm{mg} \mathrm{kg}^{-1}$ & - & 0.000 & - & - & - \\
\hline $\mathrm{Cu}$ & $\mathrm{mg} \mathrm{kg}^{-1}$ & - & 0.034 & - & - & - \\
\hline Mn & $\mathrm{mg} \mathrm{kg}^{-1}$ & - & 0.099 & - & - & - \\
\hline $\mathrm{Fe}$ & $\mathrm{mg} \mathrm{kg}^{-1}$ & - & 1.648 & - & - & - \\
\hline $\mathbf{N i}$ & $\mathrm{mg} \mathrm{kg}^{-1}$ & - & 0.054 & - & - & - \\
\hline $\mathbf{P b}$ & $\mathrm{mg} \mathrm{kg}^{-1}$ & - & 0.000 & - & - & - \\
\hline VFA & $\mathrm{mg} \mathrm{HAc} \mathrm{L} \mathrm{L}^{-1}$ & - & - & 612.39 & 528.41 & 538.90 \\
\hline $\mathbf{T A}$ & mg HAc L ${ }^{-1}$ & - & - & 22.67 & 9.33 & 12.00 \\
\hline $\begin{array}{l}\text { Theoretical volume of } \\
\mathrm{CH}_{4}\left(\mathrm{TV}_{\mathrm{CH} 4}\right)\end{array}$ & $\left(\mathrm{NL} \mathrm{CH}_{4} \mathrm{~kg}^{-1} \mathrm{VS}_{\mathrm{Ad}}\right)$ & - & - & 45.51 & 68.49 & 136.79 \\
\hline SMA & $\mathrm{L} \mathrm{CH}_{4} \mathrm{~kg} \mathrm{VS} \mathrm{d}^{-1}$. & 0.125 & - & - & - & - \\
\hline
\end{tabular}

Rev. Ambient. Água vol. 15 n. 5, e2541 - Taubaté 2020 


\subsection{Collection and Characterization of Biogas}

The collection of biogas for the characterization was performed within 24 and 48 hours of the experiment, time in which production peaks were observed. The characterization of the biogas proceeded regarding the composition of methane and carbonic gas. To this end, part of the biogas was transferred to $10 \mathrm{~mL}$ syringes with the aid of 3-way valves that allowed the connection between the syringes, and from these to gas collectors with nitrilic rubber.

The biogas was characterized in gas chromatograph Agilent Model 7890 A with detector type FID equipped with a methanator. The column used was agilentHayesep Q 80/100. $\mathrm{N}_{2}$ with flow of $25 \mathrm{~mL} \mathrm{~min}{ }^{-1}$ was used as carrier gas. The temperature of the detector was $300^{\circ} \mathrm{C}$, the temperature of the column oven was $60^{\circ} \mathrm{C}$ and the running time was $11 \mathrm{~min}$. To calculate the concentrations, two calibration curves were constructed, one for $\mathrm{CO}_{2}(250,500$ and $1000 \mathrm{ppm})$ and $\mathrm{CH}_{4}(0.5,1$ and 3 ppm).

The volume of methane produced $\left(\mathrm{VCH}_{4}\right)$ was obtained through the composition and volume of biogas, the rate of methane production was determined in relation to the VS added. The values were normalized to standard temperature and pressure (VDI, 2016).

\subsection{Morphology of the Inoculum Microbial Community}

At the end of the BMP assays, samples of the biomass contained in the reactors (inoculum) were characterized under VEGA3 TESCAN scanning electron microscope (SEM). Adapting to the methodology of Araújo et al. (2003), samples of $0.5 \mathrm{~mL}$ of sludge were fixed with phosphate buffer ( $\mathrm{pH} 7.3$ ) containing $25 \%$ glutaraldehyde, for $2 \mathrm{~h}$ at $4^{\circ} \mathrm{C}$. After fixation, dehydration with ethanol solutions was performed, washing the samples 6 times at 10-minute intervals at increasing concentrations $(45,70,80,95$ and $100 \% \mathrm{v} / \mathrm{v})$. These samples were fixed on aluminum supports (stubs) with double-sided carbon tape and dried at $30^{\circ} \mathrm{C}$ in an incubator for 2 hours. The samples were then covered with a $20 \mathrm{~nm}$ thick gold layer in the Sputter Quorum Model Q 150R ES, with $15 \mathrm{~mA}$ current and 90 seconds metallization time.

\subsection{Statistical Analysis}

The results were statistically evaluated in the Sisvar® software (Version 5.6), through descriptive statistics and analysis of variance (ANOVA) applying the Tukey test at the 5\% significance level.

\section{RESULTS AND DISCUSSION}

\subsection{Organic Removals}

Figure 1a shows the removal of volatile solids at the end of the digestion time as a function of the I/S ratios studied. There was no significant difference according to the Tukey test at 5\% significance, between the relations of 0.75 and 3.0, which provided the greatest reductions, 59.22 and $59.24 \%$, respectively. The ratio of 1.5 obtained the lowest percentage of reduction around $56.73 \%$.

In studies carried out by Li et al. $(2016 ; 2018)$ the largest VS reductions were obtained in reactors with the highest methane yields, different from the present study, in which it can be observed that the largest removals were obtained in the ratios with different load extremes. Showing an uncertain trend regarding the removal of organic matter and the inoculum/substrate ratios, as well as in Córdoba et al. (2018). Ros et al. (2016) obtained percentages of VS removal, also with grape marc residue of $12-35 \%$.

Figure $1 \mathrm{~b}$ shows that the I/S 3.0 ratio obtained the best performance in percentage of removal $(77.5 \%)$, a ratio that also obtained the best specific production of methane in relation to volatile solids. While the ratios of 1.5 and 0.75 obtained $61.7 \%$ and $57.2 \%$, respectively. 


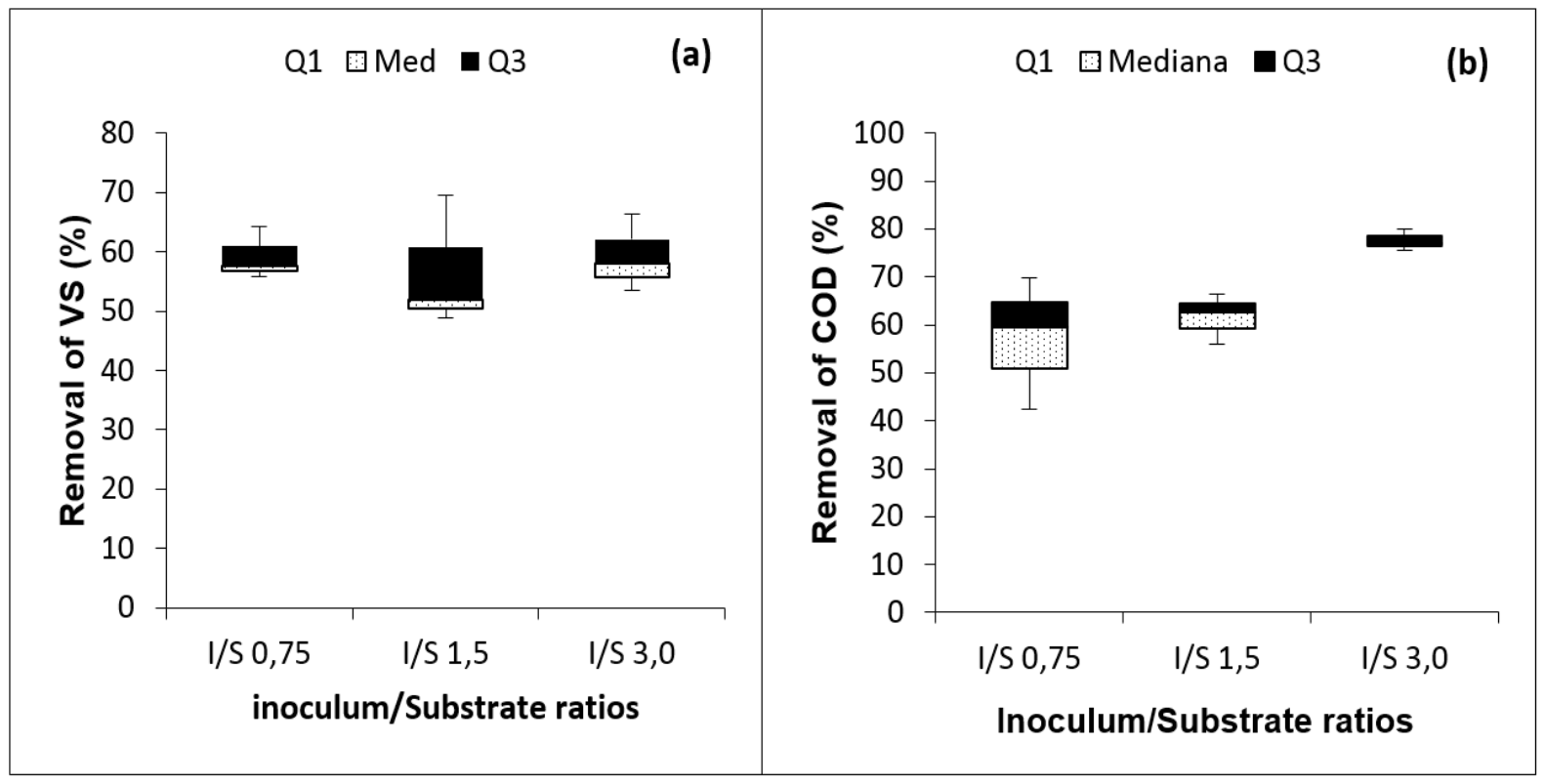

Figure 1. Organic removals in the different I/S relations. (a) Removal of VS. (b) Removal of COD.

The results were promising when compared to the study conducted by Leite et al. (2014) that when using typically vegetable waste, in addition to sewage sludge, a removal of $51 \%$ of COD was obtained. In contrast, Gueri et al. (2018) obtained a reduction of $80.98-81.63 \%$, using food waste and anaerobic sludge in bench reactors. Talha et al. (2016) working with sugarcane bagasse, obtained a COD removal of $69.64 \%$.

The organic removal of COD is more cohesive in relation to that of volatile solids, showing higher removals as the I/S ratios increase.

\subsection{Methane Yield}

For the calculation of the methane yields, the values obtained for the volume of biogas, percentage of methane and volume of methane, presented in Table 3, were used, in which there was a significant difference between the I/S ratios applied. It can be observed that the I/S ratio 3 , despite having the lowest volume of biogas produced, obtained the best percentage of methane. On the other hand, the I/S ratio of 0.75 obtained the lowest percentage of methane, even generating the highest amount of biogas.

Table 3. Biogas volume, percentage, volume and methane yields for I/S ratios.

\begin{tabular}{cccccc}
\hline \multirow{2}{*}{ I/S Ratios } & $\mathbf{V}_{\text {biogas }}$ & \multicolumn{4}{c}{$\mathbf{C H} \mathbf{4}$} \\
\cline { 2 - 6 } & $(\mathbf{m L})$ & $\%$ & $(\mathbf{m L})$ & $\mathbf{\%} \mathbf{R}$ & $\mathbf{L ~} \mathbf{C H}_{\mathbf{4}} \mathbf{K g}^{-1} \mathbf{V S}_{\mathbf{A d}}$ \\
\hline $\mathbf{0 . 7 5}$ & $136.76 \mathrm{a}$ & $26.20 \mathrm{~b}$ & $35.93 \mathrm{ab}$ & $42.80 \mathrm{~b}$ & $19.42 \mathrm{c}$ \\
$\mathbf{1 . 5}$ & $133.60 \mathrm{a}$ & $31.64 \mathrm{a}$ & $42.27 \mathrm{a}$ & $67.00 \mathrm{a}$ & $45.96 \mathrm{~b}$ \\
$\mathbf{3 . 0}$ & $87.40 \mathrm{~b}$ & $33.80 \mathrm{a}$ & $29.54 \mathrm{~b}$ & $47.00 \mathrm{~b}$ & $64.22 \mathrm{a}$ \\
\hline $\mathbf{\%} \mathbf{C V}$ & 8.30 & 6.74 & 12.41 & 7.89 & 9.63 \\
\hline
\end{tabular}

*Averages followed by the same letter in the column do not differ according to Tukey's test at 5\% significance; CV: Coefficient of variation. 
The I/S 3 ratio was statistically higher according to the Tukey test at 5\% significance (Table 3), providing the best results for the cumulative production of methane in relation to the amount of VS added as a function of time, with $64.22 \mathrm{~L} \mathrm{CH}_{4} \mathrm{Kg}^{-1} \mathrm{VS}_{\text {additioned, followed by I/S1.5 }}$ (45.96 $\mathrm{L} \mathrm{CH}_{4} \mathrm{Kg}^{-1} \mathrm{VS}_{\text {add }}$ ) and I/S 0.75 (19.42 $\mathrm{L} \mathrm{CH}_{4} \mathrm{Kg}^{-1} \mathrm{VS}_{\text {add }}$ ). Evidencing that the higher the concentration of added inoculum in relation to the substrate, the higher the production of methane per gram of volatile solids, with an increase of $70 \%$ when the I/S ratio varied from 0.75 to 3 .

Ros et al. (2016) obtained for grape marc, during 40 days, $360 \mathrm{~L} \mathrm{CH} 4 \mathrm{Kg}^{-1} \mathrm{VS}_{\text {add. }}$ Fabbri et al. (2015) also using grape marc, obtained 145-254 L CH4 $\mathrm{Kg}^{-1} \mathrm{VS}_{\text {add. }}$ This difference in yields may be associated with the fact that the above studies had an average duration of 60 days. However, in order to obtain uniformity between the duration times used in BMP tests, it is recommended that the experiment should be completed when the daily rate of biogas is equivalent to about $1 \%$ of the total volume of biogas produced up to that moment, according to the VDI 4630 (2016).

Moset et al. (2015), varying I/S ratio from 0.5 - 2, found that a higher ratio provides a higher BMP for maize (397.5 $\mathrm{L} \mathrm{CH}_{4} \mathrm{Kg}^{-1} \mathrm{VS}_{\text {add }}$ ). Pellera and Gidarakos (2016) used I/S ratios of $0.5,1,2$ and 4, obtaining the best yields in I/S ratio 4 for cotton ginning waste and in ratio 2 for grape waste (skin, seed and stalk). Rouches et al. (2019), evaluating the impact of I/S ratios $(0.9,0.5,0.3,0.1)$ on anaerobic digestion of wheat straw, observed a drastic drop in methane production in the lowest ratios.

Thus, the biochemical methane potential test is an essential technique to evaluate the implementation and optimization of anaerobic biotechnologies (Silva et al., 2018). Although this technique is characterized by long periods of digestion, from 20 to more than 100 days, which is not appropriate to the need for rapid decision-making, as in the case of agroindustries (Raposo et al., 2012; Silva et al., 2018). Thus, taking into account that the experimental period of the present study, 12 days, compared to other studies with other organic waste mentioned above, whether they come from the winemaking process or not, reveals the potential of grape marc for specific production of methane.

The methane yield (\%R) shows that the experimental methane production was above $40 \%$ for I/S ratios 0.75 and 3 of the theoretical volume of methane $\left(\mathrm{TVCH}_{4}\right)$, while the $\mathrm{I} / \mathrm{S}$ ratio 1.5 obtained $67 \%$ yield from $\mathrm{TVCH}_{4}$ (Table 3), indicating that the organic fraction removed anaerobically converted into methane, from the treatment of grape marc, and that this method is a viable alternative for the use of residues from grape processing.

\subsection{Morphology of the Inoculum Microbial Community}

In the SEM micrographs of the 0.75 inoculum I/S (Figure 2), it can be seen that even with this ratio, which provided the lowest percentage of methane among the studied ratios, there was a predominance of bacterial morphologies in the form of coconuts similar to methanosarcine $s p$ (coconuts adhered to the granule indicated by the arrows) belonging to the domain of the arches, in addition to long (ellipses) and short (circle) bacilli. Methanosarcines $s p$ are the only group together with Methanosaeta $s p$ to metabolize the acetate for methane production. Methanosarcin is capable of growing on substrates other than acetate such as hydrogen and predominates in environments with high acetate concentration and $\mathrm{pH}$ between 5.9 and 6.4. The I/S ratio of 0.75 presented a value of $4872 \mathrm{mg} \mathrm{H} \mathrm{Ac} \mathrm{L}^{-1}$ and $\mathrm{pH}$ of 6.86 .

It is also observed that short bacilli and rounded bacilli were also found (circles) indicating bacteria belonging to the order of Methanobacteriales, of which, according to Gerardi (2006), the two main genera are Methanobacterium and Methanobrevibacter. The presence of these groups of bacteria and arches demonstrates a diversified biomass suggesting a balance between the communities of acetotrophic (coconut and filamentous) and hydrogenotrophic (bacilli) methanogenic microorganisms. 


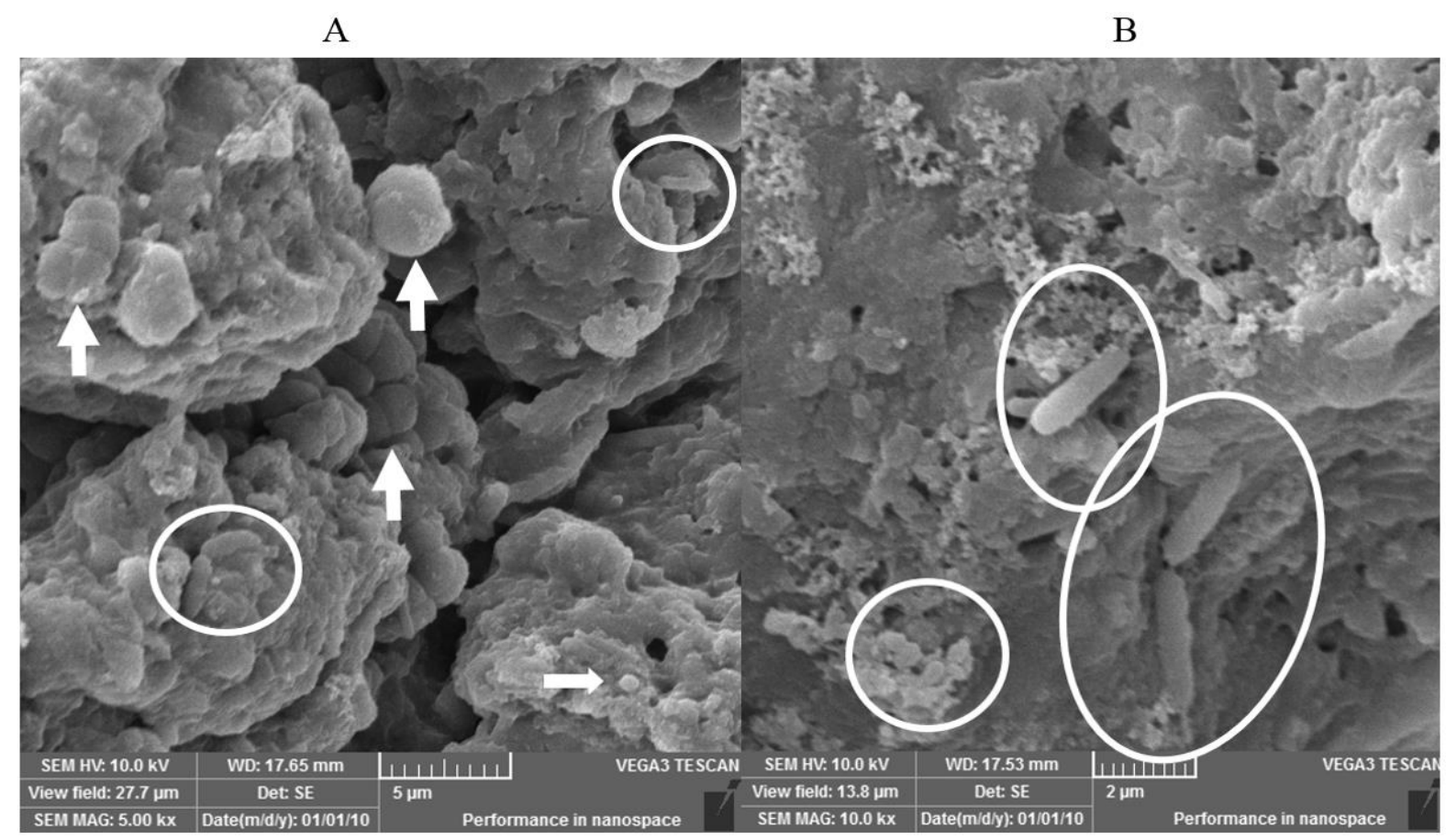

Figure 2. Sample micrograph of inoculum $\mathrm{I} / \mathrm{S}$ 0,75. (a) predominance of clustered cocci (Methanosarcines $s p$ ) and isolated cocci (arrows) besides short bacilli and bacilli with rounded ends (circles). (b) Long bacilli (ellipses) and short bacilli (circle).

\section{CONCLUSIONS}

The experimental results indicated that grape marc presents potential for biological treatment by anaerobic digestion, offering volumetric production of methane in 12 days, and showing the functionality of the BMP test in identifying the potential of grape marc establishing bases for its use as a substrate in the implementation of anaerobic biotechnologies.

The I/S 3.0 ratio obtained the best performance, providing the best performance of methane in relation to the added VS, methane and efficiency in the removal of COD, thus standing out as the most promising ratio for the loading of anaerobic digestion systems to the full-scale grape marc residue.

Microscopic analysis of the morphology of inoculum microorganisms showed microbial groups such as Methanosarcin sp. and bacilli with morphology of Methanobacteriales, even though this is the treatment with the lowest methane yield.

\section{REFERENCES}

AMORIM, S. M.; KATO, M. T.; FLORENCIO, L.; GAVAZZA, S. Influence of Redox Mediators and Electron Donors on the Anaerobic Removal of Color and Chemical Oxygen Demand from Textile Effluent. Clean, v. 41, n. 9, p. 928-933, 2013. https://doi.org/10.1002/clen.201200070

ANGELIDAKI, I.; ALVES, M.; BOLZONELLA, D.; BORZACCONI, L.; CAMPOS, J. L.; GUWY, A. J.; KALYUZHNYI, S.; JENICEK, P.; LIER, J. B. Defining the biomethane potential (BMP) of solid organic wastes and energy crops: a proposed protocol for batch assays. Water Science \& Technology, v. 59, n. 5, p. 927-934, 2009. https://doi.org/10.2166/wst.2009.040 
APHA; AWWA; WEF. Standard Methods for the examination of water and wastewater. 22nd ed. Washington, 2012. $1496 \mathrm{p}$.

ARAÚJO, J. C.; TÉRAN, F. C.; OLIVEIRA, R. A.; NOUR, E. A. A.; MONTENEGRO, A. P.; CAMPOS, J. R.; VAZOLLER, R. F. Comparison of hexamethyldisilazane and critical point drying treatments for SEM analysis of anaerobic biofilms and granular sludge. Journal of Electron Microscopy, v. 52, n. 4, p. 429-433, 2003. https://doi.org/10.1093/jmicro/52.4.429

AVACI, A. B.; SOUZA, S. N. M.; CHAVES, L. I.; NOGUEIRA, C. E. C.; NIEDZIALKOSKI, R. K.; SECCO, D. Avaliação econômico-financeira da microgeração de energia elétrica proveniente de biogás da suinocultura. Revista Brasileira de Engenharia Agrícola e Ambiental, v. 17, n. 4, p. 456-462, 2013. http://dx.doi.org/10.1590/S141543662013000400015

CHERNICHARO, C. A. L. Reatores anaeróbios: Princípios do Tratamento Biológico de Águas Residuárias. Belo Horizonte: DESA, UFMG, 2007. 380p.

CHRIST, K. L.; BURRIT, R. L. Critical environmental concerns in wine production: an integrative review. Journal of Cleaner Production, v. 53, p. 232-242, 2013. https://doi.org/10.1016/j.jclepro.2013.04.007

CÓRDOBA, V.; FERNÁNDEZ, M.; SANTALLA, E. The effect of substrate/inoculum ratio on the kinetics of methane production in swine wastewater anaerobic digestion. Environmental Science Pollution Research, v. 25, n. 22, p. 21308-21317, 2018. https://doi.org/10.1007/s11356-017-0039-6

DEVESA-REY, R.; VECINO, X.; VARELA-ALENDE, J. L.; BARRAL, M. T.; CRUZ, J. M.; MOLDES, A. B. Valorization of winery waste vs. the costs of not recycling. Waste $\begin{array}{lllllll}\text { Management, } & \text { v. } & 31, & \text { n. } & 11, & \text { p. } & 2327-2335,\end{array}$ https://doi.org/10.1016/j.wasman.2011.06.001

DUBA, K. S.; CASAZZA, A. A.; MOHAMED, H. B.; PEREGO, P.; FIORI, L. Extraction of polyphenols from grape skins and defatted grape seeds using subcritical water: Experiments and modeling. Food and Bioproducts.Processing, v. 94, p. 29-38, 2015. https://doi.org/10.1016/j.fbp.2015.01.001

FABBRI, A.; BONIFAZI, G.; SERRANTI, S. Micro-scale energy valorization of grape marcs in winery production plants. Waste Management, v. 36, p. 156-165, 2015. https://doi.org/10.1016/j.wasman.2014.11.022

FILER, J.; DING, H. H.; CHANG, S. Biochemical methane potential (BMP) assay method for anaerobic digestion research. Water, v. 11, n. 5, 2019. https://doi.org/10.3390/w11050921

GERARDI, M. H. Wastewater Bacteria. New Jersey: John Wiley \& Sons, 2006. 255 p.

GUERI, M. V. D.; SOUZA, S. N. M.; KUCZMAN, O.; SCHIRMER, W. N.; BURATTO, W. G.; RIBEIRO, C. B.; BESINELLA, G. B. Digestão anaeróbia de resíduos alimentares utilizando ensaios BMP (Anaerobic digestion of food waste using BMP assays). BIOFIX Scientific Jornal, v. 3, n. 1, p. 08-16, 2018. http://dx.doi.org/10.5380/biofix.v3i1.55831

HAIDER, M. R.; ZESHAN.; YOUSAF, S.; MALIK, R. N.; VISVANATHAN, C. Effect of mixing ratio of food waste and rice husk co-digestion and substrate to inoculum ratio on biogas production. Bioresource Technology, v. 190, p. 451-457, 2015. https://doi.org/10.1016/j.biortech.2015.02.105 
HOLLIGER, C.; ALVES, M.; ANDRADE, D.; ANGELIDAKI, I.; ASTALS, S.; BAIER, U.; BOUGRIER, C.; BUFFIERE, P.; CARBALLA, M.; WILDE, V.; EBERTSEDER, F.; FERNANDEZ, B.; FICARA, E.; FOTIDIS, I.; FRIGON, J. C.; LACLOS, H.F.; GHASIMI, D.S.M.; HACK, G.; HARTEL, M.; HEERENKLAGE, J.; HORVATH, I.S.; JENICEK, P.; KOCH, K.; KRAUTWALD, J.; LIZASOAIN, J.; LIU, J.; MOSBERGER, L.; NISTOR, M.; OECHSNER, H.; OLIVEIRA, J. V.; PATERSON, M.; PAUSS, A.; POMMIER, S.; PORQUEDDU, I.; RAPOSO, F.; RIBEIRO, T.; RUSCH, F.; STROMBERG, S.; TORRIJOS, M.; VAN EEKERT, M.; VAN LIER, J.; WEDWITSCHKA, H.; WIERINCK, I. Towards a standardization of biomethane potential tests. Water Science \& Technology, v. 74, n. 11, p. 1- 9, 2016. https://doi.org/10.2166/wst.2016.336

HOLLIGER, C.; LACLOS, H. F.; HACK, G. Methane production of full-scale anaerobic digestion plants calculated from substrates biomethane potentials compares well the one measured on-site. Frontiers in Energy Research, v. 5, p. 1-9, 2017. https://doi.org/10.3389/fenrg.2017.00012

LATIFI, P.; KARRABI, M.; DANESH, S. Anaerobic co-digestion of poultry slaughterhouse wastes with sewage sludge in batch-mode bioreactors (effect of inoculum-substrate ratio and total solids). Renewable and Sustainable Energy Reviews, v. 107, p. 288-296, 2019. https://doi.org/10.1016/j.rser.2019.03.015

LEITE, V. D.; SOUSA, J. T.; LOPES, W. S.; HENRIQUE, I. N.; BARROS, A. J. M. Bioestabilização anaeróbia de resíduos sólidos orgânicos: aspectos quantitativos. Revista Tecnológica, v. 18, n. 2, p. 90-96, 2014. http://dx.doi.org/10.17058/tecnolog.v18i2.4888

LI, Y.; LI, Y.; ZHANG, D.; LI, G.; LU, J.; LI, S. Solid state anaerobic co-digestion of tomato residues with dairy manure and corn stover for biogas production. Bioresource Technology, v. 217, p. 50-55, 2016. https://doi.org/10.1016/j.biortech.2016.01.111

LI, Y.; WANG, Y.; YU, Z.; LU, J.; LI, D.; WANG, G.; LI, Y.; WU, Y.; LI, S.; XU, F.; LI, G.; GONG, X. Effect of inoculum and substrate/inoculum ratio on the performance and methanogenic archaeal community structure in solid state anaerobic co-digestion of tomato residues with dairy manure and corn stover. Waste Management, v. 81, p. 117127, 2018. https://doi.org/10.1016/j.wasman.2018.09.042

MELLO, L. M. R. Panorama da produção de uvas no Brasil. Nota Técnica: Embrapa Uva e Vinho. Campo \& Negócio, p. 75 - 78, 2018

MOSET, V.; AL-ZOHAIRI, N.; MØLLER, H. B. The impact of inoculum source, inoculum to substrate ratio and sample preservation on methane potential from different substrates. Biomass and Bioenergy, v. 83, p. 474-482, 2015. https://doi.org/10.1016/j.biombioe.2015.10.018

PELLERA, F.; GIDARAKOS, E. Effect of substrate to inoculum ratio and inoculum type on the biochemical methane potential of solid agroindustrial waste. Journal of Environmental Chemical Engineering, v. 4, n. 3, p. 3217-3229, 2016. https://doi.org/10.1016/j.jece.2016.05.026

RAPOSO, F.; RUBIA, M. A.; FERNÁNDEZ-CEGRÍ, V.; BORJA, R. Anaerobic digestion of solid organic substrates in batch mode: an overview relating to methane yields and experimental procedures. Renewable and Sustainable Energy Reviews, v. 16, n. 1, p. 861-77, 2012. https://doi.org/10.1016/j.rser.2011.09.008 
ROS, C.; CAVINATO, C.; BOLZONELlA, D.; PAVAN, P. Renewable energy from thermophilic anaerobic digestion of winery residue: Preliminary evidence from batch and continuous lab-scale trials. Biomass and Bioenergy, v. 91, p. 150-159, 2016. https://doi.org/10.1016/j.biombioe.2016.05.017

ROUCHES, E.; ESCUDIÉ, R.; LATRILLE, E.; CARRÈRE, H. Solid-state anaerobic digestion of wheat straw: Impact of $\mathrm{S} / \mathrm{I}$ ratio and pilot-scale fungal pretreatment. Waste Management, v. 85, p. 464-476, 2019. https://doi.org/10.1016/j.wasman.2019.01.006

SILVA, C.; ASTALS, S.; PECES, M.; CAMPOS, J.L.; GUERRERO, L. Biochemical methane potential (BMP) tests: Reducing test time by early parameter estimation. Waste Management, v. 71, p. 19-24, 2018. https://doi.org/10.1016/j.wasman.2017.10.009

TALHA, Z.; DING, W.; MEHRYAR, E.; HASSAN, M.; BI, J. Alkaline Pretreatment of Sugarcane Bagasse and Filter Mud Codigested to Improve Biomethane Production. BioMed Research International, v. 2016, 2016. https://doi.org/10.1155/2016/8650597

VDI. Fermentation of organic materials-Characterisation of the substrate, sampling, collection of material data, fermentation tests. Germany, 2016. p. 92.

ZARKADAS, I.; DONTIS, G.; PILIDIS, G.; SARIGIANNIS, D. A. Exploring the potential of fur farming wastes and byproducts as substrates to anaerobic digestion process. $\begin{array}{llllll}\text { Renewable } & \text { Energy, } & \text { v. } & \text { 96, } & \text { p. }\end{array}$ https://doi.org/10.1016/j.renene.2016.03.056

ZHANG, N.; HOADLEY, A.; PATEL, J.; LIM, S.; LI, C. Sustainable options for the utilization of solid residues from wine production. Waste Management, v. 60, p. 173-183, 2017. https://doi.org/10.1016/j.wasman.2017.01.006

ZHU, J.; ZHENG, Y.; XU, F.; LI, Y. Solid-state anaerobic co-digestion of hay and soybean processing waste for biogas production. Bioresource Technology, v. 154, p. 240-247, 2014. https://doi.org/10.1016/j.biortech.2013.12.045 


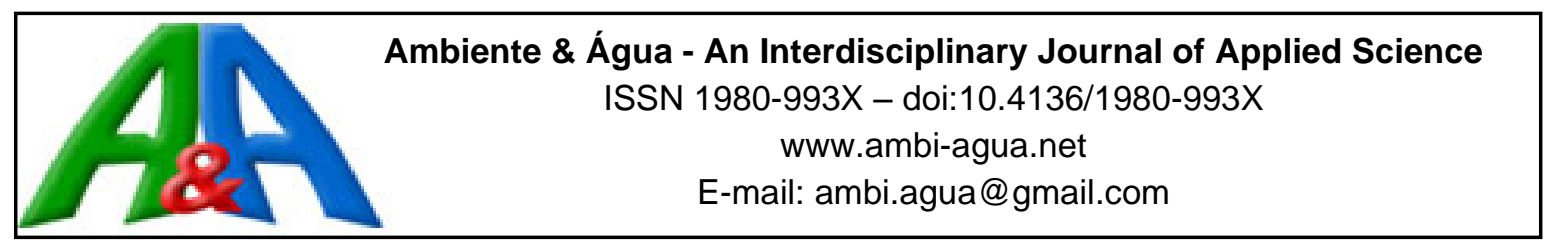

\title{
Technical and scientific aspects of dams in Brazil: a theoretical approach
}

\author{
ARTICLES doi:10.4136/ambi-agua.2552
}

Received: 30 Mar. 2020; Accepted: 07 Jul. 2020

\section{Admilson da Penha Pacheco ${ }^{1 *}$; Renato Filipe Faria Henriques ${ }^{2}$ 迆; Paulo Marcelo Vieira Ribeiro ${ }^{3}$ iD}

\footnotetext{
${ }^{1}$ Departamento de Engenharia Cartográfica e de Agrimensura. Centro de Tecnologia e Geociências. Universidade Federal de Pernambuco (UFPE), Rua Acadêmico Hélio Ramos, s/n, CEP: 50740-530, Recife, PE, Brazil.

${ }^{2}$ Departamento de Ciências da Terra. Universidade do Minho (UMinho), Campus de Gualtar, 4710-057, Braga, Portugal. E-mail: rhenriques@dct.uminho.pt

${ }^{3}$ Centro de Tecnologia e Geociências. Departamento de Engenharia Civil. Universidade Federal de Pernambuco (UFPE), Rua Acadêmico Hélio Ramos, s/n, CEP: 50740-530, Recife, PE, Brazil. E-mail: paulo.marcelo.1980@gmail.com *Corresponding author. E-mail: pacheco3p@gmail.com
}

\begin{abstract}
The safety of a dam is the result of a series of factors, including structural, geotechnical, hydraulic, operational and environmental aspects. In Brazil, Law No. 12.334 of September 2010 establishes the National Dam Safety Policy, which requires safety reports and monitoring inspections for existing dams. The inspection comprises a set of devices installed on the dam, which are used to assess the structural behavior based on performance parameters of the structure, such as displacements, flows, stresses, slopes and others. Dam auscultation procedures, historically, have been performed since the 1950s. Since then, there have been significant advances in instrumentation and dam auscultation methods. This work presents a theoretical approach on technical and scientific aspects of dams in Brazil, based on a state-ofthe-art literature review, involving auscultation of dams in the context of design codes, concepts, instrumentation, safety, procedures and monitoring methods.
\end{abstract}

Keywords: Auscultation, dams, instrumentation, safety.

\section{Aspectos técnico-científicos de barragens no Brasil: uma abordagem teórica}

\section{RESUMO}

A segurança de uma barragem é resultante de uma série de fatores, dentre os quais podem ser citados aspectos estruturais, geotécnicos, hidráulicos, operacionais e ambientais. No Brasil, a Lei $\mathrm{n}^{\circ} 12.334$ de setembro de 2010 estabelece a Política Nacional de Segurança de Barragens. A instrumentação compõe um conjunto de dispositivos instalados nas barragens, que são utilizados para avaliar o seu comportamento estrutural a partir de parâmetros de desempenho da estrutura, tais como deslocamentos, vazões, tensões, inclinações e outros. Procedimentos de auscultação de barragens, historicamente, tem sido realizado desde a década de 50, conforme a literatura. Desde então, houve avanços significativos na instrumentação e nos métodos de auscultação de barragens. Este trabalho tem como objetivo apresentar uma abordagem teórica 
sobre aspectos técnico-científicos de barragens no Brasil, fundamentada numa revisão de literatura no estado da arte, envolvendo auscultação de barragens no contexto de normas, conceitos, instrumentação, segurança, procedimentos e métodos de monitoramento.

Palavras-chave: auscultação, barragens, instrumentação, segurança.

\section{INTRODUCTION}

According to MSIB (Brasil, 2002), dams are built to raise the water level, holding back water and forming an upstream reservoir. These structures are built with earth, rock, concrete, or mixed structures, that aim to contain and control water flow to meet the diverse uses of humankind, such as irrigation, human consumption, electricity generation, among others.

Dam instrumentation is based on a set of devices installed on the monolith and adjacent structures, which are used to assess its behavior based on performance parameters, such as displacements, flows, stresses, inclinations and others.

MSIB (Brasil, 2002) comments that dams are undertakings with a high potential for risk and have significant consequences for the environment and that auscultation procedures are mandatory and essential to the dam, as they aim to correct and / or adapt processes involved in the construction, operation or maintenance of the dam. FERC (US, 2003) emphasizes that the auscultation processes of a dam are based on the observation, detection and characterization of eventual deteriorations that constitute a potential risk to the conditions of its global security.

Dam auscultation procedures, historically, have been performed since the 1950s. Since then, there have been significant advances in instrumentation and in dam auscultation methods. The literature presents important descriptions of several dam breaks in the world. These are accidents of different levels of severity, which were important to promote the scientific and technological development of current dam monitoring methods.

In Brazil, it is important to highlight Law No. 12.334 of September 2010, which establishes the National Dam Safety Policy (PNSB) for the accumulation of water for any use, in addition to creating the National Dam Safety Information System (Brasil, 2010).

The scientific community has carried out several studies and research in recent years in general, with the aim of improving the capacity and quality of dam monitoring. This is due to the availability of new technologies capable of integrating with traditional methods applied in monitoring, which involve different processes based on measurements obtained by geotechnical and geodetic sensors.

The technological advancement of sensor systems and the availability of online communication systems has currently allowed the generation of scientific research to improve the monitoring of dams, in real time, whether from the automation of geotechnical instrumentation supported by new sensors, or modern geodesic and geophysical monitoring systems.

In these circumstances, this work presents a theoretical approach on technical-scientific aspects of dam monitoring and safety in Brazil. The paper is based on a state-of-the-art literature review, involving auscultation of dams in the context of design codes, concepts, devices, security, monitoring procedures and methods.

\section{DAMS}

\subsection{General Aspects}

Article 2, Paragraph I of Brasilian Federal Law 12334/10 defines a dam as being "any structure in a permanent or temporary course of water for the purpose of containing or accumulating liquid substances or mixtures of liquids and solids, comprising the dam and 
associated structures" (Brasil, 2010).

The main types of dams are those built with concrete, called gravity dams, in arc or buttresses and embankment dams that are built from earth or a combination of earth and rocks (rockfill) (ICOLD; CIGB, 2007)

Dams, since the beginning of human evolution, have been fundamental to the development of humanity. According to CBDB (2011), dams were built using experimental procedures aimed at storing water.

According to Kutzner (1997), the oldest dams were built since the third millennium (BC) from soils and rocks, and were subsequently called "earth and rockfill dams". As Fahlbusch (2009) points out, the oldest known dams of humanity are those of Jawa (Jordan) and Sadd el Kafara, (Egypt), approximately 3000 BC and 2650 BC, respectively.

The book, "The History of Dams in Brazil - XIX, XX and XXI Centuries" (CBDB, 2011), discusses the history of the implementation of dams in Brazil and the International Commission for Large Dams (CIGB), which has been operating since the 1920s and its representation in Brazil. The emergence of the Brazilian Committee on Dams, founded in 1961, is highlighted. The book describes the history of the main electric energy concessionaires from the end of the 19 th century to the present day, the evolution of environmental and dam safety legislation beyond progress in implementing dams to contain mining waste (CBDB, 2011).

For Costa (2012), conventional dams are classified into: Earth Dams (homogeneous and zoned); Rockfill Dams (with impermeable core and with impermeable face); Concrete Dams (gravity, relieved gravity, buttress; rolled or compacted concrete and arc) and Mixed Dams (concrete and earth).

According to the Bureau of Reclamation (US, 1987), earth dams tend to remain the most prevalent type. The number of favorable locations for concrete structures is gradually decreasing. This is the result of the great development of water storage facilities.

\subsection{Dam Instrumentation and Safety}

According to Law 12.334, Article 4, Item I: "The Safety of a Dam" must be considered in its planning, design, construction, first filling, first pouring, operation, deactivation and futureuse phases" (Brasil, 2010). Law No. 12,334, in Art. 7, classifies dams by risk category, related damage and by their reservoir volume.

The safety of a dam is related to the event of a rupture, which can be caused by joint or separate events such as earthquakes, overtopping and internal erosion (piping).

USACE (1995) reports that inspections are mandatory operations on dams and should be carried out based on a preliminary analysis of the instrumentation conditions and the verification of local problems in the monitored area. Instrumentation can achieve these objectives by providing quantitative data to access useful information such as piezometric pressure, strain, total stress and water levels (USACE, 1995).

MISB (Brasil, 2002) comments on the need for preventive and corrective maintenance, directly associating them with structural safety, links predictive maintenance to monitoring and emphasizes emergency plans in order to reduce the remaining risks. Thus, it is essential to check the auscultation instrumentation based on visual and periodic inspections, combined with more detailed data analysis. These inspections must check piezometers, flow recorders, accelerometers, seismometers, joint gauges and pressure gauge points, strain gauges, clinometers, plumb lines, topographic landmarks, and level recorders (Brasil, 2002).

Risk is directly associated with danger and vulnerability. According to Metzger et al. (2006), the vulnerability can be considered as a response to risk.

MSIB (Brasil, 2002) presents a methodology based on mathematical and statistical models for the assessment of risk potential. In this study, dams are classified according to the safety aspects of their structures and risks to the downstream community. According to MSIB (Brasil, 
2002), the most accepted classification is based on the potential for loss of life and the damage (economic, social and environmental) associated with the rupture of the dam. As a result of rupture (very high, high and low), loss of life (significant, to some extent, and none) and economic, social and environmental damage (excessive, substantial, moderate or minimal) (Brasil, 2002).

Several accidents related to dam ruptures in the world have been documented by Brown et al. (2012), involving past situations, such as the dams of St. Francis and Teton, and current ones such as British dams, European tailings dams, Chinese dams and American dams (Rico et al., 2008).

Alves (2015) presents an important report of important dam accidents in the world and in Brazil, presenting damages and primary causes. Mariana in 2015, and Brumadinho in 2019, are examples of major recent dam accidents in Brazil, both in the state of Minas Gerais.

In Brazil, the number of dam ruptures is considerable, mainly in the State of Minas Gerais, where 7 mineral tailings dams have broken in the last 18 years: Information from Alves (2015) is give in Table 1 .

Table 1. Recent dam ruptures in the state of Minas Gerais, Brazil.

\begin{tabular}{cccl}
\hline Year & Dam & Location & Details \\
\hline 2001 & Macacos & Nova Lima & 5 deaths \\
2003 & Cataguases & Cataguases & $\begin{array}{l}\text { Contamination of the Paraíba do Sul River, death of animals } \\
\text { and fish and interruption of water supply to 600,000 people }\end{array}$ \\
2007 & Rio Pomba & Miraí & More than 4000 homeless or displaced people \\
2014 & Herculano & Itabirito & 3 deaths \\
2015 & $\begin{array}{c}\text { Fundão, } \\
\text { Santarém }\end{array}$ & Mariana & $\begin{array}{l}19 \text { deaths, } 8 \text { missing } 600 \text { homeless or displaced, interruption } \\
\text { of water supply to thousands of people and pollution of the } \\
\text { São Francisco River and the sea in Espírito Santo } \\
\text { 300 victims (identified and missing), immeasurable impacts } \\
\text { on historical and cultural heritage, the environment and the } \\
\text { local economy }\end{array}$ \\
\hline
\end{tabular}

Source: based on data from Alves (2015) and Almeida et al. (2019).

\section{AUSCULTATION OF DAMS}

The auscultation of a dam involves a set of monitoring procedures based on geotechnical, geodetic methods and instrumentation, aiming at the inspection, monitoring and verification of corrective measures of its safety conditions.

The dam literature presents the state of the art of dam auscultation, from the 1950's until the 21 st century, characterizing the technological evolution of instrumentation and monitoring procedures (USACE, 1995; 2004). It is important to highlight the modernization of instrumentation and auscultation methods, together with computing and automation of data acquisition, transmission, processing and analysis systems.

According to the Department of the Army (USACE, 1994), measurement and instrumentation techniques for the geometric monitoring of structural deformations are classified into two groups, described in Table 2. 
Table 2. Measure and instrumentation techniques.

\section{Measure and instrumentation techniques Description of equipment and sensors}

Geotechnical and structural measures of local deformations and displacements

Geodetic surveys
Pendulums, elongameter bases, triortogonal gauges, extensometers, inclinometers and other complementary instruments.

Land surveys, satellite positioning, photogrammetric and some special techniques (interferometry,

hydrostatic leveling and others).

Source: Department of the Army (USACE, 1994).

\subsection{Geotechnical Measurements}

Dunnicliff (1988) reports several aspects related to geotechnical auscultation, involving guidelines related to the safety of dams in the construction and operation phases, in order to provide alternatives aimed at improving the costs and effectiveness of geotechnical instrumentation programs. The use of instrumentation involves not just the selection of instruments, but a comprehensive engineering process that begins with the definition of the objective and ends with the implementation of the data (Dunnicliff, 1988).

Srivastava (2011) presents a general discussion of methods of geotechnical instrumentation for earth dams according to the USACE guidelines. Fell et al. (2014), in an important book for the area of dams, comprehensively addresses different categories of dams involving aspects of instrumentation and methods of Geotechnical Engineering for Dams.

Cruz (1996) describes general and specific aspects related to geotechnical instrumentation from the 1950s to the 1990s, where visual inspections predominated. More recent studies show the trend of automation of visual inspection in dams. Valença and Júlio (2018), for example, presented the MCrack-Dam method, which is based on image processing and is designed to automatically monitor cracks in dams. The method was tested under controlled laboratory conditions, later validated on site and applied in a pilot area of the Itaipu / Brazil dam. The results show the ability of the MCrack-Dam method to perform a comprehensive crack characterization in dams, not comparable to the traditional methods currently used (Valença and Júlio, 2017).

According to Nadia and Bouchrit (2017), many difficulties are registered to estimate the deformation modulus of landfills necessary for modeling. In this work, the authors carried out a parameterized analysis to estimate the settlement of an earth dam. This study led to the verification of the compatibility, for different values of deformation modulus, between the settlement of the dam by modelling and by monitoring in order to validate the mechanical behavior of the dam. Jia and Chi (2015) is another important reference in this theme.

Pires et al. (2019) carried out a study of structural reliability analysis in a concrete gravity dam. The work showed the importance of quantifying uncertainty, both in the design phase and in the constructed dam. The authors observed that structural reliability provides an objective assessment of the safety of the structure or its reliability, in addition to the probability of failure. The study corroborated previous results, illustrating the lack of proportionality between the safety factors, generally adopted in the project, and the assessed probabilities of failure (Pires et al., 2019). Hu and $\mathrm{Ma}$ (2018) is another important reference in this theme.

In recent years, several researchers have focused attention on the development of statistical models applied to dam monitoring (Li et al., 2013; Cheng and Zheng, 2013; Li et al., 2013; Stojanovic et al., 2016).

According to USACE (2004), automated data acquisition systems (ADAS - Automated Data Acquisition System) started at the end of the 20th century, providing the modernization of data transmission and processing. At the beginning of the 21 st century, the technological 
evolution of the geotechnical auscultation process was focused on the development of fiber optic instrumentation. Fiber-based technology has been used since the 1970s in several areas of data transmission. In the auscultation of dams, they began to be used in the monitoring of structures as an alternative to replace the traditional electronic sensors, helping to monitor parameters such as displacements, strains, temperatures, pressures, among others.

In the 1980s, a fully distributed detection technology called Brillouin Optical Time Domain Analysis (BOTDA) was proposed and developed to measure voltage and temperature (Pei et al., 2014). Pei et al. (2014) carried out an important review on the development and application of fiber optic sensors in geotechnical structures. Zeni et al. (2015) presented some experimental results of the BOTDA technology applied in geotechnical monitoring. The authors highlight the potential of these sensors applied in detecting early movements of soil slopes.

Distributed optical fiber (DOFS) sensors are important in structural and geotechnical engineering. Cheng-Yu et al. (2017) presented a comprehensive review of DOFS to monitor the performance of various geotechnical structures, including retaining walls, tunnels and landslides. The authors presented a comparative analysis of the typical advantages and limitations of different technologies for geotechnical monitoring.

Rittgers et al. (2014) presented the applicability of active and passive geophysical methods in order to monitor dams (Ijkdijk Experiment - Netherlands). The authors found that the integration of the spontaneous potential method with that of passive seismic enables identification and monitoring of hydromechanical disturbances in a dam. Planès et al. (2014), used passive seismic interferometry in the same dam, to detect temporal changes in the speed of seismic waves caused by internal erosion processes. Olivier et al. (2017), using similar seismic interferometry procedures, performed an experiment at the tailings dam in Tasmania (Australia). The results indicated that the passive seismic interferometry method can be used to monitor and locate small changes inside the tailings dam, making it a valuable tool for remotely monitoring the dam's structural stability over time (Olivier et al., 2017).

The study of the dynamic response of dams subjected to seismic actions appears expressively with the works of Chopra (1970), Chopra and Chakrabarti (1973), and Chopra (1978). These are motivated by the seismic event that took place in 1967 at the Koyna Dam (Satara, India), where the structure was damaged, despite having been designed under current seismic requirements. Until then, dams were evaluated using the Seismic Coefficient Method, which is based on the hypothesis of a rigid-mobile dam accelerated uniformly (by a fraction of the acceleration of the soil, or seismic coefficient) towards the reservoir, with a supposed incompressible fluid. In this case, the hydrodynamic pressures of the fluid-structure interaction are obtained according to the formulation proposed by Westergaard (1933), as recommended by USBR (1976).

Chopra (1978) effectively includes the elasticity of the structure and the interaction with the compressible fluid in the reservoir, defining the Pseudo-Dynamic Method, which is an extension of the Pseudo-Static Method. Additional contributions obtained by Chopra and his collaborators appear in the following years, such as Fenves and Chopra (1985), who investigated the effects of the foundation's flexibility and the absorption of waves at the bottom of the reservoir.

Studies related to local seismicity and the possible impact of these effects on structural analysis of dams are relatively recent in Brazil and became relevant with the publication of the first Brazilian code dedicated to the earthquake-resistant project in 2006 (NBR 15421, ABNT, 2006). The Seismic Coefficient Method (or Pseudo-Static Method) remains a frequent hypothesis in several dams designed in Brazil. In 2006, the national standard code NBR 15421 stimulated the interest of the Brazilian technical community (including dam engineers) by presenting prescriptions for the seismic design of structures, including analysis using the 
seismic response spectrum. This is the first and only Brazilian technical standard dedicated to this purpose.

In the following years, many publications were dedicated to the analysis of dams by more advanced methods than the Pseudo-Static Method, and possible repercussions on the structure of the dam. These appear in a majority form from the 2000s. The publications below indicate contributions in this sense, with emphasis on the last five years.

Nóbrega and Nóbrega (2016) address the importance of considering seismic actions in the analysis of civil structures, making an assessment of the seismic hazard map brought by NBR 15421, indicating procedures that must be taken for the proper design.

Duarte (2016) carried out seismic analyzes with several calculation methods in landfill dams (homogeneous and with material distributed by zones), without considering hydrodynamic effects. The author concludes that the stability of the dam is compromised in different scenarios, in different positions, being more critical for zoned dams.

Miranda (2017) presents discussions and applications of existing methods for seismic analysis of gravity dams, such as seismic coefficient, equivalent lateral force, and analysis by response spectrum. Routines were developed with MATLAB software and demonstrate results in line with those obtained in finite element models.

Silva Junior et al. (2017) carried out a case study for tensions produced by earthquakes in the "E" section of the Itaipu Dam. Applications of the Pseudo-Dynamic Method proposed by Chopra (1978) were conducted, and the evaluation of the quality of this approach concerning analyses with the response spectrum method in the ANSYS finite element program. The authors concluded that the Pseudo-Static Method produces satisfactory and conservative results.

Da Silveira (2018) carried out a two-dimensional study on finite elements of the damreservoir interaction applied to the Koyna Dam, according to the dimensions proposed by Chopra and Chakrabarti (1973). Finite element simulations reproduce the results of this pioneering study.

Løkke and Chopra (2018) present a direct approach to the non-linear analysis of the damreservoir-foundation system under earthquakes, with the consideration of semi-infinite domains. The authors discuss the benefits of this implementation over existing options with the use of commercial software.

The work of De Falco et al. (2018) indicates a recent example of how numerical strategies can be employed in the solution of multi-domain interaction with soil-structure aspects and the dissipation of waves in infinite media. According to Mendes (2018), several numerical models have been developed for the three-dimensional analysis of the dam-reservoir-foundation interaction, such as the developments by Løkke and Chopra (2018).

Additional investigations emerge in the work of Mendes (2018), which discusses the state of the art of seismic analysis of arch dams, involving several works by national and international researchers in the area, in addition to publications by researchers associated with research centers such as LNEC Portugal and Spain's CIMNE, and from US government agencies such as USACE and USBR. This author carried out detailed investigations with the Finite Element Method at progressive levels of analysis for the Morrow Point Dam (Colorado, USA).

These analyses advance to refined models with the inclusion of effects such as (i) the flexibility of the rock and elements of absorption of mechanical waves in the foundation and (ii) fluid-structure interaction with appropriate boundary conditions for radiation in infinite domains.

It is noticed that the problem is still relevant and of interest in the scientific community, mainly in the search for solutions capable of high computational efficiency and accuracy in three-dimensional numerical models. More recent work indicates some strategies developed by researchers in this direction.

Silva and Pedroso (2019) investigated the dissipative and conservative effects in the 
analysis of the dam-reservoir interaction with the hypothesis of an incompressible fluid. It is a theoretical study that allows detailed analysis of aspects such as the additional mass produced by the fluid and the influence of surface waves on the analytical solution of hydrodynamic pressures. Gao et al. (2019) performed the transient analysis of dam-reservoir interaction problems using asymptotic contours for simulating semi-infinite media with the finite element method. In this case, with immediate repercussions on the use of efficient boundary conditions for computer simulations, being able to reduce the size of the reservoir's discretization domain.

\subsection{Geodetic Measurements}

Geodetic methods enable monitoring of absolute displacements in structures using geospatial methods, with the use of instruments such as: Total Station, Digital Levels, Inclinometers, LASER System (overhead or terrestrial), GPS Receivers (Global Positioning System), Remote Sensors in UAVs (Unmanned Aerial Vehicles) and Aerial or Ground Laser Systems. According to Kahmen and Faig (1994), the determination of spatial coordinates of a point can be obtained by classical topographic methods such as polygonation, trilateration, triangulation and irradiation, geometric and trigonometric leveling or through positioning by artificial GNSS satellites (Global Navigation Satellite System).

The evolution of the automatic recognition of targets with robotic total stations, made the auscultation of structures more effective and widespread due to the automatic search of the monitored points. It is possible to use these sensors in continuous geodetic monitoring, mainly when listening to large structures.

According to Scaioni (2018), robotic total stations and GNSS (Global Satellite Navigation System) techniques, generally in an integrated manner, can provide efficient solutions for measuring 3D displacements in precise locations on the external surfaces of dams.

Global Navigation Satellite Systems (GNSS) receivers are nowadays commonly used in monitoring applications, e.g., in estimating crustal and infrastructure displacements. This is basically due to the recent improvements in GNSS instruments and methodologies that allow high-precision positioning, $24 \mathrm{~h}$ availability and semiautomatic data processing (Barzaghi et al., 2018).

Positioning by GNSS allows the obtaining of coordinates in a punctual manner on or near the Earth's surface, in relation to a pre-established geocentric geodetic framework (HofmannWellenhof et al., 2008). The term GNSS currently includes the American NAVSTAR-GPS (Navigation Satellite with Time and Ranging-Global Positioning System), the Russian GLONASS (Global Orbiting Navigation Satellite System), the European Galileo (European Satellite Navigation System), the Chinese BeiDou/ BDS / Compass (Compass Navigation Satellite System), the Indian IRNSS (Indian Regional Navigational Satellite System). GPS and GLONASS are the systems currently operational and the use of GALILEO is scheduled for mid 2020. GNSS technology is in constant process of modernization, such as the availability of the new NAVSTAR-GPS carrier, transmitting signals in three frequencies (L1 / L2 / L5).

Xiao et al. (2019) stated that the performance of the BeiDou space positioning system is comparable to GPS. Improvements in estimating high-precision geodetic networks, such as, for example, ITRF14 (International Land Reference Framework 2014), available from January 2017, provide improvements in accurate products such as orbits and satellites (Altamimi et al., 2016). The linking of these products associated with scientific "software" allows the estimation of spatial position with precision of millimeters. Monico (2008) and Hofmann-Wellenhof et al. (2008) approach in great detail the aspects of spatial positioning from GNSS data, involving description, fundamentals and applications.

Radhakrishnan (2014) evaluated the application of the GPS technique in monitoring the structural deformation of the Koyna Dam (India). The analysis of the results indicated a significant correlation between the pattern of deformation of the dam and the change in the

Rev. Ambient. Água vol. 15 n. 5, e2552 - Taubaté 2020 
water level in the reservoir (Radhakrishnan, 2014).

According to Liu et al. (2015), the accuracy of displacement monitoring for deformable objects with GPS is severely affected in highly occluded spaces, such as urban canyons and surface mines. These authors proposed an integrated GPS /Pseudolite positioning technique as an effective solution for accurate monitoring of deformation in obstructed areas. The Experimental Results showed that the proposed model can effectively eliminate the effect of multipath errors of the pseudolite in the parameter estimation, thus improving the positioning accuracy (Liu et al., 2015).

Caldera et al. (2016) analyzed the impact of low-cost hardware and software in the analysis of positioning data with GPS and GNSS receivers. According to these authors, using a low-cost GPS receiver and analyzing its data with free and open source software, movements of the order of a few millimeters can be detected. According to Xi et al. (2018), GPS technology has been widely applied to monitor displacements using direct measurements. In conventional forms of direct measurement, the displacement can achieve precision at the millimeter level: better than $1 \mathrm{~mm}$ horizontally and $2 \mathrm{~mm}$ in the vertical component (Xi et al., 2018).

Scaioni et al. (2018) performed a review of geodetic and remote sensing techniques applied in studies of dam deformation monitoring. The authors pointed out that geodetic measurements can provide horizontal / vertical displacements of the surface of control points located in key positions, while remote sensing techniques can generate a broader image of displacements over the entire structure and surroundings. Geotechnical / structural sensors can provide important information about those processes within the dam structure and foundations. This data / sensor integration can create added value and increase the data redundancy to be used for crossobservations (Scaioni et al., 2018).

Barzaghi et al. (2018) performed a comparative analysis of GNSS data time series and geotechnical observations of pendulums in a dam in Sardinia. The models were able to properly adjust the pendulum and GNSS data with a standard deviation of residues less than one millimeter. The authors found that the GNSS technique allowed a more dense description of spatial and temporal displacements of the dam, when compared with pendular observations. The monitoring configuration involving GNSS and pendulum measurements can be further improved if complementary terrestrial data from synthetic aperture radar (SAR) and observations from the total topographic station are used (Barzaghi et al., 2018). Yu et al. (2019) did an important job of revising GNSS technology applied to structural monitoring. In this context, below are listed other recent and important references: Kaloop et al. (2017); Pipitone et al. (2018); Konakoğlu and Gökalp (2018).

In Brazil, some dissertations and theses related to the application of GNSS in the monitoring of dams have been developed; however, the number of publications in journals with a high impact factor is not yet representative. Fazan (2010) and Muguio (2012) are important researches on this theme.

The use of digital mapping technologies based on aerial laser scanning technology (ALS) and terrestrial laser scanning (TLS) stand out as efficient alternatives in comparison with conventional three-dimensional methods of data acquisition for topography and cartography. Laser technology has been applied in several areas related to dams, such as flood risk assessment, structures, geomorphology, mining, seismology and land use and occupation.

Some important studies were carried out from ALS surveys to estimate the topography of dam rupture studies In general, there is a greater predominance of dam monitoring with a terrestrial laser scanner than with an aerial laser scanner. Alba et al. (2006), for example, used data from TLS, three-dimensional geometric models and finite elements in order to assess the structural behavior of a dam in Italy. The results of the study clearly showed that the use of the TLS technique can make an important contribution to the analysis of deformation of large dams, being useful for periodic monitoring, and not continuous, where current sensors are sufficient 
to control a small set of critical points (Alba et al., 2006).

The use of laser data in dam monitoring studies has been used as an integration tool with other technologies. Hu and Ma (2016), for example, used TLS in combination with GNSS to monitor three-dimensional changes in the surface between 2014 and 2015 on the permafrost slope at QTEC, which experienced two thawing periods and a freezing period.

Several later studies involving the TLS technology were carried out with the objective of evaluating deformations in structures, which can be observed in the international literature, such as in the works Lague et al. (2013), Hu and Ma (2016) and Benito-Calvo et al. (2018).

In Brazil, studies involving ALS and / or TLS technologies applied to dam monitoring are currently related to dissertations, theses, congresses and some publications in scientific journals.

Remote sensing techniques, such as terrestrial laser scanning, terrestrial SAR (synthetic aperture radar) and differential satellite interferometric SAR, offer the chance to extend the observed region to a large part of a structure and adjacent areas, integrate the information that is usually provided at a limited number of on-site control points (Scaioni et al., 2018).

The first generation of InSAR (Synthetic Aperture Interferometry Radar) technology applied in deformation measurements was known as DInSAR (Differential Interferometric Synthetic Aperture Radar). The DInSAR and PSI (Persistent Dispersion Interferometry) technologies allow detecting vertical displacements at the subcentimeter level (Fárová et al., 2019).

According to Zhou et al. (2016), the results of the InSAR technique allow the continuous investigation of dam deformation over a wide area, which includes the entire dam surface and the surrounding area, offering a clear image of the dam deformation continuously. Riccardi $e t$ al. (2017) performed an analysis of recent deformations in a dam, considering the SAR data from the C Sentinel-1 band. They found that this $20 \mathrm{~m}$ ground resolution data can provide millimeter accuracy of displacements.

Di Pasquale et al. (2018), for example, showed that radar interferometry can provide measurements of displacements of the surfaces of earth dams and vibration frequencies of their main concrete infrastructures.

Gama et al. (2019) carried out Remote Sensing studies in the Mariana / Brazil region after the rupture of the "Fundão" mining tailings dam in 2015. The authors used Advanced Differential Interferometry (A-DInSAR), SBAS (Small Baseline Subset) and PSI (Interferometry Persistent Scatterer) from TerraSAR-X and Pleiades images. The research demonstrated the potential of the SBAS and PSI techniques to monitor linear and non-linear deformations of the mining structures of the dam, presenting A-DInSAR results compatible with geodetic measurements in situ. A-DInSAR analysis, using satellite SAR coverage with short revision times, can be used to check for possible signs of stability in an area impacted by a major dam rupture, aiming at risk mitigation strategies (Gama et al., 2019).

Rotta et al. (2020) used satellite-driven soil moisture index, high spatial resolution multispectral images and InSAR products to assess pre-disaster scenarios and the direct causes of the tailings dam collapse in Brumadinho / MG / Brazil. The rapid rate of subsidence measured by the InSAR analysis (even after the lagoon drought) and the large-scale fall of the rupture collectively indicated that there was a liquid action process underway internally (Rotta et al., 2020). Reyes-Carmona et al. (2020) used the DInSAR technique to recognize and monitor landslides in the Rules Reservoir (Spain). The integration of the DInSAR results with a comprehensive geomorphological study made it possible to understand the typology, evolution and triggering factors of three active landslides (Reyes-Carmona et al., 2020).

Latrubesse et al. (2020) used a series of images from the Sentinel-1 Satellite (SAR), data from the SRTM Mission (Shuttle Radar Topography Mission) and daily rain measurements to assess the sudden violation of a saddle dike on July 23, 2018, at the perimeter the Xe Nammoy 
hydroelectric power reservoir (Mekong Basin, southern Laos). Among the various previous conclusions, the authors found that the failure of the dam does not appear to have been triggered by overlapping dams due to exceptionally heavy rains. Instead, the dam failed because the construction involved the improper use of permeable materials (Latrubesse et al., 2020).

The following are some recent works that complement the approach to technology (radar), applied in monitoring deformations in dams: Barra (2016); Gama et al. (2017); Ullo et al. (2019); and Solari et al. (2018).

According to Barbosa et al. (2019), it is possible to make inferences about the composition of water from the interaction between electromagnetic radiation and the optically active constituents (OACs) of water, such as suspended solids, photosynthetic pigments (chlorophyll) and colored dissolved organic matter. Several studies have been carried out in recent decades to monitor water quality by remote sensing. The Works of Khandelwal et al. (2017), Binding et al. (2018), and Fassoni-Andrade and De Paiva (2019) are recent representative references. In Brazil, there are several important studies carried out by the remote water sensing research group of the National Institute for Space Research (INPE), which are reported in the book by Barbosa et al. (2019).

\section{CONCLUSIONS}

The approach presented in this work gives technical and scientific context to the dam safety segment involving the state of the art of instrumentation, safety and monitoring methods.

Some companies focused on the dam security area, after the Mariana tragedy, and started using military technology to monitor dams. Remote Sensing Systems involving Orbital Satellites, Airborne Laser Systems, UAVs, Radar and Spatial Positioning through GNSS Receivers integrated with software for recording and analyzing data in real time are current examples of technologies employed in the current dam safety practice in Brazil. This characterizes efforts to ensure that extreme events can be identified in a timely manner and alert procedures can be initiated to ensure the safety of dams.

The technological advancement of sensors and software, combined with online communication, has allowed the generation of scientific research aimed at monitoring dams in real time, whether from the automation of geotechnical instrumentation or geodetic and geophysical monitoring systems. The integration and automation of these processes is the current modern trend of dam monitoring.

The new technologies and methods discussed in this study help in a more modern way the detection of structural damage and disasters with the rupture of dams, increasing operational and environmental safety. The environmental consequences resulting from structural damage and disasters with the rupture of dams generate immeasurable socioenvironmental impacts on the biotic and abiotic environment. The non-destructive technologies presented in this work for auscultation of dams, by electromagnetic radiation at a distance, allow less environmental interference.

The knowledge presented in this work, with theoretical information based on scientific and technological basis in current dam engineering practice, aims to enrich the studies of dam monitoring. It is hoped that the approach presented can add knowledge and motivate the generation of new technical-scientific publications in the area of dam safety in Brazil.

\section{ACKNOWLEDGEMENTS}

To the Institute of Earth Sciences at the University of Minho (Portugal / Pt) for the advanced post-doctoral internship carried out by the first author of this work. 


\section{REFERENCES}

ABNT. NBR 15421: Projeto de Estruturas Resistentes a Sismos - Procedimento. Rio de Janeiro, 2006.

ALBA, M. et al. Structural monitoring of a large dam by terrestrial laser scanning. International Archives of Photogrammetry. Remote Sensing and Spatial Information Science, v. 36, p. 1-6. 2006.

ALMEIDA I. M.; JACKSON FILHO, J. M.; VILELA R. A. G.; SILVA, A. J. N. Razões para investigar a dimensão organizacional nas origens da catástrofe industrial da Vale em Brumadinho, MG. Cadernos de Saúde Pública, v. 35, n. 4, p. 1-5, 2019. https://doi.org/10.1590/0102-311X00027319

ALTAMIMI, Z.; REBISCHUNG, P.; MÉTIVIER, L.; XAVIER, C. ITRF2014: A new release of the International Terrestrial Reference Frame modeling nonlinear station motions. Journal of Geophysical Research: Solid Earth, v. 121, p. 6100-6131, 2016.

ALVES H. R. O rompimento de barragens no Brasil e no mundo: desastres mistos ou tecnológicos? Belo Horizonte: Faculdade Dom Helder Câmara, 2015.

BARBOSA, C. C. F.; NOVO, E. M. L. M.; MARTINS, V. S. Introdução ao Sensoriamento Remoto de Sistemas Aquáticos: princípios e aplicações. 1. ed. São José dos Campos: LabISA/INPE, 2019. 160 p.

BARRA, A. et al. First insights on the potential of Sentinel-1 for landslides detection. Geomatics, Natural Hazards and Risk, v. 7, n. 6, p. 1874-1883, 2016. https://doi.org/10.1080/19475705.2016.1171258

BARZAGHI, R. et al. Estimating and Comparing Dam Deformation Using Classical and GNSS Techniques. Sensors, v. 18, p. 1-11. 2018. https://doi.org/10.3390/s18030756

BENITO-CALVO, A. et al. 4D Monitoring of Active Sinkholes with a Terrestrial Laser Scanner (TLS): A Case Study in the Evaporite Karst of the Ebro Valley, NE Spain. Remote Sensing. v. 10, p.1 -19, 2018. https://doi.org/10.3390/rs 10040571

BINDING, C. E.; GREENBERG, T. A.; MCCULLOUGH, G.; WATSON, S. B.; PAGE, E. An analysis of satellite-derived chlorophyll and algal bloom indices on Lake Winnipeg. Journal of Great Lakes Research, v. 44, n. 3, p. 436-446, 2018. https://doi.org/10.1016/j.jglr.2018.04.001

BRASIL. Ministério da Integração Nacional. Secretaria de Infra-Estrutura Hídrica. Manual de segurança e inspeção de barragens. Brasília, 2002. 148p.

BRASIL. Presidência da República. Lei nº 12.334, de 20 de setembro de 2010. Estabelece a Política Nacional de Segurança de Barragens destinadas à acumulação de água para quaisquer usos, à disposição final ou temporária de rejeitos e à acumulação de resíduos industriais, cria o Sistema Nacional de Informações sobre Segurança de Barragens e altera a redação do art. 35 da Lei no 9.433, de 8 de janeiro de 1997, e do art. 4o da Lei no 9.984, de 17 de julho de 2000. Diário Oficial [da] União: seção 1, Brasília, DF, 21 set. 2010.

BROWN, D. et al. Desastres mais devastadores de todos os tempos. 1. ed. São Paulo: Lafonte, 2012. 501p. 
CALDERA, S.; REALINI, E.; BARZAGHI, R.; REGUZZONI, M.; SANSO, F. Experimental study on low-cost satellite-based geodetic monitoring over short baselines. Journal of Surveying Engineering, v. 142, 2016. https://doi.org/10.1061/(ASCE)SU.19435428.0000168

COMITÊ BRASILEIRO DE BARRAGENS. A História das Barragens no Brasil nos Séculos XIX, XX e XXI: 50 Anos do Comitê Brasileiro de Barragens. Rio de Janeiro: Sindicato nacional dos editores de livros, 2011. 533p.

CHENG, L.; ZHENG, D. Two online dam safety monitoring models based on the process of extracting environmental effect. Advances in Engineering Software, v. 57, p. 48-56. 2013. https://doi.org/10.1016/j.advengsoft.2012.11.015

CHENG-YU, H. et al. Recent progress of using Brillouin distributed fiber optic sensors for geotechnical health monitoring. Sensors and Actuators A: Physical, v. 258, p. 131-145, 2017. https://doi.org/10.1016/j.sna.2017.03.017

CHOPRA, A. K. Earthquake resistant design of concrete gravity dams. Journal of the Structural Division, v. 104, n. 6, p. 953-971, 1978.

CHOPRA, A. K. Earthquake Response of Concrete Gravity Dams. Berkeley: Earthquake Engineering Research Center, University of California, 1970.

CHOPRA A. K.; CHAKRABARTI, P. The Koyna earthquake and damage to Koyna Dam. Bulletin of the Seismological Society of America, v. 63, n. 2, p. 381-3977, 1973.

COSTA, W. D. Geologia de Barragens. São Paulo: Oficina de Textos, 2012. 352 p.

CRUZ, P. T. da. 100 Barragens Brasileiras: Casos Históricos, Materiais de Construção, Projeto. São Paulo: Oficina de Textos, 1996. 648p.

DA SILVEIRA, I. V. Estudo da influência da crosta local no comportamento sísmico do sistema barragem gravidade-reservatório-fundação. 2018. 148f. Dissertação (Mestrado em Estruturas e Construção Civil) - Faculdade de Tecnologia, Universidade de Brasília, Brasília, 2018.

DE FALCO, A.; MORI, M.; SEVIERI, G. Simplified soil-structure interaction models for concrete gravity dams. In: EUROPEAN CONFERENCE ON COMPUTATIONAL FLUID DYNAMICS, 7., 11a 15 June 2018, Glasgow, UK. Proceedings[...] Barcelona: ECCOMAS, 2018.

DI PASQUALE, A. et al. Monitoring Strategies of Earth Dams by Ground-Based Radar Interferometry: How to Extract Useful Information for Seismic Risk Assessment. Sensors, v. 18, p. 1-25, 2018. https://doi.org/10.3390/s18010244

DUARTE, S. C. H. Estudo comparativo de diferentes abordagens na análise sísmica de barragens de aterro. 2016. 60f. Dissertação (Mestrado em Engenharia Civil) Faculdade de Ciências e Tecnologia, Universidade Nova de Lisboa, Lisboa, 2016.

DUNNICLIFF, J. Geotechinical Instrumentation for Monitoring Field Performance. Wiley, 1988. 577p.

FAHLBUSCH, H. Early dams. Proceedings of the Institution of Civil Engineers Engineering History and Heritage, v. 162, n. 1, p. 13-18, 2009. 
FÁROVÁ, K.; JELÉNEK, J; KOPACKOVÁ-STRNADOVÁ, V.; KYCL, P. Comparing DInSAR and PSI Techniques Employed to Sentinel-1 Data to Monitor Highway Stability: A Case Study of a Massive Dobkovicky Landslide, Czech Republic. Remote Sensing, v. 11, p. 1-23, 2019. https://doi.org/10.3390/rs11222670

FAZAN, J. A. Aplicação do teste de congruência global e análise geométrica para detecção de deslocamentos em redes geodésicas: Estudo de caso na UHE de Itaipu. 2010. $248 \mathrm{f}$. Dissertação (Mestrado) - Escola Politécnica, Universidade de São Paulo), São Paulo, 2010.

FASSONI-ANDRADE, A. C.; DE PAIVA, R. C. D. Mapping spatial-temporal sediment dynamics of river-floodplains in the Amazon. Remote sensing of environment, v. 221, 94-107, 2019. https://doi.org/10.1016/j.rse.2018.10.038

FELL, R.; STAPLEDON, D.; BELL, G; FOSTER, M. Geotechnical Engineering of Dams. 2. ed. Boca Raton: CRC Press, 2014. 1348p.

FENVES, G. F.; CHOPRA, A. K. Effects of Reservoir Bottom Absorption and Dam-WaterFoundation Rock Interaction on Frequency Response Functions for Concrete Gravity Dams. Earthquake Engineering and Structural Dynamics, v. 13, p. 13-31, 1985. https://doi.org/10.1002/eqe.4290130104

GAO, Y.; JIN, F.; XU, Y. Transient Analysis of Dam-Reservoir Interaction Using a High-Order Doubly Asymptotic Open Boundary. Journal of Engineering Mechanics, v. 145, n. 1, 2019. https://doi.org/10.1061/(ASCE)EM.1943-7889.0001553

GAMA, F. F.; CANTONE, A.; MURA, J. C.; PASQUALI, P.; PARADELLA, W. R.; DOS SANTOS, A. R.; SILVA, G. G. Monitoring subsidence of open pit iron mines at Carajás Province based on SBAS interferometric technique using TerraSAR-X data. Remote Sensing Applications: Society and Environment, v. 8, p. 199-211, 2017. https://doi.org/10.1016/j.rsase.2017.09.001

GAMA, F. F.; PARADELLA, W. R.; MURA, J. C.; OLIVEIRA, C. G. Advanced DINSAR analysis on dam stability monitoring: A case study in the Germano mining complex (Mariana, Brazil) with SBAS and PSI techniques. Remote Sensing Applications: $\begin{array}{lllllll}\text { Society and Environment, v. 16, p. } & 1-13, & \end{array}$ https://doi.org/10.1016/j.rsase.2019.100267

HOFMANN-WELLENHOF, B.; LICHTENEGGER, H.; WASLE, E. GNSS - Global Navigation Satellite Systems: Gps, Glonass, Galileo \& more. New York: SpringerVerlag, 2008. 516 p.

HU, J.; MA, F. Comprehensive Investigation Method for Sudden Increases of Uplift Pressures beneath Gravity Dams: Case Study. Journal of Performance of Constructed Facilities, v. 30, n. 5, 2016. https://doi.org/10.1061/(ASCE)CF.1943-5509.0000874

ICOLD; CIGB. Dams \& The World's Water - An educational book that explains how dams help to manage the world's water. Paris, 2007. 64p.

JIA, Y.; CHI, S. Back-analysis of soil parameters of the Malutang II concrete face rockfill dam using parallel mutation particle swarm optimization. Computers and Geotechnics, v. 65, p. 87-96, 2015. https://doi.org/10.1016/j.compgeo.2014.11.013

KAHMEN, H.; FAIG, W. Surveying. Berlin: Walter de Gruyter, 1994. 578 p. 
KALOOP, M. R.; ELBELTAGI, E.; HU, J. W., ELREFAI, A. Recent advances of structures monitoring and evaluation using GPS-time series monitoring systems: a review. ISPRS $\begin{array}{lllllll}\text { International Journal of Geo-Information, } & \text { v. } & 6, & \text { n. } & 12,\end{array}$ https://doi.org/10.3390/ijgi6120382

KHANDELWAL, A. et al. An approach for global monitoring of surface water extent variations in reservoirs using MODIS data. Remote sensing of Environment, v. 202, p. 113-128, 2017. https://doi.org/10.1016/j.rse.2017.05.039

KONAKOĞLU, B.; GÖKALP, E. Deformation Measurements and Analysis with Robust Methods A Case Study Deriner Dam. Turkish Journal of Science \& Technology, v. 13, n. 1, p. 99-103, 2018.

KUTZNER, C. Earth and rockfill dams: principles of design and construction. Rotterdam: A. A. Balkema, 1997. 333 p.

LAGUE, D.; BRODU, N.; LEROUX, J. Accurate 3D comparison of complex topography with terrestrial laser scanner: Application to the Rangitikei canyon (N-Z). ISPRS Journal of Photogrammetry and Remote Sensing, v. 82, p. 10-26, 2013. https://doi.org/10.1016/j.isprsjprs.2013.04.009

LATRUBESSE, E. M. et al. Dam failure and a catastrophic flood in the Mekong basin (Bolaven Plateau), southern Laos. Geomorphology, v. 362, p. 1-16, 2020. https://doi.org/10.1016/j.geomorph.2020.107221

LI, F. et al. Towards an Error Correction Model for dam monitoring data analysis based on Cointegration Theory. Structural Safety, v. 43, p.12-20, 2013. https://doi.org/10.1016/j.strusafe.2013.02.005

LIU, C.; GAO, J.; ZHAO, X.; ZHANG, A.; YU, X. Simulation and experiment analysis of dynamic deformation monitoring with the integrated GPS/pseudolite system. Journal of Geophysics and Engineering. v. 12, p. 45-56, 2015. https://doi.org/10.1088/1742$2132 / 12 / 1 / 45$

LØKKE, A.; CHOPRA, A. K. Direct finite element method for nonlinear analysis of semiunbounded dam-water-foundation rock systems. Earthquake Engineering \& $\begin{array}{llllllll}\text { Structural Dynamics, } & \text { v. 46, n. } & \text { 8, p. } & \text { 1267-1285, }\end{array}$ https://dx.doi.org/10.1002/eqe.2855

MENDES, N. B. Um estudo de propagação de ondas e aplicação do sismo na análise dinâmica acoplada a barragem em arco - reservatório - fundação. 2018. 289 f. Tese (Doutorado em Estruturas e Construção Civil) - Universidade de Brasília, Brasília, 2018.

METZGER, M. J.; ROUNSEVELL, M. D. A; ACOSTA-MICHLIK, L.; LEEMANS, R.; SCHOTER. D. The vulnerability of ecosystem services to land use change. Agriculture,

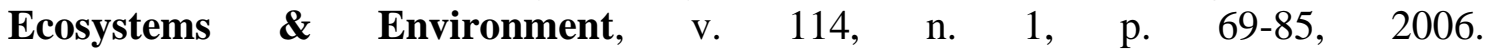
https://doi.org/10.1016/j.agee.2005.11.025

MIRANDA, R. J. G. Análise do comportamento sísmico de uma barragem gravidade tipo. 2017. 98f. Dissertação de Mestrado (Engenharia Civil) - Instituto Superior de Engenharia de Lisboa, Lisboa, 2017.

MONICO, J. F. G. Posicionamento pelo GNSS: descrição, fundamentos e aplicações. São Paulo: Editora Unesp, 2008. 477 p. 
MUGUIO, M. R. Implantação e análise da estação GNSS para o monitoramento contínuo da barragem da Usina Hidrelétrica de Mauá. 2012. 155f. (Dissertação de Mestrado em Ciências Geodésicas) - Universidade Federal do Paraná, Curitiba, 2012.

NADIA, S.; BOUCHRIT, R. Influence of deformation moduli on the settlement of earth dams. International Journal of Geomate, v. 13, n. 38, p.16-22, 2017. http://dx.doi.org/10.21660/2017.38.64964

NÓBREGA. P. G. B.; NÓBREGA, S. H. S. Perigo Sísmico no Brasil e a Responsabilidade da Engenharia de Estruturas. Holos, v. 4, p. 162-175, 2016. https://doi.org/10.15628/holos.2016.4703

OLIVIER, G.; BRENGUIER, F.; WIT, T.; LYNCH, R. Monitoring the stability of tailings dam walls with ambient seismic noise. Society of Exploration Geophysicist. The Leading Edge, v. 36, n. 4, p. 72-77, 2017. https://doi.org/10.1190/tle36040350a1.1

PEI, H.-F.; TENG, J.; YIN, J. H.; CHEN, R. A review of previous studies on the applications of optical fiber sensors in geotechnical health monitoring. Measurement, v. 58, p. 207214, 2014. https://doi.org/10.1016/j.measurement.2014.08.013

PIPITONE, C. et al. Monitoring water surface and level of a reservoir using different remote sensing approaches and comparison with dam displacements evaluated via GNSS. Remote Sensing, v. 10, n. 1, p. 71, 2018. https://doi.org/10.3390/rs10010071

PIRES, K. O.; FUTAI, M. M.; BITTENCOURT, T. N.; BECK, A. T. Reliability analysis of built concrete dam. IBRACON Structures and Materials Journal, v. 12, n. 3, p. 551 579, 2019. https://doi.org/10.1590/s1983-41952019000300007

PlAnÈ, T.; MOONEY, M. A.; RITTGERS, J. B. R.; PAREKH, M. L.; BEHM, M. SNIEDER, R. Time-lapse monitoring of internal erosion in earthen dams and levees using ambient seismic noise. Géotechnique, v. 66, n. 4, p. 301-312, 2014. https://doi.org/10.1680/jgeot.14.P.268

RADHAKRISHNAN, N. Application of GPS in structural deformation monitoring: A case study on Koyna dam. Journal of Geomatics, v. 8, n. 1, p. 48-54. 2014.

REYES-CARMONA, C. et al. Sentinel-1 DInSAR for Monitoring Active Landslides in Critical Infrastructures: The Case of the Rules Reservoir (Southern Spain). Remote Sensing, v. 12, n. 5, p. 1-13, 2020. https://doi.org/10.3390/rs12050809

RICCARDI, P.; TESSARI, G.; LECCI, D.; FLORIS, M.; PASQUALI, P. Use of Sentinel-1 SAR data to monitor Mosul dam vulnerability. 19th EGU General Assembly. In: EGU GENERAL ASSEMBLY, 19., 23-28 April, 2017, Vienna. Proceedings [...] Munich, 2017.

RICO, M.; BENITO, G.; SAlGUEIRO, A. R.; DÍEZ-HERRERO, A.; PEREIRA, H. G. Reported tailings dam failures: a review of the European incidents in the worldwide context. Journal of Hazardous Materials, v. 152, p. 846-852, 2008. https://doi.org/10.1016/j.jhazmat.2007.07.050

RITTGERS, J. B.; REVIL, A.; PLANES, T.; MOONEY, M. A.; KOELEWIJN, A. R. 4-D imaging of seepage in earthen embankments with time-lapse inversion of self-potential data constrained by acoustic emissions localization. Geophysical Journal International, v. 200, n. 2, p. 758-772, 2014. https://doi.org/10.1093/gji/ggu432 
ROTTA, L. H. S. et al. The 2019 Brumadinho tailings dam collapse: Possible cause and impacts of the worst human and environmental disaster in Brazil. International Journal of Applied Earth Observation and Geoinformation, v. 90, n. 100267, p 1-12, 2020. https://doi.org/10.1016/j.jag.2020.102119

SCAIONI et al. Geodetic and Remote-Sensing Sensors for Dam Deformation Monitoring. Sensors, v. 18, p. 1-25, 2018. https://doi.org/10.3390/s18113682

SILVA JUNIOR, E. J.; ARACAYO, L. A. S.; COELHO, D. P. Comparação entre o método pseudo-dinâmico e o método espectro de resposta aplicado como análise sísmica em uma barragem tipo: estudo de caso Itaipu. In: IBERIAN LATIN-AMERICAN CONGRESS ON COMPUTATIONAL METHODS IN ENGINEERING, 38., 2017, Florianópolis. Proceedings[...] Belo Horizonte: ABMEC, 2017.

SILVA, S. F.; PEDROSO, L. J. Interaction dam-reservoir: study of conservative and dissipative effects. Ibracon Structures and Materials Journal, v. 12, n. 4, p. 858-873, 2019. https://doi.org/10.1590/s1983-41952019000400008

SOLARI, L. et al. Satellite radar data for back-analyzing a landslide event: the Ponzano (Central Italy) case study. Landslides, v. 15, p. 773-782, 2018. https://doi.org/10.1007/s10346-018-0952-x

SRIVASTAVA, A. Geotechnical instrumentation, monitoring and surveillance in earth dam safety programme. In: INDIAN GEOTECHNICAL CONFERENCE, 15-17 Dec., 2011, Kochi. Proceedings[...] Available at: shorturl.at/gjmK8. Access: Aug. 2020. (Paper No. G-007).

STOJANOVIC, B. et al. A self-tuning system for dam behavior modeling based on evolving artificial neural networks. Advances in Engineering Software, v. 97, p. 85-95, 2016. https://doi.org/10.1016/j.advengsoft.2016.02.010

ULLO, S. L. et al. Application of DInSAR Technique to High Coherence Sentinel-1 Images for Dam Monitoring and Result Validation Through In Situ Measurements. IEEE Journal of Selected Topics in Applied Earth Observations and Remote Sensing, v. 12, n. 3, p. 875-890, 2019. https://doi.org/10.1109/JSTARS.2019.2896989

UNITED STATES. Bureau of Reclamation. Design of Gravity Dams. Denver, 1976.

UNITED STATES. Bureau of Reclamation. Design of Small Dams. 3. ed. Denver, 1987. 860p.

UNITED STATES. Army. Corps of Engineers. General Design and Construction for Earth and Rock-Fill Dams: in 1110-2-2300. Washington, D.C., 2004.

UNITED STATES. Army. Corps of Engineers. Instrumentation of Embankment Dams and Levees: Manual No. 1110-2-1908. Washington, DC., 1995. 75 p.

UNITED STATES. Army. Corps of Engineers. Manual 1110-1-1004 Deformation Monitoring and Control Surveying. Washington, DC., 1994.

UNITED STATES. Federal Energy Regulatory Commission. Engineering Guidelines for the Evaluation of Hydropower Projects. Chapter IX - Instrumentation and Monitoring. Washington, DC., 2003.

VALENÇA, J.; JÚLIO, E. MCrack-Dam: the scale-up of a method to assess cracks on concrete dams by image processing. The case study of Itaipu Dam, at the Brazil-Paraguay border. Journal of Civil Structural Health Monitoring, v. 8, n. 3, p. 857-866, 2018. https://doi.org/10.1007/s13349-018-0309-0 
WESTERGAARD, H. M. Water pressures on dams during earthquakes. Transactions of the American Society of Civil Engineers, v. 98, p. 418-433, 1993.

XIAO, R. et al. Deformation Monitoring of Reservoir Dams Using GNSS: Application to SNWD Project, China. IEEE ACCESS, v. 7, p. 54981-54992, 2019. https://doi.org/10.1109/ACCESS.2019.2912143

$\mathrm{Xi}, \mathrm{R}$. et al. Simultaneous estimation of dam displacements and reservoir level variation from GPS measurements. Measurement, v. 122, p. 247-256, 2018. https://doi.org/10.1016/j.measurement.2018.03.036

YU, J. et al. Global Navigation Satellite System-based positioning technology for structural health monitoring: a review. Structural Control and Health Monitoring, v. 27, n. 1, p. 3-27. 2019. https://doi.org/10.1002/stc. 2467

ZENI, L. et al. Brillouin optical time-domain analysis for geotechnical monitoring. Journal of Rock Mechanics and Geotechnical Engineering, v. 7, n. 4, p. 458-462, 2015. https://doi.org/10.1016/j.jrmge.2015.01.008

ZHOU, W.; LI, S.; ZHOU, Z.; CHANG, X. Remote Sensing of Deformation of a High Concrete-Faced Rockfill Dam Using InSAR: A Study of the Shuibuya Dam, China. Remote Sensing, v. 8, n. 255, p. 1-15, 2016. https://doi.org/10.3390/rs8030255 


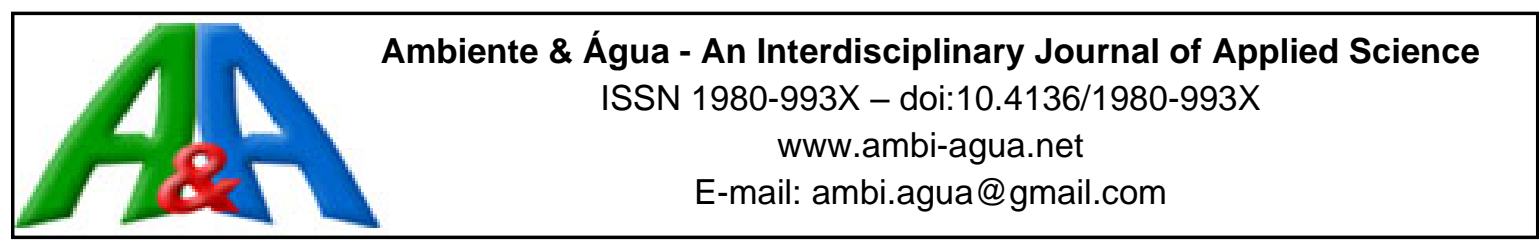

\title{
DOF/DAF comparison for the treatment of milk industry wastewater
}

\author{
ARTICLES doi:10.4136/ambi-agua.2553
}

Received: 30 Mar. 2020; Accepted: 07 Jul. 2020

\section{Magno dos Santos Pereira ${ }^{(D}$; Alisson Carraro Borges* ${ }^{*}$; Gustavo Lopes Muniz ${ }^{\circledR}$; Fernanda Fernandes Heleno $D^{D}$, Lêda Rita D'Antonino Faroni $i$}

\author{
Departamento de Engenharia Agrícola. Universidade Federal de Viçosa (UFV), Avenida PH Rolfs, s/n, \\ CEP: 36570-900, Viçosa, MG, Brazil. E-mail: magno.pereira@ufv.br, gustavolopesmuniz@yahoo.com.br, \\ fernanda.heleno@ufv.br, lfaroni@ufv.br \\ *Corresponding author. E-mail: borges@ufv.br
}

\begin{abstract}
The objective of this study was to evaluate the efficiency of dissolved ozone flotation (DOF) in comparison to dissolved air flotation (DAF) for treatment of milk industry wastewater (MW). In the first phase of the experiment, a synthetic milk wastewater (SMW) was used to evaluate DOF and DAF, with and without addition of hydrogen peroxide, at $\mathrm{pH} 4.0$ and $\mathrm{pH}$ 11.4. In the DOF tests, the concentration of ozone was equal to $19( \pm 0.5) \mathrm{mg} \mathrm{L}^{-1}$ and in the tests with addition of hydrogen peroxide, the $\mathrm{H}_{2} \mathrm{O}_{2} / \mathrm{O}_{3}$ ratios tested were $0.5,1.0$ and 1.5. In the second phase, tests were performed using three MW from three different industries to validate the results obtained and to determine the DOF system's ability to treat this type of effluent. The parameters tested during validation were turbidity, total suspended solids, oils and greases $(\mathrm{O} \& \mathrm{G})$, chemical oxygen demand (COD), biochemical oxygen demand (BOD), total nitrogen (TN) and total phosphorus (TP). It was observed that the efficiency of the treatments was better at $\mathrm{pH}$ 4.0. The results showed a reduction of the efficiency with the use of DOF. The addition of $\mathrm{H}_{2} \mathrm{O}_{2}$ in DAF and DOF also resulted in reduced system efficiency. The results obtained with SMW only approximated those obtained with the MW from one of the industries that contained the largest traces of milk and cheese.
\end{abstract}

Keywords: advanced oxidation process, dairy wastewater, dissolved ozone flotation.

\section{Comparação entre FAD e FAOD para o tratamento da água residuária de laticínios}

\section{RESUMO}

O objetivo deste estudo foi avaliar a eficiência da flotação por ar e ozônio dissolvido (FAOD) em comparação à flotação por ar dissolvido (FAD) no tratamento da água residuária de laticínios (ARL). Na primeira fase do experimento foi utilizada água residuária de laticínios sintética (ARLS) para avaliar a FAD e a FAOD, com e sem a adição de peróxido de hidrogênio em dois valores de $\mathrm{pH}, 4,0$ e 11,4. Nos testes de FAOD, a concentração de ozônio utilizada no ar foi igual a $19( \pm 0,5) \mathrm{mg} \mathrm{L}^{-1}$ e nos testes com adição de peróxido de hidrogênio, as relações $\mathrm{H}_{2} \mathrm{O}_{2} / \mathrm{O}_{3}$ testadas foram de $0,5,1,0$ e 1,5 . Na segunda parte do experimento, foram realizados testes com três ARL de três diferentes laticínios para validar os resultados obtidos e determinar a capacidade do sistema FAOD para tratar esse tipo de efluente. Os parâmetros testados durante a validação foram: turbidez, sólidos totais suspensos, óleos e graxas (O\&G), demanda química 
de oxigênio (DQO), demanda bioquímica de oxigênio (DBO), nitrogênio total $\left(\mathrm{N}_{\mathrm{T}}\right)$ e fósforo total $\left(\mathrm{P}_{\mathrm{T}}\right)$. Ao final do experimento, observou-se que a eficiência dos tratamentos foi melhor em pH 4. Os resultados mostraram uma redução da eficiência com o uso da FAOD. A adição de $\mathrm{H}_{2} \mathrm{O}_{2}$ na FAD e FAOD também resultou em menor eficiência nos dois sistemas. Os resultados obtidos com ARLS aproximaram-se apenas dos obtidos com o ARL de uma das indústrias que continham os maiores traços de leite e queijo.

Palavras-chave: efluentes de laticínios, flotação por ozônio dissolvido, processos oxidativos avançados.

\section{INTRODUCTION}

The traditional biological treatment systems present unsatisfactory results when applied to the degradation of effluents that have a high amount of bio refractory compounds (such as effluents from agri-food industries) and the development of chemical oxidation strategies becomes necessary (Martins and Quinta-Ferreira, 2014).

Ozone is a powerful oxidizing compound $\left(\mathrm{E}^{\mathrm{o}}=2.07 \mathrm{~V}\right)$ capable of reacting with various chemical species under normal conditions of pressure and temperature.

In simple ozonation (without catalyst), ozone has a double action on the pollutants according to the $\mathrm{pH}$ of the medium. At low $\mathrm{pH}$ values $(\mathrm{pH} \leq 4)$, ozone reacts directly and selectively with compounds that have sites of high electron density such as chromophoric groups and with unsaturated bonds. For alkaline conditions $(\mathrm{pH}>10)$, hydroxide ions promote the molecular decomposition of ozone into hydroxyl radicals capable of decomposing a broader range of organic pollutants (free radical pathways). For $\mathrm{pH}$ around 7, both reaction pathways are present. Thus, there were different ways in which ozone can react with polluting organic compounds. The decomposition of ozone in water can also be caused by UV radiation and hydrogen peroxide (Mahmoud and Freire, 2007; Martins and Quinta-Ferreira, 2014; Shokri, 2015; Shokri et al., 2015).

The homogeneous combination between ozone $\left(\mathrm{O}_{3}\right)$ and hydrogen peroxide $\left(\mathrm{H}_{2} \mathrm{O}_{2}\right)$ is considered a promising alternative in the removal of organic compounds from effluents. The conjugated base of hydrogen peroxide, in low concentrations, can initiate the decomposition of ozone much more rapidly, generating $\mathrm{OH}^{\bullet}$, than the hydroxide ion $\left(\mathrm{OH}^{-}\right)(\mathrm{Catalkaya}$ and Kargi, 2007). The generation of hydroxyl radicals through the combination of ozone and hydrogen peroxide is based on Equation 1 (Jaafarzadeh et al., 2017; Ahmadi and Ghanbari, 2018).

$$
2 \mathrm{O}_{3}+2 \mathrm{HO}_{2}^{-}+\mathrm{H}_{2} \mathrm{O} \rightarrow 2 \mathrm{HO}^{\bullet}+3 \mathrm{O}_{2}+\mathrm{OH}^{-}+\mathrm{HO}_{2}^{-\bullet}
$$

Dissolved ozone flotation (DOF) is an innovative water treatment process that combines the benefits of ozonation and flotation. Consequently, coagulation, separation, discoloration, odor removal and disinfection can occur simultaneously in DOF systems (Jin et al., 2015). Other benefits are: reduction in coagulant/flocculant dosage; removal of pathogens; increased biodegradability of effluents; removal of micro pollutants and reduction of the amount of biological sludge generated (Wilinski and Naumczyk, 2012).

In the past, ozone research used conventional flotation (thick bubbles), not micro or nano flotation, thus omitting the essential factor in the process. The main parameter that may limit the kinetics of the process is the mass transfer of the ozone to the liquid (Wilinski and Naumczyk, 2012).

The efficiency of the process depends on the total area of ozone bubbles in solution, because a larger area (amount of bubbles generated) increases the mass transfer of ozone and the oxidation rate of organic compounds. In conclusion, the problem of mass transfer of the ozone to the liquid medium can be solved using appropriate air dispersion technologies (micro- 
and nano-bubble generating systems) (Wilinski and Naumczyk, 2012).

Lee et al. (2008) compared the efficiencies of the dissolved ozone flotation system, and associated costs, with other technologies such as conventional ozonation, membrane filtration, electro flocculation ozonation, electrodialysis, and sand filtration followed by chlorination. According to the authors, DOF technology is highly effective and economically feasible for the treatment of effluents these days.

Due to these facts, DOF has become increasingly popular in effluent treatment. Compared to the conventional treatment process, which consists of coagulation, sedimentation and filtration, the DOF process is superior in removal of color, odor and organic matter from effluents. In addition, the hydraulic retention time (HRT) of the DOF process is three times lower than the conventional tertiary wastewater treatment process, which results in much smaller space requirements (Jin et al., 2015).

The objective of this experiment was to evaluate flotation by dissolved ozone, with and without the addition of hydrogen peroxide, compared to dissolved air flotation for the treatment of milk wastewater.

\section{MATERIALS AND METHODS}

\subsection{Samples, reagents and solutions used}

In the experiment, a synthetic milk wastewater (SMW) was used, as suggested by Silva et al. (2013). According to the authors, this formulation satisfactorily characterizes a synthetic effluent that does not contain whey derived from the manufacture of cheese. The average composition of the synthetic milk effluent used in the experiment was: $\mathrm{pH}$ equal to $7.6 ; 3065.0$ $\mathrm{mg} \mathrm{L}^{-1}$ of COD; 625.0 NTU of turbidity; $186.0 \mathrm{mg} \mathrm{L}^{-1}$ of O\&G; $3974.0 \mathrm{mg} \mathrm{L}^{-1}$ of total solids (TS); $282.0 \mathrm{mg} \mathrm{L}^{-1}$ of total suspended solids (TSS) and $1367.0 \mathrm{mg} \mathrm{L}^{-1}$ of alkalinity as $\mathrm{CaCO}_{3}$.

The agro-industrial effluent samples were collected from three milk industries in the region of Viçosa-MG. The samples, either synthetic or from the industries, were used on the same day of the tests or on the day immediately after collection, being in this case conserved at $5^{\circ} \mathrm{C}$.

The hydrogen peroxide solutions were prepared using a $30 \% \mathrm{w} / \mathrm{w} \mathrm{H}_{2} \mathrm{O}_{2}$ solution, $\left[\mathrm{H}_{2} \mathrm{O}_{2}\right]$ $=9.0 \mathrm{~mol} \mathrm{~L}^{-1}$ and density of $1.1 \mathrm{~g} \mathrm{~mL}^{-1}$. The coagulant used was ferrous sulfate heptahydrate $\left(\mathrm{FeSO}_{4} .7 \mathrm{H}_{2} \mathrm{O}\right)$. The $\mathrm{pH}$ was adjusted using 1:1 v/v solutions of sodium hydroxide $(\mathrm{NaOH})$ or hydrochloric acid $(\mathrm{HCl})$.

\subsection{Obtaining and measuring of ozone gas in air and water}

Ozone gas was obtained from an ozone generator developed by the company Ozone \& Life (São José dos Campos, SP), being used in the oxygen process (90-95\% purity) after drying and concentration of atmospheric air in the equipment.

The concentration of ozone in the air stream at a flow rate of $5 \mathrm{~L} \mathrm{~min}^{-1}$ was determined immediately before of the saturation chamber by the iodometric method (APHA et al., 2012), having a value equal to $19( \pm 0.5) \mathrm{mg} \mathrm{L}^{-1}$, which was used throughout the experiment.

The ozone dissolved in water, measured in distilled water after the release of the supersaturated water with the ozone at atmospheric pressure, was determined by the DDPD method using a Vacu-vials kit from CheMetrics, having a value equal to $5.3( \pm 0.3) \mathrm{mg} \mathrm{L}^{-1}$.

\subsection{Experimental planning}

The experiment consisted of the evaluation of the dissolved ozone flotation system (DOF), with and without the addition of hydrogen peroxide $\left(\mathrm{H}_{2} \mathrm{O}_{2}\right)$, compared to the traditional dissolved air flotation system (DAF). The tests were carried out in acidic $(\mathrm{pH}=4)$ and basic $(\mathrm{pH}=11.4)$ medium for the evaluation of the different effects of ozone on the treatment efficiency at each $\mathrm{pH}$ range of the solution.

In the tests with peroxide addition, the $\mathrm{H}_{2} \mathrm{O}_{2} / \mathrm{O}_{3}$ ratios of $0.5,1.0$ and 1.5 , calculated on the 
basis of the mass of ozone released into the flotation column, were tested according to Equation 2 adapted from Edzwald and Haarhoff (2011). Hydrogen peroxide was added and mixed to the samples in the flotation column immediately prior to flotation tests (with and without ozone).

$$
M_{o Z}=44.6 \times 10^{-3} x\left(\frac{273.15}{273.15+T}\right) \times\left(\frac{P_{a b s}}{101.3}\right) \times\left(\frac{M}{H e} \times f_{x}\right) \times \frac{R R}{100} \times V_{M W}
$$

Where: $\mathrm{M}_{\mathrm{oz}}$ - mass of ozone liberated in the flotation column (mg); $\mathrm{T}$ - solution temperature, equal to $20^{\circ} \mathrm{C} ; \mathrm{P}_{\mathrm{abs}}$ - absolute pressure within the saturation chamber, equal to $919.2 \mathrm{kPa} ; \mathrm{M}$ - ozone molar mass, equal to $48000 \mathrm{mg} \mathrm{mol}^{-1}$; He - Henry's constant for ozone, equal to $3.408 ; \mathrm{f}_{\mathrm{x}}-$ molar fraction of the ozone in the gas stream, equal to $9.56 \times 10^{-3}$; RR recirculation rate, equal to $20 \%$; $\mathrm{V}_{\mathrm{MW}}$ - milk wastewater sample volume, equal to $2 \mathrm{~L}$.

The steps of the first part of the experiment are summarized in Table 1; in all of them, three replicates of each treatment were made. For the determination of the best treatment and evaluation of the efficiency of the system in each treatment, analyses of turbidity, COD, total organic carbon (TOC) and color were made.

Table 1. Stages of the experiment for the evaluation of dissolved ozone flotation, with and without addition of hydrogen peroxide, using the synthetic milk wastewater.

\begin{tabular}{cc}
\hline Stages of the experiment & Description \\
\hline 1 & Dissolved air flotation tests \\
2 & Dissolved ozone flotation tests \\
3 & Dissolved air flotation tests with addition of $\mathrm{H}_{2} \mathrm{O}_{2}$ \\
4 & Dissolved ozone flotation tests with addition of $\mathrm{H}_{2} \mathrm{O}_{2}$ \\
\hline
\end{tabular}

After the determination of the best treatment, whether at $\mathrm{pH} 4$ or 11.4 and with or without $\mathrm{H}_{2} \mathrm{O}_{2}$ addition, tests of DAF and DOF were performed using the three milk effluents cited for validation of the best treatment. For the validation, the parameters of turbidity, chemical oxygen demand (COD), biochemical oxygen demand (BOD), oils and greases (O\&G), total suspended solids (TSS), total nitrogen (NT) and total phosphorus (PT) were analyzed, according to APHA et al. (2012).

The color analysis was done using a Konica Minolta colorimeter, Model Chroma Meters CR-400, as presented in Equation 3 (MacDougall, 2002).

$$
\text { Delta color }=\sqrt{\left(L-L_{0}\right)^{2}+\left(a-a_{0}\right)^{2}+\left(b-b_{0}\right)^{2}}
$$

Where: Delta color - color variation of the treated sample; L - luminosity of the treated sample; $\mathrm{L}_{0}$ - luminosity of distilled water; a - red/green coordinate (+a indicates red and -a indicates green) of the treated sample; a - red/green coordinate ( $+\mathrm{a}$ indicates red and -a indicates green) of the distilled water; $b-$ yellow/blue coordinate $(+b$ indicates yellow and $-b$ indicates blue) of the treated sample; $b_{0}-$ yellow/blue coordinate $(+b$ indicates yellow and $-b$ indicates blue) of the distilled water.

The values obtained for the parameters (turbidity, delta color, COD, BOD, O\&G, TSS, TN and TP) after analysis were corrected using Equation 4 due to the dilution effect caused by the water injection of the saturation chamber in the flotation column.

$$
P_{\text {cor }}=P_{\text {mes }} x\left(\frac{100+R R}{100}\right)
$$


Where: $\mathrm{P}_{\text {cor }}$ - corrected parameter value; $\mathrm{P}_{\text {mes }}$ - value of the measured parameter; $\mathrm{RR}$ recirculation ratio, equal to $20 \%$.

For the statistical analysis of the results, the Tukey test was used to compare means at a significance level of $5 \%$.

\subsection{Used system and operating conditions}

A batch dissolved ozone flotation system composed of an air compressor, a pressure regulating valve, a saturation chamber for the dissolution of the gas mixture and a flotation column was used in the experiment (Figure 1).

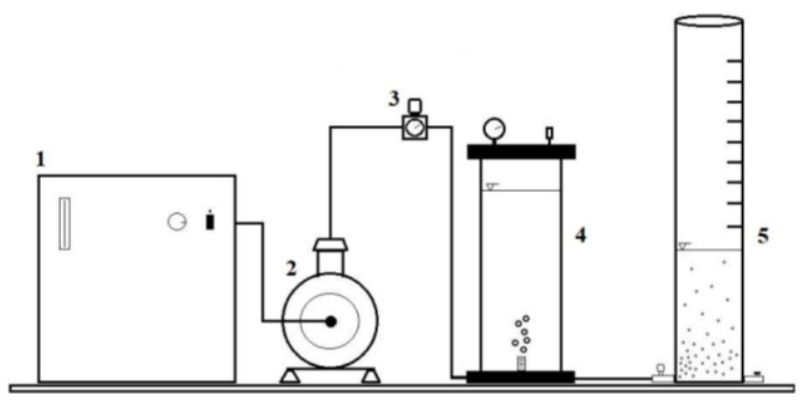

Figure 1. System used in the experiment. 1 - ozone generator; 2 - compressor; 3 - pressure regulator; 4 - saturation chamber; 5 - flotation column.

The operating conditions of the flotation system were: saturation pressure of 10 bar; recirculation ratio of $20 \%$; flotation speed of $10 \mathrm{~cm} \mathrm{~min}^{-1}$; speed gradient for coagulation of $220.0 \mathrm{G}$; speed gradient for flocculation of $80 \mathrm{G}$; flocculation time equal to 5 min and $\mathrm{FeSO}_{4}$ dose equal to $250,0 \mathrm{mg} \mathrm{\textrm {L } ^ { - 1 }}$. The parameters were adopted according to Edzwald's recommendation (Edzwald, 2010) and based on preliminary tests.

The flotation was done using the same procedure in all the tests. The air and ozone mixture were injected by the lower inlet and dissolved in potable water until the pressure of 10 bar was attained in the saturation chamber. After reaching the pressure inside the saturation chamber, the gas injection was maintained for $2 \mathrm{~min}$ for the saturation of the water. In sequence, the valve of the pipeline connecting the saturation chamber to the flotation column was opened by injecting the supersaturated water with air and ozone into the flotation column.

To maintain the pressure established in the saturation chamber, during the opening of the valve, air was injected through the upper opening of the saturation chamber to compensate for the pressure drop caused by the water exhaust of the chamber. By the process, a maximum pressure drop of 1 bar was obtained during the entire process of water release in the flotation column.

The inlet air flow into the system was adjusted to $5 \mathrm{~L} \mathrm{~min}^{-1}$ and the flotation velocity in the flotation column was set to $10.0 \pm 1 \mathrm{~cm} \mathrm{~min}^{-1}$ using needle valves in both cases.

After injection of the volume of water corresponding to the pre-established recirculation ratio, the chamber water outlet valve was closed, with the water and gas injection being withdrawn into the flotation column. After $5 \mathrm{~min}$ of flotation start, the valve was closed, and $500 \mathrm{~mL}$ of the clarified samples were collected in each trial from the bottom of the flotation column.

\section{RESULTS AND DISCUSSION}

Table 2 shows the results of the comparative tests between DAF and DOF in acidic and basic medium, respectively, using synthetic milk wastewater (SMW). 
Table 2. Results of trials in acid and basic medium.

\begin{tabular}{clcccccccc}
\hline \multirow{2}{*}{$\mathrm{pH}$} & Parameters & \multicolumn{9}{c}{ DAF } & \multicolumn{3}{c}{ DOF } \\
\cline { 3 - 9 } & & Mean & SD & CV & Efficiency & Mean & SD & CV & Efficiency \\
\hline \multirow{4}{*}{4} & Turbidity & 96.7 & 2.7 & 2.8 & $84.5(\mathrm{a})$ & 141.6 & 3.2 & 2.2 & $77.3(\mathrm{~b})$ \\
& Delta color & 2.4 & 0.04 & 1.7 & $83.1(\mathrm{a})$ & 2.9 & 0.2 & 6.0 & $79.8(\mathrm{~b})$ \\
& COD & 385.5 & 25.6 & 6.6 & $87.5(\mathrm{a})$ & 246.4 & 5.7 & 2.3 & $92.0(\mathrm{~b})$ \\
& TOC & 641.1 & 7.2 & 1.1 & $53.8(\mathrm{a})$ & 650.0 & 5.9 & 0.9 & $53.2(\mathrm{a})$ \\
\hline \multirow{3}{*}{11.4} & Turbidity & 1192.0 & 22.8 & 1.9 & $-90.7(\mathrm{a})$ & 1361.6 & 12.1 & 0.9 & $-119.6(\mathrm{~b})$ \\
& Delta color & 18.2 & 0.3 & 1.6 & $-27.9(\mathrm{a})$ & 18.8 & 0.3 & 1.6 & $-32.1(\mathrm{a})$ \\
& COD & 2571.0 & 23.8 & 0.9 & $17.9(\mathrm{a})$ & 2632.0 & 22.9 & 0.9 & $15.9(\mathrm{a})$ \\
& TOC & 940.1 & 87.9 & 9.4 & $29.4(\mathrm{a})$ & 908.2 & 61.4 & 6.8 & $31.8(\mathrm{a})$ \\
\hline
\end{tabular}

Note: CV - Coefficient of variation (in percentage); SD - Standard deviation (in percentage); Efficiency of removal (in percentage); Turbidity in NTU; Delta color - dimensionless; COD in $\mathrm{mg} \mathrm{L}^{-1}$; $\mathrm{pH}$ dimensionless; TOC in $\mathrm{mg} \mathrm{L}^{-1}$. Values on the same line followed by the same letter do not differ statistically by the Tukey test for a significance level equal to $5 \%$.

It can be observed in Table 2 that for all the tested parameters, the best results were obtained in acidic medium $(\mathrm{pH}=4)$ for DAF and DOF. Evaluating the result of each parameter alone, it is verified that for the acid medium only COD removal was statistically higher in DOF compared to DAF.

The negative results presented in Table 2 for turbidity and color are due to the higher values obtained at the end of the test compared to their initial values in the SMW (Table 1). The measured final turbidity was higher due to addition of the coagulant and the precipitation of flocs in the lower part of the flotation column or their permanence at suspension in the liquid after the flotation not being removed in the process.

There is also a tendency for ferrous sulphate to precipitate due to the formation of an iron hydroxide $\left(\mathrm{FeOH}_{2}\right.$ or $\left.\mathrm{FeOH}_{3}\right)$ gel at $\mathrm{pH}$ above 9, which leads to the formation of large and heavy flocs by the swapping effect at coagulation, which are hardly removed by DAF (Arslan, 2001).

Solid ferrous sulfate in the FeSO4.7H2O form has a light green color and may take on a yellowish, brownish, reddish brown or green color depending on the $\mathrm{pH}$ of the medium. Its reaction with $\mathrm{NaOH}$ produces $\mathrm{Fe}(\mathrm{OH})_{2}$ that has green coloration and takes darker shades with increasing $\mathrm{pH}$.

The treatment efficiency was mainly due to flotation, since ozone had a small or negative effect in the removal of most of the analyzed parameters as can be observed in Table 2 . The best results in acidic medium are due to the natural coagulation of casein at $\mathrm{pH}$ close to 4.6 (Prazeres et al., 2012), which favored the coagulation process and their removal at DAF or DOF trials.

A similar adverse effect of ozone on coagulation and particle removal efficiency was observed by Liu et al. (2006), Ntampou et al. (2006) and Liu et al. (2015).

During a study about the effects of ozone at coagulation, according to Liu et al. (2006) it was not possible to observe any beneficial effect on coagulation with the pre-ozonation of the samples, causing on the contrary deterioration of the coagulation efficiency, with delay in the formation of flocs and reduction in the removal of turbidity, dissolved organic carbon (DOC) and color $\left(\mathrm{UV}_{254}\right)$. According to the authors, after ozonation, there was only a $5 \%$ increase in DOC removal and a higher hydrophilicity was observed, which impaired DOC removal in the coagulation process. They also reported that the dose of ozone and the characteristics of the organic substances are the two main factors that affect the performance of the coagulation.

Ozonation can oxidize organic compounds by reducing their molecular weight and can

Rev. Ambient. Água vol. 15 n. 5, e2553 - Taubaté 2020 
also increase the amount of acidic functional groups, affecting in various ways the interaction between the organic matter and the coagulating agent. It may affect the coagulation of organic matter, mainly by altering the electrostatic interactions between the coagulant and the organic molecules, rather than altering the intrinsic affinity of the compounds by adsorptive sites on the surface of the coagulant. Therefore, the impact of ozonation on coagulation will depend on the characteristics of the treatment system, the particles and the type of coagulant used (Ntampou et al., 2006).

Ozonation may also reduce the concentration of hydrolyzed aluminum species (eg: $\left.\left[\mathrm{Al}(\mathrm{OH})\left(\mathrm{H}_{2} \mathrm{O}\right)_{5}\right]^{2+},\left[\mathrm{Al}(\mathrm{OH})_{2}\left(\mathrm{H}_{2} \mathrm{O}\right)_{4}\right]^{+}, \mathrm{Al}(\mathrm{OH})_{3}\right)$ and iron $\left(\mathrm{eg}: \mathrm{Fe}_{2} \mathrm{O}_{3}, \mathrm{Fe}(\mathrm{OH}) \mathrm{SO}_{4}, \mathrm{Fe}_{2}(\mathrm{SO} 4)_{3}\right.$, $\mathrm{FeOH}_{2}$ ), responsible for particle coagulation (Liu et al., 2015; Richter, 2009).

Another factor that may have contributed to the fact that ozone did not have a positive effect in increasing the treatment efficiency is the high alkalinity of the SMW (1367.0 $\left.\mathrm{mg} \mathrm{L}^{-1}\right)$ caused by the presence of bicarbonates $\left(\mathrm{HCO}_{3}{ }^{-}\right)$or carbonates $\left(\mathrm{CO}_{3}{ }^{2-}\right)$ that can act as sequestrants of the hydroxyl radicals (Beltrán, 2004).

Table 3 presents the results of the comparative tests between DAF and DOF with the addition of hydrogen peroxide, in acidic and basic medium, using the synthetic milk wastewater (SMW).

Table 3. Results of dissolved air flotation and dissolved ozone flotation trials in acid and basic medium with addition of hydrogen peroxide.

\begin{tabular}{|c|c|c|c|c|c|c|}
\hline \multirow{2}{*}{$\mathrm{pH}$} & \multirow{2}{*}{\multicolumn{2}{|c|}{$\mathrm{H}_{2} \mathrm{O}_{2} / \mathrm{O}_{3}$ ratio }} & \multicolumn{4}{|c|}{ Parameters } \\
\hline & & & Turbidity & Delta color & COD & TOC \\
\hline \multirow{12}{*}{4.0} & \multirow{4}{*}{0.5} & Mean & 151.2 & 4.7 & 547.54 & 595.27 \\
\hline & & $\mathrm{SD}$ & 1.2 & 0.23 & 42.3 & 27.65 \\
\hline & & $\mathrm{CV}(\%)$ & 0.79 & 4.97 & 7.73 & 4.64 \\
\hline & & Efficiency (\%) & 75.8 (a) & $66.8(\mathrm{a})$ & 82.0 (a) & 49.3 (a) \\
\hline & \multirow{4}{*}{1.0} & Mean & 285.6 & 6.63 & 676.18 & 602.74 \\
\hline & & SD & 2.4 & 0.52 & 17.85 & 29.38 \\
\hline & & $\mathrm{CV}(\%)$ & 0.84 & 7.81 & 2.64 & 4.87 \\
\hline & & Efficiency (\%) & 54.3 (b) & $53.3(\mathrm{~b})$ & 77.7 (b) & 48.8 (a) \\
\hline & \multirow{4}{*}{1.5} & Mean & 419.2 & 7.17 & 856.27 & 655.85 \\
\hline & & $\mathrm{SD}$ & 43.34 & 1.43 & 35.7 & 44.56 \\
\hline & & $\mathrm{CV}(\%)$ & 10.34 & 19.93 & 4.17 & 6.79 \\
\hline & & Efficiency (\%) & $32.9(\mathrm{c})$ & 49.5 (b) & $71.8(\mathrm{c})$ & 45.0 (a) \\
\hline \multirow{12}{*}{11.4} & \multirow{4}{*}{0.5} & Mean & 1101.6 & 18.31 & 2777.3 & 1025.8 \\
\hline & & SD & 4.8 & 0.27 & 81.51 & 74.76 \\
\hline & & $\mathrm{CV}(\%)$ & 0.44 & 1.48 & 2.93 & 7.29 \\
\hline & & Efficiency $(\%)$ & $-76.3(a)$ & $-28.9(a)$ & 8.1 (a) & 19.3 (a) \\
\hline & \multirow{4}{*}{1.0} & Mean & 983.20 & 17.70 & 2688.7 & 1174.9 \\
\hline & & SD & 4.74 & 14.62 & 43.96 & 35.99 \\
\hline & & $\mathrm{CV}(\%)$ & 0.48 & 82.56 & 1.64 & 3.06 \\
\hline & & Efficiency (\%) & $-57.3(b)$ & $-24.7(a)$ & $10.98(a)$ & 7.60 (a) \\
\hline & \multirow{4}{*}{1.5} & Mean & 873.60 & 18.20 & 2205.6 & 1012.4 \\
\hline & & $\mathrm{SD}$ & 25.29 & 0.38 & 17.15 & 44.11 \\
\hline & & $\mathrm{CV}(\%)$ & 2.89 & 2.11 & 0.78 & 4.36 \\
\hline & & Efficiency (\%) & $-39.8(\mathrm{c})$ & $-28.2(a)$ & $27.0(b)$ & 20.4 (a) \\
\hline
\end{tabular}

Note: Turbidity in NTU; Delta color - dimensionless; COD in $\mathrm{mg} \mathrm{L}^{-1} ; \mathrm{pH}$ - dimensionless; TOC in $\mathrm{mg}$ $\mathrm{L}^{-1}$; Values in the same column followed by the same letter do not differ statistically by the Tukey test for a significance level equal to $5 \%$. 
In Table 3, it can be observed that the addition of hydrogen peroxide in the $\mathrm{H}_{2} \mathrm{O}_{2} / \mathrm{O}_{3}$ ratios of $0.5,1$ and 1.5 did not lead to an improvement in the removal efficiency of the parameters evaluated. In the acidic medium there was a reduction in the treatment efficiency as the $\mathrm{H}_{2} \mathrm{O}_{2} / \mathrm{O}_{3}$ ratio increased. In the basic medium there was a small improvement in removal of turbidity and COD with increase of the ratio, but all the parameters had worse results compared to the treatments without addition of hydrogen peroxide (Table 2).

Effect similar to that described for ozone may have occurred with addition of hydrogen peroxide in the sample, resulting in a reduction in particle removal efficiency due to coagulation impairment or the neutralization of its oxidizing action due to the high alkalinity of the SMW. It is important to remember that $\mathrm{H}_{2} \mathrm{O}_{2}$ was used as a co oxidant with ozone and preferably, in basic medium, as a catalyst for the formation of hydroxyl radicals. However, the concentrations of ozone and peroxide used in the experiment had a small effect on the treatment.

Therefore, flotation has been shown to be the governing factor of the process and the main factor responsible for the efficiency of the treatment; its addition possibly impaired the quality of the coagulation, impacting the flotation performance, providing inferior results.

Table 4 shows the results of the analyses of the samples of milk wastewater industries.

Table 4. Average composition of milk wastewater samples.

\begin{tabular}{lccc}
\hline Parameters & Sample 1 & Sample 2 & Sample 3 \\
\hline Turbidity $\left(\mathrm{mg} \mathrm{L}^{-1}\right)$ & $3500.0( \pm 53.1)$ & $602.0( \pm 26.0)$ & $498.0( \pm 3.4)$ \\
TSS $\left(\mathrm{mg} \mathrm{L}^{-1}\right)$ & $2580.0( \pm 176.6)$ & $580.0( \pm 22.7)$ & $480.0( \pm 13.0)$ \\
pH & 7.52 & 12.55 & 6.03 \\
Delta color & $14.5( \pm 0.7)$ & $11.2( \pm 0.6)$ & $10.5( \pm 0.4)$ \\
COD $\left(\mathrm{mg} \mathrm{L}^{-1}\right)$ & $8876.4( \pm 187.7)$ & $3938.0( \pm 16.4)$ & $7653.8( \pm 27.0)$ \\
BOD $\left(\mathrm{mg} \mathrm{L}^{-1}\right)$ & $6810.0( \pm 64.3)$ & $2688.0( \pm 5.0)$ & $4590.0( \pm 17.2)$ \\
COD $/ \mathrm{BOD}^{-1}$ & 1.3 & 1.46 & 1.67 \\
O\&G $\left(\mathrm{mg} \mathrm{L}^{-1}\right)$ & $4296.7( \pm 62.6)$ & $101.0( \pm 1.6)$ & $1201.0( \pm 20.6)$ \\
TN $\left(\mathrm{mg} \mathrm{L}^{-1}\right)$ & $64.4( \pm 4.3)$ & $92.4( \pm 1.7)$ & $154.0( \pm 1.3)$ \\
TP $\left(\mathrm{mg} \mathrm{L}^{-1}\right)$ & $30.4( \pm 0.4)$ & $43.0( \pm 0.1)$ & $56.6( \pm 0.1)$ \\
\hline
\end{tabular}

From the data disclosed in Table 4, it can be observed that the characteristics of the wastewater of each industry varied widely, but the results are within the range of values found by Saraiva et al. (2009) and Begnini and Ribeiro (2014). Each industry has its follow-up of specific products, its production process and the general administration of the industry, which directly impacts the characteristic and quantity of effluent generated.

Sample 1 had white color (milk aspect), weak smell of fermented milk and suspended solids characteristic of cheese production. Sample 2 was greyish in color (sanitary sewer appearance), smelling cleaning products and no apparent suspended solids. Sample 3 presented a weak white to grayish color, smell of fermented milk with cleaning products and few suspended solids.

Among the three milk wastewater samples, Sample 1 presented the highest turbidity, TSS, COD, BOD, biodegradability and O\&G concentration. Comparing the samples with the synthetic wastewater (Table 1) used in previous stages, the COD and TSS values of the three milk effluent samples were higher. The other parameters were either higher or lower in each sample. In appearance, the sample that most resembled SMW was sample number 1.

Table 5 shows the results of the DAF and DOF tests using the wastewater samples of the three milk industries. 
Table 5. Results of the dissolved air flotation and dissolved ozone flotation.

\begin{tabular}{|c|c|c|c|c|c|c|c|c|c|}
\hline \multirow{2}{*}{ Sample } & \multirow{2}{*}{ Parameters } & \multicolumn{4}{|c|}{ DAF } & \multicolumn{4}{|c|}{ DOF } \\
\hline & & Mean & SD & $\mathrm{CV}$ & Efficiency & Mean & $\mathrm{SD}$ & $\mathrm{CV}$ & Efficiency \\
\hline \multirow{8}{*}{1} & Turbidity $\left(\mathrm{mg} \mathrm{L}^{-1}\right)$ & 117.6 & 4.3 & 3.7 & $96.6(a)$ & 167.6 & 9.1 & 5.4 & $95.2(b)$ \\
\hline & Delta Color & 3.2 & 0.4 & 11.0 & 77.8 (a) & 4.0 & 0.3 & 6.7 & 72.7 (a) \\
\hline & $\mathrm{COD}\left(\mathrm{mg} \mathrm{L}^{-1}\right)$ & 2233.8 & 95.2 & 4.3 & 74.8 (a) & 2267.1 & 79.6 & 3.5 & 74.5 (a) \\
\hline & $\mathrm{BOD}\left(\mathrm{mg} \mathrm{L}^{-1}\right)$ & 960.0 & 18.3 & 1.9 & 85.9 (a) & 982.1 & 26.8 & 2.7 & $85.6(a)$ \\
\hline & $\mathrm{O} \& \mathrm{G}\left(\mathrm{mg} \mathrm{L}^{-1}\right)$ & 218.0 & 12.0 & 5.5 & 94.9 (a) & 607.2 & 20.8 & 3.4 & 85.9 (b) \\
\hline & $\operatorname{TSS}\left(\mathrm{mg} \mathrm{L}^{-1}\right)$ & 190.4 & 26.6 & 13.9 & 92.6 (a) & 197.3 & 14.1 & 7.1 & 92.4 (a) \\
\hline & $\mathrm{TN}\left(\mathrm{mg} \mathrm{L}^{-1}\right)$ & 14.3 & 1.9 & 13.3 & 77.7 (a) & 14.6 & 1.9 & 13.3 & 77.4 (a) \\
\hline & $\mathrm{TP}\left(\mathrm{mg} \mathrm{L}^{-1}\right)$ & 18.5 & 0.5 & 2.7 & $39.2(a)$ & 20.5 & 0.3 & 1.2 & $32.6(b)$ \\
\hline \multirow{8}{*}{2} & Turbidity $\left(\mathrm{mg} \mathrm{L}^{-1}\right)$ & 113.9 & 12.1 & 10.7 & $81.1(a)$ & 166.8 & 5.5 & 3.3 & $72.3(b)$ \\
\hline & Delta Color & 5.9 & 0.7 & 11.8 & 47.4 (a) & 6.6 & 0.2 & 2.6 & 40.7 (a) \\
\hline & $\mathrm{COD}\left(\mathrm{mg} \mathrm{L}^{-1}\right)$ & 2576.8 & 21.8 & 0.8 & 34.6 (a) & 2657.8 & 21.8 & 0.8 & 32.5 (b) \\
\hline & $\mathrm{BOD}\left(\mathrm{mg} \mathrm{L}^{-1}\right)$ & 1936.8 & 7.2 & 0.4 & 27.9 (a) & 1944.0 & 7.2 & 0.4 & 27.7 (a) \\
\hline & $\mathrm{O} \& \mathrm{G}\left(\mathrm{mg} \mathrm{L}^{-1}\right)$ & 0.0 & 0.0 & 0.0 & 100.0 (a) & 0.0 & 0.0 & 0.0 & 100.0 (a) \\
\hline & $\mathrm{TSS}\left(\mathrm{mg} \mathrm{L}^{-1}\right)$ & 80.8 & 7.3 & 9.1 & 86.1 (a) & 106.4 & 3.7 & 3.4 & 81.7 (b) \\
\hline & $\mathrm{TN}\left(\mathrm{mg} \mathrm{L}^{-1}\right)$ & 43.9 & 1.6 & 3.7 & 52.5 (a) & 42.9 & 1.6 & 3.8 & 53.5 (a) \\
\hline & $\mathrm{TP}\left(\mathrm{mg} \mathrm{L}^{-1}\right)$ & 42.5 & 0.2 & 0.4 & 1.2 (a) & 42.7 & 0.1 & 0.3 & $0.7(b)$ \\
\hline \multirow{8}{*}{3} & Turbidity (mg L ${ }^{-1}$ ) & 305.6 & 4.2 & 1.4 & $38.6(a)$ & 310.8 & 2.4 & 0.8 & 37.6 (a) \\
\hline & Delta Color & 11.2 & 1.0 & 9.0 & $-6.4(a)$ & 12.6 & 0.4 & 3.2 & -20.5 (a) \\
\hline & $\mathrm{COD}\left(\mathrm{mg} \mathrm{L}^{-1}\right)$ & 5015.4 & 34.3 & 0.7 & 34.5 (a) & 4721.9 & 40.2 & 0.9 & $38.3(b)$ \\
\hline & $\mathrm{BOD}\left(\mathrm{mg} \mathrm{L}^{-1}\right)$ & 2612.0 & 18.3 & 0.7 & $43.1(a)$ & 2280.0 & 52.3 & 2.3 & $50.3(b)$ \\
\hline & $\mathrm{O} \& \mathrm{G}\left(\mathrm{mg} \mathrm{L}^{-1}\right)$ & 232.0 & 8.5 & 3.7 & 80.7 (a) & 263.6 & 17.0 & 6.5 & 78.1 (a) \\
\hline & $\operatorname{TSS}\left(\mathrm{mg} \mathrm{L}^{-1}\right)$ & 273.8 & 14.9 & 5.5 & $43.0(a)$ & 279.2 & 8.0 & 2.9 & 41.8 (a) \\
\hline & $\mathrm{TN}\left(\mathrm{mg} \mathrm{L}^{-1}\right)$ & 118.7 & 1.9 & 1.6 & 22.9 (a) & 119.8 & 1.9 & 1.6 & $22.2(a)$ \\
\hline & $\mathrm{TP}\left(\mathrm{mg} \mathrm{L}^{-1}\right)$ & 42.5 & 0.2 & 0.4 & 24.9 (a) & 42.2 & 0.3 & 0.6 & 25.3 (a) \\
\hline
\end{tabular}

Note: Values on the same line followed by the same letter do not differ statistically by the Tukey test for a significance level equal to $5 \%$.

As can be seen in Table 5 (highlighted in bold), there was a significant difference in seven comparative analyses between DAF and DOF. There was a reduction in removal efficiency of turbidity, COD, O\&G, TSS and TP of samples 1 and 2 and an increase only in the removal efficiency of COD and BOD of Sample 3.

Among the samples evaluated, the best results of the analyzed parameters were obtained for Sample 1. This fact is possibly due to the greater presence of milk and cheese remains in this sample, which contain large quantities of casein, the main milk protein and which has an isoelectric point at $\mathrm{pH}$ equal to 4.6. At this $\mathrm{pH}$, or close to it, destabilization of the casein occurs and its natural coagulation takes place, leading to better removal efficiencies of these particles in flotation systems (Prazeres et al., 2012). During the research it was observed that the SMW used did not adequately represent the characteristics of the milk effluents in general and only with one of the three milk wastewater samples was it possible to obtain results similar to those obtained with the SMW. 
Lee and Song (2006) tested a continuous-flow pilot scale DOF system with an additional contact chamber to treat bovine wastewater. In that experiment, a recirculation ratio of $20 \%$, flotation time equal to $20 \mathrm{~min}$ and ozone concentrations of 40 to $200 \mathrm{mg} \mathrm{L}^{-1}$ in the feed air were used as operational parameters. According to the authors, it was possible to obtain removal efficiencies of COD, TSS, TN and TP of $88 \%, 92 \%, 67.7 \%$ and $94.6 \%$, respectively, with the system.

According to Lee and Song (2006), increase in ozone concentration has led to higher rates of COD removal and ozone in high concentrations improves the flotation process for two reasons: the first reason is that ozone improves coagulation by oxidizing the hydrophilic colloidal particles, making them hydrophobic and facilitating their removal; the second reason is due to the higher solubility of ozone in water, so higher concentrations of ozone causes an increase in the concentration of microbubbles, improving the efficiency of the process.

Lee et al. (2008) evaluated a DOF system and a common ozonation system (large bubbles), in laboratory-scale and pilot-scale, for the treatment of a secondary effluent from a sewage treatment plant. According to the authors, DOF has been shown to be a more effective ozonization technique compared to common ozonation. In the laboratory phase, the optimum ozone concentration found in the DOF was $6.1 \mathrm{mg} \mathrm{L}^{-1}$. The DOF pilot scale system evaluated for one month provided removal efficiencies of $86.9 \%$ of turbidity, $81 \%$ of total suspended solids, $72.6 \%$ of color, $82.4 \%$ of BOD and $92 \%$ of total phosphorus. However, lower removal efficiencies of $42.9 \%$ and $33.4 \%$ were obtained for COD and TN, respectively. Nearly $100 \%$ disinfection efficiency was achieved by the removal of heterotrophic bacteria and fecal coliforms.

An ozone system by microbubbles and macrobubbles for the treatment of a textile effluent was evaluated by Chu et al. (2008). In this work, the authors verified that with the use of the microbubbles, higher rates of mass transfer of ozone to the liquid medium were obtained, higher rates of color removal ( $80 \%$ in $140 \mathrm{~min}$ compared to $280 \mathrm{~min}$ ) and 20\% higher COD removal.

Beneventi et al. (2009) used a flotation system with ozone $\left(60 \mathrm{mg} \mathrm{L}^{-1}\right)$ using a flotation column and with recirculation of the clarified water to treat the effluent of a paper industry. According to the authors, it was possible to obtain an improvement in COD removal, compared to DAF, of 41 to $63 \%$, but there was no difference in effluent color removal efficiency (92\%).

The efficiency of DAF and DOF was compared by Wilinski and Naumczyk (2012), using a pilot scale system operated in continuous flow on treatment of wastewater from fruit processing. The authors observed a greater efficiency in treatment with DOF compared to DAF. In DOF, removal efficiencies of COD, soluble COD and BOD equal to $33.8 \%, 29.3 \%$ and $34.8 \%$, respectively, were obtained. In DAF, the removal efficiencies of COD, soluble COD and BOD were equal to $20.1 \%, 6.6 \%$ and $20.3 \%$, respectively.

Jin et al. (2015) used a pilot-scale DOF system, without pressurizing, to treat a secondary effluent from a sewage treatment plant. The operating conditions of the system were: recirculation ratio of $50 \%$, hydraulic retention time of 30 minutes and concentrations of ozone ranging from 0 to $1.6 \mathrm{mg} \mathrm{L}^{-1}$. The optimum ozone dosage determined by the authors was equal to $1.6 \mathrm{mg} \mathrm{L}^{-1}$. Removal efficiencies of $80 \%$ and $60 \%$, respectively, were obtained for color and TOC. Due to the ozone effect, there was also a large reduction in the molecular weight of the effluent components, from $6000 \mathrm{Da}$ to $3000 \mathrm{Da}$, with predominance of molecules up to $500 \mathrm{Da}$.

Contrary to the results of the mentioned authors, with the system used and under the conditions of this experiment, it was not possible to obtain an effective improvement in the removal efficiency of the evaluated parameters with the use of the ozone in the flotation process. In most of the tests there was a reduction in the removal efficiency of the evaluated parameters. The dissolved air flotation process had better performance and the physical mechanisms predominated in the treatment of the milk effluent.

The small or negligible effect of ozone in the process was possibly caused by the small

Rev. Ambient. Água vol. 15 n. 5, e2553 - Taubaté 2020 
concentration of ozone used $\left(19 \mathrm{mg} \mathrm{L}^{-1}\right)$ in the inlet air of the saturation chamber, which provided a small amount of dissolved ozone, around $21.6 \mathrm{mg}$, for the degradation of the organic effluent load (COD of 2233.8 to $5015.4 \mathrm{mg} \mathrm{L}^{-1}$ ).

Hydrogen peroxide was used in this experiment, with the function of co-oxidant and a catalyst for hydroxyl radical formation. Its punctual and pre-flotation addition had a similar effect to the ozone in the treatment, impairing the coagulation/flocculation and reducing particle removal efficiency during flotation. Usually, in the process called peroxone, the addition of $\mathrm{H}_{2} \mathrm{O}_{2}$ (via solution) and ozone (via gas flow) in the liquid medium is done together and continuously for long periods of time (10 to $360 \mathrm{~min}$ ), providing at the end of treatment an amount of oxidant much higher than the one used in this work (Catalkaya and Kargi, 2007; Li et al., 2013; Paschoalato et al., 2008).

Better results could be obtained with higher concentrations of ozone, since the concentration of ozone is small in relation to the high organic load of the milk effluent. Another important factor was the batch system used, which did not allow the recirculation of the clarified effluent and the reduced contact time $(\leq 2 \mathrm{~min})$ with ozone.

As can be seen in works of Lee and Song (2006), Lee et al. (2008), Chu et al. (2008), Kim et al. (2011), Wilinski and Naumczyk (2012) and Jin et al. (2015), in all those studies in which DOF had superior performance compared to DAF, it was possible to observe that at least one of these features existed: the ozonation had an application time $\geq 1 \mathrm{~h}$ using microbubbles; pilotscale systems operated at continuous flow and with recirculation of clarified effluent; an additional ozone tank was used that was incorporated into the system, called dissolved ozone flotation with pressurized ozone oxidation (DOF-PO2) (Kim et al., 2011; Lee and Song, 2006).

The recirculation and the additional tank increase the contact time of the dissolved ozone with the effluent to be treated, promoting the oxidation of pollutants and their degradation. Continuous flow systems would also enable the continuous addition of $\mathrm{H}_{2} \mathrm{O}_{2}$ at the ideal $\mathrm{H}_{2} \mathrm{O}_{2} / \mathrm{O}_{3}$ ratio for the formation of hydroxyl radicals, which would increase the degradation capacity of the pollutants and the overall efficiency of the system.

\section{CONCLUSIONS}

In the experimental conditions of the present work, dissolved ozone flotation did not demonstrate better performance compared to dissolved air flotation, with only a slight tendency to improve the removal of COD and BOD. In all tests of dissolved air flotation and dissolved ozone flotation, with and without the addition of hydrogen peroxide, better treatment results were obtained at $\mathrm{pH} 4$.

The tests with hydrogen peroxide at $\mathrm{H}_{2} \mathrm{O}_{2} / \mathrm{O}_{3}$ ratios of $0.5,1.0$ and 1.5 at $\mathrm{pH} 4$ demonstrated a gradual reduction in treatment efficiency, with a ratio increase and a slight tendency to increase at $\mathrm{pH} 11.4$, but still significatively below the results without hydrogen peroxide.

The results with synthetic effluent differed from the results with the three milk industry effluents, being closer in only one of them that contained more traces of milk and cheese residue.

It is suggested for future experiments, using the same flotation system, that tests be made using ozone concentrations equal to $100 \mathrm{mg} \mathrm{L}^{-1}$ or above. It is also suggested that tests be made using a flotation system operated at continuous flow, with recirculation of clarified effluent and an additional ozonation tank, and that tests with hydrogen peroxide be made with its continuous addition in the complementary ozonation tank, at $\mathrm{pH}$ ranges from 8 to 12 and with $\mathrm{H}_{2} \mathrm{O}_{2} / \mathrm{O}_{3}$ ratios varying from 0.5 to 3.0 .

\section{ACKNOWLEDGEMENTS}

This work was funded by National Council for Scientific and Technological Development 
(CNPq Grant 164598/2014-6) and Coordination for the Improvement of Higher Education Personnel (CAPES Finance Code 001).

\section{REFERENCES}

APHA; AWWA; WEF. Standard methods for the examination of water and wastewater. 22nd edition. Washington, 2012.

AHMADI, M.; GHANBARI, F. Degradation of organic pollutants by photoelectroperoxone/ZVI process: Synergistic, kinetic and feasibility studies. Journal of $\begin{array}{llllll}\text { Environmental } & \text { Management, } & \text { v. } & 228, & \text { p. }\end{array}$ https://doi.org/10.1016/j.jenvman.2018.08.102

ARSLAN, I. Treatability of a simulated dispersed dye-bath by ferrous iron coagulation, ozonation, and ferrous iron-catalyzed ozonation. Journal of Hazardous Materials, v. 85, n. 3, p. 229-241, 2001. http://doi.org/10.1016/S0304-3894(01)00232-1

BEGNINI, B. C.; RIBEIRO, H. B. Plano para redução de carga poluidora em indústria de lacticínios. Saúde e Meio Ambiente: Revista Interdisciplinar, v. 3, n. 1, p. 19-30, 2014. http://dx.doi.org/10.24302/sma.v3i1.519

BELTRÁN, F. J. Ozone reaction kinetics for water and wastewater systems. Boca Raton: Lewis Publishers, 2004.

BENEVENTI, D.; ALMEIDA, F.; MARLIN, N.; CURTIL, D.; SALGUEIRO, L.; AUROUSSEAU, M. Hydrodynamics and recovered papers deinking in an ozone flotation column. Chemical Engineering and Processing. v. 48, p. 1517-1526, 2009. http://doi:10.1016/j.cep.2009.10.007

CATALKAYA, E. C.; KARGI, F. Color, TOC and AOX removals from pulp mill effluent by advanced oxidation processes: A comparative study. Journal of Hazardous Materials, v. 139, n. 2, p. 244-253, 2007. http://doi.org/10.1016/j.jhazmat.2006.06.023

CHU, L.-B.; XING, X.-H.; YU, A.-F.; SUN, X.-L.; JURCIK, B. Enhanced treatment of practical textile wastewater by microbubble ozonation. Process Safety and Environmental Protection, v. 86, n. 5, p. 389-393, 2008. http://doi.org/10.1016/j.psep.2008.02.005

EDZWALD, J.; HAARHOFF, J. Dissolved air flotation for water clarification. New York: McGraw Hill Professional, 2011.

EDZWALD, J. K. Dissolved air flotation and me. Water Research, v. 44, n. 7, p. 2077-2106, 2010. http://doi.org/10.1016/j.watres.2009.12.040

JAAFARZADEH, N.; BARZEGAR, G.; GHANBARI, F. Photo assisted electro-peroxone to degrade 2,4-D herbicide: The effects of supporting electrolytes and determining mechanism. Process Safety and Environmental Protection, v. 111, p. 520-528, 2017. https://doi.org/10.1016/j.psep.2017.08.012

JIN, X.; JIN, P.; WANG, X. A study on the effects of ozone dosage on dissolved-ozone flotation (DOF) process performance. Water Science and Technology, v. 71, n. 9, p. 1423-1428, 2015. http://doi.dx.org/10.2166/wst.2015.115 
KIM, J. H.; KIM, H. S.; LEE, B. H. Combination of sequential batch reactor (SBR) and dissolved ozone flotation-pressurized ozone oxidation (DOF-PO2) processes for treatment of pigment processing wastewater. Environmental Engineering Research, v. 16, n. 2, p. 97-102, 2011. http://doi.dx.org/10.4491/eer.2011.16.2.97

LEE, B.; SONG, W. High concentration of ozone application by the DAF (Dissolved Air Flotation) system to treat livestock wastewater. WIT Transactions on Ecology and the Environment, v. 95, p. 561-569, 2006. http://doi.dx.org/10.2495/WP060551

LEE, B. H.; SONG, W. C.; MANNA, B.; HA, J. K. Dissolved ozone flotation (DOF)-a promising technology in municipal wastewater treatment. Desalination, v. 225, n. 1, p. 260-273, 2008. http://doi.org/10.1016/j.desal.2007.07.011

LI, Z.; YUAN, S.; QIU, C.; WANG, Y.; PAN, X.; WANG, J.; WANG, C.; ZUO, J. Effective degradation of refractory organic pollutants in landfill leachate by electro-peroxone treatment. Electrochimica Acta, n. 102 p. 174-182, 2013. http://doi.org/10.1016/j.electacta.2013.04.034

LIU, H.-L.; WANG, D.-S.; SHI, B.-Y.; WANG, M.; TANG, H.-X. Effects of pre-ozonation on organic matter removal by coagulation with IPF-PACl. Journal of Environmental Sciences (China), v. 18, n. 3, p. 453-458, 2006.

LIU, H.; GUO, X.; WANG, M.; JIAO, R.; SHI, J. Effects of interaction of ozonation and coagulation on coagulation results. Huan Jing Ke Xue= Huanjing Kexue, v. 36, n. 9, p. 3285-3291, 2015.

MACDOUGALL, D. B. Colour in food: Improving quality. Cambridge: Woodhead Publishing, 2002.

MARTINS, R. C.; QUINTA-FERREIRA, R. M. A review on the applications of ozonation for the treatment of real agro-industrial wastewaters. Ozone: Science \& Engineering, v. 36, n. 1, p. 3-35, 2014. http://dx.doi.org/10.1080/01919512.2013.842158

MAHMOUD, A.; FREIRE, R. S. Métodos emergentes para aumentar a eficiência do ozônio no tratamento de águas contaminadas. Química Nova, v. 30, n. 1, p. 198-205, 2007. http://dx.doi.org/10.1590/S0100-40422007000100032

NTAMPOU, X.; ZOUBOULIS, A.; SAMARAS, P. Appropriate combination of physicochemical methods (coagulation/flocculation and ozonation) for the efficient treatment of landfill leachates. Chemosphere, v. 62, n. 5, p. 722-730, 2006. http://doi.org/10.1016/j.chemosphere.2005.04.067

PASCHOALATO, C. F. P. R.; TRIMAILOVAS, M. R.; DI BERNARDO, L. Formação de subprodutos orgânicos halogenados nas operações de pré-oxidação com cloro, ozônio e peroxônio e pós-cloração em água conténdo substância húmica. Engenharia Sanitária e Ambiental, v. 13, n. 3, p. 313-322, 2008. https://doi.org/10.1590/S141341522008000300011

PRAZERES, A. R.; CARVALHO, F.; RIVAS, J. Cheese whey management: A review, Journal of Environmental Management, n. 110, p. 48-68, 2012. http://doi.dx.org/10.1016/j.jenvman.2012.05.018

RICHTER, C. A. Água: métodos e tecnologia de tratamento. São Paulo: Edgard Blucher, 2009. 
SARAIVA, C. B.; MENDONÇA, R. C. S.; SANTOS, A. L.; PEREIRA, D. A. Consumo de água e geração de efluentes em uma indústria de laticínios. Revista do Instituto de Laticínios Cândido Tostes, v. 64, n. 367, p. 10-18, 2009.

SHOKRI, A. Degradation of 2-Nitrophenol from Petrochemical Wastewater by Ozone. Russian Journal of Applied Chemistry, v. 88, n. 12, p. 2038-2043, 2015. https://doi.org/10.1134/S10704272150120216

SHOKRI, A.; MAHANPOOR, K.; SOODBAR, D. Degradation of Ortho-Toluidine in petrochemical wastewater by ozonation, $\mathrm{UV} / \mathrm{O} 3, \mathrm{O} 3 / \mathrm{H} 2 \mathrm{O} 2$ and $\mathrm{UV} / \mathrm{O} 3 / \mathrm{H} 2 \mathrm{O} 2$ processes. Desalination and Water Treatment, v. 57, n. 35, p. 16473-16482, 2015. https://doi.org/10.1080/19443994.2015.1085454

SILVA, L. V. C.; ANDRADE, M. V.; RODRIGUES, K.; MARINHO, G. Treatment of synthetic dairy wastewater in batch reactors inoculated with Aspergillus niger AN400. Engenharia Sanitária Ambiental, v. 18, p. 371-380, 2013. https://doi.org/10.1590/S1413-41522013000400009

WILINSKI, P.; NAUMCZYK, J. Dissolved Ozone Flotation as an innovative and prospect method for treatment of micropollutants and wastewater treatment costs reduction. In: WORLD WIDE WORKSHOP FOR YOUNG ENVIRONMENTAL SCIENTISTS, 12., 21-25 May 2012, Arcueil, France, 2012. Proceedings[...] Villeurbanne: CCSD, 2012. 


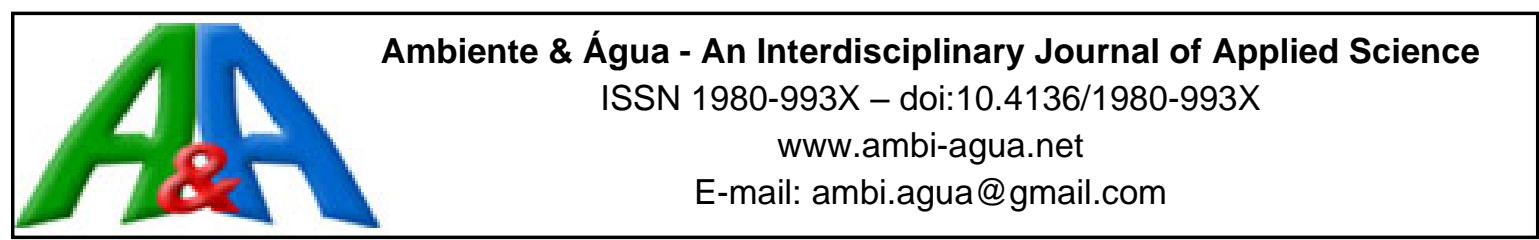

\title{
Sub-daily hydrological-hydrodynamic simulation in flash flood basins: Una river (Pernambuco/Brazil)
}

\author{
ARTICLES doi:10.4136/ambi-agua.2556
}

Received: 07 Apr. 2020; Accepted: 28 Jul. 2020

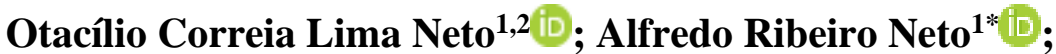 \\ Fellipe Henrique Borba Alves ${ }^{1}$; José Almir Cirilo $^{3}$ iD
}

\begin{abstract}
${ }^{1}$ Departamento de Engenharia Civil e Ambiental. Programa de Pós-Graduação em Engenharia Civil. Universidade Federal de Pernambuco (UFPE), Rua Acadêmico Hélio Ramos, s/n, Cidade Universitária, CEP: 50740-530, Recife, PE, Brazil. E-mail: otacilio.neto@cogerh.com.br, fellipehba@hotmail.com ${ }^{2}$ Núcleo Operacional da Gerência da Sub-bacia Hidrográfica do Rio Salgado. Companhia de Gestão dos Recursos Hídricos do Estado do Ceará (COGERH), Avenida Alan Kardec, n 40, CEP: 63122-295, Crato, CE, Brazil. E-mail: otacilio.neto@cogerh.com.br

${ }^{3}$ Núcleo de Tecnologia. Universidade Federal de Pernambuco (UFPE), Avenida Campina Grande, s/n, Km 59, CEP: 55014-900, Caruaru, PE, Brazil. E-mail: almir.cirilo@gmail.com *Corresponding author. E-mail: alfredo.ribeiro@ufpe.br
\end{abstract}

\begin{abstract}
Flash floods are observed in the Una River Basin, Pernambuco/Brazil. This particular type of flood is a short-duration hydrological event with occurrence of the peak flow within minutes to few hours after the onset of the rainfall, taking place typically in mountainous regions. The objective of the paper was to assess the sub-daily hydrological and hydrodynamic modeling of flood events in 2011 and 2017. Sub-daily precipitation and streamflow were applied to the models Hydrologic Engineering Center-Hydrologic Modeling System (HEC-HMS) and River Analysis System (HEC-RAS). Model evaluation methods such as Nash-Sutcliffe efficiency (NSE), percent bias, and the ratio of the root mean squared error to the standard deviation of measured data (RSR) were used in the calibration process. The maximum infiltration rate and the Snyder peak coefficient estimation were the most sensitive parameters in the hydrological model. The calibration of the HEC-HMS showed good performances (Catende station $\mathrm{NSE}=0.78$ and RSR=0.46; Palmares station NSE=0.68 and RSR=0.57). During HEC-RAS 1D flow simulations, steep regions in the Una River caused numerical instabilities. The $2 \mathrm{D}$ solution was needed to overcome this problem, allowing us to represent the water level in the city of Palmares satisfactorily.
\end{abstract}

Keywords: hydrologic modeling system, natural disasters, river analysis system, 2D simulation.

\section{Modelagem hidrológica e hidrodinâmica sub-diária em bacias de resposta rápida: Rio Una (Pernambuco/Brasil)}

\section{RESUMO}

Eventos extremos de cheia que ocorrem poucas horas após a precipitação em regiões de altas declividades, conhecidos como flash flood, são observados na bacia hidrográfica do rio Una. O artigo tem como objetivo avaliar a modelagem hidrológica e hidrodinâmica com dados sub-diários dos maiores eventos de cheia da bacia do rio Una nos anos de 2011 e 2017. 
Precipitação e vazão sub-diárias foram utilizadas nos modelos Hydrologic Engineering CenterHydrologic Modeling System (HEC-HMS) e River Analysis System (HEC-RAS). A calibração foi avaliada pela eficiência de Nash-Sutcliffe (NSE), percentual de tendência e a razão dada pelo erro quadrático médio pelo desvio padrão dos dados observados (RSR). Os parâmetros taxa de infiltração máxima e coeficiente de pico do método HU Snyder apresentaram maior sensibilidade na calibração do HEC-HMS. A calibração exibiu um bom desempenho (estação Catende NSE=0.78, RSR=0.46; estação Palmares NSE=0.68, RSR=0.57). O modelo hidrodinâmico unidimensional apresentou instabilidades devido às regiões íngremes da bacia. A solução 2D foi necessária para superar esse problema, o que permitiu representar satisfatoriamente o nível da água na cidade de palmares.

Palavras-chave: desastres naturais, simulação 2D, sistema de análise de rio, sistema de modelagem hidrológica.

\section{INTRODUCTION}

Several factors can influence the occurrences of flood events such as land-use change, mainly due to increased imperviousness in urban areas, extreme precipitation events and topographic characteristics of the watershed. Consequences from these events vary for every watershed and depend on a specific analysis for each one. Hydrologic and hydrodynamic studies are necessary for assessments aiming to minimize the impacts of floods on the population. Mitigation of flooding impacts on human activities can be done with techniques to anticipate these events for urban management and planning. Flash floods are rapid events characterized by the occurrence of the peak flow within minutes to few hours after the onset of the rainfall, taking place typically in mountainous regions. Considering cases of steep-slope river basins, for instance, in the Una River Basin in Pernambuco, Brazil, sub-daily runoff predictions are important to flood risk mapping, flood damage assessment and real-time flood forecasting.

Land-use management, floodplain regulation and environmental education are known and applied in several watersheds as flood control methods (Ohana-Levi et al., 2015). Hydrological and hydrodynamic simulation models are widely used for flood planning. These models can simulate historical flood events and search for similarities in current events, allowing the mitigation of negative impacts (Li et al., 2018), such as damage in structures (houses, buildings, transportation infrastructure, and others) and business interruption. Dantas et al. (2014) and Ribeiro Neto et al. (2015) have developed floodplain mapping using daily precipitation data for extreme events in 2000 and 2010 in the Una River Basin (URB). In the present study, these models were applied in other precipitation events for the same basin, allowing new perspectives in natural disaster management, especially in flash flood simulation. In some regions of the URB, the time interval between a precipitation event and its corresponding peak flow is less than one day. The term flash flood refers to these events, especially when highly intense rainfall occurs in mountainous areas with a rapid response for flood occurrence and only a few hours of warning. Flash floods are usually localized disasters, causing more damage, and amplifying social and economic impacts (Boithias et al., 2017; Matingo et al., 2018). The short time of concentration in these hydrological studies demands sub-daily data records for precipitation and streamflow.

The simulation of extreme rainfall events is very difficult due to the large number of parameters involved in hydrological and hydrodynamic modeling. Thus, model calibration and validation are necessary to reduce uncertainties in these simulations (Ballesteros et al., 2011; Habert et al., 2016). Calibration allows adjustment of the model parameters and validation verifies the capacity of the model to represent the physical processes of the watershed by 
comparing simulated and observed data. The gap of in situ data during the peak flow in flood events is a limitation for hydrological simulations. This can be explained by the unexpected magnitude of the values in the extreme events, and failures found in the equipment register. Hydrological and hydrodynamic studies have advantages, such as providing an easy implementation of the physical characteristics of the watershed with a fast and low-cost approach. However, the low quality of the observed data is an obstacle for model calibration and validation. Some limitations of hydrological and hydrodynamic models are the scale of the area, numerical solution approximations, and even erroneous parametrization of the model that do not represent the real physical processes in the study region (Amponsah et al., 2016).

Several cities of Pernambuco state-Brazil are impacted by flood events, which result in increased vulnerability of the riverine population. In the last decade, specifically in 2010, 2011, and 2017, many severe flash floods in these regions were identified. This study deals with aspects that in general are not treated in other similar applications. One example is the combination of medium drainage area and steep slopes that results in great discharges and high flow velocity. These characteristics of the floods in the URB have as a consequence significant impacts to cities sited along the course of the rivers. Other aspects of sub-daily simulations can be highlighted. Part of the river basins in regions with intense rainfall have a short time of concentration. Since conventional rain and stream gauges generate daily records, the flow simulated with these data hides the real behavior of the peak flow, which is significantly greater than the daily average. Among other problems, this difference can affect the extension of floodplain mapping. Rainfall-runoff simulation using sub-daily data supports the operational planning of reservoirs for flood control and the process of generation of scenarios of inundation and flood warning. In the flash flood context of the Una River Basin, the objective of the study is to explore and assess a sub-daily hydrological and hydrodynamic modeling for the more significant events in 2011 and 2017. This approach allows us to use the model as a tool of forecasting and monitoring systems for extreme flood events.

\section{METHODOLOGY}

\subsection{Study Area and Data Acquisition}

The study area selected for the modeling was the Una River Basin, located on the South coast of Pernambuco state (Figure 1), with two regions presenting distinct climate characteristics: Agreste (sited in the upper-medium part of the basin) and Zona da Mata (sited in the medium-lower part). The main course of the Una River extends for approximately 290 $\mathrm{km}$ in an area of $6786 \mathrm{~km}^{2}$. In the Agreste region, the annual mean precipitation ranges from $600 \mathrm{~mm}$ to $800 \mathrm{~mm}$, while the Zona da Mata region presents an annual mean varying between $1500 \mathrm{~mm}$ and $2000 \mathrm{~mm}$. The precipitation increases from Western to Eastern, where the annual mean value is about $2000 \mathrm{~mm}$ on the coast. The upper part of the URB has intermittent rivers due to the semiarid characteristics of the climate. In the medium and lower parts, the flow regime is perennial, and the peak flows are more pronounced (CONDEPE, 2006).

The representation of the geometry of the Una River was made with a digital terrain model (DTM), obtained in a survey using the LiDAR (Light Detection and Ranging) technique, which uses laser beams emitted from an aircraft to scan the river area and its surroundings (approximately $1 \mathrm{~km}$ on each side of the river). The DTM has a spatial resolution of $0.5 \mathrm{~m}$ and an elevation accuracy of $15 \mathrm{~cm}$ (Ribeiro Neto et al., 2015). The Shuttle Radar Topography Mission DTM was used for the pre-processing of the sub-basins using the extension HECGeoHMS. The SRTM DTM has 30 meters of spatial resolution, and it is provided by the Earth Explorer US Geological Survey.

In this study, precipitation, streamflow and water levels time series were obtained from stations of hydrometeorological networks that belong to the National Water Agency (ANA), the National Centre for Monitoring and Early Warning of Natural Disasters (CEMADEN) and 
the Pernambuco Water and Climate Agency (APAC). Daily precipitation is measured in the APAC's stations, totaling 26 in 2011 and 41 in 2017. Sub-daily precipitation data exhibited intervals of 10 minutes (CEMADEN-37 stations), and 15 minutes (ANA-11 stations) in 2017, and 1 hour in 2011 (ANA-4 stations). Considering that 2011 had only four stations with subdaily precipitation data, a routine for conversion of daily in hourly rainfall data was applied. The daily volume of precipitation is distributed throughout the day, taking into account the same temporal distribution of the nearest sub-daily rain gauge. Stream gauges (streamflow and water level) belong to the ANA's network with hourly data for Palmares (drainage area of $4,910.0 \mathrm{~km}^{2}$ ) and Catende (drainage area of $718.0 \mathrm{~km}^{2}$ ) (Figure 1).
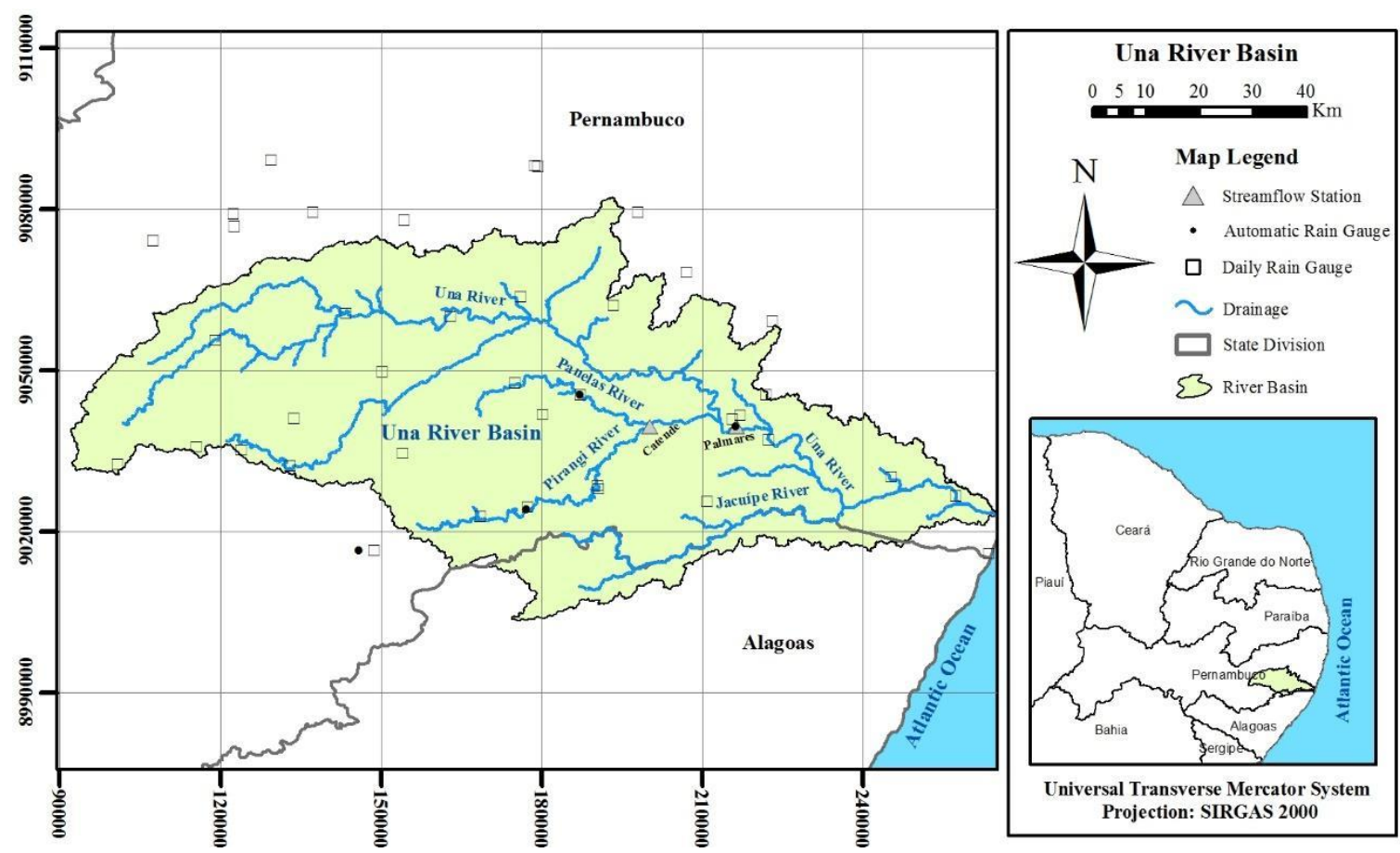

Figure 1. Una River Basin including the main rivers, reaches of the study and in situ stations.

\subsection{Hydrological Model}

The Hydrologic Engineering Center-Hydrologic Modeling System (HEC-HMS) was used in this study, having as reference previous studies (Dantas et al., 2014; Ribeiro Neto et al., 2015; Alves and Cirilo, 2017) performed with daily time step. The main reasons for choosing the HEC-HMS model are: i) ability to simulate high temporal resolution precipitation data; ii) efficient coupling with the hydrodynamic model HEC-RAS; iii) it is a free tool for research purposes; and iv) a number of successful applications worldwide (P.C. et al., 2019 and references cited by them). The pre-processing tasks consist of watershed discretization on subbasins, creation of network elements (reaches and streams), calculation of physical characteristics of the basin such as terrain slope, channel slope, channel length and drainage area. Besides precipitation data and watershed discretization with its network elements, control specifications define the period from beginning to the end of the event simulations. Great floods registered in May 2011 and May 2017, with hourly and 15-minute time-interval data, respectively, were chosen for the modeling. The next step included the representation of the meteorological processes involved in the watershed simulation described by the meteorology model in HEC-HMS. The mean precipitation per sub-basin was calculated using the inverse distance squared method.

Table 1 shows the methods used to represent the hydrological processes in the sub-basins and the respective parameters. The process of runoff generation in the watersheds was 
represented by the Soil Moisture Accounting Loss (SMA) method, which considers losses by infiltration and deep percolation, and the representation of the water storage in three layers of the soil. The excess rainfall calculated by the SMA method was transformed into a runoff with the application of the Snyder Synthetic Unit Hydrograph Model (Snyder UH). Unit Hydrograph Models (UH) theories are largely known and applied for several hydrological studies (Yue and Hashino, 2000; Harto Br et al., 2012). The UH models establish the direct runoff hydrograph produced by the effective rainfall spatially distributed and constant intensity in a specified unit of time.

Table 1. Methods used to represent the hydrological processes.

\begin{tabular}{ccl}
\hline Basin Element & Method & Parameters \\
\hline Canopy & Simple Canopy & Initial and maximum storage \\
\hline Surface & Simple Surface & Initial and maximum storage \\
Loss & $\begin{array}{c}\text { Soil Moisture } \\
\text { Accounting }\end{array}$ & $\begin{array}{l}\text { Initial soil storage, soil storage capacity, soil percolation, impervious, } \\
\text { initial groundwater, groundwater storage capacity, groundwater } \\
\text { percolation, maximum infiltration rate }\end{array}$ \\
\hline Transform & Snyder UH & Lag time and peak coefficient \\
\hline Baseflow & Linear Reservoir & Initial baseflow and groundwater coefficient \\
\hline Routing & Muskingum-Cunge & Manning coefficient \\
\hline
\end{tabular}

Equation 1 shows the computation routine for a direct runoff with the UH model in the HEC-HMS. The discharge at the outlet of the basin is obtained by multiplying the excess rainfall by the UH ordinate discretized in pulses for each time interval.

$\mathrm{Q}_{\mathrm{n}}=\sum_{\mathrm{m}=1}^{\mathrm{n} \leq \mathrm{M}} \mathrm{P}_{\mathrm{m}} \mathrm{U}_{\mathrm{n}-\mathrm{m}+1}$

Where:

$\mathrm{Q}_{\mathrm{n}}$ is the discharge at time $\mathrm{n} \Delta \mathrm{t}$

$\mathrm{P}_{\mathrm{m}}$ is the excess rainfall depth from the time interval $\mathrm{m} \Delta \mathrm{t}$ until $(\mathrm{m}+1) \Delta \mathrm{t}$

$\mathrm{M}$ is the total number of discrete rainfall pulses

$\mathrm{U}_{\mathrm{n}-\mathrm{m}+1}$ is the ordinate $\mathrm{UH}$ at the time $(\mathrm{n}-\mathrm{m}+1) \Delta \mathrm{t}$.

$\mathrm{Q}_{\mathrm{n}}$ and $\mathrm{P}_{\mathrm{m}}$ are expressed as discharge and depth, and $\mathrm{U}$ has dimensions of discharge per unit depth. The input data for the Snyder UH model is lag time in hours, and the peak coefficient, which is related to the hydrograph slope that results from a unit precipitation. In this study, the lag time was calculated, taking $60 \%$ of the time of concentration from each subbasin. The Kirpich method (Equation 2) was used to calculate the time of concentration in the sub-basins. The peak coefficient typically ranges from 0.4 to 0.8 , with lower values associated with steep-rising hydrographs. It was estimated in a trial-and-error process during the model calibration.

$\mathrm{t}_{\mathrm{c}}=57 \cdot\left(\frac{\mathrm{L}^{3}}{\mathrm{H}}\right)^{0.385}$

Where

$t_{c}$ is the time of concentration in min

$\mathrm{L}$ is the length of the largest watercourse in $\mathrm{km}$

$\mathrm{H}$ is the altitude difference between the highest and lowest points of the largest watercourse 
in meters

\subsection{Hydrodynamic Model}

Following hydrological modeling and calibration of the HEC-HMS, the sub-daily analysis of the extreme flood events in the URB was performed with the HEC-RAS (Hydrologic Engineering Center-River Analysis System) hydrodynamic model. Two types of hydrodynamic simulations were conducted. The first one consisted of one-dimensional (1D) simulation, using high-resolution DTM to represent the geometry of the rivers (cross-sections and channel bottom slope). There is only one parameter, Manning's roughness coefficient, that represents the energy loss. The reaches simulated in the HEC-RAS 1D mode and the cross sections are shown in Figure 2. The upstream and lateral inflow boundary conditions come from the HEC-HMS simulations. The downstream boundary condition was the tide variation calculated using harmonic constants of the region near the mouth of the Una River. The second approach of the HEC-RAS used in this study incorporated the two-dimensional (2D) capability for flow routing. The HEC-RAS 1D and 2D models were prepared with the HEC-GeoRAS extension, which is used to build the cross-sections, the course of the rivers, extract the geometry of the terrain, and create the 2D flow area computational mesh.

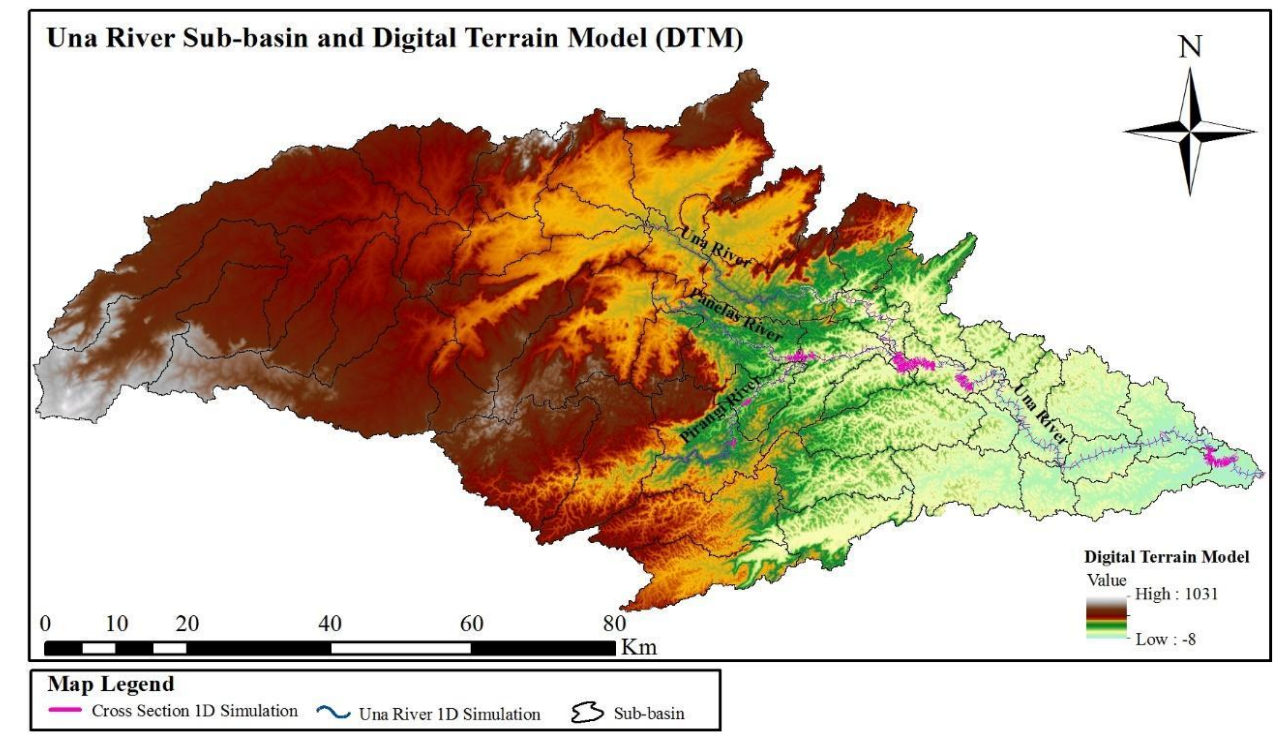

Figure 2. Simulated reaches and the cross sections in the HEC-RAS 1D model.

Unsteady flow components with subcritical flow regimes in 1D and 2D simulations are similar for the representation of the river's natural conditions. Unsteady flow routing from HEC-RAS added the continuity and momentum equations known as Saint Venant or Diffusion Wave equations (USACE and HEC, 2016). In 2D simulations, the HEC-RAS considers a gridded terrain model approach to represent the flow in two possible directions. In the 1D unsteady flow model solution, some issues are connected to instabilities of simulations, such as rapid changes in depth, area, and velocity between neighboring cross-sections due to the steepness of the channel at some reaches. USACE and HEC (2016) exposed several options to solve these cases of instabilities. One of them is the possibility of increasing the Manning's coefficient values in reaches where critical depths and steep channel bottom slopes occur. Another solution is the 2D simulations for flow routing. These solutions were executed in combination with the hydrodynamic model calibration.

\subsection{Model Calibration}

Part of the model parameters was estimated based on physical characteristics of the basins

Rev. Ambient. Água vol. 15 n. 5, e2556 - Taubaté 2020 
and other parts estimated in the process of calibration, comparing measured and simulated hydrographs. One of the parameters calibrated was the Snyder UH peak coefficient, in which there is no direct physical measurement in watersheds. The HEC-HMS model calibration was performed initially for the largest flood event in 2017, using pluviograph data and then applied for the 2011 event.

Three criteria were used to evaluate the simulations: i) Nash-Sutcliffe efficiency (NSE); ii) percent bias (Pbias), which measures the average tendency; and iii) RSR, the ratio between RMSE and the standard deviation of the measured values (STDV $\left.{ }_{\mathrm{obs}}\right)$, where RMSE is the root mean square error. The NSE (Equation 3) is equivalent to linear regression calculated by the coefficient of determination $\mathrm{R}^{2}$, with variation between 0 and 1 . However, NSE may vary from $-\infty$ to 1 , where the values lower or equal to zero do not fit to the observed values. Pbias and RSR were calculated with Equations 4 and 5. The best value of Pbias is zero. Negative values indicate an overestimation of the calculated variable, while positive values indicate underestimation.

$$
\begin{aligned}
& \text { NSE }=1-\left(\frac{\sum_{\mathrm{i}=1}^{\mathrm{n}}\left(\mathrm{q}_{\mathrm{o}}(\mathrm{i})-\mathrm{q}_{\mathrm{s}}(\mathrm{i})\right)^{2}}{\sum_{\mathrm{i}=1}^{\mathrm{n}}\left(\mathrm{q}_{\mathrm{o}}(\mathrm{i})-\mathrm{q}_{\mathrm{ave}}(\mathrm{i})\right)^{2}}\right) \\
& \text { Pbias }=\frac{\sum_{\mathrm{i}=1}^{\mathrm{n}}\left(\mathrm{q}_{\mathrm{o}}(\mathrm{i})-\mathrm{q}_{\mathrm{s}}(\mathrm{i})\right)}{\sum_{\mathrm{i}=1}^{\mathrm{n}}\left(\mathrm{q}_{\mathrm{o}}(\mathrm{i})\right)} \\
& \text { RSR }=\frac{\text { RMSE }}{\operatorname{STDV}_{\mathrm{obs}}}=\frac{\sqrt{\sum_{\mathrm{i}=1}^{\mathrm{n}}\left(\mathrm{q}_{\mathrm{o}}(\mathrm{i})-\mathrm{q}_{\mathrm{s}}(\mathrm{i})\right)^{2}}}{\sqrt{\sum_{\mathrm{i}=1}^{\mathrm{n}}\left(\mathrm{q}_{\mathrm{o}}(\mathrm{i})-\mathrm{q}_{\mathrm{ave}}(\mathrm{i})\right)^{2}}}
\end{aligned}
$$

Where $\mathrm{n}$ is the number of samples, $\mathrm{q}_{\mathrm{o}}(\mathrm{i})$ is the observed streamflow, $\mathrm{q}_{\mathrm{s}}(\mathrm{i})$ is the simulated streamflow and qave is the average observed streamflows. Moriasi et al. (2007) developed an analysis to recommend values of accuracy for hydrological simulations. Although Moriasi et al. (2007) indicate a classification for monthly time-step simulations, we took it into account as a first reference to evaluate the quality of the sub-daily simulations.

The calibration of the HEC-RAS model was performed with the estimate of the Manning's roughness coefficient, pursuing physically coherent values and stable simulations. The hydrodynamic model was validated with the observed water level time series of the Palmares stream gauge (shown in Figure 1). The entire methodological procedure is described in Figure 3.

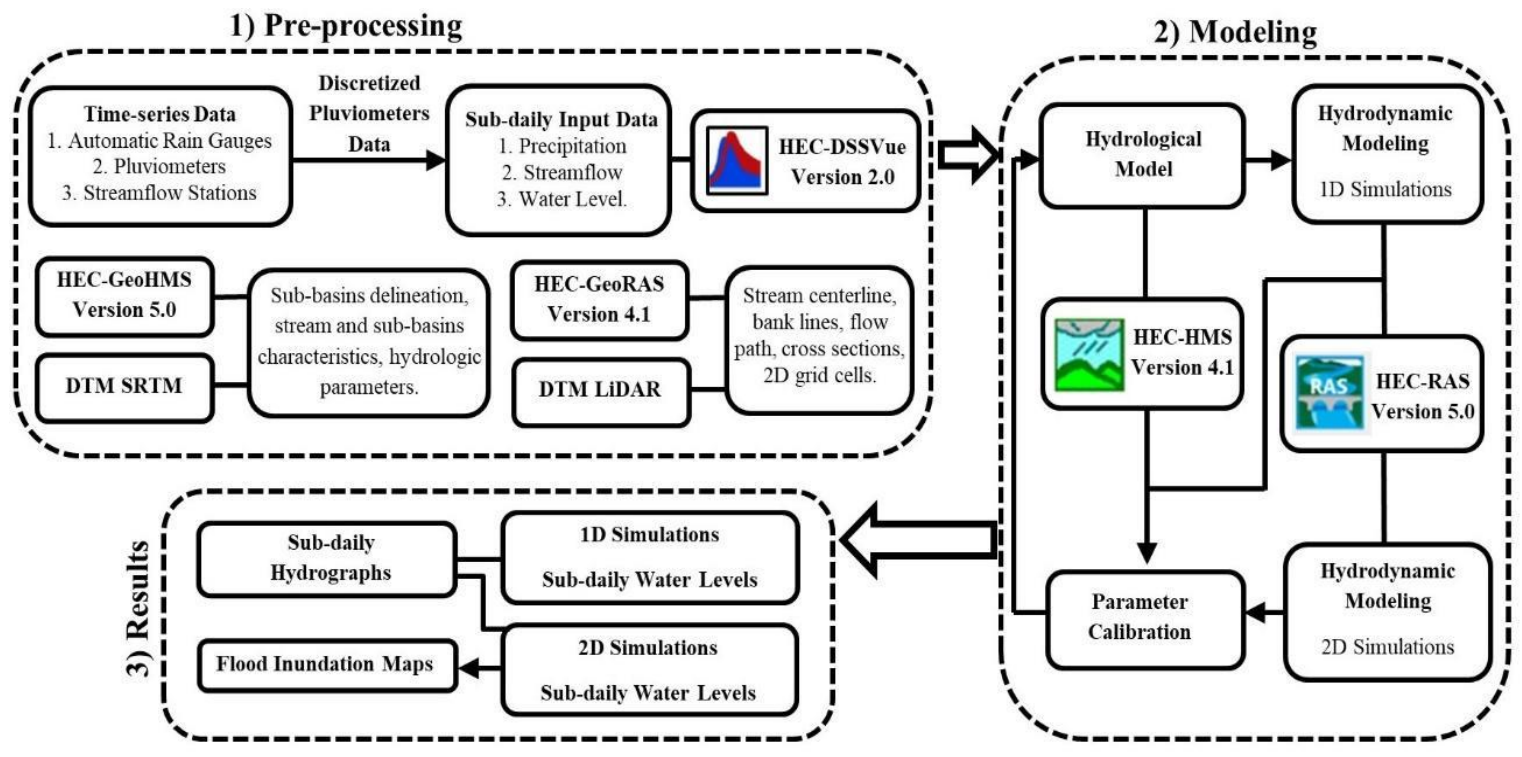

Figure 3. Methodological procedure. 


\section{RESULTS AND DISCUSSION}

\subsection{Hydrological Modeling}

The previous daily HEC-HMS simulations in the URB were performed with the SCS UH method to transform the excess rainfall in runoff. The same method applied in a sub-daily simulation generates great values of discharge due to its way of calculating the peak flow. The decision to use Snyder UH aimed to overcome this problem. The parameters of infiltration and peak coefficient (from the Snyder UH method) presented the greatest sensitivity in the calibration process of sub-daily event-based simulations. Figure 4 shows the simulated and observed streamflow of the stations Catende and Palmares for the events of May 2017 and May 2011. Table 2 shows the values of the criteria used to evaluate the calibration of the HEC-HMS. According to the classification of Moriasi et al. (2007), the simulation performance can be considered between good and very good (RSR and NSE), which reflects the agreement between the hydrographs simulated and observed after the calibration of the HEC-HMS model. Pbias had unsatisfactory values for Palmares in May 2017 due to disagreement between the hydrographs at the end of the recession. There is no data to represent the peak flow in the 2017 event because the water level rose beyond the validated segment of the rating curve, i.e., water level is available, but streamflow not.

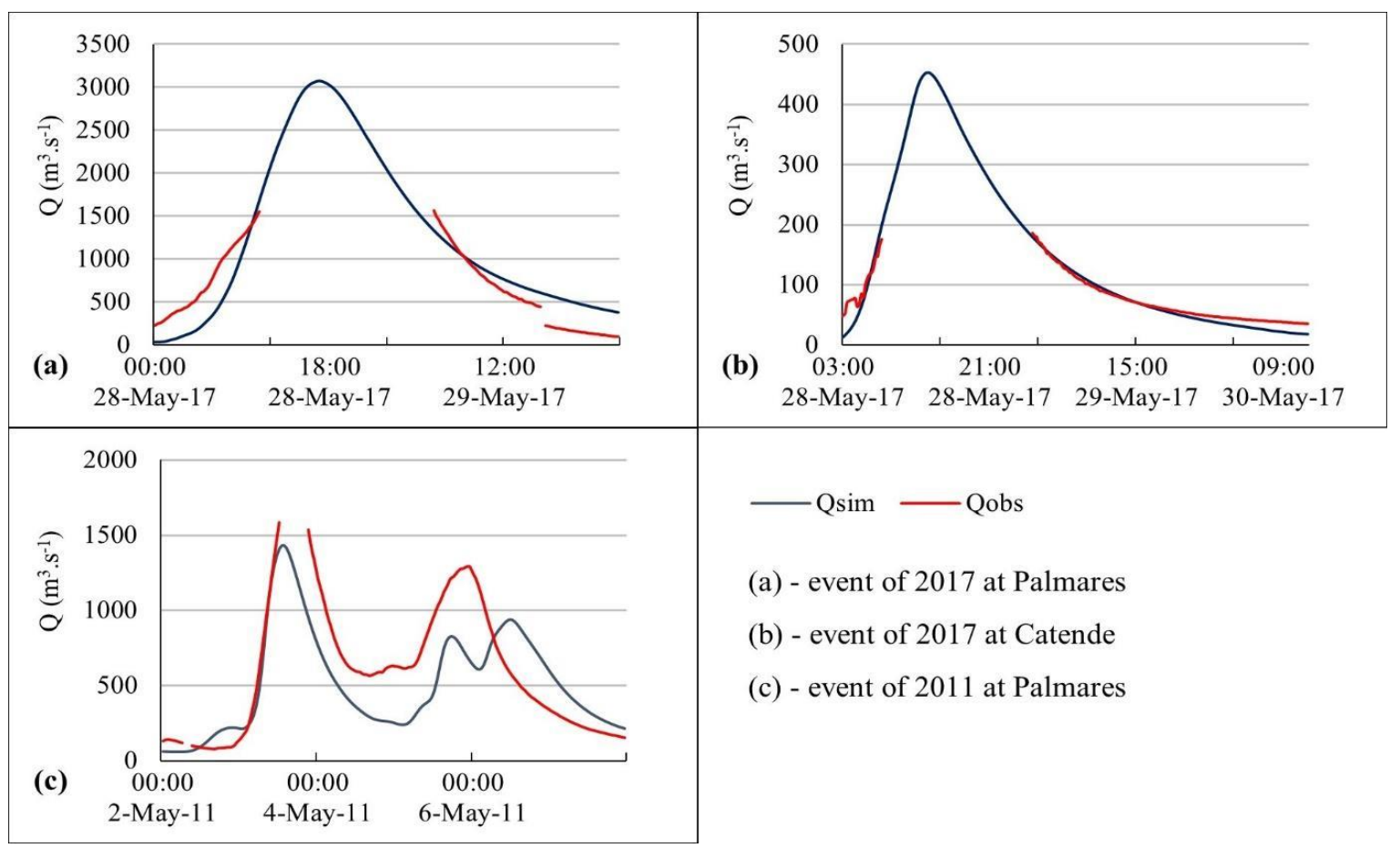

Figure 4. Streamflows observed $\left(\mathrm{Q}_{\mathrm{obs}}\right)$ and simulated $\left(\mathrm{Q}_{\mathrm{sim}}\right)$ with HEC-HMS.

Table 2. Calibration performance.

\begin{tabular}{ccccc}
\hline Station & Date & RSR & NSE & Pbias (\%) \\
\hline Catende & $28 / 05 / 2017$ & 0.46 & 0.78 & 20.5 \\
Palmares & $28 / 05 / 2017$ & 0.57 & 0.68 & -34.1 \\
Palmares & $03 / 05 / 2011$ & 0.58 & 0.64 & -4.9 \\
\hline
\end{tabular}

The number of rain gauges with sub-daily data available in 2011 was limited for the hydrological simulations, as they did not cover the entire Una River Basin. For this reason, the use of discretized data from daily rain gauges made it possible to perform the sub-daily 
simulation. Palmares was the only stream gauge with observed data for comparison in the 2011 event. The simulation performance was good according to two criteria, presenting NSE and RSR with good approximation between the observed and simulated data. Pbias had a slight tendency to underestimate the observed streamflow. This was noticeable in the hydrograph recession of the first peak flow and in the rise of the second peak (Figure 4c).

The results obtained with discretized data from daily rain gauges can be considered satisfactory after the calibration of the 2011 event. It is worth mentioning again that the classification proposed by Moriasi et al. (2007) has been based on monthly simulation, while the simulation presented here used a one-hour time step. In this case, all event results were accepted as satisfactory for the continuity of the following steps of the hydrodynamic modeling. There are not many studies that deal with hydrological simulation in watersheds with similar characteristics to URB, i.e., a medium-size drainage area and steep slope. Simulations using HEC-HMS have been very successful in small basins and rainfall representations with highresolution radar (P.C. et al., 2019; Mejía-Veintimilla et al., 2019), and, in some cases, in mountainous regions (Tu et al., 2020; Mejía-Veintimilla et al., 2019). Similar applications were not found in medium-sized basins. The better performance found in these studies in comparison to URB can be explained by the accurate representation of the spatial distribution of the precipitation using meteorological radar.

\subsection{Hydrodynamic Modeling}

The first approach considered in the modeling with HEC-RAS utilized a one-dimensional scheme according to prior studies that adopted a daily time step (Dantas et al., 2014; Ribeiro Neto et al., 2015). The reaches simulated in the URB are shown in Figure 1. In the prior studies, the results of the daily simulations were satisfactory; however, without information about the streamflow and water level behavior over the hours. The sub-daily one-dimensional simulation showed a considerable lag between the simulated and observed peak flows. Differently from the streamflow data, there was sub-daily water level data available without missing values. The sub-daily one-dimensional simulation allowed us to verify a delay of the simulated flood wave of 12 hours in the 2017 event and 7 hours in 2011. Due to this delay, the sub-daily onedimensional simulation was considered unsatisfactory according to the criteria of Moriasi et al. (2007). The peak lag occurred due to numerical instabilities of the solution for the subcritical flow regime with exacerbated water level variation between the cross-sections. The reduction of the Manning's coefficient attenuated the difference of the peak time occurrence, but, at the same time, the streamflow and the water level reduced substantially.

Steep slope rivers represent a great difficulty for hydrodynamic simulation in unsteady flow regimes. The one-dimensional solution is suitable for gradually varied flow, which is not observed in steep slope rivers. In those cases, there are reaches where there occurs rapidly varied flow with transitions from subcritical to supercritical flow and hydraulic jumps. The floods in the Una River have high water velocity and variation in reaches with a steep slope. The analysis of the one-dimensional simulation shows great changes in the hydraulic variables (water velocity, depth and area) in neighboring cross-sections, hindering a stable solution of the HECRAS 1D. For this reason, we performed two-dimensional simulation.

From Version 5.0, the HEC-RAS incorporated tools for two-dimensional hydrodynamic modeling. The software solves the Saint-Venant equations in its two-dimensional form with an implicit finite volume solution algorithm. According to USACE (2016), this method allows the solution of complex computational problems in less time than the explicit methods, and the two-dimensional hydrodynamic problems are solved with more stability and robustness. Figure 5 shows the computational grid cells for the two-dimensional modeling at the city of Palmares in Pernambuco state (only this area was simulated). The upstream boundary condition was the discharge simulated by the HEC-HMS model. 


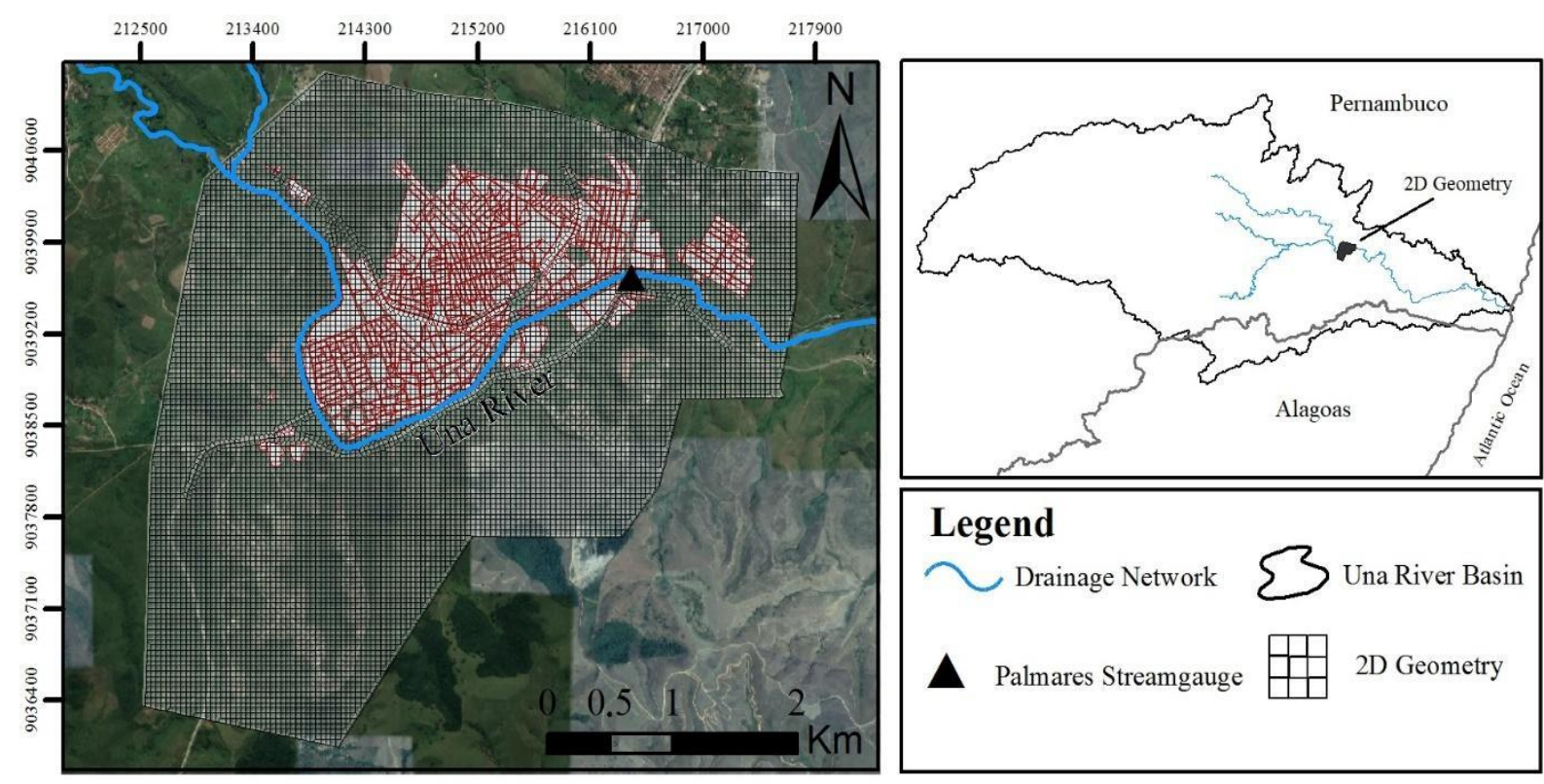

Figure 5. Computational grid cells for the two-dimensional modeling at the city of Palmares.

The result after HEC-HMS and HEC-RAS 2D simulations is shown in Figure 6, where the simulated and observed values of the peak time and the corresponding water level are also presented. In the 2011 event, the peak time and the water level simulated were the same in the first flood wave (03/05/2011). On the other hand, the water level in the rising of the first peak and in the descending water after the second peak were overestimated (Figure 6a). The water level simulated in the 2017 event also had the same value as the observed level. However, the time of the simulated peak occurred one hour before the real value. Similar to the 2011 event, the HEC-RAS 2D overestimated the water level in the descending part of the limnigram. There was an opportunity to evaluate the extension of the flood through the comparison of the map generated by HEC-RAS and information obtained in the field after the 2011 event. There was a good agreement between the maps (shown in Figure 7a), except for the central area, where the inundation estimated by the model spread beyond the limit surveyed in the field. The survey was carried out by the Geological Survey of Brazil (CPRM). The flood mapping of the 2017 event is shown in Figure 7b. In the absence of the observed flooding extent in extreme events, as occurred in 2017, the simulated flood mapping can be a reference for decision makers in charge of actions related to disaster management.

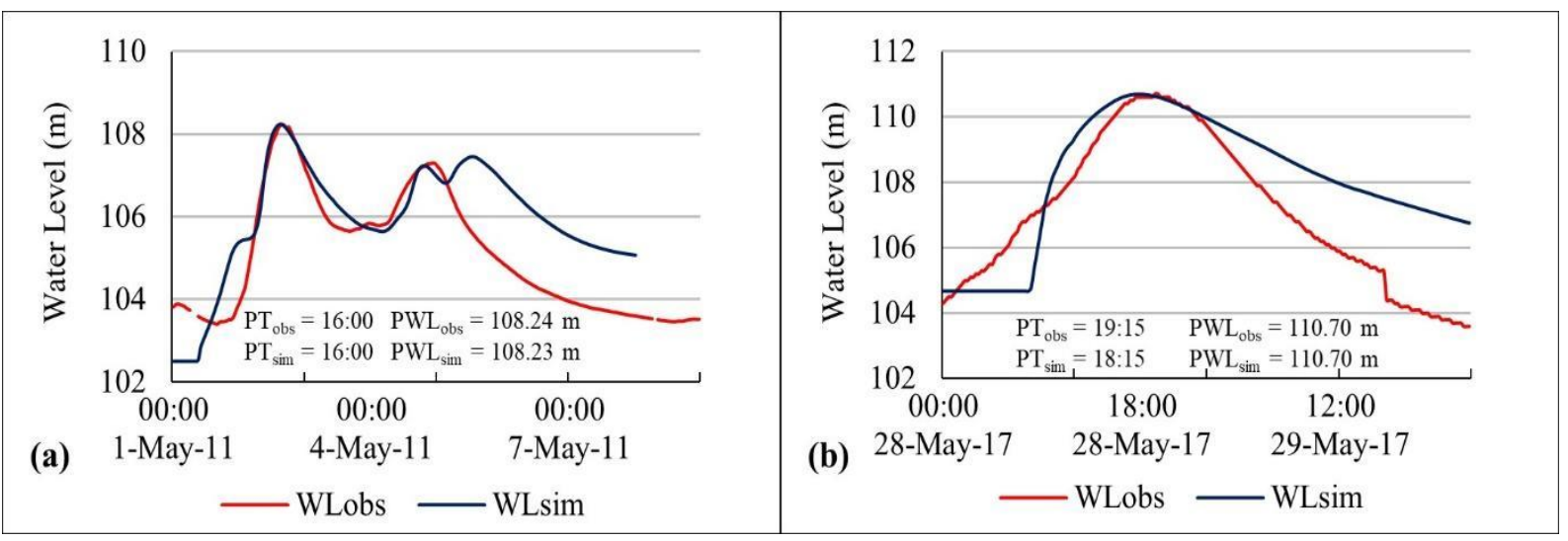

Figure 6. Water level simulated (WLsim) and observed (WLobs) in May 2011 (a) and May 2017 (b) at

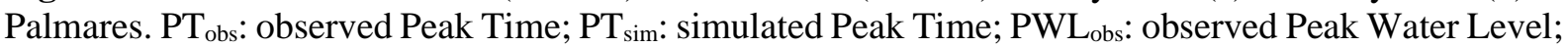
PWL $_{\text {sim: }}$ simulated Peak Water Level. 

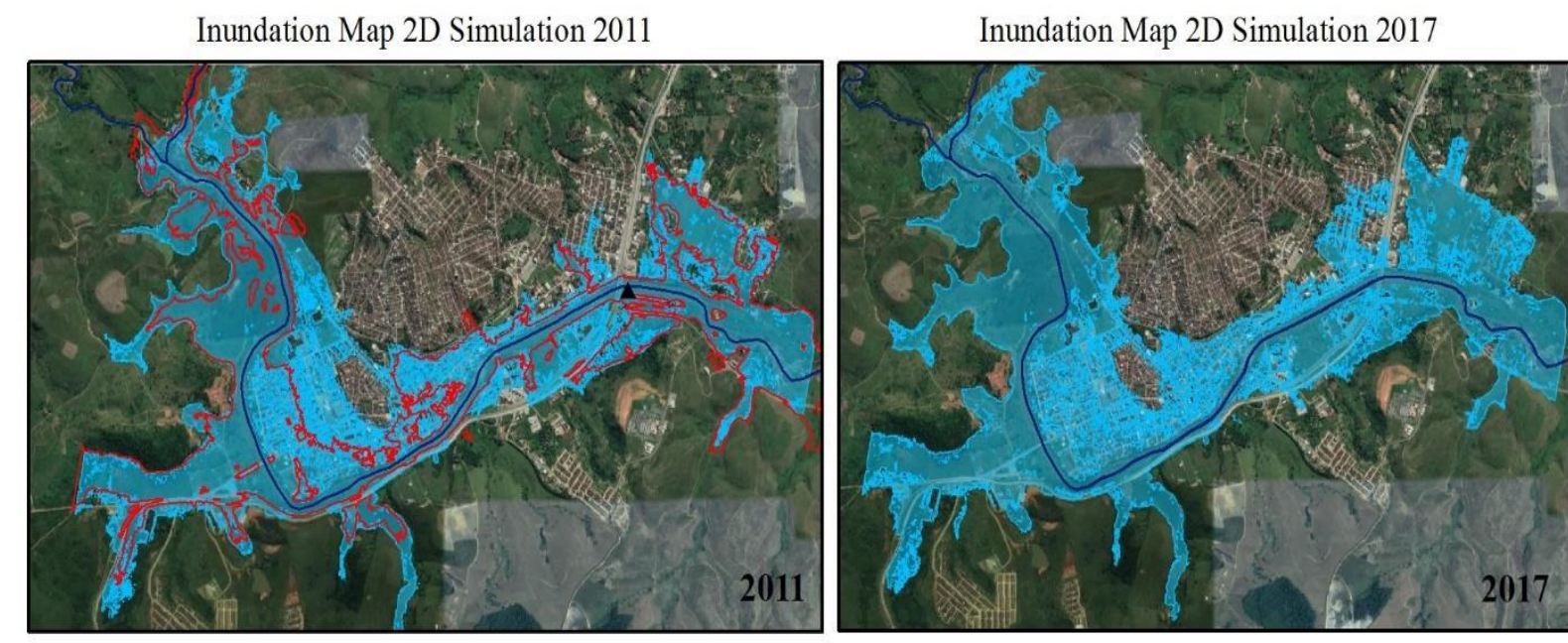

Legend

$\curvearrowleft$ Una River

$\Delta$ Palmares Station

Observed Inundation Limits 2011

Simulated Inundation Limits

Figure 7. Flood mapping of the 2011 event (with in situ survey) and 2017 event.

\section{CONCLUSIONS}

Hydrological HEC-HMS model calibration performance pointed to good efficiency of the Una River flash flood simulations with hourly and sub-hourly (15 minutes) time steps. Automatic rain gauges and discretized pluviometers data allowed knowing in detail peak flow during the day of the flood events. The hydrological calibration using rain gauge data proved satisfactory for simulation in different flood events. The conversion of daily rainfall to hourly time steps using an automatic rain gauge was shown to be reliable and could be used when subdaily data are not available.

The steep regions in the URB were the main factor of instabilities for the 1D hydrodynamic model solution. The HEC-RAS computation routine for 1D unsteady flow was not enough to describe the propagation of flood waves satisfactorily. Thus, 2D simulations provided flood wave propagation in the 2011 and 2017 events with a good approximation of the peak time and flow.

HEC-HMS and HEC-RAS models with sub-daily simulations allowed us to identify deficiencies non-observed in daily time-step simulations. In the case of the hydrological model, a previous method (SCS UH) for the transformation of excess rainfall in runoff was tested during the modeling. This methodology tends to generate great discharges with time steps lower than one day. The Snyder UH method solved this problem, being suitable for sub-daily simulations. In the case of the hydrodynamic model, there was a great discrepancy between observed and simulated data in terms of peak time representation over the day when 1D simulations were performed. This inconsistency was settled with the $2 \mathrm{D}$-simulations model scheme.

\section{ACKNOWLEDGMENTS}

This article is a contribution of the project "Medidas Adaptativas para Enfrentamento de Eventos Climáticos e Hidrológicos Extremos no Estado de Pernambuco" (contract FADE/UFPE n. 104/2017) and the Brazilian Network on Global Climate Change Research Rede CLIMA (Grant 01.13.0353-00). 


\section{REFERENCES}

ALVES, F. H. B.; CIRILO, J. A. Comparativo das precipitações dos eventos extremos de 2010 e 2017 ocorridos na bacia do rio Una em Pernambuco e estimativa dos efeitos de barragem de contenção de cheias. In: SIMPÓSIO BRASILEIRO DE RECURSOS HÍDRICOS, 2017, Florianópolis. Proceedings[...] Florianópolis: ABRH, 2017.

AMPONSAH, W.; MARCHI, L.; ZOCCATELLI, D.; BONI, G.; CAVALLI, M.; COMITI, F.; CREMA, S.; LUCÍA, A.; MARRA, F.; BORGA, M. Hydrometeorological characterization of a flash flood associated with major geomorphic effects: assessment of peak discharge uncertainties and analysis of the runoff response. American Meteorological Society, v. 17, p. 3063-3077, 2016. https://doi.org/10.1175/JHM-D-160081.1

BALLESTEROS, J. A.; BODOQUE, J. M.; DÍEZ-HERRERO, A.; SANCHEZ-SILVA, M.; STOFFEL, M. Calibration of floodplain roughness and estimation of flood discharge based on tree-ring evidence and hydraulic modeling. Journal of Hydrology, v. 403, n. 1-2, p. 103-115, 2011. https://doi.org/10.1016/j.jhydrol.2011.03.045

BOITHIAS, L.; SAUVAGE, S.; LENICA, A.; ROUX, H.; ABBASPOUR K. C.; LARNIER, K.; DARTUS, D.; SÁNCHEZ-PÉREZ, J. M. Simulating flash floods at hourly time-step using the SWAT model. Water, v. 9, n. 929, p. 1-25, 2017. https://doi.org/10.3390/w9120929

CONDEPE. Bacia hidrográfica do rio Una, quarto e quinto grupos de bacias hidrográficas de pequenos rios litorâneos - GL 4 e GL 5. Recife, 2006. 85 p.

DANTAS, C. E. O.; RIBEIRO NETO, A.; CIRILO, J. A.; DANTAS, C. E. O.; SILVA, E. R. Caracterização da formação de cheias na bacia do rio Una em Pernambuco: Análise estatística regional. Revista Brasileira de Recursos Hídricos, v. 19, n. 4, p. 239-248, 2014.

HABERT, J.; RICCI, S.; LE PAPE, E.; THUAL, O.; PIACENTINI, A.; GOUTAL, N.; JONVILLE, G.; ROCHOUX, M. Reduction of the uncertainties in the water leveldischarge relation of a $1 \mathrm{D}$ hydraulic model in the context of operational flood forecasting. $\begin{array}{lllllll}\text { Journal of Hydrology, } & \text { v. 532, p. }\end{array}$ https://doi.org/10.1016/j.jhydrol.2015.11.023

HARTO BR, S.; YUDIYANTI, I. T.; COENRAAD, R. Performance of representative unit hydrograph derived from different number of cases. Journal of the Civil Engineering Forum, v. 21, n. 2, p. 1243-1248, 2012. https://doi.org/10.22146/jcef.18930

LI, D.; QU, S.; SHI, P.; CHEN, X.; XUE, F.; GOU, J.; ZHANG, W. Development and integration of sub-daily flood modelling capability within the SWAT model and a comparison with XAJ model. Water, v. 10, n. 1263, p. 1-17, 2018. https://doi.org/10.3390/w10091263

MATINGO, T.; GUMINDOGA, W.; MAKURIRA, H. Evaluation of sub daily satellite rainfall estimates through flash flood modelling in the Lower Middle Zambezi Basin. Proceedings of the International Association of Hydrological Sciences, v. 378, p. 5965, 2018. https://dx.doi.org/10.5194/piahs-378-59-2018 
MEJÍA-VEINTIMILLA, D.; OCHOA-CUEVA, P.; SAMANIEGO-ROJAS, N.; FÉLIX, R.; ARTEAGA, J.; CRESPO, P.; OÑATE-VALDIVIESO, F.; FRIES, A. River Discharge Simulation in the High Andes of Southern Ecuador Using High-Resolution Radar Observations and Meteorological Station Data. Remote Sensing, v. 11, 2019. https://dx.doi.org/10.3390/rs11232804

MORIASI, D. N.; ARNOLD, J. G.; LIEW, M. W. V.; BINGNER, R. L.; HARMEL, R. D.; VEITH, T. L. Model evaluation guidelines for systematic quantification of accuracy in watershed simulation. American Society of Agricultural and Biological Engineers, v. 50, n. 3, p. 885-900, 2007. https://dx.doi.org/10.13031/2013.23153

OHANA-LEVI, N.; KARNIELI, A.; EGOZI, R.; GIVATI, A.; PEETERS, A. Modeling the effects of land-cover change on rainfall-runoff relationships in a semiarid, Eastern Mediterranean watershed. Advances in Meteorology, p. 1-16, 2015. https://doi.org/10.1155/2015/838070

P.C., S.; NAKATANI, T.; MISUMI, R. The Role of the Spatial Distribution of Radar Rainfall on Hydrological Modeling for an Urbanized River Basin in Japan. Water, v. 11, n. 1703, 2019. https://doi.org/10.3390/w11081703

RIBEIRO NETO, A.; CIRILO, J. A.; DANTAS, C. E. O.; SILVA, E. R. Caracterização da formação de cheias na bacia do rio Una em Pernambuco: Simulação hidrológicahidrodinâmica. Revista Brasileira de Recursos Hídricos, v. 20, n. 2, p. 394-403, 2015.

UNITED STATES. Army. Corps of Engineers; HYDROLOGIC ENGINEERING CENTER. HEC-RAS River Analysis System: Hydraulic Reference Manual: Version 5.0. Davis, 2016. $547 \mathrm{p}$.

TU, H.; WANG, X.; ZHANG, W.; PENG, H.; KE, Q.; CHEN, X. Flash Flood Early Warning Coupled with Hydrological Simulation and the Rising Rate of the Flood Stage in a Mountainous Small Watershed in Sichuan Province, China. Water, v. 12, 2020. https://dx.doi.org/10.3390/w12010255

YUE, S.; HASHINO, M. Unit hydrographs to model quick and slow runoff components of streamflow. Journal of Hydrology, v. 227, p. 195-206, 2000. https://doi.org/10.1016/S0022-1694(99)00185-7 


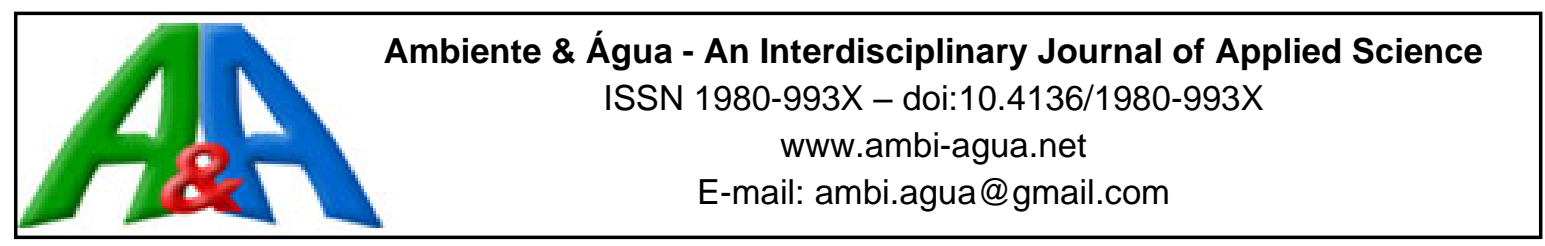

\title{
Photochemical efficiency in pineapple plants under saline water irrigation
}

\author{
ARTICLES doi:10.4136/ambi-agua.2564
}

Received: 22 Apr. 2020; Accepted: 28 Jul. 2020

\author{
Cleiton Fernando Barbosa Brito ${ }^{1 *}$; ; Varley Andrade Fonseca1(D; \\ Marcelo Rocha dos Santos ${ }^{2}$; Sérgio Luiz Rodrigues Donato ${ }^{2}$; \\ Alessandro de Magalhães Arantes ${ }^{\text {iD }}$; Aloísio José dos Santos² \\ 1Departamento de Ciências Agrárias. Universidade Estadual de Montes Claros (UNIMONTES), Caixa Postal 91, \\ CEP: 39440-000, Janaúba, MG, Brazil. E-mail: varley.ibce@ig.com.br \\ ${ }^{2}$ Setor de Agricultura. Instituto Federal de Educação, Ciência e Tecnologia Baiano (IFBaiano), Caixa Postal 09, \\ CEP: 46430-000, Guanambi, BA, Brazil. E-mail: marcelo.rocha@ifbaiano.edu.br, \\ sergio.donato@guanambi.ifbaiano.edu.br, alessandro.arantes@guanambi.ifbaiano.edu.br, \\ aloisio.santos@ifbaiano.edu.br \\ *Corresponding author. E-mail: cleiton.ibce@ hotmail.com
}

\begin{abstract}
Studies determining physiological characteristics of field-grown pineapples irrigated with low-quality water are lacking. This work evaluated the photochemical efficiency of 'Pérola' pineapple irrigated with saline water in the semiarid region of Bahia, Brazil. The experiment was carried out in randomized blocks with five treatments consisting of the following irrigation depths: $100 \%$ of $\mathrm{ET}_{\mathrm{c}}$ using water with electrical conductivity $\left(\mathrm{EC}_{\mathrm{w}}\right)$ of $0.75 \mathrm{dS} \mathrm{m}^{-1}$; and 50,75 , 100 and $125 \%$ of $\mathrm{ET}_{\mathrm{c}}$ using water with $\mathrm{EC}_{\mathrm{w}}$ of $3.6 \mathrm{dS} \mathrm{m}^{-1}$. Chlorophyll $a$ fluorescence measurements were made over the course of 13 months using a pulse-modulated fluorometer, in all treatments. Quantum efficiency $(\mathrm{Fv} / \mathrm{Fm})$ fluctuated throughout the cycle of the pineapple with values below the ideal, especially at the end of the crop cycle. Quantum yield of photosystem II (Yield), photochemical quenching ( $\left.\mathrm{q}_{\mathrm{P}}\right)$, non-photochemical quenching (NPQ) and chlorophyll fluorescence decrease ratio $\left(\mathrm{R}_{\mathrm{Fd}}\right)$ were not influenced by irrigation depths. Therefore, energy used for photosynthetic processes in pineapple plants is not affected by irrigation using saline water with electrical conductivity of $3.6 \mathrm{dS} \mathrm{m}$.
\end{abstract}

Keywords: Ananas comosus, CAM plants, chlorophyll fluorescence, salinity.

\section{Eficiência fotoquímica em plantas de abacaxi sob irrigação com água}

\section{RESUMO}

São escassos estudos que determinem as características fisiológicas do abacaxizeiro, em condições de campo, irrigadas com água de qualidade inferior. Assim, objetivou-se avaliar eficiência fotoquímica em abacaxizeiro 'Pérola' irrigado com água salina no semiárido baiano. $\mathrm{O}$ experimento foi conduzido em blocos casualizados com cinco tratamentos representados pelas lâminas de irrigação: $100 \%$ da $\mathrm{ET}_{\mathrm{c}}$ com água de condutividade elétrica $\left(\mathrm{CE}_{\mathrm{a}}\right)$ de $0,75 \mathrm{dS}$ $\mathrm{m}^{-1}$ e 50, 75, 100 e $125 \%$ da $\mathrm{ET}_{\mathrm{c}}$ com aplicação de água de $\mathrm{CE}_{\mathrm{a}}$ de $3,6 \mathrm{dS} \mathrm{m}^{-1}$. As leituras da fluorescência da clorofila "a" foram realizadas durante 13 meses através de fluorômetro de luz modulada, em todos os tratamentos. Verificou-se que a eficiência quântica (Fv/Fm) variou ao

This is an Open Access article distributed under the terms of the Creative Commons Attribution License, which permits unrestricted use, distribution, and reproduction in any medium, provided the original work is properly cited. 
longo do ciclo do abacaxizeiro com valores abaixo do ideal, principalmente, no final do ciclo. As variáveis rendimento quântico do fotossistema II (Yield), dissipação fotoquímica (qP), dissipação não-fotoquímica (NPQ) e taxa de redução de fluorescência $\left(\mathrm{R}_{\mathrm{Fd}}\right)$ não foram influenciadas pelas lâminas de irrigação avaliadas. Portanto, a utilização da energia nos processos fotossintéticos de plantas de abacaxizeiro não são influenciados pela irrigação com lâminas de água salina com condutividade elétrica de $3,6 \mathrm{dS} \mathrm{m}^{-1}$.

Palavras-chave: Ananas comosus, Fluorescência da clorofila, plantas CAM, salinidade.

\section{INTRODUCTION}

Pineapples (Ananas comosus L. Merril) are economically exploited in most Brazilian states, making an important contribution to employment and income generation (Franco et al., 2014), in which the states of Pará, Paraíba, Minas Gerais and Bahia are the biggest producers. In the state of Bahia, the municipality of Itaberaba stands out as the main producer (IBGE, 2020) and is located in the semi-arid region of the state.

In this context, the pineapple can become an alternative crop for other semiarid regions (Mota et al., 2016) since it has the potential of maintaining its yield under hotter and drier climates (Borland et al., 2014) owing to its crassulacean acid metabolism (CAM) (Zhang et al., 2014; Couto et al., 2016). CAM plants save water by closing their stomata during the day and opening them during the night with $\mathrm{CO}_{2}$ fixation, resulting in better water-use efficiency in dry conditions (Carr, 2012).

Studies were developed for irrigated pineapple grown in semiarid regions (Franco et al., 2014; Pegoraro et al., 2014; Maia et al., 2016); however, information about physiological characteristics of this crop irrigated with saline water is lacking, making field studies with pineapple subjected to saline conditions necessary (Elhag and Elzain, 2012).

Chlorophyll $a$ fluorescence is a non-invasive analysis that allows collecting data from the efficiency of the photochemistry stage of photosynthesis (Light or hill reaction) and hence is a reliable source of information about plant condition, especially under abiotic stress conditions (Murchie and Lawson, 2013; Goltsev et al., 2016).

Studies about physiological characteristics of pineapple in regard to fluorescence were mainly carried out in controlled environments such as greenhouses and laboratory, in vitro, using only plantlets (Vieira et al., 2010; Cruz et al., 2014; Couto et al., 2016). Thus field research into chlorophyll fluorescence comprising the whole pineapple cycle is much needed.

Fluorescence determination under field conditions can be useful for studies on physiological behavior of CAM plants (Díez et al., 2017), such as the pineapple, thereby shedding some light on the crop adaptability in context of the semiarid region. Therefore, this study evaluated photochemistry efficiency in 'Pérola' pineapple submitted to irrigation with saline water and water stress in the semiarid region of Bahia, Brazil.

\section{MATERIAL AND METHODS}

The study was carried out in an experimental area at the Federal Institute Baiano, Guanambi campus, located in the Irrigated Perimeter of Ceraíma, municipality of Guanambi, Bahia, Brazil. The mean annual rainfall depth of the region was $680 \mathrm{~mm}$, and the mean annual temperature was $26^{\circ} \mathrm{C}$. During the experimental period, there was a maximum average temperature $\left(\mathrm{T}_{\max }\right)$ of $32.07^{\circ} \mathrm{C}$ and a minimum averager temperature $\left(\mathrm{T}_{\min }\right)$ of $21.95^{\circ} \mathrm{C}$, relative humidity $(\mathrm{RH})$ of $55.65 \%$, gust wind of $46.70 \mathrm{~km} \mathrm{~h}^{-1}$, reference evapotranspiration $\left(\mathrm{ET}_{\mathrm{o}}\right)$ of $5.68 \mathrm{~mm} \mathrm{dia}^{-1}$ and a rain total of $728 \mathrm{~mm}$ (Figure 1).

Rev. Ambient. Água vol. 15 n. 5, e2564 - Taubaté 2020 

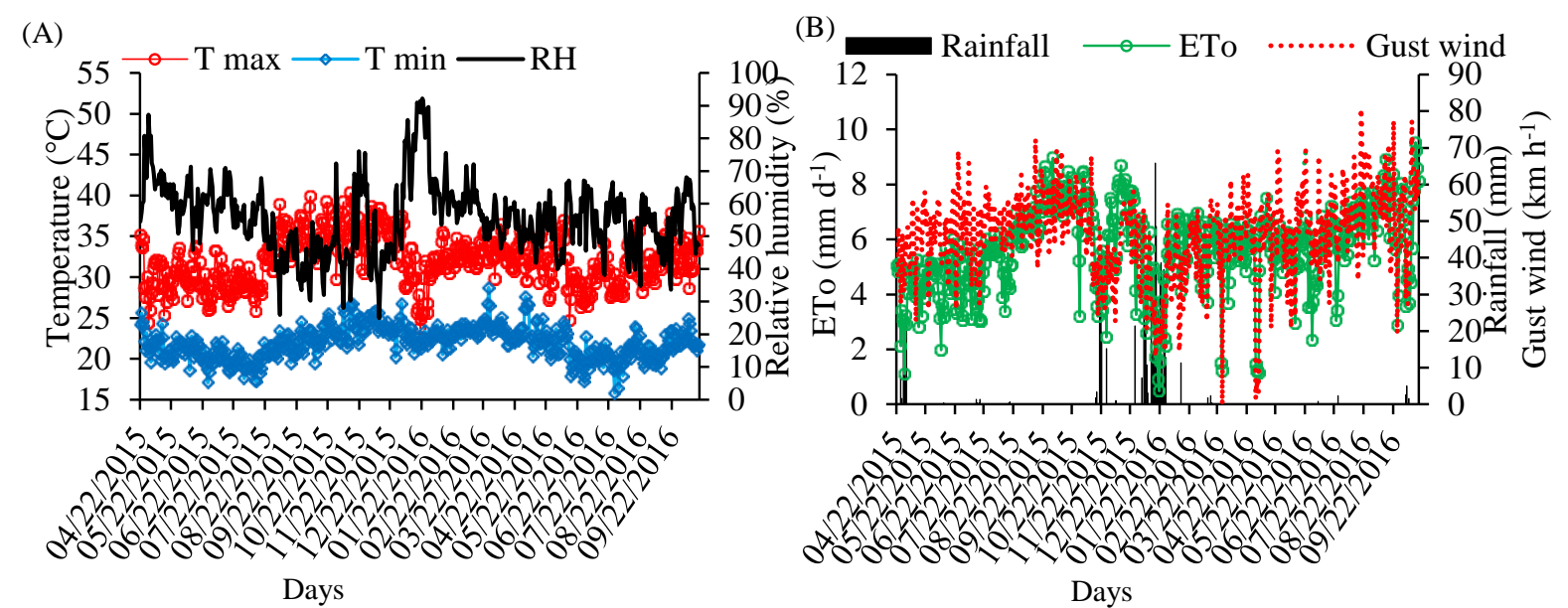

Figure 1. Temperature (maximum-Tmax and minimum-Tmin) and relative air humidity (RH) (A), gust wind speed, rainfall and reference evapotranspiration $\left(\mathrm{ET}_{\mathrm{o}}\right)(\mathrm{B})$ during the experimental period.

Pineapples were cultivated in a typic dystrophic Red Yellow Latosol, with weak A horizon, on flat to gently undulating relief. The soil chemical characteristics (Tedesco et al., 1995) in the layer of 0-20 cm before installing the experiment were: $\mathrm{pH}$ (in water) $=5.7 ; \mathrm{P}$ (Mehlich extractor $)=23.5 \mathrm{mg} \mathrm{dm}^{-3} ; \mathrm{K}$ (Mehlich extractor $)=108 \mathrm{mg} \mathrm{dm}^{-3} ; \mathrm{Na}=0.1 \mathrm{cmol}_{\mathrm{c}} \mathrm{dm}^{-3} ; \mathrm{Ca}=$ $1.4 \mathrm{cmol}_{\mathrm{c}} \mathrm{dm}^{-3} ; \mathrm{Mg}=0.6 \mathrm{cmol}_{\mathrm{c}} \mathrm{dm}^{-3} ; \mathrm{Al}=0.0 \mathrm{cmol}_{\mathrm{c}} \mathrm{dm}^{-3} ; \mathrm{H}+\mathrm{Al}=1.7 \mathrm{cmol}_{\mathrm{c}} \mathrm{dm}^{-3} ; \mathrm{SB}=2.4$ $\mathrm{cmol}_{\mathrm{c}} \mathrm{dm}^{-3} ; \mathrm{t}=2.4 \mathrm{cmol}_{\mathrm{c}} \mathrm{dm}^{-3} ; \mathrm{T}=4.1 \mathrm{cmol}_{\mathrm{c}} \mathrm{dm}^{-3} ; \mathrm{V}=58 \% ; \mathrm{B}=0.3 \mathrm{mg} \mathrm{dm}$; $\mathrm{Cu}=0.4 \mathrm{mg} \mathrm{dm}{ }^{-3} ; \mathrm{Fe}=16.0 \mathrm{mg} \mathrm{dm}^{-3} ; \mathrm{Mn}=32.5 \mathrm{mg} \mathrm{dm}{ }^{-3} ; \mathrm{Zn}=2.1 \mathrm{mg} \mathrm{dm}^{-3} ;$ $\mathrm{EC}_{\mathrm{e}}=0.7 \mathrm{dS} \mathrm{m}^{-1}$. Soil textural class was sandy loam clay (Sand $=68 \mathrm{dag} \mathrm{kg}^{-1} ;$ Silt $=11 \mathrm{dag} \mathrm{kg}^{-}$ ${ }^{1}$ and Clay $\left.=21 \mathrm{dag} \mathrm{kg}^{-1}\right)($ Embrapa, 2017).

'Pérola' pineapple seedlings (slips) were planted in April 2015 in a single row, at a spacing of $0.25 \mathrm{~m}$ between plants and $1.2 \mathrm{~m}$ between rows $\left(33,300\right.$ plants ha $\left.\mathrm{h}^{-1}\right)$. Soil correction and basal and top-dressing fertilizations were performed according to the soil analysis (Souza et al., 2007). During the experiment, cultivation and phytosanitary practices established for the crop were employed and there was low incidence of pests and diseases.

One month after planting, plants received foliar application of urea, zinc sulfate and potassium chloride $(\mathrm{KCl})$. After that, every two months, urea $\left(5 \mathrm{~g}^{\text {plant }}{ }^{-1}\right)$ and $\mathrm{KCl}$ $\left(2.5 \mathrm{~g} \mathrm{plant}^{-1}\right)$ were broadcasted.

Irrigation was applied through a drip system, using pressure-compensating emitters with nominal flow rate of $8 \mathrm{~L} \mathrm{~h}^{-1}$, spaced at $0.75 \mathrm{~m}$ apart, forming a continuous wet strip along plant rows. Until the fourth month after planting, irrigations were applied daily similarly in all plots, in order to maintain uniform soil water content and favor the initial growth of the seedlings and crop establishment. Then, irrigation depths started to be applied, and irrigation time was calculated based on crop evapotranspiration (ET $\mathrm{E}_{\mathrm{c}}$ ) (Santos et al., 2015) obtained using the reference evapotranspiration $\left(\mathrm{ET}_{\mathrm{o}}\right)$, determined daily through the Penman-Monteith method using data from a weather station installed approximately $200 \mathrm{~m}$ away from the experiment, and crop coefficient $(\mathrm{Kc})$, which was 0.8 at the initial stage of crop establishment and 1 for both the vegetative stage and after flower induction (reproductive stage), according to Santana et al. (2013).

The experiment was conducted in randomized blocks with five treatments consisting of the following irrigation depths: $100 \% \mathrm{ET}_{\mathrm{c}}$, using water with electrical conductivity $\left(\mathrm{EC}_{\mathrm{w}}\right)$ of $0.75 \mathrm{dS} \mathrm{m}^{-1}$ and C2S1 classification, and 50,75, 100 and $125 \% \mathrm{ET}_{\mathrm{c}}$, using water from a tubular well with $\mathrm{EC}_{\mathrm{w}}$ of $3.6 \mathrm{dS} \mathrm{m}^{-1}$, classified as C4S1 according to Ayers and Westcot (1985). Treatments had four replicates and the experimental unit consisted of four 8-m-long rows. Evaluations were made in plants from the central $4 \mathrm{~m}$ of the two central rows, totaling 26 
evaluated plants in the plot.

The water from tubular well has $\mathrm{pH}$ of $6.4,11.90 \mathrm{mEq} \mathrm{L}^{-1}$ of calcium, $9.54 \mathrm{mEq} \mathrm{L}^{-1}$ of magnesium, $0.48 \mathrm{mEq} \mathrm{L}^{-1}$ of potassium, $30.40 \mathrm{mEq} \mathrm{L}^{-1}$ of sodium, $0.00 \mathrm{mEq} \mathrm{L}^{-1}$ of carbonate, $4.10 \mathrm{mEq} \mathrm{L}^{-1}$ of bicarbonate and $34.80 \mathrm{mEq} \mathrm{L}^{-1}$ of chloride.

Pineapple flowering was artificially induced 13 months after planting, by applying ETHREL (240 $\mathrm{g} \mathrm{L}^{-1}$ of Ethephon), a synthetic growth regulator, precursor of the synthesis of ethylene, using a 20-L backpack sprayer. The backpack sprayer received $40 \mathrm{~mL}$ of ETHREL + $400 \mathrm{~g}$ of urea $(2 \%)$ to apply an estimated volume of $50 \mathrm{~mL}$ of the mixture inside the leaf rosette.

Chlorophyll $a$ fluorescence readings were made from August 2015 and September 2016 using a pulse-modulated fluorometer, model OS1-FL (OPTI-Sciences) in the morning (8 a.m.) and in the afternoon (2 p.m.). Clips used to measure chlorophyll fluorescence were positioned on the middle third of the ' $\mathrm{D}$ ' leaf, and the measurement was made after 5 min of dark adaptation, with an emission of a 0.3 -s-long saturation light pulse at a frequency of $0.6 \mathrm{KHz}$. Then, ground fluorescence $\left(\mathrm{F}_{0}\right)$, maximum fluorescence $(\mathrm{Fm})$, variable fluorescence $(\mathrm{Fv})$ and photochemistry efficiency (Fv/Fm) were recorded. During measurements, a clip for adapting chloroplast to the dark was used so that all photosystem II (PSII) reaction centers were "open" and heat loss was kept to a minimum (Strauss et al., 2006).

Additionally, readings were taken on light-adapted ' $D$ ' leaf, on which saturation pulses were applied to determine fluorescence under steady state (Fs), maximum fluorescence in the light-adapted state (Fms), variable fluorescence in the light-adapted state (Fvs), and quantum yield of PSII (Yield). Three dark-adapted readings and one light-adapted reading were taken at each identified plant. According to Lichtenthaler et al. (2005), photochemical quenching (qP), non-photochemical quenching (NPQ), and chlorophyll fluorescence decrease ratio $\left(\mathrm{R}_{\mathrm{Fd}}\right)$ were determined using the following Equations 1, 2 and 3:

$$
\begin{aligned}
& \mathrm{q}_{p}=(\mathrm{Fms}-\mathrm{F}) / \mathrm{Fvs} \\
& \mathrm{NPQ}=(\mathrm{Fm}-\mathrm{Fms}) / \mathrm{Fms} \\
& \mathrm{R}_{\mathrm{Fd}}=(\mathrm{Fm} / \mathrm{Fs})-1
\end{aligned}
$$

It is worth noting that the abbreviations qP (photochemical quenching), NPQ (nonphotochemical quenching) and $\mathrm{R}_{\mathrm{Fd}}$ (fluorescence decrease ratio) will be used in accordance with the international standard widely used in studies on chlorophyll fluorescence (Lichtenthaler et al., 2005).

Data were subjected to the analysis of variance and interactions were interpreted according to their significance. Variable means were compared by F-test and Tukey test $(p<0.05)$ for the factors reading times and irrigation depths, respectively; then, they were grouped by the ScottKnott criterion $(\mathrm{p}<0.05)$ for the factor evaluation season (months). Statistical analysis was performed with the statistical software 'R' (R Development Core Team, 2012).

\section{RESULTS AND DISCUSSION}

Quantum efficiency (Fv/Fm) of pineapple plants subjected to different irrigation depths with saline water over the months had a significant interaction between months and irrigation depths (Table 1). Nonetheless, significant differences were not observed across depths in all months of evaluation, except for November and December 2015. Irrigation depth $100 \%$ of ET using water with $\mathrm{EC}_{\mathrm{w}}$ of $0.75 \mathrm{dS} \mathrm{m}^{-1}$ differed from depths 50,100 and $125 \%$ of $\mathrm{ET}_{\mathrm{c}}$ using water with $3.6 \mathrm{dS} \mathrm{m}^{-1}$ in November; as for December, irrigation depth $100 \%$ of $\mathrm{ET}_{\mathrm{c}}$ using water of $\mathrm{EC}_{\mathrm{w}}$ of $0.75 \mathrm{dS} \mathrm{m}^{-1}$ differed from depths 50 and $75 \%$ of $\mathrm{ET}_{\mathrm{c}}$.

Furthermore, Fv/Fm values generated two groups within each depth, except for the depth

Rev. Ambient. Água vol. 15 n. 5, e2564 - Taubaté 2020 
$125 \%$ of $\mathrm{ET}_{\mathrm{c}}$. In general, lower values were verified in the last three months (Table 1).

Table 1. Quantum efficiency $(\mathrm{Fv} / \mathrm{Fm})$ in 'Pérola' pineapple plants subjected to different irrigation depths with non saline water and saline water over the months.

\begin{tabular}{cccccc}
\hline & \multicolumn{5}{c}{ Depths } \\
\cline { 2 - 6 } Month & $100 \% \mathrm{ET}_{\mathrm{c}}$ & $50 \% \mathrm{ET}_{\mathrm{c}}$ & $75 \% \mathrm{ET}_{\mathrm{c}}$ & $100 \% \mathrm{ET}_{\mathrm{c}}$ & $125 \% \mathrm{ET}_{\mathrm{c}}$ \\
\cline { 2 - 6 } & $0.75 \mathrm{dS} \mathrm{m}^{-1}$ & \multicolumn{5}{c}{$3.6 \mathrm{dS} \mathrm{m}{ }^{-1}$} \\
\hline Aug/15 & $0.57 \mathrm{~A}$ & $0.62 \mathrm{~A}$ & $0.56 \mathrm{~A}$ & $0.52 \mathrm{~B}$ & $0.56 \mathrm{~A}$ \\
$\mathrm{Sep} / 15$ & $0.57 \mathrm{~A}$ & $0.49 \mathrm{~B}$ & $0.55 \mathrm{~A}$ & $0.49 \mathrm{~B}$ & $0.53 \mathrm{~A}$ \\
$\mathrm{Oct} / 15$ & $0.57 \mathrm{~A}$ & $0.52 \mathrm{~B}$ & $0.54 \mathrm{~A}$ & $0.49 \mathrm{~B}$ & $0.51 \mathrm{~A}$ \\
Nov/15 & $0.65 \mathrm{Aa}$ & $0.54 \mathrm{Bb}$ & $0.58 \mathrm{Aab}$ & $0.55 \mathrm{Ab}$ & $0.54 \mathrm{Ab}$ \\
$\mathrm{Dec} / 15$ & $0.57 \mathrm{Aa}$ & $0.46 \mathrm{Bb}$ & $0.45 \mathrm{Bb}$ & $0.5 \mathrm{Bab}$ & $0.49 \mathrm{Aab}$ \\
$\mathrm{Feb} / 16$ & $0.6 \mathrm{~A}$ & $0.59 \mathrm{~A}$ & $0.57 \mathrm{~A}$ & $0.57 \mathrm{~A}$ & $0.6 \mathrm{~A}$ \\
$\mathrm{Mar} / 16$ & $0.56 \mathrm{~A}$ & $0.59 \mathrm{~A}$ & $0.61 \mathrm{~A}$ & $0.57 \mathrm{~A}$ & $0.53 \mathrm{~A}$ \\
$\mathrm{Apr} / 16$ & $0.53 \mathrm{~B}$ & $0.58 \mathrm{~A}$ & $0.59 \mathrm{~A}$ & $0.58 \mathrm{~A}$ & $0.54 \mathrm{~A}$ \\
$\mathrm{May} / 16$ & $0.52 \mathrm{~B}$ & $0.57 \mathrm{~A}$ & $0.58 \mathrm{~A}$ & $0.58 \mathrm{~A}$ & $0.5 \mathrm{~A}$ \\
$\mathrm{Jun} / 16$ & $0.55 \mathrm{~A}$ & $0.56 \mathrm{~A}$ & $0.56 \mathrm{~A}$ & $0.57 \mathrm{~A}$ & $0.5 \mathrm{~A}$ \\
$\mathrm{Jul} / 16$ & $0.48 \mathrm{~B}$ & $0.51 \mathrm{~B}$ & $0.52 \mathrm{~B}$ & $0.5 \mathrm{~B}$ & $0.52 \mathrm{~A}$ \\
Aug/16 & $0.49 \mathrm{~B}$ & $0.51 \mathrm{~B}$ & $0.5 \mathrm{~B}$ & $0.5 \mathrm{~B}$ & $0.5 \mathrm{~A}$ \\
$\mathrm{Sep} / 16$ & $0.46 \mathrm{~B}$ & $0.49 \mathrm{~B}$ & $0.5 \mathrm{~B}$ & $0.5 \mathrm{~B}$ & $0.49 \mathrm{~A}$ \\
\hline $\mathrm{cV}(\%)$ & & 40.27 & \\
\hline
\end{tabular}

* Means followed by same uppercase letters, in the column for months, belong to the same group by the Skott-Knott criterion at 5\% of significance level, and lowercase letters in the rows, for depths, do not differ from each other by the Tukey test at $5 \%$ of significance level.

Fluctuations in Fo, Fm and Fv contributed to the reduction in maximum quantum efficiency of PSII (Fv/Fm). Despite the difference between mean values resulting from the application of different irrigation depths, in the months of November and December, Fv/Fm in pineapple plants were below what is considered as optimal ( $\mathrm{Fv} / \mathrm{Fm}$ of $0.800 \pm 0.5)$, according to Bolhàr-Nordenkampf et al. (1989). Accordingly, Fv/Fm ratios indicate that the photochemical system of pineapple plants was altered. These low values of Fv/Fm are possibly due to higher photochemical energy on the leaf than the capacity of using it to drive the photosynthesis, which decreases Fv/Fm, i.e., leads to higher non-photochemical quenching. This decrease below the ideal is perhaps a defense mechanism to reduce light energy absorption and thereby decreasing the electron flow within the electron transport chain (Willadino et al., 2011).

Another important factor is that in the months that correspond to the reproductive stage, after flowering in June 2016, Fv/Fm had the lowest values.

Thus, it is evident that biotic and abiotic conditions under which the experiment was carried out damaged the photosynthetic apparatus, impairing the PSII over the time of exposition to stress (Freire et al., 2014), so the ecophysiological behavior of pineapple over the growing season in the semiarid might be a result of several environmental factors.

Regarding the readings on the light-adapted ' $\mathrm{D}$ ' leaves of pineapple, chlorophyll fluorescence under steady state (Fs), maximum fluorescence in the light-adapted state (Fms) and variable fluorescence in the light-adapted state (Fvs) were affected only by irrigation depth, regardless of reading time or evaluation season of these variables (Table 2). Fs, Fms and Fvs had the highest values for irrigation depth $100 \%$ of $\mathrm{ET}_{\mathrm{c}}$ using water with $\mathrm{EC}_{\mathrm{w}}$ of $0.75 \mathrm{dSm}^{-1}$. 
Table 2. Chlorophyll $a$ Fluorescence under steady state (Fs), maximum fluorescence in the light-adapted state (Fms), variable fluorescence in the light-adapted state (Fvs) and quantum yield of photosystem II (Yield) in 'Pérola' pineapple plants subjected to different irrigation depths with non saline water and saline water over the months.

\begin{tabular}{cccc}
\hline Depths & Fs & Fms & Fvs \\
\hline $100 \% \mathrm{ET}_{\mathrm{c}}\left(\mathrm{EC}_{\mathrm{w}}=0.75 \mathrm{dSm}^{-1}\right)$ & $403.9 \mathrm{a}$ & $688.8 \mathrm{a}$ & $284.8 \mathrm{a}$ \\
$50 \% \mathrm{ET}_{\mathrm{c}}\left(\mathrm{EC}_{\mathrm{w}}=3.6 \mathrm{dS} \mathrm{m}^{-1}\right)$ & $354.6 \mathrm{~b}$ & $547.9 \mathrm{~b}$ & $193.2 \mathrm{~b}$ \\
$75 \% \mathrm{ET}_{\mathrm{c}}\left(\mathrm{EC}_{\mathrm{w}}=3.6 \mathrm{dS} \mathrm{m}^{-1}\right)$ & $380.1 \mathrm{ab}$ & $589.5 \mathrm{~b}$ & $209.4 \mathrm{~b}$ \\
$100 \% \mathrm{ET}_{\mathrm{c}}\left(\mathrm{EC}_{\mathrm{w}}=3.6 \mathrm{dS} \mathrm{m}^{-1}\right)$ & $363.6 \mathrm{~b}$ & $572.1 \mathrm{~b}$ & $208.5 \mathrm{~b}$ \\
$125 \% \mathrm{ET}_{\mathrm{c}}\left(\mathrm{EC}_{\mathrm{w}}=3.6 \mathrm{dS} \mathrm{m}^{-1}\right)$ & $374.0 \mathrm{ab}$ & $595.2 \mathrm{~b}$ & $221.3 \mathrm{~b}$ \\
\hline $\mathrm{CV}(\%)$ & 29.78 & 48.94 & 91.74 \\
\hline
\end{tabular}

Means followed by the same letters, in the columns, do not differ from each other by Tukey test at $5 \%$ of significance level.

Fs, Fms and Fvs were higher in plants irrigated using water with $\mathrm{EC}_{\mathrm{w}}$ of $0.75 \mathrm{dSm}^{-1}$ (Table 2), although Yield did not have the same tendency. It is noted that under field conditions, salinity stress is enhanced by other environmental adversities, such as high temperatures, low relative humidity and high wind speed (Figure 1).

Chlorophyll fluorescence results presented herein prove that pineapple plants subjected to abiotic stresses such as salinity, high temperatures and low relative humidity exhibit changes in the functional state of thylakoid membranes of chloroplasts. These changes have an impact on fluorescence and, consequently, on quantum efficiency $(\mathrm{Fv} / \mathrm{Fm})$ and on potential quantum yield (Yield) (Cha-Um and Kirmanee, 2011). In spite of Fv/Fm being below the ideal, the pineapple proved to tolerate salinity since Yield, $\mathrm{qP}, \mathrm{NPQ}$ and RFd results indicate a high efficiency at converting light energy into chemical energy, without differences between using water with $\mathrm{EC}_{\mathrm{w}}$ of 0.75 and $3.6 \mathrm{dS} \mathrm{m}^{-1}$ for irrigation.

Quantum photosynthetic yield of PSII (Yield), photochemical quenching, (qp) nonphotochemical quenching (NPQ) and fluorescence decrease ratio $\left(\mathrm{R}_{\mathrm{Fd}}\right)$ were not influenced by irrigation depths (Table 3). There was only the effect of the time factor. Yield and $\mathrm{R}_{\mathrm{Fd}}$ were higher at 2 p.m. while $\mathrm{q}_{\mathrm{p}}$ was higher at 8 a.m. As for NPQ, no significant differences were observed.

Table 3. Quantum yield of photosystem II (Yield), photochemical quenching ( $\mathrm{q}_{\mathrm{p}}$ ), non-photochemical quenching (NPQ) and fluorescence decrease ratio $\left(\mathrm{R}_{\mathrm{Fd}}\right)$ in 'Pérola' pineapple plants subjected to different irrigation depths with non-saline water and saline water.

\begin{tabular}{ccccccccc}
\hline \multirow{2}{*}{ Depths } & \multicolumn{2}{c}{ Yield } & \multicolumn{2}{c}{$\mathrm{q}_{\mathrm{P}}$} & \multicolumn{2}{c}{ NPQ } & \multicolumn{2}{c}{$\mathrm{R}_{\mathrm{Fd}}$} \\
\cline { 2 - 8 } & $8 \mathrm{a} . \mathrm{m}$. & $2 \mathrm{p} . \mathrm{m}$. & $8 \mathrm{a} . \mathrm{m}$. & $2 \mathrm{a} . \mathrm{m}$. & $8 \mathrm{a} . \mathrm{m}$. & $2 \mathrm{p} . \mathrm{m}$. & $8 \mathrm{a} . \mathrm{m}$. & $2 \mathrm{p} . \mathrm{m}$. \\
\hline $100 \% \mathrm{ET}_{\mathrm{c}}\left(\mathrm{EC}_{\mathrm{w}}=0.75 \mathrm{dS} \mathrm{m}^{-1}\right)$ & $0.26 \mathrm{Ab}$ & $0.30 \mathrm{Aa}$ & $0.44 \mathrm{Aa}$ & $0.33 \mathrm{Ab}$ & $0.30 \mathrm{Aa}$ & $0.36 \mathrm{Aa}$ & $1.48 \mathrm{Ab}$ & $2.28 \mathrm{Aa}$ \\
$50 \% \mathrm{ET}_{\mathrm{c}}\left(\mathrm{EC}_{\mathrm{w}}=3.6 \mathrm{dS} \mathrm{m}^{-1}\right)$ & $0.24 \mathrm{Ab}$ & $0.30 \mathrm{Aa}$ & $0.44 \mathrm{Aa}$ & $0.34 \mathrm{Ab}$ & $0.31 \mathrm{Aa}$ & $0.35 \mathrm{Aa}$ & $1.50 \mathrm{Ab}$ & $2.24 \mathrm{Aa}$ \\
$75 \% \mathrm{ET}_{\mathrm{c}}\left(\mathrm{EC}_{\mathrm{w}}=3.6 \mathrm{dS} \mathrm{m}^{-1}\right)$ & $0.24 \mathrm{Ab}$ & $0.34 \mathrm{Aa}$ & $0.45 \mathrm{Aa}$ & $0.34 \mathrm{Ab}$ & $0.30 \mathrm{Aa}$ & $0.31 \mathrm{Aa}$ & $1.39 \mathrm{Ab}$ & $2.12 \mathrm{Aa}$ \\
$100 \% \mathrm{ET}_{\mathrm{c}}\left(\mathrm{EC}_{\mathrm{w}}=3.6 \mathrm{dS} \mathrm{m}^{-1}\right)$ & $0.26 \mathrm{Ab}$ & $0.31 \mathrm{Aa}$ & $0.45 \mathrm{Aa}$ & $0.38 \mathrm{Ab}$ & $0.27 \mathrm{Aa}$ & $0.30 \mathrm{Aa}$ & $1.38 \mathrm{Ab}$ & $1.92 \mathrm{Aa}$ \\
$125 \% \mathrm{ET}_{\mathrm{c}}\left(\mathrm{EC}_{\mathrm{w}}=3.6 \mathrm{dS} \mathrm{m}^{-1}\right)$ & $0.27 \mathrm{Aa}$ & $0.30 \mathrm{Aa}$ & $0.43 \mathrm{Aa}$ & $0.37 \mathrm{Ab}$ & $0.29 \mathrm{Aa}$ & $0.31 \mathrm{Aa}$ & $1.43 \mathrm{Ab}$ & $1.95 \mathrm{Aa}$ \\
\hline $\mathrm{CV}(\%)$ & 38.40 & \multicolumn{2}{c}{28.56} & & 51.54 & & 53.51 \\
\hline
\end{tabular}

Means followed by the same letters, in the rows, do not differ from each other by F-test at $5 \%$ of significance level. Means followed by the same uppercase letters in the column for months do not differ from each other by the Tukey test at $5 \%$ of significance level.

$\mathrm{R}_{\mathrm{Fd}}$ is used as an indicator of the Calvin cycle activity and related processes. When $\mathrm{R}_{\mathrm{Fd}}$ is below 1, $\mathrm{CO}_{2}$ fixation is believed to be severely impaired (Lichtenthaler et al., 2005; Perera- 
Castro et al., 2018). Thus, salinity did not have an effect on $\mathrm{CO}_{2}$ fixation under the experimental conditions of this study. Moreover, the higher values of $\mathrm{R}_{\mathrm{Fd}}$ at 2 p.m. possibly indicate a high amount of internal $\mathrm{CO}_{2}$ coming from the decarboxylation of malic acid, which favors Calvin cycle activity (Borland et al., 2014).

$\mathrm{R}_{\mathrm{Fd}}$ and $\mathrm{q}_{\mathrm{p}}$ results agree with $\mathrm{CO}_{2}$ fixation stages described for CAM plants (Osmond, 1978; Borland et al., 2014). Stage II begins with the presence of light at which $\mathrm{CO}_{2}$ is taken up from the atmosphere through the stomata still open. Then, at Stage III, as temperature and radiation rise, the stomata close (increasing stomatal conductance) and internal $\mathrm{CO}_{2}$ uptake ceases, which explains the lower values of RFd at 8 p.m. At this stage, malate stored in vacuoles during Stage $\mathrm{I}$ is decarboxylated, internal $\mathrm{CO}_{2}$ is released and assimilated, and starch is produced; hence, the increased values of $R_{F d}$ at 2 p.m.

NPQ indicates light energy quenching as heat in the antenna complex of PSII. In this study, salinity had no effect on energy quenching, indicating ideal use of excitation energy for $\mathrm{q}_{\mathrm{p}}$.

Salinity stress reduces photosynthetic yield in C3 plants as a result of closing stomata and inhibition of photosynthetic carbon fixation (Tatagiba et al., 2014). However, since the pineapple has characteristics of a CAM plant, as shown in this study by the values of Yield, $R_{F d}$ and $\mathrm{q}_{\mathrm{p}}$, it is suggested that applying saline water does not have a negative impact on fluorescence characteristics evaluated over the study. Decreases in yield observed when applying saline irrigation water under semiarid conditions (Brito et al., 2017) might be due to other salinity-related effects such as changes in nutrient uptake, transport, assimilation and distribution throughout the plant (Santos and Brito, 2016).

Findings shown herein are relevant because they broaden existing knowledge about pineapple physiology and enable the association with other research results, thereby improving management practices to increase yield of crops irrigated with low-quality water and grown under semiarid conditions.

\section{CONCLUSIONS}

Fluctuations in quantum efficiency $(\mathrm{Fv} / \mathrm{Fm})$ occur over the cycle of 'Pérola' pineapple grown under semiarid conditions.

Energy use for photosynthetic processes of 'Pérola' pineapple plants is not affected by irrigation using saline water with electrical conductivity of $3.6 \mathrm{dS} \mathrm{m}^{-1}$.

The results of the evaluated physiological characteristics indicate resilience of the pineapple in cultivation under irrigation water salinity conditions. Thus, new research must be developed to adjust the cultivation of pineapple with saline water in the semiarid region of Bahia.

\section{ACKNOWLEDGEMENTS}

This study was supported by the Coordination for the Improvement of Higher Education Personnel - Brazil (CAPES) (grant number 001) and by the National Council for Scientific and Technological Development (CNPq) (Project number 467901/2014-7).

\section{REFERENCES}

AYERS, R. S.; WESTCOT, D. W. A qualidade da água na agricultura. Campina Grande: UFPB, 1985. 218p.

BOLHÀR-NORDENKAMPF, H. R.; LONG, P.; BAKER, N. R.; OQUIST, G.; SCHREIBER, U.; LECHNER, E. G. Chlorophyll fluorescence as probe of the photosynthetic competence of leaves in the field: a review of current instrumentation. Functional Ecology, v. 3, n. 1, pp. 497-514, 1989. https://doi.org/10.2307/2389624 
BORLAND, A. M.; HARTWELL, J.; WESTON, D. J.; SCHLAUCH, K. A.; TSCHAPLINSKI, T. J.; TUSKAN, G. A.; YANG, X.; CUSHMAN J. C. Engineering crassulacean acid metabolism to improve water-use efficiency. Trends in Plant Science, v. 19, n. 5, p. 327 338, 2014. https://doi.org/10.1016/j.tplants.2014.01.00

BRITO, C. F. B.; SANTOS, M. R. dos; FONSECA, V. A.; ARANTES, A. M.; ALMEIDA, J. R. Physiological characteristics and yield of 'Pérola' pineapple in the semiarid region. Revista Brasileira de Engenharia Agrícola e Ambiental, v. 21, n. 12, p. 834-839, 2017. http://dx.doi.org/10.1590/1807-1929/agriambi.v21n12p834-839

CARR, M. K. V. The water relations and irrigation requirements of pineapple (Ananas comosus var. comosus): a review. Experimental Agriculture, v. 48, n. 4, p. 488-501, 2012. http://dx.doi.org/10.1017/S0014479712000385

CHA-UM, S.; KIRDMANEE, C. Remediation of salt-affected soil by the addition of organic matter: an investigation into improving glutinous rice productivity. Scientia Agrícola, v. 68, n. 4, p. 406-410, 2011. http://dx.doi.org/10.1590/S0103-90162011000400003

COUTO, T. R.; SILVA, J. R.; MORAES C. R. O.; RIBEIRO, M. S.; NETTO, A. T.; CARVALHO, V. S.; CAMPOSTRINI, E. Photosynthetic metabolismo and growth of pineapple (Ananas comosus L. Merr.) cultivated ex vitro. Theoretical and Experimental Plant Physiology, v. 28, n. 3, p. 333-339, 2016. http://dx.doi.org/10.1007/s40626-0160062-X

CRUZ, L. I. B.; CRUZ, M. C. M.; FERREIRA, E. A.; CASTRO, G. D. M.; ALMEIDA, M. O. Eficiência quântica do fotossistema II de mudas de abacaxizeiro 'Imperial' em resposta a associação com Piriformospora indica e herbicidas. Revista Brasileira de Fruticultura, v. 36, n. 4, p. 794-804, 2014. http://dx.doi.org/10.1590/0100-2945-411/13

DÍEZ, M. C.; MORENO, F.; GANTIVA, E. Effects of light intensity on the morphology and CAM photosynthesis of Vanilla planifolia Andrews. Revista Facultad Nacional de Agronomía, v. 70, n. 1, p.8023-8031, 2017. http://dx.doi.org/10.15446/rfna.v70n1.61736

ELHAG, A. Z.; ELZAIN, H. Sodium chloride tolerance of pineapple (Ananas comosus 1. Mirrl.) In vitro. Journal of Applied Agricultural Research, v. 4, n. 2, p. 105-110, 2012.

EMBRAPA. Manual de métodos de análise de solo. 3. ed. Brasília: Embrapa, 2017. 573p.

FRANCO, L. R. L.; MAIA, V. M.; LOPES, O. P.; FRANCO, W. T. N.; SANTOS, S. R. Crescimento, produção e qualidade do abacaxizeiro 'Pérola' sob diferentes lâminas de irrigação. Revista Caatinga, v. 27, n. 2, p. 132-140, 2014.

FREIRE, J. L. O.; DIAS, T. J.; CAVALCANTE, L. F.; FERNANDES, P. D.; NETO, A. J. L. Rendimento quântico e trocas gasosas em maracujazeiro amarelo sob salinidade hídrica, biofertilização e cobertura morta. Revista Ciência Agronômica, v. 45, n.1, p. 82-91, 2014.

GOLTSEV, V. N.; KALAJI, H. M.; PAUNOVA, M.; BĄBA, W.; HORACZEK, T.; MOJSKI, J.; KOCIEL, H.; ALLAKHVERDIEV, S. I. Variable chlorophyll fluorescence and its use for assessing physiological condition of plant photosynthetic apparatus. Russian Journal of Plant Physiology, v. 63, n. 6, p. 869-893, 2016. https://doi.org/10.1134/S1021443716050058

IBGE. Censo Agropecuário. 2020. Available at: http://www.sidra.ibge.gov.br. Access: 13 July 2020. 
LICHTENTHALER, H. K.; BUSCHMANN, C.; KNAPP, K. How to correctly determine the different chlorophyll fluorescence parameters and the chlorophyll fluorescence decrease ratio $\mathrm{R}_{\mathrm{Fd}}$ of leaves with the PAM fluorometer. Photosynthetica, v. 43, n. 3, p. 379-393, 2005. https://doi.org/10.1007/s11099-005-0062-6

MAIA, V. M.; OLIVEIRA, F. S.; PEGORARO, R. F.; ASPIAZÚ, I.; PEREIRA, M. C. T. 'Pérola' pineapple growth under semiarid climate conditions. Acta Horticulture, v. 1111, p. 267-263, 2016. http://dx.doi.org/10.17660/ActaHortic.2016.1111.38

MOTA, M. F. C.; PEGORARO, R. F.; BATISTA, P. S. C.; PINTO, V. de O.; MAIA, V. M.; SILVA, D. F. da. Macronutrients accumulation and growth of pineapple cultivars submitted to aluminum stress. Revista Brasileira de Engenharia Agrícola e Ambiental, v. 20 , n. 11, p. 978-983, 2016. http://dx.doi.org/10.1590/18071929/agriambi.v20n11p978-983

MURCHIE, E. H.; LAWSON, T. Chlorophyll fluorescence analysis: A guide to good practice and understanding some new applications. Journal of Experimental Botany, v. 64, n. 13, p. 3983-3998, 2013. http://dx.doi.org/10.1093/jxb/ert208

OSMOND, C. B. Crassulacean acid metabolism: A curiosity in context. Annual Review of $\begin{array}{llllllll}\text { Plant Physiology, } & \text { v. } 29, \quad \text { n. } 3, & \text { p. } & 379-414, & \end{array}$ https://doi.org/10.1146/annurev.pp.29.060178.002115

PEGORARO, R. F.; SOUZA, B. A. M.; MAIA, V. M.; AMARAL, U.; PEREIRA, M. C. T. Growth and production of irrigated 'Vitória' pineapple grown in semiarid conditions. Revista Brasileira de Fruticultura, v. 36, n. 3, p. 693- 703, 2014. http://dx.doi.org/10.1590/0100-2945-265/13

PERERA-CASTRO, A. V.; BRITO, P.; GONZÁLEZ-RODRÍGUEZ, A. M. Changes in thermic limits and acclimation assessment for an alpine plant by chlorophyll fluorescence analysis: Fv/Fm vs. Rfd. Photosynthetica, v. 56, n. 2, p. 527-536, 2018. https://dx.doi.org/10.1007/s11099-017-0691-6

$\mathrm{R}$ DEVELOPMENT CORE TEAM. $\mathbf{R}$ a language and environment for statistical computing. Vienna: R Foundation for Statistical Computing, 2012.

SANTANA, M. J. de; SOUZA, O. P. de; CAMARGOS, A. E. V.; ANDRADE, J. P. R. Coeficientes de cultura do abacaxizeiro nas condições edafoclimáticas de Uberaba, MG. Revista Brasileira de Engenharia Agrícola e Ambiental, v. 17, n. 6, p.602-607, 2013. http://dx.doi.org/10.1590/S1415-43662013000600005

SANTOS, M. R. dos.; BRITO, C. F. B. Irrigação com Água Salina, Opção Agrícola Consciente. Revista Agrotecnologia, v. 7, n. 1, p. 33-41, 2016. https://dx.doi.org/10.12971/2179-5959/agrotecnologia.v7n1p33-41

SANTOS, M. R. dos; NEVES, B. R.; SILVA, B. L.; DONATO, S. L. R. Yield, water use efficiency and physiological characteristic of 'Tommy Atkins' mango under partial root zone drying irrigation system. Journal of Water Resourceand Protection, v. 7, n. 13, p. 1029-1037, 2015. http://dx.doi.org/10.4236/jwarp.2015.713084

SOUZA, C. B. de; SILVA, BERNARDO B. da; AZEVEDO, P. V. de. Crescimento e rendimento do abacaxizeiro nas condições climáticas dos Tabuleiros Costeiros do Estado da Paraíba. Revista Brasileira de Engenharia Agrícola e Ambiental, v. 11, n. 2, p. 134141, 2007. http://dx.doi.org/10.1590/S1415-43662007000200002 
STRAUSS, A. J.; KRÜGER, G. H. J.; STRASSER, R. J.; VAN HEERDEN, P. D. R. Ranking of dark chilling tolerance in soybean genotypes probed by the chlorophyll a fluorescence transient O-J-I-P. Environmental and Experimental Botany, v. 56, n. 2, p. 147-157, 2006. https://doi.org/10.1016/j.envexpbot.2005.01.011

TATAGIBA, S. D.; MORAES, G. A. B. K.; NASCIMENTO, K. J. T.; PELOSO, A. F. Limitações Fotossintéticas em Folhas de Plantas de Tomateiro Submetidas a Crescentes Concentrações Salinas. Engenharia na Agricultura, v. 22, n. 2, p. 138-149, 2014.

TEDESCO, M. J.; GIANELLO, C.; BISSANI, C. A.; BOHNEN, H.; VOLKWEISS, S. J. Análise de solos, plantas e outros materiais. Porto Alegre: Universidade Federal do Rio Grande do Sul, 1995. 174p. (Boletim Técnico, 5).

VIEIRA, D. A. P.; PORTES, T. A.; STACCIARINI-SERAPHIN, E.; TEIXEIRA, J. B. Fluorescência e teores de clorofilas em abacaxizeiro cv. Pérola submetido a diferentes concentrações de sulfato de amônio. Revista Brasileira de Fruticultura, v. 32, n. 2, p. 360-368, 2010. http://dx.doi.org/10.1590/S0100-29452010005000061

WILLADINO, L.; OLIVEIRA FILHO, R. A.; SILVA JUNIOR, E. A.; GOUVEIA NETO, A.; CAMARA, T. R. Estresse salino em duas variedades de cana-de-açúcar: enzimas do sistema antioxidativo e fluorescência da clorofila. Revista Ciência Agronômica, v. 42, n. 2, p. 417-422, 2011.

ZHANG, J.; LIU, J.; MING, R. Genomic analyses of the CAM plant pineapple. Journal of Experimental Botany, v. 65, n. 13, p. 01-10, 2014. https://doi.org/10.1093/jxb/eru101 


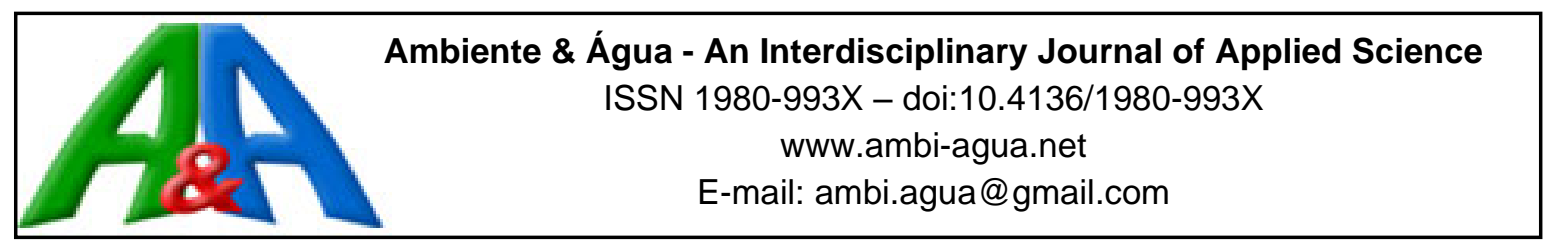

\title{
Assessment of community-managed water systems in rural areas of Espírito Santo, Brazil, using the SIASAR tool
}

\author{
ARTICLES doi:10.4136/ambi-agua.2517
}

Received: 15 Jan. 2020; Accepted: 28 Jul. 2020

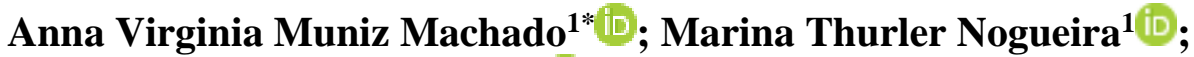
Lucas Magalhães Carneiro Alves ${ }^{1 D}$; Norbertho da Silveira Quindeler ${ }^{2}$; Juliana da Costa Dias Silva1 ${ }^{1 D}$; Pedro Antonio de Paiva Aranha1 ${ }^{1 D}$; Ricardo Pereira Gonçalves $^{1}{ }^{(D ;}$; Natália Lascas Soares de Siqueira ${ }^{1}$ (D)
\end{abstract}

${ }^{1}$ Escola de Engenharia. Laboratório de Gestão Ambiental. Universidade Federal Fluminense (UFF), Rua Passo da Pátria, n 156, CEP: 24210-240, Niterói, RJ, Brazil. E-mail: marinathurler@gmail.com, lucasmcarneiroalves@gmail.com,juliana_dias@id.uff.br, pedroaranha@id.uff.br, pereira.rlk@gmail.com,nlascas@id.uff.br

${ }^{2}$ Departamento de Engenharia Agrícola e do Meio Ambiente. Universidade Federal Fluminense (UFF), Rua Passo da Pátria, n 156, CEP: 24210-240, Niterói, RJ, Brazil. E-mail: norberthosq@id.uff.br *Corresponding author. E-mail: annav.machado@gmail.com

\begin{abstract}
Rural communities usually are poorly covered by basic services, including water supply services (WSSs). Within this context, community management of water is a promising alternative to address this issue, with many successes all over the world. This approach also contributes to the achievement of Sustainable Development Goal (SDG) 6, which intends to universalize water access. This paper evaluates the WSSs provided by eleven rural community organizations from Espírito Santo, Brazil. All of those participate in the sanitation program "Pró-Rural" created by Cesan (Companhia Espiritosantense de Saneamento), the state water concessionaire, to reach small-sized rural settlements. For this purpose, Siasar was used, an informational tool that enables the identification of elements in the rural water supply systems (RWSSs) that can enhance or hinder their performance. The results verified that the communities were able to maintain a satisfactory level of quality of the WSSs, although there were perceptible fragilities regarding the distance between internal (communities and service providers) and external (technical assistance providers) actors that can decrease the quality of the WSS or even lead to its interruption if not addressed.
\end{abstract}

Keywords: community management, rural communities, water supply.

\section{Avaliação de sistemas de água geridos por comunidade em áreas rurais do Espírito Santo, Brasil, utilizando a ferramenta SIASAR}

\section{RESUMO}

Comunidades rurais são geralmente cobertas de forma precária por serviços básicos, incluindo serviços de abastecimento de água (SAAs). Neste contexto, a gestão comunitária da água é uma alternativa promissora para tratar essa questão, com muitos casos de sucesso pelo mundo. Essa abordagem também contribui para atingir o ODS (Objetivo do Desenvolvimento Sustentável) 6, que pretende universalizar o acesso à água. Este artigo visa avaliar os serviços 
de abastecimento de água prestados por onze organizações comunitárias do Espírito Santo, Brasil. Todas as comunidades participam do programa de saneamento "Pró-Rural" criado pela Cesan (Companhia Espiritosantense de Saneamento), a concessionária de água do estado, a fim de alcançar comunidades rurais de pequeno porte. Para isso, o Siasar foi utilizado, uma ferramenta de informação que permite a identificação de elementos nos sistemas de abastecimento de água rurais (SAARs) que melhoram ou fragilizam a sua performance. Como resultado, foi verificado que as comunidades eram capazes de manter um nível satisfatório de qualidade dos SAAs, entretanto havia fragilidades relacionadas a atores internos (comunidades e prestadores de serviço) e externos (prestadores de assistência técnica), que podem reduzir a qualidade do SAA ou até mesmo levar a sua interrupção caso não tratadas.

Palavras-chave: comunidades rurais, fornecimento de água, gestão comunitária.

\section{INTRODUCTION}

Water is essential to human life. Its consumption and usage for daily tasks and for personal hygiene require basic treatment in order to maintain safety. Different papers report several waterborne diseases in regions where drinking water standards are not reached (Jalan and Ravallion, 2003; UNICEF and WHO, 2009; Grigg, 2018). It was also verified that diseases related to water pollution are the major cause of death in the world, and more than half of hospital beds host people suffering from these (Hunter et al., 2010; Palacio, 2009). Hence, concerns regarding safe drinking water provision and access arise. International efforts have been attempted to address this issue, such as the Millennium Development Goals (MDGs), supplanted in 2015 by the SDGs. The sixth objective (SDG 6), intends to ensure access to drinkable water and sanitation for all by 2030, and target 6.1 addresses particularly access to drinkable water (United Nations, 2018).

The task becomes more challenging regarding rural locations, especially in low- and middle-income countries. Their distance from urban areas hinders operation and maintenance of the system by suppliers (Barde, 2017). From an economic point of view, the implementation of the system is unfeasible, as it does not return investments made by private companies (Alves and Araújo, 2016; Ataíde et al. 2012; Calzada et al., 2017), as inhabitants with low-incomes cannot afford the high costs to maintain a quality service and the complex logistics required to support it in those areas (RWSN, 2014; Kayser et al., 2015; Calzada et al., 2017; United Nations, 2018).

According to the Pesquisa Nacional por Amostra de Domicílio (IBGE, 2016), in Brazil urban areas are greatly covered by water services, with approximately $93.9 \%$ of households connected to distribution systems. Nevertheless, rural areas remain poorly covered, with approximately $34.5 \%$ of rural households not connected to any kind of reliable water source.

However, efforts are being made to address this. In December 2019, building on the efforts of multiple stakeholders (federal, state and municipal levels, researchers, experts and those in the rural context, such as community organizations and social movements), the Programa Nacional de Saneamento Rural (PNSR) was formulated (Funasa, 2019). It is a federal program that intends to develop sanitation procedures in rural areas aiming to universalize water access (Funasa, 2017).

A relevant strategy to deal with such issues in those areas is community management of water supply systems. This is a participatory approach, i.e., the target community is responsible for operating, maintaining and managing the water plants, built with assistance of external actors that must provide constant financial, technical, institutional and political support to guarantee the systems' functionality (Kleemeier, 2000; Whittington et al., 2009; Hunter et al., 2010; Hutchings et al., 2015; Behnke et al., 2017). 
This tactic has been employed in many countries around the world, namely Brazil, Chile, Peru, Finland, Nepal and Nigeria (Heller and Pádua, 2006; Whittington et al., 2009; Opare, 2011; Borja-Vega et al., 2017; Calzada et al., 2017; Chukwuma, 2018; Rautanen and White, 2018). Among them, both successes and failures have been reported in the literature. Rautanen and White (2018) demonstrated a successful case in Nepal, where a combination of community engagement and financial transparency were deemed key factors to the sustainability of this model. Chukwuma (2018) presents case studies in Nigeria, where community management could not improve communities' quality of life due to weak institutional and political support. In the same way, Harvey and Reed (2007) observed that governmental policies were responsible for creating a scenario of isolation of rural communities through weak political representation, which contributed to several failures in water supply systems in Africa.

The state where the studied communities are located, Espírito Santo, is composed of 74 municipalities, of which 52 have the water supply services granted by a covenant with Cesan, a mixed capital company created in 1967 , that delivers drinking water to $93.2 \%$ of inhabitants from the municipalities under its concession (Cesan, 2019a).

To increase the pace of rural communities towards access to drinkable water, in 1991 Cesan created Pró-Rural, a program implemented in small and remote communities (between 50 and 1,500 inhabitants), where it is economically untenable for Cesan to operate and manage the water systems (Cesan, 2019b).

This paper evaluates community management of water supply systems in eleven communities of Espírito Santo, Brazil. The evaluation is supported by Siasar, a tool that enables the systematic data collection of the water treatment plant (WTP) and stakeholders relating to the community's WSS. Based on that, it is possible to suggest measures that could contribute to the improvement of the systems' performance.

\section{METHODOLOGY}

\subsection{Study area}

The study area includes eleven rural communities distributed in Boa Esperança, Venda Nova do Imigrante and Conceição do Castelo, three municipalities of Espírito Santo state.

Boa Esperança was the first municipality visited, in August 2016. The communities selected were Prata, Bela Vista, Cruzeiro, Km 20, Santo Antônio do Pouso Alegre, Sobradinho and Garrucha. Their choice was based on the method of simple sampling (Morettin and Bussab, 2014).

In February 2018, the research was performed in Camargo (Venda Nova do Imigrante) and Indaiá (Conceição do Castelo). Those were chosen due to logistical reasons and technical recommendations received from the state staff.

Finally, in August 2018, also in Conceição do Castelo, the communities Mata Fria and Santa Luzia were visited. Their choice considered accessibility matters, as rural communities of the southern region of Espírito Santo are widely dispersed and have limited access due to the low quality of roads.

The eleven communities were chosen because they participate in the Pró-rural program and consequently are managed by a neighborhood association, whether formally recognized or not. Figures 1, 2 and 3 represent Conceição do Castelo, Boa Esperança and Venda Nova do Imigrante, respectively. 


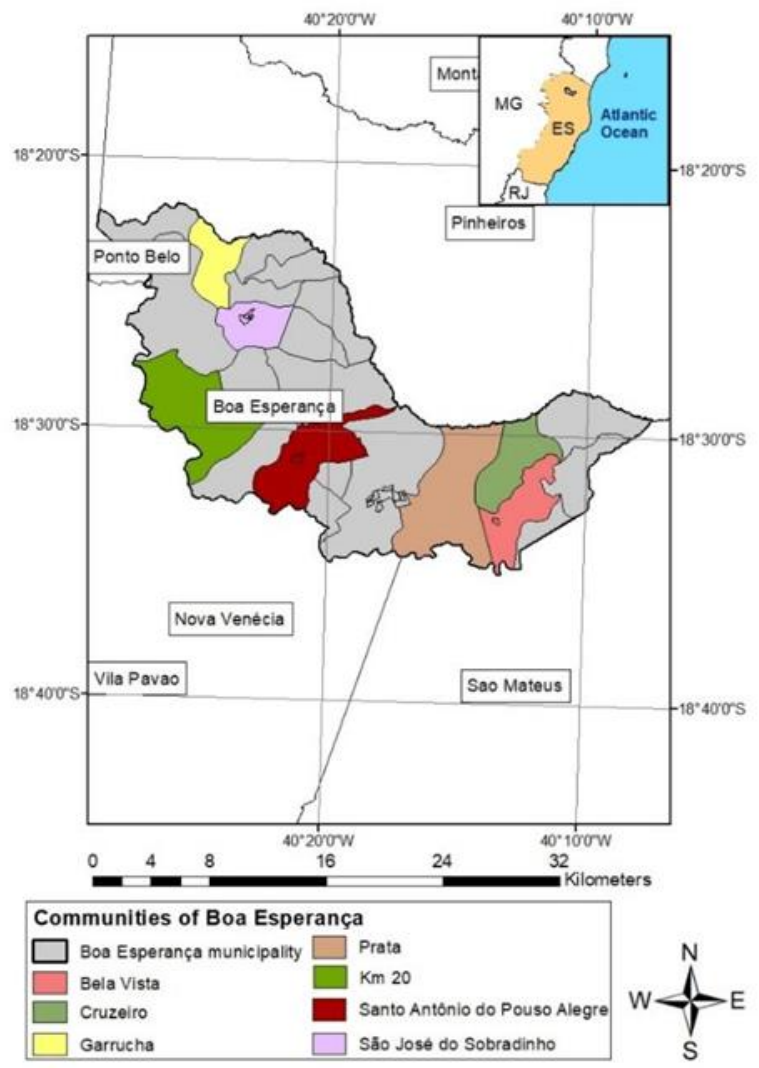

Figure 1. Map of Boa Esperança.

Source: Based on Geobases data.

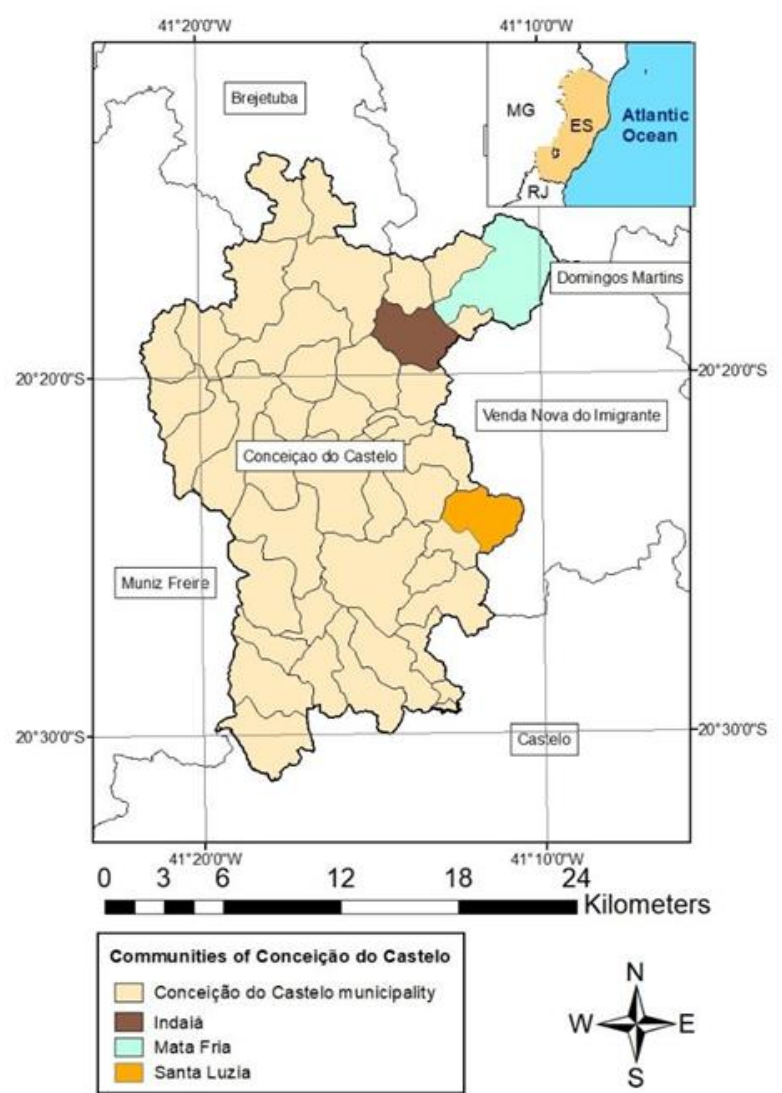

Figure 2. Map of Conceição do Castelo

Source: Based on Geobases data. 


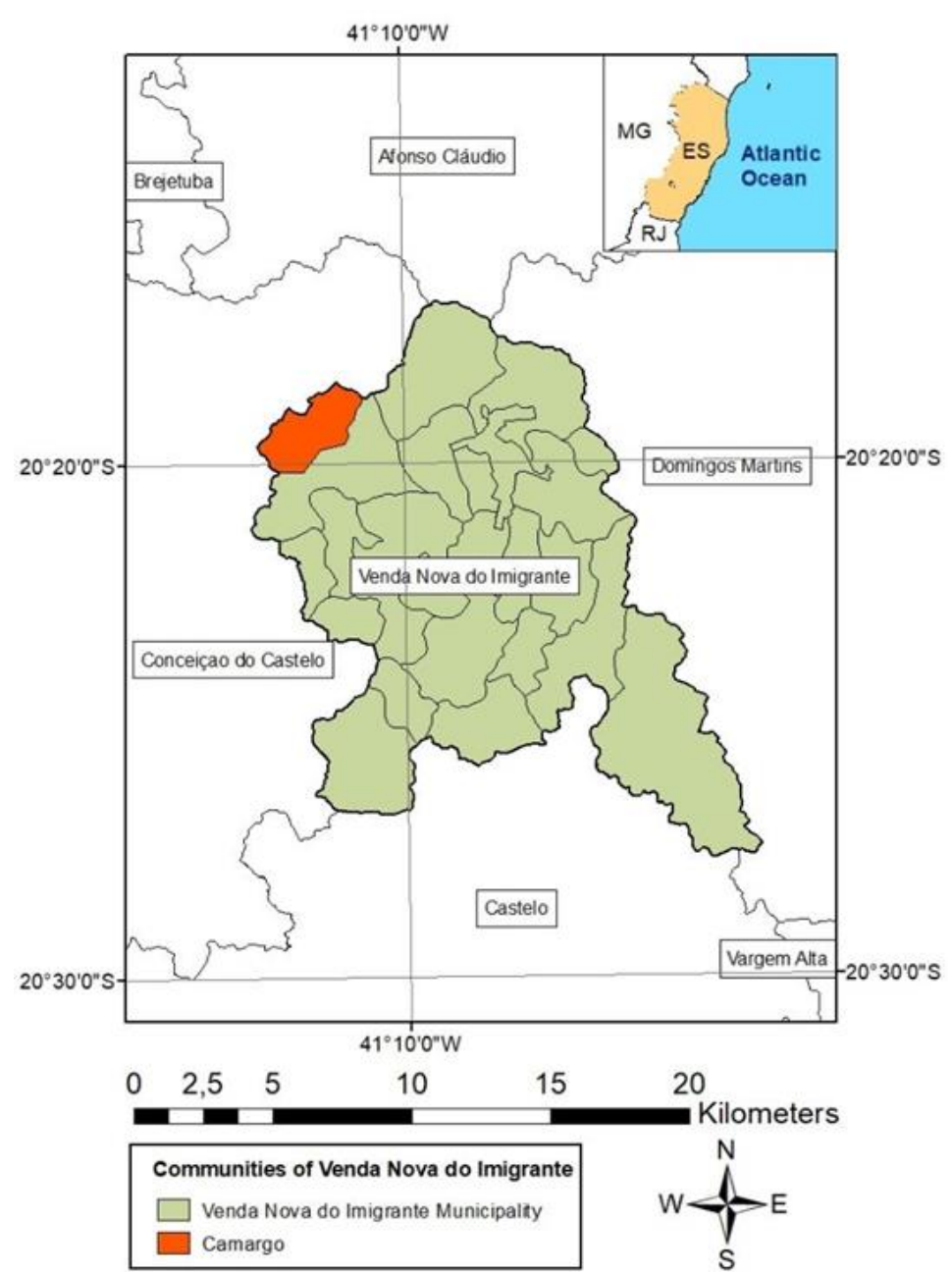

Figure 3. Map of Venda Nova do Imigrante.

Source: Based on Geobases data.

\subsection{Siasar}

Siasar is an informational tool, developed by a joint initiative between the governments of Honduras, Nicaragua and Panamá (Siasar, 2012).

This tool allows the identification of gaps and failures capable of leading to the breakdown of water systems, and the quantification of different elements that influence its sustainability. This method evaluates four main actors defined by Siasar (2016) as follows:

- Water system: The infrastructure of the water supply system, composed of catchment structure, water treatment plant and distribution system.

- Service provider: Entity responsible for providing water service to users.

- Technical assistance provider: Public or private entity responsible for offering technical support to the service provider.

- Community: Rural settlement composed of users of the water service.

Each actor has indicators that mirror their performance. Hence, the four actors are individually assessed through specific questionnaires. For this study, the 2012 version of the questionnaires was used.

The actors' classification is based on the respective indicators' score, ranging from 1 (worst situation) to 4 (best situation). The corresponding classification for community, water system and service provider is given respectively in Tables 1 and 2. 
The technical service provider was not evaluated due to the non-existence or lack of periodicity of this service verified in the communities.

Table 1. Community and service provider classifications according to their average score.

\begin{tabular}{cc}
\hline Average score & Classification \\
\hline $3.50-4.00$ & $\mathrm{~A}^{*}$ \\
$2.50-3.49$ & $\mathrm{~B}$ \\
$1.50-2.49$ & $\mathrm{C}$ \\
$<1.49$ & $\mathrm{D}$ \\
\hline
\end{tabular}

Source: Adapted from Siasar (2012).

*If any indicator receives a score of 1 , the service provider is classified as $\mathrm{B}$, even when the average score is between 3.5 and 4.0 .

Table 2. Water system classification according to its total score.

\begin{tabular}{cc}
\hline Total & Classification \\
\hline$\geq 25$ & A \\
$17-24$ & B \\
$9-16$ & C \\
$\leq 8$ & D \\
\hline Source: Adapted from Siasar (2012).
\end{tabular}

The community evaluation also considers the Water Service Sustainability Index (WSSI), based on the water system and the service provider classifications to depict the current physical, financial and managerial conditions of the RWSS being assessed. The WSSI results from Equation 1:

$W S S I=\frac{\sum N \text { o of households connected to the water system }}{N^{\circ} \text { of households in the community }} \times R W_{\text {system }} \times R W_{\text {service provider }}$

RW is the relative weight attributed to the water system and to the service provider. Therefore, it can be observed that the sustainability of the RWSS is closely attached to the performance of those actors. Table 3 shows the correspondence between the final classification of the water system and service provider and the RW.

Table 3. Correspondence between the final classification of the water system and service provider and the RW.

\begin{tabular}{cl}
\hline Classification & RW \\
\hline A & 1.00 \\
B & 0.66 \\
C & 0.33 \\
D & 0.00 \\
\hline
\end{tabular}

Source: Adapted from Siasar (2012).

\subsection{Surveys and data collection}

The survey was carried out based on overt direct observations and interviews. It used 3 
types of Siasar questionnaires to evaluate each system, "water system", "service provider", and "community".

The interviewees were community council members, operators or persons responsible for the treatment plant, mostly chosen according to their availability, since not everyone could be previously contacted. Researchers used semi-structured interviews, in order to allow the inclusion of questions according to the context.

Consent forms were elaborated by researchers in order to notify interviewees of the nature of this research, to assure their anonymity in any publication and to have their compliance. The forms were physically signed by both respondents and researchers and archived for further needs.

This research uses information collected in the field; therefore, it shows local perceptions and shares lessons learned in that reality. However, on some occasions it was necessary to rely on information given by community managers and operators, who have limited knowledge of hydraulic and water resources. Further, since data collection was performed on the spot, it was unfeasible to visit a great sample of communities.

Another aspect is that information regarding households and social care centers required by Siasar was also provided by interviewees, since they were not available in discrete form for every community.

To close this section, due to the large number of pages of the questionnaires, it was not possible to attach them to this paper. They may be found in Siasar's web page for July 2016: http://www.siasar.org/en/content/technical-documentation.

\section{RESULTS}

The overall actors' evaluation for each community using parameters of Siasar is shown in Table 4. Regarding the community actor, the classification of which is affected by the water systems and the service providers, about $54 \%$ achieved a "B" classification. $27 \%$ percent of the communities obtained an "A" classification. "C" and " $\mathrm{D}$ " classifications were both achieved by $9.5 \%$.

Table 4. Communities scoring and classification.

\begin{tabular}{lccc}
\hline Community & Water System & Service Provider & Community \\
\hline Bela Vista & A & B & B \\
Camargo & B & C & B \\
Cruzeiro & - & D & D \\
Garrucha & A & B & B \\
Indaiá & A & B & A \\
Km 20 & B & C & B \\
Mata Fria & A & B & B \\
Prata & B & D & C \\
Santa Luzia & A & B & A \\
Santo Antônio do Pouso Alegre & B & B & A \\
São José do Sobradinho & B & B & B
\end{tabular}

The evaluation process which leads to the classifications displayed in Table 4 is described in the following items. The information is indexed according to the parameters used by Siasar to qualify each actor (water system, service provider and community).

\subsection{Water System evaluation}

The indicators used to evaluate the water systems were: water intake flow, catchment structure, pipes, reservoirs, distribution system, reservoir volume, river basin and residual chlorine. Those are discussed in the following sections, focusing on the issues found.

The total scores obtained by communities regarding this actor were: Garrucha (28), Sta 
Luzia (27), Bela Vista (26), Indaiá (26), Mata Fria (26), Km 20 (24), Camargo (24), St ${ }^{\circ}$ Antônio do Pouso Alegre (24), São José do Sobradinho (24), Prata (24) and Cruzeiro (-). Since no type of treatment was performed in Cruzeiro when the research was conducted, this community was not evaluated in this actor.

\subsubsection{Water intake flow}

This indicator is linked to the capability of the water intake flow to meet the demand for the same. Most of the systems could provide drinkable water throughout the year. Only Santa Luzia, Camargo and Prata had issues during the drought season in maintaining the water supply.

In Santa Luzia, water scarcity was addressed by building a dam to stock the water conducted to it by a second channel. Camargo builds a sandbag dam in the river where water intake occurs during dry seasons. Prata did not develop any procedure to deal with the water shortage during winter besides reducing the number of hours the pump operated.

\subsubsection{Catchment structure}

The intake point indicator refers to the physical conditions of the catchment structures. The water catchment occurs in different ways among the communities. Indaiá, Camargo, Santa Luzia and Mata Fria employed a superficial water catchment, while in the communities of Boa Esperança water collection relied on wells. Only Bela Vista has a superficial intake and another approach using a well. The necessity of a second intake in Bela Vista arose from the long drought periods in the region. This expansion was financed by the municipality as well as the community association.

Mata Fria, Santo Antônio do Pouso Alegre and São José do Sobradinho presented issues regarding the catchment structure. In Mata Fria, there was the necessity of relocating and reconstructing the catchment system due to the constant displacement of the screen grid by the strong water flow. In Santo Antônio do Pouso Alegre, the pump in operation was borrowed from another community. Finally, São José do Sobradinho requires the building of a new intake. The prior well became inoperative due to the continuous drought in the region. To mitigate the situation, an inhabitant allowed water collection from a well at his estate. In exchange, users pay the electricity costs for the pump usage. It is worth highlighting that this water is also used for watering the property owner's crops, which increases the electricity expenses paid by the community. New catchment, treatment and distribution systems are in the construction phase (this labor is funded by Funasa's Pró-Rural program).

\subsubsection{Pipes}

This indicator refers to the physical conditions of the pipes leading the water from the intake points to the WTPs or to the reservoirs that were reported. In none of the communities were found disconformities regarding this element at the time of the study.

\subsubsection{Reservoirs}

This indicator refers to the physical conditions of the reservoirs. The communities with hurdles to overcome related to the reservoirs were Prata, Km 20 and Camargo. Prata's reservoir displayed excess rust and damage in the walls. A new one was being built at the time of this research. At Km 20, a new reservoir is available to replace the damaged one, although there is not enough budget for the installation. Finally, in Camargo the operators reported that during their 2 years of service in the treatment plant, no cleaning was performed on either the reservoirs or the filters.

\subsubsection{Distribution system}

This indicator corresponds to the physical conditions of the system of pipes, valves and structures responsible to conduct the water from the reservoirs to the households. Prata's distribution system featured rust and damage. For the reservoir, a new distribution system was 
under construction. São José do Sobradinho also has a damaged distribution system; like Prata, a new one was under construction, as mentioned in 3.1.2.

\subsubsection{Reservoir volume}

The capability of the reservoir volume to meet the inhabitants' needs is reported by this indicator. Only Prata's reservoir was incapable of meeting demand. The system was initially built to supply the community's school, although the number of connections to the system increased due to community's growth. As mentioned in Section 3.1.4, a new storage system was under construction at the time of this research.

\subsubsection{River basin}

This indicator corresponds to the preservation status of green areas surrounding the intake and to the basins' protection against animals and contamination sources. It also considers how these affect the water system. Most of the communities were next to plantations, representing a risk of contamination due to pesticide leaching.

No information about the surroundings of the spring could be verified in Santo Antônio do Pouso Alegre. In all the RWSSs aside from Mata Fria, risk of contamination due to chemicals used on plantations near the spring and the presence of animals was found.

In Mata Fria, there was moderate degradation of the riparian zone due to the occupation of the margins. No information about the surroundings of the spring could be verified in Santo Antônio do Pouso Alegre.

\subsubsection{Residual chlorine}

This indicator analyzes the quantity of chlorine measured in the WTP's discharge in $\mathrm{mg} / \mathrm{L}$. Table 5 shows the values measured at the time of data collection and the treatment method employed by each system.

Table 5. Residual chlorine in the outbound and treatment method of each community.

\begin{tabular}{|c|c|c|}
\hline Community & Residual chlorine $\left(\mathrm{mg} \mathrm{L}^{-1}\right)$ & Treatment method \\
\hline Bela Vista & 0.2 & Chlorination and filtration \\
\hline Camargo & $1.0-1.5$ & $\begin{array}{l}\text { Conventional treatment } \\
\text { (except fluoridation) }\end{array}$ \\
\hline Cruzeiro & Does not apply & No treatment performed \\
\hline Garrucha & 0.2 & Chlorination and filtration \\
\hline Indaiá & $0.2-1.0$ & $\begin{array}{l}\text { Conventional treatment } \\
\text { (except fluoridation) }\end{array}$ \\
\hline $\mathrm{Km} 20$ & 0.2 & Chlorination \\
\hline Mata Fria & $0.2-1.0$ & $\begin{array}{l}\text { Conventional treatment } \\
\text { (except fluoridation) }\end{array}$ \\
\hline Prata & 0.2 & Chlorination \\
\hline $\mathrm{St}^{\mathrm{a}}$ Luzia & $1.0-1.5$ & Conventional treatment (except fluoridation) \\
\hline $\mathrm{St}^{\mathrm{o}}$ Antônio do Pouso Alegre & 0.2 & Chlorination, filtration and flocculation \\
\hline São José do Sobradinho & 0.2 & Chlorination \\
\hline
\end{tabular}

*According to Heller and Pádua (2006), conventional water treatment comprises the coagulation, flocculation, sedimentation, filtration, disinfection, $\mathrm{pH}$ correction and fluoridation phases.

Points to acknowledge: In the communities where conventional treatment is employed, fluoridation is not performed due to poor technical training of operators. In São José do Sobradinho, besides chlorination, fluoride application used to be performed; however, the supply was interrupted (the product used to be provided by Cesan). In Bela Vista, there is no 
need to apply fluoride, since the substance is naturally present in the spring in the concentrations required (according to the operator).

According to Siasar, to receive the maximum score in this indicator, the concentration of residual chlorine must be between $1.0 \mathrm{mg} / \mathrm{L}$ and $1.5 \mathrm{mg} / \mathrm{L}$, concentrations below $0.2 \mathrm{mg} / \mathrm{L}$ receive the lowest score and those between $0.2 \mathrm{mg} / \mathrm{L}$ and $1.0 \mathrm{mg} / \mathrm{L}$ receive score 2 .

\subsection{Service provider evaluation}

The service provider's indicators used to evaluate the communities are: management of community organization, operation and maintenance $(\mathrm{O} \& \mathrm{M})$, basin protection, financial stability and tariff. This actor's score was calculated by the average of the indicator's grades. The average of the communities by this actor is: Garrucha (3.40), São José do Sobradinho (3.20), Indaiá (3,00), Santa Luzia (3.00), Santo Antônio do Pouso Alegre (3.00), Bela Vista (2.60), Mata Fria (2.60), KM 20 (2.40), Camargo (1.60), Prata (1.40) and Cruzeiro (1.20).

\subsubsection{Management of community organization}

The existence of a strong and well-structured community organization is essential to strengthen community-managed water systems. Among the studied RWSSs, Bela Vista, Km 20, Garrucha, São José do Sobradinho and Santo Antônio do Pouso Alegre counted with a formal organization. The communities Mata Fria, Santa Luzia, Indaiá and Camargo possess informal organizations. Prata and Cruzeiro had no kind of community organization.

From the RWSS managed by community organization, no regular meetings performed with any of the stakeholders were reported. In Siasar, an adequate number of meetings is four per semester. Also, in only São José do Sobradinho, Km 20 and Bela Vista, all positions in the council board were filled.

Another important factor related to the service provider is accountability. This indicator evaluates the accounting organization. All the discussed communities reported to the users their expenditures, aside from Prata and Cruzeiro, which did not have any form of community organization, formal or not.

From the service providers that provide accountability for users, in Mata Fria, Santa Luzia and Camargo it is performed according to users' requests. Indaiá submitted their reports at public places, such as churches. Bela Vista does it at assemblies, even though they do not occur frequently.

\subsubsection{Operation and Maintenance (O\&M)}

This indicator considered the staff available to execute O\&M activities in the WTP. Mata Fria, Camargo and São José do Sobradinho had 2 operators for O\&M. Prata did not have operators; the school staff performed the maintenance of the system. The same occurs in Cruzeiro, where the inhabitants perform small repairs and take turns to switch the pump on and off. Preventive and corrective measures are performed in all communities, except for Prata and Cruzeiro.

\subsubsection{Basin protection}

This indicator evaluates the efforts made to protect the basin, such as in Section 3.1.7. Most of the communities had a basin affected by agriculture neighboring the intake point, enabling agrochemical contamination. In addition, Mata Fria and Santa Luzia have a riparian forest degraded by human occupation. One of the houses in Mata Fria has a dam for water catchment upstream of the intake point, decreasing the river flow and the WTP catchment. Further, there is no fence protecting the riverbank in Cruzeiro and Sao José do Sobradinho, allowing cattle invasion and degradation. The basin of São José do Sobradinho is on private property, with no protection or fiscalization, and the water is used for property planting and irrigation. 


\subsubsection{Financial stability}

Regarding the financial balance of the communities, only Mata Fria, Santa Luzia, Camargo and Indaia reported that the revenue from water fees collection is greater than the water systems' operational costs. Also, it allows cost recovery and generates enough funds to cover O\&M costs and other expenses. Every community, other than Prata and Cruzeiro, keeps accounting records.

\subsubsection{Tariff}

Regarding finances, all of the communities charge users a tax, but only Mata Fria, Santa Luzia, Indaiá, Bela Vista, Garrucha, São José do Sobradinho and Santo Antônio do Pouso Alegre had a tariff based on user's consumption, due to the installation of water meters. But in Santo Antônio do Pouso Alegre, about $10 \%$ of the households did not have the device installed yet. Water meters were also being installed in $\mathrm{Km} 20$. The communities where a high number of defaulting users were verified were Km 20, São José do Sobradinho and Santo Antônio do Pouso Alegre.

The tariffs, their sufficiency to guarantee cost-recovery, and an emergency fund are displayed in Table 6. For the communities unable to self-sustain, and hence receive subsidies, the type of support and its provider are also displayed.

\subsection{Communities evaluation}

The indicators used to evaluate the communities were: improved water system coverage, improved sanitation system coverage, WSSI, coverage of sanitation hydraulic system, coverage of social care centers by improved drinking water, coverage of social care centers by improved sanitation, and healthy environment and good practices in hygiene. This actor's score was calculated by the average of the indicator's notes. The average of the communities by this actor is: Santa Luzia (3.90), Indaiá (3.80), Camargo (3.60), Garrucha (3.46), Bela Vista (3.33), São José do Sobradinho (3.30), Mata Fria (3.00), Santo Antônio do Pouso Alegre (3.00), KM 20 (2.78), Prata (2.13) and Cruzeiro (1.13).

\subsubsection{Improved water system coverage}

This indicator represents the percentage of households covered by improved drinking water. In Cruzeiro, no water treatment is employed; therefore, no household is covered by improved drinking water. Regarding the other communities, each water system can provide $100 \%$ coverage.

\subsubsection{Improved sanitation system coverage}

The coverage of households by improved sanitation facilities ${ }^{1}$ is evaluated by this indicator. The sewage from Mata Fria, Santa Luzia, São José do Sobradinho, Camargo, Santo Antônio do Pouso Alegre and Bela Vista is disposed of in septic tanks. In Mata Fria, inhabitants could not remember the last time the septic tanks were inspected. In Santa Luzia, there was a specialized company to clean them regularly. In Santo Antônio do Pouso Alegre, $90 \%$ of households have septic tanks and filters. In Camargo, all of the household sewage is sent to a septic tank and then discharged into a nearby river (the conditions of the septic tank could not be verified).

In Indaiá and Km 20, sewage is discharged into the nearest stream without treatment. Each household from Garrucha and Prata had rudimentary cesspits. Finally, the resident interviewed could not provide information for this indicator's evaluation in the Cruzeiro community.

\footnotetext{
${ }^{1}$ Siasar considers 2 types of improved sanitation facility. Type 1 uses a facility with water discharge (manual or automatic), where feces are conveyed to a piped sewer system or a septic tank. Type 2 uses a ventilated improved pit latrine, pit latrine with slab or composting latrine/toilet (Siasar, 2016).
} 


\begin{tabular}{|c|c|c|c|c|}
\hline Community & Tariff & Cost - recovery & $\begin{array}{l}\text { Emergency } \\
\text { fund }\end{array}$ & Continuous subsidies \\
\hline Bela Vista & $\$ 1.80$ the first $\mathrm{m}^{3}$ and $\$ 0.18$ each extra $\mathrm{m}^{3}$ & No & No & Municipality pays electricity bills and the operators' salary. \\
\hline Camargo & $\$ 5.16$ & Yes & No & None \\
\hline Cruzeiro & $\$ 2.58$ & No & No & Maintained by the municipality \\
\hline Garrucha & $\$ 4.63$ the first $10000 \mathrm{~m}^{3}$ and $\$ 0.51$ each extra $\mathrm{m}^{3}$ & No & Yes & $\begin{array}{c}\text { Municipality pays electricity bills and buys salt to produce } \\
\text { chlorine }\end{array}$ \\
\hline Indaiá & $\$ 5.92$ the first $15 \mathrm{~m}^{3}$ and $\$ 0.26$ each extra $\mathrm{m}^{3}$ & Yes & Yes & None \\
\hline KM 20 & $\$ 3.86$ & No & Yes & Municipality pays electricity bills \\
\hline Mata Fria & $\$ 6.44$ the first $15 \mathrm{~m}^{3}$ and $\$ 1.29$ each extra $\mathrm{m}^{3}$ & Yes & No & None \\
\hline Prata & $\$ 1.29$ & No & No & Maintained by the municipality \\
\hline Santa Luzia & $\$ 6.44$ the first $15 \mathrm{~m}^{3}$ and $\$ 1.29$ each extra $\mathrm{m}^{3}$ & Yes & Yes & None \\
\hline $\begin{array}{l}\text { Santo Antônio do Pouso } \\
\text { Alegre }\end{array}$ & $\$ 5.15$ the first $10 \mathrm{~m}^{3}$ and $\$ 0.51$ each extra $\mathrm{m}^{3}$ & No & No & Municipality pays electricity bills \\
\hline São José do Sobradinho & $\$ 3.86$ the first $10 \mathrm{~m}^{3}$ and $\$ 1.17$ each extra $\mathrm{m}^{3}$ & No & No & Municipality pays electricity bills \\
\hline
\end{tabular}




\subsubsection{WSSI}

The Water Service Sustainability Index obtained by each community using the correspondence shown in Table 4 and the WSSI's formula is displayed in Table 7.

Table 7. Communities' WSSI.

\begin{tabular}{|c|c|}
\hline Community & WSSI \\
\hline Bela Vista & 0.66 \\
\hline Garrucha & 0.66 \\
\hline Mata Fria & 0.66 \\
\hline $\mathrm{St}^{\mathrm{a}}$ Luzia & 0.66 \\
\hline Indaiá & 0.61 \\
\hline São José do Sobradinho & 0.44 \\
\hline $\mathrm{St}^{\mathrm{o}}$ Antônio do Pouso Alegre & 0.44 \\
\hline $\mathrm{Km} 20$ & 0.22 \\
\hline Camargo & 0.19 \\
\hline Prata & 0 \\
\hline Cruzeiro & 0 \\
\hline
\end{tabular}

\subsubsection{Coverage of sanitation hydraulic system}

This indicator refers to the percentage of households and other buildings connected to the system with sanitation facilities with adequate equipment for personal hygiene. Every household in each community has these facilities, therefore fulfilling the indicator.

\subsubsection{Coverage of social care centers by improved drinking water}

This indicator comprises social care centers (educational and health facilities) covered by the RWSS. Every community's social care centers are supplied by the water system. Aside from Cruzeiro, which does not have those facilities.

\subsubsection{Coverage of social care centers by improved sanitation}

It was not possible to visit every social care center in the communities. Therefore, it was considered that the same sanitation facilities attending households also attended social care centers.

\subsubsection{Healthy environment}

This indicator considered factors that lead to environmental degradation and raised public health risks. In Mata Fria, there was a contamination risk due to sewage disposal in equipment without proper maintenance. In Garrucha and Prata, rudimentary cesspits also represent risks of soil and water table contamination. In Camargo, effluents are discharged into water bodies without treatment.

Regarding solid waste collection and disposal methods, Indaiá, Camargo, Mata Fria e $\mathrm{St}^{\mathrm{a}}$ Luzia have waste collection; the disposition method is unknown. In Bela Vista, Km 20, São José do Sobradinho and $\mathrm{St}^{\circ}$ Antônio do Pouso Alegre, there is also waste collection and the final disposition is a dump. In Garrucha there is no waste collection, hence, garbage is burned. No information about waste collection and disposal in Prata and Cruzeiro was gathered.

\subsection{Good practices in hygiene}

This indicator evaluates the usage of bathroom sinks, safe water management and garbage treatment in households. Every community related compliance with this indicator (it was considered each situation). 


\section{DISCUSSION}

This chapter is included in order to evaluate the results found by the Siasar tool in light of other papers that considered community water supply management. The scope of this evaluation considers technical, financial, institutional and social elements to detect potential threats to the RWSSs' functionality. These elements, verified through the assessment of the actors according to different papers, influence the water treatment system's sustainability (Kativhu et al., 2017).

Overall, communities have managed to achieve high scores in the water system evaluations, between A and B (regardless of Prata, that was not evaluated in this category, as it did not have a WTP, just water intake). Even though the Siasar tool allocated high classifications to this actor, there are still adjustments which could provide major improvements to the quality of service. Those adjustments are linked to needs of refurbishment, rebuilding and major repairs, which realization is hindered or even infeasible due to budget deficits and low-skilled operators, factors that reflect disorders related to the service provider and the technical assistance provider.

The service providers achieved classifications between B and D. A common factor among communities was a low number of seats occupied in the community organization and infrequent meetings between participants. As seen in Braimah et al., (2016), meeting frequency was related to faster problem solving, implying positive outcomes. The small number of members in the community organization could potentially contribute to a burden of responsibilities to individuals. Also, given the voluntary nature of the job, members usually avoid the labor (Leclert et al., 2016). As verified by Harvey and Reed (2007), Leclert et al., (2016) and Lockwood and Smits (2011), this avoidance results in difficulties to ensure the RWSSs' sustainability. Moreover, this is a recurrent problem in this type of management, as reported by other researches (Braimah et al., 2016; Foster et al., 2018; Harvey and Reed, 2007; Lockwood and Smits, 2011; Osumanu, 2010).

Another factor is the informality of community organizations, also considered a problem that undermines rural WSS (Moriarty et al., 2013; Borja-Vega et al., 2017; Leclert et al., 2016). This characteristic hinders the professionalization of the service provider, which could result in loss of efficiency in the long-term. Also, the legal status of service provider gives it access to benefits, such as discounted electricity, greater trust in tariff collection (Borja-Vega et al., 2017), as well as access to credit or legally contract support services (Leclert et al., 2016). It becomes even more worrying in cases where there is not an organization focused on the WTP, as in the case of Prata (where school staff manage the WTP) and Cruzeiro (where inhabitants take turns to switch the pump on and off).

The tariff scheme is also a concern, since cost-recovery by means of water fees is feasible in $36 \%$ of the communities, the same percentage for those able to nourish an emergency fund. Therefore, service providers lack sufficient budget to perform major repairs and system refurbishment, which constitutes an important aspect to ensure long-term sustainability as stated by Rivas et al. (2014). All those communities whose revenue is not enough to assure cost-recovery reported a level of dependency on external supporters to cover O\&M expenses. Even though external financial support is a critical part of community managed RWSS, its extent must be calculated thoroughly. As claimed by Madrigal et al., (2011), the provision of excessive financial resources could generate an undesired dependency of community organizations. Therefore, less efforts from local managers would be directed towards improvements to create financial self-sufficiency of the RWSS. Behnke et al. (2017) highlight the necessity of local authorities to promote capacity-building on financial planning, allowing community organizations to gather the required knowledge to maintain a stable financial scheme and minimally depend on external financial aid. Rivas et al. (2014) state that financial 
schemes must go beyond cost recovery and be established to guarantee future system refurbishment when necessary. It is also important that community organizations can identify the costs of O\&M and to select the appropriate tariff scheme for the locality (Moriarty et al., 2013). That, plus accountability, affects the commitment of users to pay the water tariff (Chowns, 2015; Harvey and Reed, 2007; Lockwood and Smits, 2011; Madrigal et al., 2011; Schouten and Moriarty, 2004).

The distance between communities and technical assistance providers weakens the quality of the WSS. No community reported regular contact with this actor. The basic training regarding O\&M and management given by technical assistance providers before handing-over the WTP is not enough (Leclert et al., 2016). To generate the best outcomes in the RWSSs and ensure its sustainability, it is important to strengthen the relationship between external agencies and the communities (Smits et al., 2013; Kayser et al., 2014; Schouten and Moriarty, 2004). As observed, some communities' operators did not perform the fluoridation step of the treatment owing to insufficient training. In São José do Sobradinho, fluoridation was not performed since Cesan no longer provides the product needed. The cleaning of reservoirs and filters in Camargo was compromised because operators only received training 2 years after their hiring.

The community actor evaluation was mostly reduced due to the potential risks related to irregular wastewater disposal and unimproved or improperly maintained sanitation facilities. Additionally, evidence of community participation was found in any community. Barde (2017) found that implementation and community management of rural WSS projects have a growth of $6 \%$ greater than those without users' involvement. User participation and sense of ownership towards the water system are considered essential to maintain the systems' functionality and ensure the success of the approach (Kelly et al., 2017; Kleemeier, 2000; Rautanen and White, 2018). Moreover, technical assistance providers have a responsibility in the processes of creating an efficient enabling environment, where there is environmental awareness, and the empowerment and communities' engagement are feasible and stimulated. The enabling environment in the RWSS context consists of institutional and political conditions that promote the sustainability of the RWSSs. These conditions are achieved through the creation of legislation, policies, funding mechanisms and supporting programs that allow community managed RWSSs to operate sustainably (Lockwood and Smits, 2011). It has been recognized by Amjad et al. (2015) and Moriarty et al. (2013) that the enabling environment is a fundamental element to ensure positive outcomes from drinking water supply systems. By these means, the rural WSS is strengthened without creating dependence on external agency subsidies that, according to Madrigal et al. (2011) weaken or eliminate local contributions.

\section{CONCLUSION}

All the communities studied could maintain an acceptable level of functionality of the water supply systems. However, the verified failures represent threats to the systems' sustainability in the long-term. Therefore, the need for adopting measures to improve the performance of the systems and avoid prospective collapses and breakdowns arises. In the case of the considered sample of RWSSs, those measures are mostly related to needs of technical and operational support, which can be set-up as managerial assistance from state or municipal spheres. This assistance may be implemented as collaboration networks between close communities and government, so that they can support each other when needed, and exchange solutions and qualified labor supply to assist the WSS. Thus, it is possible to troubleshoot faster.

This paper found that the major threat to communities is the lack of continuous and systematic presence of the technical assistance provider, which hinders the development of a more sustainable service. This actor plays an important role in lining the other actors up in order to increase the quality of the WSS. Examples of this role based on the results presented by this 
study are: continuous capacity building of managerial and technical skills of local communities to promote the definition of more efficient tariff schemes. These schemes should be affordable for users in order to decrease defaulting and also to improve revenue for covering O\&M costs; stimulate service providers to undergo the process of legalization, which increases professionalization and the quality of service and promotes environmental awareness throughout the community, sensitizing users regarding the necessity of adequate and continuous sanitization.

\section{REFERENCES}

AMJAD, U. Q.; OJOMO, E.; DOWNS, K.; CRONK, R.; BARTRAM, J. Rethinking Sustainability, Scaling Up, and Enabling Environment: A Framework for Their Implementation in Drinking Water Supply. Water, v. 7, n. 4, p. 1497-1514, 2015. https://doi.org/10.3390/w7041497

ALVES, F. G. C.; ARAÚJO, F. T. V. Sistemas de abastecimento em comunidades rurais do semiárido: a implantação do SISAR em Cristais, Cascavel, CE. Revista Tecnologia, v. 37, n. 1, p. 78-86, 2016. https://doi.org/10.5020/23180730.2016.V37.1/2.78-86

ATAÍDE, G. V. T. L.; MORAES, L. R. S.; BORJA, P. C. Autogestão em saneamento básico no Brasil: experiências e aprendizado. In: EXPOSIÇÃO DE EXPERIÊNCIAS MUNICIPAIS EM SANEAMENTO, 16., 2012, Maringá. Anais[...] Brasília: ASSEMAE, 2012. p. 1-13.

BARDE, J. A. What Determines Access to Piped Water in Rural Areas? Evidence from SmallScale Supply Systems in Rural Brazil. World Development, v. 95, p. 88-110, 2017. https://dx.doi.org/10.1016/j.worlddev.2017.02.012

BEHNKE, N. L.; KLUG, T.; CRONK, R.; SHIELDS, K. F.; LEE, K.; KELLY, E. R.; ALLGOOD, G.; BARTRAM, J. Resource mobilization for community-managed rural water systems: Evidence from Ghana, Kenya, and Zambia. Journal of Cleaner Production, v. 156, p. 437-444, 2017. https://doi.org/10.1016/j.jclepro.2017.04.016

BORJA-VEGA, C.; PENA, L.; STIP, C. Sustainability of rural water systems: quantitative analysis of Nicaragua's monitoring data. Waterlines, v. 36, n. 1, p. $40-70,2017$. https://doi.org/10.3362/1756-3488.2017.003

BRAIMAH, I.; AMPONSAH, O.; ASIBEY, M. O. The effectiveness of the local management systems of rural water facilities for sustainable service delivery: a case study of the Sekyere East District, Ghana. Sustainable Water Resources Management, v. 2, n. 4, p. 405-418, 2016. https://doi.org/10.1007/s40899-016-0070-7

CALZADA, J.; IRANZO, S.; SANZ, A. Community-Managed Water Services: The Case of Peru. Journal of Environment and Development, v. 26, n. 4, p. 400-428, 2017. https://doi.org/10.1177/1070496517734020

CHOWNS, E. Is Community Management an Efficient and Effective Model of Public Service Delivery? Lessons from the Rural Water Supply Sector in Malawi. Public Administration and Development, v. 35, n. 4, p. 263-276, 2015. https://doi.org/10.1002/pad.1737

CHUKWUMA, O. M. Rural water supply in Nigeria: policy gaps and future directions. Water Policy, v. 20, n. 3, p. 597-616, 2018. https://doi.org/10.2166/wp.2018.129 
COMPANHIA ESPÍRITO SANTENSE DE SANEAMENTO. Abrangência. Available at: https://www.cesan.com.br/empresa/abrangencia. Access: 23 Sep. 2019a.

COMPANHIA ESPÍRITO SANTENSE DE SANEAMENTO. Responsabilidade Social. Available at: https://www.cesan.com.br/empresa/responsabilidade-social. Acess: 23 Sep. 2019 b.

FOSTER, T.; WILLETTS, J.; LANE, M.; THOMSON, P.; KATUVA, J.; HOPE, R. Risk factors associated with rural water supply failure: A 30-year retrospective study of handpumps on the south coast of Kenya. Science of the Total Environment, v. 626, p. 156-164, 2018. https://doi.org/10.1016/j.scitotenv.2017.12.302

FUNDAÇÃO NACIONAL DE SAÚDE (Brasil). Programas Institucionais. 2017. Available at: http://www.funasa.gov.br/programa-nacional-de-saneamento-rural-pnsr. Access: 14 June 2020.

FUNDAÇÃO NACIONAL DE SAÚDE (Brasil). Programa Nacional de Saneamento Rural. Brasília: Ministério da Saúde, 2019. 260 p.

GRIGG, N. S. Water-Health Nexus: Modeling the Pathways and Barriers to Water Related Diseases. Water Resources Management, v. 33, n. 1, p. 319-335, 2019. https://doi.org/10.1007/s11269-018-2104-4

HARVEY, P. A.; REED, R. A. Community-managed water supplies in Africa: Sustainable or dispensable? Community Development Journal, v. 42, n. 3, p. 365-378, 2007. https://doi.org/10.1093/cdj/bs1001

HELLER, L.; PÁDUA, V. Abastecimento de água para consumo humano. Belo Horizonte: UFMG, 2006.

HUNTER, P.; MACDONALD, A.; CARTER, R. Water supply and health. PLoS Medicine, v. 7, n. 11, 2010. https://doi.org/10.1371/journal.pmed.1000361

HUTCHINGS, P.; CHAN, M. Y.; CUADRADO, L.; EZBAKHE, F.; MESA, B.; TAMEKAWA, C.; FRANCEYS, R. A systematic review of success factors in the community management of rural water supplies over the past 30 years. Water Policy, v. 17, n. 5, p. 963-983, 2015. https://doi.org/10.2166/wp.2015.128

IBGE. Pesquisa nacional por amostra de domicílio: síntese de indicadores. Rio de Janeiro, 2016. 146 p.

JALAN, J.; RAVALLION, M. Does piped water reduce diarrhea for children in rural India? Journal of Econometrics, v. 112, n. 1, p. 153-173, 2003. https://doi.org/10.1016/S03044076(02)00158-6

KATIVHU, T.; MAZVIMAVI, D.; TEVERA, D.; NHAPI, I. Factors Influencing sustainability of communally-managed water facilities in rural areas of Zimbabue. Physics and $\begin{array}{lllllll}\text { Chemistry of the Earth, v. 100, p. 247-257, } 2017 . & \end{array}$ https://doi.org/10.1016/j.pce.2017.04.009

KAYSER, G. L.; AMJAD, U.; DALCANALE, F.; BARTRAM, J.; BENTLEY, M. E. Drinking water quality governance: A comparative case study of Brazil, Ecuador, and Malawi.

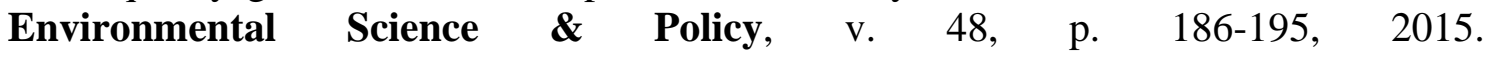
https://doi.org/10.1016/j.envsci.2014.12.019 
KELLY, E.; LEE, K.; SHIELDS, K. F.; CRONK, R.; BEHNKE, N.; KLUG, T.; BARTRAM, J. The role of social capital and sense of ownership in rural community-managed water systems: Qualitative evidence from Ghana, Kenya, and Zambia. Journal of Rural Studies, v. 56, p. 156-166, 2017.

KLEEMEIER, E. The Impact of Participation on Sustainability: An Analysis of the Malawi Rural Piped Scheme Program. World Development, v. 28, n. 5, p. 929-944, 2000. https://doi.org/10.1016/S0305-750X(99)00155-2

LECLERT, L.; NZIOKI, R. M.; FEUERSTEIN, L. Addressing Governance and Management Challenges in Small Water Supply Systems - The Integrity Management Approach in Kenya. Aquatic Procedia, v. 6, p. 2016. https://doi.org/10.1016/j.aqpro.2016.06.006

LOCKWOOD, H.; SMITS, S. Supporting Rural Water Supply: Moving Towards a Service Delivery Approach. Rugby: Practical Action, IRC and Aguaconsult, 2011. 187 p.

MADRIGAL, R.; ALPÍZAR, F.; SCHLÜTER, A. Determinants of Performance of Community-Based Drinking Water Organizations. World Development, v. 39, n. 9, p. 1663-1675, 2011. https://doi.org/10.1016/j.worlddev.2011.02.011

MORETTIN, P. A.; BUSSAB, W. de O. Estatística básica. 6. ed. São Paulo: Saraiva, 2014.

MORIARTY, P.; SMITS, S.; BUTTERWORTH, J.; FRANCEYS, R. Trends in rural water supply: Towards a service delivery approach. Water Alternatives, v. 6, n. 3, p. 329-349, 2013.

OPARE, S. Sustaining water supply through a phased community management approach: Lessons from Ghana's "oats" water supply scheme. Environment, Development and Sustainability, v. 13, n. 6, p. 1021-1042, 2011. https://doi.org/10.1007/s10668-0119303-y

OSUMANU, I. K. Community involvement in urban water and sanitation provision: The missing link in partnerships for improved service delivery in Ghana. Journal of African Studies and Development, v. 2, n. 8, p. 208-215, 2010. https://doi.org/10.5897/JASD.9000013

PALACIO, A. The Different Facets of the Water Crisis. In: LLAMAS, R.; MARTÍNEZCORTINA, L.; MUKHERJI, A. (Orgs.). Water Ethics: Marcelino Botin Water Forum 2007. Santander: Taylor \& Francis, 2009.

RAUTANEN, S.; WHITE, P. Portrait of a successful small-town water service provider in Nepal's changing landscape. Water Policy, v. 20, n. 1, p. 84-99, 2018. https://doi.org/10.2166/wp.2018.006

RIVAS, M. G.; BEERS, K.; WARNER, M. E.; WEBER-SHIRK, M. Analyzing the potential of community water systems: The case of Agua Clara. Water Policy, v. 16, n. 3, p. 557577, 2014. https://doi.org/10.2166/wp.2014.127

RURAL WATER SUPPLY NETWORK. Rural Water Supply Network Strategy 2018 2023. St. Gallen: Skat Foundation, 2014. 60 p.

SCHOUTEN, T.; MORIARTY, P. Scaling up the community management of rural water supply. Waterlines, v. 23, n. 2, p. 2-4, 2004. 
SISTEMA DE INFORMACIÓN DE ÁGUA Y SANEAMIENTO RURAL. Manual Usuario de SIASAR. 2012. 117 p.

SISTEMA DE INFORMACIÓN DE ÁGUA Y SANEAMIENTO RURAL. Reglamento del sistema de água y saneamiento rural. 2016. 17 p.

SMITS, S.; ROJAS, J.; TAMAYO, P. The impact of support to community-based rural water service providers: Evidence from Colombia. Water Alternatives, v. 6, n. 3, p. 383-404, 2013.

UNICEF; WHO. Diarrhea: Why children are still dying and what can be done. Geneva, 2009. $60 \mathrm{p}$.

UNITED NATIONS. Sustainable Development Goal 6 Synthesis Report on Water and Sanitation. New York: United Nations, 2018. 197 p.

WHITTINGTON, D.; DAVIS, J.; PROKOPY, L.; KOMIVES, K.; THORSTEN, R.; LUKACS, H.; BAKALIAN, A.; WAKEMANN, W. How Well is the Demand-Driven, Community Management Model for Rural Water Supply Systems Doing? Water Policy, v. 11, n. 2, p. 696-718, 2009. https://doi.org/10.2166/wp.2009.310 


Ambiente \& Água - An Interdisciplinary Journal of Applied Science
ISSN 1980-993X - doi:10.4136/1980-993X
www.ambi-agua.net
E-mail: ambi.agua@gmail.com

\title{
An Artemia franciscana bioassay for the monitoring of lipophilic phycotoxins in marine bivalve mollusc cultures: An alternative to screening testing?
}

\author{
ARTICLES doi:10.4136/ambi-agua.2549
}

Received: 27 Mar. 2020; Accepted: 19 Aug. 2020

\author{
Alailton dos Reis Guaralde1 ${ }^{1 D}$; Daniela Almeida de Souza1 ${ }^{1 D}$; \\ Celso Luiz Possas Guimarães Júnior ${ }^{2}{ }^{D}$; Rafael Soares Guimarães ${ }^{2}{ }^{\oplus}$; \\ Victor Barbosa Saraiva ${ }^{3}$; José Augusto Ferreira da Silva ${ }^{4}$; \\ Marcos Massao Murata ${ }^{5}$; Renato Matos Lopes $^{6}$ iD; \\ Rachel Ann Hauser-Davis ${ }^{7}$; Manildo Marcião de Oliveira $^{3 *}$
}
${ }^{1}$ Programa de Pós Graduação em Engenharia Ambiental (PPEA). Laboratório de Ecotoxicologia e Microbiologia Ambiental (LEMAM). Instituto Federal de Educação, Ciência e Tecnologia Fluminense (IFFluminense), Estrada Cabo Frio-Búzios, s/n, CEP: 28909-971, Cabo Frio, RJ, Brazil.
E-mail: alailtonreis@yahoo.com.br,danielabio@hotmail.com
${ }^{2}$ Departamento de Biologia. Instituto Federal de Educação, Ciência e Tecnologia Fluminense (IFFluminense), Estrada dos Búzios, s/n, CEP: 28293-660, Cabo Frio, RJ, Brazil.
E-mail: cj_celso@hotmail.com, luigis2guima@gmail.com
${ }^{3}$ Laboratório de Ecotoxicologia e Microbiologia Ambiental (LEMAM). Instituto Federal de Educação, Ciência e Tecnologia Fluminense (IFFluminense), Estrada Cabo Frio-Búzios, s/n, CEP: 28909-971, Cabo Frio, RJ, Brazil. E-mail: vsaraiva@iff.edu.br
${ }^{4}$ Programa de Pós Graduação em Engenharia Ambiental (PPEA). Instituto Federal de Educação, Ciência e Tecnologia Fluminense (IFFluminense), Rodovia Amaral Peixoto, Km 164, CEP: 27932-050, Macaé, RJ, Brazil. E-mail: jaferreirasilva@gmail.com
${ }^{5}$ Departamento de Biofísica e Biometria. Instituto de Biologia Roberto Alcantara Gomes (IBRAG). Universidade
Estadual do Rio de Janeiro (UERJ), Avenida Boulevard 28 de setembro, ${ }^{\circ} 87$ (fundos), CEP: 20551-030,
Rio de Janeiro, RJ, Brazil. E-mail: muratauerj@gmail.com
${ }^{6}$ Laboratório de Comunicação Celular. Instituto Oswaldo Cruz. Fundação Oswaldo Cruz (Fiocruz), Avenida Brasil, n 4.365, CEP: 21040-360, Manguinhos, RJ, Brazil. E-mail: rmatoslopes@gmail.com
${ }^{7}$ Instituto Oswaldo Cruz. Laboratório de Avaliação e Promoção da Saúde Ambiental. Fundação Oswaldo Cruz (Fiocruz), Avenida Brasil, n 4.365, CEP: 21040-360, Manguinhos, RJ, Brazil.
E-mail: rachel.hauser.davis@gmail.com
*Corresponding author. E-mail: manildodpicf@gmail.com

\begin{abstract}
In Brazil, malacoculture is developed mainly in the state of Santa Catarina, followed by São Paulo and Rio de Janeiro. In the course of the development of Brazilian mariculture, legislation has addressed the sanitary requirements necessary for bivalve commercialization. However, monitoring phycotoxins is a challenge, due to often costly reference methods. In this context, this study evaluated the use of alternative ecotoxicological and bioanalytical methods using Artemia franciscana (brine shrimp) lethality assessments. The results confirm that, although correlations between the reference mouse assay and the brine shrimp assays were not high, the alternative brine shrimp assay may be incorporated into phycotoxin monitoring programs, as hepatopancreas methanolic extracts of mussel (Perna perna) containing DSP resulted in high lethality rates. Therefore, further methodological adjustment studies and the inclusion of other enzymatic and toxicological models are required to further assess these
\end{abstract}


Alailton dos Reis Guaralde et al.

differences, and associations between ecotoxicological methods as early-alarm methods are encouraged.

Keywords: Arraial do Cabo, harmful algae, Perna perna.

\section{Bioensaios com Artemia franciscana para monitoramento de ficotoxinas lipofílicas em cultivo de moluscos bivalves marinhos: Uma alternativa para teste de alarme?}

\section{RESUMO}

No Brasil, a malacocultura é desenvolvida principalmente no estado de Santa Catarina, seguida por São Paulo e Rio de Janeiro. No curso do desenvolvimento das atividades da maricultura brasileira, a legislação se adaptou aos requisitos sanitários necessários à comercialização de bivalves. No entanto, o monitoramento de ficotoxinas é um desafio, devido a métodos de referência frequentemente caros. Nesse contexto, o objetivo deste estudo foi avaliar o uso de métodos ecotoxicológicos e bioanalíticos alternativos usando a Artemia franciscana (artemia). Os resultados confirmam que, embora as correlações entre o ensaio de referência em camundongos e os ensaios com artemia não sejam altas, o ensaio alternativo com artemia pode ser incorporado aos programas de monitoramento de ficotoxinas, pois os extratos metanólicos do hepatopâncreas de mexilhões (Perna perna) contendo DSP resultaram em altas taxas de letalidade. Portanto, estudos adicionais de ajustes metodológicos e a inclusão de outros modelos enzimáticos e toxicológicos são necessários para avaliar essas diferenças, e são encorajadas associações entre métodos ecotoxicológicos como métodos de alarme precoce.

Palavras-chave: algas nocivas, Arraial do Cabo, Perna perna.

\section{INTRODUCTION}

Bivalve mollusc cultivation has increased in the last decades, and currently obtains high yields (FAO, 2016). However, the possibility of contamination by toxins produced by certain microalgae species (phycotoxins) is an obstacle to shellfish production and consumption and may lead to product embargos when harmful algal blooms (HAB) occur in cultivation areas (Simões, 2011). HAB comprise excessive proliferation of certain phytoplankton species in short periods of time, due to favorable development conditions (Castro and Moser, 2012). As bivalve molluscs are filter feeders, many toxins can be ingested and stored in their tissues, bioaccumulating and potentially biomagnifying throughout the trophic chain (Barbosa et al., 2019), causing poisoning in several organisms, including humans, through the consumption of contaminated mollusks (Barbieri, 2009; Proença et al., 2011). In marine coastal environments, most phycotoxins are produced by dinoflagellates (Castro and Moser, 2012; Hallegraeff, 2003).

In Brazil, Interministerial Normative Instruction 07/2012 of the Ministries of Agriculture, Livestock and Supply (MAPA) and the former Ministry of Fisheries and Aquaculture (MPA) indicate which microalgae species are capable of producing toxins and list their main symptoms. The nomenclature of each intoxication is related to the main symptom caused in humans. For example, Diarrheic Shellfish Poisoning (DSP) indicates a diarrheal syndrome which produces abdominal discomfort, nausea, vomiting and diarrhea (Grattan et al., 2016), caused by okadaic acid (AO) and derivatives such as the dinophysistoxin group (DTXs), yessotoxins (YTXs) and pectonotoxins (PTXs) (Castro and Moser, 2012; Barbieri, 2009; Hallegraeff, 2003). Okadaic acid (OA) and DTX toxins are lipophilic substances that can contaminate shellfish meat (Uchida et al., 2018) produced by planktonic dinoflagellates (Castro and Moser, 2012; Hallegraeff, 2003). 
Other issues may also result from the ingestion of toxins produced by these organisms, such as tumors and mutagenic and immunotoxic effects (Kolrep et al., 2016). Specifically, cyanobacterial microcystin-LR (MC-LR), OA and DTX may also lead to inhibition of PP1 and PP2A phosphatases proteins MC-LR and OA are the most widely distributed hepatotoxins worldwide (Wu et al., 2015). Several analytical methodologies for the analysis of lipophilic phycotoxins have been applied. In this context, mass spectrometry liquid chromatography (LCMS/MS) has been set as the reference method of the EU since 2011 (EC No. 15/2011) (Suzuki et al., 2009; Garibo et al., 2012), while mouse bioassays (Yasumoto et al., 1978) are considered an alternative method in this regard (Visciano et al., 2016). A number of other alternative or complementary techniques are, however, permitted by EC Regulation No. 15/2011, either performed individually or in combination, provided they fulfill the proper role of official methods of providing protection to public health (Garibo et al., 2012). These include immunoassays and other chromatography techniques, including high performance liquid chromatography (HPLC), thin layer chromatography (TLC), gas chromatography-mass spectrometry (GC-MS) and gas chromatography-infrared spectroscopy (GC-IV) (Fujii et al., 2004). However, these methodologies have some drawbacks, i.e., they are very expensive, require specialized labor (in the case of liquid and gas chromatographies) and use methodologies that are not ethically adequate (mouse testing). Enzymatic assays, on the other hand, are less expensive than chromatographic techniques and can be applied to detect various pollutants, such as pesticides and metals (Ochoa et al., 2013, Chouteau et al., 2005), as well as their effects. In this regard, phosphatase inhibition assays have also been proposed to detect lipophilic phycotoxin effects (Garibo et al., 2012).

Ecotoxicological assays are routinely applied in monitoring polluted environments (Anselmo et al., 2011) as well as in assessing bioactive substances and phytotoxins. Assays using species belonging to the Artemia genus are a staple in many countries (Astuya et al., 2015; Chang and Gall, 2013), and have been suggested as an early ecotoxicological alarm test for evaluating the effects of palytoxin and palytoxin-related compounds produced by benthic dinoflagellates (Faimali et al., 2012).

In this regard, this study sought to verify the associated use of alternative phosphatase inhibition tests and an artemia nauplii lethality bioassay for the detection of DSP toxins as a viable alternative to monitor phytotoxin contamination in cultivated mussels.

\section{MATERIAL AND METHODS}

\subsection{Study area}

The town of Arraial do Cabo is located in the coastal zone of the state of Rio de Janeiro, $158 \mathrm{~km}$ distant from the capital, between coordinates $22^{\circ} 57^{\prime} 57^{\prime \prime} \mathrm{S}, 42^{\circ} 1^{\prime} 40^{\prime}$ ' W. It includes approximately $152,305 \mathrm{~km}^{2}$, with a population of about 27,700 (IBGE, 2020) (Figure 1).

\subsection{Bivalve mollusc sampling and processing}

Perna perna mussels (50 individuals per sampling) were collected between August 2013 and May 2014, always in the morning. Mean shell length was $8.5 \pm 0.59 \mathrm{~cm}$ and mean weight of $48.61 \pm 8.45 \mathrm{~g}$. After transportation to the laboratory, individual hepatopancreas were removed, pooled until reaching 20 to $25 \mathrm{~g}$, and stored at $-20^{\circ} \mathrm{C}$.

\subsection{Methanolic hepatopancreas extract preparation}

After drying the pooled hepatopancreas samples in an oven at constant temperature of $60^{\circ} \mathrm{C}$ for 24 hours, methanolic hepatopancreas extracts were prepared by mixing $100 \mathrm{~mL}$ methanol to $20 \mathrm{~g}$ of the dehydrated hepatopancreas samples with the aid of surgical scissors and a porcelain mortar and pestle. After homogenization and $30 \mathrm{~min}$ of rest, the supernatants were filtered (Milex ${ }^{\mathrm{TM}}, 45 \mu \mathrm{m}$, Millipore) and the same volume of methanol was added for a second 
extraction step for a further $30 \mathrm{~min}$. The two supernatants were then joined in order and were submitted to a rotary evaporation step at $60^{\circ} \mathrm{C}$ until complete evaporation.

Subsequently, the concentrated extracts were resuspended in $5 \mathrm{~mL}$ of deionized water and left to stand for $30 \mathrm{~min}$. After this period, $1 \mathrm{~mL}$ of the solutions were applied to a solid phase C18 reverse phase chromatography column containing DIAION HP 20 (Sigma Aldrich, São Paulo). The mobile phase elution step was performed by successively applying different methanol concentrations. The obtained solutions were then dried by rotary evaporation and the $100 \%$ methanol fraction was stored at $-20^{\circ} \mathrm{C}$ for subsequent toxicological and enzymatic assays.

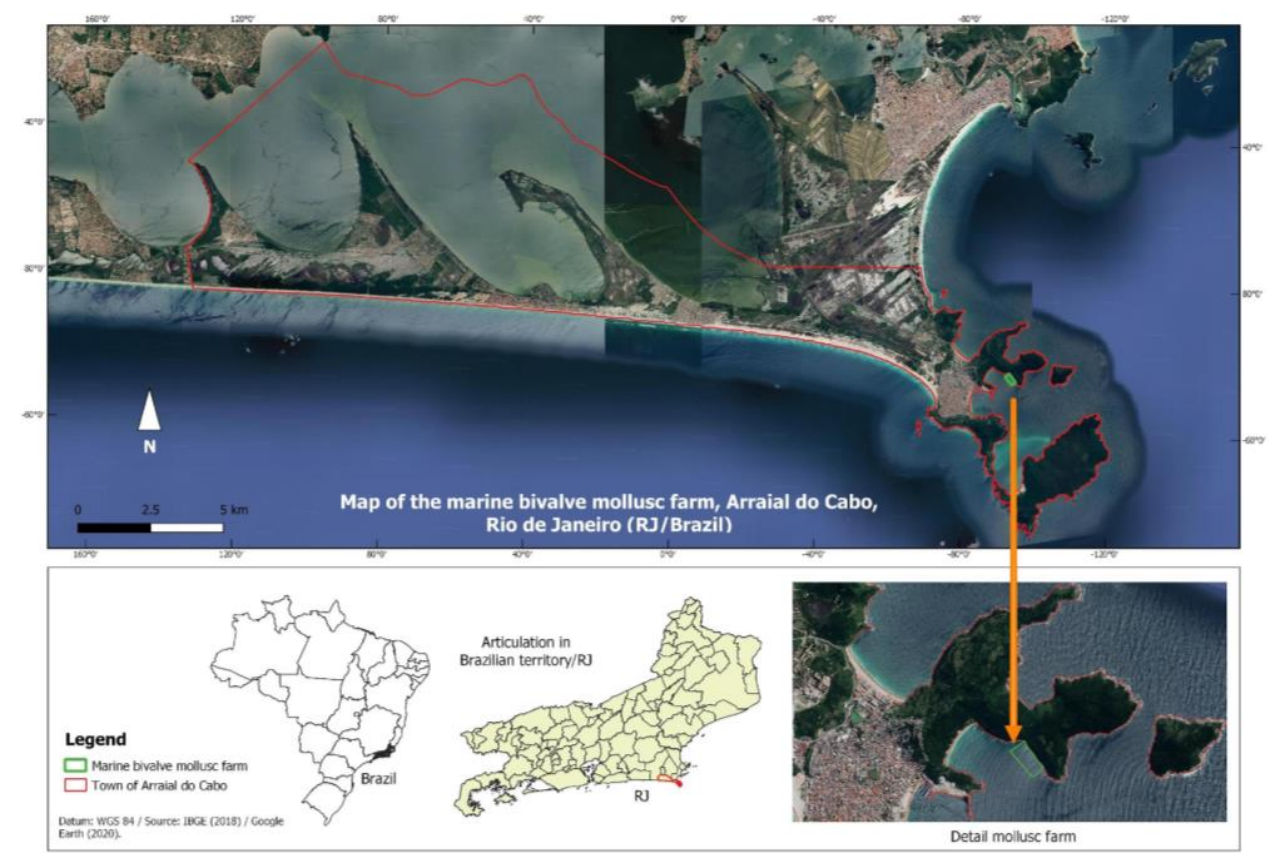

Figure 1. Map of the marine bivalve mollusc farm, Arraial do Cabo, Rio de Janeiro.

\subsection{Microcystis aeruginosa extract preparation}

Freeze-dried Microcystis aeruginosa containing the microcystin-LR toxin was used as a positive phycotoxin control for the artemia assays, cultivated from a NPLJ-4 (Laughinghouse et al., 2012) strain kindly provided from the IBCCF Ecophysiology and Cyanobacterial Toxicology Laboratory, belonging to the Federal University of Rio de Janeiro (UFRJ), and the Toxicological Biochemistry Laboratory, belonging to the State University of Rio de Janeiro (UERJ). Preparation of the M. aeruginosa extract followed the same methodology previously described for mussel hepatopancreas, with modifications in the methanol ratio, set at $2.5 \mathrm{~mL}$ methanol to $50 \mathrm{mg}$ of lyophilized M. aeruginosa cells (NPLJ-4), followed by three methanol extractions and a centrifugation step to obtain the supernatant, instead of filtering.

\subsection{Artemia franciscana ecotoxicological assays}

Artemia cysts were obtained from a commercial pet shop (Maramar Pet, Arraial do $\mathrm{Cabo} / \mathrm{RJ})$. Cysts were decapsulated using calcium hypochlorite and hatched in artificial seawater $\left(2 \mathrm{~g} . \mathrm{L}^{-1} \mathrm{NaHCO}_{3}+8 \mathrm{~g} . \mathrm{L}^{-1} \mathrm{NaCl}\right)$ at room temperature $\left(25^{\circ} \mathrm{C}\right)$ for $24 \mathrm{~h}$, under constant aeration and lighting $\left(250 \mu \mathrm{mol} \cdot \mathrm{m}^{-2} \cdot \mathrm{s}^{-1}\right)$.

Artemia franciscana ecotoxicological assays were performed according to Meyer et al. (1982), with modifications. All assays were carried out in 6-well cell culture plates, with each well containing 10 brine shrimp nauplii. The positive control consisted of a Microcystis aeruginosa strain containing the microcystin-LR toxin, while the negative control consisted of $5 \mathrm{~mL}$ of artificial seawater. The positive control and hepatopancreas extracts were resuspended 
in $1 \mathrm{~mL}$ of artificial seawater solution containing $0.01 \%$ ethanol, used to improve extract. Each well received $1 \mathrm{~mL}$ of the extract solution to be tested and $4 \mathrm{~mL}$ of artificial seawater, totaling $5 \mathrm{~mL}$. All assays were conducted in triplicate. The nauplii were exposed to the extract for 24 h. Lethality was considered when no nauplii movements were observed for at least 10 s under observation with a binocular microscope. Results are presented as nauplii mortality percentages.

\subsection{Phosphatase enzyme sample preparation and determinations}

Artemia franciscana enzymatic extracts were prepared by weighing $1 \mathrm{~g}$ of brine shrimp (recently hatched nauplii at the II-III stage) and homogenizing this mass at a 1:4 ratio in a Tris/ $\mathrm{HCl} 50 \mathrm{mmol} \mathrm{L}^{-1} \mathrm{pH} 7.4$ containing sucrose $250 \mathrm{mM}$, EDTA 5 mmol.L ${ }^{-1}$, DTT 1 mmol.L1, PMSF $0.1 \mathrm{mmol} . \mathrm{L}^{-1}$. After thirty passes in a Potter-Elvehjem tissue homogenizer (Potter, 1955), the homogenates were centrifuged at $10,000 \mathrm{~g}$ for $60 \mathrm{~min}$ at $4^{\circ} \mathrm{C}$ and the obtained supernatants were used as a source of phosphatase enzymes.

Total phosphatase (TF) activity was determined according to Rivasseau et al. (1999) and Bouaïcha et al. (2002) with modifications. Briefly, the assay buffer (40 mM Tris/HCl, pH 8.4, containing $34 \mathrm{mmol} . \mathrm{L}^{-1} \mathrm{MgCl}_{2}, 4 \mathrm{mmol} . \mathrm{L}^{-1}$ EDTA and 4 nmol.L ${ }^{-1}$ DDT) was mixed with pnitrophenyl phosphate as substrate at a final concentration $9.8 \mathrm{mmol} . \mathrm{L}^{-1}$ and $100 \mu \mathrm{L}$ of the Artemia franciscana enzyme fraction, totaling a final volume of $200 \mu \mathrm{L}$. Product formation was measured by continuous absorption at $405 \mathrm{~nm}$ on a microplate reader for 6 min and enzyme activity calculations were performed using the p-nitrophenol absorption coefficient $\left(16,890 \mathrm{M}^{-1} \cdot \mathrm{cm}^{-1}\right)$. Data were expressed as one enzyme unit (U) $\mu$ mol.min ${ }^{-1}$ p-nitrophenol per milliliter. For the inhibition test, Artemia franciscana enzyme fractions and methanolic mussel hepatopancreas extracts incubated for 1 hour at $20^{\circ} \mathrm{C}$ were used. All assays were performed in triplicate and results are presented as enzyme inhibition percentages, to facilitate interpretation and comparison to other studies.

\subsection{Statistical analyses}

Data were analyzed using the Graph Pad Prism v. 6.0 and Microsoft Excel v. 2003 software packages. A simple linear regression was observed in order to verify potential correlations (Pearson's correlation test) between the proposed brine shrimp assay and the phosphatase inhibition assay. The results are presented as means and standard deviations (means \pm SD) of triplicates and the $t$ student's test $(p<0.05)$ was applied between control samples and the extracts.

\section{RESULTS AND DISCUSSION}

DSP phycotoxins are lipophilic substances that can contaminate shellfish meat (Uchida $e t$ $a l ., 2018)$ and are produced by planktonic dinoflagellates belonging to the Dinophysis (D. acuta, D. acuminata, D. caudata, D. fortii, D. miles, D. norvegica, D. sacculus and D. tripos) and Phalacroma genera ( $P$. mitra and $P$. rotundatum); as well as benthic species belonging to the Prorocentrum genus ( $P$. lima, $P$. arenarium, $P$. belizeanum, $P$. concavum, $P$. faustiae, $P$. hoffmannianum, P. mild and P. maculosum) (Castro and Moser, 2012; Hallegraeff, 2003). In this regard, Souza et al. (2016) analyzed the same hepatopancreas mussel samples collected in January and May 2014 assessed herein using the mouse bioassay and reported the presence of Dinophysis acuminata (120). The current study assessed the same samples used by Souza et al. (2016) for the brine shrimp and phosphatase inhibition assays.

Artemia sensitivity to the positive control corroborates previous assessments carried out using another Artemia species, Artemia salina, exposed to cyanobacteria extracts, where an LC50 of below $50 \mu \mathrm{g} \mathrm{mL}^{-1}$ was reported (Falch et al., 1995). In another study, Batista et al. (2013) evaluated Artemia salina sensitivity to extracts obtained from two Microcystis sp. strains (NPLJ-4 and TAC 95) and reported high sensitivity to these cyanotoxins (LC50 24h of 5.7 
mg.L $\mathrm{L}^{-1}$ and $3.7 \mathrm{mg} . \mathrm{L}^{-1}$, respectively for NPLJ-4 and TAC 95). However, when compared to other organisms (Daphnia magna, LC50 24h $2 \mathrm{mg} . \mathrm{L}^{-1}$ and $0.8 \mathrm{mg} . \mathrm{L}^{-1}$ and Ceriodaphnia dubia, CL5024h $1.2 \mathrm{mg} . \mathrm{L}^{-1}$ and $0.6 \mathrm{mg} . \mathrm{L}^{-1}$ for MPLJ-4 strains and TAC 95, respectively) Artemia salina was more resistant, and, thus, deemed the most adequate species to assess the relationship between microcystins present in cyanobacterial strain extracts.

\subsection{Artemia franciscana lethality assay}

High A. franciscana mortality rates of over $50 \%$ for all assessed months were observed after 24 hours of exposure to the methanolic extracts. In August 2013 and May 2014, the mortality rates of the metanolic extract was comparable to the effects of the pure microcystinLR positive control, of $90 \%$ or more (Figure 2).

The dinoflagellate Dinophysis acuminate was detected in seawater (120 and 7040 Cell.L ${ }^{-1}$ ) and in Perna perna hepatopancreas samples collected in January and May 2014 by Souza et al. (2016), indicating the presence of a lipophilic toxin causing DSP in the reference mouse bioassay, which may have been responsible for the high toxicity of around $90 \%$ observed for these mussel extracts. No correlations were detected between high nauplii mortality and mouse bioassay toxicity for the other assessed months.

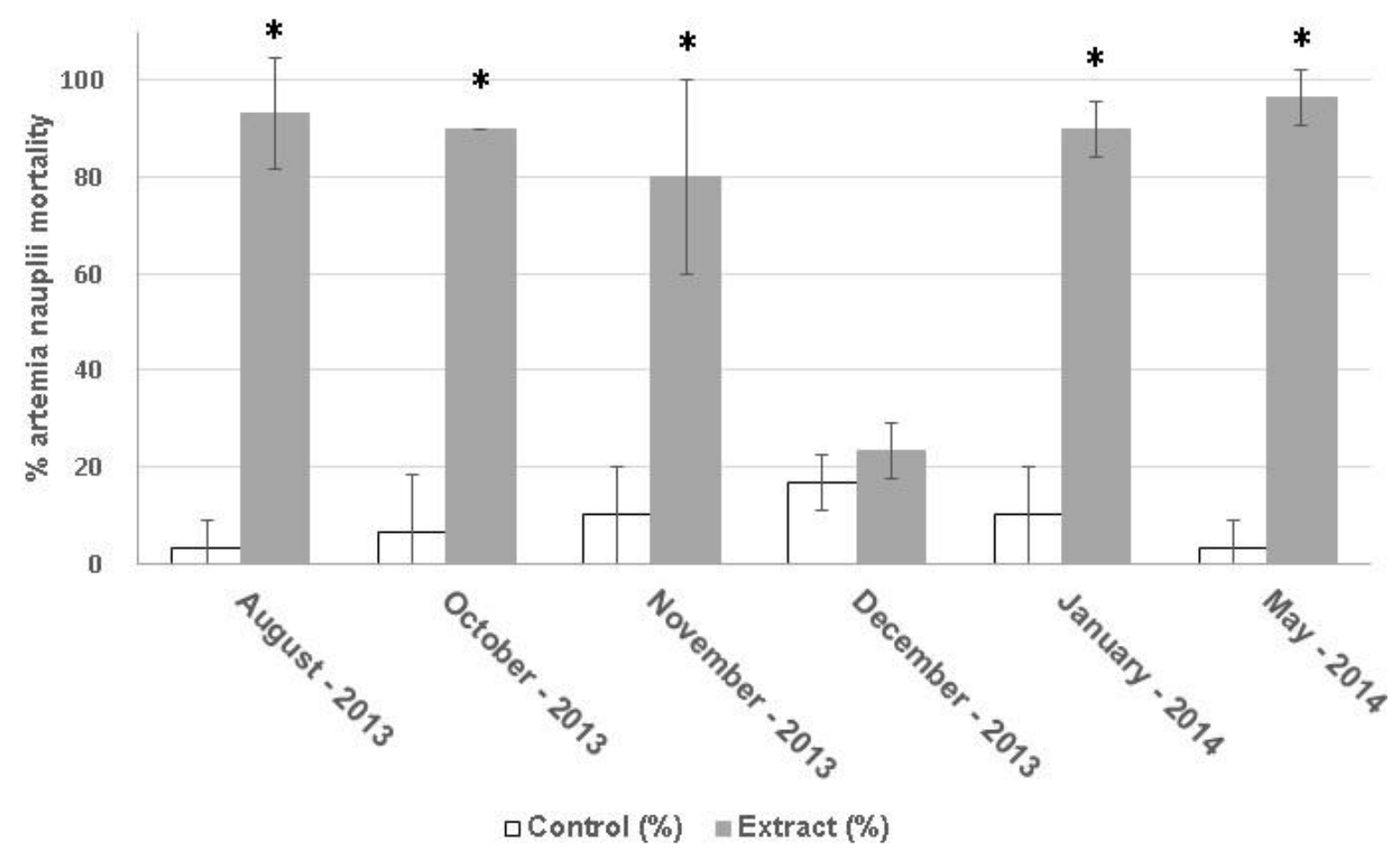

Figure 2. Mortality percentages (mean $\pm \mathrm{SD}, \mathrm{n}=3$ ) of Artemia franciscana nauplii exposed to methanolic mussel hepatopancreas extracts. (*) Indicates significant difference between the means extract vs control (Student's $t$ test, $\mathrm{p}<0.05$ ).

Several brine shrimp assays have been applied to assess the toxicity of several dinoflagellates and diatoms in the literature. For example, these shrimp assays have been reported as adequate for the assessment of the toxicity of the dinoflagellate species Amphidinium carterae, Coolia monotis and Ostreopsis ovata in a study conducted in the Northern Ionian Sea (Mediterranean Sea), applied comparatively and alongside phytotoxin evaluations concerning the larval development of sea urchin (Paracentrotus lividus) and hemolysis tests on human erythrocytes (Pagliara and Caroppo, 2012). Comparative toxicity studies of the effects of different Ostreopsis ovata concentrations on artemia nauplii and fish larvae have also been reported, and the results indicate that artemia nauplii are an adequate test 
organism due to their high sensitivity (Faimali et al., 2012).

Artemia nauplii assessments expressed as cyst hatching success have also been deemed efficient in toxicity evaluations regarding Skeletonema costatum and Nitzschia commutata diatoms and short-chain aldehydes (Caldwell et al., 2003). However, low acute toxicity was observed when artemia nauplii were exposed to Pseudochattonella and Chattonella marina strains, which are ichthyotoxic (Skjelbred et al., 2011).

\subsection{Phosphatase Enzyme Assay}

The phosphatase enzyme assay has been routinely used for the detection of cyanobacterial microcystins and okadaic acid produced by certain dinoflagellate species (Triantis et al., 2010; Eberhart et al., 2013), and no differences have been reported when comparing this method with reference methods, such as mouse bioassays and fluorometric detection high performance liquid chromatography (HPLC-FLD) using 1-bromoacetylpyrene (BAP) as the pre-column derivative reagent (Prassopoulou et al., 2009).

Only exposure to extracts obtained from samples collected in January resulted in phosphatase enzyme inhibition of about or over $50 \%$, while the other samples displayed lower than $40 \%$ inhibition rates (Figure 3).

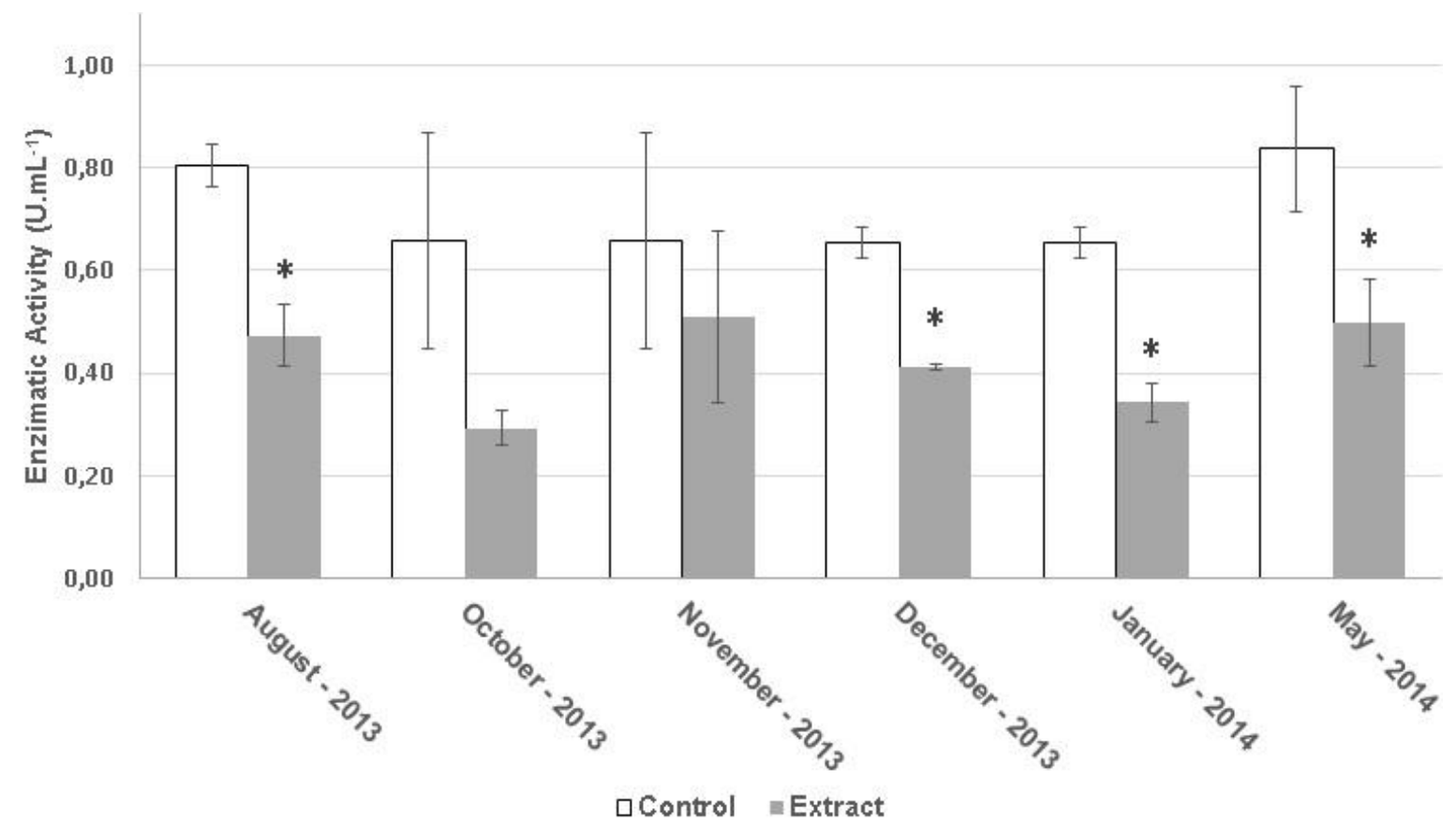

Figure 3. Enzymatic phosphatase activity (mean $\pm \mathrm{SD}, \mathrm{n}=3)$ ) in Artemia franciscana submitted to methanolic mussel hepatopancreas extracts. $(*)$ Indicates significant difference between the means extract vs control (Student's t test, $\mathrm{p}<0.05$ ).

The inhibition pattern of around $50 \%$ is similar to that reported in another study for genetically engineered phosphatases $2 \mathrm{~A}$ and purified red blood cell enzymes in samples that had accumulated lipophilic toxins, carried out by Garibo et al. (2012) when analyzing mussels and oysters collected in Catalonia and Galicia.

\subsection{Correlations between the brine shrimp lethality assay and phosphatase inhibition assay}

No correlation between phosphatase inhibition and artemia mortality was observed (Figure 4). It is probable that acute DSP toxin toxicity (okadaic acid and derivatives) may not only related to phosphatase inhibition (Munday, 2013), and that other mechanisms of action may play a role in toxicity and artemia nauplii mortality (Rossini and Hess, 2010). This has 
been reported previously in other assessments, where derivatives such as DTX-4 and 7-Odocosahexaenoyl-OA, for example, display high acute mouse toxicity and low protein phosphatase 1 and 2A inhibition (Munday, 2013).

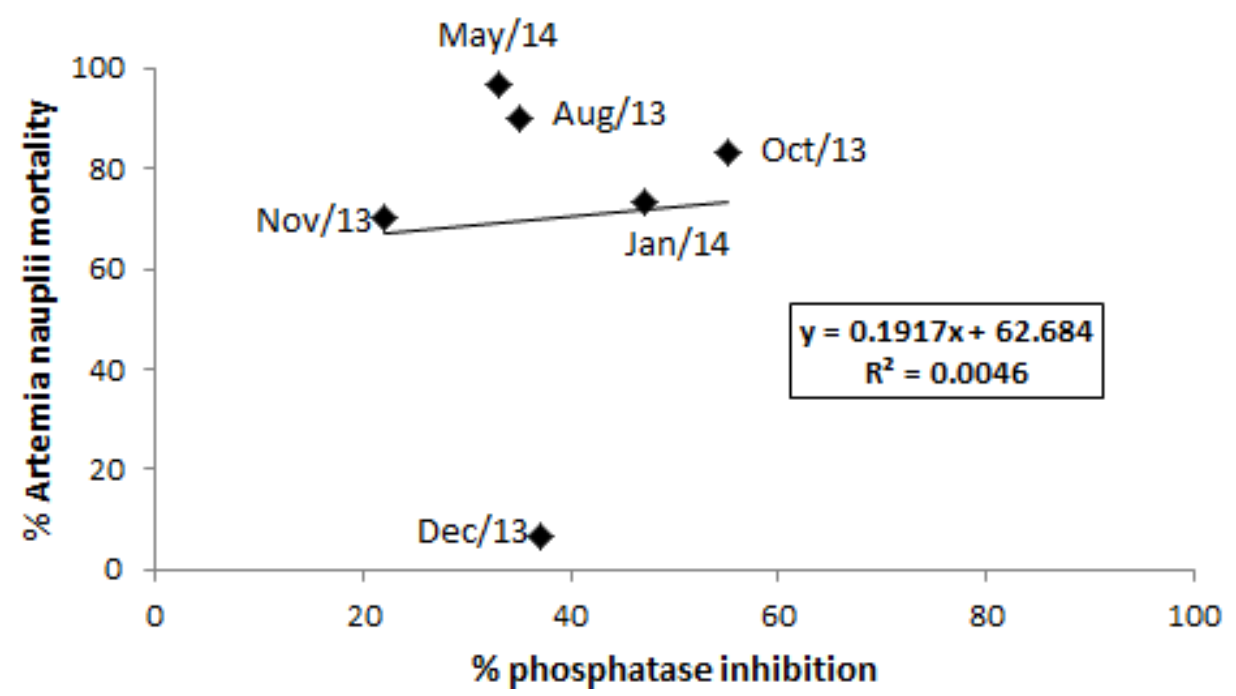

Figure 4. Correlations between artemia nauplii phosphatase activity inhibition and lethality when exposed to methanolic extracts. No correlation (Pearson's correlation coefficient $\mathrm{p}<0.05)$ was observed between the assessed variables.

\subsection{Correspondence with bioassays from another study}

The dinoflagellate Dinophysis acuminata was detected in the January and May 2014 hepatopancreas samples by Souza et al. (2016), which may have been the cause for the high mortality Artemia franciscana rates observed herein for these months. The phosphatase inhibition was significant for these sampling points.

Souza et al. (2016), using the same samples as assessed herein, carried out the DSP bioassay which assessed mouse deaths. The mouse deaths observed for the January and May samples also coincide with high mortality rates and phosphatase inhibition in the Artemia franciscana trial carried out herein, corroborating the dinoflagellate Dinophysis acuminata as the toxic agent responsible for these deaths.

A simple comparison of the brine shrimp bioassay and phosphatase assays carried out herein with the results reported by Souza et al. (2016) for the same samples concerning Perna perna microalgae content and mouse bioassay results is displayed in Table 1. In the present study, both Artemia franciscana nauplii and phosphatase enzyme displayed sensitivity to the Microcystis aeruginosa standard used as the positive control in the assays (Table 1).

Table 1. Comparison of brine shrimp bioassay and phosphatase assays results with Perna perna hepatopancreas microalgae content and mouse bioassay assessments.

\begin{tabular}{ccccc}
\hline Sampling date & $\begin{array}{c}\text { Percentage brine } \\
\text { shrimp lethality } \\
\text { (CV\%) }\end{array}$ & $\begin{array}{c}\text { Percentage } \\
\text { phosphatase inhibition } \\
(\mathrm{CV} \%)\end{array}$ & $\begin{array}{c}\text { Detected microorganism } \\
\text { (cells.L-1) } \\
\text { (Souza } \text { et al., 2016) }\end{array}$ & $\begin{array}{c}\text { Mouse DSP assay } \\
\text { (Souza } \text { et al., 2016) }\end{array}$ \\
\hline Positive control & $93(6)$ & $72(8)$ & M. aeruginosa (NPLJ-4) & - \\
Jan-14 & $74(6)$ & $48(11)$ & Dinophysis acuminata $(120)$ & Positive \\
May-14 & $96(6)$ & $42(17)$ & Dinophysis acuminata $(7040)$ & Positive \\
\hline
\end{tabular}

(CV\%) Coefficient of variation. 
A $100 \%$ agreement between fluorometric detection high performance liquid chromatography (HPLC-FLD), using 9-athryldiazomethane (ADAM) as the precolumn derivative reagent, with mass spectrometry-coupled liquid chromatography method in tandem (LC-MS / MS), applied for detection of okadaic acid has been previously reported, as well as a $97.1 \%$ agreement observed between each of these methods with the reference mouse bioassay (Louppis et al., 2010). Although a high agreement was not noted herein between brine shrimp lethality assay, the phosphatase inhibition assay and the reference mouse assay, the first two display the potential to be applied as alarm methods to aid decision-making in malaculture activities prior to further, more costly, methods using mice, as the same the January and May samples containing Dinophysis acuminata led to both high Artemia franciscana mortality rates and mice deaths in the DSP assay carried out by Souza et al. (2016).

In this regard, other enzymatic and toxicological models are required to further assess these differences, identifying the minimum inhibitory DSP concentrations and validation parameters, such as selectivity, limits of detection and quantification, accuracy, precision, linearity, sensitivity, robustness and reproducibility for each of the evaluated factors should be taken into account.

\section{CONCLUSIONS}

The present study indicates that the early-alarm method of brine shrimp assay may be incorporated into phytotoxin monitoring programs in marine-farmed bivalve molluscs. Artemia nauplii efficiently demonstrated lethality and phosphatase inhibition due to exposure to hepatopancreas methanolic extracts containing DSP, corroborated by mouse deaths caused by exposure to the same samples.

Contrasting results for the brine shrimp phosphatase inhibition assay and lethality assays may be due to different toxicodynamic pathways in place between brine shrimp and mice, probably occurring not only through phosphatase inhibition. Because of this, further methodological adjustments studies and the inclusion of other enzymatic and toxicological models are required to further assess these differences, and associations between methods for application as early-alarm methods are encouraged.

\section{REFERENCES}

ANSELMO, H. M. R.; KOERTING, L.; DEVITO, S.; VAN DEN BERG, J. H.J.; DUBBELDAM, M.; KWADIJK, C.; MURK, A. J. Early life developmental effects of marine persistent organic pollutants on the sea urchin Psammechinus miliaris. Ecotoxicology and Environmental Safety, v. 74, n. 8, p. 2182-2192, 2011. https://doi.org/10.1016/j.ecoenv.2011.07.037

ASTUYA, A.; RAMÍREZ, A. E.; ABALlAY, A.; ARAYA, J.; SILVA, J.; ULlOA, V.; FUENTEALBA, J. Neurotoxin-like compounds from the ichthyotoxic red tide alga Heterosigma akashiwo induce a TTX-like synaptic silencing in mammalian neurons. Harmful Algae, v. 47, p.1-8, 2015. https://doi.org/10.1016/j.hal.2015.04.006

BARBIERI, E. O Perigo das Biotoxinas Marinhas. São Paulo: Instituto de Pesca, 2009.

BARBOSA, V.; SANTOS, M.; ANAClETO, P.; MAUlVAUlT, A. L.; POUSÃOFERREIRA, P.; COSTA, P. R.; MARQUES, A. Paralytic Shellfish Toxins and Ocean Warming: Bioaccumulation and Ecotoxicological Responses in Juvenile Gilthead

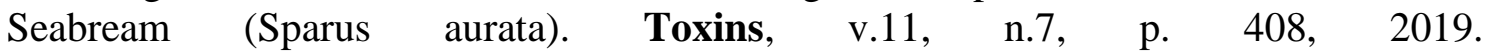
https://doi.org/10.3390/toxins11070408 
BATISTA, A. D.; SUZUKI, L. Y.; KURODA, E. K. 2013. Avaliação da toxicidade de extratos de cepas de cianobactérias com diferentes organismos-teste. Fórum Ambiental da Alta Paulista, v. 9, n. 11, p. 186-201, 2013. http://dx.doi.org/10.17271/198008279112013671

BOUAÏCHA, N.; MAATOUK, I.; VINCENT, G.; LEVI, Y. A colorimetric e fluorimetric microplate assay for the detection of microcystin LR in drinking water without preconcentration. Food and Chemical Toxicology, v. 40, p. 1677-1683, 2002. https://doi.org/10.1016/S0278-6915(02)00103-5

CALDWELL, G. S.; BENTLEY, M. G.; OLIVE, P. J. W. The use of a brine shrimp (Artemia salina) bioassay to assess the toxicity of diatom extracts and short chain aldehydes. Toxicon, v. 42, n. 3, p. 301-306, 2003. https://doi.org/10.1016/S0041-0101(03)00147-8

CASTRO, N. O.; MOSER, G. A. O. Florações de algas nocivas e seus efeitos ambientais. Oecologia Australis, v. 16, n. 2, p. 235-264, 2012.

CHANG, F. H.; GALL, M. Pigment compositions and toxic effects of three harmful Karenia species, Karenia concordia, Karenia brevisulcata and Karenia mikimotoi (Gymnodiniales, Dinophyceae), on rotifers and brine shrimps. Harmful Algae, v. 27, p. 113-120, 2013. https://doi.org/10.1016/j.hal.2013.05.005

CHOUTEAU, C.; DZYADEVYCH, S.; DURRIEU, C.; CHOVELON, J-M. A bi-enzymatic whole cell conductometric biosensor for heavy metal ions and pesticides detection in water samples. Biosensors and Bioelectronics, v. 21, n. 2, p. 273-281, 2005. https://doi.org/10.1016/j.bios.2004.09.032

EBERHART, B. T. L.; MOORE, L. K.; HARRINGTON, N.; ADAMS, N. G.; BORCHERT, J.; TRAINER, V. L. Screening Tests for the Rapid Detection of Diarrhetic Shellfish Toxins in Washington State. Marine Drugs, v. 11, n. 10, p. 3718 -3734, 2013. https://doi.org/10.3390/md11103718

FAIMALI, M.; GIUSSANI, V.; PIAZZA, V.; GARAVENTA, F.; CORRÀ, C.; ASNAGHI, V.; PRIVITERA, D.; GALLUS, L.; CATTANEO-VIETTI, R.; MANGIALAJO, L.; CHIANTORE, M. Toxic effects of harmful benthic dinoflagellate Ostreopsis ovata on invertebrate and vertebrate marine organisms. Marine Environmental Research, n. 76, p. 97-107, 2012. https://doi.org/10.1016/j.marenvres.2011.09.010

FALCH, B. S.; KÖNIG, G. M.; WRIGHT, A. D.; STICHER, O.; ANGERHOFER, C. K.; PEZZUTO, J. M.; BACHMANN, H. Biological activities of cyanobacteria: evaluation of extracts and pure compounds. Planta Medica, n. 61, p. 321-328, 1995. https://dx.doi.org/10.1055/s-2006-958092

FAO. The state of world fisheries and aquaculture. Rome, 2016.

FUJII, I.; YASUOKA, Y.; CHANG, Y. C.; KWON-CHUNG, K.; EBIZUKA, Y. Hydrolytic polyketide shortening by ayg $1 \mathrm{p}$, a novel enzyme involved in fungal melanin biosynthesis. The Journal of Biological Chemistry, v. 279, p. 44613-44620, 2004. https://dx.doi.org/10.1074/jbc.M40675820

GARIBO, D.; DÀMASO, E.; EIXARCH, H., IGLESIA, P.; FERNÁNDEZ-TEJEDOR, M.; DIOGĖNE, J.; PAZOS, Y.; CAMPÀS, M. Protein phosphatase inhibition assays for okadaic acid detection in shellfish: Matrix effects, applicability and comparison with LCMS/MS analysis. Harmful Algae, v. 19, p. 68-75, 2012. https://doi.org/10.1016/j.hal.2012.06.001 
GRATTAN, L. M.; HOLOBAUGH, S.; MORRIS JR, J. G. Harmful algal blooms and public health. Harmful algae, v. 57, p. 2-8, 2016. https://doi.org/10.1016/j.hal.2016.05.003

HALLEGRAEFF, G. M. Harmful algal blooms: a global overview. In: ALLEGRAEFF, G. M.; ANDERSON, D. M.; CEMBELlA A. D. (eds.). Manual on Harmful Marine Microalgae. Paris: UNESCO, 2003.

IBGE. Arraial do Cabo. 2020. Available at: https://cidades.ibge.gov.br/brasil/rj/arraial-docabo/panorama Access: 15 Jan. 2020.

KOLREP, F.; HESSEL, S.; THESE, A.; EHLERS, A.; REIN, K.; LAMPEN, A. Differences in metabolism of the marine biotoxin okadaic acid by human and rat cytochrome P450 monooxygenases. Archives of toxicology, v. 90, n. 8, p. 2025-2036, 2016. https://doi.org/10.1007/s00204-015-1591-9

LAUGHINGHOUSE IV, H. D.; PRÁ, D.; SILVA-STENICO, M. E.; RIEGER, A.; FRESCURA, V. D. S.; FIORE, M. F.; TEDESCO, S. B. Biomonitoring genotoxicity and cytotoxicity of Microcystis aeruginosa (Chroococcales, cyanobacteria) using the Allium cepa test. Science of the Total Environmental, v. 432, p. 180-188, 2012. https://doi.org/10.1016/j.scitotenv.2012.05.093

LOUPPIS, A. P.; BADEKA, A. V.; KATIKOU, P.; PALEOLOGOS, E. K.; KONTOMINAS, M. G. Determination of okadaic acid, dinophysistoxin-1 and related esters in Greek mussels using HPLC with fluorometric detection, LC-MS/MS and mouse bioassay. Toxicon, v. 55, n. 4, p. 724-33, 2010. https://doi.org/10.1016/j.toxicon.2009.10.026

MEYER, B. N.; FERRIGNI, N. R.; PUTNAM, J. E.; JACOBSEN, L. B.; NICHOLS, D. E.; MACLAUGHLIN, J. L. Brine shrimp: a convenient general bioassay for active plant constituents. Planta Medica, v. 45, p. 31-34, 1982. https://doi.org/10.1055/s-2007971236

MUNDAY, R. Is protein phosphatase inhibition responsible for the toxic effects of okadaic acid in animals? Toxins, v. 5, n. 2, p. 267-285, 2013. https://doi.org/10.3390/toxins5020267

OCHOA, V.; RIVA, C.; FARIA, M.; BARATA, C. Responses of B-esterase enzymes in oysters (Crassostrea gigas) transplanted to pesticide contaminated bays form the Ebro Delta (NE, Spain). Marine Pollution Bulletin, v. 66, n. 1-2, 15, p. 135-142, 2013. https://doi.org/10.1016/j.marpolbul.2012.09.032

PAGLIARA, P.; CAROPPO, C. Toxicity assessment of Amphidinium carterae, Coolia cfr. monotis and Ostreopsis cfr. ovata (Dinophyta) isolated from the northern Ionian Sea (Mediterranean Sea). Toxicon, v. 60, n. 6, p. 1203-1214, 2012. https://doi.org/10.1016/j.toxicon.2012.08.005

PRASSOPOULOU, E.; KATIKOU, P.; GOERGANTELIS, D.; KYRITSAKIS, A. Detection of okadaic acid and related esters in mussels during diarrhetic shellfish poisoning (DSP) episodes in Greece using the mouse bioassay, the PP2A inhibition assay and HPLC with fluorimetric detection. Toxicon v. 53, n.2, p. 214-227, 2009. https://doi.org/10.1016/j.toxicon.2008.11.003

PROENÇA, L. A. O.; FONSECA, R. S.; PINTO, T. O. Microalgas em área de cultivo do litoral de Santa Catarina. São Carlos: RiMa, 2011. 90 p. 
RIVASSEAU, C.; RACAUD, P.; DEGUIN, A.; HENNION, M.C. Development of a bioanalytical phosphatase inhibition test for the monitoring of microcystins in environmental water samples. Analytica Chimica Acta, v. 394, p. 243-257, 1999. https://doi.org/10.1016/S0003-2670(99)00301-3

ROSSINI, G. P.; HESS, P. Phycotoxins: chemistry, mechanisms of action and shellfish poisoning. In: Molecular, clinical and environmental toxicology. Birkhäuser Basel, v. 100, p. 65-122, 2010. https://doi.org/10.1007/978-3-7643-8338-1_3

SIMÕES, E. Impacto da floração da alga Nociva Dinophisis acuminata sobre o sistema imune de ostras Crassostrea gigas e mexilhões Perna perna cultivados em Santa Catarina. 2011. 84f. Dissertação (Mestrado em Aquicultura) - Centro de Ciências Agrárias, Universidade Federal de Santa Catarina, Florianópolis, 2011.

SKJELBRED, B.; HORSBERG, T. E.; TOLLEFSEN, K. E.; ANDERSEN, T.; EDVARDSEN, B. Toxicity of the ichthyotoxic marine flagellate Pseudochattonella (Dictyochophyceae, Heterokonta) assessed by six bioassays. Harmful Algae, v. 10, n. 2, p. 144-154, 2011. https://doi.org/10.1016/j.hal.2010.08.007

SOUZA, D. A.; OLIVEIRA, M. M.; NEVES, M. H. B. N.; SCHRAMM, M. A.; PROENÇA, L.; SARAIVA, V. B. Occurrence of DSP toxins in Perna perna mussels (Linnaeus, 1758) and toxic marine phytoplankton in Arraial do Cabo, RJ / Brazil. In: INTERNATIONAL CONFERENCE ON HARMFUL ALGAE - ICHA, 17., 2016. Florianópolis. Proceedings[...] Florianópolis: ICHA, 2016.

SUZUKI, T.; MIYAZONO, A.; BABA, K.; SUGAWARA, R.; KAMIYAMA, T. LC-MS/MS analysis of okadaic acid analogues and other lipophilic toxins in single-cell isolates of several Dinophysis species collected in Hokkaido, japan. Harmful Algae, v. 8, n. 2, p. 233-238, 2009. https://doi.org/10.1016/j.hal.2008.06.001

TRIANTIS, T.; TSIMELI, K.; KALOUDIS, T.; THANASSOULIAS, N.; LYTRAS, E.; HISKIA, A. Development of an integrated laboratory system for the monitoring of cyanotoxins in surface and drinking waters. Toxicon, v. 55, n. 5, p. 979-989, 2010. https://doi.org/10.1016/j.toxicon.2009.07.012

UCHIDA, H.; WATANABE, R.; MATSUSHIMA, R.; OIKAWA, H.; NAGAI, S.; KAMIYAMA, T.; BABA, K; MIYAZONO, A.; KOSAKA, Y.; KAGA, S.; MATSUYAMA, Y. \& SUZUKI, T. Toxin Profiles of Okadaic Acid Analogues and Other Lipophilic Toxins in Dinophysis from Japanese Coastal Waters. Toxins, v. 10, n. 11, p. 457, 2018. https://doi.org/10.3390/toxins10110457

VISCIANO, P.; SCHIRONE, M.; BERTI, M.; MILANDRI, A.; TOFALO, R.; SUZZI, G. Marine biotoxins: occurrence, toxicity, regulatory limits and reference methods. Frontiers in microbiology, v.7, 1051, 2016. https://doi.org/10.3389/fmicb.2016.01051

WU, S.; DUAN, N.; ZHANG, H.; WANG, Z. Simultaneous detection of microcysin-LR and okadaic acid using a dual fluorescence resonance energy transfer aptasensor. Analytical and bioanalytical chemistry, v.407, n. 5, p.1303-1312, 2015. https://doi.org/10.1007/s00216-014-8378-3

YASUMOTO, T.; OSHIMA, Y.; YAMAGUCHI, M. Occurrence of a new type of shellfish poisoning in the Tohoku district. Bulletin of the Japanese Society of Scientific Fisheries, v.44, n.11, p. 1249-1255, 1978. https://doi.org/10.2331/suisan.44.1249 


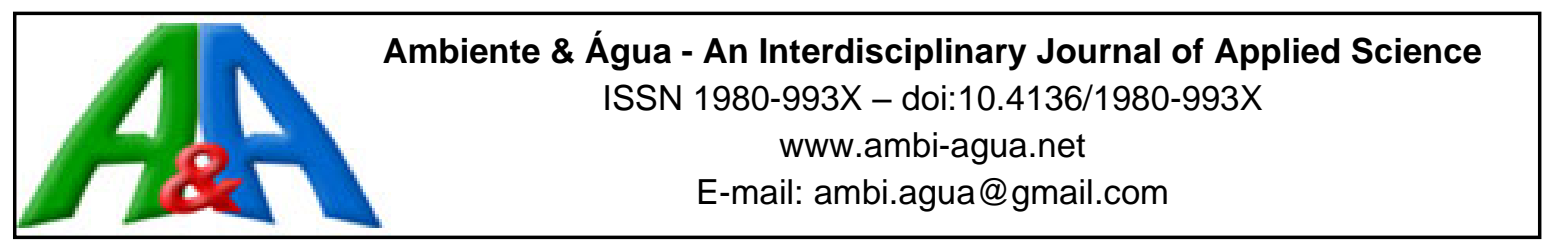

\title{
Quality of surface water and generation of sludge at water treatment plants
}

\author{
ARTICLES doi:10.4136/ambi-agua.2565
}

Received: 24 Apr. 2020; Accepted: 30 Jul. 2020

\author{
Fabiana Alves Fiore ${ }^{1^{*}(\mathbb{D})}$; Suzelei Rodgher ${ }^{1}$; Cristiane Yumi Koga Ito ${ }^{1}{ }^{(D}$; \\ Vivian Silveira dos Santos Bardini1 ${ }^{10}$; Luis Miguel Gutiérrez Klinsky² ${ }^{2}$ \\ ${ }^{1}$ Departamento de Engenharia Ambiental. Instituto de Ciência e Tecnologia de São José dos Campos. \\ Universidade Estadual Paulista Júlio de Mesquita Filho (UNESP), Rodovia Presidente Dutra, Km 137,8, \\ CEP: 12247-004, São José dos Campos, SP, Brazil. E-mail: suzelei.rodgher@unesp.br, \\ cristiane.koga-ito@unesp.br, vivian.bardini@unesp.br \\ ${ }^{2}$ Departamento de Análise de Infraestrutura. Banco de Desenvolvimento da América Latina (CAF). Rua Isaac \\ Hanono Missri, n 2000, Código Postal: 0832, Panamá. E-mail: lgutierrez@caf.com \\ *Corresponding author. E-mail: fabiana.fiore@unesp.br
}

\begin{abstract}
Among the waste produced daily by communities are those resulting from the treatment of water for public supply, with local specificities that reflect the characteristics and uses of the land. Despite the continuous generation and inadequate disposal still current in Brazil, there is little information on these residues. The data related to the composition of these sludges are essential for the study of alternatives for beneficial uses and for determining the risks to the environment and human health from inadequate disposal. It is in this context that the present study was developed, with the objective of identifying the physical-chemical characteristics of sludge produced in water treatment plants (WTPs) and of verifying the presence of these elements in the waters of the source used for supply. Such research was carried out through a case study in two WTPs in the state of São Paulo that perform surface abstraction. Therefore, in each of the WTPs, samples of densified sludge, representative of the dry and rainy periods, were characterized. The chemical findings of the sludge have been compared to the historical series of a decade of monitoring of the water quality of the sources of these WTPs. Among the main results, concentrations above the reference limits for the inert residues of aluminum, iron, manganese and barium in sludge are highlighted, as well as the existence of iron and manganese in the raw water collected and the variations in the concentrations of iron, sodium and manganese in the sludge due to the climatic conditions.
\end{abstract}

Keywords: physicochemical parameters, sludge of WTS, solid waste, water quality.

\section{Qualidade de água superficial e geração de lodos em estações de tratamento de água}

\section{RESUMO}

Dentre os resíduos cotidianamente produzidos pelas comunidades estão aqueles decorrentes do tratamento das águas para o abastecimento público, com especificidades locais que refletem as características e os usos da terra. A despeito da contínua geração e da disposição inadequada ainda vigente no Brasil, existem poucas informações sobre esses resíduos. Os dados 
relacionados à composição desses lodos são essenciais para o estudo de alternativas de usos benéficos e para a determinar os riscos ao meio ambiente e à saúde humana da disposição inadequada. É nesse contexto que o presente estudo foi desenvolvido com o objetivo de identificar as características físico-químicas de lodos produzidos em estações de tratamento de água (ETAs) e de verificar a presença desses elementos nas águas dos mananciais utilizados para o abastecimento. Tal pesquisa foi realizada por meio de estudo de caso em duas ETAs do estado de São Paulo que realizam captação superficial. Para tanto, em cada uma das ETAs foram caracterizadas amostras de lodos adensados, representativas dos períodos seco e chuvoso. Os achados químicos dos lodos foram equiparados à série histórica, de uma década de monitoramento, de qualidade das águas dos mananciais dessas ETAs. Dentre os principais resultados destacam-se as concentrações acima dos limites de referência para os resíduos inertes de alumínio, ferro, manganês e bário em lodos; a existência de ferro e manganês nas águas brutas captadas e a variação das concentrações de ferro, sódio e manganês nos lodos em decorrência da condição climática.

Palavras-chave: lodo de ETA, parâmetros físico-químicos, qualidade de águas, resíduos sólidos.

\section{INTRODUCTION}

In Brazil, the water supply is an essential service under public responsibility and aims to ensure adequate conditions of basic sanitation in the national territory. In $2017,90 \%$ of the population inhabited urban centers and the mean per capita demand of water was approximately 160 liter/day. Superficial catchment provides the water resources of $56.45 \%$ of Brazilian cities. However, in order to accomplish the current guidelines of potability, in most of the cases water is treated in complete cycle stations that generate sludge (Brasil, 2007; 2019).

The generation of sludge in water treatment stations can be estimated by empirical formulas that are dependent on the physicochemical characteristics of water and products used in the process. The dynamic anthropic use of spaces and interactions between the environments cause distortions between the estimated values and real generated volumes. Considering the generation of sludge of approximately 1 to $3 \%$ of treated water, according to Messias (2013), in Brazil the generation of sludge per day would be around 260,000 to $800,000 \mathrm{~m}^{3}$.

Water treatment station sludges contain inorganic materials (silt, sand, clay and hydrated metallic oxides) and organics (including pathogenic microorganisms) that are commonly found in the sources of raw water capture, and also products used in the water treatment, such as coagulants, coagulation auxiliary polymers and chalk. There are also several studies that pointed out the presence of metals (Ling et al., 2017, Godoy et al., 2020)

In Brazil, WTP sludges are classified as solid residuals of public services of basic sanitation. Their management is under the responsibility of the institution that generates them and must be supported by a plan of management approved by the license agency, in accordance with the current residuals management plan. According to instruction \#13/2012 from Brazilian Institute of the Environment and Renewable Natural Resources, WTP sludge are non-dangerous residuals, but the specific characterization is part of the minimal content of management plan of each unit (ABNT, 2004; Brasil, 2010).

The inadequate discard of sludge in the Brazilian territory is known; however, these residuals were not considered in the preliminary version of the National Solid Residuals Management Plan (NSRM). In the State of São Paulo, the absence of data related to the production and management of sludge, mentioned in the residuals management plan, did not represent a problem to the establishment of a goal of recycling the sludge for benefic uses, according to the principles of cleaner production. The establishment of this aim meets the guidelines of solid residuals management established by (NSRM), as follows: adoption of serial 
strategies to guarantee the non-generation, reduction, reuse, recycling and treatment of reverse solid residuals and the environmentally adequate final discard only for wastes (Brasil, 2010; 2012; São Paulo, 2014).

In WTPs, reducing the generation of sludge requires the catchment of less polluted water, development of new technologies and the use of more efficient and cheap reagents, since, according to Zhou et al. (2015), the inter recirculation of WTP sludges is limited due to the risk of water contamination. Regarding the recycling of these sludges, several alternatives of benefic uses have been pointed out as promising.

Among the most studied benefic uses, some can be cited: composting, incorporation in ceramic bricks and non-structural concrete blocks; application in soil for the recovery of degraded areas; for the conditioning and correction of soil $\mathrm{pH}$; in mixtures with natural soils for use in geotechnical work in landfills; and for production of coagulants (Turner et al., 2019; Wolowiec and Bajda, 2017; Gomes et al., 2019; Howells et al., 2018).

According to Ackah et al. (2018), the composition of WTP sludges is the main determinant of their beneficial use. In Brazil, there is no current public data on the composition of these residues. The most recent information on this subject is found in studies on the presence of contaminants in specific station locations (Wasserman et al., 2018) and on the viability of the beneficial use of the material, such as substitution of materials for concrete production (Buselatto et al., 2019), mortars (Alexandre and Luz, 2020; Godoy et al., 2020) blocks (Santos and Campos, 2018 ); geotechnical applications (Montalvan, 2016); and in mixtures to improve energy potential (Carneiro et al., 2020).

In Brazil, the control of the physical-chemical and biological characteristics of the raw water captured is compulsorily carried out by the operators of the WTPs, as determined by the Ministry of Health (Brasil, 2017). These data are usually used to control water potabilization processes but are not yet commonly related to sludge production. It is in this context that the present research was carried out, with the objective of identifying the physical-chemical characteristics of sludge produced in different climatic conditions, in WTPs located in the state of São Paulo (SP), and to evaluate the presence of sludge contaminants in the water sources used for potabilization.

\section{MATERIALS AND METHODS}

This work is an exploratory case study that used quantitative data for performing comparative classifications. Considering the need of preserving the identity of the studied WTPs according to the research cooperation agreement, they were identified as WTP1 and WTP2. Information regarding their operational characteristics and products were described by the operation technical staff of the WTPs. WTP 1 and 2 are located in different metropolitan regions of the state of São Paulo and are responsible for the potabilization of about $20 \mathrm{~m}^{3} / \mathrm{s}$ of water. Both treat water in a complete cycle (conventional) that contains the stages of coagulation, flocculation, decantation, filtration, disinfection (pre and post treatment), fluoridation and $\mathrm{pH}$ correction.

In WTP 1, the raw water is captured in a large reservoir that has interconnection with other sources to guarantee the volume of water supplied. In it, liquid aluminum sulfate, polyaluminium chloride, ferric chloride or ferric sulfate are used alternatively as coagulants of the solids present in the raw waters. For $\mathrm{pH}$ correction, lime is also used, and for disinfection, liquid and gaseous chlorine is used in the form of hypochlorite. Fluorosilicic acid is also added for fluoridation.

WTP 1 can also possibly use auxiliary chemicals, such as polyelectrolyte to increase treatment efficiency, activated carbon to remove the taste and odor from raw water and potassium permanganate for the oxidation of iron and manganese, in cases where special conditions of raw water quality are detected. At this station, the generated sludge is sent to an 
equalization tank for homogenization and application of polymers before being drained. After centrifugation, sludge cakes with up to $22 \%$ moisture content are formed.

In WTP 2, the waters are captured directly from the surface water resource and, before the coagulation stage, they pass through the grit chamber. As a coagulating agent, WTP uses ferric chloride. Granular quicklime is used for the correction of $\mathrm{pH}$, chlorine is used for disinfection and fluosilicic acid is used for fluoridation.

For the physicochemical analyses of the sludges from the WTPs, two samplings were performed, the first in October 2018, and the second in August 2019. Considering the data of a historic series of rainfall in the city of São Paulo, collected at the National Institute of Meteorology stations 83856 and 83781, the samples were collected in the periods of higher rates of rainfalls in 2018 and in the dry period of 2019. Considering these data, this study was performed with sludge samples that represent the rainy and dry periods, respectively.

The samples were collected after centrifugation, as this is one of the operational steps in the evaluated WTS. Sludges were characterized by the evaluation of raw mass, leachate and solubilized extract. The analyses were performed by different laboratories accredited by The National Institute of Metrology, Standardization and Industrial Quality, according to standards 10.004, 10.005 and 10.006 of Brazilian Association of Technical Standards (ABNT, 2004). Table 1 shows the analytic methods adopted by the laboratories for the analyses of organic and inorganic parameters evaluated in the present study. All methods adopted are regulated in Brazil (ABNT, 2004).

Table 1. Analytic methods adopted for the analyses of physicochemical parameters.

\begin{tabular}{lcc}
\hline \multirow{2}{*}{ Parameters } & \multicolumn{2}{c}{ Analytic methods } \\
\cline { 2 - 3 } & Dry period & Rainy period \\
\hline Sample color & visual & -- \\
Corrosivity & NBR 10004 (ABNT, 2004) & MELAB 45 2014 \\
Reactivity & -- & NBR 14598 (ABNT, 2012) \\
Bulk density & POP 173 Ed. 8 & NBR 14598 (ABNT, 2012) \\
Physic state & -- & NBR 14598 (ABNT, 2012) \\
Phenol & Visual & MELAB 45 2014 \\
pH & EPA 9065 (USEPA, 1986) & -- \\
Dry and solid content & NBR 10004 (ABNT, 2004) & SMEWW 4500-H+ B 2012 \\
Moisture & NBR 6457 (ABNT, 2016) & SMEWW 2540 B.E 2012 \\
Sulfide & NBR 6457 (ABNT, 2016) & MELAB 45 2014 \\
Barium & -- & SMEWW 4500 S2- D 2012 \\
Cadmium & SMEWW 3120B Ed. 22 & SMEWW 3111 B.C.D 2012 \\
Lead & -- & SMEWW 3111 B.C.D 2012 \\
Fluoride & -- & SMEWW 3111 B.C.D 2012 \\
Aluminum & POP 067 Ed. 13 & SMEWW 4500-F C 2012 \\
Chloride & SMEWW 3120B Ed. 22 & SMEWW 3500-Al B 2012 \\
Ion & SMEWW 4500B Ed. 22 & SMEWW 4500-Cl C 2012 \\
Manganese & SMEWW 3120B Ed. 22 & SMEWW 3111 B.C.D 2012 \\
Sodium & SMEWW 3120B Ed. 22 & SMEWW 3111 B.C.D 2012 \\
\hline
\end{tabular}

Data on the composition of WTP sludges that showed quantifiable values were individually shown for WTP1 and 2 and were compared to reference values from technical guides from Brazil 10.004 (ABNT, 2004) as well as their mean values. Classifications regarding the risks of these sludges were copied from the technical report that was based on the data shown in this study and on the analyses of pesticides also determined by technical guides from Brazil 10.004 (ABNT, 2004). 
Data on the analyses of raw water, including all the chemical elements identified in the composition of the sludge, was found for both WTSs. The historic data regarding the quality of water in the sources was also provided by the operational staff for the range between 2008 and 2018. According to this information, samples were collected according to Method 1060 described in Standard Methods for the Examination of Water and Wastewater (APHA et al., 1998) and the analyses were performed in the laboratory of the responsible agency, in accordance with the specific methods determined by the U.S. Environmental Protection Agency (USEPA), the Brazilian Association of Technical Standards and the American Public Health Association (APHA) for each one of the parameters in accordance with Brazilian law (Brasil, 2017).

The historic data of the sources selected for this study were compared to the quality standard adopted for Classes 1 and 2 of Resolution 357 (CONAMA, 2005), that were considered as references for the quality conditions of human supply with simplified or conventional treatment. It is worth noting that, in the State of São Paulo, the catchment of water for human supply is forbidden in hydric resources with quality below the adopted standards (São Paulo, 1997).

\section{RESULTS AND DISCUSSION}

\subsection{Physicochemical composition of sludge}

The evaluated sludges were found in a pasty physical state, brown in color and did not present characteristics of corrosivity, reactivity or flammability. There were also no detectable concentrations of pesticides in the solubilized and leached extracts. Table 2 shows the synthesis of the values found in the evaluation of the sludge from WTPs.

Table 2. Physicochemical composition of sludge from WTPs 1 and 2.

\begin{tabular}{|c|c|c|c|c|c|c|c|c|c|c|c|c|c|}
\hline \multirow{3}{*}{ Parameter } & \multirow{3}{*}{ Reference value } & \multirow{3}{*}{ Unit } & \multicolumn{5}{|c|}{ WTP 1} & \multicolumn{6}{|c|}{ WTP 2} \\
\hline & & & \multicolumn{3}{|c|}{ Dry season } & \multicolumn{2}{|c|}{ Rainy Season } & \multicolumn{3}{|c|}{ Dry season } & \multicolumn{3}{|c|}{ Rainy Season } \\
\hline & & & G.M. & Leac. & Sol. & G.M. Leac. & Sol. & G.M. & Leac. & Sol. & G.M. & Leac. & Sol. \\
\hline Phenol & -- & $\mathrm{mg} / \mathrm{Kg}$ & 6.65 & & & & & & & & & & \\
\hline $\mathrm{pH}$ & $2-12.5$ & $\mathrm{UpH}$ & 6.25 & & & 6.45 & & 7.66 & & & 7.66 & & \\
\hline Bulk density & -- & $\mathrm{g} / \mathrm{cm}^{3}$ & & & & 0.96 & & & & & 1.21 & & \\
\hline Dry solids content & -- & $\%$ & 15.38 & & & 17 & & 29.82 & & & 29.9 & & \\
\hline Moisture & -- & $\%$ & 84.62 & & & 83 & & 70.18 & & & 70.1 & & \\
\hline Sulfide & 500 & $\mathrm{mg} / \mathrm{Kg}$ & & & & 302 & & & & & & & \\
\hline Barium & $\begin{array}{l}70 \text { leac. } \\
0.7 \text { sol. }\end{array}$ & $\mathrm{mg} / \mathrm{L}$ & & 0.36 & 0.03 & & & & 0.473 & & & 7.72 & 7.59 \\
\hline Cadmium & $\begin{array}{c}0.5 \text { leac. } \\
0.005 \text { sol. }\end{array}$ & $\mathrm{mg} / \mathrm{L}$ & & & & & & & & & & 0.02 & \\
\hline Lead & $\begin{array}{l}1 \text { leac. } \\
0.01 \text { sol. }\end{array}$ & $\mathrm{mg} / \mathrm{L}$ & & & & & & & & & & 0.16 & \\
\hline Fluoride & $\begin{array}{c}150 \text { leac. } \\
1.5 \text { sol. }\end{array}$ & $\mathrm{mg} / \mathrm{L}$ & & 0.4 & & & & & 0.205 & & & & 1.1 \\
\hline Aluminum & 0.2 & $\mathrm{mg} / \mathrm{L}$ & & & 0.08 & & & & & & & & 0.49 \\
\hline Chloride & 250 & $\mathrm{mg} / \mathrm{L}$ & & & 53,8 & & 52.5 & & & 21.9 & & & 20.9 \\
\hline Total iron & 0.3 & $\mathrm{mg} / \mathrm{L}$ & & & 1.73 & & 4.92 & & & 0.53 & & & 18.21 \\
\hline Total manganese & 0.10 & $\mathrm{mg} / \mathrm{L}$ & & & 10.75 & & 1.94 & & & 0.94 & & & 0.22 \\
\hline Sodium & 200 & $\mathrm{mg} / \mathrm{L}$ & & & 3.18 & & 9.99 & & & 1.96 & & & 19.38 \\
\hline
\end{tabular}

Where: G.M. corresponds to the results of the analyses in gross mass; Leac. in leached sample and Sol. those performed in solubilized samples. The blank cells correspond to parameters not detected.

The sludge sampled from WTPs 1 and 2, in the dry and rainy seasons, was characterized according to NBR 10.004 (ABNT, 2004) as non-inert non-hazardous waste (Class II-A), in accordance with IN-IBAMA 13/2012 (IBAMA, 2012). The concentrations of inorganic 
compounds observed when the samples were solubilized supported the characterization of the residues as non-inert. Barium, aluminum, iron and manganese were detected and suggest that care must be taken regarding the handling and destination of the sludge from WTPs. The presence of aluminum, iron and manganese in sludge from WTPs was reported in sludge that used the same coagulants adopted by WTPs 1 and 2; however, in the present study, the concentrations of aluminum verified were significantly lower than the minimal reference reported in literature (Turner et al., 2019; Wolowiec et al., 2019; Do Amaral Sobrinho et al., 2018). The excessive concentration of barium in the solubilized sludge from WTP 2 is also worth mentioning, since this element, when soluble, can cause harmful effects to human health (ATSDR, 2007). It should be noted that for the sludge sample of WTP 2, in dry weather, the results of barium in the solubilized sample were below the limit of quantification of the method, more consistent with the quality of raw water in the 10-year historical series in which this metal was not observed.

When comparing the values obtained for the dry and rainy seasons, it appears that, for the $\mathrm{pH}$, humidity, dry solids and chloride parameters, the values do not change. The iron and sodium parameters have their concentrations increased in the rainy season, whereas manganese had its average concentration reduced by about five times in the rainy season. The increase in the concentration of iron is associated with the increased supply of coagulants necessary to remove the turbidity of the captured surface water. Despite the increase of the sodium concentration in the sludge of about ten times in WTP 2, the values found in the rainy season are lower than the reference values for Class II. For these WTPs, the manganese concentrations in the sludge are higher than the reference values for Class II, even in the dry period. The reduction of the average concentration in the rainy season of about five times is indicative that the contribution of the contaminant must originate from anthropic activities with constant load, regardless of climatic conditions. The increase in the concentration of iron and sodium in the rainy season was also observed by Ribeiro (2007) when evaluating sludge from WTPs in the municipality of Itabirito (MG).

The $\mathrm{pH}$ and iron values reported by Ahmad et al. (2016), in water treatment plants in India are similar to the average values verified in WTPs 1 and 2. However, the elements manganese and sodium were found in concentrations two and six times higher than those verified by the authors. It is worth noting that the studied sludge has a solids concentration six times higher than that used in the 2016 survey. Other chemical elements, such as barium and arsenic, were found in high concentrations in sludge from WTPs in India compared to values obtained in the present study (Ahmad et al., 2016).

Considering the values reported by Turner et al. (2019), the $\mathrm{pH}$, humidity, manganese and iron parameters identified in WTPs 1 and 2 are within the concentration range verified in other studies. The lead and aluminum parameters in the sludge of these WTPs are significantly lower. Compared to the composition data systematized by Wolowiec et al. (2019), which segregates the values as a function of aluminum and iron coagulants used in the water potabilization process, the sludge from WTP 1 has an aluminum concentration 600 times lower than the minimum value reported in previous research and the sludge from WTP 2 has a concentration of iron and aluminum about 80 and 4 times lower, respectively.

The data obtained in the present research were also compared to the values presented in the final report of the PROSAB project (1999), since this study still serves as a reference for most of the work carried out in the country on the subject. From this analysis, it is possible to verify that:

- the upper limit of basicity of $\mathrm{pH}$ is about $10 \%$ higher;

- the aluminum concentration is $0.15 \%$ times the lowest value reported at the time; 
- cadmium and lead are less recurrent in the samples and in no case do they exceed $20 \%$ of the reference concentration;

- chloride showed values higher than those recorded at the time for WTP 1, by about 70\%;

- the total iron sampled, which is still present in the sludge from WTP s, has an average concentration of $0.5 \%$ of the lowest value reported at the time;

- the concentration of manganese verified in WTP 1, in the dry period is higher than the highest value previously identified;

- the average sodium concentration does not reach $30 \%$ of the value reported at the time as the lowest value.

\subsection{Quality of the water source and the composition of the sludge from WTPs}

Among the chemical parameters verified in detectable concentrations for the sludge, only the manganese and iron parameters were identified in the historical series available by the WTP 1 operational team. The graphs shown in Figures 1 and 2 show how the concentration of these elements occurs in the source of that WTP, throughout the evaluated decade.

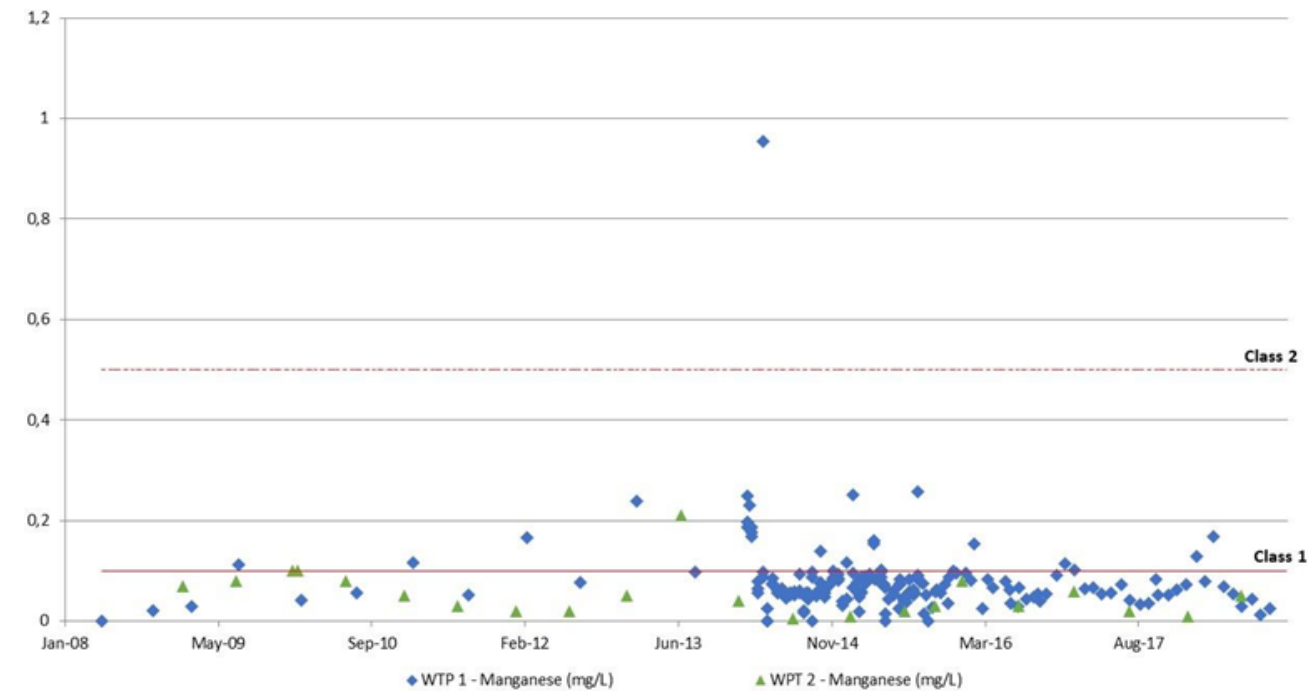

Figure 1. Manganese concentration in raw water from WTP 1 and 2.

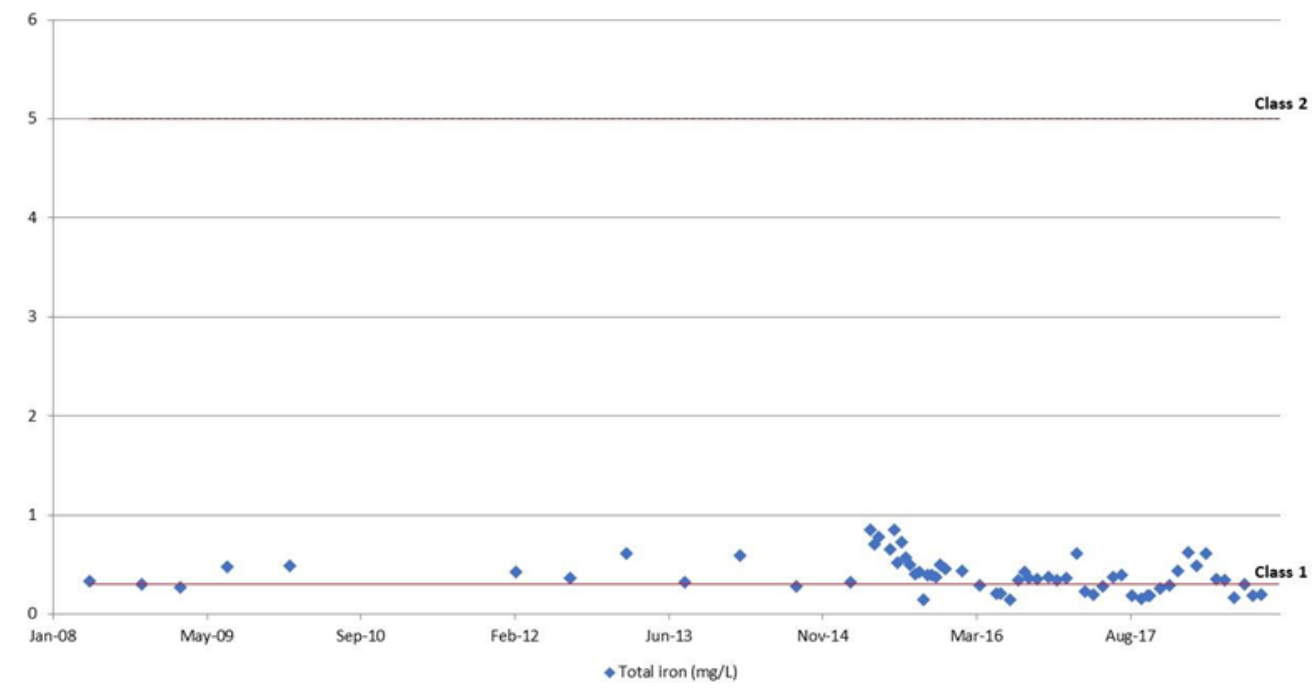

Figure 2. Total iron concentration in raw water from WTP 1. 
According to the raw water quality data, Manganese already occurs in the collected waters, in some cases, in limits higher than those established for Class 1. Considering the average value of manganese in water in the evaluated period $(0.04 \mathrm{mg} / \mathrm{L})$, and its concentration in the solubilized sludge samples, it is possible to infer that for WTP 1, in the dry period, the element was concentrated about 270 times, and in the rainy period, approximately 50 times.

For the iron that also occurs in raw water supplied by WTP 1 , in most cases in concentrations above the limits of Class 1, the excessive concentrations of the element in sludge samples, in both periods, can be associated with concentrations of this element in raw water, since during the research period no iron-based coagulant was used for water potabilization.

In the raw waters treated by WTP 2, it was found that in less than $10 \%$ of the analyses the concentration of cadmium exceeded the limits established as a reference for Class 1 waters; but in these cases, occurring in both rainy and dry periods, the maximum concentration found was $30 \%$ of the Class 2 reference value. If the cadmium values observed in the raw waters are compared to the concentrations verified in the leached sample of the sludge in the rainy season, it appears that it was 10 times more concentrated.

Despite the fact that the use of aluminum sulphate or chloride in the operational process of WTP 2 was not declared, the aluminum concentration evaluated in the sludge exceeded the reference value established for the parameter for the solubilized sample. However, since the element concentrations were not measured in the raw water collected, it cannot be said that its occurrence in the sludge is due to the use of coagulants.

The occurrence of sodium in the raw waters of this ETA was evaluated only twice, in 2009, and concentrations were found below $10 \mathrm{mg} / \mathrm{L}$; this parameter does not have quality limits established according to the classes in freshwaters. Considering the average of the analyses in raw water and the results of the sludge samples, it appears that the sodium concentrations were diluted about 4 times for the sludge during the dry season and concentrated about twice in the rainy season. Considering the small number of samples of raw water, these assertions have more significant errors than the other parameters evaluated.

In the available historical series, total Iron was measured only four times and showed concentrations of $1.19 ; 2.63 ; 0.81$ and $1.17 \mathrm{mg} / \mathrm{L}$. These values are higher than the Class 1 limits, but lower than those established as Class 2 quality criteria. For WTP 2, the percentages of the element cannot be directly related to those verified in the sludge, since in the coagulation process uses ferric chloride.

The concentrations of the manganese and chloride elements identified in the historical series, available by the WTP 2 operational team, are shown in Figures 1 and 3.

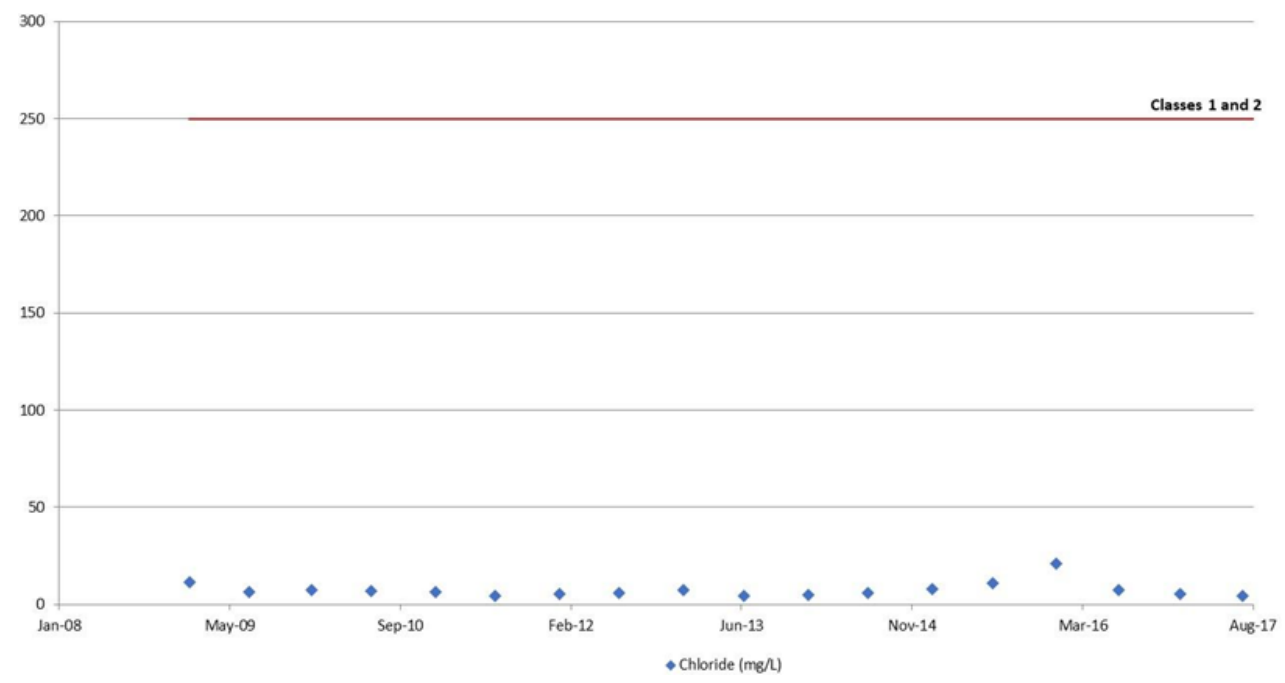

Figure 3. Chloride concentration in raw water from WTP 2. 
As can be seen, manganese was sampled less frequently for this season. However, it appears that its concentrations in these analyses are mostly within the limits established as a quality reference for Class 1 , so the Class 2 limit $(0.5 \mathrm{mg} / \mathrm{L})$ was not even shown in the graph. Considering the average concentration of the element in raw water in the evaluated period, and the concentration verified in the solubilized samples of the sludge, it can be inferred that the water treatment concentrates this pollutant in about 13 times in the dry period and approximately 3 times in the rainy season.

Also for the chloride element, sampling was not carried out frequently, but its concentrations in raw water are low when compared to the single reference value established for Classes 1 and 2, of $250 \mathrm{mg} / \mathrm{L}$. Considering the average concentration of the element in raw water in the evaluated period, and the concentration verified in the sludge, it can be inferred that the element was twice more concentrated in solubilized samples of sludge.

From the analysis of the databases provided by the operational team of the WTPs under study, it is possible to verify that they evaluate a greater number of parameters than those legally established in Brazil for the quality control of the water sources. Thus, it is understood that the continuity of this study and the development of a tool that correlates the characteristics of raw water and inputs used in WTPs with the classification of sludge generated by them can provide greater security for the management and disposal of sludge produced in different WTPs, including the reduction of cost reduction associated with frequent classification analyses.

\section{CONCLUSIONS}

According to the results, it could be concluded that the water treatment plants with surface capture evaluated in this study generate sludge that keep the chemical characteristics of the source water. In these WTPs, it is possible to verify that the sludge produced in rainy periods has higher concentrations of iron and sodium and that the concentration of manganese is minimized.

The results suggest that the plants that capture water with chemical elements above the reference values for Class 1 generate sludge with the presence of these same elements above the reference values for inert waste. It also suggests that current water potabilization processes are more efficient in the use of coagulants and, therefore, produce sludge with less potential for contamination.

\section{ACKNOWLEDGEMENTS}

This work was supported by São Paulo Research Foundation - FAPESP (Proc.: 2018/00099-0).

\section{REFERENCES}

ABNT. NBR 10.004: Resíduos sólidos - Classificação. Rio de Janeiro, 2004.

ABNT. NBR 14.598: Produtos de petróleo - Determinação do ponto de fulgor pelo aparelho de vaso fechado Pensky-Martens. Rio de Janeiro, 2012.

ABNT. NBR 6457: Amostras de solo — Preparação para ensaios de compactação e ensaios de caracterização. Rio de Janeiro, 2016.

ACKAH, L. A.; GURU, R.; PEIRAVI, M.; MOHANTY, M.; MA, X.; KUMAR, S.; LIU, J. Characterization of Southern Illinois Water Treatment Residues for Sustainable Applications. Sustainability, v. 10, n. 5, 2018. https://doi.org/10.3390/su10051374 
AHMAD, T.; AHMAD, K.; ALAM, M. Characterization of Water Treatment Plant's Sludge and its Safe Disposal Options. Procedia Environmental Sciences, v. 35, p. 950- 955, 2016. https://dx.doi.org/10.1016/j.proenv.2016.07.088

ALEXANDRE, E; LUZ, C. A. Partial replacement of CPV-ARI cement by water treatment plant sludge (WTS). Matéria, v. 25, n. 1, 2020. http://dx.doi.org/10.1590/s1517707620200001.0912

APHA; AWWA; WEF. Standard Methods for the Examination of Water and Wastewater. 20. ed. Washington, 1998.

BRASIL. Ministério da Saúde. Portaria n. 05, de 28 de setembro de 2017. Consolidação das normas sobre as ações e os serviços de saúde do Sistema Único de Saúde. Diário Oficial [da] União: seção 1, Brasília, DF, n. 190, supl. p. 516-531, 03 de out. de 2017.

BRASIL. Ministério do desenvolvimento Regional. Sistema Nacional de Informações sobre Saneamento. Diagnóstico dos Serviços de Água e Esgotos - 2017. Brasília, 2019.

BRASIL. Presidência da República. Lei no 11.445, de 5 de janeiro de 2007. Estabelece as diretrizes nacionais para o saneamento básico; cria o Comitê Interministerial de Saneamento Básico; altera as Leis nos 6.766, de 19 de dezembro de 1979, 8.666, de 21 de junho de 1993, e 8.987, de 13 de fevereiro de 1995; e revoga a Lei ${ }^{\circ} 6.528$, de 11 de maio de 1978. Diário Oficial [da] União, Brasília, DF, 08 jan. 2007.

BRASIL. Presidência da República. Lei n. 12.305, de 2 de agosto de 2010. Institui a Política Nacional de Resíduos Sólidos; altera a Lei no 9.605, de 12 de fevereiro de 1998; e dá outras providências. Diário Oficial [da] União: seção 1, Brasília, DF, 03 ago. 2010.

BRASIL. Presidência da República. Plano Nacional de Resíduos Sólidos - versão preliminar. $\quad$ Brasília, 2012. Available at: http://www.sinir.gov.br/documents/10180/12308/PNRS_Revisao_Decreto_280812.pdf/ e183f0e7-5255-4544-b9fd-15fc779a3657. Access: Jan. 2020.

BUSELATTO, D. M.; WENZEL, M. C.; DA ROCHA, G. H. et al. Use of water treatment sludge (WTS) as fine aggregate in concretes: evaluation of physical-mechanical properties. Matéria, v. 24, n. 1, 2019. https://doi.org/10.1590/s1517-707620190001.0645

CARNEIRO, M.; BILOTTA, P.; MALUCELLI, L. C. et al. Sludge and scum blends from water and sewage treatment plants for energy recovering toward a circular economy perspective. International Journal of Environmental Science and Technology, v. 17, p. 3847-3856, 2020. https://doi.org/10.1007/s13762-020-02727-8

CONAMA (Brasil). Resolução $\mathrm{n}^{\circ} 357$ de 17 de março de 2005. Dispõe sobre a classificação dos corpos de água e diretrizes ambientais para o seu enquadramento, bem como estabelece as condições e padrões de lançamento de efluentes, e dá outras providências. Diário Oficial [da] União: seção 1, Brasília, DF, n. 053, p. 58-63, 18 mar. 2005.

Do AMARAL SOBRINHO, N. M. B.; CEDDIA, M. B.; ZONTA, E. et al. Spatial variability and solubility of barium in a petroleum well-drilling waste disposal area. Environmental Monitoring and Assessment, v. 190, n. 228, 2018. https://doi.org/10.1007/s10661-018$6566-\mathrm{x}$ 
GODOY, L. G. G. D.; ROHDEN, A. B.; GARCEZ, M. R.; Da DALT, S.; BONAN GOMES, L. Production of supplementary cementitious material as a sustainable management strategy for water treatment sludge waste. Case Studies in Construction Materials, v. 12, 2020. https://doi.org/10.1016/j.cscm.2020.e00329

GOMES, S. D. C.; ZHOU, J. L.; LI, W.; LONG, G. Progress in manufacture and properties of construction materials incorporating water treatment sludge: A review. Resources, $\begin{array}{llllll}\text { Conservation and Recycling, } & \text { v. 145, p. }\end{array}$ https://doi.org/10.1016/j.resconrec.2019.02.032

HOWELLS, P. A.; LEWIS, J. S.; BEARD, B. D.; OLIVER, W. I. Water treatment residuals as soil amendments: Examining element extractability, soil porewater concentrations and effects on earthworm. Ecotoxicology and Environmental Safety, n. 162, p. 334-340, 2018. https://doi.org/10.1016/j.ecoenv.2018.06.087

IBAMA (Brasil). Instrução Normativa $n^{\circ} 13$ de 18 de dezembro de 2012. Diário Oficial [da] União, seção 1, 20 dez. 2012.

LING, Y. P. et al. Evaluation and reutilization of water sludge from fresh water processing plant as a green clay substituent. Applied Clay Science, v. 143, p. 300-306, 2017. https://doi.org/10.1016/j.clay.2017.04.007

MESSIAS, T. G. Avaliação Ecotoxicológica de Lodo Gerado por Estação de Tratamento de Água. 2013. 163 p. Tese (Doutorado) - Programa de Pós Graduação em Ciências, Centro de Energia Nuclear na Agricultura, Universidade de São Paulo, Piracicaba, 2013.

MONTALVAN, E. L. T. Investigação do comportamento geotécnico de misturas de solo arenoso com lodo da estação de tratamento de água do município de Cubatão, SP. 2016. Dissertação (Mestrado) - Escola Politécnica, Universidade de São Paulo, São Paulo, 2016.

PROSAB. Noções gerais de tratamento e disposição final de lodos de estações de tratamento de água. Rio de Janeiro: ABES, 1999.

RIBEIRO, F. L. M. Quantificação e caracterização química dos resíduos da ETA de Itabirito - MG. 2007. 133f. Dissertação (Mestrado) - Universidade de Ouro Preto, Ouro Preto, 2007.

SANTOS, S. S. A.; CAMPOS, V. P. Use of Water Treatment Plant Solid Residues (Sludge) as Raw Material to Manufacture Construction Elements. Revista Virtual de Química, v. 10, n. 2, p. 273-287, 2018. https://dx.doi.org/10.21577/1984-6835.20180021

SÃO PAULO (Estado). Secretaria do Meio Ambiente. Plano de resíduos sólidos do estado de São Paulo. São Paulo, 2014.

SÃO PAULO (Estado). Lei Estadual n. 9.866, de 28 de novembro de 1997. Dispõe sobre diretrizes e normas para a proteção e recuperação das bacias hidrográficas dos mananciais de interesse regional do Estado de São Paulo. Diário Oficial [do] Estado de São Paulo, seção 1, n. 230, 29 nov. 1997.

TURNER, T.; WHEELER, R.; STONE, A. et al. Potential Alternative Reuse Pathways for Water Treatment Residuals: Remaining Barriers and Questions-a Review. Water, Air, \& Soil Pollution, v. 230, n. 227, 2019. https://doi.org/10.1007/s11270-019-4272-0 
UNITED STATES. Agency for Toxic Substances and Disease Registry - ATSDR. Toxicological profile for barium and barium compounds. Atlanta, 2007. Available at: https://www.atsdr.cdc.gov/ToxProfiles/tp.asp?id=327\&tid=57. Access: 14 July 2020.

WASSERMAN, J. C. de; OLIVEIRA SILVA, L. de; PONTES, G. C. et al. Mercury contamination in the sludge of drinking water treatment plants dumping into a reservoir in Rio de Janeiro, Brazil. Environmental Science of Pollution Research, v. 25, p. 28713-28724, 2018. https://doi.org/10.1007/s11356-018-2899-9

WOŁOWIEC, M.; BAJDA, T. Current Stage of Knowledge Relating to the Use Ferruginous Sludge From Water Treatment Plants - a Preliminary Review of the Literature. Mineralogia, v. 48, n. 1-4, 2017. https://doi.org/10.1515/mipo-2017-0010

WOŁOWIEC, M.; KOMOROWSKA-KAUFMAN, M.; PRUSS, A.; RZEPA, G.; BAJDA, T. Removal of Heavy Metals and Metalloids from Water Using Drinking Water Treatment Residuals as Adsorbents: A Review. Minerals, v. 9, p. 487, 2019. https://doi.org/10.3390/min9080487

ZHOU, J.; HE, Z; YANG, Y; DENG, Y; TRINGE, S.G.; ALVAREZ-COHEN, L. Highthroughput metagenomic technologies for complex microbial community analysis: open and closed formats. Bio, v. 6, 2015. https://dx.doi.org/10.1128/mBio.02288-14 


Ambiente \& Água - An Interdisciplinary Journal of Applied Science
ISSN 1980-993X - doi:10.4136/1980-993X
www.ambi-agua.net
E-mail: ambi.agua@gmail.com

\title{
Estimate and evaluation of reservoir metrics in Serra da Mesa dam (GO) using the Google Earth Engine platform
}

\author{
ARTICLES doi:10.4136/ambi-agua.2584
}

Received: 22 May 2020; Accepted: 30 Jul. 2020

\begin{abstract}
Gabrielle de Oliveira Xavier ${ }^{1}\left(\mathbb{D}\right.$; Tati de Almeida ${ }^{* *(\mathbb{D})}$;
Carlos Magno Moreira de Oliveira ${ }^{2} \mathbb{D}$; Petronio Diego Silva de Oliveira $^{3}[$; Victor Hugo Barros Costa ${ }^{4}$; ; Larissa Moreira Alves Granado ${ }^{1}$ (it)

${ }^{1}$ Instituto de Geociências. Universidade de Brasília (UnB), Campus Darcy Ribeiro, CEP: 70910-900, Brasília, DF, Brazil. E-mail: gabrielleadm31@gmail.com, lary.mooreira@gmail.com

${ }^{2}$ Instituto Federal do Norte de Minas Gerais (IFNMG), Rodovia MG 202, Km 407, s/n, CEP: 38680-000, Arinos,

MG, Brazil. E-mail: cmagnoliveira@ hotmail.com

${ }^{3}$ Instituto do Meio Ambiente e dos Recursos Hídricos do Distrito Federal (IBRAM), SEPN 511, Bloco C, CEP: 70750-543, Brasília, DF, Brazil. E-mail: petroniodiego@gmail.com

${ }^{4}$ Ministério da Agricultura, Pecuária e Abastecimento (Mapa), Esplanada dos Ministérios, Bloco D, CEP: 70043-900, Brasília, DF, Brazil. E-mail: victor.baros@gmail.com

"Corresponding author. E-mail: tati_almeida@unb.br
\end{abstract}

\begin{abstract}
The goal of this study was to assess the temporal dynamics of an accumulation reservoir in an accessible and accurate way. The study was conducted on the Serra da Mesa Dam (GO) using orbital images. To estimate the flat area of the dam surface, Landsat TM and OLI images for the period 1998 to 2018 were used. The images were processed using the Google Earth Engine platform (GEE) in order to obtain the dam surface area $\left(\mathrm{km}^{2}\right)$ and relate it to the flow, altimetric height and volume of the reservoir over the years. The dam showed constant variation of water since its inception, with a decreasing trend. The highest values of the reservoir measurement metrics were observed in the years coincident with the largest areas of the dam, and inversely proportional to the years of the appearance of new dams upstream. More than $90 \%$ of the altimetric height variation of water could be explained by the flat area of the dam. The processing platform using the GEE is effective to provide extensive temporal analysis using a large volume of data in a short time, with accurate and robust results.
\end{abstract}

Keywords: accumulation reservoir, dam, time series.

\section{Estimativa e avaliação das métricas do reservatório de Serra da Mesa (GO) utilizando a plataforma Google Earth Engine}

\section{RESUMO}

Esse trabalho objetiva a avaliação da dinâmica temporal do reservatório de Serra da Mesa (GO) de maneira semi-automática e precisa, utilizando imagens orbitais. Para estimar a área plana da barragem foram utilizadas imagens Landsat TM e OLI para o período de 1998 a 2018. As imagens foram processadas por meio da plataforma Google Earth Engine a fim de obter a área da barragem $\left(\mathrm{km}^{2}\right)$, vazão, dimensão e volume do reservatório ao longo dos anos. A 
barragem apresentou variação constante de água desde o seu início, com uma tendência decrescente. Os maiores valores das métricas de medição do reservatório foram observados nos anos coincidentes com os maiores volumes da barragem e os menores volumes foram detectados após a implementação de novas barragens a montante. Mais de $90 \%$ da variação da dimensão da água pode ser explicada pela área plana da barragem. A plataforma de processamento que utiliza o GEE é eficaz para fornecer uma análise temporal extensa e com grande volume de dados em pouco tempo, com resultados precisos e robustos.

Palavras-chave: métricas, reservatório, série temporal.

\section{INTRODUCTION}

Brazil has $8 \%$ of the world's drinking water reserves and concentrates $18 \%$ of the planet's surface water potential. Several factors related to land use and economic activity may be responsible for the increased demand for water and excessive consumption. Appropriate management practices are therefore necessary to meet the needs of current and future generations (Paz et al., 2000). To meet domestic, industrial and agricultural demand, dams are built in order to retain a certain volume of water, changing the hydrograph due to the retention and release of water, in addition to changing biogeochemical activities (Busker et al., 2019).

Due to Brazilian water features, reservoirs were created in order to supply people and generate energy (Machado and Baptista, 2016). The damming of waterways is used to produce electricity, and is also important for other uses such as recreation, fishing, flood control and water supply for population (Moretto et al., 2012; Paz et al. 2000). Understanding the spacetime dynamics of the reservoirs is essential to the conservation of water resources, monitoring of ecosystem services and understanding the impacts of climate change on this feature (Duan and Bastiaanssen, 2013; Tong et al., 2016). However, monitoring changes in lakes and reservoirs is still a costly practice and rarely practiced, especially in developing regions (Alsdorf et al., 2007; Busker et al., 2019; Duan and Bastiaanssen, 2013; Gao, 2015; Tong et al., 2016).

The quantification of a reservoir can be obtained by quota-curve determined conventionally using bathymetry of the source, measuring rising depths at various points of the flooded area and making the necessary volume integration (Tong et al., 2016). There are few reservoirs with continuous monitoring of the bathymetry due to cost, which varies according to the shape and size of the reservoir (Collischonn and Clarke, 2016). When monitored by measuring stations, errors may occur due to the lack of instrument maintenance (Duan and Bastiaanssen, 2013). Another monitoring alternative is to estimate the volume through mathematical models that relate variables such as surface area, volume and depth, obtained by underwater topographic information. However, this method has a reduced accuracy over time due to the ongoing dynamics of water (Lu et al., 2013).

Remote sensing is a cheaper and precise alternative for monitoring reservoirs, considering the increasing number of reservoirs, extensive flooded areas and constant need to obtain information (Abileah et al., 2011; Collischonn and Clarke, 2016; Lopes et al., 2017; Machado and Baptista, 2016; Paz et al., 2000). Remote sensors allow continuous and systematic collection of data for qualitative and quantitative assessments of the reservoirs that includes, among other things, information about the synoptic view of large areas, trophic condition, possibility to evaluate the spatial variation of evaporation, and higher sampling frequency compared to conventional techniques (Curtarelli et al., 2013; Galo et al., 2002; Machado and Baptista, 2016; White, 1978).

Remote sensing data are made available for free by agencies such as NASA (National Aeronautics and Space Administration), USGS (United States Geological Survey), ESA (European Space Agency) and others, with different spatial and temporal scales of the earth's 
surface, yet robust software, sophisticated equipment for storage and processing data are needed, which prevents the regular monitoring of reservoirs located in different regions (Busker et al., 2019; Duan and Bastinnassen, 2013; Gorelick et al., 2017). Google Earth Engine platform (GEE) enables the processing of large amounts of geospatial information from highperformance cloud computing and access to a wide collection of satellite data through useraccessible programming language (Gorelick et al., 2017; Nguy-Robertson et al., 2018; Zhang et al., 2017). GEE allows access and free processing data from orbital satellites, such as Landsat, with considerable time series, allowing reservoir water volume estimation and lakes, indirectly, through mathematical models that use information about the variation of the watercourse extension (Medina et al., 2010).

This study there aims to investigate the space-time dynamics of the Serra da Mesa Reservoir using the GEE, from 1998 to 2019, using digital image processing techniques in order to propose a semi-automatic methodology monitoring of Brazilian hydroelectric reservoirs. A secondary goal was to evaluate the seasonality of the reservoir's dry and rainy seasons.

\section{MATERIAL AND METHODS}

This study was carried out in the hydroelectric plant of Serra da Mesa, located in the basin of the Upper Tocantins in the state of Goiás. The Serra da Mesa includes the municipalities of Minaçu, Campinorte, Campinaçu, Colinas do Sul, Uruaçu, Niquelândia, Barro Alto and São Luiz do Norte, with a total municipal area of 22,366.50 $\mathrm{km}^{2}$ and a total flooded area of $1,784.50$ $\mathrm{km}^{2}$, corresponding to $8 \%$ of the cities' area (Figure 1). The reservoir of the hydroelectric plant at Serra da Mesa is classified as an accumulation reservoir and is considered Brazil's largest reservoir volume of water, comprising about 54.40 billion cubic meters. The climate is classified as Aw by Köppen-Geiger, tropical climate, with the lowest temperature above $18^{\circ} \mathrm{C}$ and a rainy summer.

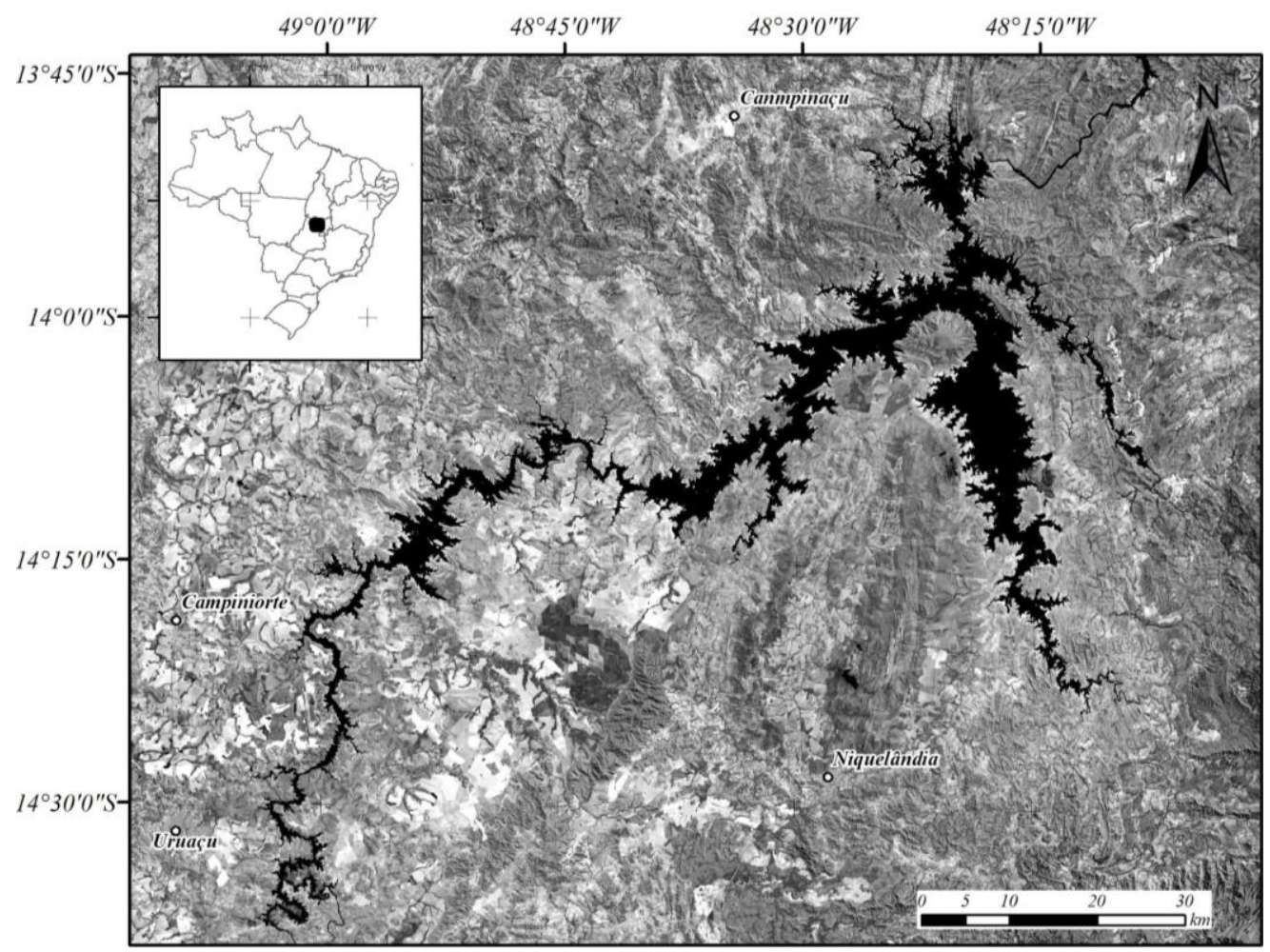

Figure 1. Location of the Serra da Mesa Reservoir (GO). 
The watershed of the Upper Tocantins presents, for the most part, a predominance of entisols and inceptisols, as oxisols at lower altitudes and flat regions. According to Martins et al. (2015), the predominant geomorphological unit in the basin is the Regional Plain Surface (RPS), characterized by not respecting lithological boundaries or structural styles making several geological units.

For characterization of rainfall in the study area, as well as the variation of maximum temperature $\left(\mathrm{T}_{\mathrm{x}}{ }^{\circ} \mathrm{C}\right)$ and minimum $\left(\mathrm{T}_{\mathrm{n}}{ }^{\circ} \mathrm{C}\right)$, monthly average values were obtained between the years 1998 and 2019 by means of automatic weather stations (AWS) belonging to the National Institute of Meteorology (Instituto Nacional de Meteorologia - INMET). As the city of Minaçu, which locates most of the reservoir, does not have AWS, AWS data closest to the reservoir, located in the municipality of Pirenópolis (GO), were used.

To estimate the reservoir area over the years, data were used from Landsat 5/TM and Landsat 8/OLI available in GEE that allows the manipulation of data by algorithms produced by the operator. In the GEE platform the user can create the data processing routine in Java through an interface, where data can be accessed from various satellites and sensors, with different processing levels. In this study, the SWIR 1, Red and Near Infrared (NIR) spectral bands from the sensors TM (RGB 543) and OLI (RGB 654) were used, with corresponding processing reflectance levels to the top of the atmosphere.

Images between the years 1998 and 2019 were selected, corresponding to the rainy season, considering the months from January to June, and the dry season, from July to December, to characterize the seasonality of the reservoir. Thus, two images were obtained per year, and for the year 2019 only an image related to the rainy season was considered, totaling 43 orbital images in Orbit 222 and Point 070. The previous selection of images in the rainy and dry seasons was to parameter filtering images with less cloud cover and pixels of better quality; this information was obtained from the image metadata. With this information, the algorithm selects the developed image and creates composite RGB bands SWIR1/NIR/R which are later transformed to HSV to identify the pixels corresponding to water. Thus, despite the errors associated with the classification of bodies of water (omission and commission), the objective of this study was to employ a simple methodology using HSV color transformation to assess the potential of Google Earth Engine when comparing the area and the metrics of the reservoir (volume, altimetry and flow).

To validate the data obtained by remote sensing and to fit linear regression models, from the observed data variable volume $\left(\mathrm{m}^{3}\right)$, altimetric height $(\mathrm{m})$ and the reservoir flow $\left(\mathrm{m}^{3} \cdot \mathrm{s}^{-1}\right)$ through Reservoir Monitoring System (SAR) were obtained, managed by the National Water Agency (ANA), from 1998 to 2019. The data can be obtained on a daily and monthly basis. Since a secondary objective of this study was to evaluate the seasonality of the reservoir's dry and rainy seasons, it was decided to use the semi-scale data, resulting in 43 observations for each variable. To assess the fit of the regression model, we used the coefficient of determination ( $\mathrm{R}^{2}$; Equation 1), adjusted coefficient of determination ( $\mathrm{R}^{2} \mathrm{aj}$; Equation 2), standard deviation $\left(\mathrm{S}_{\mathrm{xy}}\right.$; Equation 3$)$ and the standard deviation as a percentage $\left(\% \mathrm{~S}_{\mathrm{xy}}\right.$; Equation 4$)$.

$$
\begin{aligned}
& R^{2}=1-\left(\frac{S Q_{\text {res }}}{S Q_{t}}\right) \\
& R_{a j .}^{2}=1-\left(\frac{S Q_{\text {res }}}{S Q_{t}}\right) \cdot\left(\frac{n-1}{n-p-1}\right) \\
& \mathrm{S}_{\mathrm{yx}}=\sqrt{\frac{\sum_{\mathrm{i}=1}^{\mathrm{n}}\left(\mathrm{P}_{\mathrm{i}}-\mathrm{O}_{\mathrm{i}}\right)^{2}}{\mathrm{n}-\mathrm{p}-1}}
\end{aligned}
$$




$$
S_{y x} \%=\frac{S_{y x}}{\bar{o}} * 100
$$

where, $\mathrm{P}_{\mathrm{i}}$ is the ith value estimated by regression; $\mathrm{O}_{\mathrm{i}}$ is the ith observed value in monitoring the ANA; $\bar{O}$ is the arithmetic mean of the observed variable; $\mathrm{SQ}_{\text {res }}$ is the sum of squared residuals; $S_{Q}{ }_{t}$ is the total sum of squares, $n$ is the number of observed data; $p=$ number of model coefficients.

\section{RESULTS AND DISCUSSION}

The Serra da Mesa Dam is located in the Upper Tocantins Basin. A watershed has all the elements for the integration of bio-geophysical, economic and social processes and is the natural unit that allows institutional integration and joint research with management (Tundisi, 2008). The expansion of the monitoring scale assists in the management of water resources; that is, when the management considers not only the local, but mainly the basin in which the dam is located, water conservation becomes more efficient. The reflection of this analysis is visible on the dam of Serra da Mesa, where within the same basin were built two new dams, the Cana Brava Dam (2002) and Palmas Dam (2006), whose years of creation coincided with dissonant changes in temporal analysis of share and volume.

Meteorological data show that in the 20 years between 1998 and 2019, the largest volume of rainfall occurred in December 2013, or approximately $501 \mathrm{~mm}$. However, when assessing the average rainfall over 20 years, 2005 had the highest rainfall, about $174 \mathrm{~mm}$, also being the year with the highest cumulative amount of rainfall $(2,095.10 \mathrm{~mm})$. With respect to the lower precipitation years, it is observed that in 2002, four years after the construction of the reservoir, there was the lowest average annual rainfall $(112.57 \mathrm{~mm})$, the lowest value of accumulated precipitation $(1,350.90 \mathrm{~mm})$. This coincided with the year of creation of the Cana Brava Dam, which is located downstream of the Serra da Mesa Dam.

Regarding the average values for temperature, it was observed that the year 2000 had the lowest values Tx and Tn with $30.69^{\circ} \mathrm{C}$ and $17.56^{\circ} \mathrm{C}$, respectively. Already in 2002 there was an increase in the values $\mathrm{Tx}$ and $\mathrm{Tn}$, with average values of $31.80^{\circ} \mathrm{C}$ and $18.38^{\circ} \mathrm{C}$, respectively, representing the highest values in the range of 20 years evaluated.

The Serra da Mesa Reservoir, built in 1997, has shown considerable variation in the useful water volume in recent years. The three lower average useful water volumes occurred in 2001 (15.06\%) 2016 (12.18\%) and 2017 (8.49\%) (Figure 2). The useful volume of the reservoir reached $66.76 \%$ of total volume in 2011 , and had a minimum percentage of useful volume, $10.53 \%$ in 2017 (Figure 2A and 2B). These data show that the system behaves differently over the years, even considering that the region has presented regular rainfall. However, there was significant reduction in the useful volume of 2011 and 2017, both in the rainy and the dry seasons (Figure 2A and 2B).

With respect to smaller volumes of water, it is observed that in the years 2003 and 2018 the system had considerable reduction in its volume, being proportional to the surface area values found, $676.23 \mathrm{~km}^{2}$ and $632.68 \mathrm{~km}^{2}$, in that order. According to Somlyody and Varis (2006), the aggravation and the complexity of water crises stem from an uneven sector process management and response to crisis and problems without predictive attitude and systemic approach (Tundisi, 2008), i.e., the strategy for the creation of new dams should be more comprehensive, considering the current context of the existing dam. An objective dam enjoys a high gap in constant water amount throughout the year because it flattens the natural fluctuations in river discharge (Junk and Mello, 1987). This implies river-level fluctuations, thus creating new dams. Not only the dynamics of rivers is changed, but also of the pre-existing dams. Thus, the decreasing pattern of altimetric height and volume of the Serra da Mesa Dam temporally follows the creation of new dams upstream, and therefore a negative impact 
resulting from inadequate management of water resources (Figure 2).
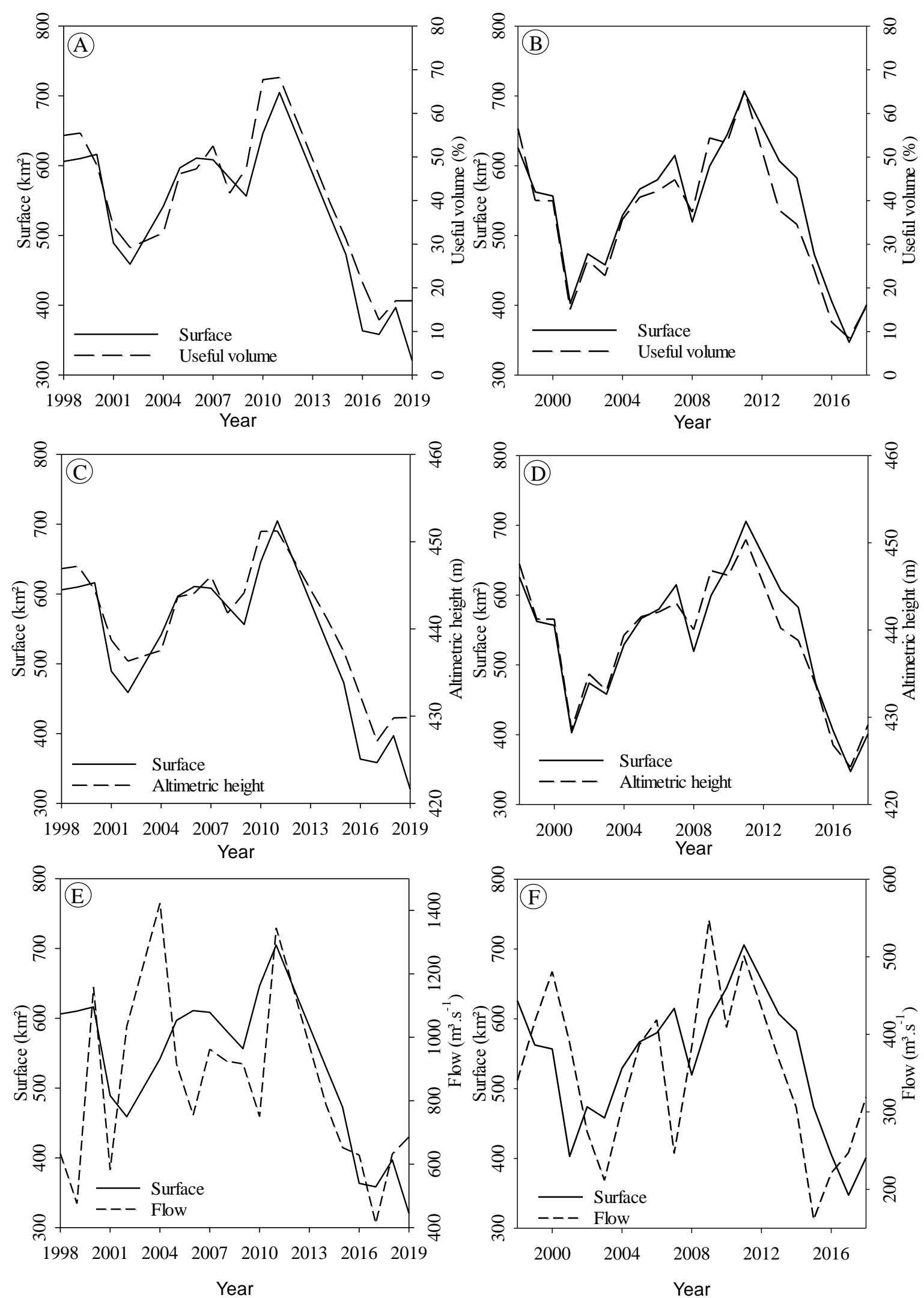

Figure 2. The relationship between the variables (A and B) useful volume (C and D), altimetric height (E and F) and flow in the wet and dry periods, respectively, for the Serra da Mesa Reservoir, GO. 
According to National Water Agency (ANA) data, the Serra da Mesa Reservoir (GO) has the highest level of quota $(\mathrm{m})$ in the second quarter of the year, with May showing the highest values compared to other months (Figure 2C and 2D). Through this analysis, the month with the highest share was in April 2012, with approximately $454.34 \mathrm{~m}$. At this time, the useful volume was $78.27 \%$ of the total capacity and throughput reached $786.31 \mathrm{~m}^{3} \cdot \mathrm{s}^{-1}$ (Figure 2E and 2F). The lowest share was observed in November 2017, reaching $422.39 \mathrm{~m}$, which represents the average volume of $5.92 \%$ of its potential reservoir capacity. The most useful volume percentage was observed in 2011, agreeing with the highest average values quota and mirror area of water estimated by means of satellite images that suggested $705.77 \mathrm{~km}^{2}$ for the full period and $704.79 \mathrm{~km}^{2}$ for the dry season. The water dynamics in the reservoir may be related to the type of reservoir, as shown in the study conducted in the Barra Bonita Reservoir, Ibitinga and Promissão, located in São Paulo and classified as storage reservoirs. In this study lower water surface was observed in the dry period; different reservoirs of liquid film-type showed an inverse behavior (Galo et al., 2002).

Due to areas with shadows or clouds, it was not possible to estimate the reservoir area during the dry season 2003, rainy and dry seasons 2012 and rainy season 2013, preventing the use of this information for the regression fit. Interference caused by clouds in optical images can be avoided when using radar images, which technology allows the survey of areas in different weather conditions (Medina et al., 2010; Nguy-Robertson et al., 2018). But the constellation of satellites with radar technology does not have global coverage and, in most cases, you need to pay to access the data, different from Landsat and MODIS satellites, that produce images with global coverage and are available for free through government repositories (Nguy-Robertson et al., 2018). Even Landsat images are sensitive to the presence of clouds; the great historical images of this project are feasible for monitoring of natural resources.

When observing the rainy season, the estimate of the useful volume and the reservoir altimetric height showed good relationship with the variable area with a determination coefficient above 0.90 , making it possible to use the variable area to estimate the useful volume over the years (Medina et al., 2010) and assess possible impacts caused by the dynamics of flooding on natural resources and the volume of the reservoir water (Nguy-Robertson et al., 2018) (Figure 3A and 3C). The estimate of the surface area of the reservoir by means of satellite images is accurate, and can be used in flood forecasting systems assisting in decision making in the event of imminent disaster (Busker et al., 2019). A study developed by Pekel et al. (2016) validated the classification with hits for permanent bodies of water, on average, greater than 98\% (commission and omission). This work associates errors with smaller water bodies, irrigated fields, floating vegetation and / or hidden by infrastructure such as tunnels and bridges. In the study area, floating vegetation is the only one of these present and is limited to a few arms, representing less than $0.1 \%$ of the reservoir, being non-representative.

The estimated flow through the reservoir area hasn't been effective, as the $R^{2}$ and $R^{2} a j$ showed lower values indicating that less than $23 \%$ of the reservoir's flow-rate variation can be explained by variation of the reservoir surface area (Figure 3E). Other factors may have a major influence on the reservoir flow, such as volume and depth (Gupta and Banerji, 1985). The result reflects the flow as a way of measurement is susceptible to the method adopted by the operator, which must consider not systematic errors, as well as the transport type, resulting in the release or water retention (Table 1). The low ratio between the area of the reservoir and the flow rate can be observed by the dispersion of waste from the model setting, which showed nearly 55\% overestimation in 1999 and $60 \%$ by underestimation 2004 (Figure 3F). The regression for volume fit had residual variation between approximately $20 \%$ and $-20 \%$. This variation was less than $1 \%$ for estimating the altimetric height of the reservoir (Figure 3B and Figure 3D). 

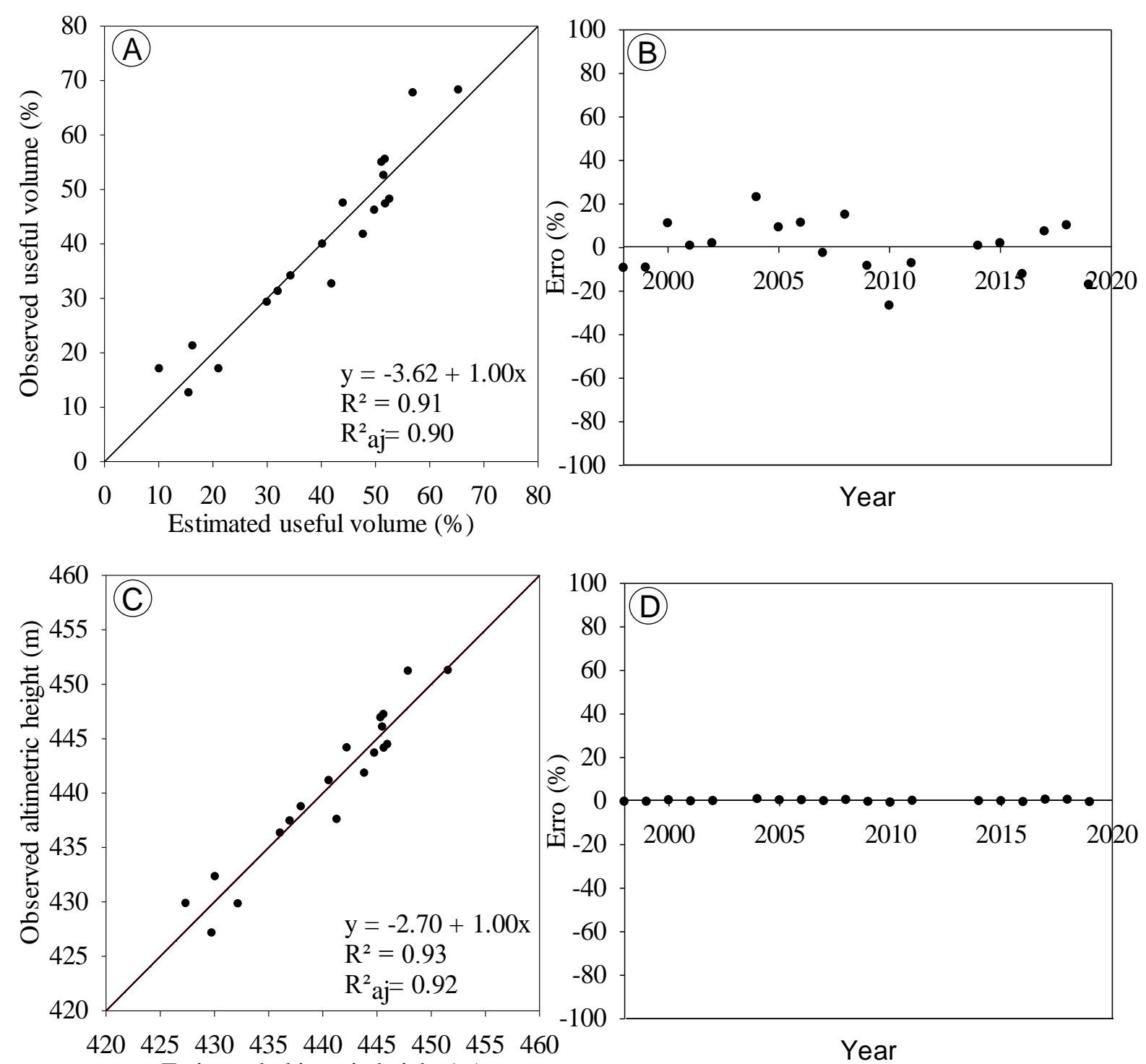

$\begin{array}{lllllllll}420 & 425 & 430 & 435 & 440 & 445 & 450 & 455 & 460\end{array}$

Estimated altimetric height $(\mathrm{m})$

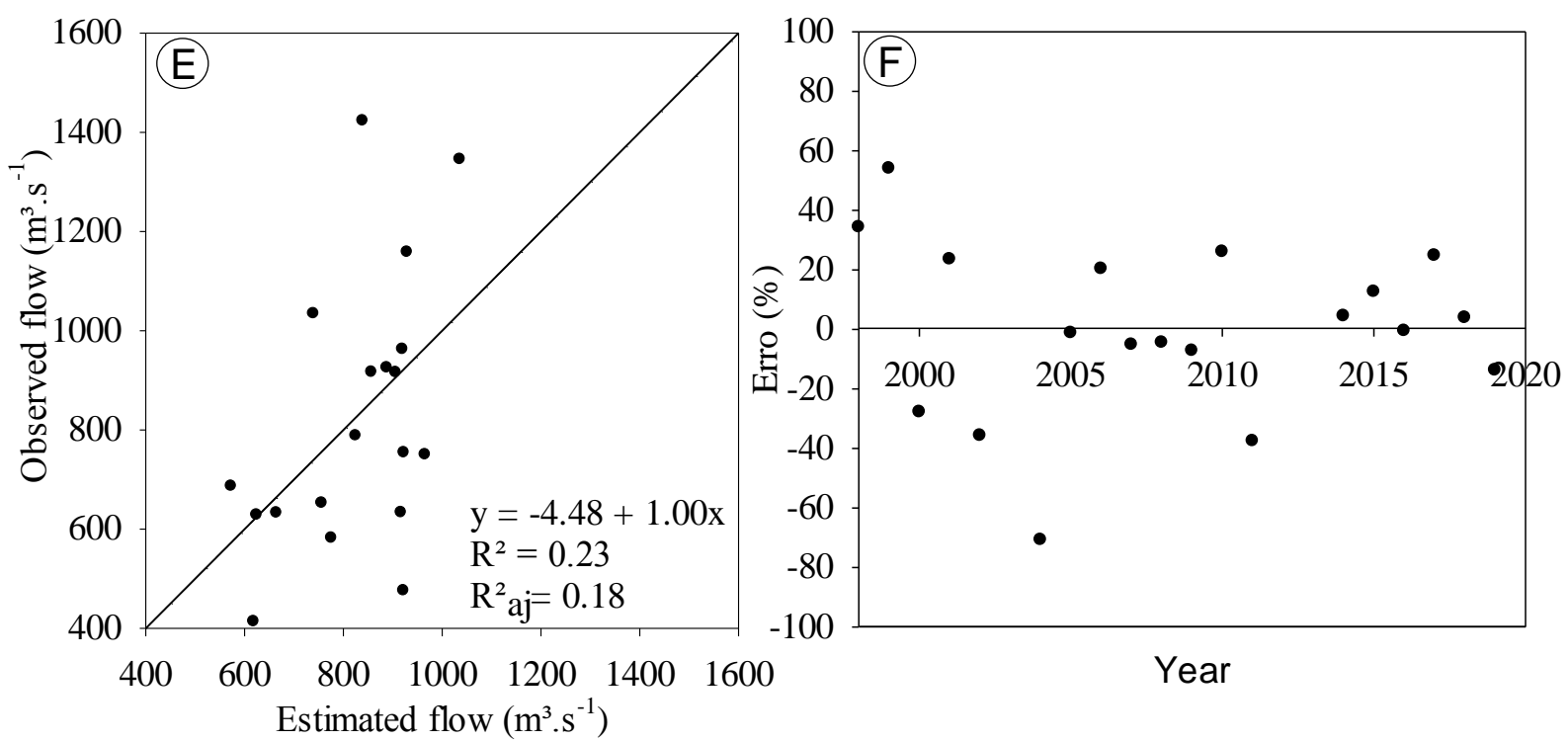

Figure 3. Relationship between observed and estimated data for the variables useful volume (A) altimetric height (C) and flow (E) in the rainy season. Distribution of residues from the set of linear regressions for variables useful volume (B) altimetric height (D) and flow rate (F) in the rainy season. 
Table 1. Statistical analysis of the data observed and estimated for the Serra da Mesa Reservoir - GO.

\begin{tabular}{|c|c|c|c|c|c|c|c|c|c|}
\hline \multirow{3}{*}{ Analysis } & \multicolumn{9}{|c|}{ Period } \\
\hline & \multicolumn{3}{|c|}{ Rainy } & \multicolumn{3}{|c|}{ Dry } & \multicolumn{3}{|c|}{ Yearly } \\
\hline & Volume & $\begin{array}{l}\text { Altimetric } \\
\text { height }\end{array}$ & $\begin{array}{l}\text { Flow } \\
\text { rate }\end{array}$ & Volume & $\begin{array}{l}\text { Altimetric } \\
\text { height }\end{array}$ & $\begin{array}{l}\text { Flow } \\
\text { rate }\end{array}$ & Volume & $\begin{array}{l}\text { Altimetri } \\
\text { height }\end{array}$ & Flow rate \\
\hline Syx & 5.09 & 2.01 & 247.68 & 4.30 & 1.83 & 86.53 & 2.96 & 1.26 & 59.56 \\
\hline Syx \% & 12.65 & 0.46 & 30.02 & 12.14 & 0.42 & 25.18 & 7.82 & 0.29 & 10.17 \\
\hline
\end{tabular}

* Units: Volume $\left(\mathrm{m}^{3}\right)$; Altimetric height $(\mathrm{m})$; Flow $\left(\mathrm{m}^{3} \cdot \mathrm{s}^{-1}\right)$

During the period of least rainfall, the reservoir has a lower useful volume, with higher average value in 2011 with $65 \%$ of its capacity. Over the evaluated years, the useful volume shows small variation in the dry season when compared to the first half of the year, characterized by higher rainfall in the region. This smaller variation of useful volume provides the best linear fit of the useful volume data with the area of the water body, making it possible to explain about $93 \%$ of the reservoir's volume change by varying the area occupied by water. Thus, rapid and inexpensive measurements using remote sensing images with high or medium spatial resolution such as Landsat design can be used to estimate the useful volume of the reservoir accurately (Figure 4A and 4B). This information is important for forecasting the water supply potential to the various sectors of society, as well as for assessing and managing the potential for energy production in hydroelectric dams in the event of severe droughts caused by climatic phenomena (Busker et al., 2019).

During the rainy season, the variable altimetric height can be estimated accurately, with less than $1 \%$ error over the years (Figure 4C and 4D). Even with less variation in the useful volume, due to low rainfall in the period, the flow did not present good seasonal relationship with the reservoir area, with overestimates above $40 \%$ in 2007 and 2015, and underestimates greater than $45 \%$ in 2009 (Figure 4E and 4F). The flow-rate error was close to $30 \%$ in the rainy season and almost $25 \%$ in the dry season (Table 1). This high amount may relate to the control of this variable by the reservoir of the operator, with the flow of the reservoir adjusted according to the downstream reservoirs' needs or due to the increased water volume in reservoirs upstream of the Tocantins River Basin (Duan and Bastiaanssen, 2013).

The fitted linear regression model per year, excluding the dry and rainy periods, shows satisfactory for the variable useful volume and flow altimetric height (Figure 5). The relation between the useful volume and the reservoir area is linear, allowing the model to fit with $\mathrm{R}^{2}$ and $\mathrm{R}^{2}$ aj above 0.90 . Thus, it is possible to estimate the useful volume from the reservoir area in any period of the year, with errors in estimated varying between $20 \%$ and - $20 \%$ approximately (Figure 5A and 5B). The estimate of the useful volume with Landsat images is promising, with error of the estimate of approximately 12\%, close to that found by Duan and Basiaanssen (2013) and Muala et al. (2014) (Table 1). With this information it is possible to evaluate the impacts caused by climate change and the climatic phenomena El Niño and La Niña on the abstraction of water in lakes and reservoirs (Busker et al., 2019) through temporal series of water flow created without the need for in situ measurements (Duan and Basiaanssen, 2013).

As with wet and dry periods, the variable altimetric height has a high relationship with the reservoir area and the estimated error is close to zero when annual periods are considered (Figure 5C and 5D). The altimetric height is measured using bathymetry and used to estimate the volume of water in the reservoir. Given the importance of this variable, we need specific equipment and calibration for accurate information, ensuring the medium and long term scheduling of the multiple uses of water. Thus, estimating the reservoir area using satellite images and using cloud processing can be an alternative to assess the quality of data measured in the field, and can identify defective equipment in the reservoir's containment structures. (Busker et al., 2019). 

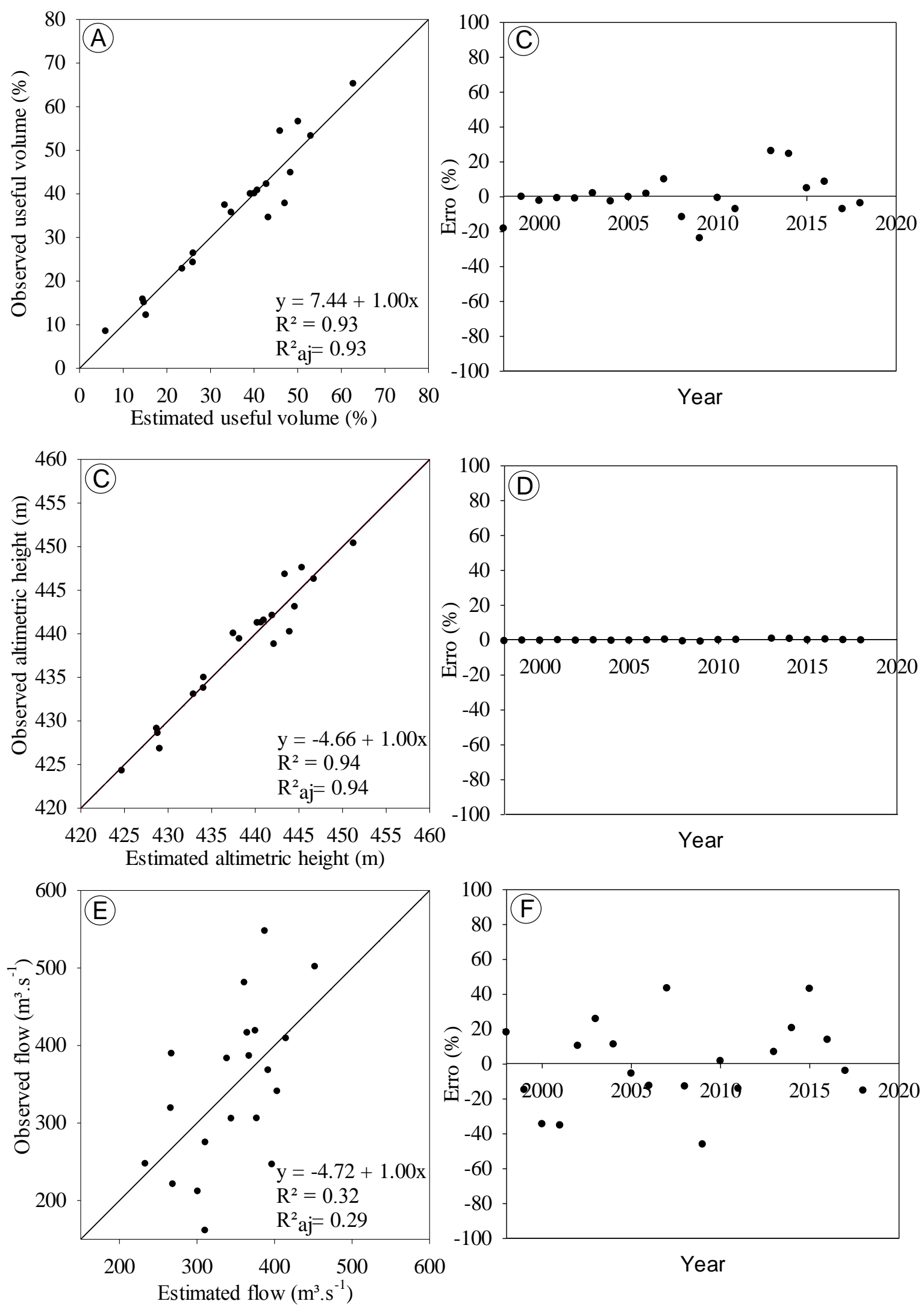

Figure 4. Ratio between observed and estimated data for the variables useful volume (A) altimetric height $(\mathrm{C})$ and flow $(\mathrm{E})$ in dry period. Distribution of residues from the set of linear regressions for useful volume variable (B) altimetric height (D) and flow (F) during the dry period. 

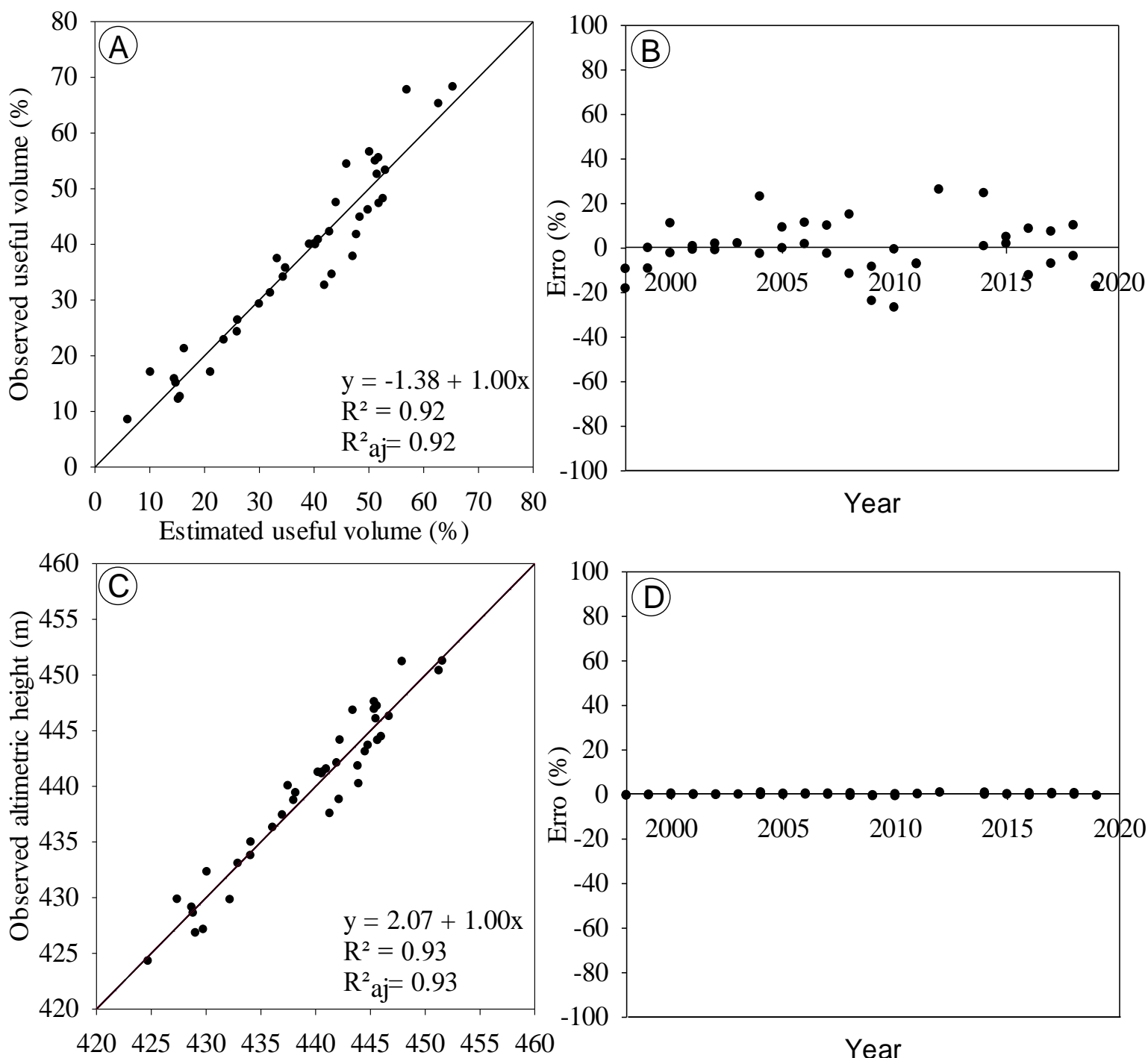

$420 \quad 425 \quad 430 \quad 435 \quad 440445 \quad 450455460$

Estimated altimetric height $(\mathrm{m})$
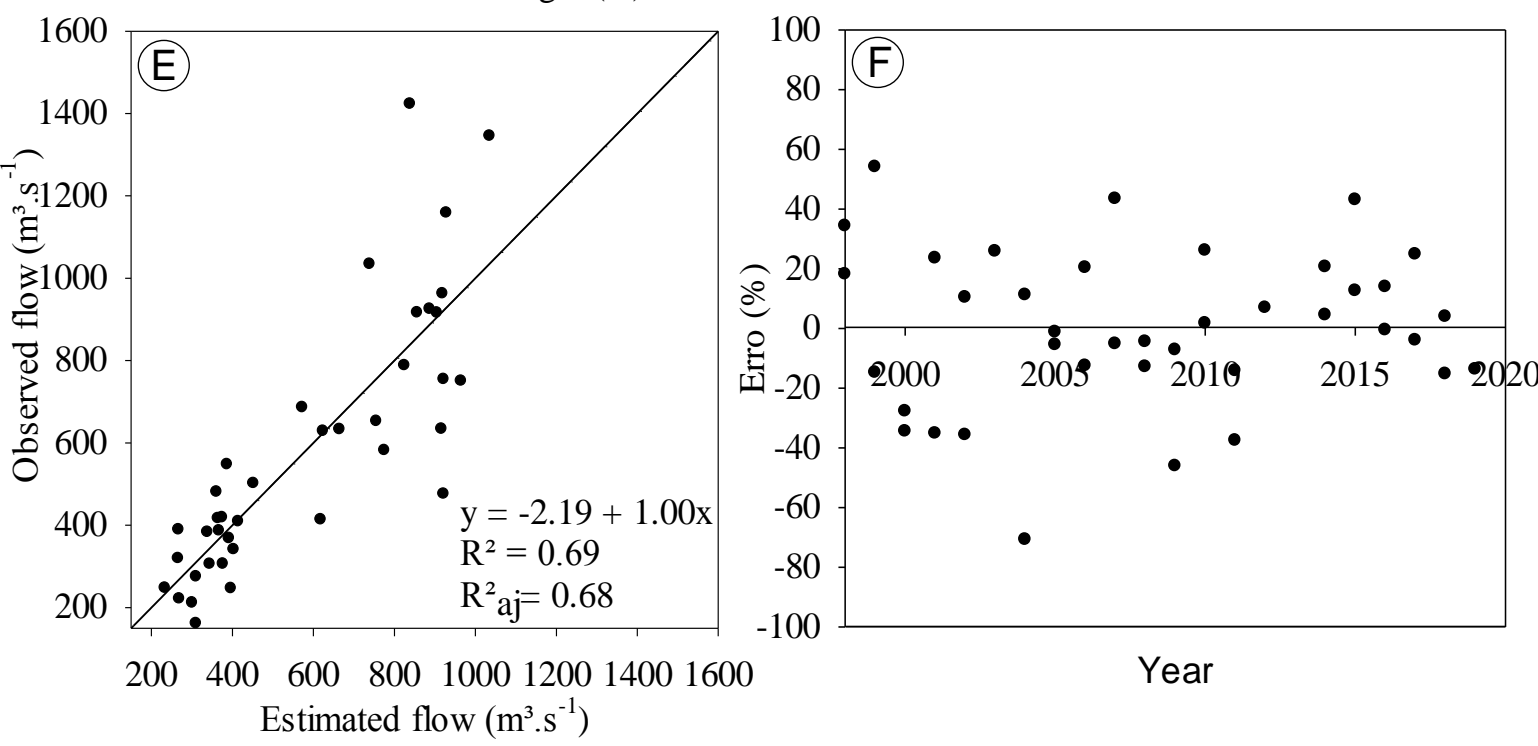

Figure 5. Relationship between observed and estimated data for variables useful volume (a) altimetric height (c) and flow (e) in wet and dry periods. Distribution of residues from the set of linear regressions for varying useful volume (b) altimetric height (d) and flow rate (F) in wet and dry periods. 
Figures 3, 4 and 5 show the differences between observed and estimated data in the dry period, the rainy period, and in both together. With this comparison, it is possible to note that the joint analysis of data conforms more closely to flow $\left(\mathrm{R}^{2}=0.69\right)$ compared to separate periods $\left(\mathrm{R}^{2}=0.18-0.29\right)$. For the Height and Volume relationships, the period does not influence much; the result was high for all $\left(\mathrm{R}^{2}>0.92\right)$.

According to Andrade et al. (2015), remote sensing techniques allow the evaluation of the responses derived from human activities and natural processes, in order to predict the impact of these actions on medium and long term sustainability conditions (Novo, 2005). In order to prevent and monitor changes in water resources, the Google Earth Engine platform (GEE) proved itself a powerful tool in the management of natural resources, allowing the processing of large-scale temporal data in a short time. Using this platform, one can access a set of geospatial data and process it with high-performance cloud computing (Gorelick et al., 2017), enabling quick and accurate assessments of reservoirs in different environments and facilitating the acquisition of information for more robust studies by entities responsible for water management (Duan and Bastiaanssen, 2013).

\section{CONCLUSIONS}

Remote sensing is presented as an efficient alternative to water monitoring, due to the inferences that can be made from information from satellite images proportional to the portion of monitoring time series over 20 years in the reservoir of Serra da Mesa (GO). The impact of the GEE platform benefits the management of natural resources, and provides extensive temporal analysis with large amounts of data efficiently in a short time, and has accurate and robust results. In addition, the methodology proposed in this study for height measurement is recommended for other storage reservoirs.

The temporal analysis of the Serra da Mesa Reservoir allows us to observe that there is a pattern of floods and droughts over the years. However, the maximum cost of flooding has been reduced over the years, which shows the reduction of reservoir quotas and water availability for power generation and human consumption. This observed pattern of reduction may reflect the creation of new dams upstream, or also the intensification of land use on the banks of the Serra da Mesa Dam; both explanations originate from anthropogenic action or omission.

Despite the climatic variations that influence dam metrics, anthropogenic factors play important parts in the dam's history and in the trend. Thus, continuous monitoring of reservoir levels and of the river basin is necessary in order to mitigate potential impacts on the multiple uses of water and find possible alternatives to perpetuate the water supply with minimal impact from flooding.

\section{ACKNOWLEDGEMENTS}

This study was financed in part by the Coordenação de Aperfeiçoamento de Pessoal de Nível Superior - Brasil (CAPES) - Finance Code 001.

\section{REFERENCES}

ABILEAH, R. et al. A Completely Remote Sensing Approach To Monitoring Reservoirs Water Volume. In: INTERNATIONAL WATER TECHNOLOGY CONFERENCE, 15., 2011, Alexandria. Papers[...] Available at: http://www.jomegak.com/Publications/2011\%20IWTC\%20Paper.pdf. Access: Aug. 2020. 
ALSDORF, D. E.; RODRÍGUEZ, E.; LETTENMAIER, D. P. Measuring surface water from space. Reviews of Geophysics, v. 45, n. 2007, p. 1-24, 2007. https://doi.org/10.1029/2006RG000197

ANDRADE, E. M. DE; LOPES, F. B.; CHAVES, L. C. G. Recurso Água e Sensoriamento Remoto. Fortaleza: Inovagri, 2015. p. 169.

BUSKER, T. et al. A global lake and reservoir volume analysis using a surface water dataset and satellite altimetry. Hydrology and Earth System Sciences, v. 23, p. 669-690, 2019. https://doi.org/10.5194/hess-23-669-2019

COLLISCHONN, B.; CLARKE, R. T. Estimativa e incerteza de curvas cota-volume por meio de sensoriamento remoto. Rbrh, v. 21, n. 4, p. 719-727, 2016. http://dx.doi.org/10.1590/2318-0331.011616022

CURTARELLI, M. P. et al. Assessment of temporal dynamics of evaporation in the Itumbiara reservoir, GO, using remote sensing data. Revista Ambiente \& Agua, v. 8, n. 1, p. 445458, 2013. https://doi.org/10.4136/ambi-agua.1083

DUAN, Z.; BASTIAANSSEN, W. G. M. Estimating water volume variations in lakes and reservoirs from four operational satellite altimetry databases and satellite imagery data. Remote Sensing of Environment, v. 134, p. 403-416, jul. 2013. https://doi.org/10.1016/j.rse.2013.03.010

GALO, M. L. B. T.; VELINI, E. D.; SANTOS, E. Uso do sensoriamento remoto orbital no monitoramento da dispersão de macrófitas nos reservatórios do Complexo Tietê. v. 20, n. M, p. 7-20, 2002. https://doi.org/10.1590/S0100-83582002000400002

GAO, H. Satellite remote sensing of large lakes and reservoirs: from elevation and area to storage. Wiley Interdisciplinary Reviews: Water, v. 2, n. 2, p. 147-157, 2015. https://doi.org/10.1002/wat2.1065

GORELICK, N. et al. Remote Sensing of Environment Google Earth Engine: Planetary-scale geospatial analysis for everyone. Remote Sensing of Environment, v. 202, p. 18-27, 2017. https://doi.org/10.1016/j.rse.2017.06.031

GUPTA, R. P.; BANERJI, S. Monitoring of reservoir volume using Landsat data. Journal of Hydrology, v. 77, p. 159-170, 1985. https://doi.org/10.1016/0022-1694(85)90204-5

JUNK, W. J.; MELLO, J. A. S. de. Impactos ecológicos das represas hidrelétricas na bacia amazônica brasileira. In: KOHLHEPP, G.; SCHRADER, A. (eds.) Homem e Natureza na Amazônia. Tübingen: Geographischen Instituts der Universität Tübingen, 1987. p. 367-385.

LOPES, F. B. et al. Modelagem da qualidade das águas a partir de sensoriamento remoto hiperespectral. Revista Brasileira de Engenharia Agrícola e Ambiental, v. 18, n. suppl, p. 13-19, 2017. https://doi.org/10.1590/1807-1929/agriambi.v18nsupps13-s19

LU, S. et al. Lake water volume calculation with time series remote-sensing images. International Journal of Remote Sensing, v. 34, n. 22, p. 7962-7973, 2013. https://doi.org/10.1080/01431161.2013.827814

MACHADO, M. T. DE S.; BAPTISTA, G. M. DE M. Sensoriamento remoto como ferramenta de monitoramento da qualidade da água do Lago Paranoá (DF). Engenharia Sanitária e Ambiental, v. 21, n. 2, p. 357-365, 2016. http://dx.doi.org/10.1590/s141341522016141970 
MARTINS, P. T. DE A. et al. Alteração na cobertura vegetal e uso da terra da Bacia Hidrográfica do Alto Rio Tocantins (Goiás): Influência das características físicas e a relação com as comunidades indígenas. Ciência e Natureza, v. 37, n. 4, p. 392-404, 2015. http://dx.doi.org/105902/2179460X15780

MEDINA, C. et al. Water volume variations in Lake Izabal (Guatemala) from in situ measurements and ENVISAT Radar Altimeter (RA-2) and Advanced Synthetic Aperture Radar (ASAR) data products. Journal of Hydrology, v. 382, n. 1-4, p. 34-48, 2010. https://doi.org/10.1016/j.jhydrol.2009.12.016

MORETTO, E. M. et al. Histórico, tendências e perspectivas no planejamento espacial de usinas hidrelétricas brasileiras: a antiga e atual fronteira Amazônica. Ambiente \& Sociedade, v. $15, \quad$ n. $3, \quad$ p. 141-164, 2012. https://doi.org/10.1590/S1414753X2012000300009

MUALA, E. et al. Estimation of Reservoir Discharges from Lake Nasser and Roseires Reservoir in the Nile Basin Using Satellite Altimetry and Imagery Data. Remote Sensing, v. 6, n. 8, p. 7522-7545, 2014. https://doi.org/10.3390/rs6087522

NGUY-ROBERTSON, A. et al. Remote Sensing Applications: Society and Environment Inferring elevation variation of lakes and reservoirs from areal extents: Calibrating with altimeter and in situ data. Remote Sensing Applications: Society and Environment, v. 9, p. 116-125, 2018. https://doi.org/10.1016/j.rsase.2018.01.001

NOVO, E. M. L. DE M. Sensoriamento remoto aplicado à ecologia aquática. In: ROLAND, F.; CÉSAR, D.; MARINHO, M. (Eds.). Lições de limnologia. São. Carlos: Rima, 2005. p. 417-432.

PAZ, V. P. DA S.; TEODORO, R. E. F.; MENDONÇA, F. C. Comunicado Técnico: Recursos Hídricos, Agricultura Irrigada e Meio Ambiente. Revista Brasileira de Engenharia Agrícola e Ambiental, v. 4, n. 3, p. 465-473, 2000. https://doi.org/10.1590/S141543662000000300025

PEKEL, J. F.; COTTAM, A.; GORELICK, N.; BELWARD, A. S. High-resolution mapping of global surface water and its long-term changes. Nature, n. 540, p. 418-422, 2016. https://doi.org/10.1038/nature20584

SOMLYODY, L.; VARI, L. Freshwater under pressure. International Review for Environmental Strategies, v. 6, n. 2, p. 181-204, 2006.

TONG, X. et al. Remote Sensing of Environment Estimating water volume variations in Lake Victoria over the past 22 years using multi-mission altimetry and remotely sensed images. Remote Sensing of Environment, v. 187, p. 400-413, 2016. https://doi.org/10.1016/j.rse.2016.10.012

TUNDISI, J. G. Recursos hídricos no futuro: problemas e soluções. Estudos Avançados, v. 22, n. 63, p. 7-16, 2008. https://doi.org/10.1590/S0103-40142008000200002

WHITE, M. E. Reservoir Surface Area from Landsat Imagery. Photogrammetric Engineering and Remote Sensing, v. 44, p. 1421-1426, 1978.

ZHANG, H. et al. A remote sensing method for estimating regional reservoir area and evaporative loss. Journal of Hydrology, v. 555, p. 213-227, 2017. https://doi.org/10.1016/j.jhydrol.2017.10.007 


\begin{tabular}{|} 
Ambiente \& Água - An Interdisciplinary Journal of Applied Science \\
ISSN 1980-993X - doi:10.4136/1980-993X \\
www.ambi-agua.net \\
E-mail: ambi.agua@gmail.com
\end{tabular}

\title{
Evaluation of physicochemical water parameters in watersheds of southern Brazil
}

\author{
ARTICLES doi:10.4136/ambi-agua.2596
}

Received: 11 Jun. 2020; Accepted: 19 Aug. 2020

\author{
Marta Sória1 ${ }^{1 D}$; Vitor Emanuel Quevedo Tavares ${ }^{2}$; \\ Marília Alves Brito Pinto ${ }^{3}$; Lizete Stumpf $^{4 *(D)}$; \\ Daiane Zarnott ${ }^{5}$; Jéssica Bubolz ${ }^{6}$; ; Bernardo Gomes Nörenberg ${ }^{7}$ (iD
}

\footnotetext{
${ }^{1}$ Departamento de Anuência Ambiental. Secretaria de Qualidade Ambiental. Prefeitura Municipal de Pelotas, Avenida Domingos de Almeida, n 1490, CEP: 96085-470, Pelotas, RS, Brazil. E-mail: martilha@yahoo.com.br ${ }^{2}$ Faculdade de Agronomia Eliseu Maciel. Departamento de Engenharia Rural. Universidade Federal de Pelotas (UFPel), Caixa Postal 354, Campus Universitário, CEP: 96010-900, Pelotas, RS, Brazil. E-mail: vtavares@ufpel.edu.br

${ }^{3}$ Centro de Desenvolvimento Tecnológico. Departamento de Engenharia Hídrica. Universidade Federal de Pelotas (UFPel), Rua Gomes Carneiro, n 1, CEP: 96010-610, Pelotas, RS, Brazil. E-mail: ma.agro@ gmail.com ${ }^{4}$ Faculdade de Agronomia Eliseu Maciel. Departamento de Solos. Universidade Federal de Pelotas (UFPel), Campus Capão do Leão, Campus Universitário, s/n, CEP: 96160-000, Capão do Leão, RS, Brazil.

${ }^{5} 1^{\circ}$ Centro de Geoinformação. Exército Brasileiro, Rua Cleveland, n 250, CEP: 90850-240, Porto Alegre, RS, Brazil. E-mail: daiahzar@gmail.com

${ }^{6}$ Faculdade de Agronomia Eliseu Maciel. Universidade Federal de Pelotas (UFPel), Campus Capão do Leão, Campus Universitário, s/n, CEP: 96160-000, Capão do Leão, RS, Brazil. E-mail: jessicabubolz@gmail.com ${ }^{7}$ Programa de Pós-Graduação em Recursos Hídricos. Universidade Federal de Pelotas (UFPel), Rua Gomes Carneiro, n 1, CEP: 96010-610, Pelotas, RS, Brazil. E-mail: bernardo.norenberg@ hotmail.com *Corresponding author. E-mail: zete.stumpf@gmail.com
}

\begin{abstract}
Water-quality monitoring is one of the main instruments for water-resource management. This work therefore evaluated the water quality of the contribution basin of the Sinnott water treatment plant as well as the relationship between physicochemical water parameters, and analyzed the seasonal variation of water quality parameters as a function of rainfall. The study area encompassed the contribution basin of the Sinnott water treatment plant, formed mainly by the drainage areas of the Pelotas stream and its tributary, the Quilombo Stream, located in the city of Pelotas - Rio Grande do Sul, Brazil. A set of 118,368 data points for each stream was analyzed between 2007 and 2012. The following water quality parameters were evaluated: turbidity, temperature, color, $\mathrm{pH}$, hardness, dissolved oxygen, organic matter, and alkalinity. Results showed that dissolved oxygen and water $\mathrm{pH}$ values conformed with Brazilian legislation in the 6 years evaluated. However, water color was the parameter that remained the greatest number of days above the set limits, mainly in the Pelotas Stream. Result indicates the need for conservation actions in the catchment, especially considering the importance of color for the assessment of water quality for public supply, in terms of both treatment costs and of public health. Highest values for water color, turbidity, and organic matter coincided with the occurrence of the highest rainfall values. Agricultural activities may potentiate sedimentation in the contribution basin of the Sinnott water treatment plant.
\end{abstract}

keywords: color, organic matter, turbidity.

This is an Open Access article distributed under the terms of the Creative Commons Attribution License, which permits unrestricted use, distribution, and reproduction in any medium, provided the original work is properly cited. 


\section{Avaliação de parâmetros físico-químicos da água em bacia hidrográfica do sul do Brasil}

\section{RESUMO}

O monitoramento da qualidade da água consiste num dos principais instrumentos para gestão de recursos hídricos. O presente trabalho teve como objetivos: (i) avaliar a qualidade da água na bacia de contribuição da estação de tratamento de água de Sinnott bem como a relação entre os parâmetros fisioquímicos da água; e (ii) analisar a variação sazonal dos parâmetros de qualidade da água em função das chuvas. A área de estudo abrangeu a bacia de contribuição da estação de tratamento de água de Sinnott, formada principalmente pelas áreas de drenagem do córrego Pelotas e seu afluente, o córrego Quilombo, localizado na cidade de Pelotas. Um conjunto de 118.368 pontos de dados foi analisado entre 2007 e 2012. Os seguintes parâmetros de qualidade da água foram avaliados foram: turbidez, temperatura, cor, $\mathrm{pH}$, dureza, oxigênio dissolvido, matéria orgânica e alcalinidade. Os resultados mostraram que os valores de oxigênio dissolvido e pH da água estavam de acordo com a legislação brasileira nos 6 anos avaliados. Entretanto, a cor da água foi o parâmetro que permaneceu o maior número de dias acima dos limites estabelecidos, ocorrendo principalmente no córrego Pelotas. Esse resultado indica a necessidade de ações de conservação na bacia hidrográfica, principalmente considerando a importância da cor na avaliação da qualidade da água para abastecimento público, tanto em termos de custos de tratamento quanto de saúde pública. Os maiores valores de cor da água, turbidez e matéria orgânica coincidiram com a ocorrência dos maiores valores de precipitação. As atividades agrícolas podem potencializar a sedimentação na bacia de contribuição da estação de tratamento de água de Sinnott.

Palavras-chave: cor, matéria orgânica, turbidez.

\section{INTRODUCTION}

Water quality is one of the important issues in water-resource management (Sutadian et al., 2016). Water quality can be classified into three broad categories: physical, chemical and biological, and each category has several parameters (Swamee and Tyagi, 2007). These parameters must be associated with the characteristics of local water uses and relating quality objectives.

Rainfall information is important in the analysis of water quality, as it directly influences the flow and quality of a body of water. Rainfall intensities establish different levels of impacts on the soil and erosive processes of varying degrees that directly influence the rate of runoff (Fraga et al., 2012).

In agricultural systems where there is no adequate soil management, sediment runoff can be substantially altered in comparison to natural biomes (Alvarez et al., 2014; Torres et al., 2017). In Brazil, Taniwaki et al. (2017) observed higher concentrations of nitrate and suspended solids in the water quality of streams which drained sugarcane fields, mainly during the wet season. In China, Xiao et al. (2019) reported a presence of trace elements such as $\mathrm{Cr}, \mathrm{Pb}, \mathrm{Cd}$, $\mathrm{Cu}$, and $\mathrm{Ag}$ in rivers, mainly due to anthropogenic inputs. In contrast, when evaluating water bodies, Wang et al. (2017) described dominant pollutants such as $\mathrm{Zn}, \mathrm{Cd}$, and $\mathrm{Pb}$, making the water unsuitable for drinking in that area.

In Southern Brazil, the contribution basin of the Sinnott water treatment plant assists water for human consumption for over 328,275 inhabitants in Pelotas city (IBGE, 2010). Although the Autonomous Service of Pelotas Water Supply (SANEP) evaluates the physicochemical water parameters for later treatment, so far few studies have evaluated these parameters over the years, as well as the relationship between them; and the relation of these parameters with 
rainfall and use of the areas around the slopes of the basin. From this perspective, the present work evaluated water quality in the contribution basin of the Sinnott water treatment plant and the relationship between physicochemical water parameters, and analyzed the seasonal variation of water quality parameters as a function of rainfall.

\section{MATERIAL AND METHODS}

\subsection{Study area}

The study area was the contribution basin of the Sinnott water treatment plant, which is located in the southeast of Rio Grande do Sul State, between the geodetic coordinates $31^{\circ} 30^{\prime}$ a $34^{\circ} 35^{\prime} \mathrm{S}$ e $53^{\circ} 31^{\prime}$ a $55^{\circ} 15^{\prime} \mathrm{O}$. The basin is formed mainly by the drainage areas of the Pelotas Stream and its tributary, the Quilombo Stream (Figure 1). The main water uses of the contribution basin are irrigation, human consumption, and animal-related.

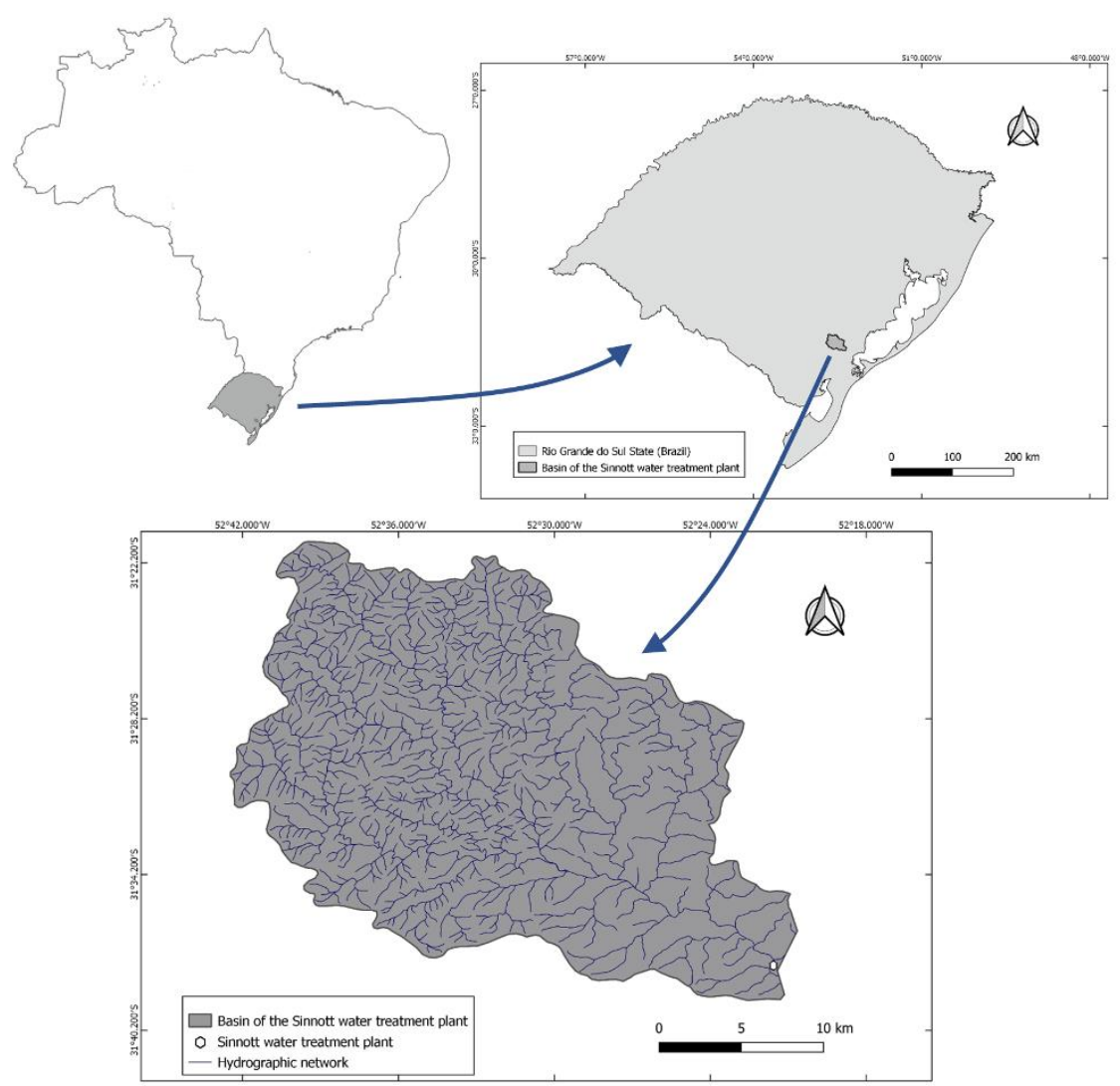

Figure 1. Basin of the Sinnott water treatment plant, located in Pelotas city, Rio Grande do Sul State, Southern Brazil.

According to the Köppen system, the climate of the region was classified as humid subtropical (Cfa), with an average annual temperature of $17^{\circ} \mathrm{C}$ and an average annual rainfall of 1,400 mm (Alvares et al., 2013). The main soil classes around the contribution basin were categorized as Ultisols, Inceptisols, Entisols, Alfisols, and Gleisols (Flores et al., 2009).

\subsection{Sampling and analysis of water quality parameters}

The data used in this study are the results of the water monitoring carried out by SANEP in the Pelotas and Quilombo Streams. SANEP provided data in handwritten spreadsheets with the following water quality parameters: turbidity, temperature, color, $\mathrm{pH}$, hardness, dissolved oxygen, organic matter, and alkalinity. The data set relates the hourly evaluation of each parameter during the period 2007 to 2012. 
Water samples were collected at two locations at the Sinnott water treatment plant

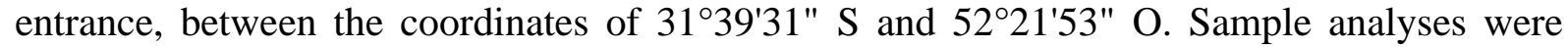
carried out by SANEP, according to the Standard Methods for the Examination of Water and Wastewater (APHA et al., 1998).

The main water uses of the Sinnott contribution basin are animal drinking, irrigation, and, after conventional treatment, human consumption. Thus, the studied parameters must comply with CONAMA Resolution $\mathrm{n}^{\circ} 357$ of 03/17/2005, in its Article 42, which classifies freshwater bodies as those of the present study as Class 2. Physicochemical water parameters were compared to the Brazilian legislation for freshwaters, specifically to Class 2 (CONAMA, 2005), according to Table 1 .

Table 1. Physicochemical water parameters suitable for freshwaters (Class 2) according to the Brazilian legislation (CONAMA Resolution $\mathrm{N}^{\circ}$ 357, March 17, 2005).

\begin{tabular}{ccc}
\hline Parameter & Unity & Class 2 \\
\hline Color & $\mathrm{mg} \mathrm{Pt} \mathrm{L}^{-1}$ & until 75 \\
Turbidity & UNT & until 100 \\
dissolved oxygen & $\mathrm{mg} \mathrm{L}^{-1} \mathrm{de} \mathrm{O}_{2}$ & not less than 5.0 \\
$\mathrm{pH}$ & - & from 6.0 to 9.0 \\
\hline
\end{tabular}

Rainfall data were obtained at Ponte Cordeiro de Farias Pluviometric Station (31 $34^{\prime} 26^{\prime \prime} \mathrm{S}$ and $\left.52^{\circ} 27^{\prime} 47^{\prime \prime} \mathrm{W}\right)$, which is inserted into the watershed boundary of the Pelotas Stream, operated by the National Water Agency of Brazil (ANA) and the Brazilian Mineral Resources Research Company (CPRM). Monthly rainfall series were organized based on the historical series available in a database on the Hidroweb- Hydrological Information System homepage.

\subsection{Statistical analyses}

Descriptive analysis of all data sets was performed by classical statistics, determining the range of values, and calculating their mean. Principal components analysis (PCA) was used to group the water quality indicators, and to therefore explain the relation between them. Pearson correlation analysis was used to verify the relationship between water quality indicators and rainfall.

\section{RESULTS AND DISCUSSION}

The maximum and minimum values of water temperature followed the seasonal trend, corresponding to the summer and winter seasons, in both the Pelotas and Quilombo Streams between 2007 and 2012 (Table 2). According to Alvarenga et al. (2012), temperature varies according to the climatic regime, and superficial water resources show seasonal and diurnal variations, making water temperature the parameter most influenced by flow seasonality.

The highest mean turbidity values were observed in the Pelotas Stream (Table 2), possibly due to the larger area of its contribution basin.

Similar to turbidity, the highest water color values were also observed in the Pelotas Stream, with a mean ranging from 65 to $180 \mathrm{mg} \mathrm{Pt} \mathrm{L}^{-1}$ between 2007 and 2012. In the Quilombo Stream, the annual average observed was between 53 and $132 \mathrm{mg} \mathrm{Pt} \mathrm{L}^{-1}$ (Table 2). The higher color values are due possibly to the organic residues of plants deposited in the stream, which promote organic matter degradation by bacteria and by forming humic and fulvic acid. Additionally, the erosive processes of agricultural areas located around the stream promote the transport of sediment, also leading to alterations in the color of the water (Oliveira et al., 2010). 
Table 2. Minimum (Min), maximum (Max) and mean values of the water quality parameters in Pelotas and Quilombo Streams between 2007 and 2012.

\begin{tabular}{|c|c|c|c|c|c|c|c|c|c|}
\hline Parâmetros & Min & Max & Mean & Min & Máx & Média & Min & Máx & Média \\
\hline & \multicolumn{3}{|c|}{2007} & \multicolumn{3}{|c|}{2008} & \multicolumn{3}{|c|}{2009} \\
\hline Water Temperature $\left({ }^{\circ} \mathrm{C}\right)$ & 6.7 & 30.0 & 18.5 & 9.0 & 28.0 & 18.2 & 7.5 & 27.0 & 18.2 \\
\hline Turbidity (UNT) & 3.1 & 160.8 & 18.5 & 2.6 & 146.1 & 20.4 & 4.7 & 111.5 & 29.3 \\
\hline Color $\left(\mathrm{mg} \mathrm{Pt} \mathrm{L}^{-1}\right)$ & 14.0 & 350 & 70.0 & 10.0 & 320.0 & 65.0 & 20.0 & 1037.0 & 180.0 \\
\hline $\mathrm{pH}$ & 6.3 & 7.7 & 7.0 & 6.6 & 7.6 & 7.1 & 6.0 & 7.6 & 7.0 \\
\hline Hardness $\left(\mathrm{CaCO}_{3} \mathrm{mg} \mathrm{L}^{-1}\right)$ & 7.5 & 25.0 & 17.3 & 12.0 & 29.0 & 18.1 & 6.0 & 23.0 & 15.1 \\
\hline Alkalinity $\left(\mathrm{CaCO}_{3} \mathrm{mg} \mathrm{L}^{-1}\right)$ & 11.0 & 38.2 & 23.8 & 9.2 & 37.2 & 23.0 & 11.0 & 28.1 & 21.1 \\
\hline $\mathrm{CO}_{2}$ free $\left(\mathrm{mg} \mathrm{L}^{-1}\right)$ & 2.8 & 28.8 & 8.3 & 2.4 & 12.0 & 5.8 & 3.2 & 14.4 & 6.2 \\
\hline Dissolved oxygen $\left(\mathrm{mg} \mathrm{L}^{-1}\right)$ & 5.4 & 11.6 & 8.9 & 6.5 & 10.4 & 8.3 & 5.4 & 11.1 & 8.3 \\
\hline \multirow[t]{2}{*}{ Organic matter $\left(\mathrm{mg} \mathrm{L}^{-1}\right)$} & 1.4 & 16.0 & 5.1 & 1.5 & 16.6 & 4.8 & 1.0 & 17.2 & 5.1 \\
\hline & \multicolumn{3}{|c|}{2010} & \multicolumn{3}{|c|}{2011} & \multicolumn{3}{|c|}{2012} \\
\hline Water Temperature $\left({ }^{\circ} \mathrm{C}\right)$ & 9.0 & 29.0 & 19.3 & 8.0 & 28.0 & 19.5 & 9.0 & 29.0 & 20.3 \\
\hline Turbidity (UNT) & 5.3 & 151.4 & 24.3 & 6.9 & 181.3 & 32.2 & 6.1 & 274.4 & 36.0 \\
\hline Color (mg Pt L $\left.\mathrm{L}^{-1}\right)$ & 31.0 & 1410.0 & 135.0 & 29.0 & 785.0 & 121.0 & 21.0 & 720.0 & 109.0 \\
\hline $\mathrm{pH}$ & 5.8 & 7.5 & 7.1 & 6.5 & 7.8 & 7.0 & 6.3 & 7.3 & 6.9 \\
\hline Hardness $\left(\mathrm{CaCO}_{3} \mathrm{mg} \mathrm{L}^{-1}\right)$ & 12.0 & 28.0 & 17.2 & 8.5 & 22.0 & 16.5 & 14.0 & 29.0 & 20.5 \\
\hline Alkalinity $\left(\mathrm{CaCO}_{3} \mathrm{mg} \mathrm{L}^{-1}\right)$ & 13.8 & 35.0 & 25.2 & 12.9 & 33.7 & 23.1 & 10.1 & 33.0 & 25.6 \\
\hline $\mathrm{CO}_{2}$ free $\left(\mathrm{mg} \mathrm{L}^{-1}\right)$ & 3.2 & 18.0 & 5.3 & 3.2 & 11.6 & 5.1 & 3.2 & 16.0 & 6.2 \\
\hline Dissolved oxygen $\left(\mathrm{mg} \mathrm{L}^{-1}\right)$ & 5.5 & 11.8 & 9.1 & 5.3 & 10.7 & 8.4 & 5.1 & 17.0 & 8.5 \\
\hline \multirow[t]{2}{*}{ Organic matter $\left(\mathrm{mg} \mathrm{L}^{-1}\right)$} & 1.3 & 27.8 & 4.7 & 1.5 & 19.6 & 4.6 & 1.5 & 18.4 & 4.7 \\
\hline & \multicolumn{3}{|c|}{2007} & \multicolumn{3}{|c|}{2008} & \multicolumn{3}{|c|}{2009} \\
\hline Water Temperature $\left({ }^{\circ} \mathrm{C}\right)$ & 8.0 & 27.0 & 18.4 & 9.0 & 28.0 & 19.0 & 9.7 & 28.0 & 19.7 \\
\hline Turbidity (UNT) & 0.6 & 116.6 & 14.7 & 1.6 & 313.1 & 20.6 & 1.6 & 564.3 & 25.5 \\
\hline Color (mg Pt L $\left.\mathrm{L}^{-1}\right)$ & 8.0 & 1037.0 & 80.0 & 9.0 & 826.0 & 73.0 & 5.0 & 886.0 & 65.0 \\
\hline $\mathrm{pH}$ & 6.1 & 7.8 & 7.3 & 6.4 & 7.6 & 7.2 & 6.5 & 7.6 & 7.2 \\
\hline Hardness $\left(\mathrm{CaCO}_{3} \mathrm{mg} \mathrm{L}^{-1}\right)$ & 13.0 & 29.0 & 17.1 & 8.0 & 24.0 & 17.1 & 14.0 & 30.0 & 20.4 \\
\hline Alkalinity $\left(\mathrm{CaCO}_{3} \mathrm{mg} \mathrm{L}^{-1}\right)$ & 12.8 & 36.1 & 24.7 & 13.5 & 31.3 & 23.3 & 12.8 & 30.6 & 24.7 \\
\hline $\mathrm{CO}_{2}$ free $\left(\mathrm{mg} \mathrm{L}^{-1}\right)$ & 2.0 & 12.0 & 4.9 & 2.4 & 8.0 & 4.5 & 2.4 & 12.0 & 5.1 \\
\hline Dissolved oxygen $\left(\mathrm{mg} \mathrm{L}^{-1}\right)$ & 6.4 & 12.9 & 9.1 & 6.1 & 10.6 & 8.6 & 5.8 & 11.3 & 8.6 \\
\hline \multirow[t]{2}{*}{ Organic matter $\left(\mathrm{mg} \mathrm{L}^{-1}\right)$} & 0.8 & 19.8 & 3.2 & 0.8 & 20.0 & 3.1 & 0.8 & 17.8 & 3.0 \\
\hline & \multicolumn{3}{|c|}{2010} & \multicolumn{3}{|c|}{2011} & \multicolumn{3}{|c|}{2012} \\
\hline Water Temperature $\left({ }^{\circ} \mathrm{C}\right)$ & 8.0 & 29.0 & 18.1 & 10.0 & 28.0 & 18.4 & 6.0 & 26.0 & 17.6 \\
\hline Turbidity (UNT) & 1.7 & 193.2 & 14.8 & 1.4 & 186.2 & 16.4 & 1.4 & 125.5 & 21.6 \\
\hline Color (mg Pt L $\left.\mathrm{L}^{-1}\right)$ & 15.0 & 400.0 & 56.0 & 10.0 & 350.0 & 53.0 & 8.0 & 1808.0 & 132.0 \\
\hline $\mathrm{pH}$ & 6.4 & 7.5 & 7.1 & 6.6 & 7.7 & 7.3 & 6.2 & 7.6 & 7.2 \\
\hline Hardness $\left(\mathrm{CaCO}_{3} \mathrm{mg} \mathrm{L}^{-1}\right)$ & 5.0 & 27.0 & 17.0 & 5.7 & 20.0 & 9.1 & 8.0 & 20.0 & 15.1 \\
\hline Alkalinity $\left(\mathrm{CaCO}_{3} \mathrm{mg} \mathrm{L}^{-1}\right)$ & 12.0 & 37.0 & 23.5 & 12.7 & 35.0 & 22.8 & 10.0 & 28.4 & 21.3 \\
\hline $\mathrm{CO}_{2}$ free $\left(\mathrm{mg} \mathrm{L}^{-1}\right)$ & 2.4 & 22.0 & 5.8 & 2.8 & 12.0 & 4.4 & 2.8 & 14.0 & 4.8 \\
\hline Dissolved oxygen $\left(\mathrm{mg} \mathrm{L}^{-1}\right)$ & 6.3 & 12.1 & 9.2 & 4.0 & 10.7 & 8.5 & 6.2 & 12.0 & 8.5 \\
\hline Organic matter $\left(\mathrm{mg} \mathrm{L}^{-1}\right)$ & 0.9 & 17.3 & 3.7 & 0.0 & 9.2 & 1.7 & 0.4 & 18.5 & 3.6 \\
\hline
\end{tabular}


Values for $\mathrm{pH}$ ranged between 6.0 and 8.0 in both the Pelotas and Quilombo Streams, considered appropriate according to the Brazilian legislation (Table 2). These results could reflect either the buffering capacity by the ecosystem (Siqueira et al., 2012) or could be potentially related to the fact that soil use and occupation around the analyzed points were essentially agricultural, which in general does not tend to affect $\mathrm{pH}$ values. Similar results were observed by Piratoba et al. (2017). According to Derisio (2016), changes in the pH values of water are caused by industrial wastes.

Mean water hardness values for Pelotas Stream ranged from 15.1 to $20.5 \mathrm{mg} \mathrm{CaCO}_{3} \mathrm{~L}^{-1}$, whereas in the Quilombo Stream values ranged from 9.1 to $20.4 \mathrm{mg} \mathrm{CaCO}_{3} \mathrm{~L}^{-1}$ between 2007 and 2012 (Table 2). Similar results were observed by Estrela et al. (2010), when evaluating irrigation water quality in family farms located near the present study, probably due to the presence of the same soil class (Ultisols) in the area around the stream. In both streams, the hardness values were below $50 \mathrm{mg} \mathrm{CaCO}_{3} \mathrm{~L}^{-1}$ (Table 2) which classifies the water as soft and low-risk to cause damage to the irrigation system.

Water alkalinity varied between 21.1 and $25.6 \mathrm{mg} \mathrm{L}^{-1}$ in the Pelotas Stream, and 21.3 and $24.7 \mathrm{~m} \mathrm{~L}^{-1}$ in the Quilombo Stream (Table 2). Water hardness and alkalinity can be altered by seasonality and location of sampling points (Piratoba et al, 2017). According to Von Sperling (2007), the main constituents of alkalinity are bicarbonates $\left(\mathrm{HCO}_{3}^{-}\right)$and hydroxides $\left(\mathrm{OH}^{-}\right)$, which vary according to $\mathrm{pH}(\mathrm{pH}>9.4$ : hydroxides and carbonates; $\mathrm{pH}$ between 8.3 and 9.4: carbonates and bicarbonates; $\mathrm{pH}$ between 4.4 and 8.3: only bicarbonates). The water $\mathrm{pH}$ in the present study remained around 7.0 (Table 2), corresponding to a greater presence of bicarbonates in the Pelotas and Quilombo Streams.

The mean values for $\mathrm{CO}_{2}$ ranged from 5.1 to $8.3 \mathrm{mg} \mathrm{L}^{-1}$ in the Pelotas Stream, whereas in the Quilombo Stream values ranged from 4.4 to $5.8 \mathrm{mg} \mathrm{L}^{-1}$ between 2007 and 2012. In general, the Pelotas Stream showed higher free $\mathrm{CO}_{2}$ values in water, possibly due to higher organic matter values in comparison with the Quilombo Stream (Table 2).

The waters classified as Class 2 must have dissolved oxygen concentrations greater than 5 $\mathrm{mg} \mathrm{L}^{-1}$ (Table 1); it is observed that in all evaluated years the average values of dissolved oxygen exceeded the minimum stipulated value (Table 2). The highest values of dissolved oxygen were observed in the Quilombo Stream between 2007 and 2012, possibly due to lower values of organic matter (Table 2). According to Siqueira and Aprile (2013), higher organic matter content in water can lead to oxidation-reduction reactions, as oxygen is used as the final acceptor of electrons during the processes associated with organic material degradation.

Between 2007 and 2012, the mean organic matter values ranged from 4.6 to $5.1 \mathrm{mg} \mathrm{L}^{-1}$ in the Pelotas Stream, whereas in the Quilombo Stream values ranged from 1.7 to $3.7 \mathrm{mg} \mathrm{L}^{-1}$. It should be emphasized that, in all the evaluated years, the Pelotas Stream presented higher organic matter content in comparison to the Quilombo Stream (Table 2). Bezerra Lopes et al. (2008) mention the increase of primary production promoting the generation of a large amount of particulate organic material, resulting in water turbidity with a tendency towards higher values, as observed in the present study. In terms of annual average values, higher organic matter content was found in the Pelotas Stream, leading to higher turbidity and water color values as a consequence (Table 2).

Only in the Quilombo Stream in $0.3 \%$ of the days of 2008, the oxygen dissolved values did not meet the values stipulated by legislation (Table 3 ). This may be related to temperature, since in general the higher the minimum water temperature, the lower the dissolved oxygen.

Turbidity values for both the Pelotas and Quilombo Streams were found to be higher than 100 UNT during the period from 2007 to 2011, in less than 3\% of the days of each year. On the other hand, in 2012 turbidity values exceeded the limits of the Brazilian legislation in 4.6 and $5.5 \%$ of the days of each year, for the Pelotas and Quilombo Streams, respectively (Table 3). The increased turbidity values may be related to the activity related to sand mining, which 
generally promotes silting of the Pelotas slopes due to the sediment extraction, as well as due to the use of granite stones and Quarry fines, commonly used as a base for the roads illegally constructed on the stream banks.

Higher color values in the Pelotas Stream were observed in around $30 \%$ of the days in 2007 and 2008, above the limit established by the legislation, whereas from 2009 to 2012 the color values exceeded $75 \mathrm{mg} \mathrm{Pt} \mathrm{L}^{-1}$ in over $50 \%$ of the days of each year (Table 3).

Considering all the water quality parameters evaluated, principal components analysis revealed that these factors had an accumulated eigenvalue of $58.95 \%$ for the Pelotas Stream and $54.07 \%$ for the Quilombo Stream. The first main component resulted from a linear combination of the 9 variables studied, and explained $37.18 \%$ and $34.03 \%$ of the total variance, whereas the second component explained $21.76 \%$ and $20.05 \%$ for the Pelotas and Quilombo Streams, respectively.

Table 3. Percentage of days in which the dissolved oxygen, turbidity, color and $\mathrm{pH}$ values exceeded the values suitable for freshwaters (Class 2) according to Brazilian legislation (CONAMA Resolution $N^{\circ} 357$, March 17, 2005).

\begin{tabular}{|c|c|c|c|c|c|c|}
\hline \multirow{2}{*}{ Parameters } & \multicolumn{6}{|c|}{ Days (\%) } \\
\hline & 2007 & 2008 & 2009 & 2010 & 2011 & 2012 \\
\hline & \multicolumn{6}{|c|}{ PELOTAS STREAM } \\
\hline Dissolved oxygen $\left(\mathrm{mg} \mathrm{L}^{-1}\right)$ & 0.0 & 0.0 & 0.0 & 0.0 & 0.0 & 0.0 \\
\hline Turbidity (UNT) & 1.1 & 0.5 & 0.8 & 1.1 & 2.7 & 4.6 \\
\hline Color $\left(\mathrm{mgPt} \mathrm{L}^{-1}\right)$ & 30.1 & 30.6 & 76.2 & 67.4 & 60.0 & 54.9 \\
\hline \multirow[t]{2}{*}{$\mathrm{pH}$} & 0.0 & 0.0 & 0.0 & 1.1 & 0.0 & 0.0 \\
\hline & \multicolumn{6}{|c|}{ QUILOMBO STREAM } \\
\hline Dissolved oxygen $\left(\mathrm{mg} \mathrm{L}^{-1}\right)$ & 0.0 & 0.3 & 0.0 & 0.0 & 0.0 & 0.0 \\
\hline Turbidity (UNT) & 1.1 & 2.2 & 2.2 & 0.5 & 1.4 & 5.5 \\
\hline Color $\left(\mathrm{mgPt} \mathrm{L}^{-1}\right)$ & 17.8 & 19.4 & 44.1 & 24.7 & 22.2 & 17.8 \\
\hline $\mathrm{pH}$ & 0.0 & 0.0 & 0.0 & 0.0 & 0.0 & 0.0 \\
\hline
\end{tabular}

The first component positively correlated the variables color, organic matter, turbidity, and $\mathrm{CO}_{2}$, particularly the turbidity parameter, which presented the highest values of correlation with the first component in the Pelotas (Figure 2a) and Quilombo (Figure 2b) Streams. Therefore the physical parameters related to the transport of sediments and their effect on the concentration of $\mathrm{CO}_{2}$ in the waters. The soil carried to the river directly impacts water color and turbidity, and the soil organic matter increases the $\mathrm{CO}_{2}$ concentrations, since, in the organic matter oxidation process by aerobic microorganisms, there is the release of carbon dioxide. For both the Pelotas (Figure 2a) and the Quilombo (Figure 2b) Streams, the first component negatively correlated the parameters that are more related to the intrinsic characteristics of the basin, such as climate (water temperature), geomorphology (alkalinity and hardness), soil types, and uses ( $\mathrm{pH}$ and dissolved oxygen).

The second component was positively correlated with parameters such as water temperature, hardness, alkalinity, $\mathrm{pH}$, organic matter, color, turbidity, and negatively correlated with dissolved oxygen (Figure 2a, b). Water temperature and dissolved oxygen showed the highest correlations, and the relationship between them was inversely proportional. Silva et al. (2009) also observed lower water temperatures as directly linked to higher concentrations of dissolved oxygen. According to Post et al. (2018), water temperature is the primary regulating metric that determines how much dissolved oxygen water can hold; dissolved oxygen is inversely dependent on water temperature. Increases in water temperature would thus further reduce dissolved oxygen and negatively impact water quality. 


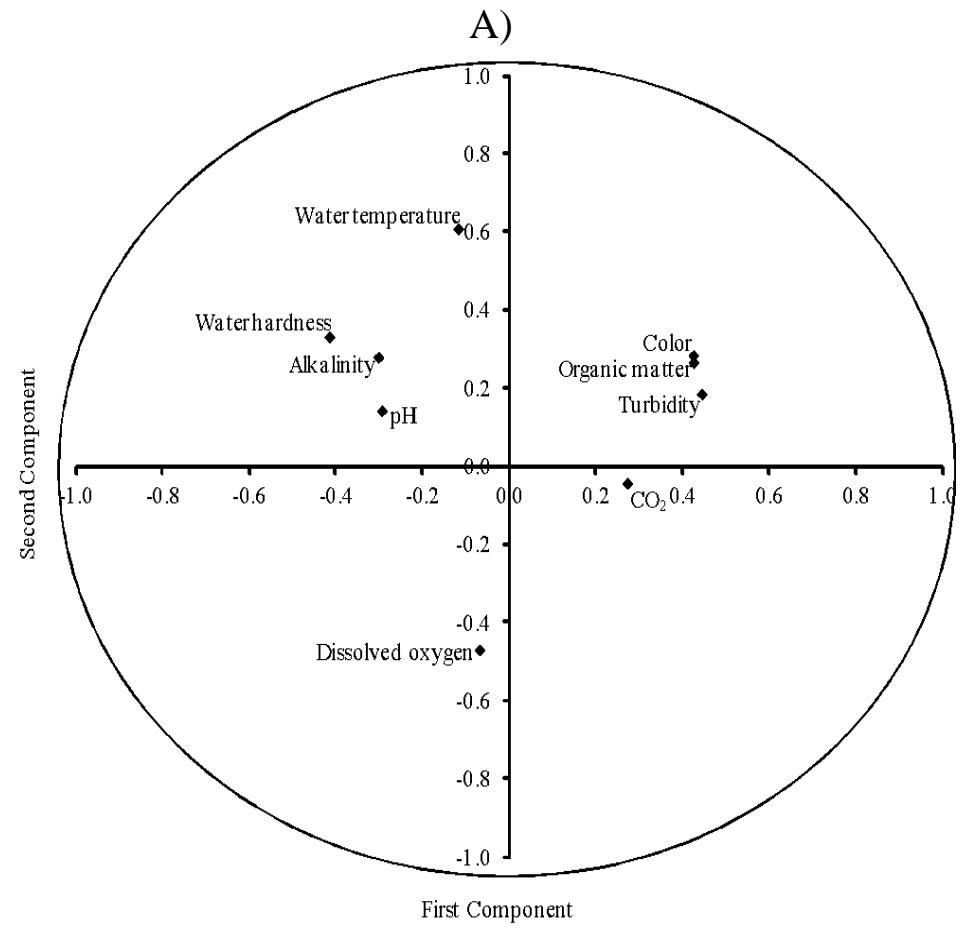

B)

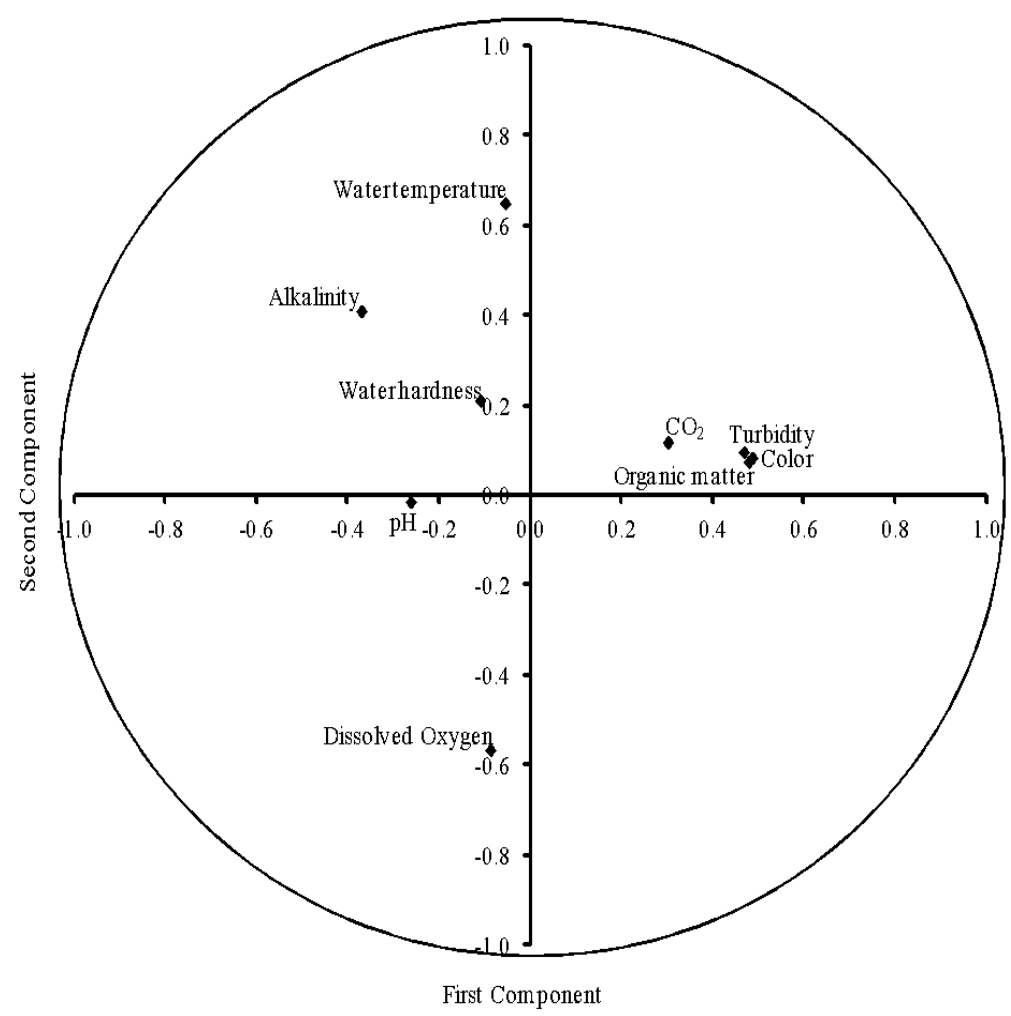

Figure 2. Multivariate analysis between water quality parameters of Pelotas (a) and Quilombo (b) Streams.

Pearson correlation values between the monthly means of the water quality parameters of the Pelotas and Quilombo Streams and the monthly averages of rainfall are found in Table 4. A significant positive correlation between turbidity, color, and organic matter with rainfall was observed in both of the studied streams. Fraga et al. (2012) and Silva et al. (2009) also observed a positive relation between turbidity values and rainfall accumulated in water sources in 
different regions of Brazil, indicating the impacts resulting from land use. Similar results were observed by Luíz et al. (2012), which found high color values (greater than $75 \mathrm{mg} \mathrm{Pt} \mathrm{L}^{-1}$ ) on days when rainfall was equal to or greater than $25 \mathrm{~mm}$. This can happen because rainfall causes erosion and the runoff of water into the rivers. That increases turbidity, color, and organic matter content in the waters.

Table 4. Pearson correlation between the monthly means of the water quality parameters of the Pelotas and Quilombo Streams and the monthly averages of rainfall.

\begin{tabular}{|c|c|c|c|c|c|c|c|c|c|}
\hline & $\begin{array}{c}\text { Water } \\
\text { Temperature }\end{array}$ & Turbidity & Color & $\mathrm{pH}$ & $\begin{array}{c}\text { Water } \\
\text { Hardness }\end{array}$ & Alkalinity & $\begin{array}{l}\text { Free } \\
\mathrm{CO}_{2}\end{array}$ & $\begin{array}{l}\text { Oxygen } \\
\text { dissolved }\end{array}$ & $\begin{array}{c}\text { Organic } \\
\text { matter }\end{array}$ \\
\hline & \multicolumn{9}{|c|}{ PELOTAS STREAM } \\
\hline \multirow[t]{2}{*}{ Rainfall } & $0.37^{\mathrm{NS}}$ & $0.52 *$ & $0.74 *$ & $-0.31^{\mathrm{NS}}$ & $-0.01^{\mathrm{NS}}$ & $0.31^{\mathrm{NS}}$ & $0.23^{\mathrm{NS}}$ & $-0.43^{\mathrm{NS}}$ & $0.54^{*}$ \\
\hline & \multicolumn{9}{|c|}{ QUILOMBO STREAM } \\
\hline Rainfall & $0.20^{\mathrm{NS}}$ & $0.62 *$ & $0.92 * * *$ & $-0.52^{\mathrm{NS}}$ & $-0.49^{\mathrm{NS}}$ & $0.30^{\mathrm{NS}}$ & $0.43^{\mathrm{NS}}$ & $-0.20^{\mathrm{NS}}$ & $0.75^{* *}$ \\
\hline
\end{tabular}

NS: no significant; $* \mathrm{p}<0.05 ; * * \mathrm{p}<0.01 ; * * * \mathrm{p}<0.1 \%$.

Fonseca and Salvador (2005) observed a decrease in the values of dissolved oxygen during periods of rainfall, related to an increase of organic matter transported on the soil surface by rain. The positive correlation between organic matter and rainfall was observed in both streams analyzed in the present study (Table 4).

The high values of water turbidity and color, sometimes higher than the limit in Brazilian legislation, in both Pelotas and Quilombo Streams, as well as the positive and significant correlation of these parameters with rainfall, can be associated with agricultural activities carried out in the basin area. During soil preparation for the implantation of summer crops in conventional planting areas, the soil is uncovered and disaggregated due to plowing and harrowing operations; its particles are therefore easily carried by rainwater. The summer crops implanted in the region (corn, soy, and tobacco) are not grown, most of the time, in conservationist soil management systems; consequently, little vegetative cover exists, leaving a large area of uncovered soil. This facilitates the transport of soil particles, fertilizers and pesticides by rainwater.

\section{CONCLUSIONS}

Values of $\mathrm{pH}$ and dissolved oxygen of water conformed with Brazilian legislation for the 6 years evaluated.

Concerning the values put forth by the Brazilian legislation, watercolor was the parameter that remained above the proposed limit for the greatest number of days, occurring mainly in the Pelotas Stream. Such findings indicate the need for soil conservation actions in the area of the contribution basin.

The highest values of color, turbidity, and organic matter occurred when the highest rainfall values were observed, showing a probable sediment transport effect in the basin. Agricultural activities may potentiate sedimentation in the contribution basin of the Sinnott water treatment plant.

\section{REFERENCES}

ALVARENGA, L. A.; MARTINS, M. P. P.; CUARTAS, L. A.; PENTEADO, V. A.; ANDRADE, A. Estudo da qualidade e quantidade da água em microbacia, afluente do rio Paraíba do Sul - São Paulo, após ações de prevenção ambiental. Revista Ambiente \& Água, n. 3, p. 228-240, 2012. https://doi.org/10.4136/ambi-agua.987 
ALVARES, C. A.; STAPE, J. L.; SENTELHAS, P. C.; GONÇALVES, J. L. M.; SPAROVEK, G. Köppen's climate classification map for Brazil. Meteorologische Zeitschrift, n. 6, p. 711-728, 2013. https://doi.org/10.1127/0941-2948/2013/0507

ALVAREZ, J. W. R.; PELLEGRINI, A.; KOCHEM, M. L.; SCHAEFER, G. L.; CAPOANE, V.; TIECHER, T.; FORNARI, M. R.; DOS SANTOS, D. R. Erosão hídrica e perda de sedimento, água e nutrientes durante eventos pluviais em duas bacias hidrográficas rurais. Investigación Agraria, n. 2, p. 113-123, 2014.

APHA; AWWA; WEF. Standard Methods for the Examination of Water and Wastewater. 20. ed. Washington, 1998.

BEZERRA LOPES, F.; SANTOS TEIXEIRA, A. D.; ANDRADE, E. M. D.; NASCIMENTO AQUINO, D. D.; PEREIRA ARAÚJO, L. D. F. Mapa da qualidade das águas do rio Acaraú, pelo emprego do IQA e Geoprocessamento. Revista Ciência Agronômica, n. 3, p. 392-402, 2008.

CONAMA (Brasil). Resolução n 357 de 17 de março de 2005. Dispõe sobre a classificação dos corpos de água e diretrizes ambientais para o seu enquadramento, bem como estabelece as condições e padrões de lançamento de efluentes, e dá outras providências. Diário Oficial [da] União: seção 1, Brasília, DF, n. 053, p. 58-63, 18 mar. 2005.

DERISIO, J. C. Introdução ao controle de poluição ambiental. 4. ed. São Paulo: Oficina de Textos, 2016.

ESTRELA, C. C.; TAVARES, V. E. Q.; TIMM, L. C.; REISSER JUNIOR, C.; MATTOS, M. L. T.; PEREIRA, G. C.; VENZKE, C. D. Caracterização das Fontes de Captação de Água Utilizadas para a Irrigação na Cadeia Produtiva de Morangos, no Município de Turuçu, RS. Current Agricultural Science and Technology, n. 1-4, p. 143-147, 2010.

FLORES, C. A.; FILIPPINI ALBA, J. M.; WREGE, M. S. Zoneamento agroclimático do eucalipto para o Estado do Rio Grande do Sul e edafoclimático na região do Corede Sul- RS. Pelotas: Embrapa Clima Temperado, 2009. 87p.

FONSECA, H. S.; SALVADOR, N. N. B. Estudo integrado da qualidade das águas da bacia hidrográfica do Rio Bonito em Descalvado-SP. Revista do Instituto Adolfo Lutz, n. 2, p. 179-185, 2005.

FRAGA, R. S.; TAVARES, V. E. Q.; TIMM, L. C.; ESTRELA, C. C.; BARTELS, G. K. Influência da precipitação sobre parâmetros de qualidade da água utilizada para irrigação do morangueiro no município de Turuçu-RS. Current Agricultural Science and Technology, n. 1, p. 81-94, 2012. http://dx.doi.org/10.18539/cast.v18i1.2491

IBGE. Pelotas. 2010. Available at: https://cidades.ibge.gov.br/brasil/rs/pelotas/panorama Access: June 2020.

LUÍZ, A. M.; PINTO, M. L. C.; SCHEFFER, E. W. O. Parâmetros de cor e turbidez como indicadores de impactos resultantes do uso do solo, na bacia hidrográfica do rio Taquaral, São Mateus do Sul-PR. Raega, n. 1, p. 290-310, 2012. http://dx.doi.org/10.5380/raega.v24i0.26264

OLIVEIRA, C. N. D.; CAMPOS, V. P.; MEDEIROS, Y. D. P. Avaliação e identificação de parâmetros importantes para a qualidade de corpos d'água no semiárido baiano. Estudo de caso: bacia hidrográfica do Rio Salitre. Química Nova, n. 5, p. 1059-1066, 2010. https://doi.org/10.1590/S0100-40422010000500010 
PIRATOBA, A. R. A.; RIBEIRO, H. M. C.; MORALES, G. P.; GONÇALVES, W. G. Caracterização de parâmetros de qualidade da água na área portuária de Barcarena, PA, Brasil. Revista Ambiente \& Água, n. 3, p. 435-456, 2017. https://doi.org/10.4136/ambiagua. 1910

POST, C. J.; COPE, M. P.; GERARD, P. D.; MASTO, N. M.; VINE, J. R.; STIGLITZ, R. Y.; HALLSTROM, J. O.; NEWMAN, J. C.; MIKHAILOVA, E. A. Monitoring spatial and temporal variation of dissolved oxygen and water temperature in the Savannah River using a sensor network. Environmental Monitoring and assessment, n. 190, p. 272, 2018. https://doi.org/10.1007/s10661-018-6646-y

SILVA, A. P. S.; DIAS, H. C. T.; BASTOS, R. K. X.; SILVA, E. Qualidade da água do Reservatório da Usina Hidrelétrica (UHE) de Peti, Minas Gerais. Revista Árvore, n. 6, p. 1063-1069, 2009. https://doi.org/10.1590/S0100-67622009000600009

SIQUEIRA, G. W.; APRILE, F.; MIGUÉIS, A. M. Diagnóstico da qualidade da água do rio Parauapebas (Pará-Brasil). Acta Amazonica, n. 3, p. 413-422, 2012. https://doi.org/10.1590/S0044-59672012000300014

SIQUEIRA, G. W.; APRILE, F. Avaliação de risco ambiental por contaminação metálica e material orgânico em sedimento do rio Aurá, Região Metropolitana de Belém-PA. Acta Amazonica, n. 1, p. 51-62, 2013. https://doi.org/10.1590/S0044-59672013000100007

SUTADIAN, A. D.; MUTTIL, N.; YILMAZ, A. G.; PERERA, B. J. C. Development of river water quality indices - a review. Environmental Monitoring and Assessment, n. 1, p. 58, 2016. https://doi.org/10.1007/s10661-015-5050-0

SWAMEE, P.; TYAGI, A. Improved method for aggregation of water quality subindices.

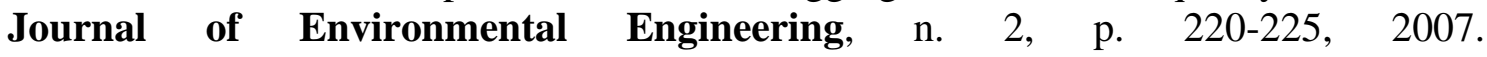
https://doi.org/10.1061/(ASCE)0733-9372(2007)133:2(220)

TANIWAKI, R. H.; CASSIANO, C. C.; FILOSO, S.; DE BARROS FERRAZ, S. F.; DE CAMARGO, P. B.; MARTINELLI, L. A. Impacts of converting low-intensity pastureland to high-intensity bioenergy cropland on the water quality of tropical streams in Brazil. Science Total Environmental, p. 339-347, 2017. https://doi.org/10.1016/j.scitotenv.2016.12.150

TORRES, I. A.; SILVA, T. M. F.; RODRIGUES, L. S.; SILVA, I. J.; COSTA, T. A.; SOTOBLANCO, B.; MELO, M. M. Physicochemical analysis of water, sediment and riparian vegetation of a fish farming located in an agroindustrial area at the border of Ribeirão da Mata. Engenharia Sanitária Ambiental, n. 4, p. 773-780, 2017. https://doi.org/10.1590/s1413-41522017110861

VON SPERLING, M. Wastewater characteristics, treatment and disposal. London: IWA publishing, 2007. 306p.

WANG, J.; LIU, G.; LIU, H.; LAM, P. K. Multivariate statistical evaluation of dissolved trace elements and a water quality assessment in the middle reaches of Huaihe River, Anhui, $\begin{array}{lllll}\text { China. Science Total Environmental, p. 421-431, } 2017 . & \end{array}$ https://doi.org/10.1016/j.scitotenv.2017.01.088

XIAO, J.; WANG, L.; DENG, L.; JIN, Z. Characteristics, sources, water quality and health risk assessment of trace elements in river water and well water in the Chinese Loess Plateau. $\begin{array}{lllll}\text { Science } & \text { Total } & \text { Environmental, } & \text { p. } & \text { 2004-2012, }\end{array}$ https://doi.org/10.1016/j.scitotenv.2018.09.322 


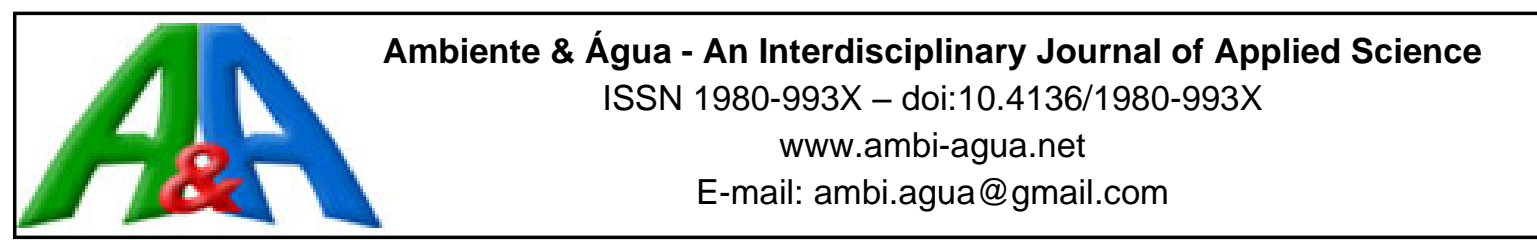

\title{
Metal phytosorption potential of Hydrocotyle ranunculoides for mitigation of water pollution in high Andean wetlands of Peru
}

\author{
ARTICLES doi:10.4136/ambi-agua.2535
}

Received: 24 Feb. 2020; Accepted: 28 Jul. 2020

\author{
Walter Javier Cuadrado Campó1(i); María Custodio ${ }^{2 *(D)}$; \\ Carmela Emperatriz Vicuña Orihuela ${ }^{1}$; Richard Pavel Peñaloza Fernández ${ }^{2}$ it \\ ${ }^{1}$ Universidad Nacional del Centro del Perú. Facultad de Ciencias Aplicadas, Carretera Central \\ Km 4.5, Tarma, Perú. E-mail: wjcuadrado@ hotmail.com, carmelavic@ hotmail.com \\ ${ }^{2}$ Universidad Nacional del Centro del Perú. Facultad de Medicina Humana. Centro de Investigación en Medicina \\ de Altura y Medio Ambiente, Avenida Mariscal Castilla nº 3089, Huancayo, Perú. \\ E-mail: drach_89@hotmail.com \\ "Corresponding author. E-mail: mcustodio@uncp.edu.pe
}

\begin{abstract}
The phytosorption potential of metals of Hydrocotyle ranunculoides was evaluated for the mitigation of water pollution in the high Andean wetlands of Peru. The plants were selected from 10 wetland sites in the community of Pomachaca- Tarma and were washed with potable water, dried, ground, weighed, chemically digested and read with Varian AA 240 atomic absorption equipment. The plant showed copper concentrations in the root $(12.08 \pm 1.67 \mathrm{mg} / \mathrm{kg})$ greater than the stem $(7.37 \pm 1.00 \mathrm{mg} / \mathrm{kg})$, followed by the leaves $(7.37 \pm 1.56 \mathrm{mg} / \mathrm{kg})$. Lead concentration in the root was $0.228 \pm 0.711 \mathrm{mg} / \mathrm{kg}$, but was not found in the stem or leaves. The highest zinc concentration was in the root $(67.52 \pm 12.57 \mathrm{mg} / \mathrm{kg})$ to the stem $(53.30 \pm 0.61$ $\mathrm{mg} / \mathrm{kg})$, followed by the leaves $(43.99 \pm 8.49 \mathrm{mg} / \mathrm{kg})$. Finally, iron was higher in the root $(5571.28 \pm 693.94 \mathrm{mg} / \mathrm{kg})$ than in the leaves $(342.76 \pm 122.09 \mathrm{mg} / \mathrm{kg})$, followed by the stem (291.94 $\pm 54.84 \mathrm{mg} / \mathrm{kg}$ ). Surrounding water had $\mathrm{pH}$ between 7.2 and 7.6; no copper and lead were found, zinc was $0.005 \pm 0.012 \mathrm{mg} / \mathrm{L}$ and iron was $0.009 \pm 0.007 \mathrm{mg} / \mathrm{L}$. In the sediment, copper was $26.12 \pm 0.65 \mathrm{mg} / \mathrm{kg}$, lead $28.25 \pm 2.41 \mathrm{mg} / \mathrm{kg}$, zinc $85.98 \pm 11.38 \mathrm{mg} / \mathrm{kg}$ and iron $26111.89 \pm 614.37 \mathrm{mg} / \mathrm{kg}$. These results indicate that this plant absorbs metals in the order of $\mathrm{Fe}>\mathrm{Zn}>\mathrm{Cu}>\mathrm{Pb}$ and is an alternative for the development of phytotechnology, oriented to the treatment of effluents with metals that contaminate water in wetlands.
\end{abstract}

Keywords: aquatic environment, heavy metal, Hydrocotyle ranunculoides, phytoabsorbing potential, pollution.

\section{Potencial de fitoabsorção de metais por Hydrocotyle ranunculoides para a mitigação de poluição de água nas áreas úmidas altas andinas do Peru}

\section{RESUMO}

O potencial de fitoabsorção de metais provenientes de Hydrocotyle ranunculoides foi avaliado para mitigar a contaminação da água nas áreas úmidas altas andinas do Peru. As plantas foram selecionadas de 10 zonas úmidas da comunidade de Pomachaca-Tarma e lavadas com água potável, secas, moídas, pesadas, quimicamente digeridas e lidas com o equipamento 
de absorção atómica Varian AA 240. A planta apresentava concentrações de cobre na raiz de $12.08 \pm 1.67 \mathrm{mg} / \mathrm{kg}$ seco, no caule de $7.37 \pm 1.00 \mathrm{mg} / \mathrm{kg}$ seco e nas folhas de $7.37 \pm 1.56 \mathrm{mg} / \mathrm{kg}$ seco. Quanto às concentrações de chumbo na raiz foi de $0.228 \pm 0.711 \mathrm{mg} / \mathrm{kg}$ seco, no caule e nas folhas não foi encontrado. O zinco mais elevado estava na raiz $67.52 \pm 12.57 \mathrm{mg} / \mathrm{kg}$ seco, no caule $53.30 \pm 0.61 \mathrm{mg} / \mathrm{kg}$ seco e seguido pelas folhas $43.99 \pm 8.49 \mathrm{mg} / \mathrm{kg}$ seco. Finalmente, o ferro era mais elevado na raiz com $5571.28 \pm 693.94 \mathrm{mg} / \mathrm{kg}$ seco, depois nas folhas 342.76 $\pm 122.09 \mathrm{mg} / \mathrm{kg}$ seco e seguido do caule $291.94 \pm 54.84 \mathrm{mg} / \mathrm{kg}$ seco. A água circundante tinha $\mathrm{pH}$ entre 7.2 e 7.6. Não foram encontrados cobre e chumbo, o zinco foi $0.005 \pm 0.012 \mathrm{mg} / \mathrm{L} \mathrm{e}$ o ferro $0.009 \pm 0.007 \mathrm{mg} / \mathrm{L}$. No sedimento, o cobre foi $26.12 \pm 0.65 \mathrm{mg} / \mathrm{kg}$ seco, o chumbo $28.25 \pm 2.41 \mathrm{mg} / \mathrm{kg}$ seco, o zinco $85.98 \pm 11.38 \mathrm{mg} / \mathrm{kg}$ seco e o ferro $26111.89 \pm 614.37 \mathrm{mg} / \mathrm{kg}$ seco. Estes resultados indicam que esta planta absorve metais na ordem de $\mathrm{Fe}>\mathrm{Zn}>\mathrm{Cu}>\mathrm{Pb}$ e é uma alternativa para o desenvolvimento da fitotécnica, orientada para o tratamento de efluentes com metais que contaminam a água em zonas úmidas.

Palavras-chave: ambiente aquático, Hydrocotyle ranunculoides, metais pesados, poluição, potencial de fitoabsorção.

\section{INTRODUCTION}

The pollution of the aquatic environment by potentially toxic contaminants has been of concern to humans for the last few decades (Mimba et al., 2018). Anthropogenic sources have been identified as significant contributors to environmental pollution problems (Väänänen $e t$ $a l ., 2018)$. As a result, ecosystems are damaged or altered by products containing heavy metals, such as copper $(\mathrm{Cu})$, calcium $(\mathrm{Ca})$, zinc $(\mathrm{Zn})$, manganese $(\mathrm{Mn})$ and iron $(\mathrm{Fe})$, many of which are essential micronutrients for plant metabolism, but when present in excess can become extremely toxic (Chatterjee et al., 2011). The importance of the environmental problem in modern society is the pollution of water by heavy metals that enter aquatic ecosystems through the discharge of wastewater from industrial, urban and agricultural runoff (Nazeer et al., 2014). Compared to organic contaminants, natural decomposition processes do not remove heavy metals.

In contrast, they can accumulate in aquatic biota and develop into organic complexes, which can potentially become more toxic (Mazej and Germen, 2009). The accumulation of metals by macrophytes is affected by the concentrations of metals in water and sediments and by the speciation of metals such as free ions and humic complexes (Kramer, 2010). Aquatic macrophytes are predominant organisms in lake ecosystems that, in comparison with other plant species, can absorb metals through their roots as well as through their leaves (Twardowska and Kyziol, 2003; Lojko et al.,2015). Hydrocotyle ranunculoides, as well as the cattail (Scirpus californicus) in the study area, serves as animal feed.

Tarma, a province of the Junin region, has a population whose main activity is agriculture and livestock. In the community of Pomachaca, cattle farmers feed their cattle with $H$. ranunculoides, which are contaminated with heavy metals. They use the manure of these animals in agriculture and their meat for food, causing possible damage to the health of the inhabitants. The objective of this study was to determine the phytosorption potential of metals from $H$. ranunculoides, to be used as an alternative to mitigate water pollution in high Andean wetlands in Peru.

\section{METHODS AND RESOURCES}

\subsection{Study area}

The study area is located in the province of Tarma in the central Andes of Peru, latitude

Rev. Ambient. Água vol. 15 n. 5, e2535 - Taubaté 2020 
$11^{\circ} 22^{\prime} 51.9^{\prime \prime} \mathrm{S}$ and longitude $75^{\circ} 41^{\prime} 12^{\prime \prime} \mathrm{W}$, at an altitude of 3031 masl (Figure 1). In wetlands of the area, Hydrocotyle ranunculoides is the predominant macrophyte and very important for the Pomachaca community, because their life activities depend on livestock and agriculture. Their livestock feed on these aquatic plants which, due to their characteristics, absorb heavy metals, compromising the health of the people who feed on the meat and milk of this livestock.

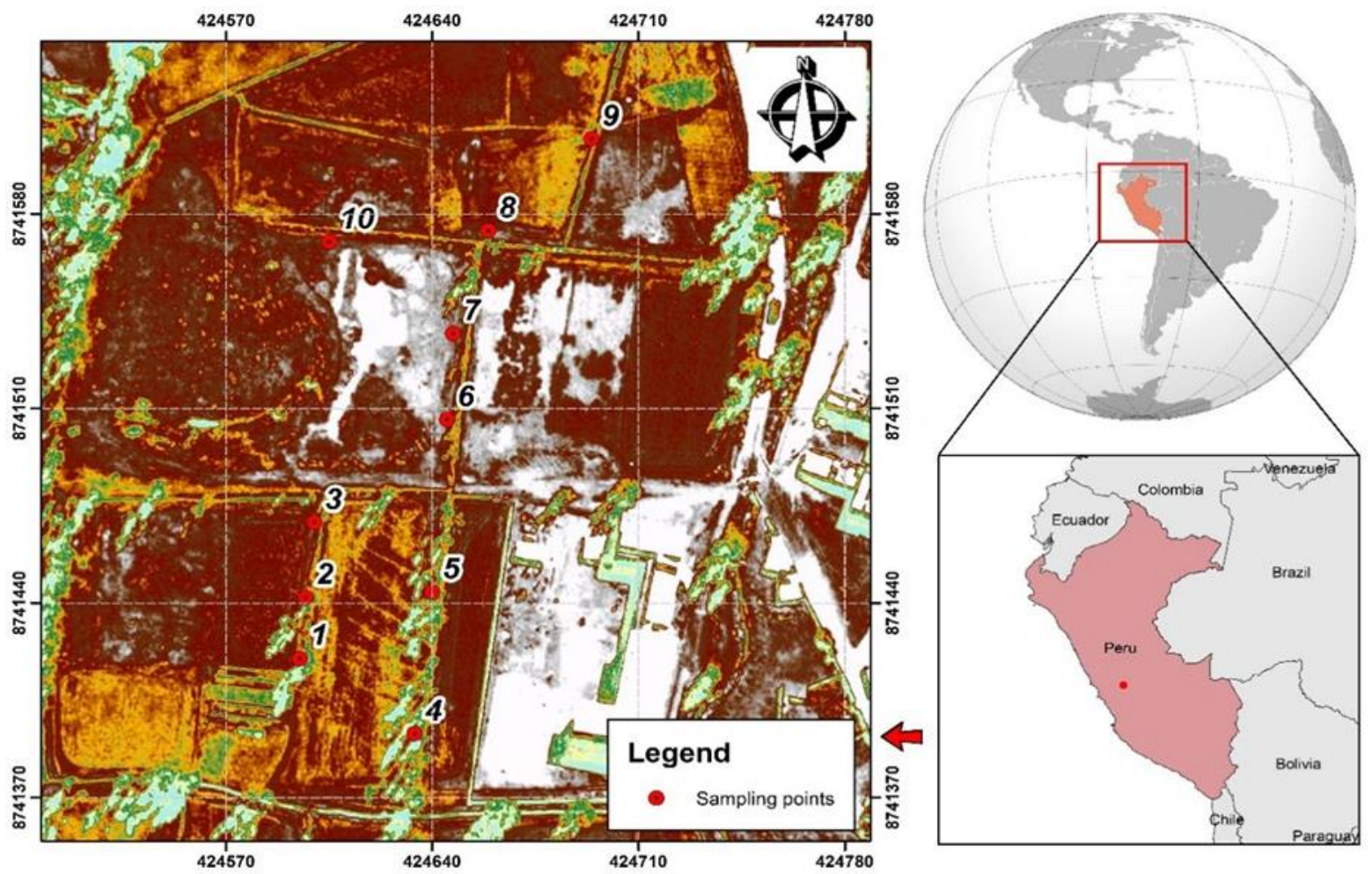

Figure 1. Location map of the study area in high Andean wetlands of Peru.

\subsection{Sampling and analysis of plants, sediment and water}

Ten sampling sites in the wetlands were selected; from each site three single samples were taken to form a composite sample of $3 \mathrm{~kg}$ of plants, passing a visual inspection, such as size, good physical condition and maturity (Figure 2). The water was collected from each sampling site in a one-litre volumetric glass bottle. Similarly, $2 \mathrm{~kg}$ of sediment sample was obtained in polyethylene bags. All samples, with their respective identification, were taken directly to the Chemistry and Environment Laboratory of the Universidad Nacional del Centro del Perú for their respective analyses.

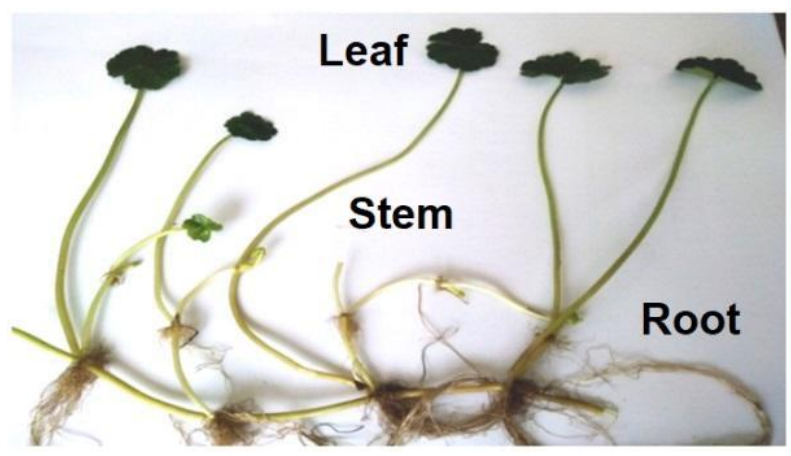

Figure 2. Macrophyte Hydrocotyle ranunculoides.

The determination of the concentration of metals in the plant, sediment and water was performed by chemical digestion with hydrochloric acid, nitric acid and chemically pure 
perchloric acid at $80^{\circ} \mathrm{C}$, according to the standardized method of atomic absorption (APHA $e t$ $a l .$, 2012), as shown in Figure 3.
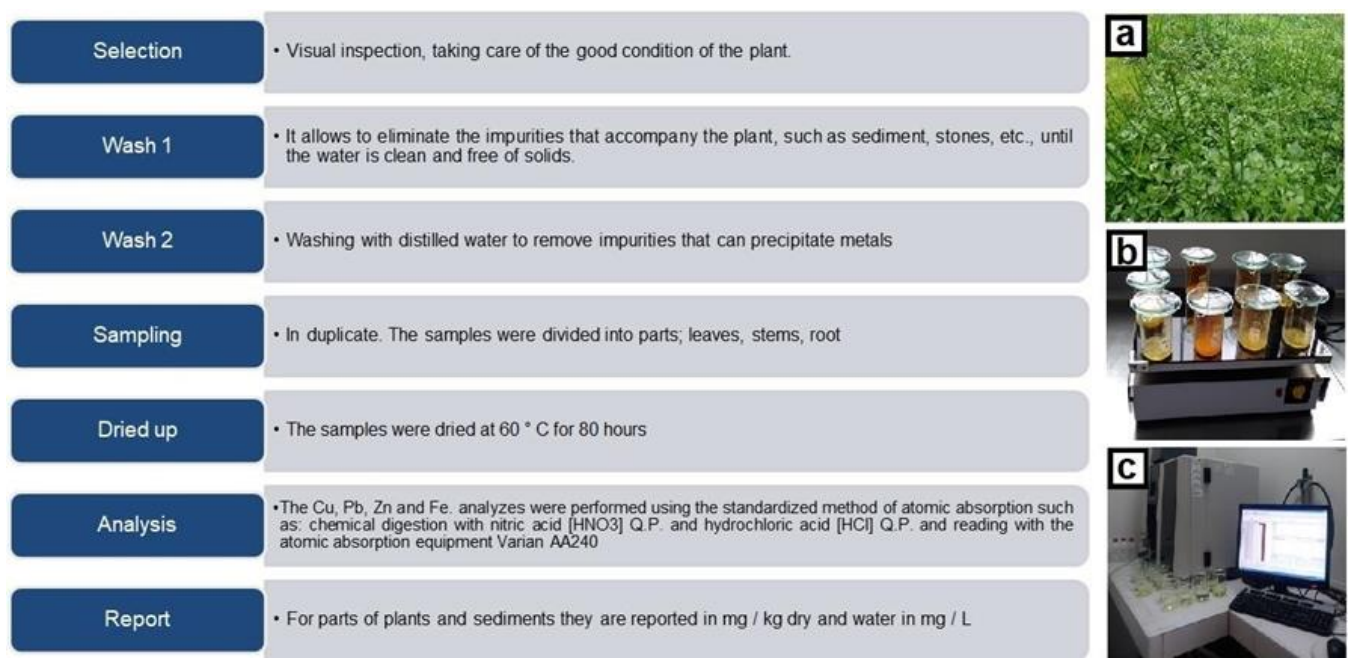

Figure 3. Flowchart of the evaluation of the Hydrocotyle ranunculoides plant: (a) sampling site, (b) sample digestion, (c) atomic absorption analysis.

\subsection{Analysis of data}

For the comparison of the concentration of each metal by the factor evaluated (water, sediment and plant part), the Kruskall Wallis test was used with a post hoc procedure (Kruskal and Wallis, 1952; Katz and Mcsweeney, 1980), with null hypothesis indicating statistical similarity in the concentrations of elements. To test the relationship between element concentrations in water and sediment with element concentrations in plant tissues, a redundancy analysis (RDA) was performed using Canoco software. RDA is used in ecology for management by direct gradient analysis, where a matrix of response variables, $\mathrm{Y}$, is analyzed with respect to a corresponding matrix of environmental variables, X (Gan et al., 2017). RDA can be described as a series of multiple regressions followed by a principal component analysis (Legendre and Andersson, 1999). Here, instead of one vector for one variable, y, we are analyzing a data matrix with many variables, Y. Each vector variable, y, is regressed on the matrix of dummy variables corresponding to the environmental variables, $\mathrm{X}$ (Legendre and Andersson, 1999).

\section{RESULTS AND DISCUSSION}

The plant, like any living being, has the capacity to absorb or adsorb substances such as heavy metals. However, many of them are beneficial for its subsistence, while others are harmful to its physiological processes. The heavy metal contents in the samples are listed in Table 1, for each part of the plant evaluated (leaf, stem and root) and each characteristic of the growing environment (water and sediment). It should be noted that, in order of concentration, Fe is significantly higher in all the factors under study $(\mathrm{p}<0.05)$, with the logical sequence of concentration $\mathrm{Fe}>\mathrm{Zn}>\mathrm{Cu}>\mathrm{Pb}$, for all the factors under study. Because $H$. ranunculoides, like other macrophytes, absorb $\mathrm{Cu}, \mathrm{Pb}, \mathrm{Zn}$ and $\mathrm{Fe}$ (Cuadrado et al., 2019). This behavior is due to the greater capacity of plants to absorb micronutrients compared to non-essential or toxic elements, for which plants can generate tolerance strategies (Kabata-Pendias, 2011).

A range of $\mathrm{Zn}$ concentrations between 70 and $400 \mathrm{mg} / \mathrm{Kg}$ could be considered toxic to plants, while the level of toxic $\mathrm{Zn}$ in plant tissue is $23 \mathrm{mg} / \mathrm{Kg}$ tolerance (Kabata-Pendias, 2011; Li et al., 2009). This plant has the capacity to absorb significant amounts of Fe in its leaves and stems and the largest amount was in the root. The tolerance of plants to high concentrations of 
heavy metals is determined by several internal and external factors, such as phenology, vigor, growth, speciation of elements and water chemistry (Yang and Ye, 2009). Pb, is more toxic than other metals and immobile due to its strong bond with organic matter and other plant components (Aksoy et al., 2005; Kastratović et al., 2013). The results obtained are supported by Zevallos et al. (2015), who report that the accumulation of $\mathrm{Pb}^{2+}$ in plants is regulated by physicochemical parameters such as the $\mathrm{pH}$ of the medium, the presence of exudates, the cation exchange capacity of its surface, etc. Vascular plants absorb and accumulate $\mathrm{Pb}^{2+}$ mainly in the roots and only a small part moves to the air part (Marmiroli et al., 2005).

Table 1. Mean heavy metal concentration in plants, sediments and water in the study area $(\mathrm{mg} / \mathrm{L}$ water and $\mathrm{mg} / \mathrm{Kg}$ sediment and plant).

\begin{tabular}{ccccccccccccccccc}
\hline & \multicolumn{3}{c}{ Leaf } & \multicolumn{4}{c}{ Stem } & \multicolumn{4}{c}{ Root } & \multicolumn{3}{c}{ Sediment } & \multicolumn{3}{c}{ Water } \\
\hline & Mean & & SD & Mean & & SD & Mean & & SD & Mean & SD & Mean & SD \\
\hline Copper & $7.37^{\mathrm{c}}$ & \pm & 1.56 & $7.37^{\mathrm{c}}$ & \pm & 1 & $12.08^{\mathrm{b}}$ & \pm & 1.67 & $26.12^{\mathrm{a}}$ & \pm & 0.65 & $0 \mathrm{~d}$ & \pm & 0 \\
Lead & $0^{\mathrm{c}}$ & \pm & 0 & $0^{\mathrm{c}}$ & \pm & 0 & $0.226^{\mathrm{b}}$ & \pm & 0.711 & $28.25^{\mathrm{a}}$ & \pm & 2.412 & $0^{\mathrm{c}}$ & \pm & 0 \\
Zinc & $43.9^{\mathrm{d}}$ & \pm & 8.49 & $53.3^{\mathrm{c}}$ & \pm & 0.61 & $67.52^{\mathrm{b}}$ & \pm & 12.57 & $85.98^{\mathrm{a}}$ & \pm & 11.38 & $0.005^{\mathrm{e}}$ & \pm & 0.012 \\
Iron & $342.8^{\mathrm{c}}$ & \pm & 122.1 & $291.9^{\mathrm{c}}$ & \pm & 54.84 & $5571^{\mathrm{b}}$ & \pm & 693.9 & $26112^{\mathrm{a}}$ & \pm & 614.4 & $0.009^{\mathrm{d}}$ & \pm & 0.007 \\
\hline
\end{tabular}

* Kruskal Wallis analysis, where the different letters as coefficient in the mean (a, b, c, d and e) show significant difference against the mean value of each heavy metal $(p<0.05)$ due to the effect of the location factor (leaf, stem, root, sediment and water).

Table 1 shows the results of the Kruskall Wallis test, summarizing and comparing the concentrations of the four metals evaluated in different parts of the plant (stem, leaf and root), water and sediment. The distribution of the concentrations shows significant differences depending on the part of the plant evaluated as being superior to the average values of each element evaluated. A similar behavior to the transfer factor is observed, both for the concentration of metals in the roots and leaves with respect to their environment (water and sediment). Therefore, the analysis was given according to these last two factors, since the concentrations of elements found in the plant respond to the concentration of elements from its development environment.

The results show that, in the case of $\mathrm{Cu}$, the root tends to significantly absorb this metal, since the disparities in concentrations tend to be half of what is reported in the sediment. However, the distribution of this metal along the leaves and the stem with concentrations of 7 to $8 \mathrm{mg} / \mathrm{kg}$ for both is one third of what is reported in the sediment. In addition, the $\mathrm{Cu}$ concentrations detected in the sediment are significantly higher than those recorded in the other factors under study, either in the water or in the plant parts.

In the case of lead, the Kruskal Wallis analysis shown in Table 1 indicates that concentrations in the sediment are significantly higher than reported. The capacity of the plant to absorb lead is not significant, although there is a slope that the root absorbs much more lead from the sediment and that lead is not distributed along the leaf and stem. However, no lead concentrations were reported in the water. The case of zinc tends to have a similar distribution in relation to the absorption and distribution of copper, probably because they are essential metals and are more easily distributed. While it is true that zinc concentrations in water are significantly lower $(0.005 \pm 0.012 \mathrm{mg} / \mathrm{kg})$, there is no inclination for zinc and copper elements to have been absorbed from water. In general, a higher absorption of metals is observed in relation to the sediment. It is observed that copper shows a distribution that tends to be significant in the stem and leaf compared to the concentration in the root, while iron and lead tend to be concentrated in the root.

Table 2 shows the maximum permissible limits of heavy metals in water and sediments, showing that the average of the metals evaluated and detected in water are significantly lower than the maximum allowed $(\mathrm{p}>0.05)$. However, in the sediment it was found that the average 
copper concentration was significantly higher than the maximum allowed value $(\mathrm{p}<0.05)$; while the average concentrations of the other elements are less or equal to the maximum allowed.

Table 2. Permissible levels of heavy metals in various components of international agencies ( $\mathrm{mg} / \mathrm{L}$ water and $\mathrm{mg} / \mathrm{Kg}$ sediment).

\begin{tabular}{ccccccc}
\hline Factor & International agencies & $\mathbf{C u}$ & $\mathbf{P b}$ & $\mathbf{Z n}$ & $\mathbf{F e}$ & Reference \\
\hline \multirow{2}{*}{ Water } & EPA & 0.007 & 0.01 & 0.086 & 0.3 & Nazeer et al. (2014) \\
\multirow{2}{*}{ Sediment } & WHO & 2 & 0.01 & 3 & 0.3 & WHO (1993) \\
& CEQG & 18.7 & 30.2 & 124 & NA & CEQG (2001) \\
\hline
\end{tabular}

Redundancy analysis of correlations between plant metal concentrations and environmental factors are presented in the biplot for each plant part and environmental factor studied. Figure 4A shows the correlation between the matrices of the distribution of metal concentrations in the water and leaf independently. The eigenvalues for the first and second coordinates are 0.79 and 0.0082 ; i.e., the explained variation of what happens in the original data can only be interpreted as a function of the first common axis $79.45 \%$, since the second axis has a low level of explained variation of $0.82 \%$. The PCO 1 tends to have a higher correlation with the $\mathrm{X}$ axis, and whose vector is wider. In addition, the analysis indicates that Sample 1 is the one that mainly determines the distribution of environmental and biological vectors with respect to the concentration of metals. Direct selection redundancy analysis of the table indicates that the concentrations of zinc and iron present in the leaf correlate with the distribution of zinc and iron concentrations in the water; although the iron vector tends to have a different orientation, it is the weight of the second coordinate that determines that orientation is not significant.

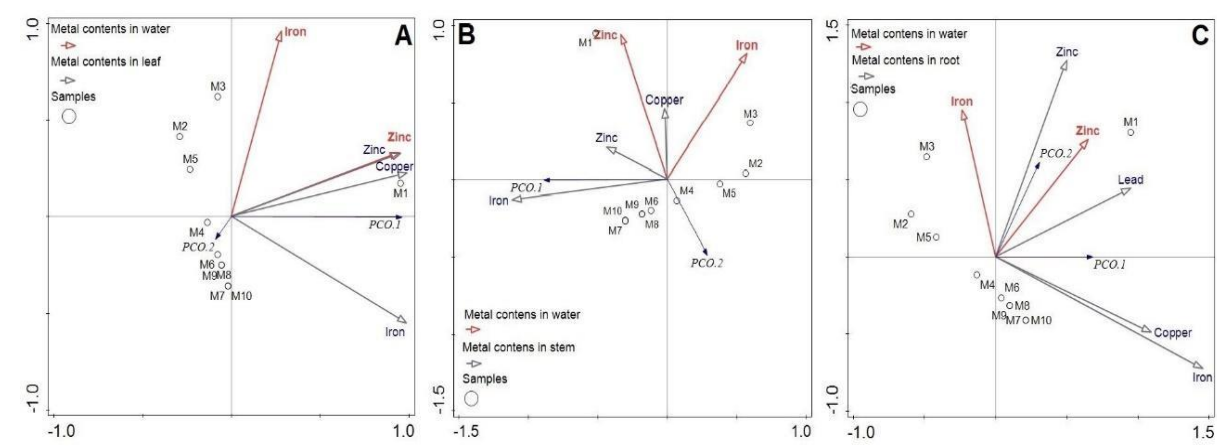

Figure 4. Redundancy analysis of the correlations between the metal content in leaves (blue lines), total metal concentrations in water (red lines) and vector direction of the first two coordinates (black lines).

For the correlation of the concentration of metals present in the water and in the plant stem, Figure 4B shows the same distribution trend and behavior pattern of the samples, and the coordinates tend to have the same loads. Coordinate one was found to have an explained variation of $77.02 \%$, and the second coordinate of only $0.96 \%$, with the latter not being very relevant in the interpretation. The analysis shows the interaction of the two matrices of metal concentrations in the water and in the stem, finding that it is ample 1 that determines the distribution of the observations.

Table 3 shows Zinc as the only element that tends to correlate with its pair for both water and stem in relation to its concentrations, indicating that zinc is the only element that is significantly transferred from water to the stem. For the correlation of the element concentrations of the water that are transferred to the root, Figure $4 \mathrm{C}$ shows redundancy analysis of the integration of the two matrices, showing that the loads for the first and second 
coordinates are significantly lower compared to the correlation of the leaves and stems. The first coordinate has an explained variation of $47.1 \%$ and the second coordinate has a significantly lower variation of $0.01 \%$. This is due to the fact that the distributions of the samples do not tend to correspond for both matrices, and as shown in Table 3, in the direct selection redundancy analysis neither of the elements that present concentrations of zinc or iron in the water presents a significant correspondence in relation to the distribution of the concentrations in the root of the plant; that is to say that the concentrations of elements found in the water tend to explain the concentration of elements found in the root of the plant.

Table 4 shows the direct selection redundancy analysis for the correlation of metal concentration matrices in the plant explained by the sediment. The first analysis of metal concentration in sediment and the correlation of the distribution of the samples for the metal content in the leaves is summarized in Figure 5A. The redundancy analysis indicated that the load for the first coordinate was $82.89 \%$ variation explained and the second a load of $2.41 \%$. The biplot indicates that Sample 1 determines the distribution of the observations in relation to the others, although there is a tendency for horizontal ordering favored by the trajectory of the first coordinate. The perceptual map shows that $\mathrm{Cu}, \mathrm{Fe}$ and $\mathrm{Pb}$ in sediment have a negative correlation, while in the concentration in the leaf there is a certain tendency of positive correlation between $\mathrm{Cu}$ and $\mathrm{Zn}$. Direct selection redundancy analysis indicates that $\mathrm{Zn}$ is the only element that tends to bioaccumulate significantly in leaves.

Table 3. Redundancy analysis based on distance, step by step direct selection for water factor.

\begin{tabular}{ccccc}
\hline Name & Explains \% & Contribution \% & pseudo-F & P \\
\hline \multicolumn{5}{c}{ Forward Selection Results: Water - root } \\
\hline $\mathrm{Zn}$ & 20 & 42.5 & 2 & 0.206 \\
$\mathrm{Fe}$ & 27.1 & 57.5 & 3.6 & 0.092 \\
\hline \multicolumn{5}{c}{ Forward Selection Results: Water - stem } \\
\hline $\mathrm{Fe}$ & 25.9 & 33.2 & 2.8 & 0.122 \\
$\mathrm{Zn}$ & 52.1 & 66.8 & 16.6 & 0.012 \\
\hline \multicolumn{5}{c}{} \\
\hline $\mathrm{Zn}$ & 70.8 & 88.2 & 19.4 & 0.04 \\
$\mathrm{Fe}$ & 9.5 & 11.8 & 3.4 & 0.038 \\
\hline
\end{tabular}

Table 4. Redundancy analysis based on distance, step by step direct selection for sediment factor.

\begin{tabular}{lcccc}
\hline Name & Explains \% & Contribution $\%$ & pseudo-F & P \\
\hline \multicolumn{5}{c}{ Forward Selection Results:Sediment - root } \\
\hline $\mathrm{Pb}$ & 57.3 & 65.2 & 10.7 & 0.068 \\
$\mathrm{Zn}$ & 22 & 25.1 & 7.5 & 0.01 \\
$\mathrm{Fe}$ & 6.1 & 7 & 2.5 & 0.092 \\
$\mathrm{Cu}$ & 2.5 & 2.8 & 1 & 0.342 \\
\hline \multicolumn{5}{c}{ Forward Selection Results: Sediment - stem } \\
\hline $\mathrm{Pb}$ & 26.9 & 62.2 & 2.9 & 0.12 \\
$\mathrm{Fe}$ & 15.4 & 35.6 & 1.9 & 0.252 \\
$\mathrm{Zn}$ & 0.8 & 1.8 & $<0.1$ & 0.856 \\
$\mathrm{Cu}$ & 0.1 & 0.3 & $<0.1$ & 0.988 \\
\hline \multicolumn{5}{c}{} \\
\hline $\mathrm{Zn}$ & Forward Selection Results: Sediment -1 leaf & \\
$\mathrm{Cu}$ & 56.9 & 66.6 & 10.6 & 0.048 \\
$\mathrm{Fe}$ & 16.9 & 19.8 & 4.5 & 0.058 \\
$\mathrm{~Pb}$ & 7.2 & 8.4 & 2.3 & 0.146 \\
$\mathrm{~F}$ & 4.5 & 5.3 & 1.5 & 0.228 \\
\hline
\end{tabular}




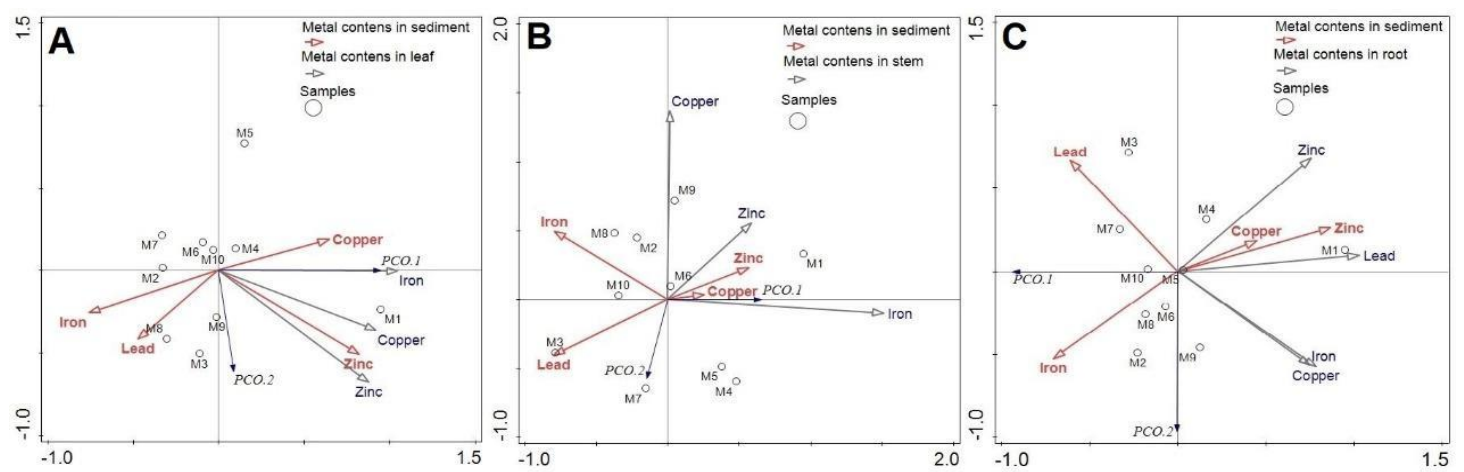

Figure 5. Redundancy analysis of correlations between metal content in parts of the plant A, $\mathrm{B}$ y $\mathrm{C}$ (blue lines), total metal concentrations in sediment (red lines) and vector direction of the first two coordinates (black lines).

For matrix correlations of element concentrations that bioaccumulate from the sediment to the stem, the loads for the first two coordinates of the redundancy analysis are lower. For the first coordinate, the explained percentage of pressure is 41.9 percent, and for the second coordinate 0.84 percent; these values indicate that there is apparently no correspondence between the distribution of observations for the element concentration matrices in the sediment and the element concentration in the stem. Figure 5B shows the distribution of the vectors and their direction either for the element variables in the sediment or in the stem, since no correlation slope is observed for any of the variables. In addition, Table 4 of the direct selection redundancy analysis for the case of the sediment with the stem indicates that none of the elements evaluated are affected in their distribution for both factors. That is, even at a significance level of 0.05 , we can infer that the concentrations of elements found in the stem are not a function of the concentrations of elements present in the sediment, and that these concentrations are probably a product of transfer from the root to the stem.

Finally, the correlation analysis of the matrices of element concentration in the sediment and root tend to have a better perspective, since the load of the coordinates in the analysis and redundancy are significantly higher than all other loads of the correlations evaluated. The first two coordinates have an explained cumulative variation of $87.84 \%$, having for the first coordinate an explained variation of $75.08 \%$ and $12.76 \%$ for the second coordinate. These values indicate that there is a better representativeness and a better adjustment of the matrices that explains the distribution of the observations and variables studied. In addition, a high degree of explained variation of the second component compared to the other one shows that interpretation for the $\mathrm{Y}$-axis is feasible, as shown in Figure 5C. This indicates that for the concentrations of elements in the root there is a positive correlation between $\mathrm{Fe}$ and $\mathrm{Cu}$, in addition to the positive correlation of $\mathrm{Pb}$ in the root and $\mathrm{Zn}$ in the sediment. The direct selection redundancy analysis in Table 4 shows the integration of all matrices for element concentration in the sediment and in the root. In addition, $\mathrm{Zn}$ is the only element that corresponds to its distribution for both the root and the sediment. That is, at a significance level of 0.05 , the $\mathrm{Zn}$ concentrations reported in the sediment tend to have a higher affinity for transfer to the root.

\section{CONCLUSIONS}

Polluted water treatment systems based on the use of aquatic plants have proven to be highly efficient in removing metals. H. ranunculoides showed phytoabsorbing potential for $\mathrm{Cu}$, $\mathrm{Zn}$ and Fe concentrations in its root, stem and leaves, which exceed the concentrations in plants in normal conditions. Taking into account each characteristic of the growth environment (water and sediment), in order of concentration Fe was significantly higher in all factors under study 
( $\mathrm{p}<0.05$ ), having the logical sequence of concentration $\mathrm{Fe}>\mathrm{Zn}>\mathrm{Cu}>\mathrm{Pb}$. Therefore, it is considered as a potential accumulator, mainly in the root of the majority of heavy metals investigated; the mechanism involved allows for the removal of heavy metals from water and sediments, except for $\mathrm{Pb}$, for which the capacity of the plant to absorb is not significant. However, there is a slope that the root absorbs much more $\mathrm{Pb}$ from the sediment, and this is not distributed along the leaf and stem. These results generate knowledge and contribute to the development of phytotechnologies oriented to the treatment of effluents contaminated with heavy metals to mitigate water pollution in wetlands.

\section{ACKNOWLEDGEMENTS}

The authors express their gratitude to the Laboratory of Chemistry and Environment of the Faculty of Applied Sciences of the Universidad Nacional del Centro del Perú for allowing us to make use of the equipment and materials for this study.

\section{REFERENCES}

AKSOY, A.; DUMAN, F.; SEZEN, G. Heavy Metal Accumulation and distribution in narrowleaved cattail (Typha angustifolia) and common reed (Phragmites australis). Journal of $\begin{array}{lllllll}\text { Freshwater Ecology, v. 20, n. 4, p. 783-785, } 2005 . & \text { n. }\end{array}$ https://doi.org/10.1080/02705060.2005.9664806

APHA; AWWA; WEF. Standard methods for the examination of water and wastewater. 22th ed. Washington DC, 2012. 1360 p.

CANADIAN COUNCIL OF MINISTERS OF THE ENVIRONMENT. Canadian Sediment Quality Guidelines for the Protection of Aquatic Life: Summary tables. Winnipeg, 2001.

CHATTERJEE, S.; CHETIA, M.; SINGH, L.; CHATTOPADHYAY, B.; DATTA, S.; MUKHOPADHYAY, S.K. A study on the phytoaccumulation of waste elements in wetland plants of a Ramsar site in India. Environmental Monitoring and Assessment, v. 178, p. 361-371, 2011. https://doi.org/10.1007/s10661-010-1695-x

CUADRADO, W.; CUSTODIO, M.; ESPINOZA, C.; VICUÑA, C.; URIBE, M. Capacity of absorption and removal of heavy metals from Scirpus californicus and Its potential use in the remediation of polluted aquatic environment. Open Journal of Marine Science, v. 9, n. 2, p. 74-85, 2019. https://doi.org/10.4236/ojms.2019.92006

GAN, Y.; WANG, L; YANG, G.; DAI, J.; WANG, R.; WANG, W. Multiple factors impact the contents of heavy metals in vegetables in high natural background area of China. $\begin{array}{llllll}\text { Chemosphere, } & \text { v. } & 184, & \text { n. } & 27, & 1388-1395,\end{array}$ https://doi.org/10.1016/j.chemosphere.2017.06.072

KABATA-PENDIAS, A. Trace elements in soils and plants. Boca Raton: CRC Press, 2011. https://doi.org/10.1201/b10158

KASTRATOVIĆ, V.; KRIVOKAPIĆ, S.; ĐUROVIĆ, D.; BLAGOJEVIĆ, N. Seasonal changes in metal accumulation and distribution in the organs of Phragmites australis (common reed) from lake Skadar, Montenegro. Journal of the Serbian Chemical Society, v. 78, p. 1241-1258, 2013. https://doi.org/10.2298/JSC121026153K 
KATZ, B. M.; MCSWEENEY, M. A multivariate kruskal-wallis test with post hoc procedures. Multivariate Behavioral Research, v. 15, n. 3, p. 281-297, 1980. https://doi.org/10.1207/s15327906mbr15034

KRAMER, U. Metal hyperaccumulation in plants. Annual review of plant biology, v. 61, p. 517-534, 2010. https://doi.org/10.1146/annurev-arplant-042809-112156

KRUSKAL, W.; WALLIS, W. Use of ranks in one-criterion variance analysis. Journal of the

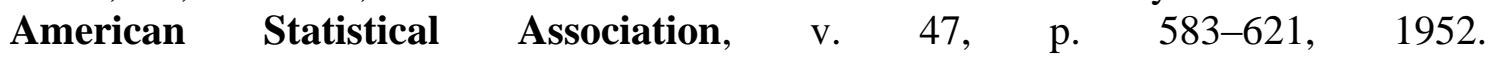
https://doi.org/10.1080/01621459.1952.10483441

LI, T. Q,; YANG, X. E.; LU, L. L.; ISLAM, E.; HE, Z. N. Effects of zinc and cadmium interactions on root morphology and metal translocation in a hyperaccumulating species under hydroponic conditions. Journal of Hazardous materials, v. 169, n. 1-3, p. 73474, 2009. https://doi.org/10.1016/j.jhazmat.2009.04.004

LEGENDRE, P.; ANDERSSON, M. Distance-based redundancy analysis: Testing multispecies responses in multifactorial ecological experiments. Ecological Monographs, v. 69, n. 1, p. 1-24, 1999. https://doi.org/10.1890/0012-9615(1999)069[0001:DBRATM]2.0.CO;2

LOJKO, R.; POLECHOŃSKA, L.; KLINK, A.; KOSIBA, P. Trace metal concentrations and their transfer from sediment to leaves of four common aquatic macrophytes. Environmental Science and Pollution Research, v. 22, p. 15123-15131, 2015. https://doi.org/10.1007/s11356-015-4641-1

NAZEER, S.; HASHMI, M. Z.; MALIK, R. N. Heavy metals distribution, risk assessment and water quality characterization by water quality index of the River Soan, Pakistan. $\begin{array}{llllll}\text { Ecological Indicators, } & \text { v. } & 43, & \text { p. } & 262-270,\end{array}$ http://dx.doi.org/10.1016/j.ecolind.2014.03.010

MARMIROLI, M.; ANTONIOLI, G.; MAESTRI, E.; MARMIROLI, N. Evidence of the involvement of plant ligno-cellulosic structure in the sequestration of $\mathrm{Pb}$ : An X-ray spectroscopy-based analysis. Environmental Pollution, v. 134, n. 2, p. 217-227, 2005. https://doi.org/10.1016/j.envpol.2004.08.004

MAZEJ, Z.; GERM, M. Trace element accumulation and distribution in four aquatic $\begin{array}{lllllll}\text { macrophytes. Chemosphere, v. 74, n. 5, p. 642-647, } 2009 . & \text {. }\end{array}$ https://doi.org/10.1016/j.chemosphere.2008.10.019

MIMBA, M. E.; OHBA, T.; NGUEMHE FILS, S. C.; NFORBA, M.T.; NUMANAMI, N.; BAFON, T. G.; AKA, F. T.; SUH, C. E. Regional geochemical baseline concentration of potentially toxic trace metals in the mineralized Lom Basin, East Cameroon: a tool for contamination assessment. Geochemical Transactions, v. 19, p. 1-17, 2018. https://doi.org/10.1186/s12932-018-0056-5

TWARDOWSKA, I.; KYZIOL, J. Sorption of metals onto natural organic matter as a function of complexation and adsorbent-adsorbate contact mode. Environment International, v. 28, n. 8, p. 783-791, 2003. https://doi.org/10.1016/S0160-4120(02)00106-X

VÄÄNÄNEN, K.; LEPPÄNEN, M. T.; CHEN, X. P.; AKKANEN, J. Metal bioavailability in ecological risk assessment of freshwater ecosystems: From science to environmental management. Ecotoxicology and Environmental Safety, v. 147, p. 430-446, 2018. https://doi.org/10.1016/j.ecoenv.2017.08.064 
WHO. Guidelines for drinking water quality. 2nd ed. Geneva, 1993.

YANG, J. X.; YE, Z. H. Metal accumulation and tolerance in wetland plants. Frontiers of Biology in China, v. 4, p. 282-288, 2009. https://doi.org/10.1007/s11515-009-0024-7

ZEVALlOS, W. T.; SALVATIERRA, L. M.; PÉREZ, L. M. Evaluación de los mecanismos de eliminación de $\mathrm{Pb} 2+$ en sistemas de fitorremediación en lotes operados con Salvinia biloba raddi (acordeón de agua). Energía, v. 13, n. 13, p. 9-17, 2015. 


Ambiente \& Água - An Interdisciplinary Journal of Applied Science
ISSN 1980-993X - doi:10.4136/1980-993X
www.ambi-agua.net
E-mail: ambi.agua@gmail.com

\title{
Variations in soil water replacement levels promote changes in forage cactus mineral composition and biomass productivity
}

\author{
ARTICLES doi:10.4136/ambi-agua.2537
}

Received: 01 Mar. 2020; Accepted: 28 Jul. 2020

\section{Rener Luciano de Souza Ferraz ${ }^{1 *}$; José Dantas Neto ${ }^{2}$; ${\text { Patrícia da Silva } \text { Costa }^{2} \text {; }}$; Antônio Suassuna de Lima ${ }^{2}$; Patrícia Ferreira da Silva ${ }^{2}$; Rigoberto Moreira de Matos ${ }^{2}$; ; Alberto Soares de Melo ${ }^{3}$}

\author{
${ }^{1}$ Departamento de Agroecologia e Agropecuária. Universidade Estadual da Paraíba (UEPB), Sítio Imbaúba, \\ s/n, CEP: 58.117-000, Lagoa Seca, PB, Brazil. \\ ${ }^{2}$ Centro de Tecnologia e Recursos Naturais (CTRN). Unidade Acadêmica de Engenharia Agrícola (UAEA). \\ Universidade Federal de Campina Grande (UFCG), Rua Aprígio Veloso, nº 882, CEP: 58429-900, \\ Campina Grande, PB, Brazil. E-mail: zedantas1955@gmail.com, patriciagroambiental@gmail.com, \\ suassunaagro@gmail.com, patrycyafs@yahoo.com.br, rigobertomoreira@gmail.com \\ ${ }^{3}$ Centro de Ciências Biológicas e da Saúde. Coordenação do Programa de Pós-Graduação em Ciências Agrárias. \\ Universidade Estadual da Paraíba (UEPB), Rua Domitila Cabral de Castro, s/n, CEP: 58.429-570, \\ Campina Grande, PB, Brazil. E-mail: albertosoares915@gmail.com \\ ${ }^{*}$ Corresponding author. E-mail: ferragroestat@gmail.com
}

\begin{abstract}
Population growth and the need to exploit natural resources to produce food and guarantee food sovereignty reduce water availability, which can influence nutrient absorption capacity and production of plants. This study evaluated whether variations in soil water replacement levels promote changes in the mineral composition and biomass productivity of forage cactus varieties. A field experiment was conducted in a randomized block design with five levels of reference evapotranspiration replacement $(25,50,75,100$ and $125 \%$ ETo $)$ and three replicates. Contents of the macronutrients $\mathrm{N}, \mathrm{P}, \mathrm{K}, \mathrm{Ca}, \mathrm{Mg}$ and $\mathrm{S}$; micronutrients $\mathrm{Cu}, \mathrm{Fe}, \mathrm{Mn}, \mathrm{Zn}, \mathrm{Cl}, \mathrm{Na}$ and $\mathrm{B}$; and biomass productivity were quantified in two varieties of forage cactus ('Orelha de Elefante Mexicana' and 'Miúda'). The data were subjected to principal component and multivariate variance analysis. The mineral composition of the forage cactus varieties 'Miúda' and 'Orelha de Elefante Mexicana' can be optimized from soil water management, so as to obtain adequate nutritional balance for higher yield. The replacement level of $75 \%$ ETo promoted greater balance between nutrients in the cladodes of the forage cactus variety 'Miúda', while 'Orelha de Elefante Mexicana' had better nutritional balance with the replacement levels of 100 and $125 \%$ ETo. Soil water replacement levels of 100 and $125 \%$ ETo promote high accumulation of $\mathrm{Na}^{+}$and $\mathrm{Cl}^{-}$ions in the cladodes of the forage cactus varieties studied. Highest biomass productivity of the varieties 'Orelha de Elefante Mexicana' and 'Miúda' was obtained with 75 and 100\% ETo replacement levels, respectively. Among the varieties, 'Orelha de Elefante Mexicana' had a higher capacity for nutrient accumulation and biomass productivity, followed by 'Miúda', under the edaphoclimatic conditions of the Brazilian semiarid region.
\end{abstract}

Keywords: irrigation, mineral nutrition, Nopalea, Opuntia, water requirement.

This is an Open Access article distributed under the terms of the Creative Commons Attribution License, which permits unrestricted use, distribution, and reproduction in any medium, provided the original work is properly cited. 


\section{Variações nos níveis de reposição hídrica no solo promovem mudanças na composição mineral e produtividade de biomassa de palma forrageira}

\section{RESUMO}

O aumento populacional e necessidade de exploração de recursos naturais para produção de alimentos e garantia da soberania alimentar reduzem a disponibilidade hídrica e isso pode influenciar a capacidade de absorção de nutrientes e produção das plantas. Objetivou-se avaliar se as variações nos níveis de reposição hídrica no solo promoveram mudanças na composição mineral e produtividade de biomassa de variedades de palma forrageira. Foi instalado experimento de campo em delineamento de blocos casualizados com cinco níveis de reposição da evapotranspiração de referência $(25,50,75,100$ e $125 \%$ da ETo) e três repetições. Em duas variedades de palma forrageira (Miúda e Orelha de Elefante Mexicana) foram quantificados os teores dos macronutrientes, N, P, K, Ca, Mg e S; dos micronutrientes $\mathrm{Cu}, \mathrm{Fe}, \mathrm{Mn}, \mathrm{Zn}, \mathrm{Cl}, \mathrm{Na}$ e $\mathrm{B}$; e produtividade de biomassa. Os dados foram submetidos à análise de componentes principais e variância multivariada. A composição mineral das variedades de palma forrageira 'Miúda' e 'Orelha de Elefante Mexicana' pode ser otimizada a partir do manejo de água no solo, de modo a ser obter balanço nutricional adequado para maior produtividade. O nível de reposição de $75 \%$ da $\mathrm{ET}_{\mathrm{o}}$ proporcionou maior equilíbrio entre os nutrientes nos cladódios da variedade de palma forrageira 'Miúda', já a variedade 'Orelha de Elefante Mexicana' teve melhor balanço nutricional com os níveis de reposição de 100 e $125 \%$ da ETo. Os níveis de reposição de água no solo de 100 e $125 \%$ da ETo promovem elevado acúmulo de íons $\mathrm{Na}^{+}$e $\mathrm{Cl}^{-}$nos cladódios das variedades de palma forrageira estudadas. Maior produtividade de biomassa das variedades 'Orelha de Elefante Mexicana' e 'Miúda' foi obtida com reposições 75 e $100 \%$ da ETo, respectivamente. Dentre as variedades, a 'Orelha de Elefante Mexicana' teve maior capacidade de acúmulo de nutrientes e produtividade de biomassa, seguida da 'Miúda' nas condições edafoclimáticas do semiárido brasileiro.

Palavras-chave: demanda hídrica, irrigação, Nopalea, nutrição mineral, Opuntia.

\section{INTRODUCTION}

Growing water scarcity can be defined as the imbalance between high demand due to population growth and economic development and low availability of water that can occur due to the effects of climate change (Santana et al., 2019; Benites-Lazaro et al., 2020). The Brazilian semiarid region undergoes constant changes in land use due to deforestation and high seasonality of water, represented among other variables by the decline in soil moisture content (Queiroz et al., 2020; Santos et al., 2020).

Soil moisture content is a vital component of the hydrological cycle, with a strong effect on the dynamics of carbon, water and energy at the surface-atmosphere interface. This is a determining factor in the patterns of plant distribution and growth in arid and semiarid environments (Medeiros et al., 2020). Indeed, soil moisture maintenance acts in the dynamics of microorganisms that are fundamental for nutrient cycling and fertility of agroecosystems, which stimulates plant growth and production (Zhou et al., 2020).

All this information highlights the importance of strategies of coexistence with the edaphoclimatic characteristics of the semiarid region. Thus, the cultivation of adapted plants is an efficient alternative for production in limiting environments. Cactus species (e.g. Nopalea ssp. and Opuntia ssp.) have anatomical and morphophysiological characteristics that favor their adaptation to the environmental conditions in these regions (Cardoso et al., 2019). 
Forage cactus is a plant with CAM (Crassulacean Acid Metabolism), a photosynthetic adaptation that facilitates the absorption of carbon dioxide at night, hence increasing water use efficiency, which enables crops to grow in arid and semiarid climates and, at the same time, produce aboveground biomass comparable to $\mathrm{C}_{3}$ and $\mathrm{C}_{4}$ crops with only $20 \%$ of water needs (Krümpel et al., 2020).

In Brazil, it is estimated that currently there are approximately 600,000 hectares cultivated with Opuntia ficus-indica (L.) Mill. and Nopalea cochenillifera (L.) Salm-Dyck (Cardoso et al., 2019). Opuntia is a drought-tolerant cactus, widely cultivated in semiarid and arid regions and has fruits and cladodes that can be used as sources of nutrients and phytochemicals (Salehi et al., 2019; Liguori et al., 2020). Nopalea stands out for having nutritional qualities and resistance to cochineal (Cardoso et al., 2019).

Forage cactus plays a supplemental role in the feeding of herds during the dry season (Rezende et al., 2020). However, studies indicate that adequate management, fertilization and irrigation are necessary for the satisfactory increase in its yield, so that the crop can express its best production potential, especially in regions with high seasonality of production and irregularity of rains such as the semiarid region (Silva et al., 2019).

In a systematic review and meta-analysis study, Ferraz et al. (2019) found that irrigated forage cactus crops promote yield increment of $53.54 \mathrm{t} \mathrm{ha}^{-1}$ year $^{-1}$ when compared to rainfed crops, with possible yields of $80.25 \mathrm{t} \mathrm{ha}^{-1}$ year $^{-1}$ under high irrigation depths and $26.83 \mathrm{tha}^{-1}$ year $^{-1}$ with lower irrigation depths in environments with higher rainfall. However, the significant increase in yield may result in a reduction in nutrient contents in forage cactus.

In irrigated forage cactus cultivation systems with high yield, it is essential to monitor the mineral composition of cladodes, because the increase in biomass can generate a nutrient dilution effect and compromise the nutritional quality of this feed for herds, since Nopalea ssp. and Opuntia ssp. provide food and water for animals and reductions in nutritional contents can influence the production and quality of meat (Moura et al., 2020). In this context, this study evaluated whether variations in soil water replacement levels promote changes in the mineral composition and biomass productivity of forage cactus varieties.

\section{MATERIAL AND METHODS}

\subsection{Experimental area location and characterization}

The experiment was conducted between May 2015 and December 2016, under field conditions, on the Poço Redondo farm, municipality of Santa Luzia, Seridó Ocidental Paraibano microregion, latitude of $06^{\circ} 52^{\prime} 27^{\prime}$ ' S, longitude of $36^{\circ} 56^{\prime} 00^{\prime}$ ' W Gr, and altitude of $299 \mathrm{~m}$.

The climate of the region is Bsh-Tropical, hot-dry semiarid with summer rains, according to Köppen's classification (Köppen and Geiger, 1928). Annually, the average precipitation of the region is $500 \mathrm{~mm}$, with a minimum temperature of $22.3^{\circ} \mathrm{C}$, average temperature of $27.6^{\circ} \mathrm{C}$, maximum temperature of $33.0^{\circ} \mathrm{C}$ and relative humidity ranging from 50 to $70 \%$. During the experiment, meteorological variables were monitored and expressed in climograph (Figure 1).

The soil of the experimental area was classified according to texture as sandy loam. For this, single samples were collected at depths of 0-0.20 m and 0.20-0.40 m, homogenized, placed in plastic bags and transported to the Irrigation and Salinity Laboratory (LIS) of the Center for Technology and Natural Resources (CTRN) of the Federal University of Campina Grande (UFCG) for chemical and physical-hydraulic characterization (Tables 1 and 2).

The water used for irrigation during the experiment was monitored for its chemical composition. For this, water samples from a shallow well (Amazonas type) located $80 \mathrm{~m}$ away from the experimental area were collected every three months. The samples were transported to LIS/CTRN/UFCG, and the following average data of chemical composition of the water were obtained: $\mathrm{pH}=7.48, \mathrm{Ca}=2.21 \mathrm{meq} \mathrm{L}^{-1}, \mathrm{Mg}=2.98 \mathrm{meq} \mathrm{L}^{-1}, \mathrm{Na}=8.44 \mathrm{meq} \mathrm{L}^{-1}, \mathrm{~K}=0.56$ 
meq $\mathrm{L}^{-1}, \mathrm{CO}_{3}=0.64$ meq $\mathrm{L}^{-1}, \mathrm{HCO}_{3}=3.25 \mathrm{meq} \mathrm{L}{ }^{-1}, \mathrm{Cl}=11.47 \mathrm{meq} \mathrm{L}{ }^{-1}$, sulfates $=$ present, sodium adsorption ratio $-\mathrm{SAR}=5.24 \mathrm{meq} \mathrm{L}^{-1}$ and electrical conductivity $-\mathrm{ECw}=1.37 \mathrm{dS} \mathrm{m}^{-}$ 1 , being classified as $\mathrm{C}_{3} \mathrm{~S}_{1}$, according to the classification of the United States Salinity Laboratory -USSL.

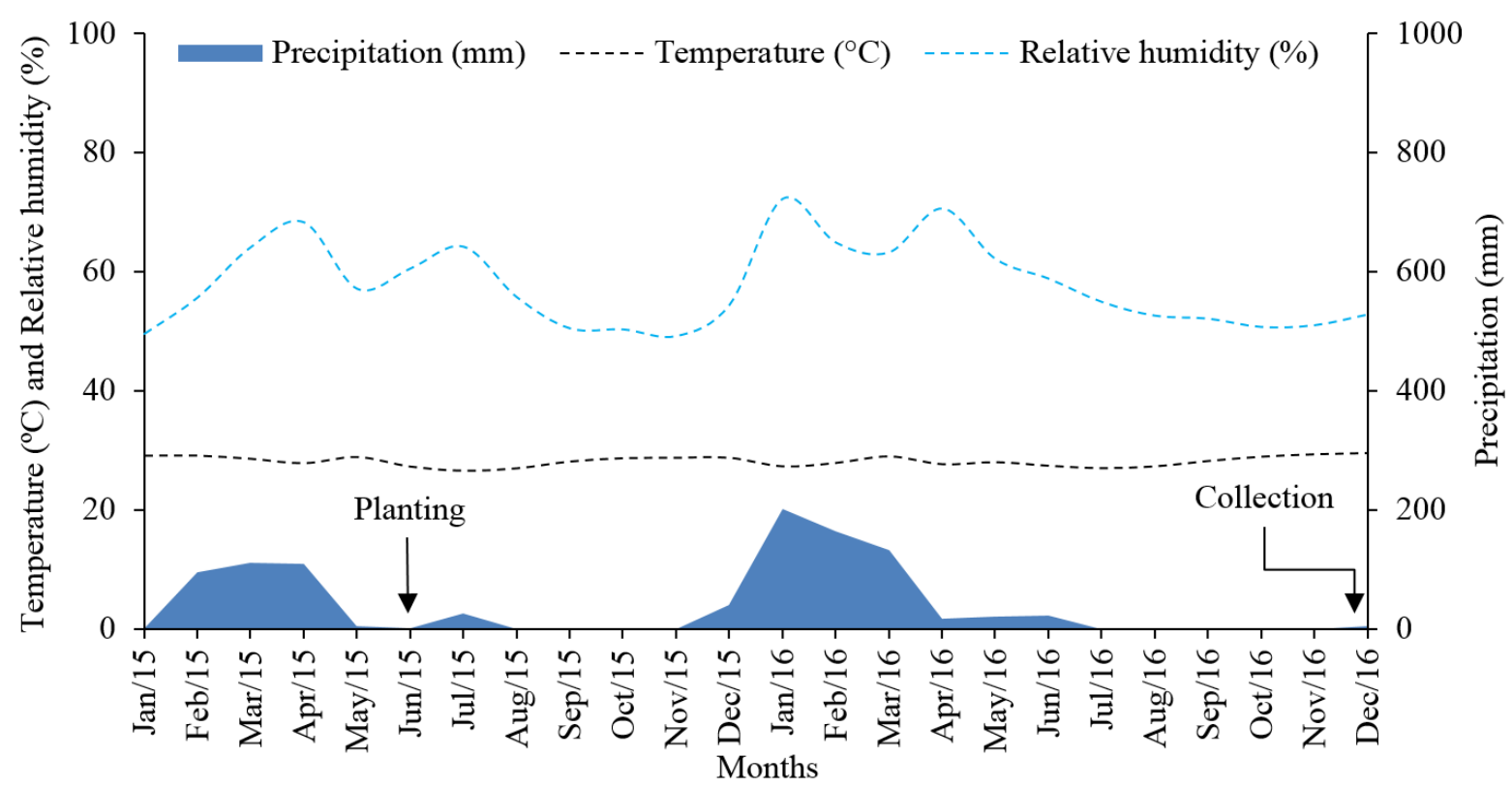

Figure 1. Climograph with the meteorological variables recorded during the experimental period.

Table 1. Chemical characterization of the sorption complex and saturation extract of the soil of the experimental area at two depths.

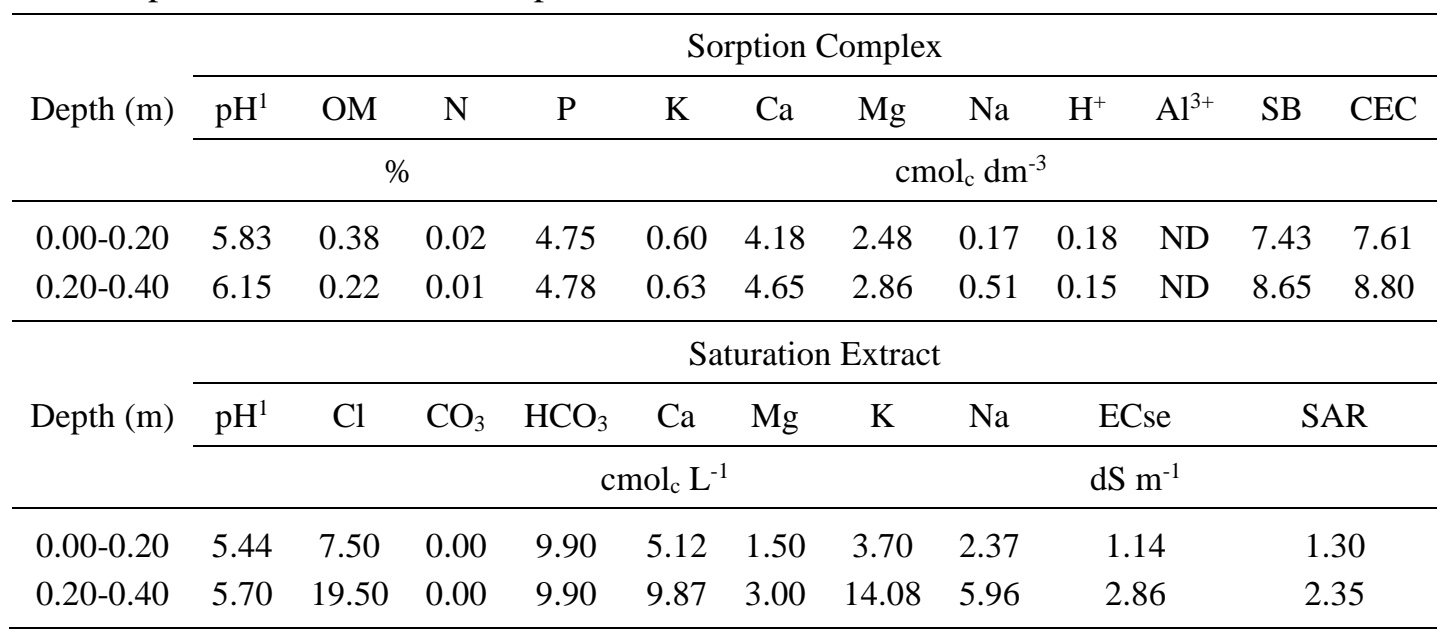

${ }^{1}: \mathrm{pH}$ in water; OM: organic matter; $\mathrm{SB}$ : sum of bases; CEC: cation exchange capacity; ECse: electrical conductivity of the soil saturation extract; SAR: sodium adsorption ratio; and ND: not detected.

Table 2. Physical-hydraulic characterization of the soil of the experimental area at two depths.

\begin{tabular}{|c|c|c|c|c|c|c|c|c|c|c|c|c|c|}
\hline \multirow{2}{*}{ Depth (m) } & Sand & Silt & Clay & $\mathrm{n}$ & $\mathrm{BD}$ & PD & $\mathrm{U}-0.1$ & U-0.3 & $\mathrm{U}-1.0$ & $\mathrm{U}-5.0$ & $\mathrm{U}-10.0$ & U-15.0 & AW \\
\hline & \multicolumn{4}{|c|}{$\%$} & \multicolumn{2}{|c|}{$\mathrm{g} \mathrm{cm}^{-3}$} & \multicolumn{7}{|c|}{$\%$} \\
\hline $0.00-0.20$ & 74.83 & 17.28 & 7.89 & 44.23 & 1.47 & 1.39 & 18.56 & 12.10 & 9.34 & 5.15 & 4.88 & 4.44 & 7.66 \\
\hline $0.20-0.40$ & 67.71 & 18.30 & 13.99 & 46.48 & 1.39 & 2.60 & 20.14 & 14.79 & 10.28 & 6.29 & 6.01 & 5.39 & 9.40 \\
\hline
\end{tabular}

n: porosity, BD: bulk density, PD: particle density, U: soil moisture between 0.1 and 15 atmosphere; AW: available water in the soil. 


\subsection{Experimental design}

The experiment was installed in a randomized block design and the treatments consisted of five levels of reference evapotranspiration replacement $(25,50,75,100$ and 125\% ETo) with three replicates (blocks), using two varieties of forage cactus - MI = Miúda (Nopalea cochenillifera Salm - Dyck) and - OR = Orelha de Elefante Mexicana (Opuntia ficus-indica (L.) Mill.). Each plot had an area of $14.4 \mathrm{~m}^{2}$, consisting of a double row with spacing of $0.4 \mathrm{~m}$ between rows, $2.0 \mathrm{~m}$ between double rows and $0.25 \mathrm{~m}$ between plants, with length of $5 \mathrm{~m}$ and border of $1 \mathrm{~m}$, adopting a usable area of $0.6 \mathrm{~m}^{2}$ in the plot.

From soil fertility analysis, organic fertilization was performed with $1.0 \mathrm{~kg}$ of bovine manure per linear meter. Following the recommendation of Santos et al. (2006), phosphate fertilization was also performed with $100 \mathrm{~kg} \mathrm{ha}^{-1}$ of $\mathrm{P}_{2} \mathrm{O}_{5}$ and potassium fertilization with 65 $\mathrm{kg} \mathrm{ha}^{-1}$ of $\mathrm{K}_{2} \mathrm{O}$, using $200 \mathrm{~kg} \mathrm{ha}^{-1}$ monoammonium phosphate (MAP) and $108.33 \mathrm{~kg} \mathrm{ha}^{-1}$ of potassium chloride $(\mathrm{KCl})$ as sources of these nutrients. Nitrogen fertilization was performed using $900 \mathrm{~kg} \mathrm{ha}^{-1}$ nitrogen $(\mathrm{N})$, applying 2,000 $\mathrm{kg} \mathrm{ha}^{-1}$ of urea as a source of $\mathrm{N}$, supplied via monthly fertigation, split and applied over 18 months.

\subsection{Vegetative propagules and planting}

The vegetative propagules (cladodes) were obtained from rural producers in the municipality of Santarém, PB, in partnership with the National Institute of the Semiarid Region (INSA). This material was selected by opting for uniform cladodes that were free of pests and diseases. After screening, the cladodes were kept in an open environment with reduced lighting for seven days, for partial dehydration and healing of the lesions caused by the cutting. The cladodes were planted on May 29, 2015, by placing the propagative material in the planting furrows, with the cladode facing the sunrise, at a $45^{\circ}$ angle, and $50 \%$ of the cladode buried in the soil in a bilateral alignment.

\subsection{Application of treatments and cultivation practices}

ETo levels were replaced using a localized drip irrigation system, consisting of a drip tube with a wall thickness of $0.2 \mathrm{~mm}$, internal diameter of $16 \mathrm{~mm}$, spacing between drippers of 0.20 $\mathrm{m}$; nominal pressure of $68.6 \mathrm{kPa}$; flow rate of $6.0 \mathrm{~L} \mathrm{~h}^{-1} \mathrm{~m}^{-1}$. The emitter equation was $\mathrm{q}=0.46$ $\mathrm{x} \mathrm{p}^{0.5}$, and the application efficiency of the system was 0.96 .

The irrigation system was pressurized using a 3-HP centrifugal motor-pump set. A 2" disc filter was used in the discharge piping, and Bourdon-type manometers tested and calibrated before irrigations were used in the lateral lines. At the beginning of the experimental area, a hydrometer was installed to monitor the amount of water applied during the experimental period.

For each ETo replacement level, the following components were quantified: net irrigation depth $\left(\mathrm{D}_{\mathrm{NET}}\right)$, in $\mathrm{mm}$, taking into account the fraction applied in each plot $\left(\mathrm{D}_{\mathrm{AP}}\right)$, decimal, and the effective precipitation in the period $(\mathrm{P})$, in mm, obtained using the expression: $D_{N E T}=(E T o$ * $\left.D_{A P}\right)$ - $P$. The gross irrigation depth (D $\mathrm{D}_{\mathrm{GROSS}}$ ) was calculated based on the system's efficiency of application (Ea), in decimal, using the expression: $D_{G R O S S}=D_{N E T} / E a$. The volumes applied by irrigation in each treatment corresponded to $111.32,222.65,333.98,445.31$ and $556.64 \mathrm{~mm}$, which added to the precipitation during the period, reached 578.22, 689.55, 800.88, 912.21 and $1,023.54 \mathrm{~mm}$.

The irrigation system's intensity of application (Ia), in $\mathrm{mm} \mathrm{h}^{-1}$, was calculated considering: number of emitters $(\mathrm{Ne})$ - two per plant; flow rate - $1.21 \mathrm{~L} \mathrm{~h}^{-1}$; and area occupied by the plant (A) $-0.30 \mathrm{~m}^{2}$, using the expression: $I a=(N e * q) / A$. The irrigation time (Ti) required for ETo replacement in each treatment was calculated based on the gross irrigation depth (DGRoss) in $\mathrm{mm}$; and the irrigation system's intensity of application (Ia), in $\mathrm{mm} \mathrm{h}^{-1}$, using the expression: $T i=D_{\text {GROSS }} / I a$. 


\subsection{Analysis of cladode mineral composition and biomass productivity}

At 540 days after planting (DAP), three cladodes were collected from different plants in the usable area of each plot, standardized by weight, size, development stage and position on the plant. The samples were weighed to obtain the fresh mass (g) and taken to the Irrigation and Drainage Engineering Laboratory (LEID) of CTRN/UFCG, where they were cut into pieces, placed in previously identified paper bags and dried in a forced air circulation oven at $60^{\circ} \mathrm{C}$ until they reached constant weight. Subsequently, the material was weighed, crushed, sieved using 1.0-mm-mesh sieves and stored in hermetically sealed containers.

The containers with the samples were transported to the Laboratory of Soil Chemistry and Fertility of the Center for Agrarian Sciences (CCA) of the Federal University of Paraíba (UFPB) for the analysis of mineral composition, expressed through the contents of macronutrients, N, $\mathrm{P}, \mathrm{K}, \mathrm{Ca}, \mathrm{Mg}$ and $\mathrm{S}$, and micronutrients, $\mathrm{Cu}, \mathrm{Fe}, \mathrm{Mn}, \mathrm{Zn}, \mathrm{Cl}, \mathrm{Na}$ and $\mathrm{B}$, using the methodology of Embrapa (2009).

To evaluate biomass productivity (BP), the cladodes subsequent to the basal cladode of the usable area of each plot were cut and weighed on a scale with precision of \pm 0.01 . Productivity $\left(\mathrm{t} \mathrm{ha}^{-1}\right)$ was estimated by multiplying the average mass of cladodes by the average number of cladodes per plant and by the number of plants per hectare.

\subsection{Statistical analysis}

The data were normalized for zero mean $(\bar{X}=0.0)$ and unit variance $\left(\sigma^{2}=1.0\right)$. The multivariate structure of the results was evaluated using the exploratory Principal Component Analysis (PCA), condensing the amount of relevant information contained in the original data set in a smaller number of dimensions, resulting from linear combinations of the original variables generated from the highest eigenvalues $(\lambda>1.0)$ in the correlation matrix, explaining a percentage greater than $10 \%$ of $\sigma^{2}$ (Govaerts et al., 2007).

Only variables with Pearson's correlation coefficient above 0.5 were maintained in the composition of each Principal Component (PC) (Hair Jr. et al., 2009). Correlations were classified according to Dancey and Reidy (2013) as weak $(r=0.10-0.30)$, moderate $(r=0.40$ 0.60 and strong $(r=0.70-1.00)$. Variables not associated with PCs $(r<0.5)$ were removed from the normalized database and a new analysis was performed. Four variables were removed and 10 were considered for the variety 'Miúda' and two variables were removed and 12 were considered for the variety 'Orelha de Elefante Mexicana'.

Variables on each PC were submitted to multivariate analysis of variance (MANOVA) by Hotelling's test $(\mathrm{P}<0.05)$. Not associated original variables data with $\mathrm{PCs}$ were submitted to univariate analysis of variance (ANOVA) by F test $(\mathrm{P}<0.05)$ and means were compared using the Tukey test, as the regression deviations were significant. Varieties were not compared because they are different species. The analyses were carried out using Statistica software v. 7.0 .

\section{RESULTS AND DISCUSSION}

In the forage cactus 'Miúda', the contents of macro and micronutrients were correlated in two dimensions $\left(\mathrm{PC}_{1}\right.$ and $\left.\mathrm{PC}_{2}\right)$, which represent $90.53 \%$ of the total experimental variance. $\mathrm{PC}_{1}$ accounts for $60.72 \%$ of the total variance, formed from the linear combination between the contents of $\mathrm{N}, \mathrm{P}, \mathrm{K}, \mathrm{Mg}, \mathrm{Cl}, \mathrm{B}, \mathrm{Fe}$ and $\mathrm{Mn}$; and $\mathrm{PC}_{2}$ represents $29.81 \%$ of the remaining variance, formed from the contents of $\mathrm{Na}$ and $\mathrm{Cu}$ (Table 3). $\mathrm{Ca}, \mathrm{S}, \mathrm{Zn}$ contents and $\mathrm{BP}$ were not related in $\mathrm{PC}_{1}$ and $\mathrm{PC}_{2}$. The results of PCA and absolute contents of macro and micronutrients of 'Miúda' forage cactus obtained at each level of ETo replacement are presented in Table 3. 
Table 3. Eigenvalues, variance, coefficients of correlation between Principal Components and variables and means of treatments for the forage cactus variety 'Miúda'.

\begin{tabular}{|c|c|c|c|c|c|c|c|c|c|c|c|c|c|c|c|c|c|}
\hline \multirow{2}{*}{ PCs } & \multirow{2}{*}{$\lambda$} & \multirow{2}{*}{$\sigma^{2 \%}$} & \multirow{2}{*}{$P$} & \multicolumn{14}{|c|}{ Factorial Loadings (r) } \\
\hline & & & & $\mathrm{N}^{1}$ & $\mathrm{P}^{1}$ & $\mathrm{~K}^{1}$ & $\mathrm{Ca}^{1}$ & $\mathrm{Mg}^{1}$ & $\mathrm{Na}^{1}$ & $\mathrm{Cl}^{1}$ & $S^{2}$ & $\mathrm{~B}^{2}$ & $\mathrm{Cu}^{2}$ & $\mathrm{Zn}^{2}$ & $\mathrm{Fe}^{2}$ & $\mathrm{Mn}^{2}$ & $\mathrm{BP}^{3}$ \\
\hline $\mathrm{PC}_{1}$ & 6.07 & 60.72 & $<0.001$ & $-0.84^{*}$ & $-0.86^{*}$ & $-0.92^{*}$ & $\mathrm{R}$ & $-0.78^{*}$ & 0.05 & $-0.96^{*}$ & $\mathrm{R}$ & $-0.95^{*}$ & -0.31 & $\mathrm{R}$ & $-0.73^{*}$ & $-0.84^{*}$ & $\mathrm{R}$ \\
\hline \multirow[t]{7}{*}{$\mathrm{PC}_{2}$} & 2.98 & 29.81 & $<0.001$ & 0.28 & 0.48 & 0.37 & $\mathrm{R}$ & -0.59 & $-0.96^{*}$ & -0.22 & $\mathrm{R}$ & 0.01 & $-0.86^{*}$ & $\mathrm{R}$ & 0.46 & -0.52 & $\mathrm{R}$ \\
\hline & ETo & & & & & & & & & & leans & & & & & & \\
\hline & $25 \%$ & & & 14.18 & 0.14 & 11.68 & 4.46 & 13.54 & 2.64 & 32.86 & 75.38 & 66.41 & 5.58 & 18.07 & 49.07 & 348.60 & 204.16 \\
\hline & $50 \%$ & & & 17.35 & 0.20 & 18.48 & 3.47 & 14.04 & 2.26 & 41.34 & 94.73 & 69.81 & 6.16 & 18.00 & 133.44 & 434.45 & 130.55 \\
\hline & $75 \%$ & & & 21.35 & 0.23 & 34.73 & 4.46 & 18.47 & 1.88 & 60.42 & 67.12 & 97.02 & 8.64 & 18.64 & 148.51 & 746.21 & 91.67 \\
\hline & $100 \%$ & & & 23.10 & 0.20 & 26.16 & 4.14 & 22.00 & 3.28 & 64.66 & 67.63 & 86.25 & 9.64 & 29.12 & 104.15 & 747.81 & 241.66 \\
\hline & $125 \%$ & & & 14.88 & 0.17 & 16.37 & 4.46 & 20.40 & 3.67 & 53.00 & 86.99 & 80.58 & 18.44 & 15.22 & 95.22 & 814.67 & 125.00 \\
\hline
\end{tabular}

PCs: principal components; $\lambda$ : eigenvalues; $\sigma^{2} \%$ : portion of the variance explained; 1 : means in $\mathrm{g} \mathrm{kg}^{-1} ; 2$ : means in $\mathrm{mg} \mathrm{kg}^{-1} ; 3: \mathrm{means}$ in $\mathrm{t} \mathrm{ha}{ }^{-1}$; ETo: reference evapotranspiration; R: variable removed from principal component analysis; P: probability of the significance test by Hotelling's test; and

*: variables considered in the PC; $r=0.10-0.30$ (weak correlation); $r=0.40-0.60$ (moderate correlation); $r=0.70-1.00$ (strong correlation).

Regardless of the ETo replacement level, the order of magnitude of macronutrient accumulation in cladodes of 'Miúda' forage cactus, in g $\mathrm{kg}^{-1}$, was: $\mathrm{Ca}(41.94 \pm 3.84)>\mathrm{K}(21.48 \pm 8.11)>\mathrm{N}(18.17 \pm 3.52)>\mathrm{Mg}(17.69 \pm 3.38)>\mathrm{P}(1.90 \pm 0.31)>\mathrm{S}(0.08 \pm 0.01)$; and for micronutrients, in $\mathrm{mg} \mathrm{kg}{ }^{-1}$, the order was: $\mathrm{Cl}(50456.00 \pm 11834.08)>\mathrm{Na}(2746.00 \pm 65365)>\mathrm{Mn}(618.35 \pm 188.80)>\mathrm{Fe}(108.08 \pm 34.41)>\mathrm{B}(80.01 \pm 11.11)>\mathrm{Zn}$ $(19.81 \pm 4.80)>\mathrm{Cu}(9.69 \pm 4.63)$.

In $\mathrm{PC}_{1}$, it was found that the forage cactus 'Miúda' has higher relative accumulation of N, P, K, B and Fe under replacement of $75 \%$ ETo, whereas relative contents of $\mathrm{Cl}, \mathrm{Mg}$ and $\mathrm{Mn}$ are accumulated in greater quantity with $100 \%$ ETo replacement. It should be emphasized that lower accumulation of these nutrients was observed with $25 \%$ ETo replacement. $\mathrm{In}_{\mathrm{PC}}$, it was found that the forage cactus 'Miúda' accumulates higher contents of $\mathrm{Na}$ and $\mathrm{Cu}$ when $125 \%$ of ETo is replaced, while lower contents of these nutrients were found with 50\% ETo (Figure 2 A and B).

$\mathrm{Ca}$ contents were reduced when the forage cactus 'Miúda' was irrigated with 50\% ETo replacement, whereas the other levels did not cause differences (Figure 2 C). S contents did not differ with variation in ETo levels (Figure 2 D). Replacement of 100\% ETo increased Zn contents in the cladodes (Figure 2 E). Irrigation with 25 or $100 \%$ ETo promoted higher biomass productivity (Figure $2 \mathrm{~F}$ ). 

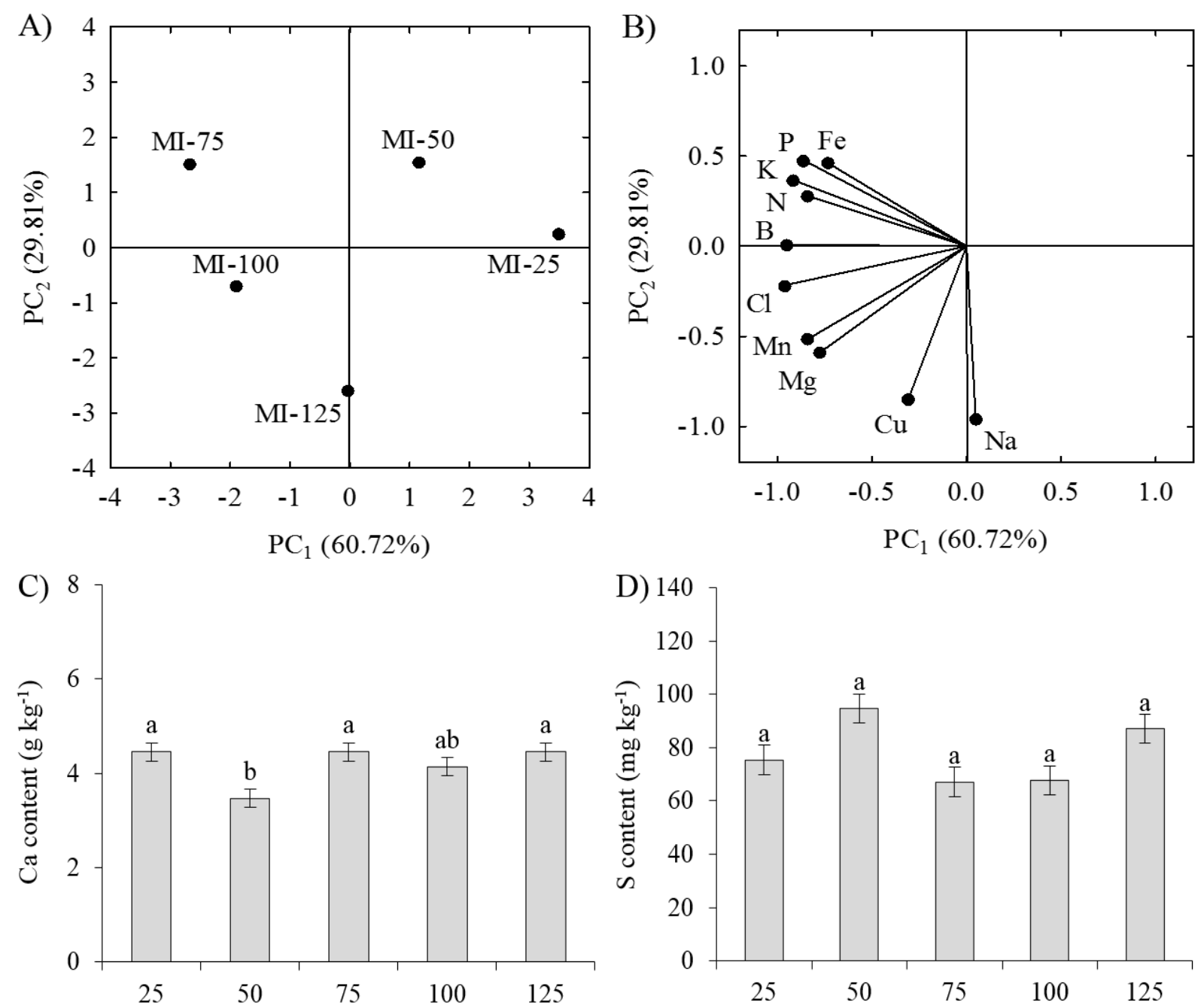

ETo replacement levels (\%)
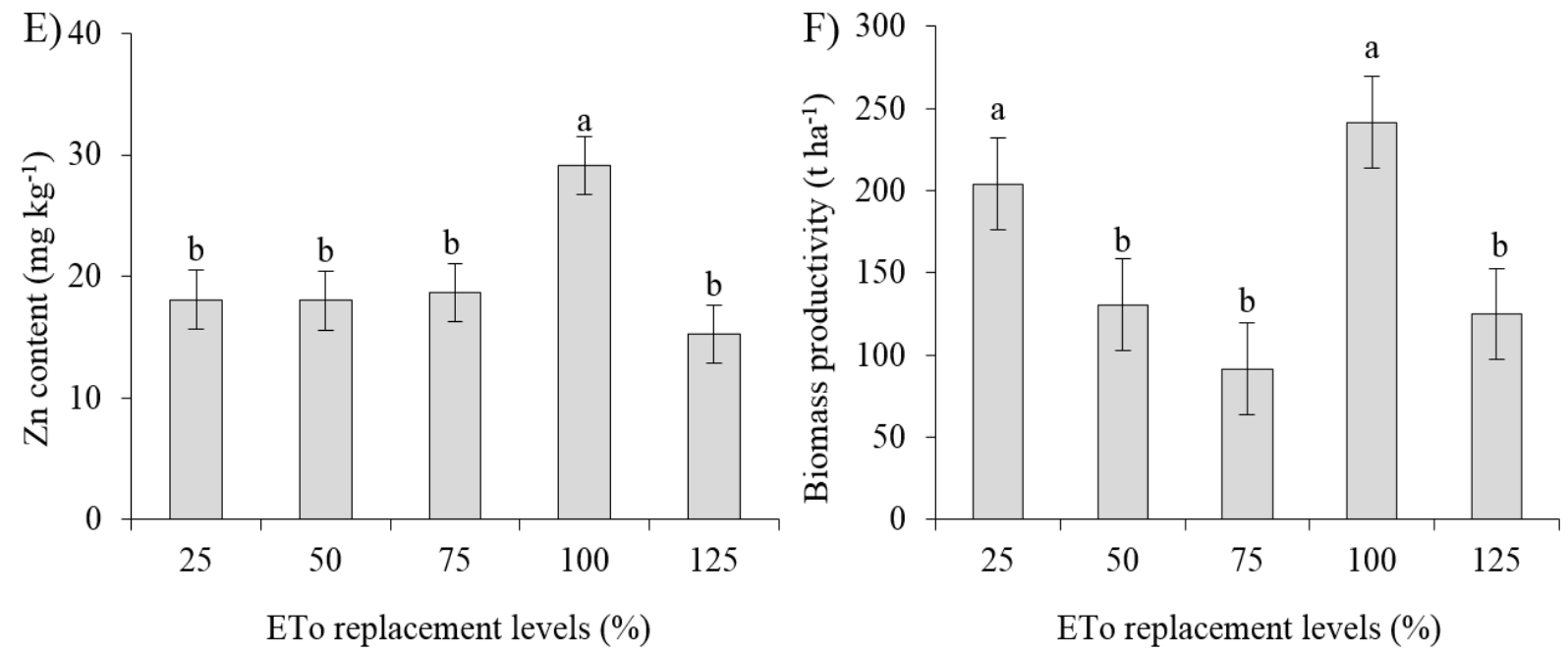

ETo replacement levels (\%)

ETo replacement levels (\%)

Figure 2. Two-dimensional projection (Biplot) of ETo replacement levels (A) and correlation of variables (B) in the first two Principal Components $\left(\mathrm{PC}_{1}\right.$ and $\left.\mathrm{PC}_{2}\right), \mathrm{Ca}(\mathrm{C}), \mathrm{S}(\mathrm{D})$ and $\mathrm{Zn}(\mathrm{E})$ contents and $\mathrm{BP}(\mathrm{F})$ for the forage cactus variety 'Miúda' under water replacement levels.

For the forage cactus 'Miúda' (Nopalea cochenillifera (L.) Salm-Dyck), the classic contents of macronutrients, in $\mathrm{g} \mathrm{kg}^{-1}$ of dry matter, reported in the literature are: $\mathrm{N}$ (6.7-10.5), $\mathrm{P}$ (1.0-1.6), K (8.3-12.1), Ca (20.6-22.5), Mg (10.4-17.0) and S (0.9-1.9). The classic contents of micronutrientes, in $\mathrm{mg} \mathrm{kg}^{-1}$ of dry matter, are: $\mathrm{Cu}(4.0), \mathrm{Fe}$ (59.0), $\mathrm{Mn}(430.0), \mathrm{Zn}(70.0)$ and 
$\mathrm{Na}$ (143.0) (Germano et al., 1991; Batista et al., 2003; Menezes et al., 2005; Santos et al., 2006; Frota et al., 2015).

The forage cactus 'Miúda' had higher accumulation of $\mathrm{N}, \mathrm{K}, \mathrm{Ca}, \mathrm{Mg}, \mathrm{Cu}, \mathrm{Fe}, \mathrm{Mn}$ and $\mathrm{Na}$ than those reported in the literature for the species Nopalea cochenillifera (L.) Salm-Dyck, while the contents of $\mathrm{P}, \mathrm{S}$ and $\mathrm{Zn}$ were lower. The observed increments occurred because the replacement levels of 75, 100 and $125 \%$ ETo promoted higher water availability in the soil and favored greater water absorption, rise and transpiration by plants, and this process is fundamental for the assimilation and remobilization of nutrients (Taiz et al., 2017).

Greater availability of water and nitrogen may have induced the growth and development of roots, because the forage cactus has a root system formed by many thin roots $(<1 \mathrm{~mm})$ distributed in a network, located in the surface layer of the soil profile $(0-20 \mathrm{~cm})$, adapted for absorbing water from light rains and even dew. Thus, greater water supply may have promoted root growth in deeper layers due to percolation of water and transport of nutrients to these zones (Oliveira et al., 2010). It must be pointed out that in areas of arid and semiarid climate, soil moisture is usually the main factor influencing root growth (Wilcox et al., 2004).

The above-mentioned information is ratified by Snyman (2006), who found that the mass and length of forage cactus roots decreased significantly under water deficit, while the root mass/length ratio increased significantly. In this context, the supply of water and nitrogen may have promoted greater accumulation of root biomass, besides stimulating root elongation, increasing the specific surface for nutrient absorption, which justifies the high contents quantified in this study.

The low content of $\mathrm{P}$ observed under $25 \%$ ETo replacement may be related to its low mobility in the soil (Santos et al., 2008). In addition, the low soil moisture content inhibits mycorrhizal colonization and reduces nutrient absorption, notably due to the smaller diameter of the fungi hyphae and consequent reduction in the hypha-soil contact surface, converged to limit the ability to store polyphosphates in vacuoles (Santos, 2018).

Indeed, the low moisture may have limited these processes, especially since these fungi increase the availability of nutrients, notably those with lower mobility, as in the case of phosphorus (Abboud et al., 2018), enhance water absorption and ensure greater drought resistance in host plants (Balota et al., 2011). Complementarily, the reduction of $\mathrm{P}$ content under $125 \%$ ETo replacement may have occurred due to the greater solubilization and flow of the mass of water with phosphate to deeper layers, where there is lower root density, and to the transport of the nutrient (Costa et al., 2014).

For the forage cactus 'Orelha de Elefante Mexicana', two Principal Components $\left(\mathrm{PC}_{1}\right.$ and $\mathrm{PC}_{2}$ ) were formed with eigenvalues greater than one, with accumulated total variance of $87.01 \%$ in the experiment. The contents of $\mathrm{N}, \mathrm{P}, \mathrm{Ca}, \mathrm{Na}, \mathrm{Cl}, \mathrm{S}, \mathrm{B}$, and Fe were combined to form $\mathrm{PC}_{1}$, which accounts for $47.73 \%$ of the total variance, while $\mathrm{PC}_{2}$ accounts for $39.28 \%$ of the remaining variance and was formed by the linear combination of the $\mathrm{Mg}, \mathrm{Cu}, \mathrm{Zn}$ and $\mathrm{Mn}$ contents (Table 4). K contents and $\mathrm{BP}$ were not related in $\mathrm{PC}_{1}$ and $\mathrm{PC}_{2}$.

The absolute contents of macro and micronutrients in the forage cactus 'Orelha de Elefante Mexicana' obtained at each level of ETo replacement are presented in Table 4. Regardless of ETo replacement level, the order of magnitude of macronutrient accumulation in the cladodes of 'Orelha de Elefante Mexicana', in $\mathrm{g} \mathrm{kg}^{-1}$, was: $\mathrm{Ca}(45.24 \pm 5.60)>\mathrm{Mg}(21.77 \pm 1.41)>\mathrm{N}$ $(18.17 \pm 2.48)>\mathrm{K}(18.15 \pm 2.48)>\mathrm{P}(1.90 \pm 0.31)>\mathrm{S}(0.07 \pm 0.03)$; and for micronutrients, in $\mathrm{mg}$ $\mathrm{kg}^{-1}$, the order was: $\mathrm{Cl}(65508.00 \pm 7943.64)>\mathrm{Na}(2906.00 \pm 1309.76)>\mathrm{Mn}(995.66 \pm 163.35)>$ $\mathrm{Fe}(108.08 \pm 34.41)>\mathrm{B}(105.41 \pm 19.56)>\mathrm{Zn}(22.65 \pm 3.17)>\mathrm{Cu}(13.44 \pm 2.56)$. 
Table 4. Eigenvalues, variance, coefficients of correlation between Principal Components and variables and means of treatments for the forage cactus variety 'Orelha de Elefante Mexicana'.

\begin{tabular}{|c|c|c|c|c|c|c|c|c|c|c|c|c|c|c|c|c|c|}
\hline \multirow{2}{*}{ PCs } & \multirow{2}{*}{$\lambda$} & \multirow{2}{*}{$\sigma^{2} \%$} & \multirow{2}{*}{$P$} & \multicolumn{14}{|c|}{ Factorial Loadings (r) } \\
\hline & & & & $\mathbf{N}^{1}$ & $\mathrm{P}^{1}$ & $\mathrm{~K}^{1}$ & $\mathrm{Ca}^{1}$ & $\mathrm{Mg}^{1}$ & $\mathrm{Na}^{1}$ & $\mathrm{Cl}^{1}$ & $\mathrm{~S}^{2}$ & $\mathrm{~B}^{2}$ & $\mathrm{Cu}^{2}$ & $\mathrm{Zn}^{2}$ & $\mathrm{Fe}^{2}$ & $\mathrm{Mn}^{2}$ & $\mathrm{BP}^{3}$ \\
\hline \multirow[t]{7}{*}{$\mathrm{PC}_{2}$} & 4.71 & 39.28 & $<0.001$ & 0.40 & 0.43 & $\mathrm{R}$ & -0.57 & $0.97^{*}$ & 0.63 & 0.04 & 0.52 & 0.01 & $0.68^{*}$ & $0.98^{*}$ & -0.20 & $-0.98^{*}$ & $\mathrm{R}$ \\
\hline & ETo & & & & & & & & & & Means & & & & & & \\
\hline & $25 \%$ & & & 23.80 & 0.22 & 16.82 & 44.50 & 23.98 & 3.22 & 57.24 & 93.44 & 95.32 & 15.96 & 26.79 & 126.10 & 803.63 & 280.55 \\
\hline & $50 \%$ & & & 18.03 & 0.17 & 16.12 & 49.50 & 21.74 & 2.13 & 61.48 & 63.76 & 102.69 & 12.74 & 22.33 & 104.73 & 1058.23 & 213.89 \\
\hline & $75 \%$ & & & 17.68 & 0.16 & 18.94 & 49.50 & 19.55 & 1.73 & 63.60 & 35.38 & 112.33 & 11.94 & 17.10 & 167.16 & 1262.35 & 686.10 \\
\hline & $100 \%$ & & & 17.50 & 0.18 & 22.66 & 48.00 & 21.53 & 2.12 & 64.66 & 98.60 & 78.88 & 9.86 & 22.99 & 81.13 & 1004.77 & 538.88 \\
\hline & $125 \%$ & & & 13.83 & 0.13 & 16.19 & 34.65 & 22.05 & 5.33 & 80.56 & 40.54 & 137.84 & 16.72 & 24.06 & 156.28 & 849.32 & 416.66 \\
\hline
\end{tabular}

PCs: principal components; $\lambda$ : eigenvalues; $\sigma^{2} \%$ : portion of the variance explained; $1:$ means in $\mathrm{g} \mathrm{kg}^{-1} ; 2: \mathrm{means} \mathrm{in} \mathrm{mg} \mathrm{kg}^{-1} ; 3:$ means in $\mathrm{t}$ $\mathrm{ha}^{-1}$; ETo: reference evapotranspiration; R: variable removed from principal component analysis; P: probability of the significance test by

Hotelling's test; and *: variables considered in the PC; $r=0.10-0.30$ (weak correlation); $r=0.40-0.60$ (moderate correlation); $r=0.70-1.00$ (strong correlation).

It was found that, in $\mathrm{PC}_{1}$, the forage cactus $\mathrm{OR}$ had higher relative accumulation of $\mathrm{N}, \mathrm{P}$ and $\mathrm{S}$ under $25 \%$ ETo replacement. Also in $\mathrm{PC}_{1}$, the OR variety obtained a higher $\mathrm{Ca}$ content with $50 \%$ ETo replacement, more substantial contents of $\mathrm{Na}, \mathrm{Cl}$ and $\mathrm{B}$ under $125 \% \mathrm{ETo}$, and higher accumulation of $\mathrm{Fe}$ when $75 \%$ ETo replacement. $\mathrm{In}_{2}$, the forage cactus variety $\mathrm{OR}$ had a higher relative accumulation of $\mathrm{Mg}$ and $\mathrm{Zn}$ with the replacement of $25 \%$ ETo, while higher relative contents of $\mathrm{Mn}$ and $\mathrm{Cu}$ were obtained in plants subjected to $75 \%$ and $125 \%$ ETo, respectively (Figure $3 \mathrm{~A}$ and B). K contents did not differ in response to the ETo replacement levels (Figure $3 \mathrm{C}$ ). Higher biomass productivity (BP) was obtained when 'Orelha de Elefante Meicana' was irrigated with 75\% ETo, showing intermediate productivity under replacements of 100 and $125 \%$ ETo and lower productivity under replacements of 25 and $50 \%$ ETo (Figure 3 D). 

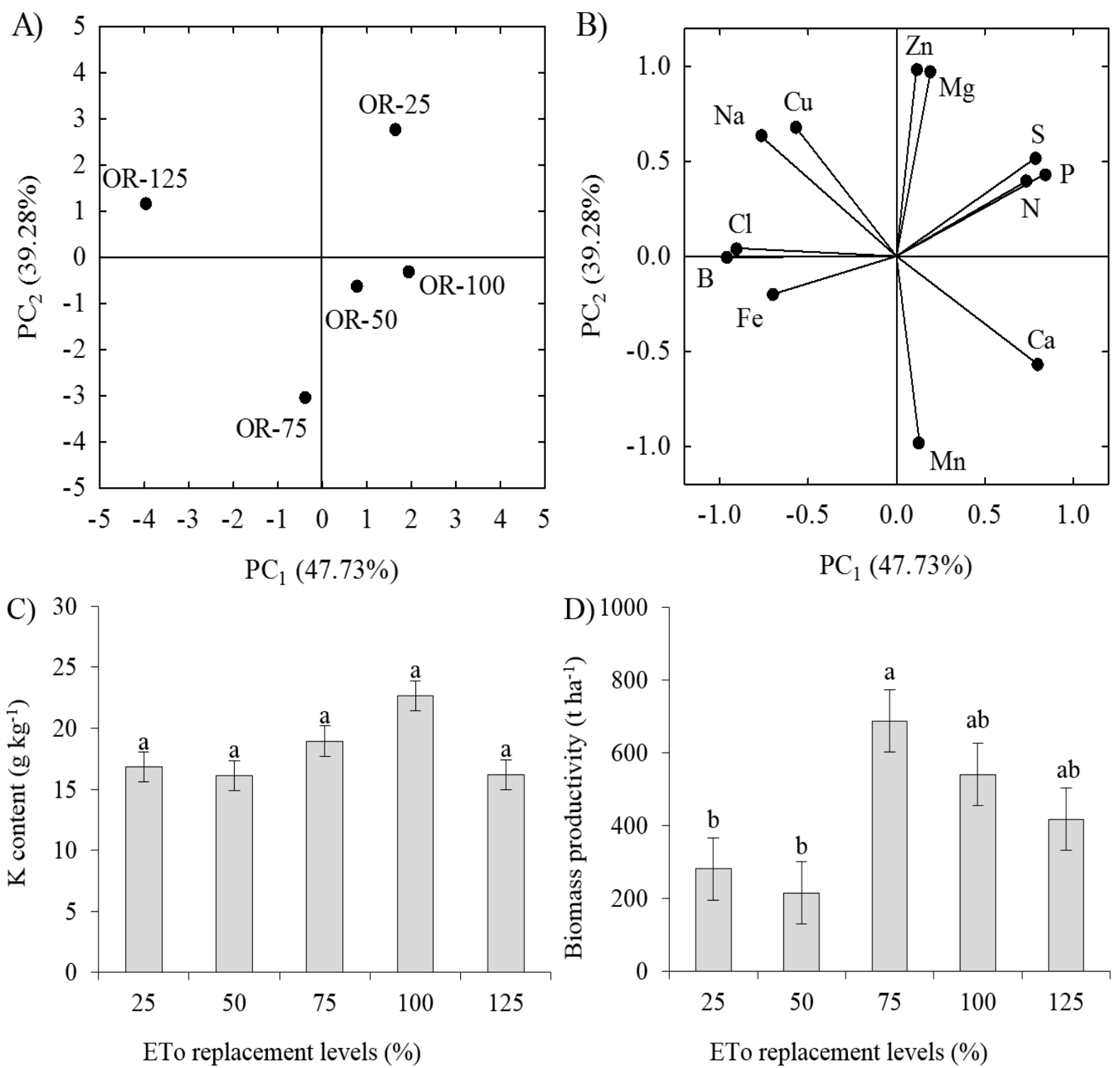

Figure 3. Two-dimensional projection (Biplot) of ETo replacement levels (A) and correlation of variables $(\mathrm{B})$ in the first two Principal Components $\left(\mathrm{PC}_{1}\right.$ and $\left.\mathrm{PC}_{2}\right), \mathrm{K}$ content $(\mathrm{C})$ and $\mathrm{BP}(\mathrm{D})$ for the forage cactus variety 'Orelha de Elefante Mexicana' under water replacement levels.

In the pertinent literature, the classic contents of macronutrients in forage cactus (Opuntia ficus-indica (L.) Mill), a species of the variety 'Orelha de Elefante Mexicana', in $\mathrm{g} \mathrm{kg}^{-1}$ of dry matter, are: N (6.7-20.6), P (0.8-4.7), K (23.0-33.4), Ca (14.9-42.0), Mg (5.9-14.0) and S (1.7$6.1)$; and the classic contents of micronutrients, in $\mathrm{mg} \mathrm{kg}^{-1}$ of dry matter, are: $\mathrm{Fe}$ (77.0-128.0), $\mathrm{Zn}$ (62.0-108.6), Mn (182.0-686.9), $\mathrm{Cu}$ (4.0-1 2.2), B (15.8-22.4) and $\mathrm{Na}$ (40.2-135.9) (Menezes et al., 2005; Silva et al., 2012).

The contents of $\mathrm{Ca}, \mathrm{Mg}, \mathrm{Na}, \mathrm{B}, \mathrm{Cu}$ and $\mathrm{Mn}$ in the variety 'Orelha de Elefante Mexicana' were higher than those reported in the literature, except for Ca contents under replacement of $125 \%$ ETo and $\mathrm{Cu}$ contents under replacements of 75 and $100 \%$ ETo, which are within the concentration range reported for the species. $\mathrm{N}$ and Fe contents are within the concentrations reported in the literature, except under replacement of $25 \%$ ETo, where the accumulation of $\mathrm{N}$ is higher, and under replacements of 75 and $100 \%$ ETo, where Fe contents are higher. The contents of $\mathrm{P}, \mathrm{K}, \mathrm{S}$ and $\mathrm{Zn}$ are below the concentration range.

The high contents of $\mathrm{Ca}, \mathrm{Mg}, \mathrm{Na}, \mathrm{B}, \mathrm{Cu}$ and $\mathrm{Mn}$ may be related to the greater availability of water and nitrogen in the soil due to fertigation, a situation that promotes the development 
of adaptation mechanisms for better absorption of water and nutrients in arid and semiarid regions (Edvan et al., 2013). There may have been a change in root structure, especially increase in the absorption surface, notably due to the inhibition of growth of the main root and stimulation of growth and density of lateral roots and root hairs, besides the increase in their diameter and hydraulic conductivity (Morgan and Connolly, 2013; Xia et al., 2018).

In addition to root changes, the greater supply of water and nitrogen may have increased water potential and turgor pressure in the cells, resulting in a higher concentration of organic solutes in the cytosol and extracellular matrices, a condition that leads to osmotic adjustment and may have influenced the transpiration flow and the consequent influx of water and nutrients into plants (Merwad et al., 2018). Indeed, the accumulation of $\mathrm{K}, \mathrm{Cl}, \mathrm{Na}$ and nitrate $\left(\mathrm{NO}_{3}-\right)$ may have stimulated cell elongation and division in the apical meristem region of lateral roots, contributing to greater growth and exploration of the soil profile and consequent interception and absorption of nutrients by the roots of the variety 'Orelha de Elefante Mexicana' (Taiz et al., 2017).

The reduction in phosphorus contents observed with the increment in ETo replacement levels are probably related to the leaching caused by the greater dissociation of phosphate granules and water percolation movement by mass flow, conditions that enabled phosphate movement between soil particles to deeper regions (Harger et al., 2007; Gonçalves et al., 2008; Costa et al., 2014).

In another perspective, there may have been adsorption and precipitation of $\mathrm{P}$ to soil particles and to organic matter, notably due to electrostatic or covalent bonds and the consequent formation of insoluble compounds, which makes the element unavailable for plants (Corrêa et al., 2011). Indeed, the increase in water supply in the soil may have promoted greater biomass accumulation in spontaneous plants (weed) and consequent increase in organic matter, which favors greater adsorption and complexation of $\mathrm{P}$ to $\mathrm{Fe}$ oxides, $\mathrm{Al}$ oxides and clay minerals, due to the occupation of adsorption sites (Abboud et al., 2018).

According to Silva (2017), the increase in ETo replacement levels associated with the greater availability of $\mathrm{N}$ via fertigation promoted greater accumulation of biomass in the cladodes of the forage cactus variety 'Orelha de Elefante Mexicana'. These increments in water and biomass may have favored greater remobilization of $\mathrm{P}$ in the cladode tissues, due to the high mobility of $\mathrm{P}$ in the plant (Luengo et al., 2018), which reflects greater nutrient dilution effect on parenchymatic tissues of the forage cactus (Dubeux Júnior et al., 2006).

The low K contents recorded in the variety 'Orelha de Elefante Mexicana' are possibly due to the leaching of the nutrient to deeper zones that are not explored by the root system. This information is ratified by Albuquerque et al. (2011), who mentioned that unabsorbed $\mathrm{K}$ is leached, and this process is responsible for up to $10 \%$ of $\mathrm{K}$ losses in the rhizosphere. It should be emphasized that the mobility of $\mathrm{K}^{+}$ions in the soil occurs primarily by diffusion, so the amount of $\mathrm{K}$ reaching the roots by mass flow is much lower than the absorption rate, justifying the low contents recorded even in irrigated cultivation (Neves et al., 2009).

Conversely, it is possible that excess salts in irrigation water $\left(\mathrm{C}_{3} \mathrm{~S}_{1}\right)$, besides limiting water availability, may have caused nutritional disorders in the plant, notably for preventing the absorption of $\mathrm{K}$, which converges to nutritional unbalance (Albuquerque et al., 2011). In this context, it can be inferred that there was an absorption of $\mathrm{Na}$ instead of $\mathrm{K}$, given the high $\mathrm{Na}$ content found in the cladode tissues. Indeed, Na may have acted on the enzymatic activation of ATPase, osmoregulation, absorption of macronutrients, cell permeability, carbohydrate synthesis, stomatal opening and closure, and in the transport of carbon dioxide (Inocencio et al., 2014).

The low contents of $\mathrm{S}$ in the cladodes may have occurred because excess water carried the nutrient to deeper layers, especially because of its high mobility in the soil. This is due to the high contents of $\mathrm{Na}$ from the irrigation water, which may have been linked to sulfate $\left(\mathrm{SO}_{4}{ }^{2-}\right)$, 
which can be confirmed by the increase in the solubilization of ions, such as $\mathrm{Ca}^{2+}$ and $\mathrm{Mg}^{2+}$, notably by the high contents of these nutrients found in the cladodes (Giordano and Raven, 2014; Araujo et al., 2015). The low contents of $\mathrm{Zn}$ in the cladodes may have occurred due to the greater supply of organic matter resulting from the increase of weed and consequent adsorption of this nutrient to the organic fraction or to $\mathrm{Fe}$ and $\mathrm{Al}$ oxides in the soil matrix (Smanhotto et al., 2010).

\section{CONCLUSIONS}

The mineral composition of the forage cactus varieties 'Miúda' and 'Orelha de Elefante Mexicana' can be optimized from soil water management, so as to obtain adequate nutritional balance for higher yield.

The replacement level of $75 \%$ ETo promoted greater balance between nutrients in the cladodes of the forage cactus variety 'Miúda', while 'Orelha de Elefante Mexicana' had better nutritional balance with the replacement levels of 100 and $125 \%$ ETo.

Soil water replacement levels of 100 and $125 \%$ ETo promote high accumulation of $\mathrm{Na}^{+}$ and $\mathrm{Cl}^{-}$ions in the cladodes of the forage cactus varieties studied.

Highest biomass productivity of the varieties 'Orelha de Elefante Mexicana' and 'Miúda' was obtained with 75 and 100\% ETo replacement levels, respectively.

Among the varieties, 'Orelha de Elefante Mexicana' had higher capacity to accumulate nutrients and biomass productivity, followed by 'Miúda' under the edaphoclimatic conditions of the Brazilian semiarid region.

\section{REFERENCES}

ABBOUD, F. Y.; FAVARETTO, N.; MOTTA, A. C. V.; BARTH, G.; GOULARTE, G. D. Phosphorus mobility and degree of saturation in oxisol under no-tillage after long-term dairy liquid manure application. Soil \& Tillage Research, v. 177, p. 45-53, 2018. https://doi.org/10.1016/j.still.2017.11.014

ALbUQUERQUE, F. da S.; SILVA, E. F. de F. e; SOUZA, A. E. R. de; ROLIM, M. M. Lixiviação de potássio em um cultivo de pimentão sob lâminas de irrigação e doses de potássio. Revista Caatinga, v. 24, n. 3, p. 135-144, 2011.

ARAUJO, J. L.; SEVERO, P. J. da S.; LUCENA, F. T. C.; VERIATO, R. G.; PAIVA, K. F. de. Enxofre elementar ou sulfato de cálcio para remediação de solos salino-sódicos? Pesquisa Agropecuária Tropical, v. 45, n. 4, p. 388-396, 2015. https://doi.org/10.1590/1983-40632015v4537090

BALOTA, E. L.; MACHINESKI, O.; STENZEL, N. M. C. Resposta da acerola à inoculação de fungos micorrízicos arbusculares em solo com diferentes níveis de fósforo. Bragantia, v. 70, n. 1, p. 166-175, 2011. https://doi.org/10.1590/S0006-87052011000100023

BATISTA, A. M. V.; MUSTAFA, A. F.; MCALliSTER, T.; WANG, Y.; SOITA, H.; MCKINNON, J. J. Effects of variety on chemical composition, in situ nutrient disappearance and in vitro gas production of spineless cacti. Journal of the Science of Food and Agriculture, v. 83, n. 5, p. 440-445, 2003. https://doi.org/10.1002/jsfa.1393

BENITES-LAZARO, L. L.; GIATTI, L. L.; SOUSA JUNIOR, W. C.; GIAROLLA, A. Landwater-food nexus of biofuels: Discourse and policy debates in Brazil. Environmental Development, v. 33, p. 100491, 2020. https://doi.org/10.1016/j.envdev.2019.100491 
CARDOSO, D. B.; CARVALHO, F. F. R.; MEDEIROS, G. R.; GUIM, A.; CABRAL, A. M. D.; VÉRAS, R. M. L.; SANTOS, K. C.; DANTAS, L. C. N.; NASCIMENTO, A. G. O. Levels of inclusion of spineless cactus (Nopalea cochenillifera Salm Dyck) in the diet of lambs. Animal Feed Science and Technology, v. 247, p. 23-31, 2019. https://doi.org/10.1016/j.anifeedsci.2018.10.016

CORRÊA, R. M.; NASCIMENTO, C. W. A.; ROCHA, A. T. Adsorção de fósforo em dez solos do Estado de Pernambuco e suas relações com parâmetros físicos e químicos. Acta Scientiarum. Agronomy, v. 33, n. 1, p. 153-159, 2011. https://doi.org/10.4025/actasciagron.v33i1.3129

COSTA, L. A. de M.; COSTA, M. S. S. de M.; PEREIRA, D. C. Lixiviação do fósforo do solo por meio de adubos fosfatados e palhas de plantas de cobertura. Revista Varia Scientia Agrárias, v. 4, n. 1, p. 23-37, 2014. https://doi.org/10.13140/RG.2.2.19333.96480

DANCEY, C.; REIDY, J. Estatística sem matemática para psicologia. Porto Alegre: Artmed, 2013. 608 p.

DUBEUX JÚNIOR, J. C. B.; SANTOS, M. V. F. dos; LIRA, M. de A.; SANTOS, D. C. dos; FARIAS, I.; LIMA, L. E.; FERREIRA, R. L. C. Productivity of Opuntia fícus-indica (L.) Mill., under different $\mathrm{N}$ and $\mathrm{P}$ fertilization and plant population in North- east Brazil. Journal of Arid Environments, v. 67, n. 3, p. 357-372, 2006. https://doi.org/10.1016/j.jaridenv.2006.02.015

EDVAN, R. L.; FERNANDES, P. D.; CARNEIRO, M. S. de S.; NEDER, D. G.; ARAUJO, J. S.; ANDRADE, A. P. de; SOUTO FILHO, L. T. Acúmulo de biomassa e crescimento radicular da palma forrageira em diferentes épocas de colheita. Revista Acadêmica: Ciências Agrárias e Ambientais, v. 11, n. 4, p. 373-381, 2013. http://dx.doi.org/10.7213/academico.011.004.AO04

EMBRAPA. Manual de análises químicas de solos, plantas e fertilizantes. 2. ed. rev. ampl. Brasília: Embrapa informação Tecnológica, 2009. 627 p.

FERRAZ, R. L. S; COSTA, P. S.; DANTAS NETO, J.; VIÉGAS, P. R. A.; MELO, A. S.; COSTA, F. S.; MEDEIROS, A. S.; MAGALHÃES, I. D.; LIMA, A. S.; CAVALCANTE JÚNIOR, C. A.; LIMA, V. L. A. Estimation of productivity gain by irrigated and fertilized forage palm plants (Opuntia ficus-indica (L.) Mill. and Nopalea cochenillifera (L.) SalmDyck): systematic review and meta-analysis. Australian Journal of Crop Science, v. 13, n. 11, p. 1873-1882, 2019.

FROTA, M. N. L.; CARNEIRO, M. S. de S.; CARVALHO, G. M. C.; ARAÚJO NETO, R. B. de. Palma Forrageira na Alimentação Animal. 21. ed. Teresina: Embrapa Meio-Norte, 2015. $47 \mathrm{p}$.

GERMANO, R. H.; BARBOSA, H. P.; COSTA, R. G.; MEDEIROS, A. N. Avaliação da composição química e mineral de seis cactáceas do semi-árido paraibano. In: REUNIÃO DA SOCIEDADE BRASILEIRA DE ZOOTECNIA, 28., 1991, João Pessoa. Anais[...] João Pessoa: Sociedade Brasileira de Zootecnia, 1991. p. 3.

GIORDANO, M.; RAVEN, J. A. Nitrogen and sulfur assimilation in plants and algae. Aquatic Botany, v. 118, p. 45-61, 2014. https://doi.org/10.1016/j.aquabot.2014.06.012

GONÇALVES, G. K.; SOUSA, R. O.; VAHL, L. C.; BORTOLON, L. Solubilização dos fosfatos naturais patos de minas e arad em dois solos alagados. Revista Brasileira de Ciência do Solo, v. 32, n. 5, p. 2157-2164, 2008. https://doi.org/10.1590/S010006832008000500036 
GOVAERTS, B.; SAYRE, K. D.; LICHTER, K.; DENDOOVEN, L.; DECKERS, J. Influence of permanent raised bed planting and residue management on physical and chemical soil quality in rain fed maize/wheat systems. Plant and Soil, v. 291, p. 39-54, 2007. https://doi.org/10.1007/s11104-006-9172-6

HAIR Jr., F. J.; BLACK, W. C.; BABIN, B. J.; ANDERSON, R. E.; TATHAM, R. L. Análise Multivariada de Dados. 6. ed. Porto Alegre: Bookman, 2009.

HARGER, N.; BRITO, O. R.; RALISCH, R.; ORTIZ, F. R.; WATANABE, T. S. Avaliação de fontes e doses de fósforo no crescimento inicial do milho. Semina: Ciências Agrárias, v. 28, n. 1, p. 39-44, 2007. https://doi.org/10.5433/1679-0359.2007v28n1p39

INOCENCIO, M. F.; CARVALHO, J. G. de; FURTINI NETO, A. E. Potássio, sódio e crescimento inicial de espécies florestais sob substituição de potássio por sódio. Revista Árvore, v. 38, n. 1, p. 113-123, 2014. https://doi.org/10.1590/S010067622014000100011

KÖPPEN, W.; GEIGER, R. Klimate der Erde. Gotha: Verlag Justus Perthes, 1928. Wall-map.

KRÜMPEL, J.; GEORGE, T.; GASSTON, B.; FRANCIS, G.; LEMMER, A. Suitability of Opuntia ficus-indica Opuntia ficus-indica (L) Mill. and Euphorbia tirucalli L. as energy crops for anaerobic digestion. Journal of Arid Environments, v. 174, p. 104047, 2020. https://doi.org/10.1016/j.jaridenv.2019.104047

LIGUORI, G.; GENTILE, C.; GAGLIO, R.; PERRONE, A.; GUARCELLO, R.; FRANCESCA, N.; FRETTO, S.; INGLESE, P.; SETTANNI, L. Effect of addition of Opuntia ficus-indica mucilage on the biological leavening, physical, nutritional, antioxidant and sensory aspects of bread. Journal of Bioscience and Bioengineering, $\mathrm{v}$. 129, n. 2, p. 184-191, 2020. https://doi.org/10.1016/j.jbiosc.2019.08.009

LUENGO, R. de F. A.; BUTRUILLE, N. M. dos S.; MELO, R. A. de C. e; SILVA, J. da; MALDONADE, I. R.; COSTA JÚNIOR, A. D. Determinação de minerais no solo e análise de folhas de couve produzida em Brasília. Brazilian Journal of Food Technology, v. 21, p. 1-9, 2018. https://doi.org/10.1590/1981-6723.14117

MEDEIROS, A. S.; MAIA, S. M. F.; SANTOS, T. C.; GOMES, T. C. A. Soil carbon losses in conventional farming systems due to land-use change in the Brazilian semi-arid region. Agriculture, Ecosystems \& Environment, v. 287, p. 106690, 2020. https://doi.org/10.1016/j.agee.2019.106690

MENEZES, R. S. C.; SIMÕES, D. A.; SAMPAIO, E. V. S. B. A palma no Nordeste do Brasil: conhecimento atual e novas perspectivas de uso. 2. ed. Recife: Editora Universitária da UFPE, 2005. $258 \mathrm{p}$.

MERWAD, A. R. M. A.; DESOKY, E. S. M.; RADY, M. M. Response of water deficit-stressed Vigna unguiculata performances to silicon, proline or methionine foliar application. $\begin{array}{llllll}\text { Scientia Horticulturae, } & \text { v. 228, } & \text { p. }\end{array}$ https://doi.org/10.1016/j.scienta.2017.10.008

MORGAN, J. B.; CONNOLLY, E. L. Plant-Soil Interactions: Nutrient Uptake. Nature Education Knowledge, v. 4, n. 8, 2013.

MOURA, M. S. C.; GUIM, A.; BATISTA, A. M. V.; MACIEL, M. V.; CARDOSO, D. B.; LIMA JÚNIOR, D. M.; CARVALHO, F. F. R. The inclusion of spineless cactus in the diet of lambs increases fattening of the carcass. Meat Science, v. 160, p. 107975, 2020. https://doi.org/10.1016/j.meatsci.2019.107975 
NEVES, L. S. das; ERNANI, P. R.; SIMONETE, M. A. Mobilidade de potássio em solos decorrente da adição de doses de cloreto de potássio. Revista Brasileira de Ciência do Solo, v. 33, p. 25-32, 2009. https://doi.org/10.1590/S0100-06832009000100003

OLIVEIRA, F. T. de; SOUTO, J. S.; SILVA, R. P. da; ANDRADE FILHO, F. C. de; PEREIRA JÚNIOR, E. B. Palma forrageira: adaptação e importância para os ecossistemas áridos e semiáridos. Revista Verde de Agroecologia e Desenvolvimento Sustentável, v. 5, n. 4, p. 27-37, 2010.

QUEIROZ, M. G.; SILVA, T. G. F.; ZOLNIER, S.; JARDIM, A. M. R. F.; SOUZA, C. A. A.; RAÚJO JÚNIOR, G. N.; MORAIS, J. E. F.; SOUZA, L. S. B. Spatial and temporal dynamics of soil moisture for surfaces with a change in land use in the semi-arid region of Brazil. Catena, v. 188, p. 104457, 2020. https://doi.org/10.1016/j.catena.2020.104457

REZENDE, F. M.; VÉRAS, A. S. C.; SIQUEIRA, M. C. B.; CONCEIÇÃO, M. G.; LIMA, C. L.; ALMEIDA, M. P.; MORA-LUNA, R. E.; NEVES, M. L. M. W.; MONTEIRO, C. C. F.; FERREIRA, M. A. Nutritional effects of using cactus cladodes (Opuntia stricta Opuntia stricta Haw Haw) to replace sorghum silage in sheep diet. Tropical Animal Health and Production, v. 52, p. 1875-1880, Edinburgh, 2020. https://doi.org/10.1007/s11250-02002213-w

SALEHI, E.; EMAM-DJOMEH, Z.; ASKARI, G.; FATHI, M. Opuntia ficus indica fruit gum: Extraction, characterization, antioxidant activity and functional properties. $\begin{array}{llllll}\text { Carbohydrate Polymers, } & \text { v. 206, p. } & \text { 565-572, }\end{array}$ https://doi.org/10.1016/j.carbpol.2018.11.035

SANTANA, R. A.; BEZERRA, S. T. M.; SANTOS, S. M.; COUTINHO, A. P.; COELHO, I. C. L.; PESSOA, R. V. S. Assessing alternatives for meeting water demand: A case study of water resource management in the Brazilian Semiarid region. Utilities Policy, v. 61, p. 100974, 2019. https://doi.org/10.1016/j.jup.2019.100974

SANTOS, C. A. C.; MARIANO, D. A.; NASCIMENTO, F. C. A.; DANTAS, F. R. C.; OLIVEIRA, G.; SILVA, M. T.; SILVA, L. L.; SILVA, B. B.; BEZERRA, B. G.; SAFA, B.; MEDEIROS, S. S.; NEALE, C. M. U. Spatio-temporal patterns of energy exchange and evapotranspiration during an intense drought for drylands in Brazil. International Journal of Applied Earth Observation and Geoinformation, v. 85, p. 101982, 2020. https://doi.org/10.1016/j.jag.2019.101982

SANTOS, D. C. dos; FARIAS, I.; LIRA, M. de A.; SANTOS, M. V. F. dos; ARRUDA, G. P. de; COELHO, R. S. B.; DIAS, F. M.; MELO, J. N. de. Manejo e utilização da palma forrageira (Opuntia e Nopalea) em Pernambuco. Recife: IPA, 2006. 48 p. (IPA. Documentos, 30).

SANTOS, D. R. dos; GATIBONI, L. C.; KAMINSKI, J. Fatores que afetam a disponibilidade do fósforo e o manejo da adubação fosfatada em solos sob sistema plantio direto. Ciência Rural, v. 38, n. 2, p. 576-586, 2008. https://doi.org/10.1590/S0103-84782008000200049

SANTOS, R. P. R. Avaliação da taxa de colonização por fungos micorrízicos arbusculares em solo em consórcio com resíduos de corte de granito e macrófitas aquáticas. Revista Gestão e Sustentabilidade Ambiental, v. 7, n. 2, p. 690-703, 2018. https://doi.org/10.19177/rgsa.v7e22018690-703 
SILVA, A. S.; SANTOS, E. M.; RAMOS, J. P. F.; PERAZZO, A. F.; MUNIZ, A. C. S.; SANTOS, F. N. S.; PEREIRA, D. M.; CRUZ, G. F. L. Características agronômicas de variedades de Opuntia cochenillifera e Nopalea cochenillifera sob diferentes densidades de plantio. Colloquium Agrariae, v. 15, n. 6, p. 88-96, 2019. https://doi.org/10.5747/ca.2019.v15.n6.a340

SILVA, J. A. da; BONOMO, P.; DONATO, S. L. R.; PIRES, A. J. V.; ROSA, R. C. C.; DONATO, P. E. R. Composição mineral em cladódios de palma forrageira sob diferentes espaçamentos e adubações química. Revista Brasileira de Ciências Agrárias, v. 7, p. 866-875, 2012. https://doi.org/10.5039/agraria.v7isa2134

SILVA, P. F. da. Crescimento e produtividade de palma forrageira sob diferentes lâminas de irrigação e adubação nitrogenada. 2017. 79f. Tese (Doutorado em Engenharia Agrícola) - Universidade Federal de Campina Grande, Campina Grande, 2017.

SMANHOTTO, A.; SOUSA, A. de P.; SAMPAIO, S. C.; NÓBREGA, L. H. P.; PRIOR, M. Cobre e zinco no material percolado e no solo com a aplicação de água residuária de suinocultura em solo cultivado com soja. Engenharia Agrícola, v. 30, n. 2, p. 346-357, 2010. https://doi.org/10.1590/S0100-69162010000200017

SNYMAN, H. A. A greenhouse study on root dynamics of cactus pears, Opuntia ficus-indica and Opuntia robusta. Journal of Arid Environments, v. 65, n. 4, p. 529-542, 2006. https://doi.org/10.1016/j.jaridenv.2005.10.004

TAIZ, L.; ZEIGER, E.; MOLLER, I. M.; MURPHY, A. Fisiologia e desenvolvimento vegetal. 6. ed. Porto Alegre: Artmed, 2017. 888 p.

WILCOX, C. S.; FERGUSON, J. W.; FERNANDEZ, G. C. J.; NOWAK, R. S. Fine root growth dynamics of four Mojave Desert shrubs as related to soil moisture and microsite. Journal of Arid Environments, v. 56, n. 1, p. 129-148, 2004. https://doi.org/10.1016/S01401963(02)00324-5

XIA, C.; CHRISTENSEN, M. J.; ZHANG, X.; NAN, Z. Effect of Epichloë gansuensis endophyte and transgenerational effects on the water use efficiency, nutrient and biomass accumulation of Achnatherum inebrians under soil water deficit. Plant and Soil, v. 424, n. 1-2, p. 555-571, 2018. https://doi.org/10.1007/s11104-018-3561-5

ZHOU, Y.; BASTIDA, F.; ZHOU, B.; SUN, Y.; GU, T.; LI, S.; LI, Y. Soil fertility and crop production are fostered by micro-nano bubble irrigation with associated changes in soil bacterial community. Soil Biology and Biochemistry, v. 141, p. 107663, 2020. https://doi.org/10.1016/j.soilbio.2019.107663 


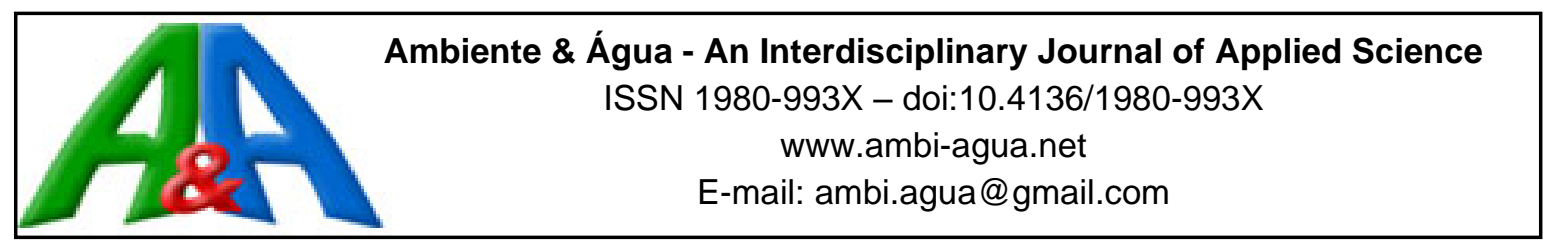

\title{
Influence of parent material on organic phosphorus fractions in vineyard soils in Santa Catarina, Brazil
}

\author{
ARTICLES doi:10.4136/ambi-agua.2546
}

Received: 26 Mar. 2020; Accepted: 23. Jun. 2020

\section{Shirlei Almeida Assunção ${ }^{10}$; Marcos Gervasio Pereira ${ }^{\text {*(D); }}$ Denilson Dortzbach ${ }^{2}$; Eduardo Carvalho da Silva Neto ${ }^{1}$ (D)}

\footnotetext{
${ }^{1}$ Departamento de Solos. Instituto de Agronomia. Universidade Federal Rural do Rio de Janeiro (UFRRJ), BR 465, km 7, CEP: 23897-000, Seropédica, RJ, Brazil.

E-mail: shirleiaassuncao@gmail.com, netocseduardo@gmail.com

${ }^{2}$ Centro de Informações de Recursos Ambientais e de Hidrometeorologia de Santa Catarina (CIRAM). Empresa de Pesquisa Agropecuária e Extensão Rural de Santa Catarina (EPAGRI), Rodovia Admar Gonzaga, n 1347, CEP: 88034-901, Florianópolis, SC, Brazil. E-mail: denilson@epagri.sc.gov.br

*Corresponding author. E-mail: mgervasiopereira01@gmail.com
}

\begin{abstract}
Phosphorus $(\mathrm{P})$ is an essential element for vineyard productivity. This study assessed the influence of parent material on organic $\mathrm{P}$ fractions in vineyard soils of basaltic and rhyodacitic origin. The experiment was conducted in four municipalities located in mountainous regions in Santa Catarina, Brazil: Urubici, São Joaquim, Campos Novos, and Água Doce. Disturbed soil samples were collected between grapevine rows at depths of $0.00-0.05,0.05-0.10,0.10-0.20$, and $0.20-0.40 \mathrm{~m}$. Soil chemical attributes ( $\mathrm{pH}$ in $\mathrm{H}_{2} \mathrm{O}, \mathrm{Ca}^{2+}, \mathrm{Mg}^{2+}, \mathrm{Al}^{3+}, \mathrm{P}, \mathrm{K}^{+}$, and $\mathrm{H}+\mathrm{Al}$ ), total organic carbon (TOC), available and residual $\mathrm{P}$, labile $\mathrm{P}$ (extracted with sodium bicarbonate), moderately labile $\mathrm{P}$ (extracted with sulfuric acid), and moderately resistant $\mathrm{P}$ (extracted with sodium hydroxide) were determined. Soil parent material influenced the dynamics of phosphorus in vineyard soils. Both $\mathrm{P}$ forms (available and solution equilibrium $\mathrm{P}$ ) and $\mathrm{P}$ organic fractions (labile, moderately labile, and moderately resistant $\mathrm{P}$ ), are affected by the parent material. Basaltic soils had higher TOC, available and residual $\mathrm{P}$, and moderately labile and moderately resistant $\mathrm{P}$, whereas rhyodacitic soils showed higher labile $\mathrm{P}$. The high levels of moderately labile and moderately resistant $\mathrm{P}$ fractions in basaltic soil were attributed to its high TOC, available $\mathrm{P}$, and residual $\mathrm{P}$ contents. Parent material was found to influence organic $\mathrm{P}$ fractions in vineyard soils.
\end{abstract}

Keywords: grapevine, organic carbon, soil acidity, soil management, wine.

\section{Influência do material de origem nas frações de fósforo orgânico em solos de vinhedos em Santa Catarina, Brasil}

\section{RESUMO}

O fósforo (P) é um elemento essencial para a produtividade dos vinhedos. Este estudo avaliou a influência do material de origem nas frações orgânicas de $\mathrm{P}$ em solos de vinhedos formados e áreas de solos origem basáltica e riodacítica. $\mathrm{O}$ estudo foi conduzido em quatro municípios localizados nas regiões montanhosas de Santa Catarina, Brasil: Urubici, São Joaquim, Campos Novos e Água Doce. Amostras de solo foram coletadas nas entrelinhas das 
videiras nas profundidades de $0,00-0,05,0,05-0,10,0,10-0,20$ e $0,20-0,40 \mathrm{~m}$. Foram avaliados os atributos químicos do solo ( $\mathrm{pH}$ em $\mathrm{H}_{2} \mathrm{O}, \mathrm{Ca}^{2+}, \mathrm{Mg}^{2+}, \mathrm{Al}^{3+}, \mathrm{P}, \mathrm{K}+\mathrm{e} \mathrm{H}+\mathrm{Al}$ ), carbono orgânico total (COT), $\mathrm{P}$ disponível e residual, $\mathrm{P}$ lábil (extraído com bicarbonato de sódio), moderadamente lábil (extraído com ácido sulfúrico) e P moderadamente resistente (extraído com hidróxido de sódio). Nas áreas de solos formados a partir de material de origem de natureza basáltica foram verificados os maiores teores de COT, $\mathrm{P}$ disponível e residual, e $\mathrm{P}$ moderadamente lábil e moderadamente resistente, enquanto naqueles formados a partir de rochas como riodacitos observaram-se valores de $\mathrm{P}$ lábil mais elevados. Os altos níveis das frações $\mathrm{P}$ moderadamente lábeis e moderadamente resistentes nos solos formados a partir de basalto foram atribuídos ao seu alto COT, P disponível e conteúdo residual de P. Verificou-se que o material de origem dos solos influencia as frações orgânicas de P nos solos dos vinhedos.

Palavras-chave: acidez do solo, carbono orgânico, manejo do solo, videira, vinho.

\section{INTRODUCTION}

Brazil is the fifth-largest wine producer in the Southern Hemisphere and has one of the fastest-growing wine markets in the world, with over 79 thousand hectares of vineyards (Ibravin, 2018). Wine production is mainly concentrated in the southern region, where, in addition to being an important economic activity, it has a significant sociocultural value. In 2012, 21 million liters of wine were produced in Santa Catarina, 72.57\% of which was table wine (Mello, 2013).

Grapes produced in Santa Catarina differ from those produced in other regions of the country because of the unique climate characteristics of the state. Santa Catarina's mild summers allow grapevines to have a long growth cycle and reach full maturation, important factors to produce high-quality wines (Borghezan et al., 2011). The organoleptic properties, quality, and types of wine are influenced by viticultural and enological practices (human factors) as well as geographical and environmental factors, such as soil, vegetation, and climate (Tonietto, 2001). High altitudes affect night temperatures at harvest, resulting in a more complete phenolic maturation and, thus, better product quality (Camargo et al., 2011).

The importance of soil quality for grapevine cultivation is recognized by most producers; however, it is considered of secondary importance compared with climate and viticultural techniques (Santos, 2006). Adequate nutrient and soil management can contribute greatly to increasing yield and quality of grapes and, consequently, of wine. These aspects denote the importance of using a land agricultural suitability evaluation system adapted to this crop and its management (Dortzbach et al., 2016).

Phosphorus (P) is essential for crop productivity (Liu et al., 2017). In Santa Catarina, the cold and humid climate favors the leaching of base cations, leading to an increase in the levels of exchangeable aluminum (Al) and soil acidity (Almeida et al., 2000) and a consequent decrease in $\mathrm{P}$ availability. $\mathrm{P}$ fractions have very complex dynamics influenced by soil texture (Tokura et al., 2011), fertilization (Cereta et al., 2010), management (Guareschi et al., 2015), and biotic and abiotic factors (Resende et al., 2011). P occurs in organic and inorganic forms in soil. Inorganic $\mathrm{P}$ is soluble or bound to soil organic matter (SOM) or mineral fractions (Shen et al., 2011).

High-altitude soils in the state of Santa Catarina naturally present nutritional limitations, and phosphorus is the most limiting macronutrient, whose application to the soil is required for the crop to express its maximum productive potential (Dortzbach et al., 2016). Very low and very high phosphorus contents can cause problems to grape production. This nutrient is important for the formation of the canopy, fruiting, root development. It favors wort fermentation and strengthens the aroma and flavor of wines (Regina et al., 2006). 
Considering the importance of $\mathrm{P}$ for the production and management of vineyards, this study aimed to assess the influence of different soil parent materials on organic $\mathrm{P}$ fractions in vineyard soils.

\section{MATERIAL AND METHODS}

The study area is located within the Serra Geral Formation. It comprises four municipalities located in mountainous regions of the state of Santa Catarina, Brazil: Urubici, São Joaquim, Campos Novos and Água Doce. The region is a major producer of quality wine from highaltitude regions in the state of Santa Catarina (Dortzbach et al., 2016).

The soil parent material consists of rocks with different levels of resistance to weathering, such as basalt and rhyodacite. The region's primary characteristic is its heterogeneity caused by different magma cooling conditions which act on the textural and mineralogical composition of each geological deposition (Dortzbach et al., 2016). The geomorphology is characterized by two geomorphological units which occur, the Planalto dos Campos Gerais that is distributed in the landscape as isolated blocks, and the Planalto Dissecado Rio Iguaçu/Rio Uruguai (Santa Catarina, 1986).

The dominant soil types in Urubici, São Joaquim, and Água Doce are Dystric Cambisols associated with Rhodic Nitisols and Litholic Neosols (FAO, 2015). In Campos Novos, the soils are predominantly Rhodic Nitisols associated with Dystric Cambisols and Rhodic Latosols (FAO, 2015). In general, these soils are characterized by high acidity, high Al levels, and high SOM accumulation in surface horizons.

The local climate is humid subtropical with mild summers ( $\mathrm{Cfb}$ in the Köppen climate classification). Rainfall is evenly distributed throughout the year, and there are no dry seasons. The average temperature of the warmest month is below $22^{\circ} \mathrm{C}$. The primary vegetation is subtropical forest, particularly Araucaria forests, a type of mixed ombrophilous forest that extends from the coastal mountains to the Santa Catarina Plateau, mainly at elevations above $500 \mathrm{~m}$. Subtropical grasslands are the dominant vegetation of the Santa Catarina Plateau (Santa Catarina, 1986).

The sampled sites included six vineyards planted in 2001-2005 for wine production from three different rural properties. In each property, a vineyard with basaltic (VB) and rhyodacitic (VR) soil was sampled. Disturbed soil samples were collected between grapevine rows at the $0.00-0.05,0.05-0.10,0.10-0.20$, and $0.20-0.40 \mathrm{~m}$ depths, comprising the plowing soil layer. At each sampling point, five samples were taken from each depth, forming composite samples. Samples were identified and packed in plastic bags, transported to the laboratory, air-dried, ground, and sieved through $2 \mathrm{~mm}$ sieves to obtain air-dried fine earth for analysis.

Total organic carbon (TOC) was quantified according to Yeomans and Brenner (1988). The following parameters were determined: $\mathrm{pH}$ in $\mathrm{H}_{2} \mathrm{O}$ (1:2.5 ratio); available $\mathrm{P}$ and $\mathrm{K}^{+}$, extracted with Mehlich-1 $\left(0.0125 \mathrm{~mol} \mathrm{~L}^{-1} \mathrm{H}_{2} \mathrm{SO}_{4}\right.$ and $\left.0.050 \mathrm{~mol} \mathrm{~L}^{-1} \mathrm{HCl}\right)$; exchangeable $\mathrm{Ca}^{2+}$, $\mathrm{Mg}^{2+}$, and $\mathrm{Al}^{3+}$, extracted with $1 \mathrm{~mol} \mathrm{~L}^{-1} \mathrm{KCl}$; and $\mathrm{H}+\mathrm{Al}$, extracted with $0.5 \mathrm{~mol} \mathrm{~L}{ }^{-1}$ calcium acetate (pH 7) and titrated with $0.0125 \mathrm{~mol} \mathrm{~L}^{-1} \mathrm{NaOH}$ (Teixeira et al., 2017).

Solution equilibrium $P$ was determined according to Alvarez and Fonseca (1990). Five cubic centimeters of air-dried fine earth was added to $0.01 \mathrm{~mol} \mathrm{~L}^{-1} \mathrm{CaCl}_{2}$ and $60 \mathrm{mg} \mathrm{L}^{-1} \mathrm{P}$ for $1 \mathrm{~h}$. After agitation, solid and liquid phases were separated, and the solution equilibrium $\mathrm{P}$ concentration was determined in the equilibrium solution by the molybdenum blue/ascorbic acid method. Sample absorbance was read using a spectrophotometer (Braga and Defelipo, 1974).

The extraction and quantification of $\mathrm{P}$ fractions in the soil was done according to the method proposed by Bowman (1989). In summary, the $\mathrm{P}$ fractionation method is based on the sequential extraction of labile, moderately labile and moderately resistant forms in a sample of $1.00 \mathrm{~g}$ of air-dried fine earth, in which the Po and Pi forms are separated according to their 
availability to plants using, sequentially, extractors from the lowest to the highest extraction intensity. Labile phosphorus is extracted with $0.5 \mathrm{~mol} \mathrm{~L}^{-1} \mathrm{NaHCO}_{3}$ at $\mathrm{pH} 8$; moderately labile phosphorus is extracted with $0.5 \mathrm{~mol} \mathrm{~L}^{-1} \mathrm{H}_{2} \mathrm{SO}_{4}$; and moderately resistant phosphorus is extracted with $0.5 \mathrm{~mol} \mathrm{~L}^{-1} \mathrm{NaOH}$.

The determination of the $\mathrm{P}$ of each fraction is obtained by colorimetry method, after the reduction of the phosphomolybdic complex with ascorbic acid, in the presence of bismuth salt (Teixeira et al., 2017). The total $\mathrm{P}$ in each fraction is determined in an aliquot that was submitted to perchloric digestion and inorganic $\mathrm{P}$ in undigested extracts (Bowman, 1989). Organic $\mathrm{P}$ was calculated as total $\mathrm{P}$ minus inorganic $\mathrm{P}$.

This is a measurement study based on pseudo-replication and, therefore, data do not meet the assumptions of conventional experimental designs. Data $(n=4)$ were subjected to descriptive analysis, and results are presented as mean and standard error.

\section{RESULTS AND DISCUSSION}

The chemical attributes of vineyard soils are presented in Figure 1 . The mean $\mathrm{pH}$ value was $6.22 \pm 0.20$ in the vineyards with basaltic soils (VB) and $5.86 \pm 0.13$ in the vineyards with rhyodacitic soils (VR) (Figure 1a). Soils were limed to this $\mathrm{pH}$ because of their acidic nature; in some cases, liming was performed even after planting. At all depths, the highest $\mathrm{Al}^{3+}$ values were found in rhyodacitic soils (mean $\mathrm{Al}^{3+}=0.44 \pm 0.17 \mathrm{cmol}_{\mathrm{c}} \cdot \mathrm{dcm}^{-3}$ ) (Figure $1 \mathrm{~b}$ ). In vineyards with basaltic soils the mean value was $\mathrm{Al}^{3+}=0.16 \pm 0.09 \mathrm{cmol}_{\mathrm{c}} \cdot \mathrm{dcm}^{-3}$. The levels of $\mathrm{Al}^{3+}$ increased from the $0.00-0.05 \mathrm{~m}$ to the $0.05-0.10 \mathrm{~m}$ layer, decreasing sharply at higher depths, especially in rhyodacitic soils. High $\mathrm{Al}^{3+}$ levels were probably due to the characteristics of the parent material. Rhyodacite is an acidic rock; thus, its weathering results in soil with high levels of bases, which are easily leached under humid conditions, favoring the accumulation of $\mathrm{Al}^{3+}$ in the soil solution (Dortzbach et al., 2016; Clemente and Azevedo, 2007).

Basaltic soils showed higher levels of $\mathrm{Ca}^{2+}$ at all depths (mean $\mathrm{Ca}^{2+}$ in $\mathrm{VB}=9.09 \pm 0.50$ $\mathrm{cmol}_{\mathrm{c}} \cdot \mathrm{dcm}^{-3}$ and $\mathrm{Ca}^{2+}$ in $\mathrm{VR}=6.09 \pm 0.42 \mathrm{cmol}_{\mathrm{c}} \cdot \mathrm{dcm}^{-3}$ ). In all soils the $\mathrm{Ca}^{2+}$ levels were higher in the $0.10-0.20 \mathrm{~m}$ depth than in the $0.05-0.10 \mathrm{~m}$ depth layer. Similarly, $\mathrm{Mg}^{2+}$ contents were higher in basaltic soils (mean $\mathrm{Mg}^{2+}$ in $\mathrm{VB}=5.30 \pm 0.28 \mathrm{cmol}_{\mathrm{c}} \cdot \mathrm{dcm}^{-3}$ and mean $\mathrm{Mg}^{2+}$ in $\mathrm{VR}=$ $\left.2.93 \pm 0.38 \mathrm{cmol}_{\mathrm{c}} \cdot \mathrm{dcm}^{-3}\right)$. Also, the highest $\mathrm{Mg}^{2+}$ levels were observed at the $0.05-0.10$ and $0.10-0.20 \mathrm{~m}$ depths. $\mathrm{K}^{+}$levels were also higher in the vineyards with basaltic soils (mean $\mathrm{K}^{+}$in $\mathrm{VB}=1.23 \pm 0.26 \mathrm{cmol}_{\mathrm{c}} \cdot \mathrm{dcm}^{-3}$ and mean $\mathrm{K}^{+}$in $\mathrm{VR}=0.46 \pm 0.09 \mathrm{cmol}_{\mathrm{c}} \cdot \mathrm{dcm}^{-3}$ ) and decreased with soil depth. These results are similar to those observed in other studies conducted in southern Brazil (Dortzbach et al., 2016; Almeida et al., 2000; Clemente and Azevedo, 2007).

The $\mathrm{H}+\mathrm{Al}$ contents ranged from 2.5 to $4.0 \mathrm{cmol}_{\mathrm{c}} \mathrm{dcm}^{-3}$ (mean $\mathrm{H}+\mathrm{Al}$ in $\mathrm{VB}=2.43 \pm 0.19$ $\mathrm{cmol}_{\mathrm{c}} \cdot \mathrm{dcm}^{-3}$ and mean $\mathrm{H}+\mathrm{Al}$ in $\left.\mathrm{VR}=3.51 \pm 0.25 \mathrm{cmol}_{\mathrm{c}} \cdot \mathrm{dcm}^{-3}\right)$. Up to the $0.20 \mathrm{~m}$ depth, $\mathrm{H}+\mathrm{Al}$ levels were higher in basaltic soils, whereas at the $0.20-0.40 \mathrm{~m}$ depth, levels were higher in rhyodacitic soils. $\mathrm{H}+\mathrm{Al}$ levels are positively correlated with $\mathrm{SOM}$; that is, a high $\mathrm{H}+\mathrm{Al}$ content indicates a high SOM content (Simas et al., 2005). The reduction in TOC with depth (Figure 2) corroborates the low $\mathrm{H}+\mathrm{Al}$ levels observed in subsoil layers. TOC levels (20-35 $\left.\mathrm{g} \mathrm{kg}^{-1}\right)$ were higher in basaltic soils at all depths (mean TOC in $\mathrm{VB}=28.1 \pm 5.8 \mathrm{~g} \cdot \mathrm{kg}^{-1}$ and mean TOC in $\mathrm{VR}=24.7 \pm 4.1 \mathrm{cmol}_{\mathrm{c}} \cdot \mathrm{dcm}^{-3}$ ). This difference was particularly pronounced at the $0.10-0.20 \mathrm{~m}$ depth.

Soil TOC levels generally decrease with depth, as surface layers are high in biological activity and plant litter. However, tillage or other soil preparation techniques can alter this profile, leading to higher TOC levels in subsurface layers. The differences in TOC levels between vineyard soils of different origins may be explained by the basic nature of basalt. Soils formed on basic parent material have a more clayey texture, which decreases organic carbon oxidation, whether by adsorption of organic molecules on clay or by aggregate formation 
(Dieckow et al., 2009; Dalmolin et al., 2006).
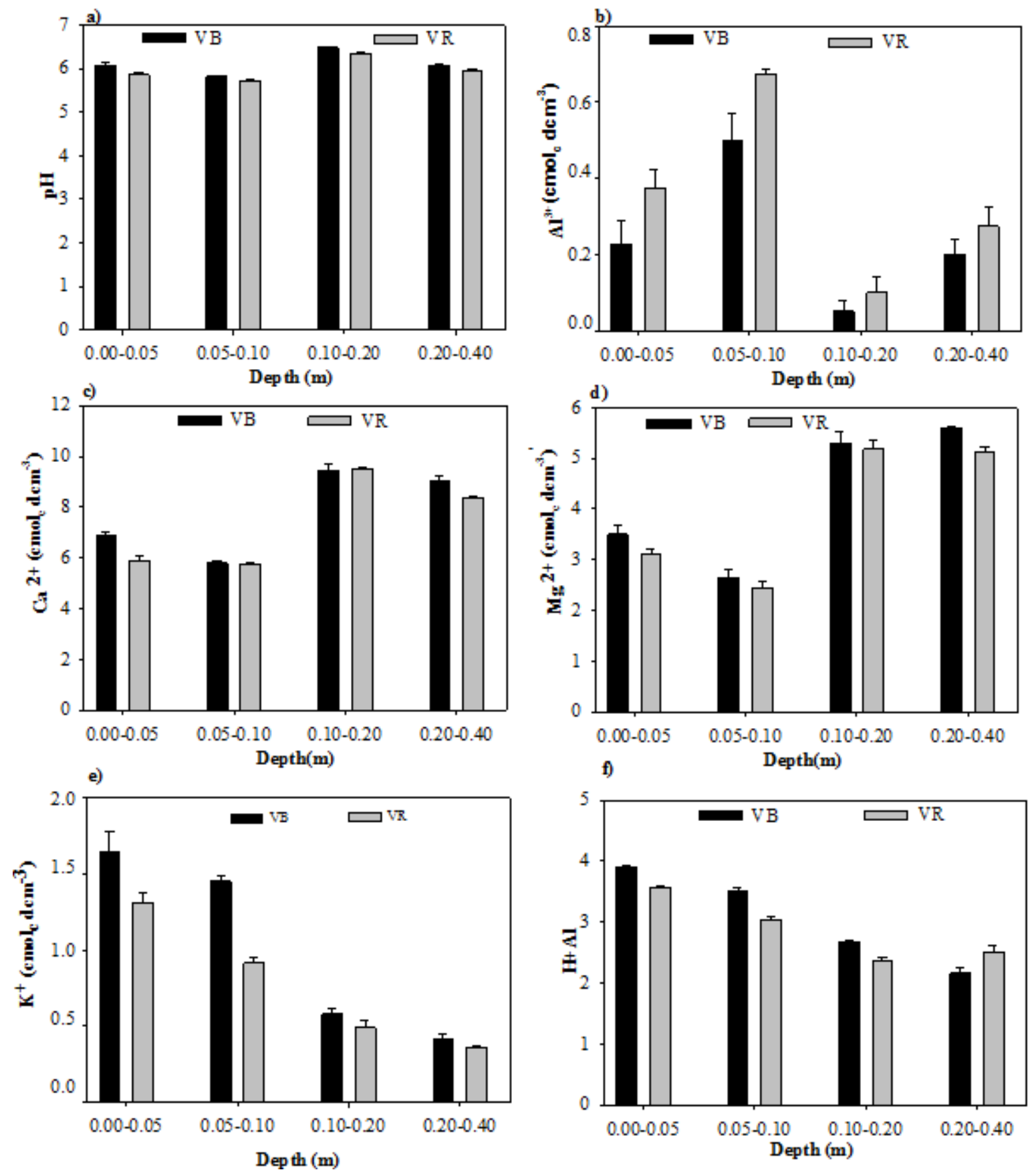

Figure 1. Chemical attributes of vineyard soils of basaltic (VB) and rhyodacitic (VR) origin at depths of $0.00-0.05,0.05-0.10,0.10-0.20$, and $0.20-0.40 \mathrm{~m}$.

Available and solution equilibrium $P$ levels are presented in Figure 3. Available P levels ranged from 6 to $10 \mathrm{mg} \mathrm{kg}^{-1}$ (Figure 3a). Available $\mathrm{P}$ was highest at the $0.20 \mathrm{~m}$ depth in basaltic soil. At the $0.20-0.40 \mathrm{~m}$ depth, both types of soil showed similar available P levels. The higher available $\mathrm{P}$ content in basaltic soil can be explained by $\mathrm{P}$ fertilization and decomposition of basaltic rock. Both factors contribute to an increased level of exchangeable bases in soil, thereby influencing the amount of available $\mathrm{P}$ (Dieckow et al., 2009). This assumption is supported by the higher concentrations of $\mathrm{Ca}^{2+}$ and $\mathrm{Mg}^{2+}$ at the $0.10-0.20$ and $0.20-0.40 \mathrm{~m}$ depths (Figure $1 \mathrm{c}$ and $\mathrm{d})$. 


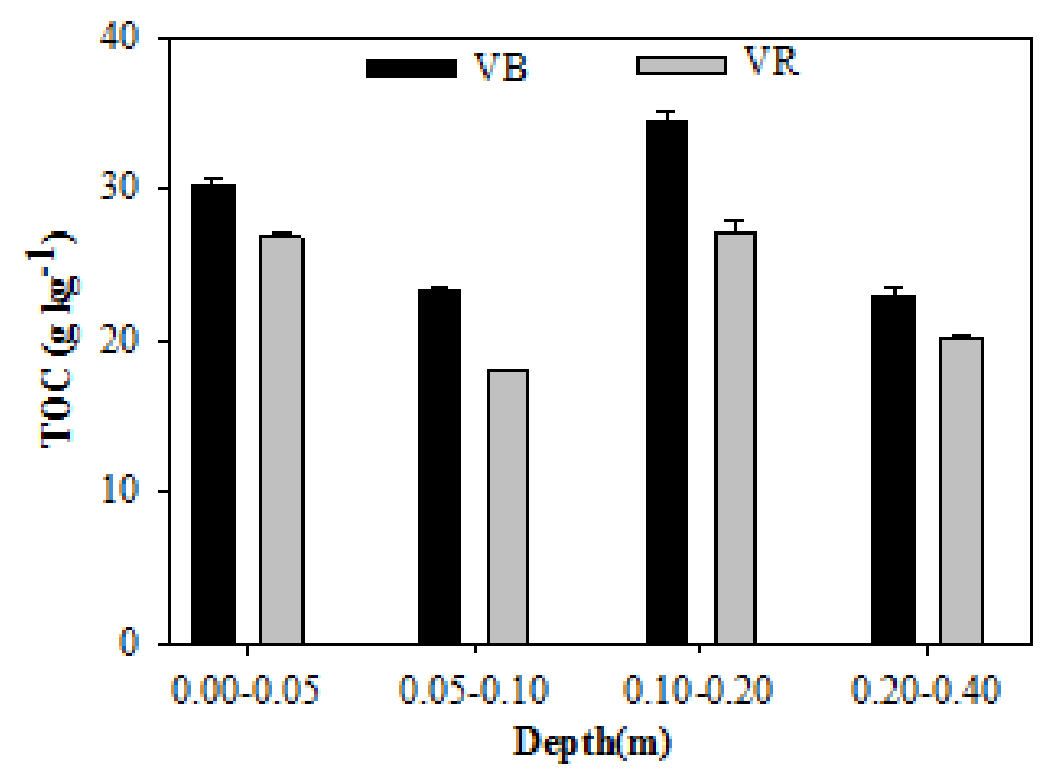

Figure 2. Total organic carbon (TOC) content in vineyard soils of basaltic (VB) and rhyodacitic (VR) origin at depths of $0.00-0.05$, $0.05-0.10,0.10-0.20$, and $0.20-0.40 \mathrm{~m}$.
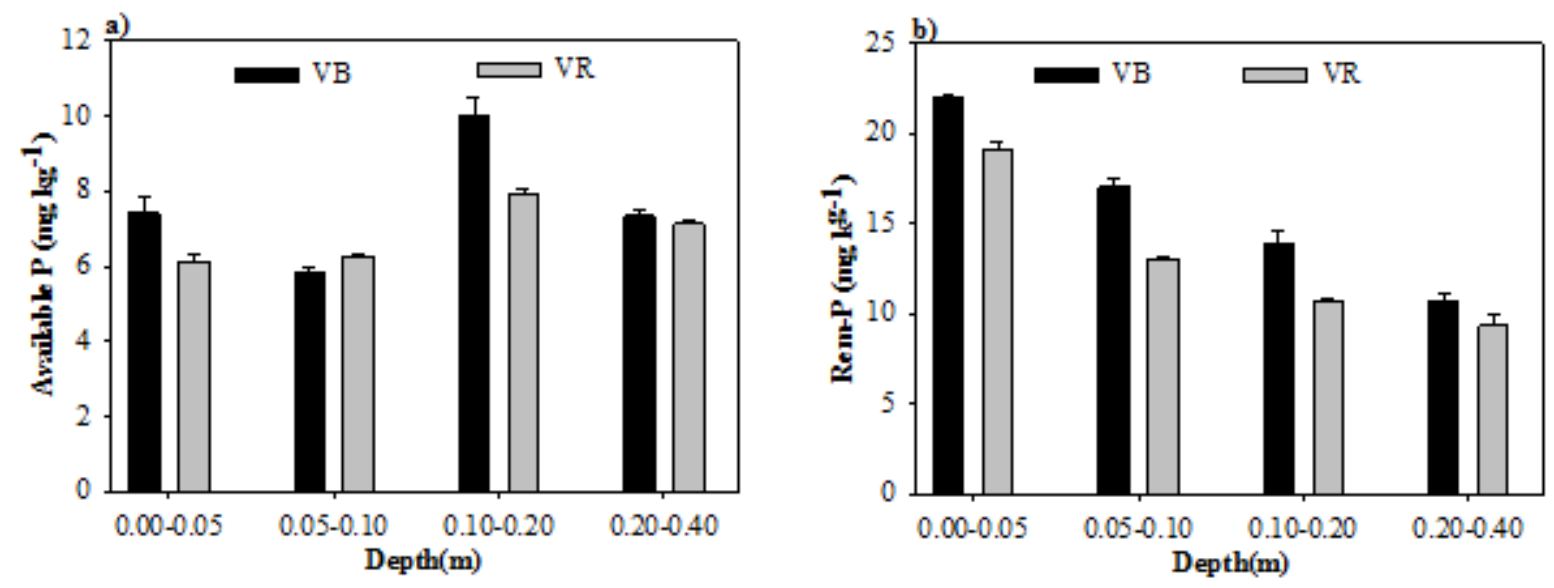

Figure 3. Available and solution equilibrium $P$ contents in vineyard soils of basaltic (VB) and rhyodacitic (VR) origin at depths of $0.00-0.05,0.05-0.10,0.10-0.20$, and $0.20-0.40 \mathrm{~m}$.

Solution equilibrium $\mathrm{P}$ contents (10-23 $\mathrm{mg} \mathrm{kg}^{-1}$ ) (Figure $2 \mathrm{~b}$ ) were highest in basaltic soil at all layers and decreased with increasing depth. $\mathrm{P}$ adsorption is greater in oxidic and acid soils because of the strong interactions between Fe and $\mathrm{Al}$ oxides and phosphate (Dortzbach et al., 2016; Almeida et al., 2010).

$\mathrm{P}$ is found in organic and inorganic forms in soil. The predominance of one form over the other varies with the solubility of ionic species. P can form highly stable compounds with SOM and mineral fractions (Shen et al., 2011). Organic P forms are important sources of $\mathrm{P}$ for plants; they comprise microbial biomass and compounds released during organic matter decomposition with varying degrees of recalcitrance (Nash et al., 2014).

Figure 4 shows the levels of labile $\mathrm{P}$ extracted with sodium bicarbonate. Total $\mathrm{P}$ extracted with sodium bicarbonate ranged from 100 to $550 \mathrm{mg} \mathrm{kg}^{-1}$ (Figure 4a) and was higher in basaltic soil at $0.05-0.020 \mathrm{~m}$ depths. Inorganic $\mathrm{P}$ was higher in basaltic than in rhyodacitic soil at all depths; the highest levels were found at the $0.00-0.05 \mathrm{~m}$ depth $\left(>100 \mathrm{mg} \mathrm{kg}^{-1}\right.$, Figure $\left.4 \mathrm{~b}\right)$. Organic $\mathrm{P}$ was higher in rhyodacitic soil at the $0.00-0.05 \mathrm{~m}$ depth but higher in basaltic soil at other depths, ranging from 80 to $500 \mathrm{mg} \mathrm{kg}^{-1}$ (Figure 4c). 

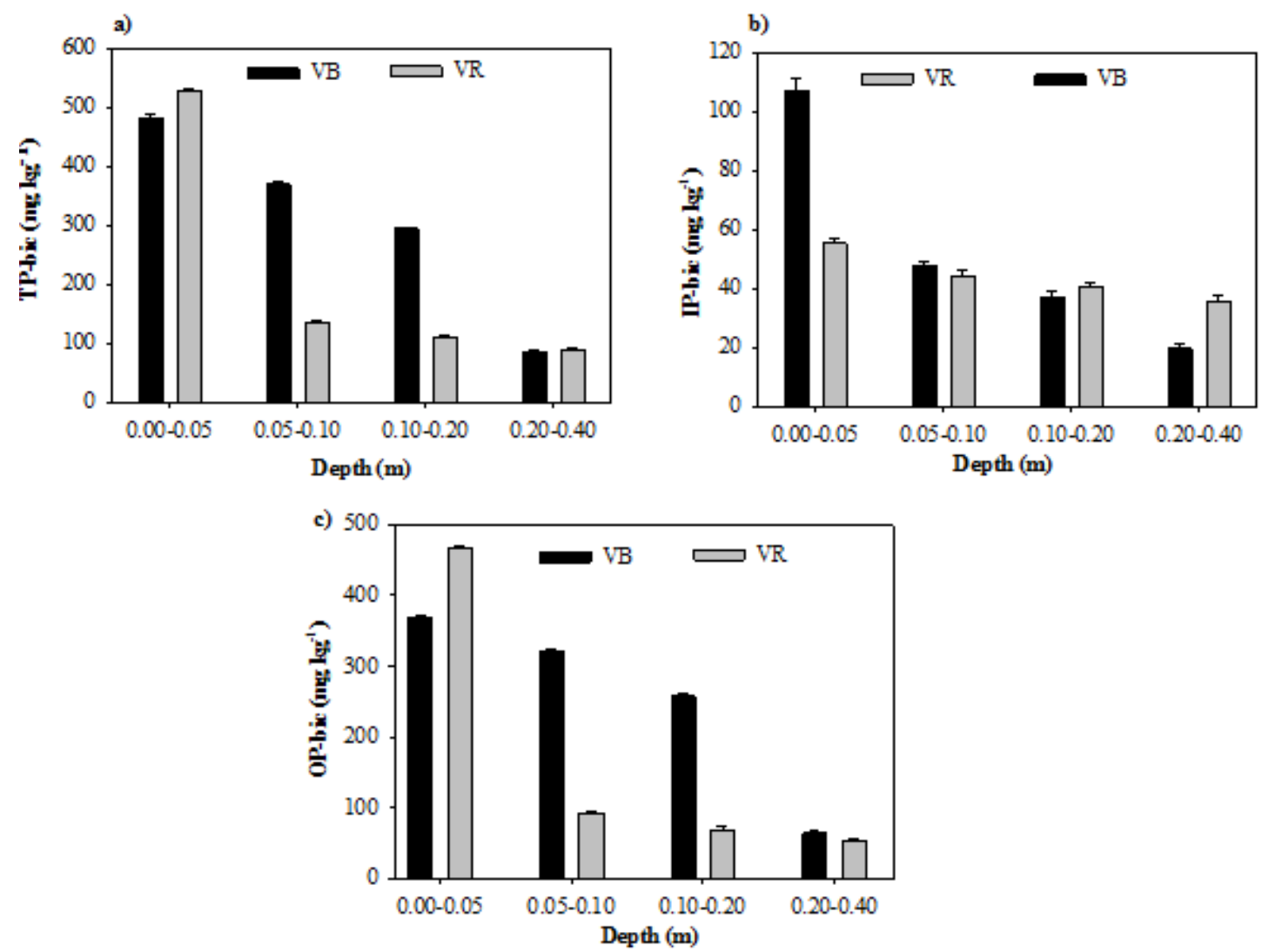

Figure 4. Labile phosphorus $(\mathrm{P})$ fraction in vineyard soils of basaltic $(\mathrm{VB})$ and rhyodacitic (VR) origin at depths of $0.00-0.05,0.05-0.10,0.10-0.20$, and $0.20-0.40 \mathrm{~m}$. TP-bic, total P extracted with sodium bicarbonate $\left(\mathrm{NaHCO}_{3}\right)$; IP-bic, inorganic $\mathrm{P}$ extracted with $\mathrm{NaHCO}_{3}$; OP-bic, organic P extracted with $\mathrm{NaHCO}_{3}$.

P extracted with sodium bicarbonate is considered highly stable (Bowman and Cole, 1978). The high levels of $\mathrm{P}$ fractions extracted with sodium bicarbonate in basaltic soil can be attributed to $\mathrm{P}$ turnover, which was more intense in this soil because of the use of phosphate fertilizers (Gatiboni et al., 2008). Phosphate fertilization contributes to P lability, resulting from the gradual saturation of high-affinity $\mathrm{P}$ adsorption sites (Bravo et al., 2007). Labile $\mathrm{P}$ is essential for grapevine growth because it increases nutrient availability for plants (Schmitt et al., 2013).

In tropical climate regions, $\mathrm{P}$ occurs mostly in inorganic forms linked to mineral fractions (adsorbed P) and organic forms that are physically and chemically stable (Santos et al., 2008). Labile $\mathrm{P}$ is mainly found in the organic form. The higher levels of labile $\mathrm{P}$ in surface layers is likely due to the presence of plant litter, phosphate fertilizer, microbial biomass, and byproducts of their decomposition (Schmitt et al., 2013; Martinazzo et al., 2007).

$\mathrm{P}$ fractions extracted with $\mathrm{H}_{2} \mathrm{SO}_{4}$ are moderately labile (Bowman and Cole, 1978). Total $\mathrm{P}$ contents in the moderately labile fraction ranged from 200 to $600 \mathrm{mg} \mathrm{kg}^{-1}$ (Figure 5a), inorganic $\mathrm{P}$ contents from 30 to $90 \mathrm{mg} \mathrm{kg}^{-1}$ (Figure 5b), and organic $\mathrm{P}$ contents from 100 to $500 \mathrm{mg} \mathrm{kg}^{-1}$ (Figure 5c). The major part of moderately labile $\mathrm{P}$ occurred in the organic form. In general, rhyodacitic soil had higher levels of moderately labile $\mathrm{P}$ in all layers, except for total and organic $\mathrm{P}$ at the $0.10-0.20$ and $0.20-0.40 \mathrm{~m}$ depths.

The higher P levels in the moderately labile fraction of rhyodacitic soil can be attributed to its lower clay content. This leads to low $\mathrm{P}$ adsorption, contributing to the presence of moderately labile $\mathrm{P}$ fractions. When $\mathrm{P}$ is applied to the soil in higher quantities than that absorbed by plants, it accumulates in moderately labile forms, affecting $\mathrm{P}$ uptake. However, when $\mathrm{P}$ is applied in small quantities, moderately labile $\mathrm{P}$ can act as a source of $\mathrm{P}$, meeting the nutrient demands of 
the crop (Schmitt et al., 2013; Gatiboni et al., 2008).
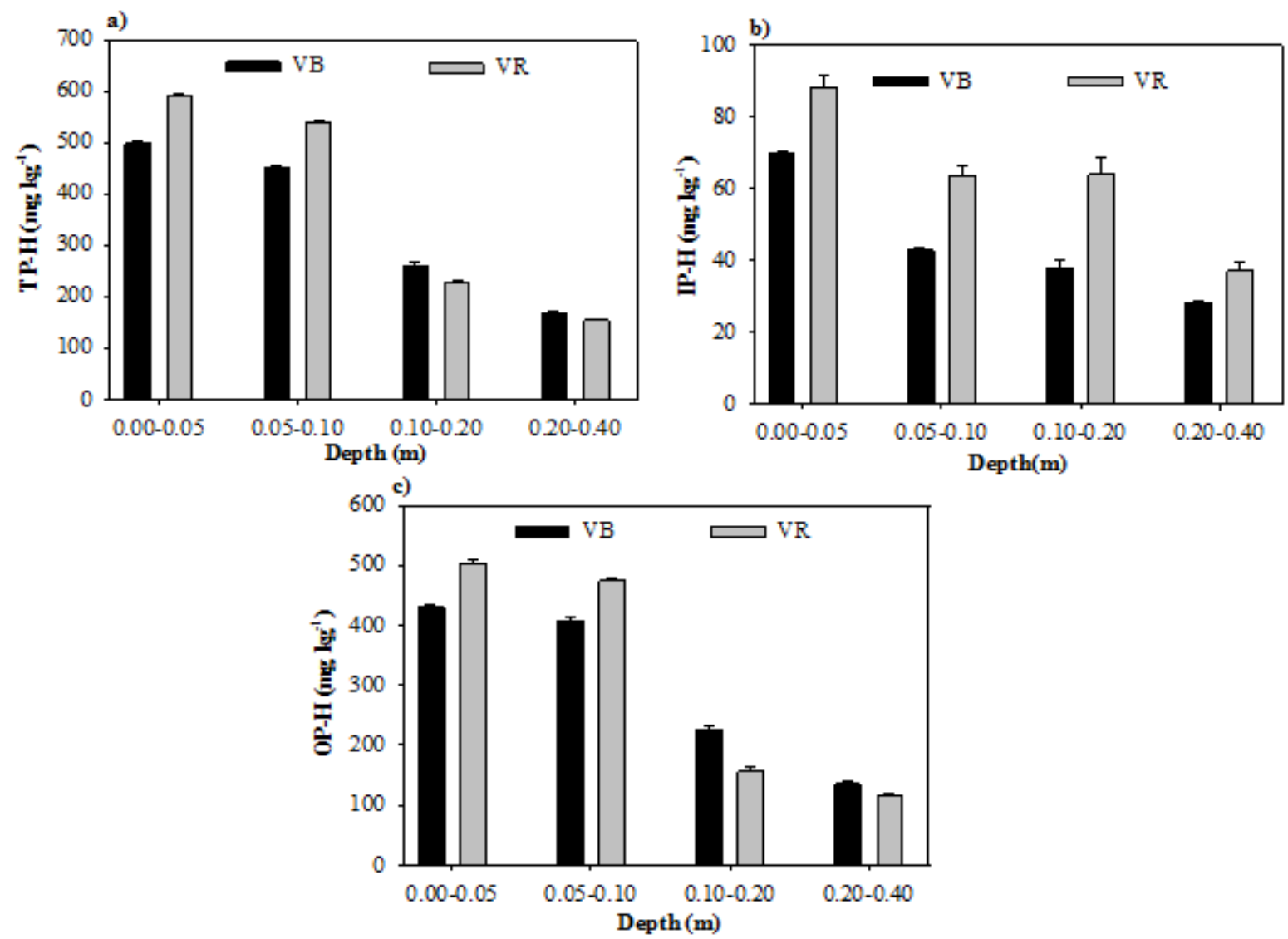

Figure 5. Moderately labile phosphorus $(\mathrm{P})$ fraction in vineyard soils of basaltic (VB) and rhyodacitic (VR) origin at depths of $0.00-0.05,0.05-0.10,0.10-0.20$, and $0.20-0.40 \mathrm{~m}$. TP-H, total $\mathrm{P}$ extracted with sulfuric acid $\left(\mathrm{H}_{2} \mathrm{SO}_{4}\right)$; IP-H, inorganic P extracted with $\mathrm{H}_{2} \mathrm{SO}_{4}$; OP-H, organic $\mathrm{P}$ extracted with $\mathrm{H}_{2} \mathrm{SO}_{4}$.

The degree of stability of the P forms is influenced by the microbial activity, the content of organic matter in the soil, the degree of weathering, the texture and mineralogical composition of the soil (Rheinheimer and Anghinoni, 2001). In general, the most prevalent forms of $\mathrm{P}$ in Brazilian soils are the slightly labile inorganic ones, because in the intensely weathered tropical soils the cycling of organic phosphorus from labile fractions is intense and accelerated.

$\mathrm{P}$ fractions extracted with $\mathrm{NaOH}$ are moderately resistant, as reported by Bowman and Cole (1978). In highly weathered soil, $\mathrm{P}$ usually occurs in moderately recalcitrant forms, which are highly correlated with $\mathrm{Fe}$ and $\mathrm{Al}$ oxides, kaolinite, and organic matter (Conte et al., 2003). Total P levels in the moderately resistant fraction (100-250 mg kg${ }^{-1}$, Figure 6a) were higher in basaltic soil at the $0.00-0.05 \mathrm{~m}$ depth. At other depths, both types of soil showed similar total $\mathrm{P}$ levels. Inorganic P contents ranged from 50 to $200 \mathrm{mg} \mathrm{kg}^{-1}$ (Figure $6 \mathrm{~b}$ ) and were higher in basaltic soils at all depths. Different from that observed in labile and moderately labile $\mathrm{P}$ fractions, inorganic fractions were more predominant than organic fractions. Organic $\mathrm{P}$ contents ranged from 55 to $70 \mathrm{mg} \mathrm{kg}^{-1}$ (Figure 6c); levels were highest at the $0.05-0.10 \mathrm{~m}$ depth in rhyodacitic soil but did not differ between soils at the $0.00-00.05 \mathrm{~m}$ depth.

The higher levels of moderately resistant $\mathrm{P}$ in basaltic soil can be explained by the high TOC content (Figure 2), as this fraction is highly correlated with SOM (Cunha et al., 2007; Beutler et al., 2015). The clayey texture of the soil may also have influenced the results. In the soil, phosphorus can be found in inorganic and organic forms, representing two large groups, 
retained in clay minerals and present in organic compounds with varying degrees of energy. Organic phosphorus originates from organic residues added to the soil, from the tissue of microbial biomass and from its decomposition products. The biological and biochemical processes regulate the dynamics and distribution of $\mathrm{P}$ in the edaphic system, and the recycling of the organic form is an important factor in making this macronutrient available to vegetables (Rossi et al., 2013).
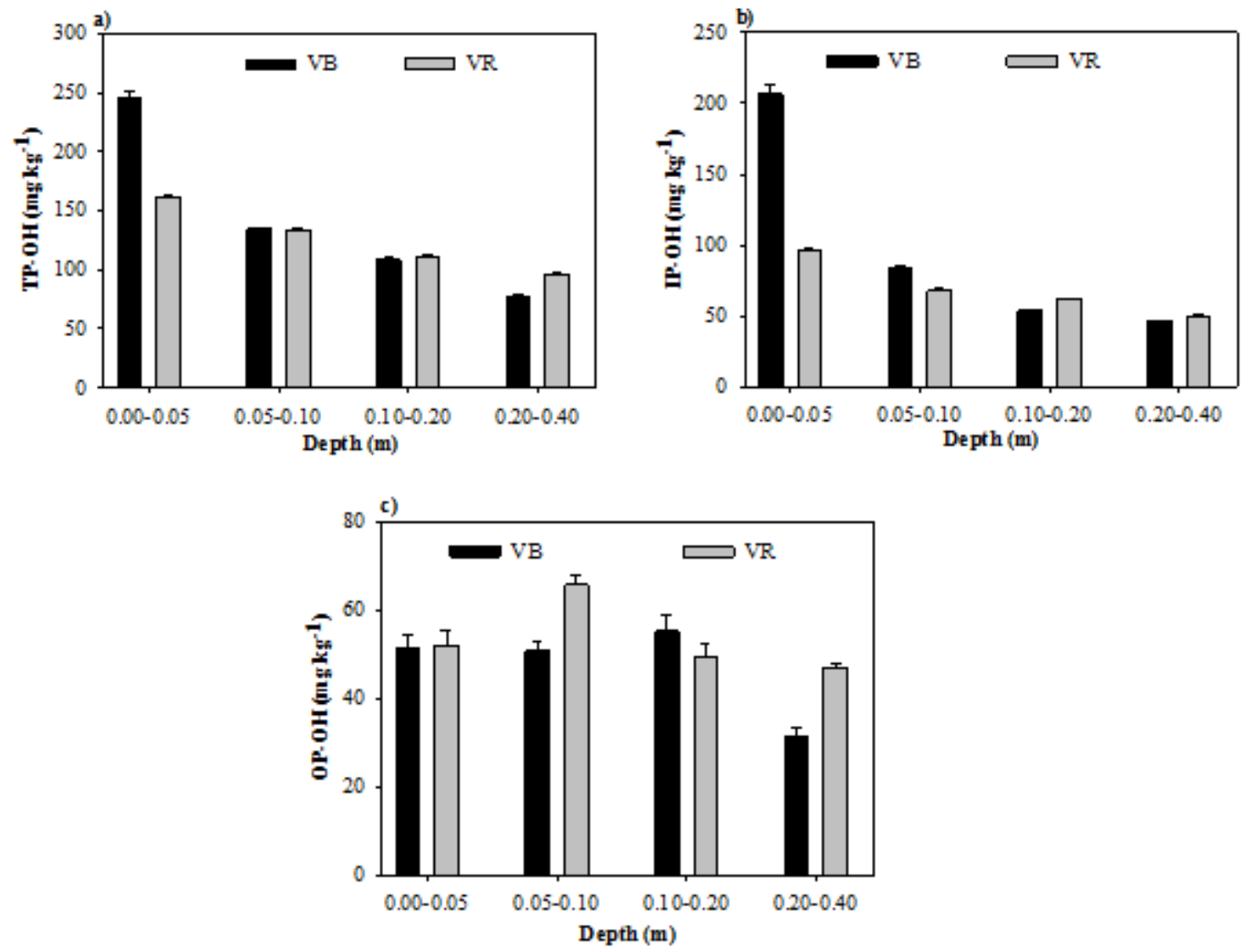

Figure 6. Moderately resistant phosphorus $(\mathrm{P})$ fraction in vineyard soils of basaltic $(\mathrm{VB})$ and rhyodacitic (VR) origin at depths of $0.00-0.05,0.05-0.10,0.10-0.20$, and $0.20-0.40 \mathrm{~m}$. TP$\mathrm{OH}$, total $\mathrm{P}$ extracted with sodium hydroxide $(\mathrm{NaOH})$; IP-OH, inorganic P extracted with $\mathrm{NaOH}$; OP-OH, organic $\mathrm{P}$ extracted with $\mathrm{NaOH}$.

\section{CONCLUSIONS}

Soil parent material influenced the dynamics of phosphorus in vineyard soils. Both $\mathrm{P}$ forms (available and solution equilibrium $\mathrm{P}$ ) and $\mathrm{P}$ organic fractions (labile, moderately labile, and moderately resistant $\mathrm{P}$ ), are affected by the parent material. Vineyard soils of basaltic origin contained higher levels of labile and moderately labile $\mathrm{P}$, whereas vineyard soils of rhyodacitic origin had higher levels of moderately resistant $\mathrm{P}$. The predominance of the more labile $\mathrm{P}$ fractions in basaltic vineyard soil may be related to the higher TOC and available and solution equilibrium $\mathrm{P}$ contents.

\section{ACKNOWLEDGEMENTS}

This study was financed in part by the Brazilian Federal Agency for Support and Evaluation of Graduate Education (CAPES, Finance Code 001). 


\section{REFERENCES}

ALMEIDA, J. A.; MAÇANEIRO, K. C.; KLAMT, E. Mineralogia da fração argila de solos vermelhos com horizontes superficiais brunados do Planalto de Lages (SC). Revista Brasileira de Ciência do solo, v. 24, p. 815-828, 2000. https://doi.org/10.1590/S010006832000000400014

ALVAREZ, V. H.; FONSECA, D. M. Definição de doses de fósforo para determinação da capacidade máxima de adsorção de fosfatos e para ensaios em casa de vegetação. Revista Brasileira de Ciência do Solo, v. 14, p. 49-55, 1990. https://doi.org/10.1590/S010390162007000600007

BEUTLER, S. J.; PEREIRA, M. G.; LOSS, A.; PERIN, A.; CUNHA dos ANJOS, L. H. Humic substances and phosphorus fractions in areas with crop-livestock integration, pasture and natural Cerrado vegetation in Goiás, Brazil. Tropical and Subtropical Agroecosystems, v. 18, n. 1, p. 11-25, 2015.

BORGHEZAN, M.; GAVIOLI, O.; PIT, F. A.; SILVA, A. L. da. Comportamento vegetativo e produtivo da videira e composição da uva em São Joaquim, Santa Catarina. Pesquisa. Agropecuária Brasileira, v. 46, n. 4, p. 398-405, 2011. https://doi.org/10.1590/S0100204X2011000400009

BOWMAN, R. A. A sequential extraction procedure with concentrated sulfuric acid and dilute base for soil organic phosphorus. Soil Science Society of America Journal, v. 53, p. 326-366, 1989. https://dx.doi.org/10.2136/sssaj1989.03615995005300020008x

BOWMAN, R. A.; COLE, C. V. Transformation of organic phosphorus substrates in soil as evaluated by $\mathrm{NaHCO}_{3}$ extraction. Soil Science, v. 125, p. 95-101, 1978.

BRAGA, J. M.; DEFELIPO, B. V. Determinação espectrofotométrica de fósforo em extratos de solo e material vegetal. Revista Ceres, v. 21, p. 73-85, 1974.

BRAVO, C. A.; GIRALDEZ, J. V.; ORDOÑEZ, R.; GONZALEZ, P.; TORRES, F. P. Long term influence of conservation tillage on chemical properties of surface horizon and legume crops yield in a Vertisol of Southern Spain. Soil Science, v. 172, n. 2, p. 141-148, 2007. https://dx.doi.org/10.1097/ss.0b013e31802db198

CAMARGO, U. A.; TONIETTO, J.; HOFFMANN, A. Progressos na viticultura brasileira. Revista Brasileira de Fruticultura, v. 33, p. 144-149, 2011. https://doi.org/10.1590/S0100-29452011000500017

CERETA, C. A.; LORENSINI, F.; BRUNETTO, G.; GIROTTO, E.; GATIBONI, L. C.; LOURENZI, C. R.; TIECHER, T. L.; TRENTIN, G.; MIOTTO, A. Frações de fósforo no solo após sucessivas aplicações de dejetos de suínos em plantio direto. Pesquisa Agropecuária Brasileira, v. 45, p. 593-602, 2010. https://doi.org/10.1590/S0100204X2010000600009

CLEMENTE, C. A.; AZEVEDO, A. C. Mineral weathering in acid saprolites from subtropical, Southern Brazil. Scientia Agricola, v. 64, p. 601-607, 2007. https://doi.org/10.1590/S0103-90162007000600007 
CONTE, E.; ANGHINONI, I.; RHEINHEIMER, D. S. Frações de fósforo acumuladas em Latossolo argiloso pela aplicação de fosfato no sistema plantio direto. Revista Brasileira de Ciência do Solo, v. 27, n. 5, p. 893-900, 2003. https://doi.org/10.1590/S010006832003000500014

CUNHA, G. D. M.; da GAMA-RODRIGUES, A. C.; COSTA, G. S.; VEllosO, A. C. X. Fósforo orgânico em solos sob florestas montanas, pastagens e eucalipto no norte fluminense. Revista Brasileira de Ciência do Solo, v. 31, n. 4, p. 667-672, 2007. https://doi.org/10.1590/S0100-06832007000400007

DALMOLIN, R. S. D.; GONÇALVES, C. N.; DICK, D. P.; KNICKER, H.; KLAMT, E.; KÖGEL-KNABNER, I. Organic matter characteristics and distribution in Ferralsol profiles of a climosequence in southern Brazil. European Journal of Soil Science, v. 57, n. 5, p. 644-654, 2006. https://doi.org/10.1111/j.1365-2389.2005.00755.x

DIECKOW, J.; BAYER, C.; CONCEIÇÃO, P. C.; ZANATTA, J. A.; MARTIN-NETO, L.; MILORI, D. B. M.; HERNANI, L. C. Land use, tillage, texture and organic matter stock and composition in tropical and subtropical Brazilian soils. European Journal of Soil Science, v. 60, n. 2, p. 240-249, 2009. https://doi.org/10.1111/j.1365-2389.2008.01101.x

DORTZBACH, D.; PEREIRA, M. G.; ANJOS, L. H. C. D.; FONTANA, A.; SILVA NETO, E. D. C. Genesis and classification of soils from subtropical mountain regions of southern Brazil. Revista Brasileira de Ciência do Solo, v. 40, p. 1-16, 2016. https://doi.org/10.1590/18069657rbcs20150503

FAO. World reference base for soil resources 2014: International soil classification system for naming soils and creating legends for soil maps: Update 2015. Rome, 2015.

GATIBONI, L. C.; BRUNETTO, G.; KAMINSKI, J.; RHEINHEIMER, D. S.; CERETTA, C. A.; BASSO, C. J. Formas de fósforo no solo após sucessivas adições de dejeto líquido de suínos em pastagem natural. Revista Brasileira de Ciência do Solo, v. 32, p. 1753-1761, 2008. https://doi.org/10.1590/S0100-06832008000400040

GUARESCHI, R. F.; PEREIRA, M. G.; PERIN, A. Adsorption of P and forms of iron in notillage areas in the 'Cerrado' biome. Acta Scientiarum Agronomy, v. 37, n. 1, p. 109116, 2015. http://dx.doi.org/doi:10.4025/actasciagron.v37i1.17686

IBRAVIN. Panorama Geral. 2018. Available at: http://www.ibravin.org.br/panorama-geral. Access: 12 Sep. 2019.

LIU, S.; MENG, J.; JIANG, L.; YANG, X.; LAN, Y.; CHENG, X.; CHEN, W. Rice husk biochar impacts soil phosphorus availability, phosphatase activities and bacterial community characteristics in three different soil types. Applied Soil Ecology, v. 116, p. 12-22, 2017. https://doi.org/10.1016/j.apsoil.2017.03.020

MARTINAZZO, R.; RHEINHEIMER, D. S.; GATIBONI, L. C.; BRUNETTO, G.; KAMINSKI, J. Fósforo microbiano do solo sob sistema plantio direto em resposta à adição de fosfato solúvel. Revista Brasileira de Ciência do Solo, v. 31, p. 563-570, 2007. https://dx.doi.org/10.1590/S0100-06832007000300016

MELLO, L. M. R. de. Vitivinicultura Brasileira: panorama 2012. Bento Gonçalves: Embrapa Uva e Vinho, 2013. 
NASH, D. M.; HAYGARTH, P. M.; TURNER, B. L.; CONDRON, L. M.; MCDOWELL, R. W.; RICHARDSON, A. E.; HEAVEN, M. W. Using organic phosphorus to sustain pasture productivity: a perspective. Geoderma, v. 221, p. 11-19, 2014. https://doi.org/10.1016/j.geoderma.2013.12.004

NOVAIS, R. F.; SMYTH, T. J.; NUNES, F. N. Fósforo. In: NOVAIS, R. F.; ALVAREZ V.; V. H.; BARROS, N. F.; FONTES, R. L. F.; CANTARUTTI, R. B.; NEVES, J. C. L. (Eds.) Fertilidade do solo. Viçosa, MG: SBCS, 2007. p. 471-537.

REGINA, M. A.; FRÁGUAS, J. C.; ALVARENGA, A.; SOUZA, C. R.; AMORIM, D.; FÁVERO, R. Implantação e manejo do vinhedo para produção de vinhos de qualidade. Informe Agropecuário, v. 27, n. 234, p. 16-31, 2006. https://doi.org/10.1590/S010029452011000500017

RESENDE, J. C. F.; BUSTAMANTE, M. M. C.; MARKEWITZ, D.; KLINK, C. A.; DAVIDSON, E. A. Phosphorus cycling in a small watershed in the Brazilian Cerrado: impacts of frequent burning. Biogeochemistry, v. 105, p. 105-118, 2011. https://doi.org/10.1007/s10533-010-9531-5

RHEINHEIMER, D. S.; ANGHINONI, I. Distribuição do fósforo inorgânico em sistemas de manejo de solo. Pesquisa Agropecuária Brasileira, v. 36, n. 1, p. 151-160, 2001. https://doi.org/10.1590/S0100-204X2001000100019

ROSSI, C. Q.; PEREIRA, M. G.; GARCÍA, A. C.; PERIN, A.; GAZOLlA, P. R.; GONZÁLEZ, A. P. Fósforo em cronossequência de cana-de-açúcar queimada no cerrado goiano: análise de ácidos húmicos por RMN de 31P. Química Nova, v. 36, n. 8, p. 11261130, 2013. https://doi.org/10.1590/S0100-40422013000800009

SANTA CATARINA. Gabinete de Planejamento e Coordenação Geral. Subchefia de Estatística, Geografia e Informática. Atlas de Santa Catarina. Florianópolis, 1986. 173p.

SANTOS, H. P. Aspectos ecofisiológicos na condução da videira e sua influência na produtividade do vinhedo e na qualidade dos vinhos. Bento Gonçalves: Embrapa Uva e Vinho, 2006. 9 p. (Comunicado Técnico, 71).

SANTOS, J. Z. L.; FURTINI NETO, A. E.; RESENDE, Á.V.; CURI, N.; CARNEIRO, L. F.; COSTA, S. E. V. G. A. Frações de fósforo em solo adubado com fosfatos em diferentes modos de aplicação e cultivado com milho. Revista Brasileira de Ciência do Solo, v. 32, p. 705-714, 2008. https://doi.org/10.1590/S0100-06832008000200025

SCHMITT, D. E.; COMIN, J. J.; GATIBONI, L. C.; TIECHER, T.; LORENSINI, F.; MELLO, G. W. B.; GIROTTO, E.; GUARDINI, R.; HEINZEN, J.; BRUNETTO, G. Phosphorus fractions in sandy soils of vineyards in southern Brazil. Revista Brasileira de Ciência do Solo, v. 37, p. 472-481, 2013. https://doi.org/10.1590/S0100-06832013000200018

SHEN, J.; YUAN, L.; ZHANG, J.; LI, H.; BAI, Z.; CHEN, X.; ZHANG, F. Phosphorus dynamics: from soil to plant. Plant physiology, v. 156, n. 3, p. 997-1005, 2011. https://dx.doi.org/10.1104/pp.111.175232

SIMAS, F. N.; SCHAEFER, C. E.; FERNANDES FILHO, E. I.; CHAGAS, A. C.; BRANDAO, P. C. Chemistry, mineralogy and micropedology of highland soils on crystalline rocks of Serra da Mantiqueira, southeastern Brazil. Geoderma, v. 125, n. 3-4, p. 187-201, 2005. https://doi.org/10.1016/j.geoderma.2004.07.013 
TEIXEIRA, P. C.; DONAGEMMA, G. K., FONTANA, A., TEIXEIRA, W. G. Manual de métodos de análise de solo. Embrapa, Brasília. 2017, 434p.

TOKURA, A. M., FURTINI, A. E.; CARNEIRO, L. F.; CURI, N.; SANTOS, J. Z. L.; ALOVISI, A. A. Dynamics of phosphorus forms in soils with contrasting texture and mineralogy cultivated with rice. Acta Scientiarum. Agronomy, v. 33, p. 171-179, 2011. https://doi.org/10.4025/actasciagron.v33i1.1435

TONIETTO, J. Valorização do ecossistema: importância da regionalização vitivinícola na produção de vinhos de qualidade. In: CONGRESO LATINOAMERICANO DE VITICUlTURA Y ENOLOGIA, 8., 2001, Montevidéu. Annales[...] Montevidéu: Asociación de Enólogos del Uruguay, 2001. p.1-9. (CD rom).

YEOMANS, J. C.; BREMNER, J. M. A rapid and precise method for routine determination of organic carbon in soil. Communication in Soil Science and Plant Analysis, v. 19, p. 1467-1476, 2008. https://doi.org/10.1080/001036288093680271988 


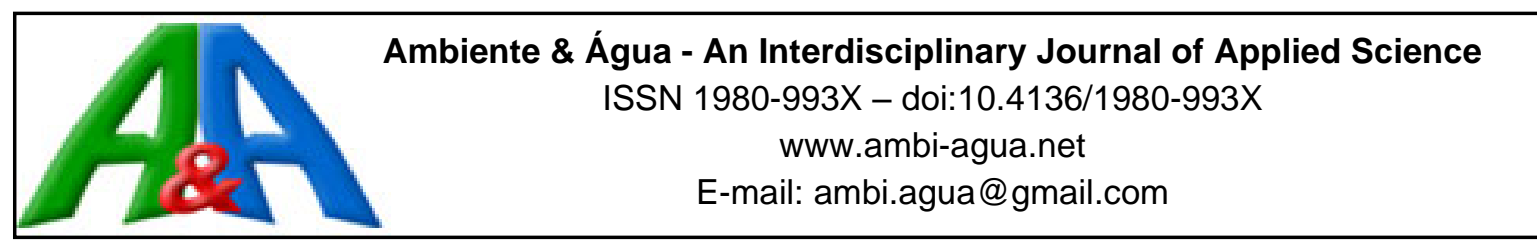

\title{
Brazilian offshore oil exploration areas: an overview of hydrocarbon pollution
}

\author{
ARTICLES doi:10.4136/ambi-agua.2569
}

Received: 03 May 2020; Accepted: 07 Jul. 2020

\author{
Daniel Constantino Zacharias*iD; Adalgiza Fornaro \\ Departamento de Ciências Atmosféricas. Instituto de Astronomia, Geofísica e Ciências Atmosféricas (IAG). \\ Universidade de São Paulo (USP), Rua do Matão, n 1226, CEP: 05508-090, Butantã, SP, Brazil. \\ E-mail: adalgiza.fornaro@iag.usp.br \\ *Corresponding author. E-mail: danizach@gmail.com
}

\begin{abstract}
The basins of Campos and Santos, the most important offshore oil reserves in Brazil, hold potential for being the largest offshore oil exploration fields in the next decades, mainly due to the oil located in the pre-salt layer. This region presents real conditions for the occurrence of intense atmospheric events added to the high velocity of the meanders of the Brazilian current. However, the increasing risk of accidents and damage in the region has been the subject of concern and discussion. The risks in the basins of Campos (2011) and Santos (2012) may not exhibit the the same potential for disastrous events as do those in the oil fields of Alaska and of the Gulf of Mexico, but accidents in these areas are not unlikely, as already evidenced by previous accidents under similar operating conditions (e.g. Chevron Platform accident in Campos Basin, RJ, Brazil, 2011). This paper highlights discussion of the multidisciplinary and substantial environmental features in oil exploration fields along the Brazilian coast based on Semi-Systematic Review methodology. The aspects evaluated cover not only geological traits, oceanic and meteorological circulation, but also current oil production, the most significant oil spill accidents recorded up to 2019 and the discussion about some current levels of seawater contamination.
\end{abstract}

Keywords: Campos basin, offshore contamination, oil spill, pre-salt layer, Santos basin.

\section{Área de exploração de petróleo na costa brasileira: uma visão geral poluição por hidrocarbonetos}

\section{RESUMO}

As bacias de Campos e Santos são as reservas de petróleo offshore mais importantes do Brasil e possuem potencial para serem os maiores campo de exploração de petróleo offshore nas próximas décadas, principalmente devido ao óleo localizado na camada do pré-sal. Esta região apresenta condições reais para a ocorrência de eventos atmosféricos intensos, somados à alta velocidade dos meandros da corrente marítimas brasileira. No entanto, o risco crescente de acidentes e danos na região tem sido objeto de preocupações e discussões. Os riscos nas bacias de Campos (2011) e Santos (2012) podem não apresentar potencial para eventos desastrosos como nos campos de petróleo no Alasca e no Golfo do México, mas os acidentes nessas áreas não são improváveis, como já evidenciados por acidentes anteriores em condições operacionais semelhantes (por exemplo, acidente na plataforma da Chevron na Bacia de 
Campos, em 2011). Este artigo mostra a discussão sobre as características multidisciplinares e ambientais substanciais em campos de exploração de petróleo ao longo da costa brasileira, com base na metodologia de Revisão Semi-Sistemática. Os aspectos avaliados abrangem não apenas características geológicas, circulações oceânicas e meteorológicas, mas também se destacando a atual produção de petróleo, os acidentes de derramamento de óleo mais significativos registrados até 2019 e a discussão sobre alguns níveis atuais de contaminação da água do mar.

Palavras-chave: bacia de Campos, bacia de Santos, contaminação nas águas costeiras, derramamento de óleo, pré-sal.

\section{INTRODUCTION}

Brazil holds the $15^{\text {th }}$ largest oil reserve worldwide and the $2^{\text {nd }}$ in Latin America with 12.2 billion barrels in offshore fields and 0.6 billion barrels in onshore fields. The Campos and Santos oceanic sedimentary basins hold $94 \%$ of all Brazilian oil (ANP, 2018). In 2017, Pre-Salt ultra-deep fields produced 1.3 million barrels per year of oil and 18.2 billion $\mathrm{m}^{3}$ per year of natural gas, which means almost half of all Brazilian oil and $45 \%$ of its natural gas oil (ANP, 2018).

Santos Basin, the largest sedimentary offshore basin in Brazil, spans from Cabo Frio city (Rio de Janeiro state - RJ) to Florianópolis city (Santa Catarina state - SC), covering an area of more than $350,000 \mathrm{~km}^{2}$, where the deepest oil platforms are installed on the Brazilian coast (Petrobras, 2018). Most wells are located between the parallels $21^{\circ} \mathrm{S}$ and $23^{\circ} \mathrm{S}$, covering an area of approximately $100,000 \mathrm{~km}^{2}$. The basin carries out intense oil-related activities, such as drilling, transportation and ship-to-ship transfers, which cause high risk of contamination for the ocean biome (Wagener et al., 2012).

Research related to oil exploration has become increasingly complex, and the multidisciplinary approach to existing knowledge plays an essential role for new advances in scientific development in the area. This task requires precision as a priority, in addition to the breadth of the topics covered, by synthesizing previous and current knowledge by systematic methods of literature review, leading to important research questions which are not found in single studies (Snyder, 2019).

The present paper explores the discussion regarding multidisciplinary and substantial environmental features in oil exploration fields along the Brazilian coast based on SemiSystematic Review methodology. The aspects evaluated cover not only geological traits, oceanic and meteorological circulation, but also highlight current oil production, the most significant oil spill accidents recorded up to 2019 and the discussion about some current levels of seawater contamination. The objective is to show and discuss the current conditions of offshore oil exploration at Campos and Santos Basins, summarizing some useful environmental aspects to support further studies such as oil-spill modeling and environmental impact assessment and providing integrated and critical information for modelers and policy makers in order to discuss levels of water contamination. This integrated knowledge was evaluated considering its influence on environmental impact assessments and oil-spill computational simulations.

\section{MATERIALS AND METHODS}

There are a number of existing guidelines for literature reviews, with all types being appropriate to a specific aim. These approaches can be qualitative, quantitative, or mixed depending on the phase of the review. In specific goals and circumstances, some of these strategies can be useful to answer a particular research question, based on literature review methods such as systematic, semi-systematic and integrative (Snyder, 2019). 
The methodology chosen for this article was the semi-systematic, because the purpose of semi-systematic review is to present an overview of the research area and sometimes to track the development of the research or theme over time (Snyder, 2019).

In the semi-systematic approach, the search strategy may or not be systematic with quantitative or qualitative analysis and evaluation, contributing to the state-of-the-art knowledge, themes in literature, historical overviews, research agendas or theoretical models (Snyder, 2019). As the studied topic is very broad, the search universe was expanded (quantitative articles, research articles, books and other published texts), which is more usual in the integrated methodology (Snyder, 2019).

The semi-systematic approach, also called narrative review, is designed for topics that have been conceptualized differently and studied within diverse disciplines that hinder a full systematic review process. In general, the semi-systematic approach seeks to identify and understand all potentially relevant research traditions that have implications for the studied topic, instead of measuring effect size to provide understanding of complex areas (Snyder, 2019).

The present work was systematized as follows:

- Purpose: Environment overview research on Campos and Santos Basins; and the development of oil exploration and spills in recent decades.

- Research questions: What are some environmental conditions that influence Campos and Santos Basins?

What is the condition of oil production in these basins, including spills?

Have current knowledge and legal instruments (environmental impact assessment EIA) been sufficient to prevent contamination of sea water?

- Search strategy: Not systematic.

- Sample Characteristics: Quantitative articles, research articles, books and other published texts.

- Analysis and Evaluation: Qualitative.

- Expected Contribution: State of the art knowledge; historical overview; interdisciplinary discussion; discussion of current water quality policy.

The present work shows the semi-systematic methodology to analyze aspects usually present in oil spill modeling and EIA: study area background, geology, oceanic circulation, atmospheric circulation, current status of oil use/exploration, water quality and residual impacts summary (Glasson and Therivel, 2012).

\section{RESULTS AND DISCUSSION}

\subsection{Geological Aspects of Southeast Coast of Brazil}

The Southeast coast of Brazil comprises the states of Espírito Santo (ES), Rio de Janeiro (RJ), São Paulo (SP), Paraná (PR), Santa Catarina (SC) and Rio Grande do Sul (RS), as well as the sedimentary basins of Espírito Santo, Campos, Santos and Pelotas, where the main offshore oil fields and pre-salt reserves are located (Figure 1). 


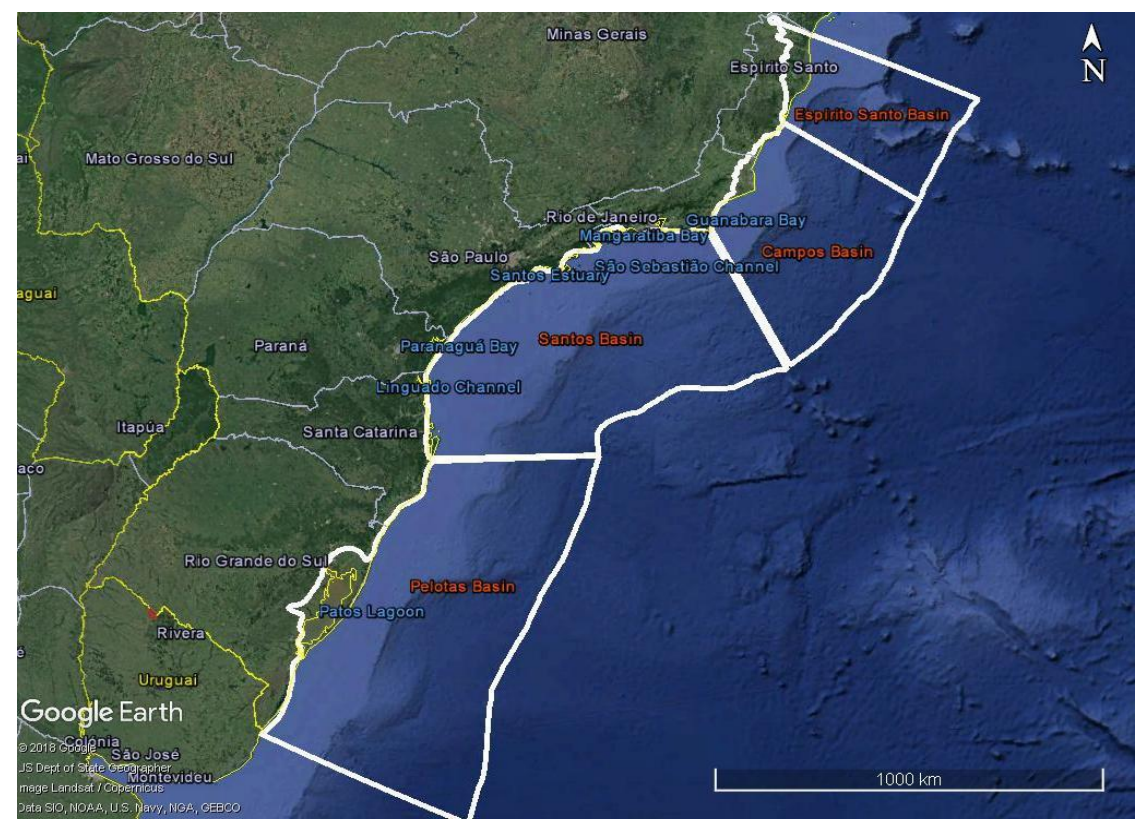

Figure 1. The oceanic sedimentary basins of the Brazilian South and Southeast coasts. Source: Google Earth and Domingos (2011).

The Santos Sedimentary Basin covers $352,000 \mathrm{~km}^{2}$ and is located in the South Atlantic Ocean, between $23^{\circ} \mathrm{S}$ and $28^{\circ} \mathrm{S}$ (Figure 1). It exhibits a bathymetric dimension that reaches 3,000 meters of depth and a sedimentary thickness of more than 10,000 meters, and represents one of the largest sedimentary basins in Brazil with one of the biggest continental margin depressions (Papaterra, 2010).

The Pelotas sedimentary basin, with an area of $210,000 \mathrm{~km}^{2}$ is located between $28^{\circ} \mathrm{S}$ and $34^{\circ} \mathrm{S}$ on the coast of Santa Catarina and Rio Grande do Sul states (Figure 1). The Campos Sedimentary Basin, between $21^{\circ} \mathrm{S}$ and $23^{\circ} \mathrm{S}$, covering a total area of $115,000 \mathrm{~km}^{2}$, is the smallest of the three basins in the studied area, stretching along the coasts of Rio de Janeiro and Espírito Santo states, being limited by the Santos Basin in the South near Cabo Frio (CPRM, 2018).

The Santos Basin can be divided, according to its geology, in two distinct parts separated by a slope. The shallow continental shelf of Santos, no more than $200 \mathrm{~m}$ deep, is delimited by the coast and a canyon structure. The extension of the basin is the São Paulo Plateau, which is bordered by the slope in its portion close to the coast, oriented towards the interior of the ocean, and reaching depths of 4,000 $\mathrm{m}$ (Pellizzon, 2005).

The main oil reservoirs in Brazil are located in the sedimentary basins of Santos and Campos, which were originally interconnected and resulted from the initiation of the rifting process that caused its formation due to deep geological faults. The onset of Santos and Campos Basins dates back to approximately 130 million years ago, in the Cretaceous period, and they are characterized as rift (lake), post-rift (gulf) and drift (ocean) stages (Riccomini et al., 2012).

The rift stage was initiated with volcanism (Figure 2), where the movement of geological faults led to basin formation due to the deposition of lake sediments, such as basalt, sandstone, quartz, feldspar, silt and shale rich in organic matter, which means a potential oil generator (Mello et al., 1995).

The second stage, the post-rift, was initiated by the sea entrance in the south, controlled by basaltic rock reliefs, becoming an elongated and narrow gulf shape. The persistency of weathering caused by floor sinking, water salinity, hot temperature and high evaporation rates, raised an extensive 2,500 m thick layer of salt, which consists mostly of halite and anhydrite (Papaterra, 2010). 


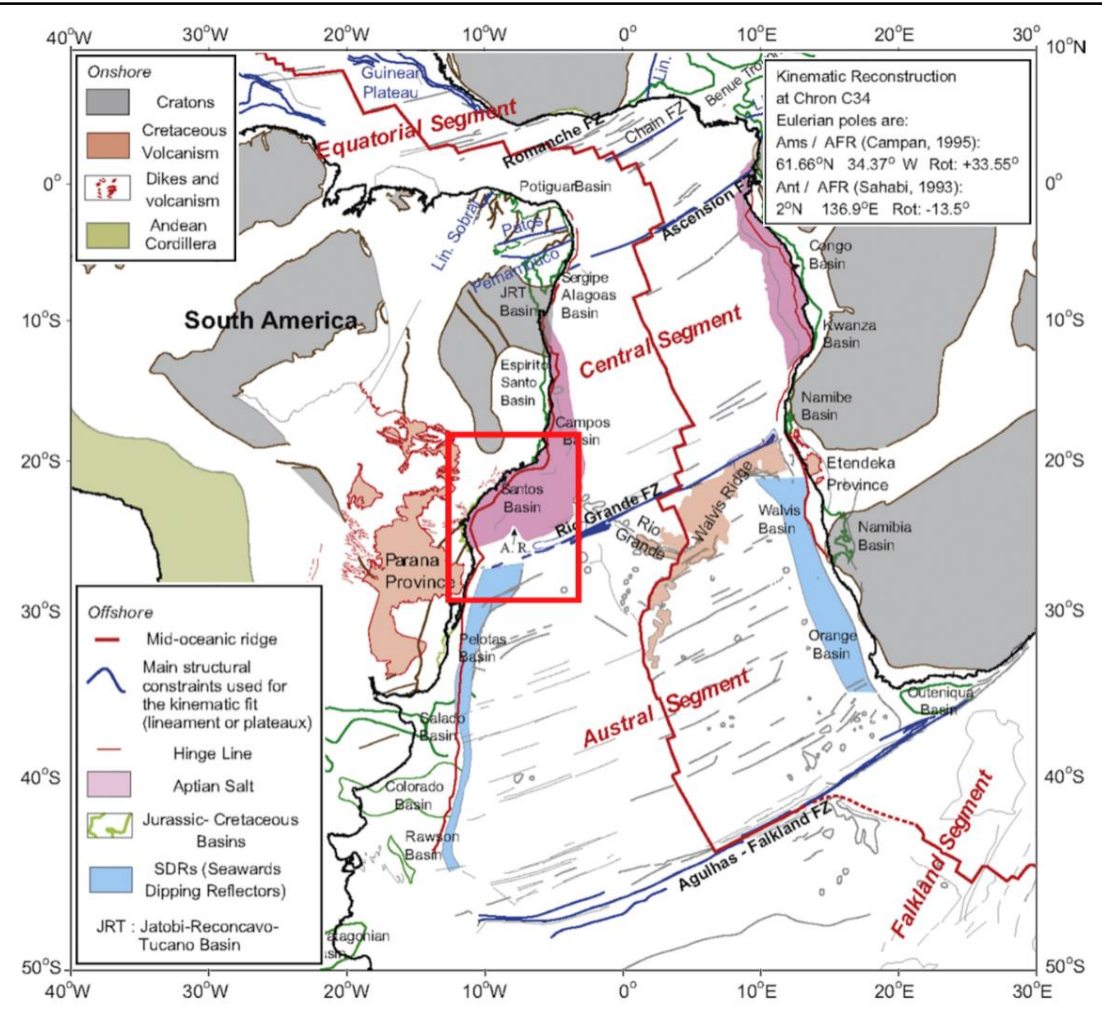

Figure 2. The tectonic-structural and bathymetric features of the South Atlantic Ocean at Chron-34 using the Eulerian pole data. The red square highlights the location of the studied area. Source: Adapted from Alves et al. (2017).

Those areas, accumulated by volcanic basalt rocks with their characteristic patterns, such as high porosity and permeability fractures, can be considered excellent reservoirs. The pre-salt deposit functions as a reservoir of carbonate rocks, which form an exploratory area of oil accumulation with varied topography of high and low reliefs. The salt and sediment pile over the salt layer exerts the sealant function, burying the previous layer and completing the pre-salt oil system in the region (Riccomini et al., 2012).

The Santos Basin (Figure 2) was initially part of an extensive region of continental rifting, separating South America and Africa. The latest Jurassic and Early Cretaceous rifting, Late Cretaceous salt tectonics and continental breakup were triggered in the Austral segment during the Late Jurassic period. Later, they were propagated northwards into the equatorial segment during multiple phases of tectonism related to the Andean Orogeny (Alves et al., 2017).

\subsection{Oceanic Circulation}

The oceanic area evaluated in this study is characterized mainly by the Brazil Current (BC) (Figure 3), a western boundary current, which is associated with the South Atlantic Subtropical Gyre (Peterson and Stramma, 1991). The Brazil Current originates near the Brazilian Northeastern Coast, at the bifurcation of the Equatorial South Current, flowing from $9^{\circ} \mathrm{S}$ to $38^{\circ} \mathrm{S}$ and carrying warm subtropical water (Silveira et al., 1994). It reaches the Subtropical Convergence between $33^{\circ} \mathrm{S}$ and $38^{\circ} \mathrm{S}$, converging with the Malvinas Current, Brazil-Malvinas Confluence (BMC), and moves away from the coast. The BC, being a western boundary current characterized by intense, narrow and well-defined flow along the coast (Figure 3), is relatively weak when compared to the North Atlantic current (Silveira et al., 2000). The Brazil Current region, formed by the stacking of water masses characteristic of the South Atlantic, has its first three kilometers of depth originated from tropical waters. Its depth is followed by South Atlantic and Antarctic waters, and finally, by Upper Circumpolar and North Atlantic deepest waters (Silveira et al., 2000). 


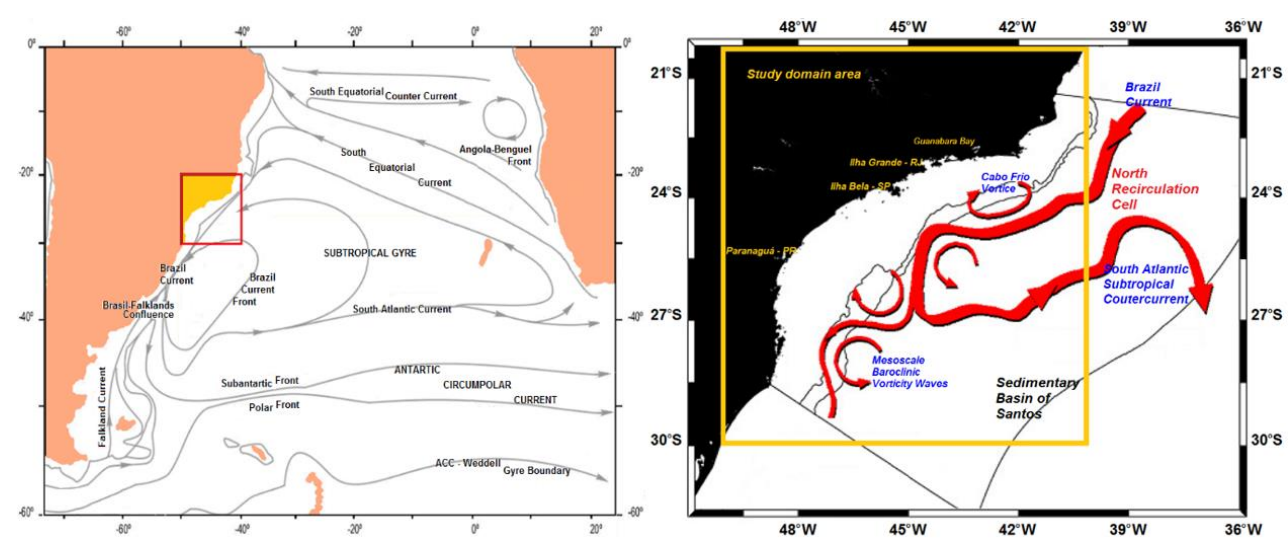

Figure 3. The Brazil Current (BC) and the boundaries of the studied area are highlighted by the surface currents (gray lines) and the surface recirculation systems (red arrows). Source: Adapted from Peterson and Stramma (1991); Mattos (2006); Soares (2014).

Ocean data estimate that the $\mathrm{BC}$ becomes deeper and more intense towards the South, varying from $200 \mathrm{~m}$ at Cabo Frio surroundings, $22^{\circ} \mathrm{S}$, to $670 \mathrm{~m}$ near Cabo Santa Marta, $28^{\circ} \mathrm{S}$ (Silveira et al., 2000). The transient phenomena of the BC are also very relevant factors for its dynamics (Figure 3), with intense mesoscale activity, meanders and vortices, mainly between Vitoria $\left(20^{\circ} \mathrm{S}\right)$ and Cabo Santa Marta $\left(28^{\circ} \mathrm{S}\right)$. The BC begins to reach deeper areas near Cabo Frio, stretching and acquiring cyclonic vorticity, triggering a wave of vorticity along Santos Basin (Silveira, 2007). It is important to highlight that, in Cabo Frio, this process is caused by the abrupt change in the orientation of the coastline and by the bathymetric gradient (Soares, 2014).

The existence of recirculation cells associated with the western boundary currents could explain the volume variations of the sea water transport along their route (Figure 3), which causes the subdivision of the South Atlantic Subtropical in two circulation cells, centered between $23^{\circ} \mathrm{S}$ and $30^{\circ} \mathrm{S}$, with anticyclonic movement close to $27^{\circ} \mathrm{S}$. The first part of the BC stream moves from the western contour $\left(44^{\circ} \mathrm{W}\right)$ to the east $\left(37^{\circ} \mathrm{W}\right)$, characterizing the South Atlantic Subtropical Countercurrent. The second moves towards the southwest, characterizing the Southern branch of the Northern Recirculation Cell (Mattos, 2006). The movement of a coldwater plume flowing northwards was observed in the Brazilian southeastern continental shelf (Figure 3). The resurgence in the Arraial do Cabo region-RJ is also included in the domain of the study, originating from the divergence generated by the presence of the coast and the rotational wind field in open ocean (Soares, 2014). Many studies about relative vorticity indicated that vortices could occur in the Brazilian Current throughout the year, especially in the Cabo Frio Vortex (Figure 3) (Soares, 2014).

\subsection{Atmospheric Circulation}

On the southeastern coast of Brazil, atmospheric circulation is characterized, on a synoptic scale, mainly by the movement of transient systems such as: cyclonic vortices, frontal systems, and the South Atlantic Convergence Zone (SACZ) (Barros et al., 2000; Carvalho et al., 2004; Siqueira and Machado, 2004; Taschetto and Wainer, 2008).

The South Atlantic Convergence Zone (SACZ) is a band of cloud cover extending from the Atlantic Ocean in the South and Southeast regions of Brazil, passing through areas of oil exploration, and entering the continent. This type of formation remains stationary for more than three days, resulting in long rainy periods (Carvalho et al., 2004; Ambrizzi and Ferraz, 2015).

The climatic conditions in this region present transitional characteristics between the tropics and subtropics, and the local atmosphere ends up being marked by cycles of tropical and extratropical systems. The dynamic of the atmospheric circulation is characterized by the polar 
front passages (Figure 4), alternating with the influence of the South Atlantic Subtropical High (SASH) on the region (Rocha et al., 2019).
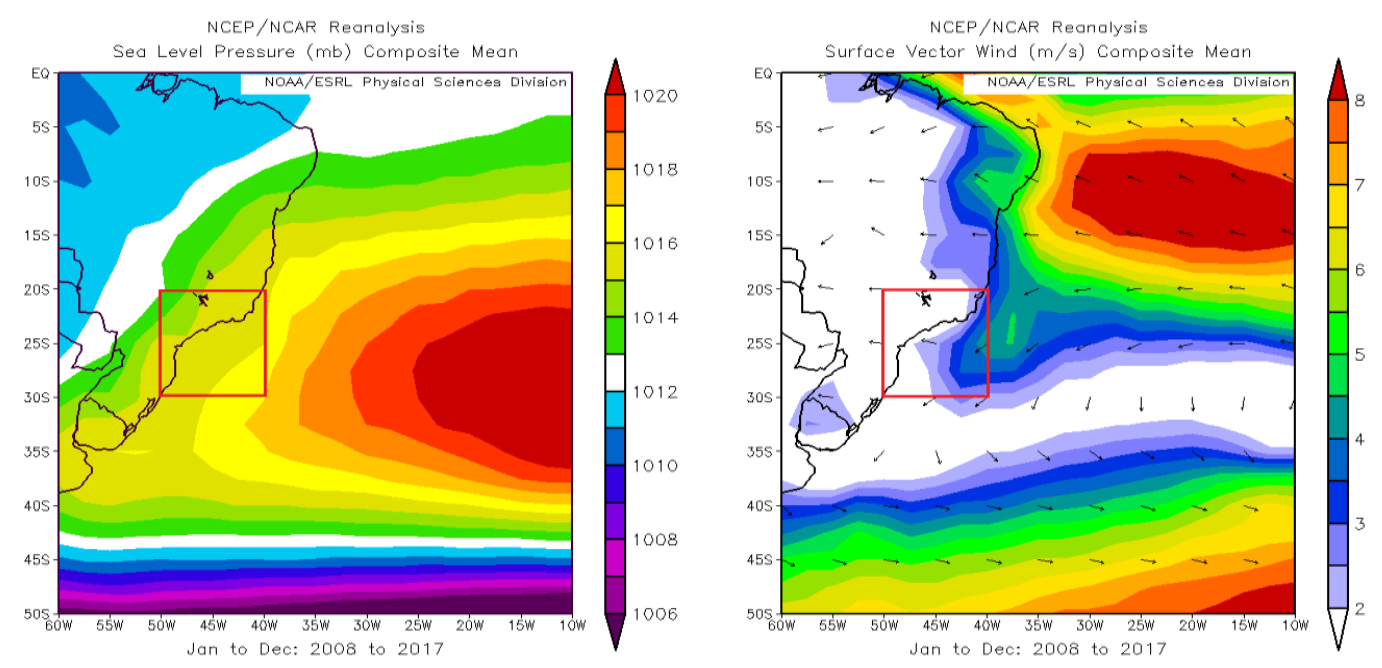

Figure 4. Reduced pressure at sea level and surface wind climatology (10-year mean) from the NCEP re-analyzes (National Centers for Environmental Prediction) data, highlighting the limits of the studied domain (red square). Source: NOAA (2020).

The subtropical highs, relatively warm semi-permanent systems compared to high migratory pressures, are high-pressure systems located around $30^{\circ} \mathrm{S}$, with their center between $20^{\circ} \mathrm{S}$ and $40^{\circ} \mathrm{S}$ over the oceans in the Southern hemisphere, these semi-permanent anticyclones are associated with the subsidence area of Hadley cells circulation (Rocha et al., 2019). The South Atlantic Subtropical High (SASH) moves over the South Atlantic Ocean according to the seasons (Gilliland and Klein, 2018), covering a larger area during winter and becoming more restricted and more defined during summer (Rocha et al., 2019).

In the basic climatological conditions, it is expected that the main direction of both wind (Figure 4) and stream (Figure 3) carry the spilled oil to the southern coast of Brazil. The wind regime on the oceanic portion of the domain originates from E/NE (Figure 4), following the Brazil Current (Figure 3). In oil spills under the influence of high pressure conditions, the winds are predominantly weak and less capable of determining the trajectory of the slick than the vortices and meanders of Brazil and Subtropical South Atlantic Currents (Figure 3). Although the basic climatological condition is influenced by SASH on the domain, a slight wind rotation contour is also observed clockwise within the domain (Figure 4), resulting from the synoptic scale flow perturbations in large-scale flow, mainly cyclonic and frontal systems.

Cyclones are synoptic scale systems characterized by low surface atmospheric pressure, clockwise rotation in the South Hemisphere (SH), presenting the ability to change wind flow. They are also a significant mechanism of energy transport and humidity between latitudes (Dutra, 2012). On the SE coast of Brazil, the development and passage of cyclones can directly affect weather conditions, which results in heavy rains, strong winds and maritime agitation, negatively affecting the port and shipping activities (Dutra, 2012). Subtropical cyclones, like tropical and extratropical, are hybrid systems presenting warm and cold cores at low and upper levels, respectively. They occur mostly over the sea, generating intense winds near the surface, which seriously affects human activities and ecosystems (Rocha et al., 2019).

Regardless of the cyclone types that may occur, the area for oil exploration is located in one of the three regions of the South American cyclogenesis and very close to the other two (Reboita et al., 2010a; 2010b). In a very simplified analysis, cyclogenesis usually occurs at least once a month within, or very close to, the domain area (Figure 5). 


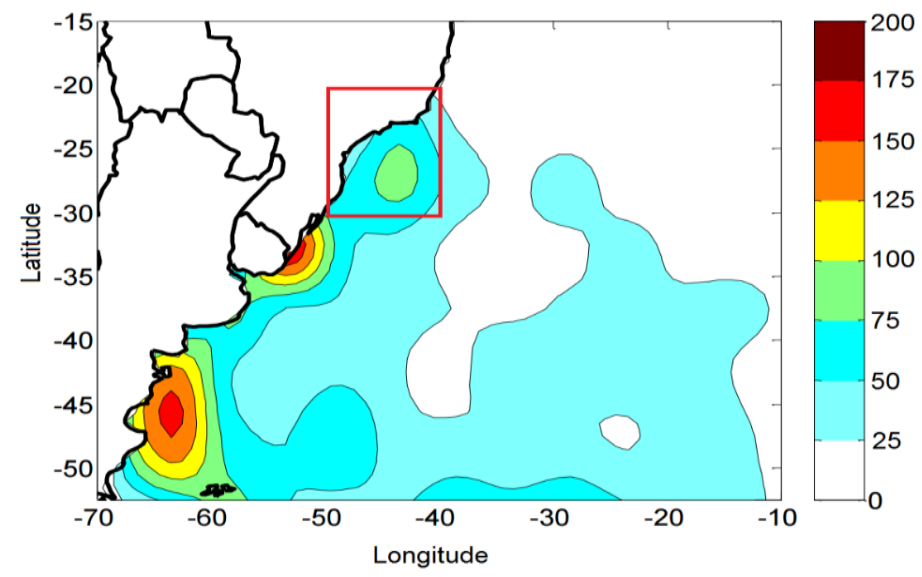

Figure 5. Number of cyclogeneses detected yearly with initial vorticity below $1.5 \times 10^{-5} \mathrm{~s}^{-1}$ and lifetime of over 24 hours, considering data from the NCEP (National Centers for Environmental Prediction) re-analysis, from 1979 to 1999. Red square highlights the Santos Basin central area. Source: Adapted from Reboita et al. (2010b).

The climatological condition in the grid region shows a predominance of winds from the E/NE quadrants (Figure 4), with an orientation similar to Brazil Current (Figure 3). In contrast to this situation, there are transient (migratory) cyclonic systems (Figure 5) altering the winds from this region to NW origin (pre-frontal position) and S/SW (post-frontal position).

Wind data from the Santos buoy (Argos ID: 69150|WMO ID: 31374, Figure 6), obtained from GOOS-BRASIL (Prediction and Research Moored Array in the Tropical Atlantic PIRATA), showed that in the Santos Basin, the wind flows towards the coast at a $30 \%$ frequency, causing more risks to environment. Intense winds $\left(>10 \mathrm{~ms}^{-1}\right)$ flow $18 \%$ of the time, increasing risks to maritime activities.
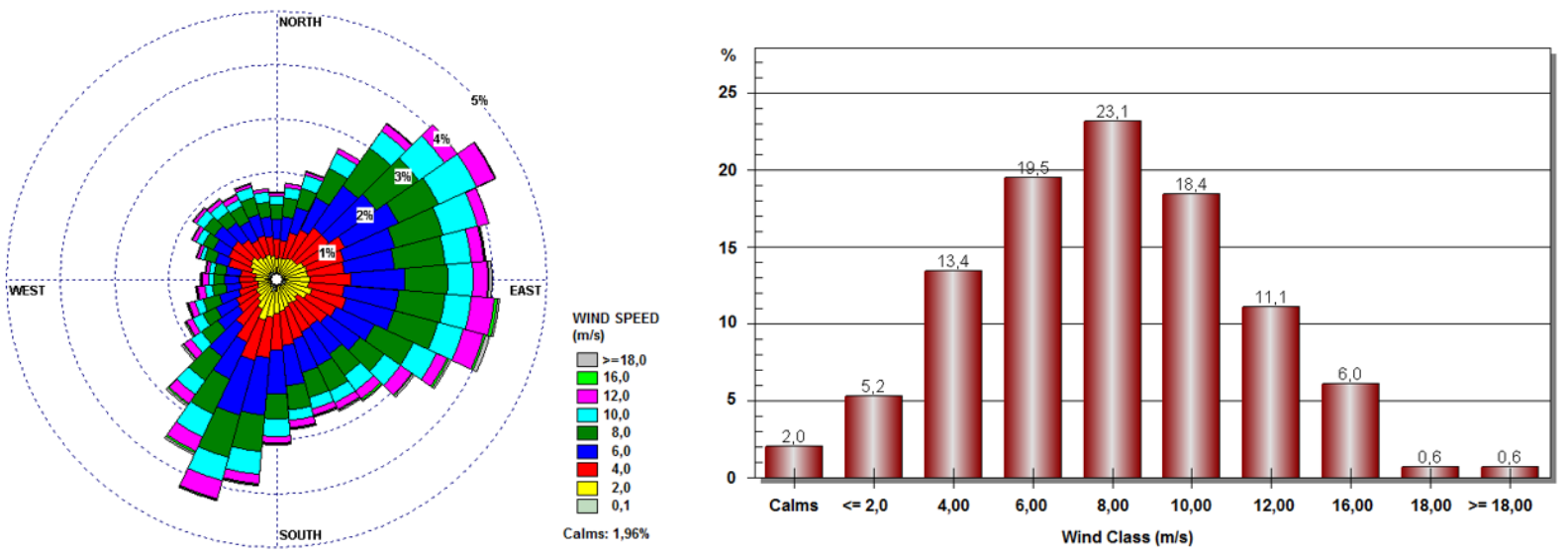

Figure 6. Wind directional histogram at 10 meters, measured with the Santos Buoy (Argos ID: 69150 WMO ID: 31374). Source: GOOS-Brasil (2020).

\subsection{Oil Offshore Exploration}

Brazilian offshore oil exploration started before the current environmental legislation, protection rules and federal agency.

Environmental impact assessment (EIA) started in early 1960s in United States, followed by Europe in middle of 1980s; however, it reached international status only in 1992, with the Rio de Janeiro Declaration on Environment and Development, in its Principle 17 (Devuyst, 2000; Roos et al., 2020), to which Brazil was a signatory. 
The Federal Constitution of Brazil (Brasil, 1988) required the execution of an EIA in any project with potential for environmental damage and created the IBAMA (Brazilian Institute of the Environment and Natural Resources); since then, environmental impact assessment has been used in the licensing processes for oil extraction activities in Brazilian waters (in new and previous fields) to prevent contamination and pollution.

The Campos Basin exploration started in the Garoupa field in 1976, but the Enchova field was the first to reach 10,000 barrels per day of oil production, in 1977 (Santos et al., 2017). After a 40-year exploration, although the fields (Figure 7) are still currently mature considering the peak of oil and gas production, decommissioning and changes of platforms and extraction points are expected in the next decades (Coelho, 2010). Oil production in Brazil grew 8\% in 2015 compared to 2014 due to the increase of pre-salt wells extraction (Oliveira, 2016). The average production in 2015, 2016 and 2017 totaled almost 13 billion barrels per year (ANP, 2018).

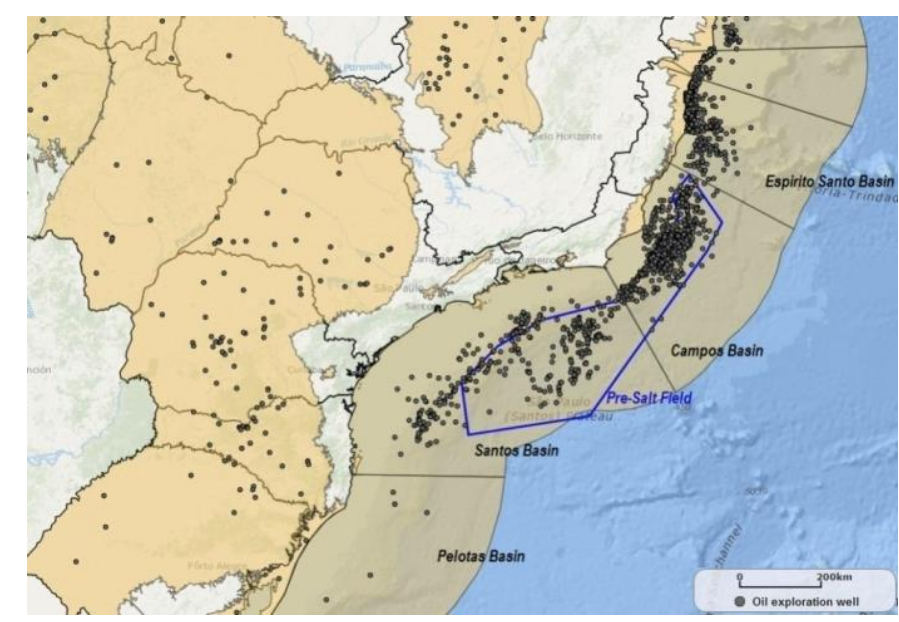

Figure 7. The pre-salt area in sedimentary basins at the southeast of Brazil and respective operational oil wells in 2018. Source: ANP (2020).

The offshore oil production data in the Santos Basin are even more impressive than those collected before pre-salt. Since the start of the pre-salt oil exploration, São Paulo state increased its production from 89 thousand $\mathrm{m}^{3}$ per year (2000) to 16 million $\mathrm{m}^{3}$ per year (2016), and the expectation for 2017 has exceeded 18 million $\mathrm{m}^{3}$ per year (ANP, 2018).

In 2017, the Campos Basin had a total of 863 offshore drilled wells, 537 of which produced oil (Figure 7). On the other hand, the Santos Basin presented lower values, with 114 offshore drilled wells and 55 in production at that time (ANP, 2018). Moreover, there are more than 977 potential risk points of leakage in the domain analyzed in this study, without considering the possibility of spillage due to ship leakage.

\subsection{Brazilian Offshore Oil Spill}

A four-hour leak oil spill in the Guanabara Bay pipeline, Rio de Janeiro, on January 18, 2000 , struck the nearby mangrove swamp, causing significant damage to the environment. This accident hampered essential activities such as fishing and tourism, and provoked a direct impact on the design and planning of Brazilian environmental guidelines for that sector (Ferreira et al., 2003).

In order to control such accidents, Brazilian Federal Law 9966 was enacted on April 28, 2000 to regulate the prevention, control and monitoring of the pollution caused by the release of substances into water, and was overseen by the National Environment Council (CONAMA) Resolution 293 on December 12, 2001 (Ferreira et al., 2003). This resolution defines, among 
other things, the Individual Emergency Plan, which includes identification of risks of potential sources of spills, discussion of accidental hypotheses, vulnerability analysis, and definition of potentially affected areas. The changes in the Brazilian legislation were essential for a better management of the sector (Zacharias, 2017). Although (Brazilian Environmental Agency (IBAMA) has been receiving oil spill communications since 2001, only in 2010 did this Agency begin to include that information in a database (Maggi et al., 2014).

The Guanabara Bay pipeline accident (January 18, 2000), considering the Brazilian reality, was an event comparable to Exxon-Valdez. The Deepwater Horizon spill was a warning for the potential risk embedded in spills in the basins of Campos and Santos (Table 1). The Brazilian statistics for oil spills are not as accurate and complete as those provided by the Bureau of Ocean Energy Management (BOEM). An initial table listing the main accidents on the Brazilian coast between 1960 and 2004 was elaborated by Souza Filho (2006), and continued to be amplified until 2016 (Table 1). The number of accidents (2012-14) involving oil discharge, harmful or dangerous substances comprised approximately 374 events, with a total spilled volume of $140 \mathrm{~m}^{3}$ (Santos et al., 2017). Although the volume of these discharges was relatively small, some of the spilled substances, such as pure acetic acid, liquid xylene, and others, were potentially very dangerous for marine life (Santos et al., 2017).

The Sinclair spill (1960) was one of the 50 largest offshore spills in the world until 2010 (Fingas, 2010). It was the first significant accident in Brazilian waters (Table 1), with spilled volume far superior to all subsequent spills. However, due to political, historical and media conditions, it did not have the same impact on public opinion. On the other hand, the smaller pipeline spill in Rio de Janeiro, 2000 (Table 1), had historical importance, resulting in significant changes in Brazilian environmental legislation (Ferreira et al., 2003).

The unknown South Atlantic oil spill (2019) was first identified on the Brazilian coast on August $30^{\text {th }} 2019$, reaching 4,334 $\mathrm{km}$ of coastline. This disaster is considered the worst oil spill in Brazil's history and one of the largest on record in the world. The crude oil spill has compromised the health of 360,000 artisanal fishers in Northeast Brazil, besides those living on the coast in the states of Espírito Santo and Rio de Janeiro in the Southeast. Considering the territorial extension and affected population, this oil spill disaster is the equivalent of hundreds of Brazilian refineries and petrochemical factories having their workplaces contaminated and being closed down due to sudden, uncontrolled exposure to petroleum and aromatic hydrocarbons, and without the health sector's protection (Pena et al., 2020).

The worldwide expectation is to keep decreasing this type of accident through improved technologies of processes, control systems and integrated management. Furthermore, in order to maintain the downward trend of these accidents, even considering increased production, continuous investments in technology, knowledge and innovation must be made (Table 2).

Brazilian offshore oil exploration follows a worldwide trend of increasing production and reducing accidents (Table 1 and 2), but even with significant rates of accident reduction, recent events like the Deepwater Horizon (Beyer et al., 2016) and the Sanchi collision (Yin et al., 2018) show that oil extraction still presents many environmental risks due to the large number of oil operations over the oceans around the world.

Pre-Salt oil extraction in ultra-deep waters requires drilling technology capable of overcoming 2,100 meters of seawater and drilling more than 5,000 meters under the seafloor (totaling more than 7,100 meters deep) with at least 2,000 m of salt. In these conditions, the continuous improvement of the management of all risks involved in the oil extraction becomes essential (Beltrão et al., 2009).

The depths involved in the pre-salt field exploration are similar to those found in the Macondo oil field, which resulted in the Deepwater Horizon accident (Beyer et al., 2016), showing the environmental risks involved in ultra-deep oil production. 
Table 1. Data on the main accidents with oil products spills in Brazil from 1960 to 2016.

\begin{tabular}{|c|c|c|c|}
\hline Year & Source & Site & Spilled quantity $\left(\mathrm{m}^{3}\right)$ \\
\hline 1960 & Sinclair Petrolore & Near Brazilian Coast & 66,000 \\
\hline 1974 & Takimyia Maru & São Sebastião Channel, SP & 7,000 \\
\hline 1974 & Esso Garden State & Indefinite terminal & 5,800 \\
\hline 1975 & Tarik Ibn Ziyad & Guanabara Bay, RJ & $7,000-18,000$ \\
\hline 1978 & Brazilian Marina & São Sebastião Channel, SP & $6,000-40,000$ \\
\hline 1978 & Aminona & Banco do Meio, ZEE & 23,000 \\
\hline 1979 & Gunvor MAERSK & Amazonas River & $12,000-17,000$ \\
\hline 1983 & Pipeline & São Sebastião - Cubatão, SP & 2,500 \\
\hline 1985 & Marina & São Sebastião, SP & $2,000-3,000$ \\
\hline 1986 & Brotas & Litoral RJ & 1,600 \\
\hline 1994 & Pipeline & São Sebastião - Cubatão, SP & 2,700 \\
\hline 1997 & Pipeline & Guanabara Bay, RJ & $1,000-3,000$ \\
\hline 2000 & Pipeline & Guanabara Bay, RJ & 1,300 \\
\hline 2000 & Pipeline & Barigüi River, PR & 4,000 \\
\hline 2001 & Platform P36 & Campos Basin & 1,500 \\
\hline 2004 & Pipeline & São Sebastião - Cubatão, SP & Unknown \\
\hline 2004 & Vicuña & Paranaguá Bay, PR & 6,500 \\
\hline 2011 & Chevron Platform & Campos Basin & 3,700 \\
\hline 2012 & Transpetro Pipeline & Tramandaí, RS & 140 \\
\hline 2012 & Dynamic Producer & Santos Basin & 160 \\
\hline 2014 & Transpetro Pipeline & Tramandaí, RS & 24 \\
\hline 2016 & Transpetro Pipeline & Tramandaí, RS & 150 \\
\hline 2019 & P58 - Pipeline & Jubarte Field, ES & 260 \\
\hline 2019 & Equatorial Atlantic & South Atlantic & Unknown \\
\hline
\end{tabular}

Source: adapted from Souza Filho (2006) and Zacharias (2017). 
Table 2. Accident statistics with volume spilled above 1,000 bbl during the handling operations around the world from 1974 to 2018.

\begin{tabular}{ccccc}
\hline Period & $\begin{array}{c}\text { Crude Oil Handled } \\
\text { (in 10 }\end{array}$ & Spills Occurred & Number of Spills per year & $\begin{array}{c}\text { Spills per } \\
10^{12} \text { bbl Handled }\end{array}$ \\
\hline $1974-1979$ & 62.13 & 113 & 18.8 & 1.82 \\
$1980-1989$ & 74.97 & 90 & 9.0 & 1.20 \\
$1990-1999$ & 102.55 & 73 & 7.3 & 0.71 \\
$2000-2009$ & 134.14 & 20 & 2.0 & 0.15 \\
$2010-2018$ & 111.07 & 12 & 1.3 & 0.11 \\
\hline
\end{tabular}

Source: BSEE Report (US, 2016) and ITOPF report (ITOPF, 2019).

\subsection{Oil Pollution in Brazilian Coastal Waters}

Oil pollution in water can occur in many ways, either directly by discarding oil from platforms and ships, or indirectly, by discharged water from cleaning tanks and piping production, or oil removal from platforms and equipment by the rain. Industrialization of municipalities near offshore oil fields also results in new direct and indirect sources of estuarine and coastal water pollution. Anthropogenic emissions have been increasing the concentrations of oil derivative pollutants in coastal waters, as well as across drainage basins and in marine waters. The mussels in those waters have been considered significant environmental indicators of sea life contamination by toxic components of oil (Santiago et al., 2016).

The effluent emissions in Brazilian seawaters is regulated by CONAMA resolution $357 / 2005$, which defines the emission limit less than $10 \mathrm{mg} \mathrm{l}^{-1}$ of TOC (total organic carbon) in treated effluent without dilution. The emission limit is a way of minimizing the environmental impact, since the volume of water produced on a platform is of the same magnitude as the volume of oil produced. Even though the emission limit is low, the large volume of produced water discarded at sea results in a large amount of oil being thrown into the sea every day.

Although Guanabara Bay is of great environmental and socio-economic importance on Brazilian southeastern coast, its current state of degradation poses risks in its surroundings not only to the human population, but also to the bay ecosystem. Even though several recovery programs involving Guanabara Bay have started, the available data indicate that they have not achieved their goals yet (Soares-Gomes et al., 2016).

Macaé municipality, on a coastal area, is located $150 \mathrm{~km}$ from the Rio de Janeiro state refineries (REDUC, REFIT and COMPERJ) and receives $16 \%$ of oil and 19.7 million $\mathrm{m}^{3}$ of gas from Campos Basin (ANP, 2018). Water contamination was evaluated using Brown mussels from four sites along the Macaé coast: Macaé River Estuary (MRE), Campista Beach (BC), Santana Island (SI) and Pedrinhas Beach (PB). MRE and BC are located close to the urban area, while SI and PB, $8 \mathrm{~km}$ far from the urban area (Santiago et al., 2016). The mussels presented high contamination values of polycyclic aromatic hydrocarbons (PAHs) at MRE, revealing an incidence of significant oil contamination. On the other hand, $\% \sum 16 \mathrm{PAHs}$ related to the total content were higher in remote sites (SI and PB) than in urban areas (MRE and BC). These results unveiled a possible initial oil contamination in unsuspected sites (Table 3), since PAH ratios in mussels are influenced by petrogenic sources (Santiago et al., 2016).

The Paranaguá Bay, in Santos Basin, is an estuary with two significant exportation ports (Paranaguá and Antonina) and about 11\% movement of petroleum-derived products (Brasil, 2018). In Paranaguá Bay, the total PAHs levels in sediments (133.61 $\mathrm{ng} \mathrm{g}^{-1}$ ) and water 
$\left(162.37 \mu \mathrm{g} \mathrm{l}^{-1}\right)$ represented lower contamination; while the concentrations found in dry weight plankton (2096.10 $\mathrm{ng} \mathrm{g}^{-1}$ ) and fish (2055.00 $\mathrm{ng} \mathrm{g}^{-1}$ ) were alarmingly higher (Froehner et al., 2018). In sections of Paranaguá Bay, labeled as unpolluted, there were lower contaminant concentrations in water and sediments. The values obtained in organisms were more than $1000 \%$ higher than those obtained in sediments due to the bioaccumulation process (Froehner et al., 2018).

Table 3. Data compilation for total PAH concentrations in some environmental matrixes of the Brazilian Coast near offshore oil fields from 2016 to 2018 (in dry weight conditions).

\begin{tabular}{|c|c|c|c|c|}
\hline Site & Matrix & Component & Range (ng g $\mathrm{g}^{-1}$ ) & Author \\
\hline São Paulo Estuary/BA & Sediment & $\sum \mathrm{PAH}$ & $12-1,825$ & Nascimento et al. (2017) \\
\hline Todos Santos Bay/BA & Sediment & $\sum \mathrm{PAH}$ & $13-511$ & Santos et al. (2017) \\
\hline Camamu Bay/BA & Sediment & $\sum \mathrm{PAH}$ & $1-313$ & Pedreira et al. (2017) \\
\hline Vitória/ES & Sediment & $\sum \mathrm{PAH}$ & $89-432$ & Pinheiro et al. (2017) \\
\hline Campos Basin/RJ & Fish & $\underset{\sum \mathrm{PAH}}{\sum 16 \mathrm{PAH}}$ & $\begin{array}{l}21-600 \\
10-148\end{array}$ & Lourenço et al. (2018) \\
\hline Macaé Coast/RJ & Brown Mussels & $\begin{array}{c}\sum \mathrm{PAH} \\
\sum 16 \mathrm{PAH}\end{array}$ & $\begin{array}{c}317-6,101 \\
79-169\end{array}$ & Santiago et al. (2016) \\
\hline Sepetiba/RJ & Sediment & $\sum \mathrm{PAH}$ & $45-3,138$ & Pinheiro et al. (2017) \\
\hline Guanabara Bay/RJ & Sediment & $\sum \mathrm{PAH}$ & $101-4,148$ & Camargo et al. (2017) \\
\hline Rio de Janeiro/RJ & Sediment & $\sum \mathrm{PAH}$ & $259-8,064$ & Pinheiro et al. (2017) \\
\hline Angra dos Reis/RJ & Sediment & $\sum \mathrm{PAH}$ & $48-2,626$ & Pinheiro et al. (2017) \\
\hline São Sebastião/SP & Bentic & $\sum \mathrm{PAH}$ & $1-524$ & Checon et al. (2018) \\
\hline São Sebastião/SP & Sediment & $\sum \mathrm{PAH}$ & $1-621$ & Kim et al. (2018) \\
\hline São Sebastião/SP & Sediment & $\sum \mathrm{PAH}$ & $201-1,494$ & Pinheiro et al. (2017) \\
\hline Santos/SP & Sediment & $\sum \mathrm{PAH}$ & $181-3,397$ & Pinheiro et al. (2017) \\
\hline Paranaguá Bay/PR & $\begin{array}{l}\text { Water } \\
\text { Sediment } \\
\text { Plancton }\end{array}$ & $\sum \mathrm{PAH}$ & $\begin{array}{c}51-162 \\
15-133 \\
175-2,096\end{array}$ & Froehner et al. (2018) \\
\hline Laranjeiras Bay/PR & Sediment & $\sum$ PAH & $1-8$ & Camargo et al. (2017) \\
\hline Itajaí-Açu/SC & Sediment & $\sum \mathrm{PAH}$ & $64-1,459$ & Frena et al. (2017) \\
\hline
\end{tabular}

Source: adapted from Pinheiro et al. (2017).

The Laboratory of Applied Ichthyology (LAB PEIXE - UVV) conducted experiments with Echinometralucunter to determine the decrease in fertilization rates and reduction of larvae pluteus development rate due to concentrations of benzene, toluene, ethylbenzene and xylenes (BTEX) and PAHs in water (Pereira et al., 2018).

Concentrations of PAHs in Paranaguá Bay water $\left(162.37 \mu \mathrm{g} \mathrm{l}^{-1}\right)$ indicated a worrying situation compared to results of toxicity tests conducted by LAB PEIXE (Pereira et al., 2018), 
with potential decreases of $80-90 \%$ of the fertilization and larvae pluteus development rates. In biota, the accumulation is associated with the level in the trophic chain and lipid content; plankton presented 39\% and fish 38\% of the total PAHs quantified (Froehner et al., 2018).

A study conducted with fish samples (Cathorops spixii and Atherinella brasiliensis) in Paranaguá Bay showed elevated levels of contamination affecting both fish species (Santos et al., 2018). The analyses showed five times higher concentrations of two-ringed PAH metabolites in the bile of the two fish species in Paranaguá Bay in comparison to those in the control site (Santos et al., 2018).

The PAHs pollution levels were investigated in the ocean by produced water discharge around the P19 and P40 offshore platforms in Campos Basin, using two species of fish, Caranxcrysos and Tylosurusacus (Lourenço et al., 2018). The non discharging produced water platform P25 was taken as an uncontaminated reference. The average concentration of PAH observed in the C. crysos muscle tissue was $219.38 \mathrm{ng} \mathrm{g}^{-1}$ (P40), followed by $68.26 \mathrm{ng} \mathrm{g}^{-1}$ (P19) and $12.95 \mathrm{ng} \mathrm{g}^{-1}$ (P25, control group). The average value observed for $\mathrm{T}$. acus was $42.21 \mathrm{ng} \mathrm{g}^{-1}$ (P40), followed by $40.07 \mathrm{ng} \mathrm{g}^{-1}$ (P19) and $18.04 \mathrm{ng} \mathrm{g}^{-1}$ (P25, control group). These results with fish study confirmed a previous bioaccumulation of PAH by produced water discharge detected with bivalves under the platforms (P19 and P40) at Campos Basin (Lourenço et al., 2018). Produced water had small quantities of oil and derivatives, being usually well diluted because of the continuous discharge. The bioaccumulation of tested fish could be considered as minimally contaminated with PAH, even if the concentration of PAH in the muscle tissues of both species were low and not genotoxic (Lourenço et al., 2018).

A study conducted at seven sites, classified in three groups (Praia Grande, Ubatuba and Espírito Santo), along the southeastern coast of Brazil has shown that green sea turtles (Chelonia mydas) may be developing Fibropapillomatosis (FP) due to exposure to PAH, especially because of phenanthrene (Vilca et al., 2018). Turtles of the Espírito Santo Group developed more Fibropapillomatosis (FP) individually than those in other groups, 17 with an FP of 19 C. mydas collected. In general, Espírito Santo presented more environmental problems than other sites. These results might be due to its association with a large port, water discharge and heavy industry, which could have explained the individuals with more FP in this group (Vilca et al., 2018).

The studies above showed evidence of oil contamination with PAH low concentrations, even in smaller areas far from large industrial centers and without accidental spills. The total PAHs levels presented significant variability from studies between 2016 and 2018 in the Brazilian coast waters near offshore oil exploitation fields, showing higher concentrations near harbors than in the other position sites (Table 3). This data compilation represents an initial diagnosis of water quality conditions and its contamination by oil along the Brazilian southeastern coast. The PAH levels found in the studies were quite heterogeneous (Table 2), indicating that pollution is not yet massively spread throughout the coast, being concentrated only in few areas, and just detectable at low levels in areas of preservation.

\section{CONCLUSIONS}

The Brazilian offshore oil production follows the worldwide trend of increasing production and reducing accidents, but despite the significant accident reduction rates, events like those of Deepwater Horizon, show environmental risks of ultra-deep oil exploration.

Campos and Santos Basins are the most important offshore oil reserves under exploration in Brazil, with huge potential to be explored in the next decades, mainly concerning the oil located in the pre-salt layer with large environmental risks resulting from ultra-deep oil exploration. A large part of the exploration is over coastal platforms, in very shallow waters, which makes the dispersion and dilution of heavy hydrocarbons difficult, influencing some 
bioaccumulation found in marine life.

Studies of the geophysical aspects of the region as well as the possible environmental impacts are still very segmented by areas of knowledge, but hold great potential for more integrated, multi- and interdisciplinary studies. The onset of the environmental licensing phases of the wells and of prevention of accidents, plus studies on how to remediate contaminated areas, must be integrated in the future oceanic engineering projects and platforms.

The environmental description of the Brazilian southeastern coast shows that the intense atmospheric events due to the potential formation of cyclones in the region, added to the high velocity of the Brazil Current meanders are good for oil pollution dispersion, contributing unfavorably to the exploration of that region. These conditions are not so extreme when compared to the Alaskan and Mexican Gulfs and, therefore, Brazilian platforms are not at severe risk due to the weathering. However, exploration of the pre-salt fields brings many risks because of the ultra-deep distances, as evidenced by previous accidents at the Chevron platform in the Campos Basin (3,700 $\mathrm{m}^{3}$ of oil spilled in 2011) and Dynamic Producer in the Santos Basin $\left(160 \mathrm{~m}^{3}\right.$ of oil spilled in 2012).

Brazil still does not have a reliable database to unify all oil spill information reported to IBAMA, despite the attempt made in 2014 by Maggi. The creation of a database substantiated on federal Law $\mathrm{n}^{\mathrm{o}} 12.527 / 2011$ would allow broad access to existing information, increasing knowledge and allowing further studies on the environmental impacts of oil spills. This database could also have data on the allowed discharge of produced water at each point of launch along the Brazilian coast, according to the environmental licenses issued.

Despite efforts of environmental impact assessment and effluent emission limits, there are many studies showing some levels of PAH contamination in environmental matrices along the coast. It is possible that the continuous emission of effluents, uncontrolled oil spills, large unremoved oil spills, untreated ballast water, oil removal from platforms and equipment by the rain, are creating (or increasing) PAH background concentrations along the coast. Low-level emissions in produced water causes a residual impact in water quality However, the large amounts of oil wells and their arising operations, such as transport, ship-to-ship, among others, are resulting in some background pollution and not only in residual impacts.

The polycyclic aromatic hydrocarbons (PAH) pollution levels evaluation have been showing that there are still preserved areas on Brazilian coast which are not risk free, and contamination levels could increase due to the growth of offshore oil production.

\section{ACKNOWLEDGMENTS}

The authors thank the financial support - CAPES-PROEX (Post-graduation program in Meteorology), fellowship CNPq. Department of Atmospheric Sciences, Institute of Astronomy, Geophysics and Atmospheric Sciences, University of São Paulo, IAG/USP.

\section{REFERENCES}

ALVES, T. M.; FETTER, M.; LIMA, C.; CARTWRIGHT, J. A.; COSGROVE, J.; GANGÁ, A.; QUEIROZ, C. L.; STRUGALE, M. An incomplete correlation between pre-salt topography, top reservoir erosion, and salt deformation in deep-water Santos Basin (SE Brazil). Marine and Petroleum Geology, v. 79, p. 300-320, 2017. https://dx.doi.org/10.1016/j.marpetgeo.2016.10.015

AMBRIZZI, T.; FERRAZ, S. E. An objective criterion for determining the South Atlantic Convergence Zone. Frontiers in Environmental Science, v. 3, p. 23. 2015. https://dx.doi.org/10.3389/fenvs.2015.00023 
AGÊNCIA NACIONAL DO PETRÓLEO (Brasil). Anuário Estatístico Brasileiro do Petróleo, Gás Natural e Biocombustíveis. Rio de Janeiro, 2018.

AGÊNCIA NACIONAL DO PETRÓLEO (Brasil). Webmapas. Available at: http://webmaps.anp.gov.br/mapas/Lists/DSPAppPages/MapasBrasil.aspx Access: 24 Feb. 2020.

BARROS, V.; GONZALEZ, M.; LIEBMANN, B.; CAMILLONI, I. Influence of the South Atlantic convergence zone and South Atlantic Sea surface temperature on interannual summer rainfall variability in Southeastern South America. Theoretical and Applied Climatology, v. 67, n. 3-4, p. 123-133, 2000. https://dx.doi.org/10.1007/s007040070002

BELTRÃO, R. L.; SOMBRA, C. L.; LAGE, A. C.; FAGUNDES-NETTO, J. R.; HENRIQUES, C. C. Challenges and new technologies for the development of the pre-salt cluster, Santos Basin, Brazil. In: OFFSHORE TECHNOLOGY CONFERENCE, 4-7 May 2009, Houston, Texas. Papers[...] OTC, 2009. p. 1-11. https://dx.doi.org/10.4043/19880-MS

BEYER, J.; TRANNUM, H. C.; BAKKE, T.; HODSON, P. V.; COOLIER, T. K. Environmental effects of the Deepwater Horizon oil spill: A review. Marine Pollution $\begin{array}{llllllll}\text { Bulletin, } & \text { v. } & 11 & 0, & \text { n. } & 1, & \text { p. } & 28-51,\end{array}$ https://dx.doi.org/10.1016/j.marpolbul.2016.06.027

BRASIL. Ministério dos Transportes, Portos e Aviação Civil. Complexo Portuário de Paranaguá e Antonina - Sumário Executivo. Paranaguá, 2018.

BRASIL. Presidência da República. Constituição da República Federativa do Brasil de 1988. Diário Oficial [da] União: seção 1, Brasília, DF, n. 191-A, p. 1-32, 05 out. 1988.

CAMARGO, M. Z.; SANDRINI-NETO, L.; CARREIRA, R. S.; CAMARGO, M. G. Effects of hydrocarbon pollution in the structure of macrobenthic assemblages from two large estuaries in Brazil. Marine Pollution Bulletin, v. 125, p. 66-76, 2017. https://dx.doi.org/10.1016/j.marpolbul.2017.07.074

CARVAlHO, L. M.; JONES, C.; LIEBMANN, B. The South Atlantic Convergence Zone: Intensity, Form, Persistence, and Relationships with Intraseasonal to Interannual Activity and Extreme Rainfall. Journal of Climate, v. 17, p. 88-108, 2004. https://dx.doi.org/10.1175/1520-0442(2004)017<0088:TSACZI >2.0.CO;2

CHECON, H. H.; CORTE, G. N.; MUNIZ, P.; BRAUKO, K. M.; DI DOMENICO, M.; BÍCEGO, M. C.; SIEGLE, E.; FIGUEIRA, R. C. L.; AMARAL, A. C. Z. Unraveling the performance of the benthic index AMBI in a subtropical bay: The effects of data transformations and exclusion of low-reliability sites. Marine Pollution Bulletin, v. 126, p. 438-448, 2018. https://dx.doi.org/10.1016/j.marpolbul.2017.11.059

COELHO, A. C. Operational risk in the decommissioning of fixed maritime oil exploration and production unit. 2010. Masters Dissertation - Fluminense Federal University - UFF, Technological Center, Niterói, 2010.

CPRM. Bacias sedimentares da margem continental brasileira. 2018. Available at: http://www.cprm.gov.br/publique/media/recursos_minerais/livro_geo_tec_rm/capIIIg.pdf_Access: 2020.

DEVUYST, D. Linking impact assessment and sustainable development at the local level: the introduction of sustainability assessment systems. Sustain. Dev. 8 (2),67-78, 2000. 
DOMINGOS, D. de O. Bacias Sedimentares em KMZ. 28 Jul. 2011. Available at: http://www.danilodomingos.com.br/bacias_sedimentares_kmz.php Access: 2020.

DUTRA, L. M. Subtropical cyclones on the South Atlantic: analysis of the dynamic structure of events. 2012. Master Thesis - Institute of Astronomy, Geophysics and Atmospheric Sciences, University of São Paulo, São Paulo, 2012.

FERREIRA, H. O.; CABRAL, A.; SOUZA JUNIOR, Á. An application of worst-case scenario concept in oil spill response planning for offshore drilling operation in Brazil. International Oil Spill Conference Proceedings, v. 2003, n. 1, p. 371-376, 2003. http://dx.doi.org/10.7901/2169-3358-2003-1-i

FINGAS, M. Oil spill science and technology. Prevention, Response and Clean-up. $1^{\text {st }}$ ed. Houston: Gulf Professional Publishing, 2010.

FRENA, M.; BATAGLION, G. A.; SANDINI, S. S.; KUROSHIMA, K. N.; EBERLIN, M. N.; MADUREIRA, L. Distribution and sources of aliphatic and polycyclic aromatic hydrocarbons in surface sediments of Itajaí-Açu estuarine system in Brazil. Journal of Brazilian Chemical Society, v. 28, n. 4, p. 603-614, 2017. https://dx.doi.org/10.21577/0103-5053.20160205

FROEHNER, S.; RIZZI, J.; VIEIRA, L. M.; SANEZ, J. PAHs in water, sediment and biota in an area with port activities. Archives of Environmental Contamination and Toxicology, v. 75, p. 236-246, 2018. https://dx.doi.org/10.1007/s00244-018-0538-6

GILLILAND, J. M., KEIM, B. D. Position of the South Atlantic Anticyclone and Its Impact on Surface Conditions across Brazil. Journal of Applied Meteorology and Climatology, v. 57, n. 3, p. 535-553, 2018. https://dx.doi.org/10.1175/JAMC-D-17-0178.1

GLASSON, J.; THERIVEL, R. Introduction to Environmental Impact Assessment. $4^{\text {th }}$ ed. London: Routledge, 2012. p. 6-10.

GOOS-BRASIL. Programa Nacional de Boias. Available at: http://www.goosbrasil.org/pnboia/dados/ Access: 24 Feb. 2020.

ITOPF. Oil Tanker Spill Statistics. 2019. Available at: https://www.itopf.org/fileadmin/data/Documents/Company_Lit/Oil_Spill_Stats_2019.p df. Access 2020.

KIM, B.; BÍCEGO, M.; TANIGUCHI, S.; SIEGLE, E.; OLIVEIRA, R.; ALCÁNTARACARRIÓ, J.; FIGUEIRA, R. Organic and inorganic contamination in sediments from AraçáBay, São Sebastião, Brazil. Ocean and Coastal Management, v. 164, p. 42-51, 2018. https://dx.doi.org/10.1016/j.ocecoaman.2017.12.028

LOURENÇO, R. A.; FRANCIONI, E.; SILVA, A.; MAGAlHÃES, C. A.; GALlOTTA, F. D.; OLIVEIRA, F. F.; SOUZA, J. M., ARAÚJO, L. F. M.; ARAÚJO, L. P.; ARAÚJOJR, M. A. G.; MENICONI, M. F. G.; LOPES, M. A. F. S. B. G. Bioaccumulation study of produced water discharges from Southeastern Brazilian offshore petroleum industry using Feral Fishes. Archives of Environmental Contamination and Toxicology, v. 74, n. 3, p. 461-470, 2018. https://dx.doi.org/10.1007/s00244-018-0510-5

MAGGI, P.; MORGADO, C. R.; ALMEIDA, J. C. Offshore oil spill incidents: creating a database in Brazil. International Oil Spill Conference Proceedings, v. 2014, n. 1, p. 26-30, 2014. https://dx.doi.org/10.7901:2169-3358-2014.1.26 
MATTOS, R. A. Meso and large scale features of the Brazilian current off the Brazilian southeast. 2006. Masters Dissertation - Oceanographic Institute, São Paulo University, São Paulo, 2006.

MELLO, U. T.; KARNER, G. D.; ANDERSON, R. N. Role of salt in restraining the maturation of subsalt source rocks. Marine and Petroleum Geology, v. 12, n. 7, p. 697-716, 1995. https://dx.doi.org/10.1016/0264-8172(95)93596-V

NASCIMENTO, R. A.; ALMEIDA, M.; ESCOBAR, N.; FERREIRA, S.; MORTATTI, J.; QUEIROZ, A. Sources and distribution of polycyclic aromatic hydrocarbons (PAHs) and organic matter in surface sediments of an estuary under petroleum activity influence, Todos os Santos Bay, Brazil. Marine Pollution Bulletin, v. 119, p. 223-230, 2017. https://dx.doi.org/10.1016/j.marpolbul.2017.03.069

NOAA Physical Sciences Laboratory. Composites. Available at: https://www.esrl.noaa.gov/psd/cgi-bin/data/composites Access: 24 Feb. 2020.

OLIVEIRA, A. I. Technical-economic analysis of $\mathrm{CO}_{2}$ injection in reservoirs with Brazilian pre-salt characteristics. 2016. Masters Dissertation - Rio Grande do Norte Federal University, Natal, 2016.

PAPATERRA, G. E. Pre-Salt: Geological conceptualization on a new exploratory frontier in Brazil. 2010. Masters Dissertation - Departament of Geology, Rio de Janeiro Federal University, Rio de Janeiro, 2010.

PEDREIRA, R.; BARROS, F.; FARIAS, C.; WAGENER, A.; HATJE, V. A tropical bay as a reference area defined by multiple lines of evidence. Marine Pollution Bulletin, v. 123, p. 291-303, 2017. https://dx.doi.org/10.1016/j.marpolbul.2017.08.041

PELLIZZON, M. M. Characterization of Seismic Units, Sedimentary Processes and Age of Almirante Camara Canyon, Campos Basin. 2005. 84 f. Masters Dissertation - Federal Fluminense University, Niteroi, 2005.

PENA, P. G. L.; NORTHCROSS, A. L.; LIMA, M. A. G.; RÊGO, R. C. F. The crude oil spill on the Brazilian coast in 2019: the question of public health emergency. Cadernos de Saúde Pública, v. 36, n. 2, 2020. https://dx.doi.org/10.1590/0102-311x00231019

PEREIRA, T. M.; MERÇON, J.; PASSOS, L. S.; COPPO, G. C.; LOPES, T.; CABRAL, D. S.; SCHERER, R.; CHIPPARI-GOMES, A. R. Effects of the water-soluble fraction of diesel oil (WSD) on the fertilization and development of a sea urchin (Echinometralucunter). Ecotoxicology and Environmental Safety, v. 162, p. 59-62, 2018. https://dx.doi.org/10.1016/j.ecoenv.2018.06.040

PETERSON, R. G.; STRAMMA, L. Upper-level circulation in the South Atlantic Ocean. Progress in Oceanography, v. 26, n. 1, p. 1-73, 1991. https://dx.doi.org/10.1016/00796611(91)90006-8

PETROBRAS. Bacia de Santos. 2018. Available at: http://www.petrobras.com.br/pt/nossasatividades/principais-operacoes/bacias/bacia-de-santos.htm Access: 2020.

PINHEIRO, P.; MASSONE, C. G.; CARREIRA, R. S. Distribution, sources and toxicity potential of hydrocarbons in harbor sediments: A regional assessment in SE Brazil. $\begin{array}{llllll}\text { Marine Pollution Bulletin, v. 120, p. } & 617 .\end{array}$ https://dx.doi.org/10.1016/j.marpolbul.2017.04.049 
REBOITA, M. S.; NIETO, R., GIMENO, L., ROCHA, R. P., AMBRIZZI, T., GARREAUD, R., KRUGER, L. F. Climatological features of cutoff low systems in the Southern Hemisphere. Journal of Geophysical Research, v. 115, 2010a. https://dx.doi.org/10.1029/2009JD013251

REBOITA, M. S.; ROCHA, R. P.; AMBRIZZI, T.; SUGAHARA, S. South Atlantic Ocean cyclogenesis climatology simulated by regional climate model (RegCM3). Climate Dynamics, v. 35, n. 7-8, p. 1331-1347, 2010b. https://dx.doi.org/10.1007/s00382-009-0668-7

RICCOMINI, C.; SANT'ANNA, L. G.; TASSINARI, C. C. Pré-sal: geologia e exploração. Revista USP, v. 95, p. 33-42, 2012. https://dx.doi.org/10.11606/issn.23169036.v0i95p33-42

ROCHA, R. P.; REBOITA, M. S.; GOZZO, L. F.; DUTRA, L. M.; JESUS, E. M. Subtropical cyclones over the oceanic basins: a review. Annals of the New York Academy of Sciences, v. 1436, p. 138-156, 2019. https://dx.doi.org/10.1111/nyas.13927

ROOS, C.; CILliERSA, D. P.; RETIEF, F. P.; AlBERTS, R. C.; BOND, A. J. Regulators' perceptions of environmental impact assessment (EIA) benefits in a sustainable development context. Environmental Impact Assessment Review, v. 81, 2020. https://dx.doi.org/10.1016/j.eiar.2019.106360

SANTIAGO, I. U.; MOLISANI, M. M.; NUDI, A. H.; SCOFIELD, A. L.; WAGENER, A. L.; LIMAVERDE FILHO, A. M. Hydrocarbons and trace metals in mussels in the Macaécoast: Preliminary assessment for a coastal zone under influence of offshore oil field exploration in southeastern Brazil. Marine Pollution Bulletin, v. 103, p. 349-353, 2016. https://dx.doi.org/10.1016/j.marpolbul.2015.12.034

SANTOS, G. S.; PIANCINI, L. D. S.; TINCANI, F. H.; KLINGELFUS, T.; YAMAMOTO, F. Y.; RIBEIRO, C. A. O.; GUILOSKI, I. C.; ASSIS, H. C. S.; CESTARI, M. M. Liver damage in two neotropical fish species from a polluted estuarine area. Ecotoxicology and Environmental Contamination, v. 13, n. 1, p. 39-50, 2018. https://dx.doi.org/10.5132/eec.2018.01.05

SANTOS, M. D.; AMARAL, V. N.; MARTINS, E. R.; QUINTAL, R. S.; MAGNO, B. D. Incidentes de descarga de óleo, substâncias nocivas ou perigosas na bacia de Campos: uma análise do método de análise preliminar de risco. Revista da Universidade Vale do Rio Verde, v. 15, n. 1, p. 94-105, 2017. https://dx.doi.org/10.5892/ruvrd.v15i1.3712

SILVEIRA, I. C. The current system of Brazil in the Campos basin, RJ. 2007. Professor's Thesis - Oceanographic Institute - São Paulo University, São Paulo, 2007.

SILVEIRA, I. C.; MIRANDA, L. B.; BROWN, W. S. On the origins of the North Brazil Current. Journal of Geophysics Research, v. 99, p. 22501-22512, 1994. https://dx.doi.org/10.1029/94JC01776

SILVEIRA, I. C.; SCHMIDT, A. C.; CAMPOS, E. J.; GODOI, S. S.; IKEDA, Y. A corrente do Brasil ao largo da costa leste brasileira. Revista Brasileira de Oceanografia, v. 48, n. 2, p. 171-183, 2000. https://dx.doi.org/10.1590/S1413-77392000000200008

SIQUEIRA, J. R.; MACHADO, L. A. Influence of the frontal systems on the day-to-day convection variability over South America. Journal of Climate, v. 17, p. 1754-1766, 2004. https://dx.doi.org/10.1175/1520-0442(2004)017<1754:IOTFSO>2.0.CO.2 
SNYDER, H. Literature review as a research methodology: An overview and guidelines. Journal of Business Research, v. 104, p. 333-339, 2019. https://dx.doi.org/10.1016/j.jbusres.2019.07.039

SOARES, F. L. Study of the superficial ocean circulation on the southeast coast of Brazil through hydrodynamic modeling. Masters Dissertation - COPPE, Rio de Janeiro Federal University, Rio de Janeiro, 2014.

SOARES-GOMES, A.; GAMA, B.; BAPTISTA NETO, J. A.; FREIRE, D. G.; CORDEIRO, R. C.; MACHADO, W.; BERNARDES, M. C.; COUTINHO, R.; THOMPSON, F. L.; PEREIRA, R. C. An environmental overview of Guanabara Bay, Rio de Janeiro. Regional

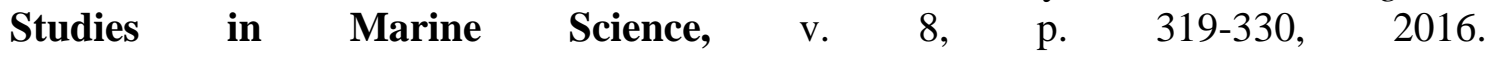
https://dx.doi.org/10.1016/j.rsma.2016.01.009

SOUZA FILHO, A. M. National contingency plans for oil spill care: Analysis of countries representative of the Americas for implementation in the case of Brazil. Masters Dissertation - Rio de Janeiro Federal University, Rio de Janeiro, 2006.

TASCHETTO, A. S.; WAINER, I. The impact of the subtropical South Atlantic SST on South American precipitation. Annales Geophysicae, v. 26, p. 3457-3476, 2008.

UNITED STATES. Bureau of Safety and Environmental Enforcement. Occurrence Rates for Offshore Oil Spills. 2016. Available at: https://www.bsee.gov/sites/bsee.gov/files/osrroil-spill-response-research/1086aa.pdf Access: 2020.

VILCA, F. Z.; ROSSI, S.; OLINDA, R. A.; SÁNCHEZ-SARMIENTO, A. Z.; PRIOSTE, F.; MATUSHIMA, E. R.; TORNISIELO, V. L. Concentrations of polycyclic aromatic hydrocarbons in liver samples of juvenile green sea turtles from Brazil: Can these compounds play a role in the development of fibropapillomatosis? Marine Pollution Bulletin, v. 130, p. 215-222, 2018. https://dx.doi.org/10.1016/j.marpolbul.2018.03.021

WAGENER, A. L. R.; MENICONI, M. F.; HAMACHER, C.; FARIAS, C. O.; SILVA, G. C.; GABARDO, T. I.; SCOFIELD, A. L. Hydrocarbons in sediments of a chronically contaminated bay: The challenge of source assignment. Marine Pollution Bulletin, v. 64, n. 2, p. 284-294, 2012. https://dx.doi.org/10.1016/j.marpolbul.2011.11.018

YIN, L.; ZHANG, M.; ZHANG, Y.; QIAO, F. The long-term prediction of the oil-contaminated water from the Sanchi collision in the East China Sea. Acta Oceanologia Sinica, v. 37, n. 3, p. 69-72, 2018. https://dx.doi.org/10.1007/s13131-018-1193-5

ZACHARIAS, D. C. Development of STFM (Spill, Transport and Fate Model): Lagrangian Computation Model of Transport and Weathering of Oil Slick. 2017. Doctoral Thesis - Institute of Astronomy, Geophysics and Atmospheric Sciences, University of São Paulo, São Paulo, 2017. 


\begin{tabular}{|} 
Ambiente \& Água - An Interdisciplinary Journal of Applied Science \\
ISSN 1980-993X - doi:10.4136/1980-993X \\
www.ambi-agua.net \\
E-mail: ambi.agua@gmail.com
\end{tabular}

\title{
Multivariate statistical analysis applied to assess the dispersion of contaminants in a mining tailings basin in the semiarid region of Bahia - Brazil
}

\author{
ARTICLES doi:10.4136/ambi-agua.2572
}

Received: 05 May 2020; Accepted: 28 Jul. 2020

\author{
Nelize Lima Santos ${ }^{1 *}$; Maria da Conceição Rabelo Gomes ${ }^{2}{ }^{\mathbb{D}}$; \\ José Ângelo Sebastião Araújo dos Anjos ${ }^{2}$; Fernanda Gonçalves Cunha ${ }^{3}$ \\ ${ }^{1}$ Instituto de Geociências. Programa de pós-graduação em Geologia. Universidade Federal da Bahia (UFBA), \\ Rua Barão de Jeremoabo, s/n, CEP: 40170-290, Salvador, BA, Brazil. \\ ${ }^{2}$ Departamento de Geologia. Instituto de Geociências. Universidade Federal da Bahia (UFBA), \\ Rua Barão de Jeremoabo, s/n, CEP: 40170-020, Salvador, BA, Brazil. \\ E-mail: conceicaorabelo@yahoo.com.br, jose.anjos@ufba.br \\ ${ }^{3}$ Consultora independente, Rua Paissandu, no 370, CEP: 22210-080, Flamengo, RJ, Brazil. \\ E-mail: nandagcunha@gmail.com \\ *Corresponding author. E-mail: nelizelima.geo@gmail.com
}

\begin{abstract}
This study employed multivariate analysis techniques to identify and evaluate the chemical variables responsible for the contamination of the urban area of Boquira, Bahia, due to the abandonment of the tailings basin of $\mathrm{Pb}-\mathrm{Zn}$ mining, in order to assist in the environmental management of the area. Factor analysis was performed on main and grouping components. The factor analysis allowed grouping the variables into two main factors for street sediment samples, adding up to $72 \%$ of the total accumulated variance, and three factors for house dust samples, which explained $77 \%$ of the total variance. The variables have a strong correlation with the composition of the tailings basin. Cluster analysis classified the samples according to the concentration of metals in the area, where the influence of the tailings basin and the natural background of the region's rocks in the contamination distribution can be identified.
\end{abstract}

Keywords: cluster analysis, contamination, main component analysis.

\section{Análise estatística multivariada aplicada na avaliação da dispersão de contaminantes de uma bacia de rejeitos de mineração no semiárido baiano - Brasil}

\section{RESUMO}

As técnicas de análise multivariada utilizadas nesta pesquisa tiveram por objetivo identificar e avaliar as variáveis químicas responsáveis pela contaminação da área urbana de Boquira, Bahia, devido ao abandono da bacia de rejeitos da mineração de $\mathrm{Pb}-\mathrm{Zn}$, com a finalidade de auxiliar nas medidas de gerenciamento ambiental na área. Foram realizadas a análise fatorial em componentes principais e de agrupamento. A análise fatorial permitiu agrupar as variáveis em dois fatores principais para as amostras de sedimentos de rua, somando $72 \%$ da variância total acumulada e em três fatores para as amostras de poeira de casas, que 
explicaram $77 \%$ do total da variância. As variáveis apresentam forte correlação com a composição da bacia de rejeitos. A análise de agrupamento classificou as amostras de acordo com a concentração dos metais na área, onde pode-se concluir a influência da bacia de rejeitos e do backgound natural das rochas da região na distribuição da contaminação.

Palavras-chave: análise de agrupamento, análise de componentes principais, contaminação.

\section{INTRODUCTION}

The municipality of Boquira, located in the south-central region of the state of Bahia, is located on the geological domain of the Paramirim deformation corridor, composed of, among other lithotypes, rocks from the Boquira Unit that provide this region with a high natural background for lead and zinc (Gomes et al., 2020). Because of this characteristic, the municipality was the scene of mineral exploration from the late 1950s to 1992 . The extensive production at the mine resulted in the generation of a tailings basin of approximately $3360 \mathrm{~m}^{2}$ in area and $894 \times 10^{3} \mathrm{~m}^{3}$ in volume, consisting of heavy metals associated with the mineralogical composition of the geological framework of the area.

The tailings basin, abandoned with the end of extraction activities, was the target of an inefficient revegetation program, and its fine-grained material is therefore constantly susceptible to wind erosion. Two aggravating factors in this situation are the location of the tailings basin, immediately next to the urban area and cultivation areas of the municipality, and the creation of the municipal dump over the basin. The atmospheric dispersion of material from the tailings basin exposes the municipality to a series of toxic metals that can cause damage to the health of the population.

Studies on the behavior of toxic metals in urban areas make it possible to interpret the potential risks of these elements; however, the assessment of the environmental quality of an area generally involves a wide range of variables, making it difficult to understand their interrelations (Gomes et al., 2020). Multivariate analysis of the data makes it possible to establish variables essential to environmental management, as this method allows the selection of the variables with greater participation in the contamination that must be monitored and thus reduce costs with less important parameters.

This work therefore aims to define the most important variables in the contamination of the urban area of the municipality due to the presence of the tailings basin through the use of multivariate analysis techniques, in order to assist in the environmental management of the municipality.

\section{METHODOLOGY}

In the present study, the contamination data were obtained by the Low Density Geochemical Survey of the State of Bahia (Cunha et al., 2016), which contains information on 110 house dust samples and 66 street sediment samples collected at different points of the urban area of the Boquira municipality.

The chemical variables for the home dust samples considered in this study were: aluminum $(\mathrm{Al})$, arsenic (As), barium (Ba), bismuth (Bi), calcium (Ca), cadmium (Cd), cobalt (Co) ), chromium $(\mathrm{Cr})$, copper $(\mathrm{Cu})$, lead $(\mathrm{Pb})$, sulfur $(\mathrm{S})$, strontium $(\mathrm{Sr})$, iron $(\mathrm{Fe})$, phosphorus $(\mathrm{P})$, lithium (Li), magnesium (Mg), manganese (Mn ), molybdenum (Mo), nickel (Ni), potassium $(\mathrm{K})$, sodium $(\mathrm{Na})$, vanadium $(\mathrm{V})$, zinc $(\mathrm{Zn})$. The 110 samples analyzed and the 23 chemical analyses add up to 2530 results for house dust. In addition to the 23 cited elements above, 28 other elements were considered for the street sediment samples, namely, antimony ( $\mathrm{Sb}$ ), boron (B), beryllium (Be), cesium (Cs), scandium ( $\mathrm{Sc})$, tin $(\mathrm{Sn})$, phosphorus $(\mathrm{P})$, germanium $(\mathrm{Ge})$, gallium $(\mathrm{Ga})$, hafnium $(\mathrm{Hf})$, indium $(\mathrm{In})$, lanthanum $(\mathrm{La})$, mercury $(\mathrm{Hg})$, niobium $(\mathrm{nb})$, gold 
$(\mathrm{Au})$, palladium $(\mathrm{Pd})$, platinum $(\mathrm{Pt})$, silver $(\mathrm{Ag})$, rhenium $(\mathrm{Re})$, rubidium $(\mathrm{Rb})$, selenium $(\mathrm{Se})$, tungsten $(\mathrm{W})$, thallium $(\mathrm{Tl})$, tellurium $(\mathrm{Te})$, thorium $(\mathrm{Th})$, tantalum $(\mathrm{Ta})$, titanium $(\mathrm{Ti})$, uranium (U), in street sediment samples. The 66 samples analyzed and 51 chemical analyses add up to 3366 results for street sediment.

For statistical analysis in this study, the SPSS Statistics software, Version 17.0, was used, where the techniques of factor analysis and cluster analysis were performed. The mathematical model of factor analysis is controlled by the following Equation 1:

$X_{i}=a_{i 1} F_{1}+a_{i 2} F_{2}+a_{i 3} F_{3}+\ldots+a_{i j} F_{j}+e_{i}$

Where: $\mathrm{X}_{\mathrm{i}}$ are the standardized variables, $\mathrm{a}_{\mathrm{i}}$ are the factor loads, $\mathrm{F}_{\mathrm{j}}$ are the common factors not related to each other and $e_{i}$ is an error that represents the variation portion of variable $i$ that is unique to it and cannot be explained by a factor nor by another variable in the analyzed set (Bezerra, 2014).

The factorial analysis aimed to group information contained in a group of original variables into a smaller set of statistical variables; these variables are calculated by the linear combination of the original variables. The factor analysis was divided into the calculation of the correlation matrix, the extraction of factors and the rotation of the matrix.

An examination of the correlations between the variables was performed to obtain the correlation matrix that made it possible to identify the subsets of variables that were highly correlated with each other. The factor extraction method was based on Principal Component Analysis through a linear combination between the variables and the analysis of the variables was carried out based on the similarities between the variables (Mode R).

In order to observe whether the data were sufficiently linked to carry out the factor analysis, the correlation matrix was calculated using the Kaiser-Meyer-Olkin Measure of Sampling Adequacy (KMO) method, which determines the adequacy of the data, where values between 0.5 and 0.9 indicate the degree of correlation between the variables, therefore a satisfactory factor analysis. Still, the Bartlett Test of Sphericity (BTS) was used, which tests the hypothesis that there is no correlation between the variables analyzed, thus indicating whether there was a sufficient relationship between the variables for the application of factor analysis.

In order to improve the explanatory potential of the variables, an orthogonal rotation of the factors was carried out using the Varimax Method (Johnson and Wichern, 2007), in order to minimize the number of variables with high loads in different factors, allowing the association of a variable with a single factor (Gomes et al, 2020).

The analysis of hierarchical clustering of the samples was used to identify subgroups statistically different from each other, but composed of individuals or similar variables according to some criterion. Ward's method was used to measure the similarity given by the square Euclidean distance (Equation 2), from the total sum of the squared values of the deviations of each object in relation to the average value of the group in which it was inserted.

$d_{i j}^{2}=\sum_{k=1}^{p}\left(x_{i k}-x_{j k}\right)^{2}$

Where: $d_{i j}$ is the distance between two observations that corresponds to the sum of the squares of the differences between $i$ and $j$ for all $p$ variables (Landim, 2011).

The environmental quality assessment was carried out using the clusters formed based on CONAMA Resolution No. 420 of 2009 (CONAMA, 2009) which establishes guidelines for the environmental management of areas contaminated by these substances as a result of anthropic activities. This resolution was used due to the lack of Brazilian legislation that determines guiding values for street sediments and house dust in relation to human health. 


\section{RESULTS AND DISCUSSION}

The factor analysis aimed to order the variables so that it was possible to understand the distribution of concentrations of contaminants in the urban area of the municipality.

The factor analysis in street sediments was initially performed with the 51 chemical variables. Three simulations were necessary to obtain a satisfactory result, taking into account the criteria adopted for this analysis. The final simulation significantly reduced the number of variables, resulting in 6 variables ( $\mathrm{Al}, \mathrm{Pb}, \mathrm{Ca}, \mathrm{Fe}, \mathrm{Mg}$ and $\mathrm{Na}$ ). Table 1 shows the correlation matrix for the analyzed attributes, where one can observe that $40 \%$ of the pairs showed good correlation index $(\geq 0.50)$, only $20 \%$ in the range of $0.6<[\mathrm{r}]<0.9$ indicating a strong correlation, according to the classification by Callegari-Jaques (2003).

Table 1. Correlation matrix of the chemical variables of street sediment samples, in bold are the strong correlations and in italic, the weakest correlation. Sampling period: July / 2013

\begin{tabular}{lcccccc}
\hline Variables & Al & Pb & Ca & Fe & Mg & Na \\
\hline Aluminum (Al) & 1.000 & & & & & \\
Lead (Pb) & 0.278 & 1.000 & & & & \\
Calcium (Ca) & 0.497 & 0.123 & 1.000 & & & \\
Iron (Fe) & $\mathbf{0 . 6 7 8}$ & 0.197 & 0.371 & 1.000 & & \\
Magnesium (Mg) & $\mathbf{0 . 6 6 1}$ & 0.295 & $\mathbf{0 . 7 3 9}$ & $\mathbf{. 5 4 1}$ & 1.000 & \\
Sodium (Na) & 0.123 & -.083 & $\mathbf{0 . 5 2 7}$ & 0.105 & $\mathbf{0 . 5 6 8}$ & 1.000 \\
\hline
\end{tabular}

The results obtained through the correlation matrix allowed the identification of subsets of variables correlated strongly with each other, but little related to other variables. It was observed that there is a strong and positive correlation between the pairs of the variables $\mathrm{Fe}-\mathrm{Al}, \mathrm{Mg}-\mathrm{Al}$ and $\mathrm{Ca}-\mathrm{Mg}$ and the lowest correlation is between $\mathrm{Na}-\mathrm{Pb}$. The KMO index of the set of attributes analyzed was 0.706 and Bartlett's sphericity statistical test was significant with sig $=0.00$, indicating that the factors can adequately describe the data variation (Table 2).

Table 2. Factor loads, commonality and variance explained in the factor analysis of the analyzed variables, after rotation by the Varimax method for street sediment samples. Sampling period: July / 2013.

\begin{tabular}{lccc}
\hline Variables & Factor 1 & Factor 2 & Communalities \\
\hline Aluminium (Al) & 0.349 & $\mathbf{0 . 8 0 6}$ & 0.772 \\
Lead (Pb) & -0.156 & $\mathbf{0 . 6 6 4}$ & 0.466 \\
Calcium (Ca) & $\mathbf{0 . 8 0 7}$ & 0.319 & 0.753 \\
Iron (Fe) & 0.269 & $\mathbf{0 . 7 5 9}$ & 0.648 \\
Magnesium (Mg) & $\mathbf{0 . 7 6 4}$ & 0.541 & 0.875 \\
Sodium (Na) & $\mathbf{0 . 8 8 8}$ & -0.178 & 0.820 \\
\hline Variance explained by factors (\%) & 51.062 & 21.164 & \\
\hline Accumulated variance (\%) & 72.226 \\
\hline
\end{tabular}

Concentration units: $\mathrm{mg} \mathrm{L}^{-1}$, except $\mathrm{EC}(\mu \mathrm{S} / \mathrm{cm}) . \mathrm{KMO}=0.706$.

The factor analysis of the main component applied to street sediments condensed the analyzed variables into two ordered factors, which account for $72 \%$ of the total variance. Using 
Varimax orthogonal rotation, it was observed that Factor 1 (F1) was responsible for $51 \%$ of this variance and Factor $2(\mathrm{~F} 2)$ was responsible for $21 \%$ of the total variance. The variables present in Factor 1 were $\mathrm{Na}(0.888), \mathrm{Ca}(0.807)$ and $\mathrm{Mg}(0.764)$, whereas Factor 2 included the variables $\mathrm{Al}(0.806), \mathrm{Fe}(0.759)$ and $\mathrm{Pb}(0.664)$.

Factor 1 , represented by the variables $\mathrm{Ca}, \mathrm{Mg}, \mathrm{Na}$, is strongly correlated to the mineralogical composition of the geological framework of the area. The Boquira Unit, outcropping in the region, consists of a sedimentary chemical-terrestrial sequence, with associations of metacarbonates, quartzites, shales and banded iron formations (Carvalho, 2000; Garcia, 2011). The Boquira Unit's iron formation can be subdivided into five different facies, one of which is composed of, among other types of carbonates, dolomites (rock formed by double calcium and magnesium carbonate, [CaMg (CO3) 2]).

Factor 2, which comprises the variables $\mathrm{Al}, \mathrm{Pb}, \mathrm{Fe}$, correlates strongly with the indicator attributes of clay mineral formation ( $\mathrm{Al}$ and $\mathrm{Fe}$ ) through chemical weathering in the soil. Factor 2 also indicated the presence of $\mathrm{Pb}$, which is related to both concentration by natural processes in the Boquira Unit (Carvalho, 2000; Garcia, 2011) and exposure due to the mineral exploration and abandonment process in the municipality. Despite this, the presence of a moderate form suggests its atmospheric dispersion due to $\mathrm{Pb}$ being generally associated with particles smaller than $53 \mu \mathrm{m}$ in size (Alves et al., 2018).

Factor analysis on house dust was performed initially with the 23 chemical variables. Four simulations were necessary to obtain a satisfactory result, taking into account the criteria adopted for this analysis. The final simulation was reduced to 13 variables ( $\mathrm{Al}, \mathrm{Pb}, \mathrm{Cr}, \mathrm{Cd}, \mathrm{Sr}$, $\mathrm{Fe}, \mathrm{P}, \mathrm{Zn}, \mathrm{Mn}, \mathrm{Mo}, \mathrm{Ni}, \mathrm{K}$ and V). Table 3 shows the correlation matrix for the analyzed attributes, where it can be seen that $23 \%$ of the total pairs had a good correlation index $(\geq 0.50)$, with only $15 \%$ in the range of $0.6<[\mathrm{r}]<0.9$ indicating a strong correlation, according to the Callegari-Jaques (2003) classification.

The results obtained through the correlation matrix allowed the identification of subsets of variables strongly correlated with each other, but little related to other variables. It was observed that there is a strong and positive correlation between the pairs of variables $\mathrm{Cd}-\mathrm{Pb}, \mathrm{Cd}-\mathrm{Zn}$ and $\mathrm{Pb}-\mathrm{Zn}$. On the other hand, the correlations involving the variables $\mathrm{Ni}, \mathrm{Sr}, \mathrm{K}$ and Mo have a low to moderate correlation with the other variables. The KMO index of the set of attributes analyzed was 0.752 and Bartlett's sphericity statistical test was significant with sig $=0.00$, indicating that the factors can adequately describe the data variation (Table 4).

The factor analysis of the main component applied to street sediments condensed the analyzed variables into three ordered factors, which account for $77 \%$ of the total variance. Using Varimax orthogonal rotation, it was observed that Factor 1 (F1) was responsible for 35\% of this variance, Factor 2 (F2) was responsible for $24 \%$ and Factor $3(\mathrm{~F} 3)$ was responsible for $18 \%$ of total variance. The variables present in Factor 1 were $\mathrm{Pb}(0.954), \mathrm{Zn}(0.917), \mathrm{Cd}(0.892), \mathrm{Mn}$ (0.815), $\mathrm{Fe}(0.789)$ and $\mathrm{P}(0.591)$, in Factor 2 were $\mathrm{Al}(0.851), \mathrm{V}(0.847), \mathrm{Cr}(0.800)$ and $\mathrm{Ni}$ (0.750) and in Factor 3 were K (0.970), Mo (0.969) and Sr (0.893).

Factor 1 is represented by the variables $\mathrm{Cd}, \mathrm{Pb}, \mathrm{Zn}, \mathrm{Mn}, \mathrm{Fe}$ and $\mathrm{P}$, and maintains a strict relationship with the elements present in the tailings basin. Chemical analyses performed in the tailings basin show a correspondence with the mineralogical association of the primary ore (Carvalho, 2000; Garcia, 2011; Alves et al., 2018) and point out $\mathrm{Pb}$ and $\mathrm{Zn}$ as the main metals that make up the basin (Cunha et al., 2016; Alves et al., 2018).

The granulo-chemical analyses of the tailings basin indicate a concentration in the granulometry range below $105 \mu \mathrm{m}$, with more than half being smaller than $53 \mu \mathrm{m}$ in size (Alves et al., 2018). Because it is located immediately next to the urban area of the municipality and does not have any type of erosion control, the material from the tailings basin has been dispersed in the region, especially by air. 
Table 3. Correlation matrix of the chemical variables of house dust samples, in bold are the strong correlations and in italic, the weakest correlations. Sampling period: July / 2013.

\begin{tabular}{|c|c|c|c|c|c|c|c|c|c|c|c|c|c|}
\hline Variables & $\mathrm{Al}$ & $\mathrm{Cd}$ & $\mathrm{Pb}$ & $\mathrm{Cr}$ & $\mathrm{Sr}$ & $\mathrm{Fe}$ & $\mathrm{P}$ & $\mathrm{Mn}$ & Mo & $\mathrm{Ni}$ & K & V & $\mathrm{Zn}$ \\
\hline $\mathrm{Al}$ & 1.000 & & & & & & & & & & & & \\
\hline $\mathrm{Cd}$ & -0.116 & 1.000 & & & & & & & & & & & \\
\hline $\mathrm{Pb}$ & -0.106 & 0.880 & 1.000 & & & & & & & & & & \\
\hline $\mathrm{Cr}$ & 0.548 & 0.056 & 0.138 & 1.000 & & & & & & & & & \\
\hline $\mathrm{Sr}$ & -0.338 & 0.067 & 0.032 & -0.067 & 1.000 & & & & & & & & \\
\hline $\mathrm{Fe}$ & 0.211 & 0.559 & 0.692 & 0.453 & -0.076 & 1.000 & & & & & & & \\
\hline $\mathrm{P}$ & 0.213 & 0.525 & 0.491 & 0.216 & -0.175 & 0.401 & 1.000 & & & & & & \\
\hline $\mathrm{Mn}$ & -0.050 & 0.574 & 0.783 & 0.263 & -0.034 & 0.684 & 0.349 & 1.000 & & & & & \\
\hline Mo & -0.225 & -0.038 & -0.060 & -0.141 & 0.787 & -0.155 & -0.202 & -0.085 & 1.000 & & & & \\
\hline $\mathrm{Ni}$ & 0.498 & -0.246 & -0.198 & 0.515 & -0.032 & 0.094 & 0.037 & -0.102 & 0.057 & 1.000 & & & \\
\hline K & -0.227 & -0.036 & -0.058 & -0.142 & 0.788 & -0.153 & -0.202 & -0.084 & 1.000 & 0.056 & 1.000 & & \\
\hline V & .803 & -0.021 & 0.094 & 0.623 & -0.285 & 0.422 & 0.179 & 0.224 & -0.169 & 0.392 & -0.170 & 1.000 & \\
\hline $\mathrm{Zn}$ & 0.013 & 0.836 & 0.846 & 0.263 & 0.053 & 0.686 & 0.487 & 0.651 & -0.067 & -0.178 & -0.066 & 0.162 & 1.000 \\
\hline
\end{tabular}

Subtitle: Al - Aluminium; Cd - Cadmium; $\mathrm{Pb}$ - Lead; Cr-Chrome; $\mathrm{Sr}$ - Strontium; Fe - Iron; P - Phosphor; Mn - Manganese; Mo - Molybdenum; Ni - Nickel; K - Potassium; V - Vanadium; Zn - Zinc. 
Table 4. Factor loads, commonality and variance explained in the factor analysis of the analyzed variables, after rotation by the Varimax method for street sediment samples. Sampling period: July / 2013.

\begin{tabular}{lcccc}
\hline Variables & Factor 1 & Factor 2 & Factor 3 & Communalities \\
\hline Aluminium (Al) & -0.035 & $\mathbf{0 . 8 5 1}$ & -0.237 & 0.781 \\
Cadmium (Cd) & $\mathbf{0 . 8 9 2}$ & -0.176 & 0.024 & 0.827 \\
Lead (Pb) & $\mathbf{0 . 9 5 4}$ & -0.089 & 0.013 & 0.918 \\
Chrome (Cr) & 0.251 & $\mathbf{0 . 8 0 0}$ & -0.030 & 0.704 \\
Strontium (Sr) & 0.031 & -0.145 & $\mathbf{0 . 8 9 3}$ & 0.820 \\
Iron (Fe) & $\mathbf{0 . 7 8 9}$ & 0.342 & -0.062 & 0.743 \\
Phosphor (P) & $\mathbf{0 . 5 9 1}$ & 0.154 & -0.201 & 0.413 \\
Manganese (Mn) & $\mathbf{0 . 8 1 5}$ & 0.064 & -0.016 & 0.669 \\
Molybdenum (Mo) & -0.082 & -0.044 & -0.969 & 0.948 \\
Nickel (Ni) & -0.188 & $\mathbf{0 . 7 5 0}$ & 0.118 & 0.612 \\
Potassium (K) & -0.080 & -0.046 & 0.970 & 0.949 \\
Vanadium (V) & 0.168 & $\mathbf{0 . 8 4 7}$ & -0.161 & 0.771 \\
Zinc (Zn) & $\mathbf{0 . 9 1 7}$ & 0.017 & 0.018 & 0.842 \\
\hline Variance explained by factors $(\%)$ & 34.788 & 24.517 & 17.596 & \\
\hline Accumulated variance (\%) & \multicolumn{5}{c}{76.901} \\
\hline Concent
\end{tabular}

Concentration units: $\mathrm{mg} \mathrm{L}^{-1}$, except $\mathrm{EC}(\mu \mathrm{S} / \mathrm{cm}) . \mathrm{KMO}=0.706$.

Particles larger than $100 \mu \mathrm{m}$ can be suspended in the atmosphere for short periods, but tend to settle quickly, while particles ranging in size between 0.002 and $100 \mu \mathrm{m}$ tend to remain in suspension longer (Finlayson-Pitts and Pitts, 2000) and are transported over greater distances (Järup, 2013). Thus, unlike the concentration in street sediments, the significant presence of these metals in house dust samples may indicate that the material disposed irregularly in the tailings basin has been transported by air, deposited in the open areas, but remobilized and redeposited in the environments urban areas.

The chemical composition of the tailings basin showed a moderate correlation with Factor 2, which included the variables $\mathrm{Ni}, \mathrm{Cr}, \mathrm{V}$ and $\mathrm{Al}$, and an even lower correlation with Factor 3, represented by the variables $\mathrm{Sr}$, Mo and $\mathrm{K}$. The variables mentioned above were found in the basin of tailings, however at low concentrations (Cunha et al., 2016).

The hierarchical cluster analysis applied to the analysis of toxic metal contamination in the urban area of the municipality allowed the classification of contaminants in different groups, but with similar chemical characteristics in each factor. In street sediment samples, the number of clusters was defined from cut-off point 5 for Factors 1 and 2, where the formation of three homogeneous groups for Factor 1 and two groups for Factor 2 was observed.

According to the Factor 1 variables ( $\mathrm{Ca}, \mathrm{Mg}$ and $\mathrm{Na}$ ), three similar groups were generated, comprising $6 \%, 2 \%$ and $88 \%$ of the samples analyzed in clusters 1, 2 and 3, respectively (Figure 1A). This factor is composed of sediments without a concentration of toxic metals, which have no indication of maximum values allowed in CONAMA Resolution No. 420/2009.

Cluster 1 was characterized by sediments with high concentrations of essential, non-toxic metals. In this group, the concentration of calcium (Ca) varied between 6.85 and $13.10 \mathrm{mg} \mathrm{L}^{-1}$, magnesium $\left(\mathrm{Mg}\right.$ ) varied between 0.61 and $4.52 \mathrm{mg} \mathrm{L}^{-1}$ and sodium (Na) varied between 0.01 and $3.73 \mathrm{mg} \mathrm{L}^{-1}$. Cluster 2 was represented by only one sample (60) and characterized by the highest concentration of $\mathrm{Ca}$ with $23.10 \mathrm{mg} \mathrm{L}^{-1}$, while $\mathrm{Mg}$ and $\mathrm{Na}$ showed similar values to 
Cluster 1, with $3.48 \mathrm{mg} \mathrm{L}^{-1}$ and $2,37 \mathrm{mg} \mathrm{L}^{-1}$, respectively. Cluster 3 was characterized by sediments with low concentrations of essential metals. In this group, the Ca concentration varied between 0.01 and $4.33 \mathrm{mg} \mathrm{L}^{-1}, \mathrm{Mg}$ varied between 0.01 and $2.20 \mathrm{mg} \mathrm{L}^{-1}$ and $\mathrm{Na}$ varied between 0.01 and $1.22 \mathrm{mg} \mathrm{L}^{-1}$.

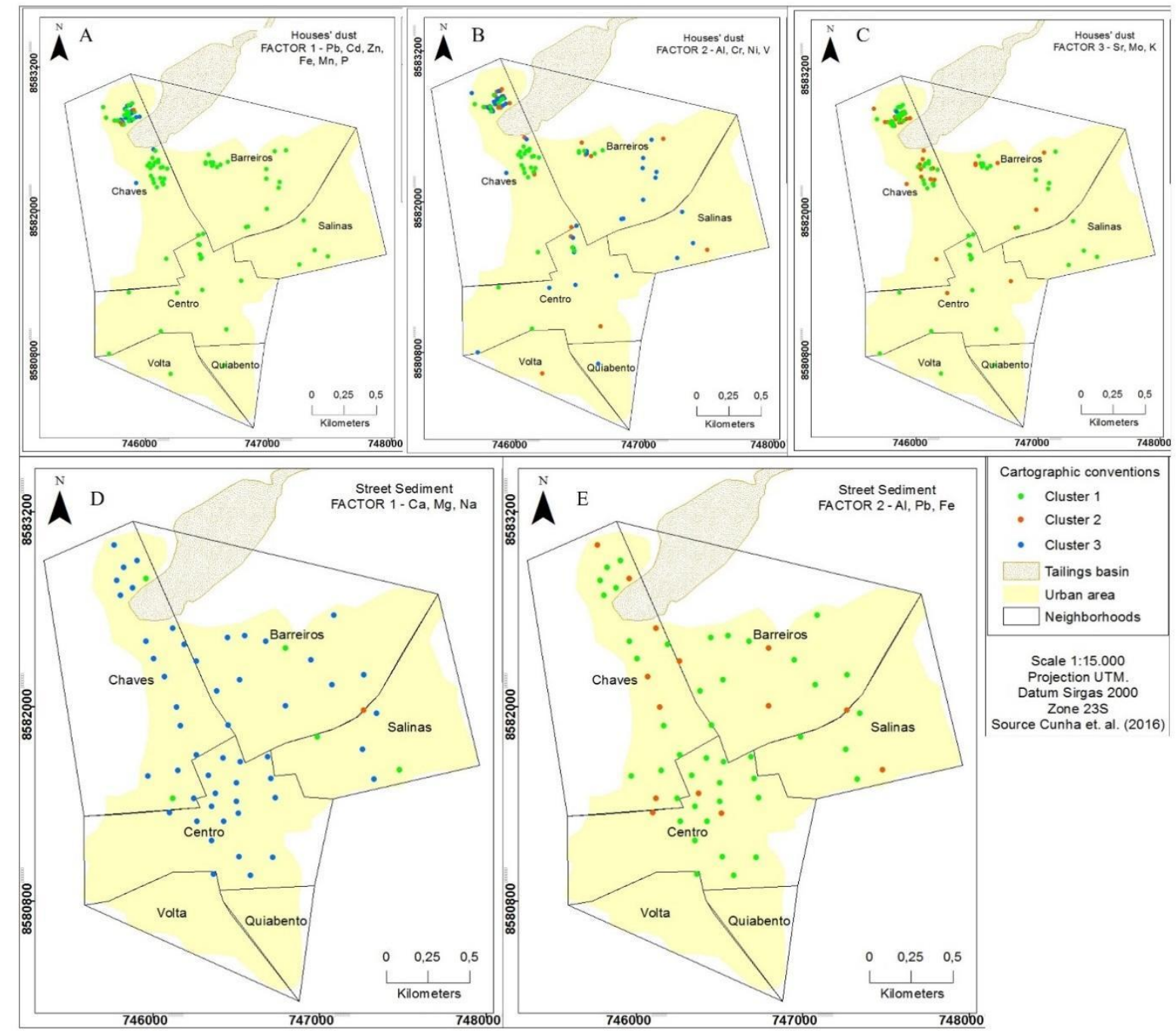

Figure 1. Distribution of variables by clusters. (A) Factor 1 and (B) Factor 2 for street sediment samples and (C) Factor 1, (D) Factor 2 and (E) Factor 3 for house dust samples. Sampling period: July / 2013. Source of data: Cunha et al. (2016).

According to the variables of Factor 2 ( $\mathrm{Al}, \mathrm{Pb}$ and $\mathrm{Fe}$ ), two similar groups were generated, comprising $45 \%$ and $10 \%$ of the samples analyzed in Clusters 1 and 2, respectively (Figure 1B). This factor is composed of sediments with a concentration of contaminating metals, although $\mathrm{Al}$ and $\mathrm{Fe}$ do not have maximum permissible values determined by CONAMA Resolution No. 420/2009.

Cluster 1 was characterized by sediments with a higher concentration of contaminating metals. In this group, the concentration of aluminum (Al) varied between 0.80 and $4.65 \mathrm{mg} \mathrm{L}^{-1}$, lead $(\mathrm{Pb})$ varied between 0.10 and $1.10 \mathrm{mg} \mathrm{L}^{-1}$ and iron $(\mathrm{Fe})$ varied between 5.58 and $12.40 \mathrm{mg} \mathrm{L}^{-1}$. Cluster 2 was characterized by sediments with lower concentrations, where the $\mathrm{Al}$ concentration varied between 0.01 and $2.86 \mathrm{mg} \mathrm{L}^{-1}, \mathrm{~Pb}$ varied between 0.10 and $1.20 \mathrm{mg}$ $\mathrm{L}^{-1}$ and $\mathrm{Fe}$ varied between 0.02 and $5.04 \mathrm{mg} \mathrm{L}^{-1}$. Pb concentrations showed values below the maximum allowed values, according to CONAMA Resolution No. 420/2009, as limits for prevention $\left(72 \mathrm{mg} / \mathrm{L}^{-1}\right)$ and investigation $\left(300 \mathrm{mg} / \mathrm{L}^{-1}\right)$. 
The samples of street sediment in both factors indicated a dispersion of the metals in a homogeneous manner throughout the entire urban area, due to the erosion and sedimentation, in the long term, of the metals. Studies carried out in Mariana (MG), after a disaster (Silva et al., 2019), indicate that suspended material can remain in the air and reach a coverage area of up to 1.5 kilometers from its source. From this perspective, all locations in the urban area of Boquira (BA) are under the influence of contamination from the tailings basin. The low presence of metals indicates constant remobilization of street sediments due to the erosive action of winds, street cleaning procedures and vehicle traffic, as discussed by Vianna et al., 2011; Pereira et al., 2015; Abiye et al, 2016.

For house dust samples, the number of clusters was defined from cut-off point 5 for Factors 1, 2 and 3, where the formation of three groups was observed for each factor. According to the Factor 1 variables $(\mathrm{Cd}, \mathrm{Pb}, \mathrm{Zn}, \mathrm{Mn}, \mathrm{Fe}$ and $\mathrm{P})$, three similar groups were generated, comprising $81 \%, 2 \%$ and $17 \%$ of the samples analyzed in clusters 1, 2 and 3, respectively (Figure 1C). This factor is composed of dust from houses with a concentration of contaminating metals and essential metals, but which have a contaminating character in high concentrations.

Cluster 1 was characterized by dust from houses with lower concentrations of metals. In this group, the concentration of cadmium (Cd) varied between 0.01 and $8.0 \mathrm{mg} \mathrm{L}^{-1}$, which means that 10 samples have a concentration above the maximum allowed values, as prevention limits $\left(1.3 \mathrm{mg} / \mathrm{L}^{-1}\right)$ but below the investigation limits $\left(8.0 \mathrm{mg} / \mathrm{L}^{-1}\right)$, according to CONAMA Resolution No. 420/2009. Lead (Pb) varied between 0.2 and $2080.0 \mathrm{mg} \mathrm{L}^{-1}$, with $27 \%$ of the samples above the prevention limit $\left(72 \mathrm{mg} / \mathrm{L}^{-1}\right)$ and $39 \%$ above the investigation limits (300 $\left.\mathrm{mg} / \mathrm{L}^{-1}\right)$, according to CONAMA Resolution No. 420/2009. Zinc (Zn) varied between 1.0 and $3340.0 \mathrm{mg} \mathrm{L}^{-1}$, with $22 \%$ of the samples above the prevention limit $\left(300 \mathrm{mg} / \mathrm{L}^{-1}\right)$ and $12 \%$ above the investigation limits $\left(1000 \mathrm{mg} / \mathrm{L}^{-1}\right)$, according to CONAMA Resolution No. 420/2009. In turn, iron ( $\mathrm{Fe})$, manganese ( $\mathrm{Mn})$ and phosphorus $(\mathrm{P})$ do not have maximum allowable values defined by CONAMA Resolution No. 420/2009, Fe varied between 0.6 and $11.3 \mathrm{mg} \mathrm{L}^{-1}$, Mn between 99.0 and $2080.0 \mathrm{mg} \mathrm{L}^{-1}$ and $\mathrm{P}$ between 26.0 and $1710.0 \mathrm{mg} \mathrm{L}^{-1}$.

Cluster 2 was characterized by two samples with higher concentrations of contaminating metals, the concentrations of cadmium $(\mathrm{Cd})$ were 54.0 and $95.0 \mathrm{mg} \mathrm{L}^{-1}$, with the samples above the prevention limits $\left(1.3 \mathrm{mg} / \mathrm{L}^{-1}\right)$ and research $\left(8.0 \mathrm{mg} / \mathrm{L}^{-1}\right)$, according to CONAMA Resolution No. 420/2009. The lead (Pb) was 6360.0 and $9020.0 \mathrm{mg} \mathrm{L}^{-1}$, above the prevention (72 mg / $\mathrm{L}^{-1}$ ) and investigation (300 mg / $\left.\mathrm{L}^{-1}\right)$ limits, according to CONAMA Resolution No. 420 / 2009. The zinc ( $\mathrm{Zn}$ ) was 4290.0 and $5790.0 \mathrm{mg} \mathrm{L}^{-1}$, above the limit of prevention (300 $\left.\mathrm{mg} / \mathrm{L}^{-1}\right)$ and investigation (1000 mg / $\left.\mathrm{L}^{-1}\right)$, according to CONAMA Resolution $\mathrm{n}^{\circ} 420 / 2009$. Iron $(\mathrm{Fe})$ presented concentrations of 8.3 and $10.3 \mathrm{mg} \mathrm{L}^{-1}$, manganese $(\mathrm{Mn}) 2020.0$ and 3790.0 $\mathrm{mg} \mathrm{L}^{-1}$ and phosphorus (P) 1360.0 and $2770.0 \mathrm{mg} \mathrm{L}^{-1}$.

Cluster 3 was characterized by dust samples from houses with intermediate values of concentration of contaminating metals. In this group, the concentration of cadmium $(\mathrm{Cd})$ varied between 0.0 and $61.0 \mathrm{mg} \mathrm{L}^{-1}$, with $84 \%$ of the samples above the investigation limits $(8.0 \mathrm{mg} /$ $\mathrm{L}^{-1}$ ), according to CONAMA Resolution $\mathrm{n}^{\circ} 420 / 2009$. Lead $(\mathrm{Pb})$ varied between 1590.0 and $5210.0 \mathrm{mg} \mathrm{L}^{-1}$, with all samples showing values above the investigation limits $\left(300 \mathrm{mg} / \mathrm{L}^{-1}\right)$, according to CONAMA Resolution No. 420/2009. The zinc (Zn) varied between 1180.0 and $4130.0 \mathrm{mg} \mathrm{L}^{-1}$, with all samples showing values above the investigation limits $\left(1000 \mathrm{mg} / \mathrm{L}^{-1}\right)$, according to CONAMA Resolution No. 420/2009. Iron (Fe), manganese (Mn) and phosphorus (P) varied between 4.1 and $9.1 \mathrm{mg} \mathrm{L}^{-1}, 774.0$ and $4350.0 \mathrm{mg} \mathrm{L}^{-1}$ and 569.0 and $1900.0 \mathrm{mg} \mathrm{L}^{-1}$, respectively.

According to the Factor 2 variables ( $\mathrm{Al}, \mathrm{Cr}, \mathrm{Ni}$ and $\mathrm{V})$, three similar groups were generated, comprising 33\%, 33\% and 34\% of the samples analyzed in Clusters 1, 2 and 3, respectively (Figure 1D). This factor is formed by contaminating metals and essential metals that, if in high concentrations, can damage human health. 
Cluster 1 was characterized by dust samples from houses with higher concentrations. Aluminum (Al) and vanadium (V) do not have maximum allowable values defined by CONAMA Resolution No. 420/2009; Al varied between 1.9 and $4.1 \mathrm{mg} \mathrm{L}^{-1}$ and $\mathrm{V}$ between 45.0 and $108,0 \mathrm{mg} \mathrm{L}^{-1}$. The concentration of chromium $(\mathrm{Cr})$ varied between 37.0 and $91.0 \mathrm{mg}$ $\mathrm{L}^{-1}$, with two samples above the prevention limit $\left(75.0 \mathrm{mg} / \mathrm{L}^{-1}\right)$ but below the investigation limit (300.0 mg / $\left.\mathrm{L}^{-1}\right)$, in accordance with CONAMA Resolution No. 420/2009. Nickel (Ni) varied between 7.0 and $41.0 \mathrm{mg} \mathrm{L}^{-1}$, with two samples above the prevention limit (30.0 mg / $\left.\mathrm{L}^{-1}\right)$ but below the investigation limit $\left(100.0 \mathrm{mg} / \mathrm{L}^{-1}\right)$, according to CONAMA Resolution No. 420/2009.

Cluster 2 is composed of samples with concentration of metals in intermediate values. Aluminum (Al) and vanadium (V) varied between 1.4 and $3.1 \mathrm{mg} \mathrm{L}^{-1}$ and 39.0 and $65.0 \mathrm{mg} \mathrm{L}^{-1}$, respectively. The concentration of chromium $(\mathrm{Cr})$ varied between 24.0 and 68.0 $\mathrm{mg} \mathrm{L} \mathrm{L}^{-1}$, with all samples below the prevention limit $\left(75.0 \mathrm{mg} / \mathrm{L}^{-1}\right)$, according to CONAMA Resolution No. 420/2009. Nickel (Ni) varied between 0.5 and $29.0 \mathrm{mg} \mathrm{L}^{-1}$, with all samples below the prevention limit (30.0 mg / $\left.\mathrm{L}^{-1}\right)$, according to CONAMA Resolution No. 420/2009.

Cluster 3 was characterized by house dust samples with lower concentrations of metals. Aluminum (Al) and vanadium (V) varied between 0.8 and $2.9 \mathrm{mg} \mathrm{L}^{-1}$ and $\mathrm{V}$ between 1.0 and $47.0 \mathrm{mg} \mathrm{L}^{-1}$, respectively. The concentration of chromium $(\mathrm{Cr})$ varied between 9.0 and $63.0 \mathrm{mg}$ $\mathrm{L}^{-1}$, with all samples below the prevention limit $\left(75.0 \mathrm{mg} / \mathrm{L}^{-1}\right)$, according to CONAMA Resolution No. 420/2009. Nickel (Ni) varied between 0.5 and $27.0 \mathrm{mg} \mathrm{L}^{-1}$, with all samples below the prevention limit (30.0 mg / $\left.\mathrm{L}^{-1}\right)$, according to CONAMA Resolution No. 420/2009.

According to the Factor 3 variables ( $\mathrm{Sr}$, Mo and $\mathrm{K}$ ), three similar groups were generated, which comprised $66 \%, 33 \%$ and $1 \%$ of the samples analyzed in Clusters 1,2 and 3, respectively (Figure 1E). Cluster 1 was characterized by low concentrations of strontium $(\mathrm{Sr})$ and potassium (K), varying between 36.0 and $112.0 \mathrm{mg} \mathrm{L}^{-1}$ and 0.1 and $2.8 \mathrm{mg} \mathrm{L}^{-1}$, respectively, both do not have reference value in CONAMA Resolution No. 420/2009. The concentration of molybdenum (Mo) was the same for all samples, $0.1 \mathrm{mg} \mathrm{L}^{-1}$, below the prevention limit (30.0 $\mathrm{mg} / \mathrm{L}^{-1}$ ) of CONAMA Resolution No. 420/2009. Cluster 2 was characterized by intermediate concentrations of strontium (Sr) and potassium (K), varying between 119.0 and $296.0 \mathrm{mg} \mathrm{L}^{-1}$ and 0.1 and $3.4 \mathrm{mg} \mathrm{L}^{-1}$, respectively. The concentration of molybdenum (Mo) did not vary between samples, remaining $0.1 \mathrm{mg} \mathrm{L}^{-1}$. Cluster 3, on the other hand, presented a higher value for the three variables, with a concentration of $755.0 \mathrm{mg} \mathrm{L}^{-1}$ for $\mathrm{Sr}, 1340.0 \mathrm{mg} \mathrm{L}^{-1}$ for $\mathrm{K}$ and $11.0 \mathrm{mg} \mathrm{L}^{-1}$ for Mo.

The dust samples from houses in Factor 1 showed higher values of metal concentration in places closer to the tailings basin, with higher concentration in the Chaves district, suggesting that this source of contamination still plays an important role in the contamination of the urban area of the municipality. This result agrees with the studies carried out by Machado et al. (2010) and Quiterio et al. (2001).

Although the results obtained by Quiterio et al. (2001) have indicated a higher concentration of these metals in the external area than inside the houses; this divergence can be explained by the methodological differences used in the two studies: the collection carried out by these authors was carried out in places subject to constant cleaning, such as carpets, furniture and curtains, while the research carried out by Cunha et al. (2016) sought to collect samples of dust located in places of difficult access, such as roof rafters, half-walls and behind the pictures. In areas more distant from the tailings basin, the presence of metals deposited inside the houses is accentuated due to the remobilization of sediments from the external area of the municipality.

The heavy metals found in the area have been associated with adverse effects on human health, being extensively studied by international bodies (Jarup, 2013). $\mathrm{Pb}, \mathrm{Cd}$ and $\mathrm{Zn}$ presented the highest concentrations, well above that established by CONAMA Resolution 420/2009. These metals can cause renal, gastrointestinal effects and respiratory and neurological damage 
in humans (Cetesb, 2018) $\mathrm{Cr}$ and $\mathrm{Ni}$ also showed values above the established in CONAMA Resolution 420/2009. These metals, although essential at low concentrations, can cause kidney disease, gastric irritation, dermatitis and allergic reactions in humans (Cetesb, 2018).

Heavy metals (K, V and Mn) do not have reference values, but in high concentrations they can result in respiratory, renal and neurological problems or even lead to death (Cetesb, 2018). In addition to the toxicity of these metals, the risk of effects on human health is related to longtime of exposure to these toxic metals, which can come into contact with humans through direct ingestion, dermal contact or inhalation of waste, street sediments and house dust.

\section{CONCLUSION}

The factor analysis allowed the classification of the most significant variables for the assessment of environmental quality, especially related to the dispersion of toxic metals that cause risk to human health. The cluster analysis classified the metals according to the main sources and allowed the analysis of environmental quality, according to CONAMA Resolution 420/2009, by different groups (Clusters). The street sediment samples resulted in three groups for Factor 1 and two groups for Factor 2, while the samples for house dust formed three groups for the three factors generated.

This allowed us to conclude that the region's natural background influences metal concentrations in the urban area, but that the main source of contamination by toxic metals is the tailings basin, abandoned since 1960. The concentration of these metals was above the maximum limits established for human exposure, such as cadmium, lead and zinc (Clusters 1, 2 and 3 of Factor 1) and chromium and nickel (Cluster 1 of Factor 2).

The results obtained through the multivariate analysis allow the formulation of a more assertive environmental management plan, able to assist in the risk assessment to human health due to the exposure to toxic metals in the municipality.

\section{ACKNOWLEDGMENTS}

The authors would like to thank the Coordination for the Improvement of Higher Education Personnel (CAPES) for financing this research, through the process: 88882.452960 / 2019-01.

\section{REFERENCES}

ABIYE, O. E.; SUNMONU, L. A.; AJAO, A. I.; AKINOIA, O. E.; AYOOLA, M. A.; JEGEDE,

O. O. Atmospheric dispersion modeling of uncontrolled gaseous pollutants ( $\mathrm{SO} 2$ and NOX) emission from a scrap-iron recycling factory in Ile-Ife, Southwest Nigeria. Cogent $\begin{array}{llllll}\text { Environmental Science, } & \text { v. } & 2, & \text { p. } & 1275413,\end{array}$ https://doi.org/10.1080/23311843.2016.1275413

ALVES, F. E. A.; BERTOLINO, L. C.; MENDES, J. Mineralogical Characterization of Lead Mine Tailing in Boquira, Bahia State, Brazil. Anuário do Instituto de Geociências, v. 40, n. 3, p. 14-23, 2018.

BEZERRA, F. A. Análise Fatorial. In: CORRAR, L. J.; PAULO, E.; DIAS FILHO, J.M. (ed.). Análise Multivariada. São Paulo: Atlas, 2014, p. 73-130.

CALLEGARI-JACQUES, S. M. Bioestatística: princípios e aplicações. Porto Alegre: Artemed, 2003. 255p. 
CARVALHO, I. G. Chemical deposits associated to meta volcano sedimentary sequences of the central portion of the São Francisco craton. The state of Bahia, Brazil: a review. Revista Brasileira de Geociências, v. 2, n. 30, p. 279-284, 2000.

CETESB. Informações Toxicológicas. 2018. Available at: https://cetesb.sp.gov.br/laboratorios/servicos/informacoestoxicologicas/\#1530563846759-63efbc36-4e83 Access: 09 Apr. 2020.

CONAMA (Brasil). Resolução no 420 de 28 de dezembro de 2009. Dispõe sobre critérios e valores orientadores de qualidade do solo quanto à presença de substâncias químicas e estabelece diretrizes para o gerenciamento ambiental de áreas contaminadas por essas substâncias em decorrência de atividades antrópicas. Diário Oficial [da] União: seção 1, Brasília, DF, n. 249, p. 81-84, 30 dez. 2009.

CUNHA, F. G. da; VIGLIO, E. P.; ANJOS, J. A. S. A.; LOUREIRO, T. B. Estudos geoquímicos no município de Boquira - Estado da Bahia. Salvador: CPRM, 2016. 37p.

FINLAYSON-PITTS, B. J.; PITTS, J. N. P. Chemistry of the Upper and Lower Atmosphere. San Diego: Academic Press, 2000. 696p.

GARCIA, P. M. P. Análise comparativa de dados geológicos, litogeoquímicos e geofísicos das formações ferríferas do Complexo Boquira e supergrupo espinhaço na região de Boquira, BA. 2011, 165f. Monografia (Graduação em Geologia) - Instituto de Geociências, Universidade Federal da Bahia, Salvador, 2011.

GOMES, M. C. R.; ANJOS, J. A. S. A.; DALTRO, R. R. Multivariate statistical analysis applied to the evaluation of groundwater quality in the central-southern portion of the state of Bahia - Brazil. Revista Ambiente \& Água, v. 15, n. 1, 2020. https://dx.doi.org/10.4136/ambi-agua.2408

JÄRUP, L. Hazards of heavy metal contamination. British Medical Bulletin, v. 68, n. 1, p. 167-182, 2013. https://doi.org/10.1093/bmb/ldg032

JOHNSON, R. A.; WICHERN, D. W. Applied Multivariate Statistical Analysis. 6. ed. Upper Saddle River: Pearson/Prentice Hall, 2007. 794p.

LANDIM, P. M. B. Análise estatística de dados geológicos multivariados. São Paulo: Oficina de textos, 2011. $208 \mathrm{p}$.

MACHADO, S. L.; PORTELLA, R. B; CESANA, E.; RABELO, T. S.; LOPES, D. O. M. Estudo da influência na contaminação do solo por metais pesados derivada das emissões atmosféricas de uma metalúrgica desativada no município de Santo Amaro - BA. In: SIMPÓSIO ÍTALO-BRASILEIRO DE ENGENHARIA SANITÁRIA E AMBIENTAL, 10. 2010. Artigos[...] São Paulo: ABES, 2010.

PEREIRA, J. L. G.; FORTES, J. D. N.; MARTINS, E. M. Poluição do ar por material particulado em área intraurbana no Rio de Janeiro: aspectos metodológicos. Revista Eletrônica de Engenharia Civil, v. 10, n. 3, p. 53-67, 2015. https://doi.org/10.5216/reec.v10i3.32901

QUITERIO, S. L.; SILVA, C. R. S; VAITSMAN, D. S.; MARTINHON, P. T; MOREIRA, M. F. R; ARAÚJO, U. C.; MATTOS, R. C. C. C.; SANTOS, L. S. C. Uso da poeira e do ar como indicadores de contaminação ambiental em áreas circunvizinhas a uma fonte de emissão estacionária de chumbo. Cadernos de Saúde Pública, v. 17, n. 3, p. 501-508, 2001. 
SILVA, A. P. S.; ASMUS, C. I. F.; PAVIH, J. L. P.; LACERDA, J. C. V.; SALES, L. B. F.; RESENDE, M. T.; SARAIVA, R. D. S.; CARMA, T. F. M. Estudo de avaliação de risco à saúde humana em localidades atingidas pelo rompimento da barragem do Fundão - MG. Relatório técnico final. São Paulo: Ambios Engenharia e Processos, 2019. 369p.

VIANNA, N. A.; GONÇALVES, D.; BRANDÃO, F.; BARROS, R. P.; AMADO FILHO, G. M.; MEIRE, R. O.; TORRES, J. P. M.; MALM, O.; D’OLIVEIRA JÚNIOR, A.; ANDRADE, L. R. Assessment of heavy metals in the particulate matter of two Brazilian metropolitan areas by using Tillandsia usneoides as atmospheric biomonitor. Environmental Science and Pollution Research, v. 18, n. 3, p. 416-427, 2011. https://doi.org/10.1007/s11356-010-0387-y 


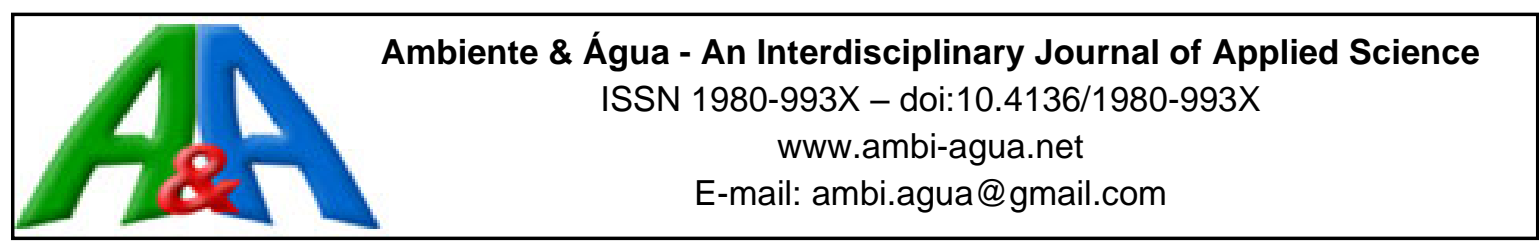

\title{
Use of organic fertilization with irrigation in coffee production in brazilian cerrado
}

\author{
ARTICLES doi:10.4136/ambi-agua.2578
}

Received: 14 May 2020; Accepted: 30 Jul. 2020

\begin{abstract}
André Luís Teixeira Fernandes ${ }^{1 *}$; Eusímio Felisbino Fraga Júnior ${ }^{2}$; Márcio José de Santana ${ }^{3}$; Reginaldo de Oliveira Silva ${ }^{4}$; Marcelo Moreira Dias ${ }^{5}$

${ }^{1}$ Pró-Reitoria de Pesquisa, Pós Graduação e Extensão. Universidade de Uberaba (UNIUBE), Avenida Nenê Sabino, $\mathrm{n}^{\circ}$ 1801, CEP: 38055-500, Uberaba, MG, Brazil.

2Instituto de Ciências Agrárias. Universidade Federal de Uberlândia (UFU), Rodovia LMG 746, km 1, s/n, Bloco 1, CEP: 38500-000, Monte Carmelo, MG, Brazil. E-mail: eusimiofraga@ufu.br

${ }^{3}$ Setor de Irrigação e Drenagem. Instituto Federal de Educação, Ciência e Tecnologia do Triângulo Mineiro (IFTM), Rua João Batista Ribeiro, n 4000, CEP: 38064-790, Uberaba, MG, Brazil.

E-mail: marciosantana@iftm.edu.br

${ }^{4}$ Departamento de Pesquisa e Desenvolvimento. Associação dos Cafeicultores de Araguari (ACA), Rodovia MG 14, KM 09, s/n, CEP: 38440-970, Araguari, MG, Brazil. E-mail: rs5059@gmail.com

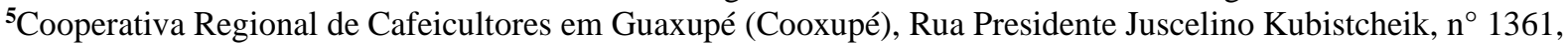
CEP: 38445-090, Guaxupé, MG, Brazil. E-mail: mmdias10@ hotmail.com

*Corresponding author. E-mail: andre.fernandes@uniube.br
\end{abstract}

\begin{abstract}
Coffee irrigation has increased in the main Brazilian coffee regions. However, in recent years, with climate change, years with water deficits greater than $150 \mathrm{~mm}$ have been observed, affecting the vegetative and productive development of the crop and also the replenishment of surface and underground springs. One practice that increases soil water retention capacity is organic fertilization. This work evaluated different combinations of irrigation and organic fertilization on the yield and quality of coffee produced in the Minas Gerais cerrado region. The treatments were: T1: total irrigation; T2: no irrigation; T3: total irrigation + organic fertilization (chicken manure, 10 ton $\mathrm{ha}^{-1}$ ); T4: no irrigation + organic fertilization (chicken manure, 10 ton $\mathrm{ha}^{-1}$ ); T5: 50\% irrigation + organic fertilization (chicken manure, 10 ton ha ${ }^{-1}$ ). After 7 harvests, it was concluded that the treatment that combined organic fertilization with application of half of the necessary irrigation presented the best yield, superior to the treatment with total irrigation and exclusively mineral nutrition.
\end{abstract}

Keywords: Coffea arabica, irrigation, poultry manure.

\section{Associação da adubação orgânica com a irrigação na produção de café no cerrado Mineiro}

\section{RESUMO}

A irrigação do cafeeiro já é realidade na maior parte das regiões produtoras do Brasil, já atingindo 300.000 ha. Na região do cerrado mineiro, grande parte das lavouras de café é irrigada. Porém, nos últimos anos, com alterações climáticas, têm sido observados anos com déficits superiores a $150 \mathrm{~mm}$, afetando o desenvolvimento vegetativo e produtivo da cultura e também o reabastecimento dos mananciais superficiais e subterrâneos. Uma prática que permite 
aumentar a capacidade de retenção de água no solo é a adubação orgânica. Dentro deste contexto, propôs-se o presente trabalho que teve como objetivo avaliar diferentes combinações de irrigação e adubação orgânica na produtividade e qualidade do café produzido no cerrado mineiro. Os tratamentos foram: T1: Irrigação total; T2: Sem irrigação; T3: Irrigação Total + Adubação Orgânica (esterco de galinha, 10 ton. $\mathrm{Ha}^{-1}$ ); T4: Sem irrigação + adubação orgânica (esterco de galinha, 10 ton. ha ${ }^{-1}$ ); T5: Irrigação 50\% + adubação orgânica (esterco de galinha, 10 ton. ha ${ }^{-1}$ ). Após 7 safras, concluiu-se que o tratamento que combinou a adubação orgânica a aplicação de metade da irrigação necessária apresentou o melhor resultado em produtividade, superior ao tratamento com irrigação total e nutrição exclusivamente mineral.

Palavras-chave: Coffea arabica, esterco de aves, irrigação.

\section{INTRODUCTION}

Coffee is one of the most consumed drinks in the world (Loftfield et al., 2018). As reported by Tverdal et al. (2020), globally coffee is the most frequently used stimulant drink and probably the safest one. Arabica coffee production provides a livelihood for millions of people worldwide (Verhage et al., 2017).

Specifically in Brazil, coffee farming is one of the most important chains in agribusiness. According to Volsi et al. (2019), there is evidence that both geographic distribution and the varieties of coffee have changed in all coffee growing regions over time. These structural changes seem to be the result of reductions in government intervention and establishing a new dynamic of coffee production and marketing in the country. Brazilian coffee farming plays an important role in generating jobs, resources and foreign currency and is quite diversified, with regional particularities (Vicente et al., 2017).

The Brazilian cerrado covers more than 200 million hectares (ha), being located in the States of Minas Gerais, Goiás, Mato Grosso, Mato Grosso do Sul, Tocantins, Bahia, Piauí, Maranhão and the Federal District, and has stood out with production exceeding 5 million sacks per hectare, mainly of Coffea arabica () L. Coffee growing in this region is characterized by productivity above the national average and by using agricultural inputs, irrigation, appropriate genotypes and mechanization, among other practices, more efficiently. The most used irrigation systems are conventional sprinkler, in mesh and central pivot) and localized (drip and modified). The climate is favorable to coffee quality because at the time of the harvest, conditions of low relative humidity occur, with the rains being concentrated in the summer. There is also, in the Cerrado, a greater amount of sunlight, especially in the autumn and winter months, which is also favorable to productivity and quality. The most planted varieties are from the Catuaí and Mundo Novo groups, and other promising materials have also been introduced with regard to productivity and resistance to drought and disease (Fernandes et al., 2012).

Coffee irrigation has increased considerably in the last 20 years due to several factors, such as the expansion of coffee production to new frontiers; the evolution of the irrigation technique; the reduction of irrigation system cost and the mentality of the coffee grower in the coffee production system, prioritizing the efficiency and quality of production (Mantovani and Soares, 2003; Santinato et al., 2008; Santinato and Fernandes, 2012, Garcia et al., 2019, Liu et al., 2018; Ho et al., 2018; Fernandes et al., 2019; Lima et al., 2019, Vicente et al., 2018). Especially in regions considered marginal with regard to water deficit, the use of irrigation has become increasingly frequent for coffee cultivation. However, the irrigation does not always follow correct sizing and management standards (Santinato and Fernandes, 2012). According to (Perdoná and Soratto, 2020), coffee can provide the farmer with a net result of 2,600.00 USD year $^{-1}$, a value similar to that found by (Fernandes et al., 2016), and which seems to be very satisfactory.

Brazil already has 300,000 ha of irrigated coffee distributed in several states, 
predominantly in Minas Gerais, Espírito Santo and Bahia; it's around 15\% of total area of coffee It is necessary to study the various coffee irrigation systems in detail and comparatively in order to make practical recommendations to coffee growers, both in the recovery of current plantations, and in the expansion of the Triângulo Mineiro's irrigated coffee cultivation (Santinato et al., 2008).

The creation and adaptation of coffee production technologies under total and supplementary irrigation are essential in order to allow high continuous and economic productivity without environmental damage (Costa et al., 2020). Most of the experimental work on coffee irrigation shows increases of 20 to 30 bags produced per hectare, regardless of the systems used and depending on the region under study (Santinato and Fernandes, 2012). However, in recent years, with climate change, there have been years with deficits greater than $150 \mathrm{~mm}$, affecting the vegetative and productive development of crops and promoting the depletion of aquifers, thus making coffee irrigation difficult.

A practice that may allow for improved water retention in the soil is organic fertilization. It constitutes a source of organic matter for the soil, with levels of nitrogen $(\mathrm{N})$, phosphorus $(\mathrm{P})$, potassium $(\mathrm{K})$ and sulfur $(\mathrm{S})$, in addition to providing micronutrients that promote beneficial effects on the soil. Siqueira et al. (2011) reported that the growth of organic coffee cultivation is considered more environmentally sustainable than the conventional way, as a new market opportunity. Friberg and Sanctuary (2018) observe that market shares for organic products are still modest, despite widespread consumer interest in purchasing organic products.

One of the most-used types of organic matter in coffee growing is poultry manure. It can be added with the use of poultry litter, which consists of peanut hay, rice straw, coffee husk and other by-products. Several other organic compounds may also be present (Matiello et al., 2010). Organic matter improves the physico-chemical and biological properties of the soil, which will directly or indirectly influence soil fertility (Malavolta, 2006). Organic matter improves aeration, permeability, soil moisture retention, availability of nutrients to plants and it increases cation exchange capacity (CEC). Within this context, this work evaluated the effects of different combinations of irrigation and organic fertilization (manure) on the productivity and quality of coffee produced in the Cerrado region of Minas Gerais.

\section{MATERIAL AND METHODS}

The experiment was set up in an experimental field of a coffee plantation belonging to the ACA (Associação dos Cafeicultores de Araguari), located on FAZENDA CHAPARRAL (CHAPARRAL FARM), on the edge of the Rodovia do Café, Km 09, municipality of Araguari (MG), latitude $18^{\circ} 38^{\prime}$, altitude $820 \mathrm{~m}$. The climate is classified by the Köppen Method, as Aw, tropical, hot and humid, with cold and dry winters. The annual precipitation was $1606.0 \mathrm{~mm}$ and the average annual temperature was $21.9^{\circ} \mathrm{C}$. The drip irrigation system has selfcompensating emitters and a flow-rate of $2.31 \mathrm{~h}^{-1}$ spaced every $0.70 \mathrm{~m}$. The coffee used was of the Catuaí IAC 62 yellow variety, aged 11 years, in a spacing of 3.70 between lines and $0.70 \mathrm{~m}$ between plants.

The meteorological data during the experiment was obtained from an automatic agrometeorological station (Davis, model Vantage Pro 2), and was installed next to the experimental plots. Through the measurements obtained by the sensors (temperature, relative humidity, wind speed and solar radiation), the evapotranspiration from the crop was estimated by the Penman Monteith Method. This method is an adaptation of the original Penman model, introducing the concepts of canopy resistance (rc) and aerodynamic resistance (ra) and is recommended by the FAO, according to Smith (1991).

In order to determine the irrigation time, the following was considered: the flow-rate of the emitters, the spacing between emitters, the spacing between lateral lines and an adjustment factor related to the reduction of the wet area, as it is localized irrigation. 
The Crop Evapotranspiration $\left(\mathrm{ET}_{\mathrm{c}}\right)$ was estimated by Equation 1:

$E T_{c}=E T_{0} \cdot K_{c} \cdot K_{m}$

In which:

$\mathrm{ET}_{0}$ - Reference Crop Evapotranspiration, estimated by the Penman Monteith Equation, with data from the automatic weather station, mm.dia ${ }^{-1}$;

$K_{c}$ - crop coefficient, decimal (Table 1)

$\mathrm{K}_{\mathrm{m}}$ - evapotranspiration adjustment factor for micro-irrigation, decimal, calculated by Equation 2.

$K_{m}=\sqrt{A S}$

in which:

As - fraction of the area shaded by the crop at noon, decimal.

The treatments were: T1: irrigation of $100 \%$ of the coffee water requirement; T2: non irrigated; T3: irrigation of $100 \%$ of the coffee water requirement + organic fertilization (poultry manure, 10 ton $\mathrm{ha}^{-1}$ ); T4: non irrigated + organic fertilization (poultry manure, 10 ton ha ${ }^{-1}$ ); T5: irrigation of 50\% of the coffee water requirement + organic fertilization (poultry manure, 10 ton $\mathrm{ha}^{-1}$ ). The design was completely randomized, with 5 treatments and 4 repetitions, totaling 20 experimental plots. Each plot contained 20 plants, with the 10 central plants being considered useful.

In regards to fertilization, 4 annual topdressing applications were carried out for all treatments following the recommendations of MAPA/ Procafé for the region (Matiello et al., 2010). The control and combat of the main pests and diseases were carried out according to recommendations proposed by Matiello et al. (2010), with Triazole fungicides paired with Strobilurin fungicides for the control of Rust (Hemileia vastatrix) and Cercosporiosis (Cercospora coffeella). For the Phoma and Ascochyta complex (Phoma spp. and Aschochyta spp), Boscalide was used. Rynaxypyr was used to control the infestation of Bicho mineiro (Leucoptera cofeeella). All cultivation, nutritional and phytosanitary treatments were similar in the evaluated treatments.

In Table 1, there is water replacement data for treatment with total irrigation, replacing the water deficit according to the climatological water balance. In the 7-year experiment period, treatments were applied with total irrigation replacement and 50\% replacement, 1406 and 703 $\mathrm{mm}$, respectively. The year with the greatest need for irrigation was 2013/2014 (Year 7), with a replacement of $274 \mathrm{~mm}$ in the total irrigation treatment, and the year with the least need for irrigation was 2014/2015 (Year 6), with a replacement of $132 \mathrm{~mm}$.

The experiment was carried out for nine years: two years designated for the formation of the crop, period of development of the plants until they became productive, and seven consecutive harvests from thereafter. The evaluations consisted of productivity and distribution measurements by sieves in each treatment. These evaluations consisted of seven harvests, harvesting only the fruit from the ten central plants of each plot when they presented a maximum of $15 \%$ green fruit. The harvested coffees had their volumes measured through a graduated container and were placed to dry until ready for processing. With the weight of the processed coffee, it was transformed into $60.0 \mathrm{~kg} \mathrm{ha}^{-1}$ processed bags per plot. For processing, samples of $1.0 \mathrm{Kg}$ dried coffee fruit were taken from each treatment and passed through a vibrating electric machine. Afterwards, classification of the sieves was done manually (mesh and with diameters of $19,18,17,16,15,14,<14)$. 
Table 1. Application depths applied in treatments with $50 *$ and $100 \% * *$ Water Replacement (WR), according to the climatological water balance.

\begin{tabular}{|c|c|c|c|c|c|c|c|c|c|c|c|c|c|c|}
\hline Meses & & Year 1 & & Year 2 & & Year 3 & & Year 4 & & Year 5 & & Year 6 & & Year 7 \\
\hline & $\begin{array}{l}\mathbf{5 0 \%} \\
\text { WR }\end{array}$ & $\begin{array}{c}100 \% \\
\text { WR }\end{array}$ & $\begin{array}{l}\mathbf{5 0 \%} \\
\text { WR }\end{array}$ & $\begin{array}{c}100 \% \\
\text { WR }\end{array}$ & $\begin{array}{l}50 \% \\
\text { WR }\end{array}$ & $\begin{array}{c}100 \% \\
\text { WR }\end{array}$ & $\begin{array}{l}\mathbf{5 0 \%} \\
\text { WR }\end{array}$ & $\begin{array}{c}100 \% \\
\text { WR }\end{array}$ & $\begin{array}{l}\mathbf{5 0 \%} \\
\text { WR }\end{array}$ & $\begin{array}{c}100 \% \\
\text { WR }\end{array}$ & $\begin{array}{l}\mathbf{5 0 \%} \\
\text { WR } \\
\end{array}$ & $\begin{array}{c}100 \% \\
\text { WR }\end{array}$ & $\begin{array}{l}50 \% \\
\text { WR }\end{array}$ & $\begin{array}{c}100 \% \\
\text { WR }\end{array}$ \\
\hline january & 0 & 0 & 0 & 0 & 0 & 0 & 0 & 0 & 0 & 0 & 0 & 0 & 0 & 0 \\
\hline february & 0 & 0 & 0 & 0 & 0 & 0 & 0 & 0 & 0 & 0 & 0 & 0 & 0 & 0 \\
\hline march & 0 & 0 & 0 & 0 & 0 & 0 & 0 & 0 & 0 & 0 & 0 & 0 & 0 & 0 \\
\hline april & 3 & 5 & 0 & 0 & 3 & 5 & 0 & 0 & 0 & 0 & 0 & 0 & 14 & 28 \\
\hline may & 5 & 9 & 10 & 20 & 3 & 5 & 0 & 0 & 3 & 5 & 0 & 0 & 14 & 27 \\
\hline june & 7 & 13 & 6 & 12 & 3 & 5 & 10 & 19 & 14 & 27 & 3 & 5 & 6 & 12 \\
\hline july & 18 & 35 & 23 & 45 & 15 & 29 & 20 & 39 & 11 & 21 & 13 & 25 & 26 & 52 \\
\hline august & 28 & 56 & 34 & 67 & 24 & 48 & 25 & 50 & 30 & 60 & 26 & 52 & 30 & 59 \\
\hline september & 27 & 53 & 4 & 7 & 18 & 35 & 26 & 51 & 19 & 38 & 11 & 21 & 48 & 96 \\
\hline october & 15 & 29 & 0 & 0 & 26 & 52 & 0 & 0 & 46 & 91 & 15 & 29 & 0 & 0 \\
\hline november & 0 & 0 & 0 & 0 & 0 & 0 & 0 & 0 & 0 & 0 & 0 & 0 & 0 & 0 \\
\hline dezember & 0 & 0 & 0 & 0 & 0 & 0 & 0 & 0 & 0 & 0 & 0 & 0 & 0 & 0 \\
\hline Total & 100 & 200 & 75,5 & 151 & 89,5 & 179 & 79,5 & 159 & 121 & 242 & 66 & 132 & 137 & 274 \\
\hline
\end{tabular}

Only the results from the largest sieves (17 or above) were presented, which obtain the best-accepted product on the market. Throughout the experiment, the nutrient content in leaves and soil was monitored annually. Data on $\mathrm{pH}$, phosphorus, potassium, organic matter, aluminum and base saturation were evaluated for all 7 years of the experiment. The collection of soils was done by plot and chemical analyses were made by joining the plots, by treatment.

In order to evaluate the normality and homoscedasticity of the data on productivity, the Kolmogorov-Smirnov and Bartlett tests were used, respectively. After verifying the normality and homoscedasticity of the data, ANOVA was used. After verifying the significance of ANOVA, the Tukey test was used for multiple comparisons between treatment averages, using the SISVAR® software (Ferreira, 2011). 


\section{RESULTS AND DISCUSSION}

In Figure 1, the monthly results of monitored meteorological variables are presented.
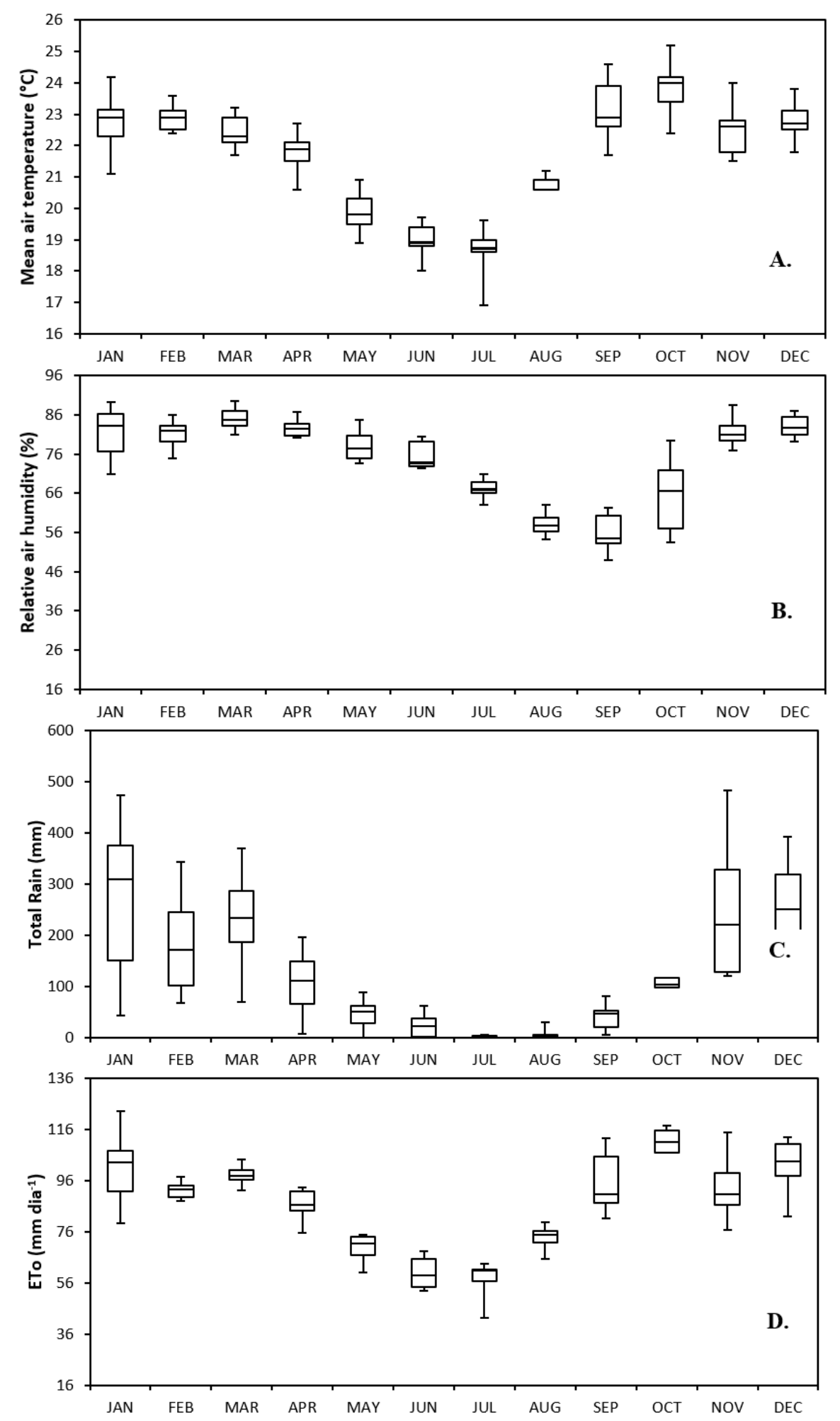

Figure 1. Box-plot graphs for mean air temperature (A), relative air humidity (B), rain (C) and reference evapotranspiration (D) for the years of the experiment.

Among the climatic parameters, temperature is a very important factor, as it has a direct impact on the development of the crop and also acts on the duration of the crop reproductive 
cycle (Pezzopane et al., 2003). The ideal annual mean temperatures for coffee development are in the range of $17^{\circ} \mathrm{C}$ to $23^{\circ} \mathrm{C}$ (Assad et al., 2001), but minimum, maximum temperature and the water deficit will increase significantly from 1980-2010 to 2040-2070 in the Arabica production regions of Brazil (Verhage et al., 2017).

The highest mean monthly temperatures were observed in October, which had a mean temperature of $23.7^{\circ} \mathrm{C}$. This month, the beginning of the spring season is characterized by an increase in the balance of radiation available in the environment and, because there is still no water vapor available in the atmosphere, much of this energy is partitioned in sensitive heat, that is, an increase in air temperature. For the data on minimum temperature, mean values of $18.7^{\circ} \mathrm{C}$ were observed in June and July. In the Brazilian Arabica coffee producing regions, the mean temperature after flowering is projected to increase by $1.3^{\circ} \mathrm{C}$, while the annual water deficit is projected to increase by $54 \mathrm{~mm}$ (Vergage et al., 2017). As a result, yield losses due to high air temperatures and water deficit are projected to increase.

In the summer months and early autumn, the highest relative humidity (RH) was observed, always above $80 \%$; between August and September, the lowest RH values occurred, between 56 and $58 \%$.

The months of December and January were the rainiest, but with considerable variability between the years monitored due to the occurrence of periods of unusually dry weather in otherwise rainy months. The months of July and August had the lowest rainfall.

In Figure 2, the water balance is shown for the irrigated coffee during the experiment, with total replacement of the coffee tree's needs. Considering the irrigation performed in the treatment with total irrigation, the monthly storage (MS) did not exceed the threshold of $40 \%$ of the available water capacity (AWC), indicating good water conditions for the plants.

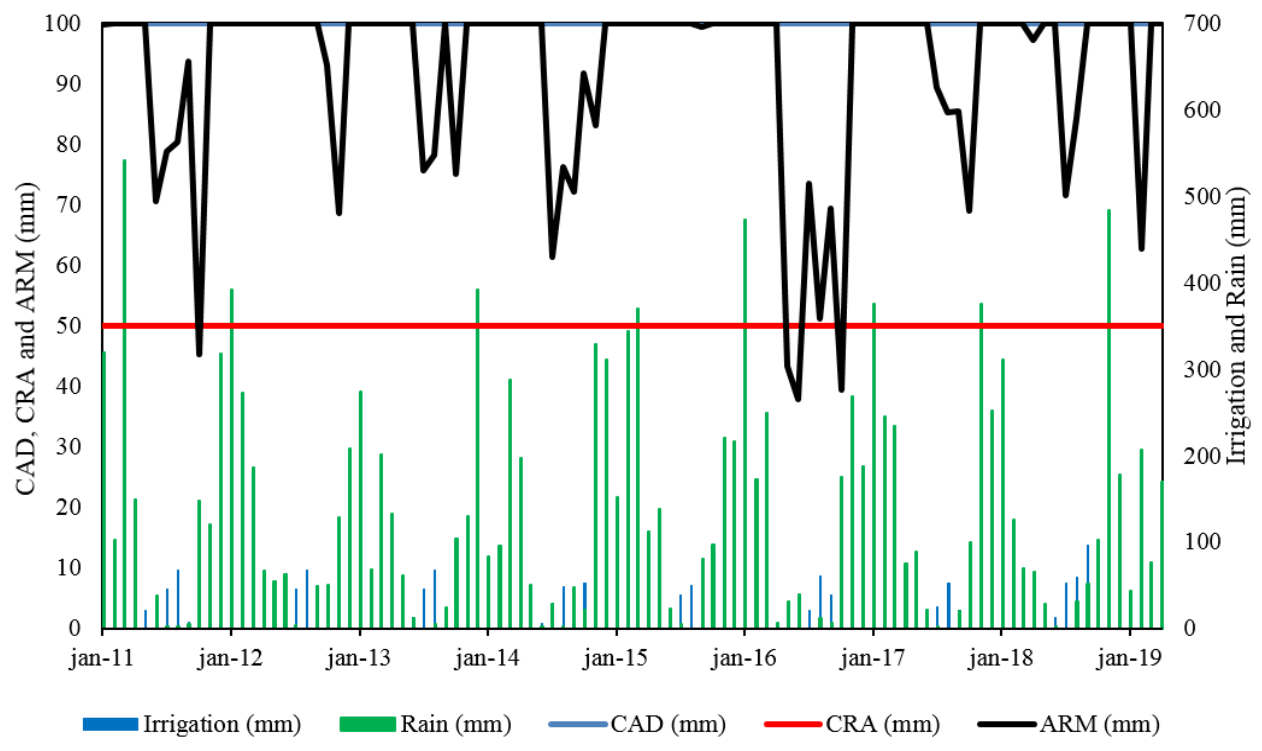

Figure 2. Account of the sequential climatological water balance for drip irrigated coffee. $\mathrm{AWC}=100 \mathrm{~mm}$.

In Table 2, productivity results are shown per year for the different treatments. Assigning the value of $100 \%$ for the treatment with total irrigation (Treatment 1), in seven harvests, it was observed that the control without irrigation produced 56\% less (19.4 processed bags ha $\left.{ }^{-1}\right)$, corroborating what was reported by DaMatta and Ramalho (2006), who described the relationship between water and the coffee tree studied by several researchers in recent decades. Coffee plant productivity is strongly influenced by an adequate supply of water (Sakai et al., 2015). The reduction in coffee productivity caused by water deficit is reported in the literature by many other authors, such as Silva et al. (2008), Fernandes et al. (2016), Gomes et al. (2007), 
Chemura (2014), among others. Irrigation has a significant effect on coffee crop water deficit (Verhage et al., 2017).

Table 2. Productivity for different treatments, 7 harvests, Izidoro Bronzi Experimental Field, Araguari - MG. 1 bags produced - $60 \mathrm{~kg}$ of green coffee.

\begin{tabular}{|c|c|c|c|c|c|c|c|c|}
\hline \multirow{2}{*}{ Treatments } & \multicolumn{8}{|c|}{ Production and Average Seven Harvests - Bags produced/ha. } \\
\hline & $2009 / 2010$ & $2010 / 2011$ & $2011 / 2012$ & $2012 / 2013$ & $2013 / 2014$ & $2014 / 2015$ & $2015 / 2016$ & Mean \\
\hline $\begin{array}{l}\text { T1: Total } \\
\text { irrigation }\end{array}$ & $21.8 \mathrm{a}$ & $53.8 \mathrm{c}$ & $46.7 b$ & $36.2 b$ & $58.6 \mathrm{a}$ & $36.8 \mathrm{ab}$ & $58.5 \mathrm{a}$ & 44.6b \\
\hline T2: No irrigation & $15.7 \mathrm{~d}$ & $37.2 \mathrm{e}$ & $18.3 \mathrm{~d}$ & $5.2 \mathrm{c}$ & $29.9 \mathrm{c}$ & $9.2 \mathrm{c}$ & $20.2 d$ & 19.4d \\
\hline $\begin{array}{l}\text { T3: Total } \\
\text { irrigation }+ \\
\text { Organic fertilizer } \\
(\text { chicken manure, } \\
10 \text { ton }^{-1} \text { ) }\end{array}$ & $19.6 \mathrm{c}$ & $62.5 \mathrm{a}$ & $55.0 \mathrm{a}$ & $54.6 \mathrm{a}$ & $53.2 \mathrm{ab}$ & $49.7 \mathrm{a}$ & $57.5 \mathrm{a}$ & $\mathbf{5 0 . 3 a}$ \\
\hline $\begin{array}{l}\text { T4: No irrigation } \\
\text { + organic } \\
\text { fertilizer }\end{array}$ & $20.5 b c$ & $42.1 \mathrm{~d}$ & $35.5 \mathrm{c}$ & $25.6 \mathrm{~b}$ & $35.3 \mathrm{c}$ & $29.4 b$ & $32.9 \mathrm{c}$ & $31.6 \mathrm{c}$ \\
\hline $\begin{array}{l}\text { T5: Irrigation } \\
50 \%+\text { organic } \\
\text { fertilizer }\end{array}$ & $20.8 \mathrm{ab}$ & $59.7 b$ & $58.6 \mathrm{a}$ & $51.0 \mathrm{a}$ & $49.2 b$ & $43.7 \mathrm{ab}$ & $54.3 b$ & 48.2a \\
\hline C.V.\% & 18.3 & 9.5 & 12.8 & 15.0 & 6.8 & 15.11 & 12.51 & 12.22 \\
\hline
\end{tabular}

When adding 10 ton $\mathrm{ha}^{-1}$ of chicken manure (Treatment 4), the reduction was smaller, only $29 \%$ compared to total irrigation without organic matter. According to Chemura (2014), organic matter in the soil plays an important role in moisture retention and, therefore, the use of organic fertilizers is considered a strategy for adapting to climate change.

By adding organic fertilizer to the treatment with total irrigation (Treatment 3), it was possible to obtain the highest productivity over 7 years, 50.3 bags produced per hectare, $13 \%$ above the treatment with total irrigation without organic fertilizer. Due to the higher concentration of organic matter, nutrients and soil moisture levels, the superficial layers (0-10 and $10-20 \mathrm{~cm})$ tend to have a higher root concentration, optimizing water and nutrient absorption (Vicente et al., 2017).

Another extremely satisfactory result was obtained by using only half of the necessary irrigation, $50 \%$ (Treatment 5), with organic fertilizer, which allowed an average of 48.2 processed bags per hectare in 7 harvests, results justified by Chemura (2014), who mentioned that the interaction between nutrient sources and irrigation levels is very important, especially in the context of reducing production costs and adapting to climate change. When adding 10 ton $\mathrm{ha}^{-1}$ of organic fertilizer was added, productivity was $8 \%$ higher than when compared to the treatment with only total irrigation; however, there was no statistical difference between the two treatments, using half of the necessary water. The effect of organic matter on coffee productivity was confirmed by Fernandes et al. (2013), who concluded that the use of chicken manure as a source of $\mathrm{N}, \mathrm{P}, \mathrm{K}$ and $\mathrm{S}$ is feasible in reducing these nutrients in the exclusive mineral fertilization of coffee. The contribution of organic residues, such as the chicken manure used in this test, associated with the humification process, promotes an improvement in soil attributes and guarantees the farmer the maintenance of the productive system (Coelho et al., 2013).

Analyzing the classification by sieves and considering sieves 17 or above, which are related to the larger seeds and generally associated with a better final product price, the best results were obtained with irrigated treatments $(100 \%$ of the coffee water requirement + organic matter) and irrigation of $50 \%$ of the coffee water requirement + organic matter, with 
percentages of 32.2 and $32.0 \%$, respectively, with larger results in 11 and $10 \%$, respectively, when the treatment is considered standard (total irrigation, without organic matter - Treatment 1). The treatment without irrigation and without organic matter (T2) had $42 \%$ less fruit with the largest sieves (17 or above), with a total of $16.8 \%$. The use of irrigation increases coffee fruit size. The finding of increased coffee grain size was also reported by Fernandes et al. (2019), Rezende et al. (2006), Soares et al. (2005), Teodoro et al. (2005) and Miranda et al. (2020).

Regarding $\mathrm{pH}$, the highest values were obtained in treatments with organic matter, Treatments 3 to 5, with values of 5.8; 5.4 and 5.7, respectively, which are within the range considered standard for coffee cultivation by Santinato et al. (2008). The same happened with the phosphorus values, with the highest values occurring with the use of organic fertilizer, with values 63,75 and $81 \mathrm{mg} \mathrm{dm}^{-3}$. For potassium, the highest mean values were observed in Treatments 3 and 5, with 176 and $149 \mathrm{mg} \mathrm{dm}^{-3}$ of potassium, respectively. As expected, the highest values of organic matter in the soil were obtained with treatments that used organic sources, with averages over 7 years of $3.9 ; 3.7$ and $3.9 \mathrm{dag} \mathrm{Kg}^{-1}$, compared to treatments without organic matter ( 1 and 2), with values of $3.1 \mathrm{dag} \mathrm{Kg}^{-1}$. The lowest aluminum values in the soil were observed in treatments with organic matter (Treatments 3,4 and 5), with values of 0.2. 0.1 and $0.0 \mathrm{cmolc} \mathrm{dm}^{-3}$, compared to treatments without organic matter ( 1 and 2), with values of 0.5 and 0.4 , respectively. Finally, base saturation was also higher in treatments using chicken manure, with values of 51, 52 and 51, respectively, for Treatments 3, 4 and 5. This was higher than Treatments 1 and 2, without organic matter, with values of 42 and $40 \%$ (Figure 3).

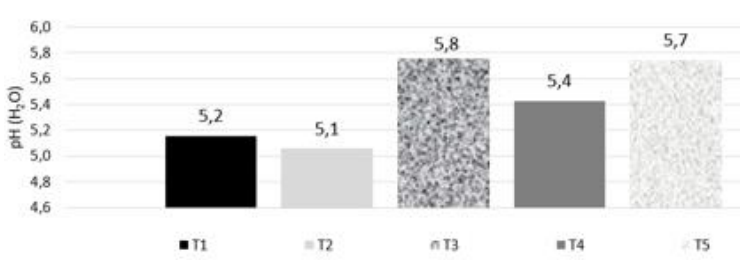

(a)

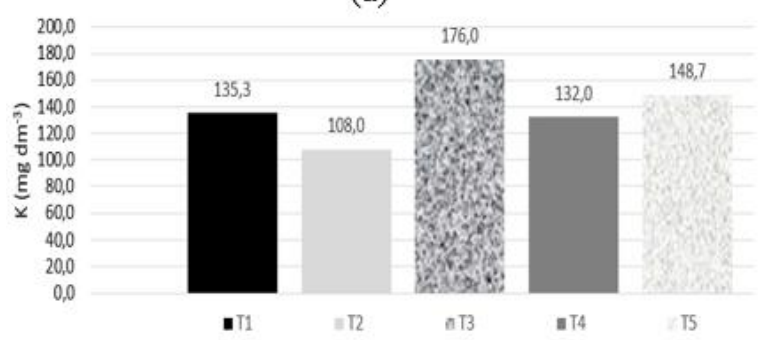

(c)
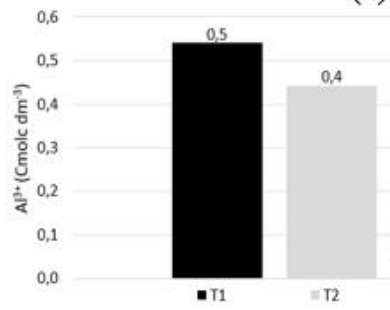

(e)

T1: Total irrigation

A T3: Total Irrigation + organic nutrition

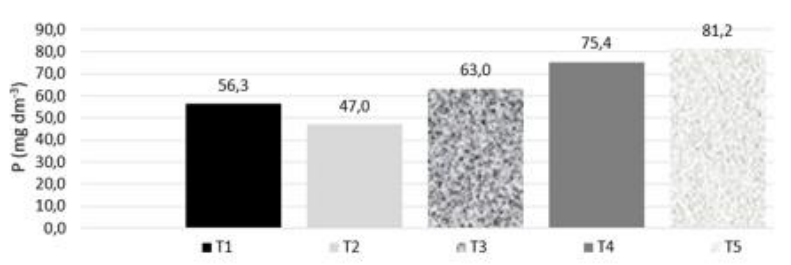

(b)

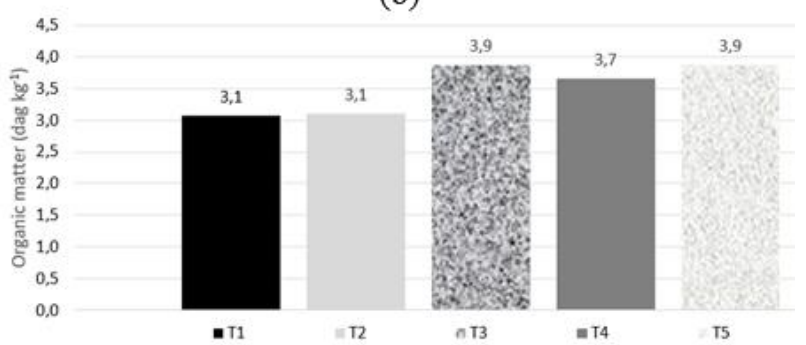

(d)

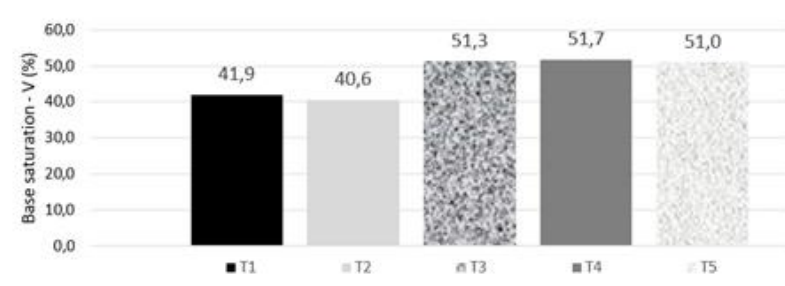

(f)

T2: Without irrigation

- T4: Without irrigation + organic nutrition

T5: Irrigation $50 \%$ + organic matter

Figure 3. pH Values (a), Phosphorus - P, in Melich (b), Potassium - K (c), Organic matter (d), Aluminum - $\mathrm{Al}$ (e) and base saturation - V\% (e) averages per treatment after seven harvests, Izidoro Bronzi Experimental Field, Araguari - MG. 


\section{CONCLUSIONS}

After 7 harvests, it can be concluded that:

- The use of organic matter allows the reduction in the irrigation depth applied to the coffee crop, which may allow the coffee grower to irrigate twice the area with the same availability of water but with about a $4 \%$ reduction in grain size.

- Adding organic matter to the irrigated treatments allowed for the harvest of fruit from larger sieves.

- The use of poultry manure, associated with or without irrigation, allowed for the best soil chemical results.

\section{REFERENCES}

ASSAD, E. D. et al. Zoneamento agroclimático para a cultura de café (Coffea arabica L.) no estado de Goiás e sudoeste do estado da Bahia. Revista brasileira de Agrometeorologia, v. 9, n. 3, p. 510-518, 2001.

CHEMURA, A. The Growth Response of Coffee (Coffea arabica L) Plants to Organic Manure, Inorganic Fertilizers and Integrated Soil Fertility Management under Different Irrigation Water Supply Levels. International Journal of Recycling of Organic Waste in Agriculture, v. 3, n. 2, p. 3-11, 2014. https://doi.org/10.1007/s40093-014-0059-X

COELHO, M. S. et al. Qualidade da matéria orgânica de solos sob cultivo de café consórciado com adubos verdes. Revista Brasileira de Ciência do Solo, v. 37, n. 6, p. 1576-1586, 2013. https://doi.org/10.1590/S0100-06832013000600014

COSTA, J. O.; COELHO, R. D.; BARROS, T. H. S.; FRAGA JR., E. F.; FERNANDES, A. L. T. Canopy Thermal Response to Water Deficit of Coffee Plants under Drip Irrigation. Irrigation and Drainage, v. 69, n. 3, p. 472-482, 2020. https://doi.org/10.1002/ird.2429

DAMATTA, F. M.; RAMALHO, J. D. C. Impacts of Drought and Temperature Stress on Coffee Physiology and Production: A Review. Brazilian Journal of Plant Physiology, 2006. https://doi.org/10.1590/S1677-04202006000100006

FERNANDES, A. L. T.; SANTINATO, F.; FERREIRA, R. T.; SANTINATO, R. Adubação orgânica do cafeeiro, com uso do esterco de galinha, em substituição à adubação mineral. $\begin{array}{llllllll}\text { Coffee } & \text { Science, } & \text { v. } & 8, & \text { n. } & 4, & \text { p. } & 486-499,\end{array}$ http://www.sbicafe.ufv.br/handle/123456789/8003

FERNANDES, A. L. T.; SILVA, R. de O.; SALDANHA, L.; BETINI, M. O.; BROETTO, F. Effect of seaweed extract formulation on coffee plants at different irrigation levels. Asian Academic Research Journal of Multidisciplinary, v. 6, p. 60-74, 2019.

FERNANDES, A. L. T.; TAVARES, T. O.; FERREIRA, R. T.; SANTINATO, R. Technical and Economic Viability of Drip Irrigation of Coffee in Araxá, MG. Coffee Science, v. 11, n. 3, p. 347-58, 2016. https://doi.org/10.25186/cs.v11i3.1090

FERNANDES, A. L. T.; PARTELlI, F. L.; BONOMO, R.; GOLYNSKI, A. A moderna cafeicultura dos cerrados brasileiros. Pesquisa Agropecuária Tropical, v. 42, p. 231240, 2012. 
FERREIRA, D. F. Sisvar: a computer statistical analysis system. Ciência e Agrotecnologia, v. 35, n. 6, p. 1039-1042, 2011. https://doi.org/10.1590/S1413-70542011000600001

FRIBERG, R.; SANCTUARY, M. Market Stealing and Market Expansion: An Examination of Product Introductions in the Organic Coffee Market. Environmental Economics and Policy Studies, v. 20, n. 2, p. 287-303, 2018. https://doi.org/10.1007/s10018-017-0194-5

GARCIA, F. H. S. et al. Análise fisiológica em mudas de cafeeiro com cercosporiose submetida a diferentes lâminas de irrigação. Summa Phytopathology, v. 45, p. 83-88, 2019. https://doi.org/10.1590/0100-5405/185711

GOMES, N. M; LIMA, L. A.; CUSTÓDIO, A. A. Vegetative Growth and Yield of Irrigated Coffee in Southern Region of State of Minas Gerais - Brazil. Revista Brasileira de Engenharia Agrícola e Ambiental, v. 11, n. 6, p. 564-70, 2007. https://doi.org/10.1590/S1415-43662007000600003

HO, T. Q.; HOANG, V. N.; WILSON, C.; NGUYEN, T. T. Eco-efficiency analysis of sustainability-certified coffee production in Vietnam. Journal of Cleaner Production, v. 183, p. 251-2560, 2018. https://doi.org/10.1016/j.jclepro.2018.02.147

LIMA, J. V. O.; FERNANDES, A. L. T.; FRAGA JR, E. F.; CRUZ, P. O. H.; CRUZ, J. P. H.; SANTANA, M. J. Irrigation management with IoT sensors in three phenological phases of coffee crop. Asian Academic Research Journal of Multidisciplinary, v. 6, p. 78-96, 2019 .

LIU, X.; QI, F. L.; YANG, Q.; YU, L. Impacts of regulated deficit irrigation on yield, quality and water use efficiency of Arabica coffee under different shading levels in dry and hot regions of southwest China. Agricultural water management, v. 204, p. 192-300, 2018. https://doi.org/10.1016/j.agwat.2018.04.024

LOFTFIELD, E.; CORNELIS, M. C.; CAPORASO, N.; YOU, K.; SINHA, R.; FREEDMAN, $\mathrm{N}$. Association of coffee drinking with mortality by genetic variation in caffeine metabolism. JAMA International Medicine, v. 178, n. 8, p. 1086-1097, 2018. https://dx.doi.org/10.1001/jamainternmed.2018.2425

MALAVOLTA, E. Manual de nutrição de plantas. São Paulo: Agronômica Ceres, 2006. 631 p.

MANTOVANI, E. C.; SOARES, A. R. Irrigação do cafeeiro: informações técnicas e coletânea de trabalhos. Viçosa: Associação dos Engenheiros Agrícolas de Minas Gerais; UFV; DEA, 2003. 260p. (Boletim Técnico, 8).

MATIELLO, J. B. et al. Cultura do café no Brasil: manual de recomendações. Varginha: Fundação Procafé, 2010. 542 p.

MIRANDA, F. L.; DRUMOND, L. C. D.; RONCHI, C. P. Synchronizing coffee blossoming and fruit ripening in irrigated crops of the Brazilian Cerrado Mineiro Region. Australian Journal of Crop Science, v. 14, n. 4, p. 605-613, 2020.

PERDONÁ, M. J., SORATTO, R. P. Arabica Coffee-Macadamia Intercropping: Yield and Profitability with Mechanized Coffee Harvesting. Agronomy Journal, v. 112, n. 1, p. 429-440, 2020. https://doi.org/10.1002/agj2.20016

PEZZOPANE, J. R. M. et al. Escala para avaliação de estádios fenológicos do cafeeiro arábica. Bragantia, v. $62, \quad$ n. 3, p. 499-505, 2003. https://doi.org/10.1590/S000687052003000300015 
REZENDE, F. C.; OLIVEIRA, S. R.; FARIA, M. A.; ARANTES, K. R. Características produtivas do cafeeiro (Coffea arabica L. cv., Topázio MG-1190) recepado e irrigado por gotejamento. Coffee Science, v. 1, n. 2, p. 103-110, 2006. http://www.sbicafe.ufv.br/handle/123456789/3897

SAKAI, E.; BARBOSA, E. A. A.; SILVEIRA, J. M. de C.; PIRES, R. C. de M. Coffee productivity and root systems in cultivation schemes with different population arrangements and with and without drip irrigation. Agricultural Water Management, v. 148, p. 16-23, 2015. https://dx.doi.org/10.1016/j.agwat.2014.08.020

SANTINATO, R.; FERNANDES, A. L. T. Cultivo do cafeeiro irrigado por gotejamento. 2. ed. Uberaba: Universidade de Uberaba, 2012. 378 p.

SANTINATO, R.; FERNANDES, A. L. T.; FERNANDES, D. R. Irrigação na Cultura do Café. 2. ed. Belo Horizonte: O Lutador, 2008. 476 p.

SILVA, C. A. da; TEODORO, R. E. F.; MELO, B. Produtividade e Rendimento Do Cafeeiro Submetido a Lâminas de Irrigação. Pesquisa Agropecuária Brasileira, v. 43, n. 3, p. 387-394, 2008. https://doi.org/10.1590/S0100-204X2008000300014

SIQUEIRA, H. M. L. de; SOUZA, P. M.; PONCIANO, N. J. Café Convencional versus Café Orgânico: Perspectivas de Sustentabilidade Socioeconômica Dos Agricultores Familiares Do Espírito Santo. Revista Ceres, v. 58, n. 2, p. 155-60, 2011. https://doi.org/10.1590/s0034-737x2011000200004

SOARES, A. R.; MANTOVANI, E. C.; RENA, A. B.; COELHO, M. B.; SOARES, A. A. Avaliação do efeito da aplicação de diferentes lâminas de irrigação na produtividade do cafeeiro para a região do cerrado de Minas Gerais. In: SIMPÓSIO BRASILEIRO DE PESQUISA EM CAFEICULTURA IRRIGADA, 7., 2005, Araguari. Anais[...] Araguari: Associação dos Cafeicultores de Araguari, 2005. p. 50-53.

TEODORO, R. E. F.; MELO, B.; CARVALHO, H. P.; GUIRELLI, J. E.; BENEDETTI, T. C.; BUENO, M. R. Influência de diferentes lâminas de irrigação nos parâmetros de produção do cafeeiro cultivado em região de cerrado. In: SIMPÓSIO BRASILEIRO DE PESQUISA EM CAFEICULTURA IRRIGADA, 7., 2005, Araguari. Anais[...] Araguari: Associação dos Cafeicultores de Araguari, 2005. p. 161-165.

TVERDAL, A.; SELMER, R.; COHEN, J. M.; THELLE, D. S. Coffee consumption and mortality from cardiovascular diseases and total mortality: does the brewing method matter? European Journal of Preventive Cardiology, p.1-8, 2020. https://doi.org/10.1177\%2F2047487320914443

VERHAGE, F. Y.; ANTEN, N. P. R.; SENTELHAS, P. C. Carbon dioxide fertilization offsets negative impacts of climate change on Arabica coffee yield in Brazil. Climatic Change, v. 144, p. 671-685, 2017. https://doi.org/10.1007/s10584-017-2068-z

VICENTE, M. R.; MANTOVANI, E. C.; FERNANDES, A. L. T.; NEVES, J. C. L.; FIGUEIREDO, E. M.; DELAZARI, F. T. Spacial distribution of fertigated coffee root system. Ciência e Agrotecnologia, v. 41, p. 72-80, 2017. https://doi.org/10.1590/141370542016411021316 
VICENTE, M. R.; MANTOVANI, E. C.; FERNANDES, A. L. T.; NEVES, J. C. L.; FIGUEREDO, E. M. Development and production of fertigated coffee trees in the West Region of Bahia, Brazil. Coffee Science, v. 13, p. 90-97, 2018. http://dx.doi.org/10.25186/cs.v13i1.1383

VICENTE, M. R.; MANTOVANI, E. C.; FERnANDES, A. L. T.; NEVES, J. C. L.; DELAZARI, F. T.; FIGUEREDO, E. M. Effects of Irrigation on the Production and Development of Coffee in the West Region of Bahia. Coffee Science, v. 12, n. 4, p. 544551, 2017. https://doi.org/10.25186/cs.v12i4.1367

VOLSI, B.; TELLES, T. S.; CALDARELLI, C. E.; CAMARA, M. R. G. The Dynamics of Coffee Production in Brazil. PLoS ONE, v. 14, n. 7, p. 1-15, 2019. https://doi.org/10.1371/journal.pone.0219742 


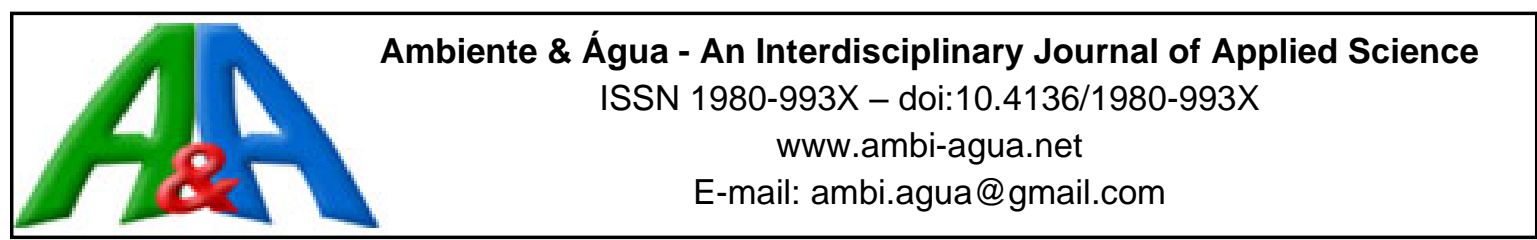

\title{
New Water and Biotic Quality Assessment Indices for a tropical reservoir based on fuzzy logic
}

\author{
ARTICLES doi:10.4136/ambi-agua.2597
}

Received: 14 Jun. 2020; Accepted: 06 Aug. 2020

\section{Andres Paladines Andrade1(D); Marley Vellasco ${ }^{1 *}$; Karla Figueiredo $^{2}($; Francisco Gerson Araújo ${ }^{3}$; Christina Wyss Castelo Branco ${ }^{4}$}

${ }^{\mathbf{1} D e p a r t a m e n t o ~ d e ~ E n e r g i a ~ E l e ́ t r i c a . ~ C e n t r o ~ T e ́ c n i c o ~ C i e n t i ́ f i c o . ~ P o n t i f i ́ c i a ~ U n i v e r s i d a d e ~ C a t o ́ l i c a ~ d o ~ R i o ~ d e ~}$ Janeiro (PUC-Rio), Rua Marquês de São Vicente, nº 225, CEP: 22451-900, Gávea, RJ, Brazil.

E-mail: paladinesandres@gmail.com

${ }^{2}$ Departamento de Ciência da Computação. Instituto de Matemática e Estatística. Universidade do Estado do Rio de Janeiro (UERJ), Rua São Francisco Xavier, n 524, CEP: 20550-900, Maracanã, RJ, Brazil.

E-mail: karla.figueiredo@gmail.com

${ }^{3}$ Departamento de Biologia Animal. Laboratório de Ecologia de Peixes. Universidade Federal Rural do Rio de Janeiro (UFRRJ), BR 465, km 7, CEP: 23897-030, Seropédica, RJ, Brazil.

E-mail: gerson@ufrrj.br

${ }^{4}$ Departamento de Zoologia. Instituto de Biociências. Universidade Federal do Estado do Rio de Janeiro (UNIRIO), Avenida Pasteur, n 458, CEP: 22290-240, Rio de Janeiro, RJ, Brazil.

E-mail: cbranco@unirio.br

*Corresponding author. E-mail: marley@ele.puc-rio.br

\begin{abstract}
The complexity of evaluating the quality of an aquatic environment with its numerous variables has resulted in several quality indexes to synthesize all information in a single value. However, most of these indexes are based on few environmental variables, losing information from other relevant variables. This article presents a new model capable of representing the quality level of a tropical oligo-mesotrophic reservoir on a numerical scale, considering the subjectivity implicit in the concept of quality, and involving several physical, chemical and biological variables. The proposed model, called "Fuzzy Indices for Water Quality Assessment and Biotics" (FUZZY-WBQAI), is based on fuzzy inference systems, providing a way to deal with the uncertainty between the quality categories. A computational tool was developed, which automatically assesses the quality of water, considering different methodologies that depend on the stratification conditions and the longitudinal zone of the reservoir. The model calculates two indices: one for water quality and one biotic that uses metrics from the fish assembly. The model was effective in revealing the decrease in water quality in summer months with higher temperature and precipitation. The effect of the mixture of the stratified reservoir in winter in decreasing the water quality in an area of fish cultivation was highlighted. The biotic index was sensitive to spatial changes in the environmental quality of the reservoir. The results were considered satisfactory, in agreement with the specialized knowledge, and can provide a rapid diagnosis of water conditions in oligo-mesotrophic reservoirs in the tropics.
\end{abstract}

Keywords: environmental index, fuzzy inference system, FUZZY-WBQAI model, hydropower reservoir, tropical reservoir, water quality index. 


\section{Novos índices de avaliação da qualidade da água e biótica de um reservatório tropical baseado em Lógica Fuzzy}

\section{RESUMO}

A complexidade de avaliar a qualidade de um ambiente aquático com suas inúmeras variáveis resultou na criação de vários índices de qualidade para sintetizar todas as informações em um único valor. No entanto, a maioria desses índices é baseada em poucas variáveis, perdendo informações de outras variáveis relevantes. Este artigo apresenta um novo modelo capaz de representar o nível de qualidade de um reservatório oligo-mesotrófico tropical em escala numérica, considerando a subjetividade implícita no conceito de qualidade e envolvendo diversas variáveis físicas, químicas e biológicas. O modelo proposto, denominado "Índices Fuzzy de Avaliação da Qualidade da Água e Biótica" (FUZZY-WBQAI), é baseado em sistemas de inferência fuzzy, fornecendo uma forma de lidar com a incerteza entre as categorias de qualidade. Uma ferramenta computacional foi elaborada, a qual avalia automaticamente a qualidade da água, considerando diferentes metodologias que dependem das condições de estratificação e zona longitudinal do reservatório. O modelo calcula dois índices: um de qualidade da água e um biótico que utiliza métricas da assembleia de peixes. O modelo foi eficaz ao revelar a diminuição da qualidade da água nos meses de verão com temperatura e precipitação mais elevadas. Destacou-se o efeito da mistura do reservatório estratificado no inverno sobre a diminuição da qualidade da água em área de cultivo de peixes. $\mathrm{O}$ índice biótico foi sensível a mudanças espaciais na qualidade ambiental do reservatório. Os resultados foram considerados satisfatórios, concordando com o conhecimento especializado, e podem propiciar diagnósticos rápidos das condições da água em reservatórios oligo-mesotróficos nos trópicos.

Palavras-chave: índice ambiental, índice de qualidade da água, modelo FUZZY-WBQAI, reservatório de hidrelétrica, reservatório tropical, sistema de inferência fuzzy.

\section{INTRODUCTION}

Water is an indispensable natural resource for human survival, and is used in many human activities, including irrigation, food production, industrial processes, generation of energy, navigation, and landscaping. Hence, numerous countries have laws that specify strict limits for any water use, as well as treatment requirements according to the type of water use (Vargas $e t$ al., 2018). In Brazil, resolution 357/2005 of the National Environment Council (CONAMA, 2005) addresses the classification of water bodies, establishes environmental guidelines and sets the conditions and patterns for the discharge of effluents.

Therefore, for efficient management and control of water resources, it is imperative to continuously monitor water quality, in order to supply the information required for proper management of surface waters (Branco et al., 2019; Rocha et al., 2019) and groundwater (Gholami et al., 2015; 2020). A standard method for estimating water quality is to analyse features of several physical, chemical, and biological variables. Nevertheless, water quality indices are the preferred solution for integrated management, since they incorporate a large number of variables in a single value that can be easily understood. Current literature offers several quality indices for aquatic environments.

In 1965, Horton (1965) formulated the first water quality index based on a numerical scale to represent grades of water quality. Brown et al. (1970) developed a water quality index that is similar in structure to the Horton index, but substantially more rigorous in the selection of variables and the attribution of weights for the development of a common scale. Based on the research by Brown et al. (1970), the São Paulo State Environmental Company (Companhia de Tecnologia e Saneamento Ambiental - CETESB) in Brazil adapted and developed their own 
Water Quality Index (Índice de Qualidade das Águas-IQA) (CETESB, 2006). This index was specifically designed for public water supply and incorporates nine variables considered relevant for water quality evaluations. Recently, Garcia et al. (2018) presented a review of water quality indices, discussing their evolution and future perspectives.

Most indices available in the literature, however, are formulated for running waters, having little to no applicability in lentic environments. Lakes and reservoirs are usually classified by trophic state, based on biomass of phytoplankton and on the content of total phosphorus, water transparency, and chlorophyll-a (Cunha et al., 2013; Klippel et al., 2020).

The assessment of the water quality conditions in Brazilian reservoirs has been of paramount importance for establishing management strategies for stakeholders. The increase in efficiency and speed in environmental evaluation is crucial, since around 64\% of the energy used in Brazil comes from hydroelectric power plants with reservoirs (ANEEL, 2020). Besides power generation, the waters of Brazilian reservoirs are used for domestic and industrial supply, recreation, fishing and agriculture. Considering this scenario, new and more efficient approaches using artificial intelligence techniques for environmental evaluation of these systems, are clearly welcome. Although trophic state indices have been used as a base for comparison of water quality in Brazilian reservoirs (Cunha et al., 2013; Klippel et al., 2020), most of them are based on few environmental variables and may lose important information related to other monitored variables. Furthermore, they do not reflect the subjective aspects inherent to their qualitative counterparts, being less representative than quality indices.

The term quality implies a subjective judgment that is best kept separate from the concept of a trophic state. "The definition of trophic state and its index should remain neutral to such subjective judgments, remaining a framework within which various evaluations of water quality can be made" (Carlson, 1977). Therefore, to provide a quality index that naturally incorporates subjective aspects of environmental aspects, new indices should be developed considering the diversity of existing aquatic systems, which is a challenge especially for the tropical regions.

The natural environment must be analyzed as a complex system, and an integrated vision can promote a good understanding of the impacts occurring in water bodies, regarding the distinct nature of the factors and environmental quality legislation (Santos et al., 2019; Gholami et al., 2020). Under this perspective, fuzzy logic allows a flexible and realistic modeling system, and consists of a set of methods based on the concept of fuzzy sets and fuzzy operations (Salski, 2007). Recent studies have shown that fuzzy logic systems are universal surrogates for general non-linear functional relationships, to any degree of accuracy, making them a powerful tool for exploring complex, non-linear biological problems such as estimating and forecasting (Soyupak and Chen, 2004). The use of fuzzy logic as an environmental evaluation method began in the 1990s and has been used broadly for determining trophic status and water quality indices in rivers (Lee and Chang, 2005; Chang, 2008; Lermontov et al., 2009; Semiromi et al., 2011; Ocampo-Duque et al., 2006; 2013; Mourhir et al., 2014), natural lakes (Chen and Mynett, 2003; Icaga, 2007), reservoirs (Lu et al., 1999; Soyupak and Chen, 2004; Liou and Lo, 2005; Taheriyoun et al., 2010) and in evaluation of groundwater quality (Gholami et al., 2017); but none of these uses involved tropical regions. The fuzzy approach has also been used in water quality and watershed evaluations combined with other techniques, such as self-organizing maps (Lu and Lo, 2002), and geographic information system (GIS) (Pinto et al., 2016; Gholami et al., 2017).

This research presents the proposal of a new intelligent model capable of representing the quality level of a tropical oligo-mesotrophic reservoir in a numerical scale, considering the implicit subjectivity in the concept of quality. The proposed model, named "Fuzzy Water and Biotic Quality Assessment Indices" (FUZZY-WBQAI), evaluates water and biotic quality of the reservoir based on fuzzy inference systems, providing a natural way to deal with uncertainty among quality categories. Fuzzy logic is conceptually simple, but the real power of the 
methodology comes from the ability to integrate different kinds of observations in a way that permits a balance between favourable and unfavourable observations, the information with more flexibility than discrete measures to ordinary sets, such as "acceptable versus unacceptable" (Silvert, 2000; Icaga, 2007). The proposed fuzzy model is capable of representing, in a more efficient form, the limits of the intervals of several quality variables, such as $\mathrm{pH}$ or dissolved oxygen. The range of the intervals for the variables was established based on water quality standards for Class 1, which according to resolution CONAMA 357/2005 (CONAMA, 2005) are waters that can be used as supply for human consumption, after simplified treatment, for primary contact recreation, such as swimming, water skiing, diving, and for the protection of aquatic communities. Additionally, the FUZZY-WBQAI provides a fish assemblage index in a set of subjective categories, e.g., low or poor, when those limits are imprecise or not well defined. The proposed FUZZY-WBQAI model is based on two hierarchical fuzzy inference systems developed for water and biotic quality assessment, respectively. A user-friendly computational tool was designed to easily evaluate the water and biotic quality of tropical reservoirs and can be very useful for hydroelectric power companies with the generator matrix supported by reservoirs.

\section{MATERIALS AND METHODS}

\subsection{Study Area}

The Lajes Reservoir was built in 1905 to generate hydroelectric power and belongs to a system of reservoirs operated by the Light Energy SA Company since 1940, which generates $612 \mathrm{MW}$ of electricity and provided $96 \%$ of the water consumed by the municipalities of Rio de Janeiro (Guarino et al., 2005; Soares et al., 2008; Branco et al., 2009). Currently, the Lajes Reservoir alone provides the domestic water supply for approximately one million people. The reservoir is also used for sports fishing and, recently, for fish farming in net-tanks in one of its bays.

The Lajes Reservoir ( $22^{\circ} 43^{\prime} \mathrm{S}$ to $22^{\circ} 46^{\prime} \mathrm{S}$ and $44^{\circ} 30^{\prime} \mathrm{W}$ to $44^{\circ} 60^{\prime} \mathrm{W}$ ) is situated between the hills of Serra das Araras, in a protected area with tropical forests. The Lajes Reservoir is located $415 \mathrm{~m}$ above sea level, and has a surface area of $38.9 \mathrm{~km}^{2}$, a maximum depth of $40 \mathrm{~m}$, a mean depth of $15 \mathrm{~m}$, and an accumulated volume of $450 \times 10^{6} \mathrm{~m}^{3}$ (Soares et al., 2008). The climate in the region of Lajes Reservoir is subtropical humid with rainfall between 1000 and $1700 \mathrm{~mm}$ per year and presents two well-defined periods: a rainy season (November to March) and a dry season (April to October).

The reservoir has been considered as an oligo-mesotrophic system (Klippel et al., 2020). Nevertheless, the low values of chlorophyll- $a$, picocyanobacteria accounts for most of the phytoplankton abundance in this reservoir (Recknagel et al., 2015). Regardless of phosphorus limiting conditions, picocyanobacteria can be influenced by water column stability and electrical conductivity (Rocha et al., 2019). Because of its high retention time of 300 days, the reservoir is considered vulnerable to eutrophication (Guarino et al., 2005). Recent human activity, such as fish farming, can accelerate the growth of nutrient inputs in the reservoir, which has not occurred for decades.

According to Branco et al. (2009), the Lajes Reservoir is a monomictic reservoir with a tendency to mix the water column in the winter depending on the weather conditions. The prolonged stratification period leads to an anoxic hypolimnion that is rich in nutrients, which causes the reservoir to present poor water quality in its deepest part.

Two databases were used as sources of analytical information about the Lajes Reservoir. The first database (655 water samples from February 2000 to December 2009) is from Federal University of Rio de Janeiro State (UNIRIO). The second database (417 fish samplings from January 1994 to August 2012) is from Federal Rural University of Rio de Janeiro (UFRRJ). For 
the physical and chemical variables, the data were extracted from five sampling locations. For the fish assemblage metrics, data were obtained from twenty-four locations (Figure 1).

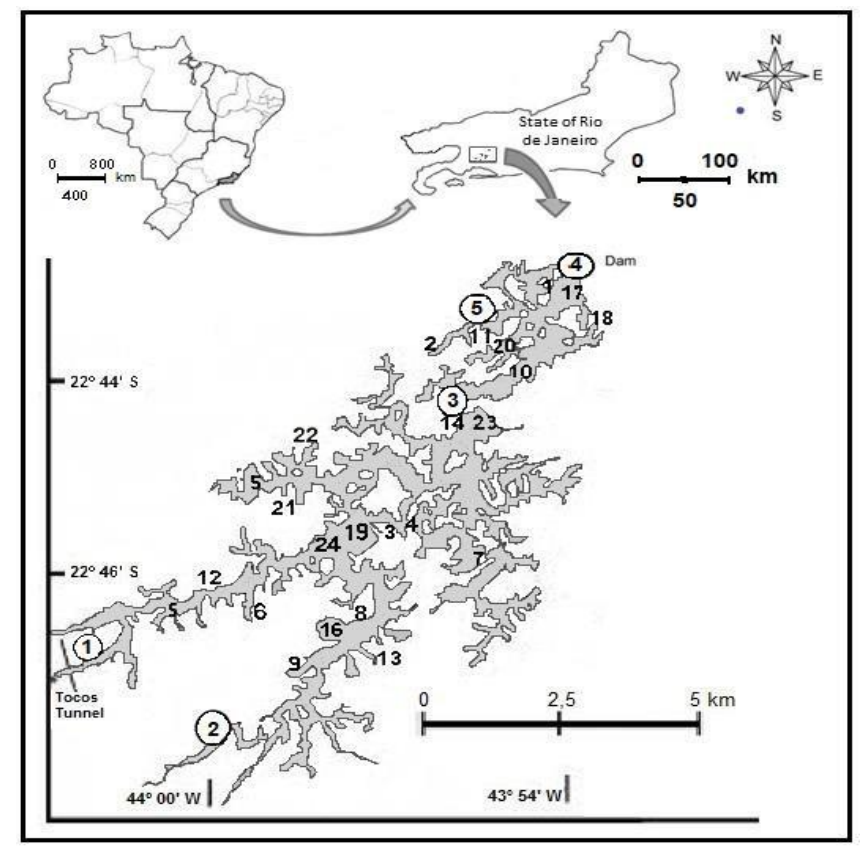

Figure 1. The geographic location of the physical, chemical and biological samples. The numbers in circles represent the sample locations of the physical and chemical samples; other numbers show sampling location of fish assemblage metrics.

\subsection{Reservoir Fish Assemblage Index-RFAI}

Multimetric fish-based indices of biological integrity (IBIs) have been developed for streams and rivers throughout the world (Roset et al., 2007). However, few such indices have been developed for lakes (Appelberg et al., 2000; Drake and Pereira, 2002) and even fewer for reservoirs (Jennings et al., 1995). The use of multimetric indices to monitor reservoir biological condition is an infrequently applied approach, which reflects the difficulty of implementing such indices to artificial systems relative to rivers. Jennings et al. (1995) were the first to propose an adaptation of the IBI for assessing reservoirs. They suggested a new name for the index, the Reservoir Fish Assemblage Index (RFAI).

The RFAI may be an efficient tool to monitor reservoirs; however, it needs to be adapted for transitional river and reservoir zones. A river-reservoir RFAI (RRFAI) would enable environmental managers to monitor river-reservoir systems and to assess the impact of reservoirs on what previously were entirely lotic systems. Such monitoring programs for transitional river-reservoir systems are necessary for Brazil, where almost all electricity and urban water supplies are generated by/from dammed rivers. A preliminary RRFAI from fish assemblage data was proposed by Terra and Araújo (2011). Based on the values of these metrics and using the criteria for assigning grades detailed in Table 1, the RRFAI is formulated by adding the grades attributed to each metric following the applied fishing effort. The standardized sampling unit, the fishing effort, was defined as the total number of fishes caught during each sampling occasion at each site, using three gillnets of different mesh sizes $(25,50$, and $75 \mathrm{~mm}$ stretched mesh) encompassing $150 \mathrm{~m}^{2}$. The nets were set up at sunset and retrieved the following morning, remaining for $15 \mathrm{~h}$.

Thus, the value of the RRFAI is reflected in the biotic quality of a reservoir. Accordingly, RRFAI <25 corresponds to a Bad biotic quality, 25 - 50 to a Regular, and > 50 to a Good (Terra and Araújo, 2011). 
Table 1. Criteria for the attribution of grades-RRFAI (Terra and Araújo, 2011).

\begin{tabular}{lccc}
\hline \multirow{2}{*}{ Attributes } & \multicolumn{3}{c}{ Criteria for attribution of grades } \\
\cline { 2 - 4 } & $\mathbf{0}$ & $\mathbf{5}$ & $\mathbf{1 0}$ \\
\hline Number of native species & $<5$ & 5 to 8 & $>8$ \\
Number of native Siluriformes & 0 & 1 to 3 & $>3$ \\
Number of native Characiformes & 0 & 1 to 3 & $>3$ \\
Percentage of non-native species biomass & $>75$ & 50 to 75 & $<50$ \\
Dominance & $>0.6$ & 0.3 to 0.6 & $<0.3$ \\
Shannon index H' & $<1$ & 1 to 1.5 & $>1.5$ \\
Astyanax N & $<50$ & 50 to 100 & $>100$ \\
Hypostomus affinis & $<4$ & 4 to 8 & $>8$ \\
\hline
\end{tabular}

As can be noted, this biotic quality index considers crisp boundaries between each quality category, which hinders a more detailed analysis close to the borders. Those crisp boundaries are the main drawback of most water and biotic quality indices available in the literature, since they do not consider the intrinsic imprecision of the limits imposed between quality categories boundaries.

\subsection{FUZZY-WBQAI: Proposed Intelligent Model}

The proposed FUZZY-WBQAI was developed for the tropical oligo-mesotrophic Lajes Reservoir. Therefore, the model considers thermal stratification as well as mixing of the water column in the formulation of its indices. This characteristic is significant, since vertical gradients of temperature in the water column of a lake influence numerous physical and chemical variables, which, in turn, determine the basic features of its function. This aspect is further substantiated in the case of reservoirs with long retention time, which is particularly true for the Lajes Reservoir. In other words, the FUZZY-WBQAI model attempts to differentiate quality calculations among the epilimnion, metalimnion, hypolimnion, and possible mixing of water. Note that the intrusion effect was not considered in the proposed model.

As a function of the horizontal location of a sample, the FUZZY-WBQAI also aims to differentiate the quality calculation between river zones, transition zones, and lake zones. These three zones of a reservoir possess their own biological, physical, and chemical properties (Thorton, 1999), providing another reason for their relevance in the model. By differentiating between vertical zones and longitudinal zones in the quality calculation, the FUZZY-WBQAI aims to capture the features of each sampling point of the reservoir. The possible combinations between zones are as follows: 1. Lake zone-Epilimnion; 2. Lake zone-Metalimnion; 3. Lake zone - Hypolimnion; 3. Lake zone - Mixture; 4. Transition zone - Epilimnion; 5. Transition zone - Metalimnion; 6. Transition zone-Hypolimnion; 7. Transition zone - Mixture, and 8. River zone.

However, according to the limnological characteristics of the reservoir, the transition zone and lake zone may be regarded as homogeneous, due to the horizontal spatial heterogeneity (Guarino et al., 2005). Therefore, the two zones were treated as one. This deliberation reduces the number of possible heterogeneous regions to five: 1. Epilimnion zone; 2. Metalimnion zone; 3. Hypolimnion zone; 4. Mixture zone; 5. River zone.

The FUZZY-WBQAI model, therefore, comprises five distinct methodologies, each one applicable to a specific zone. The proposed model is based on the hierarchical fuzzy inference system approach, which is known to reduce the complexity of a fuzzy inference system when the number of input variables increases (Jin, 2000), improving its interpretability. Depending on the zone, two hierarchical fuzzy inference systems are developed, providing water and biotic quality indices, respectively. 
All fuzzy inference systems were developed using the following steps:

- Choice of input variables for each index: first, the quality indicators and metrics considered decisive in the implementation of each index were selected;

- Definition of the universes of the discourse of each input variable: then, the universes of discourse (range of possible values) were specified for each input variable, i.e., quality indicators and fish assemblage metrics;

- Definition of the membership functions: the membership functions of each fuzzy set, with their respective linguistic labels, for each input variable, were defined;

- Determining the sub-indices: the hierarchical nature of the fuzzy inference systems proposed in this work produces intermediate results, or quality sub-indices. So, the most suitable sub-indices for the water quality index and biotic index, their universes of discourse, and their membership functions must be determined;

- Construction of the rule bases: finally, the fuzzy rule base, with their antecedents and consequents, for each sub-index and for the final indices must be established.

The five methodologies (one for each considered reservoir region) use the same selection of input variables and the same structure of sub-indices. However, the universes of discourse for each variable, their membership functions and their associate rule base are specific for each methodology.

The FUZZY-WBQAI model was developed based on the knowledge of specialists from the Laboratory of Limnology of the UNIRIO and from the Animal Biology Department of the UFRRJ that, for several years, have been conducting research in the Lajes Reservoir. Additionally, the limits for each variable established by the resolution CONAMA 357/2005 (CONAMA, 2005) for waters of Class 1 were considered. Therefore, all steps were developed through discussions with those specialists in water and environmental quality and were based on the notion that "expert judgment is the key for any environmental assessment, evaluation, or diagnosis" (Scardi et al., 2008). The selection of relevant environmental variables is a common problem in ecological modelling, and the selection by expert decreases model complexity and the amount of data required to estimate model parameters efficiently (D'heygere et al., 2003; Forio et al., 2017).

\subsubsection{General View of the Indices Calculation Methodology}

In evaluating the water and biotic quality of a reservoir, the proposed model considers the following:

- Ten environmental indicators (or physical, chemical and biological indicators) for water quality calculation: water temperature, dissolved oxygen, $\mathrm{pH}$, chlorophyll- $a$, nitrate, total phosphorus, nitrite, ammonium, conductivity, and turbidity;

- Eight metrics of fish community assemblies for the calculation of biotic quality: number of native species, number of native Siluriformes, number of native Characiformes, percentage of non-native species biomass, dominance (D), Shannon index (H), number of Astyanax fish (N), and number of Hypostomus affinis;

- Stratification and possible mixing of the water column;

- Horizontal location of the sample: river zone, transition, or lake;

- Vertical location of the sample;

- Date of sampling. 
The model evaluates the water and biotic quality of a sample according to its horizontal and vertical locations in the reservoir, and considers possible thermal stratification at the sampling time. The ten water quality indicators and eight fish assemblage metrics are considered inputs to the system.

Since the reservoir used as the basis for the design of the proposed model is the Lajes Reservoir, the entire process of designing and programming this tool considered limnological information obtained from previous studies of the reservoir. The proposed model is based on the limnological characteristics described in Guarino et al. (2005), Soares et al. (2008) and Branco et al. (2009). Other environmental variables included were shown as important for phytoplankton increases in this aquatic ecosystem, such as nitrogen and phosphate compounds (Recknagel et al., 2015), water column stability and electrical conductivity (Rocha et al., 2019). It must be emphasized, however, that although the proposed FUZZY-WBQAI model was developed using Lajes Reservoir as the basis, it can be applied to any other tropical oligomesotrophic reservoir with similar limnological characteristics.

First, the model locates the sample longitudinally in the reservoir using Cartesian coordinates in degrees, minutes, and seconds. The tool identifies whether the sample is located in the river, transition, or lake zone. According to the limnological characteristics of the reservoir, the transition zone and lake zone may be considered homogenous because of their horizontal spatial homogeneity (Busch and Sly, 1992). Therefore, the quality calculation methodology for those zones in the Lajes Reservoir is the same.

If the sample is located in the transition or the lake zone, the model will determine whether there is any presence of stratification or mixture. If there is stratification, the computational tool then identifies the stratification layer to which the sample belongs. The model analyses the presence of stratification or mixture using a temperature vs. depth curve based on the temperature and depth of the water column. Once the sample is located, and horizontal zone and layer (epilimnion, metalimnion or hypolimnion) to which it belongs are identified, the model uses one of the available calculation methodologies to evaluate the water quality.

As previously explained, five calculation methodologies were created: one methodology for the river zone and four methodologies for the transition and lake zones. These methodologies correspond to the stratification layers of the epilimnion, metalimnion, hypolimnion, and a possible mixture of water. Figure 2 shows the flowchart for selecting the appropriate calculation methodology. If the sample is located in the epilimnion or river zone (methodologies \#1 and \#2), the model calculates two indices: a water quality index, and a biotic index that utilizes the fish assemblage metrics. In the metalimnion and hypolimnion zones, only the water quality index is calculated, as the number of fish collected in these layers is limited.

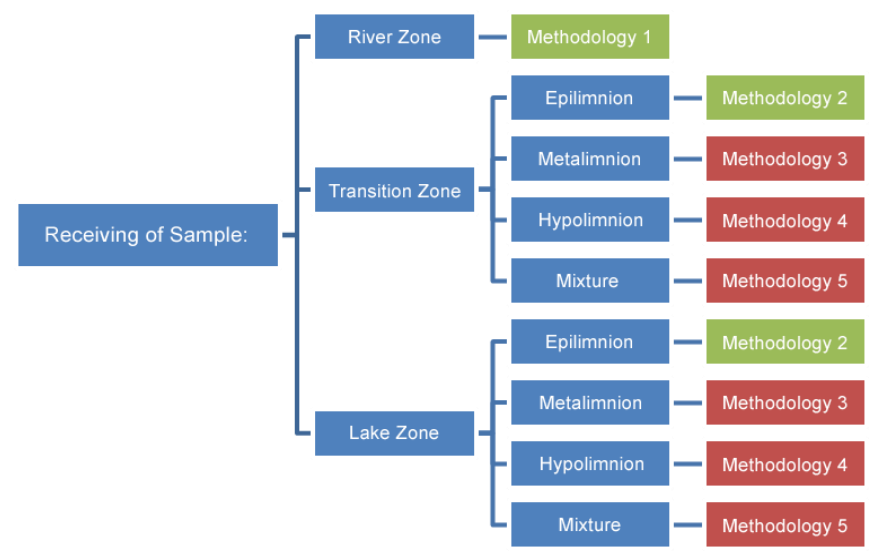

Figure 2. Selection of the calculation methodology for the evaluation of the water and biotic quality.

Source: authors.

Rev. Ambient. Água vol. 15 n. 5, e2597 - Taubaté 2020 


\subsubsection{Hierarchical Fuzzy Inference System: Quality Sub-indices}

The development of fuzzy inference systems with more than four input variables becomes a significant challenge, with the exponential growth of the number of rules and interpretability reduction (Gonçalves et al., 2006). Thus, input variables are usually divided into intermediate fuzzy systems, where their outputs are used as inputs to the final system. In the proposed FUZZY-WBQAI model, the ten water quality variables and eight biotic quality variables are divided into groups of two, originating quality sub-indices, which in turn are used as inputs to the final indices (Figure 3).

\section{(A)}

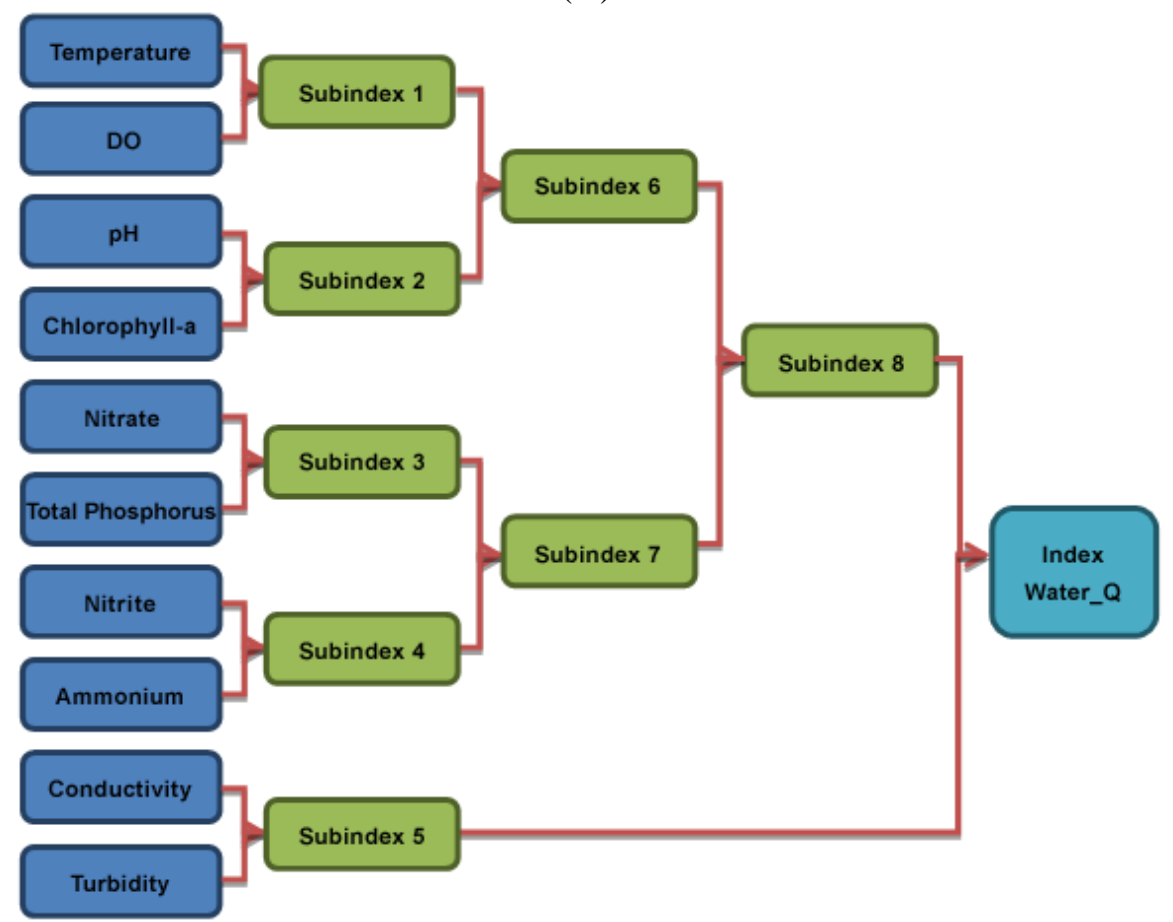

(B)

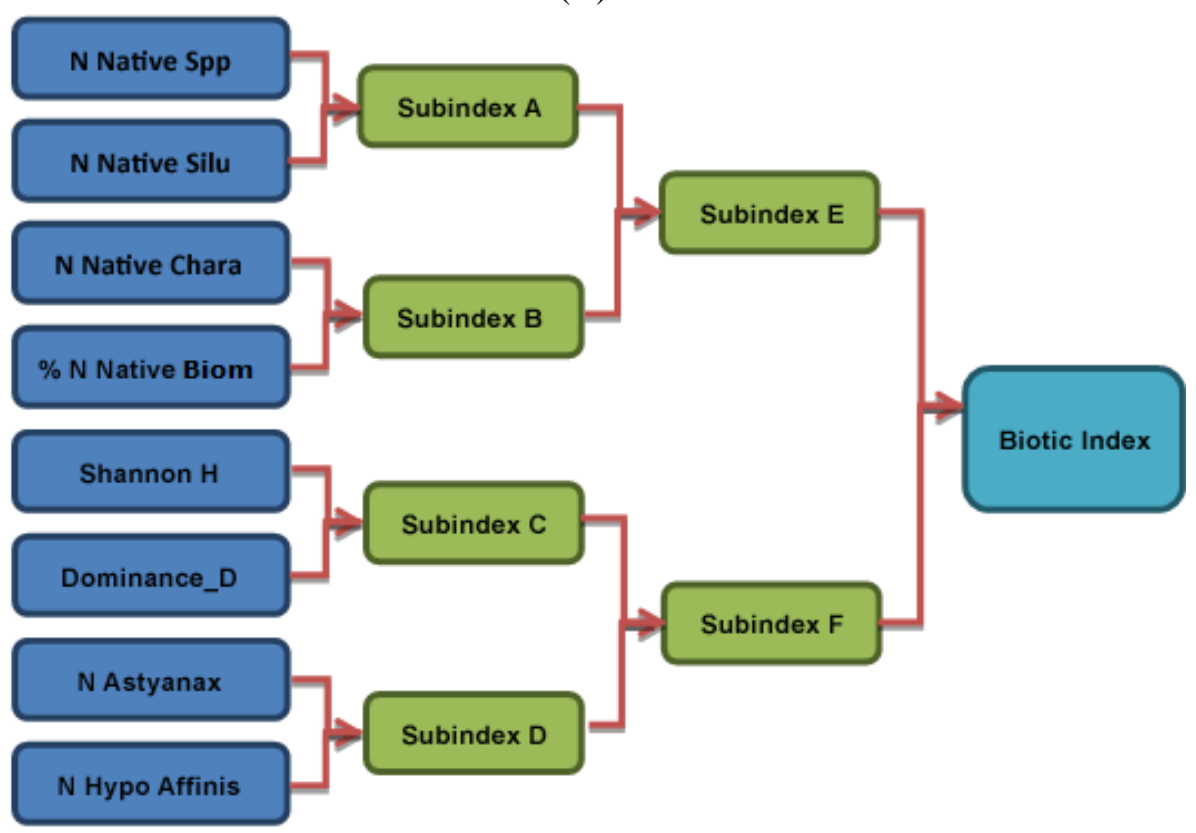

Figure 3. a) Flowchart of the sub-indices that compose the Water Quality Index; b) Flowchart of the sub-indices that compose the Biotic Quality Index. \\ IPABH}




\subsubsection{Fuzzy Sets Definition}

The universe of discourse for each variable and the support of each fuzzy set were defined by limnology specialists (co-authors of this study) and adjusted during the evaluation of the proposed model. All input variables were partitioned into five fuzzy sets: Low, Average-Low, Average, Average-High and High. Figure 4 presents an example of the fuzzy sets of the linguistic variables used in water and biotic quality indices, respectively, for temperature, dissolved oxygen, $\mathrm{pH}$ and chlorophyll- $a$ in Methodology \#2 (Epilimnion region).

Sub-indices and indices' variables were also partitioned into five fuzzy sets, with the following labels: Poor, Average-Poor, Average, Average-Good and Good, as shown in Figure 4. The same fuzzy partitioning is used in all methodologies (Epilimnion, Metalimnion and Hypolimnion).
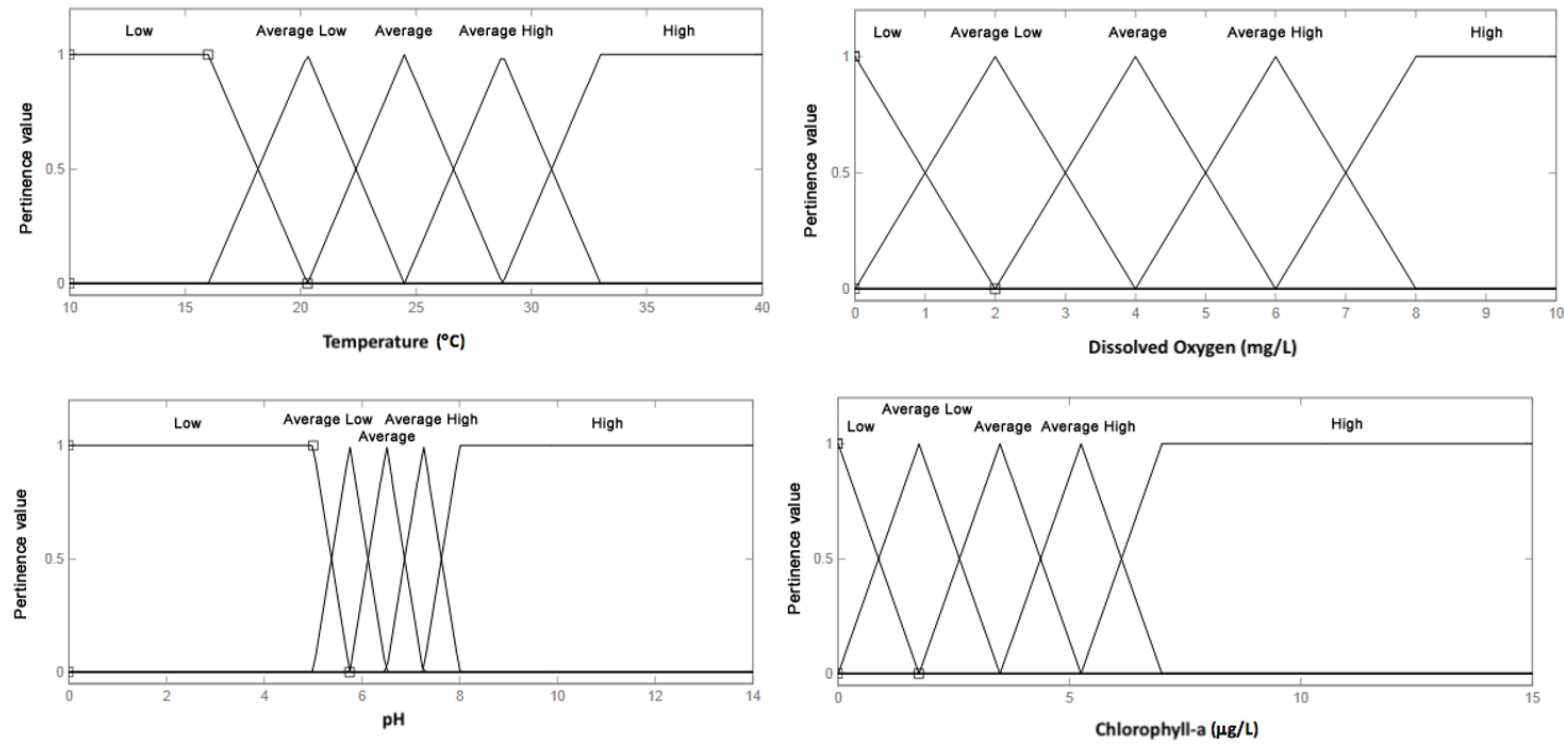

Figure 4. Example of fuzzy sets of water quality index for the variables water temperature, dissolved oxygen, $\mathrm{pH}$ and chlorophyll- $a$.

\subsubsection{Rule Bases}

The fuzzy rule bases for all sub-indices and final indices were provided by the specialists mentioned above. It is important to emphasize that the rule bases are dependent on the characteristics of the body of water for which the system is originally designed or on limits recommended in the legislation for that class of water. Thus, the rule base can only be extended to other reservoirs that share similar limnological characteristics or are included in the same type of water. The features of a reservoir act directly on the vertical and horizontal structures of the lake, which in turn directly influence the water quality. Consequently, when considering the use of the proposed model for the evaluation of a reservoir other than the Lajes Reservoir, the following limnological characteristics must be similar to those of the Lajes Reservoir:

- Reservoir size, geographic region, and climate

- Hydrographical characteristics

- Water retention time

- Class type of water (according to the legislation CONAMA 357/2005)

For reservoirs that significantly differ from the Lajes Reservoir, in addition to altering the rule base, the calculation methodologies might also require modification.

The fuzzy rule bases for all methodologies (epilimnion, metalimnion and hypolimnion), as 
well as for all sub-indices related to each methodology, can be found in Andrade (2013). Each fuzzy inference system is developed using the Mamdani inference system (Jang and Sun, 1995). The intersection and implication operators can be configured by the user (min or prod), so as the defuzzification method, as described in the next section.

The values of all sub-indices, as well as the final FUZZ-WBQAI index, vary between 0 and 100 .

\subsubsection{FUZZY-WBQAI: The computational Tool}

The proposed FUZZ-WBQAI model was implemented in a user-friendly computational tool, programmed using C\# programming language together with Microsoft Visual Studio and Microsoft Excel. The final tool was developed as a Windows application for ease of use and then synchronized with an Excel file. To further simplify the application, the tool's configuration, processing control and results presentation are configured through the software interface. On the other hand, to facilitate data entry, the complete database is provided through an Excel file, containing the required information for tool operation, i.e., the values of all input variables: sample depth; sample geographic coordinates; rule bases and membership functions of each methodology; and temperature vs. local water column depth. According to the description of the model, to determine the calculation methodology, the application imports and analyses all the required information from the Excel file before proceeding with the calculation of the sub-indices and indices.

\section{RESULTS AND DISCUSSION}

\subsection{The computational program}

The development of a software tool for decision support, based on the application of fuzzy logic techniques and considering the support of experts has been already applied with success in water quality monitoring (Angulo et al., 2012). In the present study, the interface is organized in four subdivisions: Controls, Fuzzy Inference System, Spatial Characteristics, and Indices, which can control, supervise, and visualize the state of the reservoir and results of the subindices and final indices. The Controls subdivision includes the only four command buttons of the application. The excel button opens the Excel file that contains the database to feed the program. The load button loads the data from the Excel file. The calculate button starts the calculation of the sub-indices and final indices using the calculation methodology chosen by the program. The close button closes the application.

In the Fuzzy Inference System subdivision, specific characteristics of the fuzzy inference system (FIS) of each sub-index and final index are easily configured, including the fuzzy tnorm operator that is used in the antecedent (min or prod) and defuzzification method (area centroid or half of the maxima). The complete graphical interface of the application is shown in Figure 5.

In contrast to the Controls and Fuzzy Inference System subdivisions, spatial characteristics is a visualization subdivision, and not a control or configuration subdivision. This subdivision presents the thermal stratification curve, temperature vs. reservoir depth, and the horizontal zone where the sample was collected (river, transition or lake zone). The depth of the sample, the temperature at this depth, and thermal stratification layer attributed by the tool to the specified depth are presented on the left side; the beginning and end of each layer are shown on the right side with their respective estimated temperatures. Figure 6 presents the spatial characteristics before and after the indices calculation.

Finally, the Indices subdivision presents the Water and Biotic Quality Indices, as well as the value of their respective sub-indices. As specified in Section 2.3, the calculation methodology used in the evaluation of the sub-indices and final indices is selected by the tool, according to the horizontal location (river, transition and lake zone) and the thermal 
stratification layers to which the sample belongs. The thermal stratification layer is automatically calculated by the same tool using the depth data of the sample as specified in the Excel file.

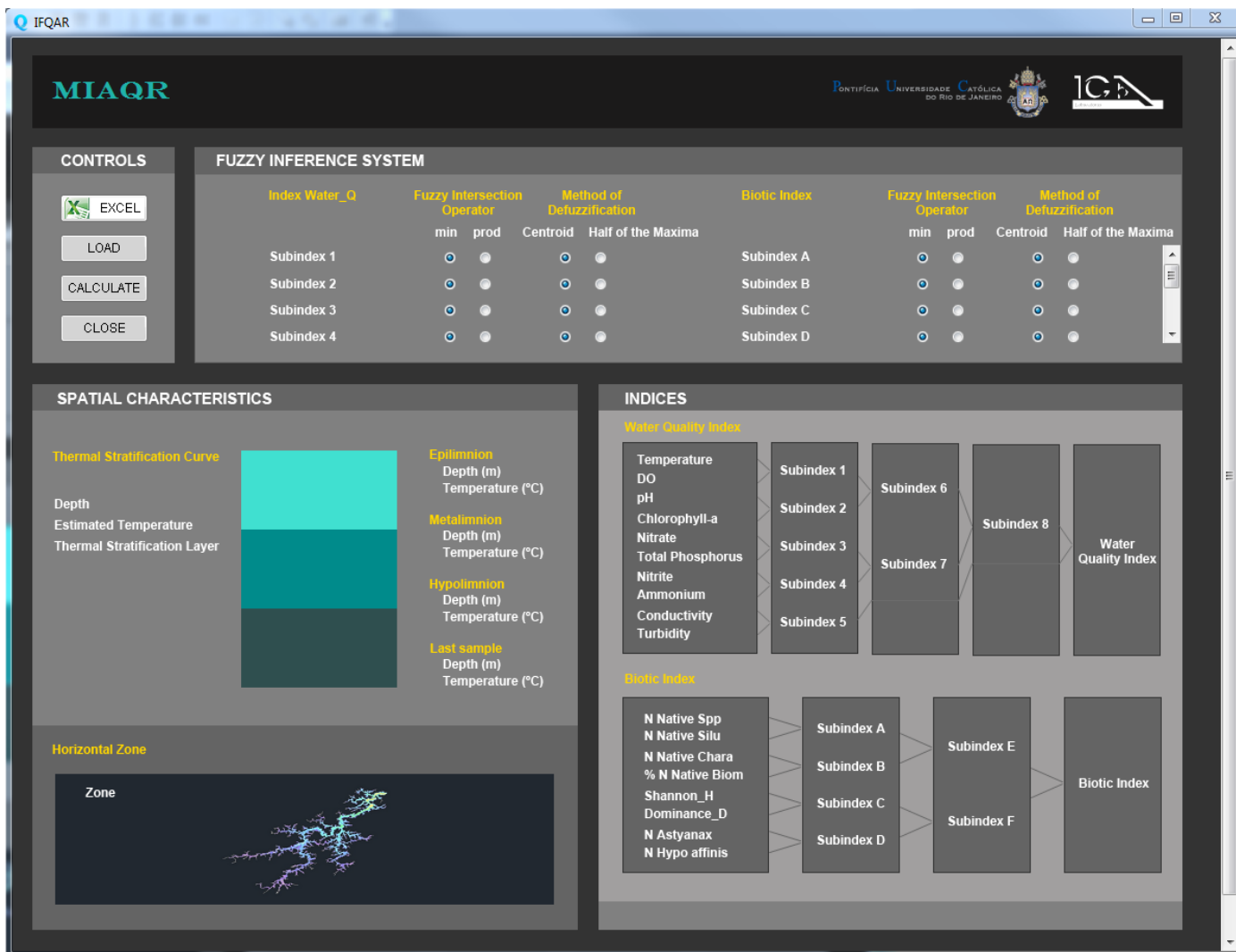

Figure 5. The graphical interface of the application.

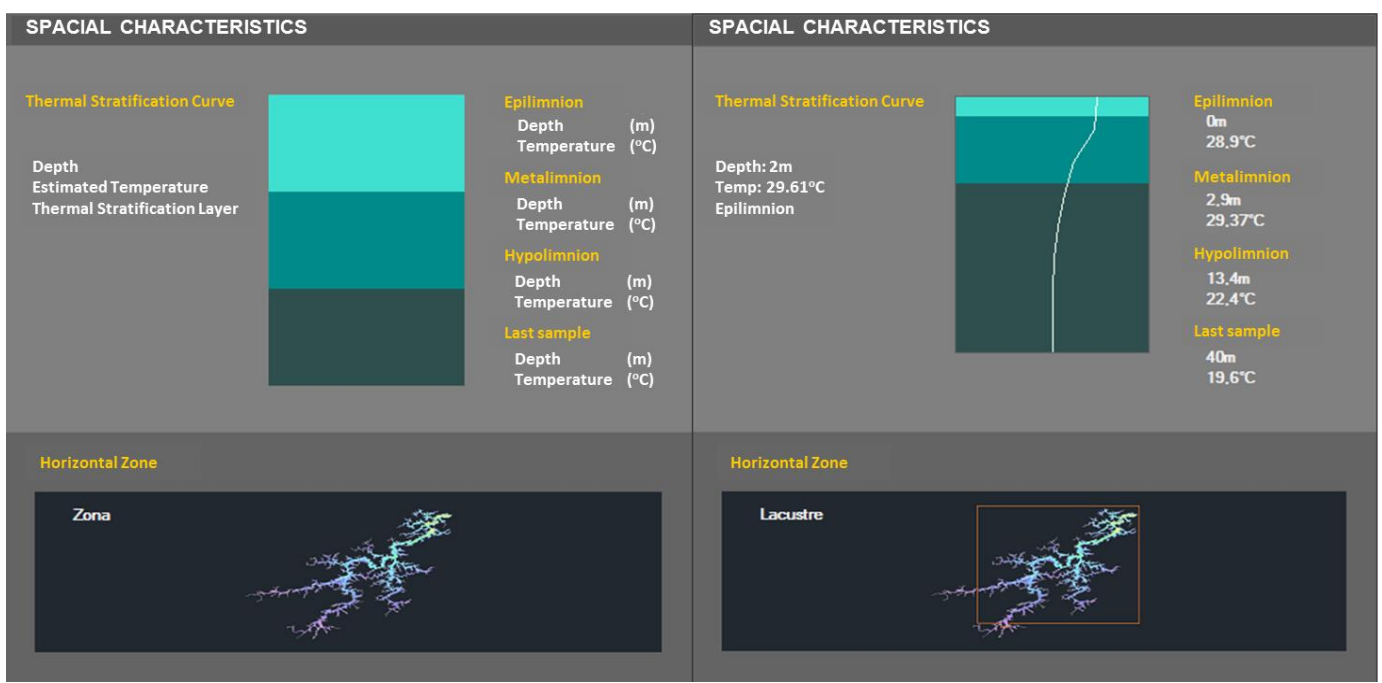

Figure 6. Spatial Characteristics of a sample, before and after indices calculation.

\subsection{Evaluation of the FUZZY-WBQAI for Water Quality Analysis}

\subsubsection{Response analysis of the model for each variable}

For all the inference systems, ten variables in the water quality index and seven in the biotic index were used. They were chosen based on their importance, taking into account the legislation for water quality (CONAMA, 2005) and metrics from the fish assemblage index 
(Terra and Araújo, 2011). The variables were configured as follows:

- Minimum t-norm as fuzzy operator AND of the antecedents. No rule was implemented with the operator OR;

- Minimum as implication operator;

- Maximum in the aggregation of the consequents;

- Area Centroid in the defuzzification.

With the purpose of testing each variable in its complete range of variation, simulated data as input values were used. Two different evaluation databases were created: a database for the water quality index and another for the biotic index. The data in the databases consisted of values that were proportionally separated inside the most extensive variation range of each indicator or metric. The ranges were obtained from the UNIRIO and UFRRJ databases, and 21 values were considered sufficient to represent the entire variation range of each input variable satisfactorily.

The behaviour of the model for the ten water quality indicators was analysed. The behaviour test consisted of varying the input value of a single indicator along with the entire interval, while all other indicators remain fixed. Consequently, the final index and sub-indices reflect only the variations of the tested indicator.

The chosen values of the other indicators that were not part of the test and remained fixed were the average of the amounts of all of the collections among the five sampling locations L1, L2, L3, L4, and L5, performed in the year 2009.

Because the final index is the result of intermediate fuzzy systems, and only the subsystems with two input variables were used in this study, the sub-indices with both input constants were also constant. Some comments about the behaviour analysis for the following variables water temperature, dissolved oxygen, $\mathrm{pH}$, nitrate, nitrite, ammonium, total phosphorus, chlorophyll$a$, electrical conductivity and turbidity are provided below:

- High temperatures exerted a negative influence on water quality. The remarkable influence of the temperature variable was easily observed in the result of sub-index 1 . Thus, we infer that for temperature values above $24.5^{\circ} \mathrm{C}$, the result of the sub-index shows an inversely proportional trend. Water temperature directly influences dissolved oxygen saturation in the water; additionally, in the tropical regions oxygen values can show an overall downward trend during high temperature in the summertime, which can be a threat for aquatic life (Souza et al., 2011).

- A directly proportional relationship occurs between the water quality and dissolved oxygen variable. A directly proportional relationship was observed between the values of dissolved oxygen and results of sub-index 1; the corresponding influence of the indicator on sub-indices 6 and 8 up to the final index was also observed.

- There is a marked influence of the dissolved oxygen on the final index. Besides being essential for aquatic life, the dissolved oxygen has a concentration limit for water used for human consumption supply with disinfection, such as the waters of Lajes Reservoir. According to the CONAMA 357/2005 (CONAMA, 2005), dissolved oxygen, in any sample, cannot be less than $6 \mathrm{mg} . \mathrm{L}^{-1}$.

- Better water quality was indicated by $\mathrm{pH}$ values close to 6.5. In Lajes Reservoir, pH presented values around this value at sampling sites without human influence across years of studies (Guarino et al., 2005; Soares et al., 2008; Rocha et al., 2019).

- An inversely proportional relationship occurs between the water quality and increments in the nitrogen series, total phosphorus and chlorophyll-a. As an oligo-mesotrophic reservoir, 
the increase of nutrients can mean a change in trophic conditions, especially in a reservoir with a high retention time (Klippel et al., 2020). The differentiated condition of an oligo-mesotrophic system used for domestic water supply was shown by the importance of maintaining chlorophyll- $a$ values below $5 \mu \mathrm{g} . \mathrm{L}^{-1}$ for better water quality. This value is lower than that recommended by the CONAMA 357/2005 (CONAMA, 2005), which is $10 \mu \mathrm{g} . \mathrm{L}^{-1}$.

- Regarding turbidity and conductivity: no significant variations in water quality were observed by varying conductivity and turbidity. Lajes Reservoir characteristically presents low values of these two variables throughout the years. The surroundings protected by rainforest and the control of human activities in the creeks entering the reservoir explain the good water conditions of the reservoir (Branco et al., 2009; Rocha et al., 2019).

More generally, it can be observed that there was a predominance of one sub-index over the others. Sub-index 8 had a strong influence, while sub-index 5 exhibited a weak impact on the final water quality index. Furthermore, a predominance of one variable over the others was shown since the influence of oxygen in sub-index 1 was clearly more significant than the influence of temperature.

\subsubsection{Water Quality analysis using real data}

Unlike the previous test, real sample data were used in this trial. Due to the lack of samples at low depths, the index was evaluated at the surface of the reservoir. This test used only superficial samples collected in the year 2009 and from sampling locations L1, L2, L3, L4, and L5. A detailed analysis of the behaviour of the sub-indices and final index was performed for locations L1 and L5 (Figure 7a and b), respectively, near the main tributary of the reservoir and near an area of fish cage aquaculture.

As a result of the test, at sampling location L1, formulation of the sub-indices followed the complete logic used in the formulation of the rules. For example, in sub-index 1, average temperatures between 15 and $20^{\circ} \mathrm{C}$ and high values of dissolved oxygen between 8 and $10 \mathrm{mg} . \mathrm{L}^{-1}$ generated good water quality values. In sub-index 2 , the average $\mathrm{pH}$ value of 6.56 and high chlorophyll- $a$ value of $7.4 \mu \mathrm{g} . \mathrm{L}^{-1}$ in January generated a relatively low sub-index 2 score of 8.38, which represents poor water quality for the Lajes Reservoir at L1. However, in October, the average $\mathrm{pH}$ of 6.3 can be characterized as good and low average chlorophyll- $a$ of $2.2 \mu \mathrm{g} . \mathrm{L}-1$ resulted in an average sub-index 2 of 58.42, which indicates intermediate quality. In this example, the predominance of one variable over another was observed. A higher chlorophyll- $a$ value had greater weight in the evaluation of water quality for human consumption than did a good $\mathrm{pH}$ value. In sub-index 3 , low values of nitrate of approximately $0.1 \mathrm{mg} . \mathrm{L}^{-1}$ and low values of total phosphorus of around $0.05 \mathrm{mg} . \mathrm{L}^{-1}$ generated good quality results. Considering the final FUZZY-WBQAI water index, the worst values are among the months from November to February (Figure 7a), which are related to months with higher average temperature, and increase of nutrients input by rains. Augmentation of the content of phosphate and nitrate in water due to more intense rainfall in summer has been shown for other Brazilian reservoirs (Brandimarte et al., 2008; Branco et al., 2019).

The results from sampling location L5 (Figure 7b), exhibited the same tendencies as found in the previous tests. Furthermore, in the final index, a decrease in the water quality was noticeable in May and June. Differently from location L1, L5 is not influenced by rainfall. The mixture of the water column at the beginning of the dry season increasing values of ammonium and nitrite in May and June influenced a decrease in sub-index 4. The result was transmitted by sub-indices 7 and 8 to the final index. Guarino et al., (2005) and Branco et al., (2009) reported the increase of nitrogen content in the water surface in Lajes Reservoir caused by the winter mixing of the water column, consequently decreasing water quality.

For the sites L2, L3, and L4, only the results for the last index are shown (Figure 8). All 
these locations have a decline of water quality in the months at the end and at the beginning of the year (except for L4 whose deterioration was not so marked), which correspond to the rainy season in summer. Higher water temperature in this period corresponded to a decrease of dissolved oxygen (decreasing subindex 1) and a rise in chlorophyll- $a$ values (decrease of subindex 2). A positive association between water temperature and chlorophyll- $a$ has been shown in several Brazilian reservoirs (Silva et al., 2014). Further, the washing of surrounding soils by rainfall meant an increase of nutrients carried into the waters, especially nitrogen compounds and total phosphorus (decreasing subindex 3 and 4). These scenarios provided by the rainy season helped to explain a lower final FUZZY-WBQAI water index in November and December in most sites.

(A)
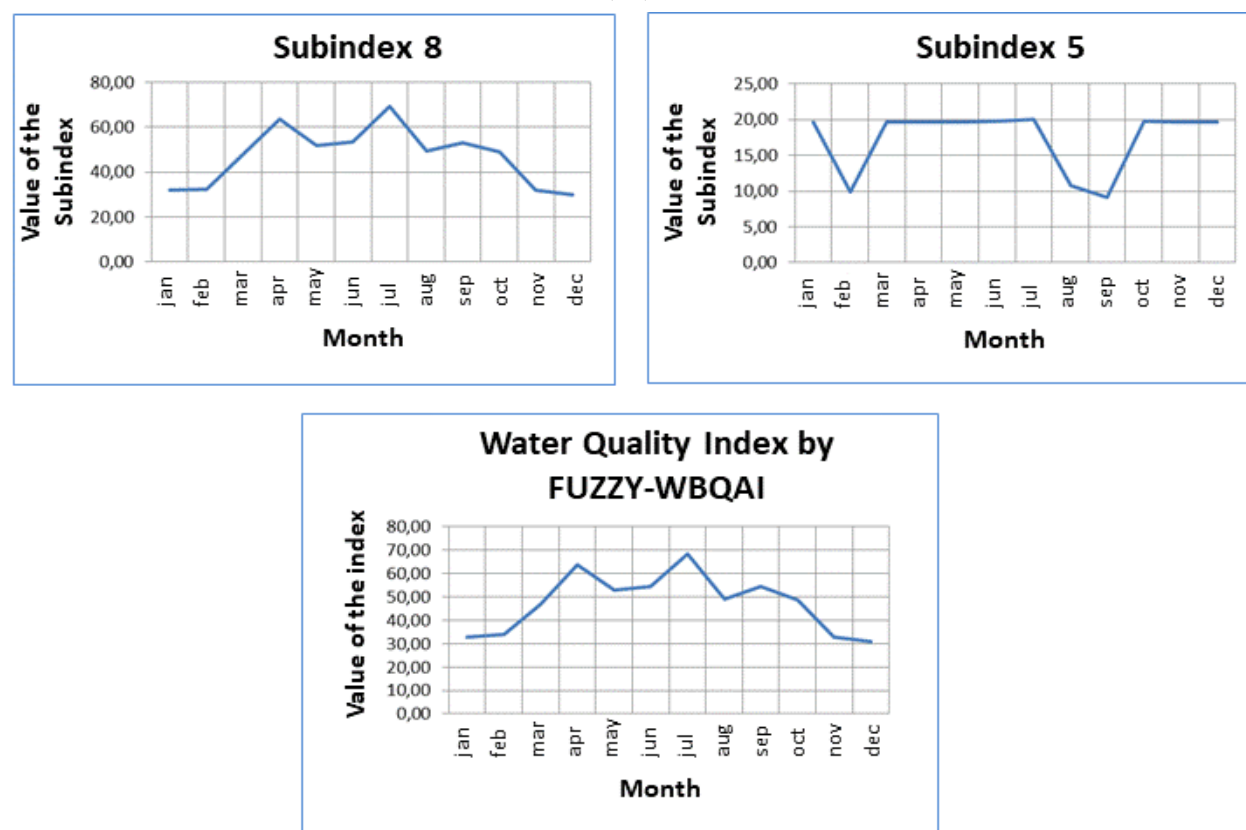

(B)
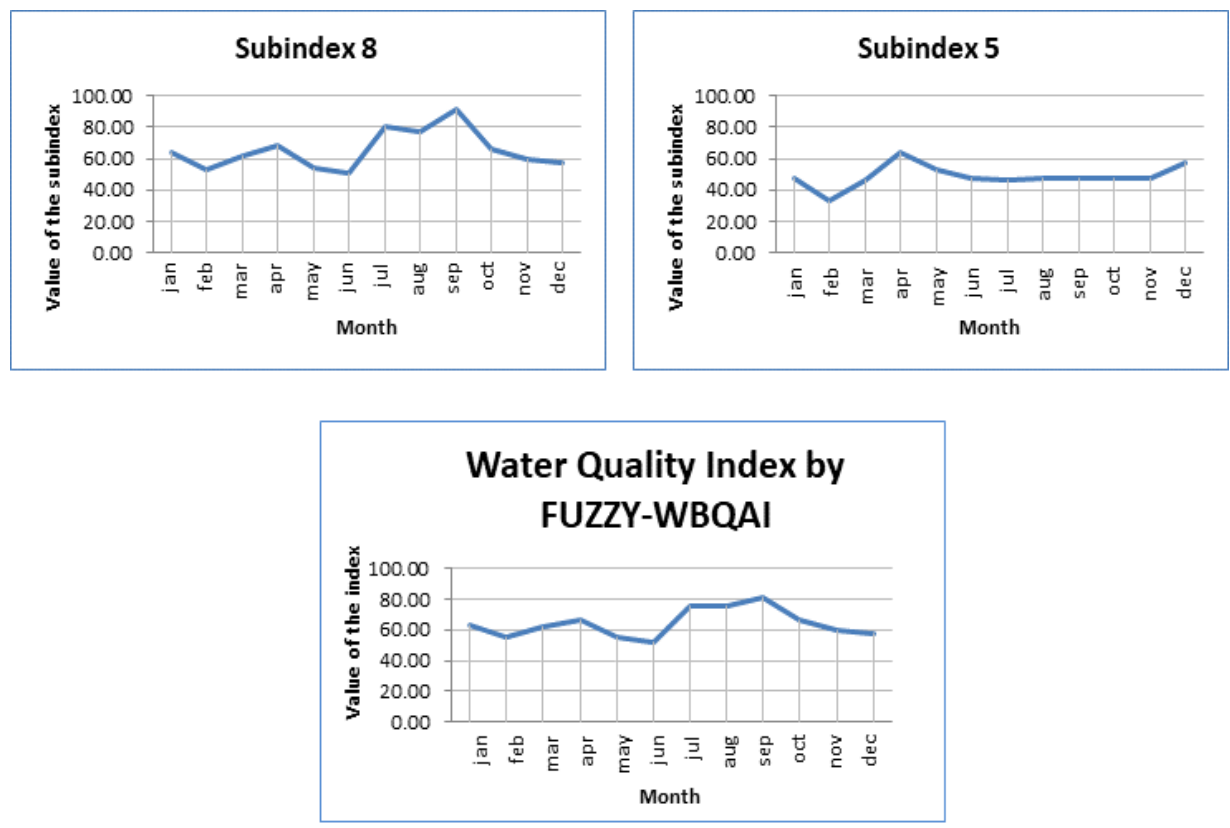

Figure 7. Water Quality Index by FUZZY-WBQAI using real data - sampling location L1 (a) and sampling location L5 (b) - Final index's behaviour. 


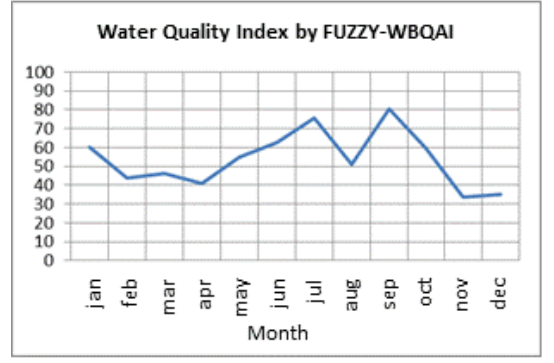

(a)

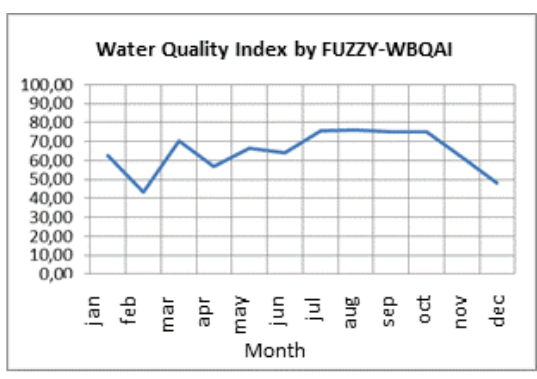

(b)

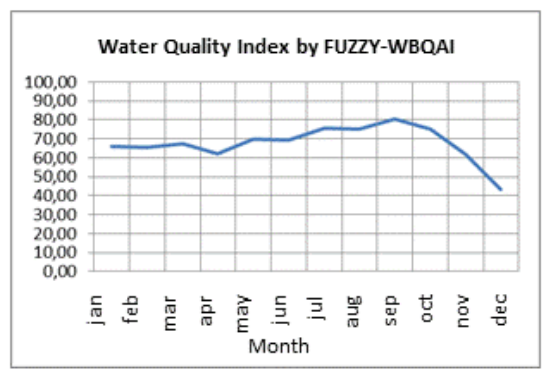

(c)

Figure 8. Water Quality Index by FUZZY-WBQAI using real data sampling locations L2 (a), L3(b) e L4(c) (Final index's behaviour).

\subsection{Evaluation of the FUZZY-WBQAI for Biotic Quality Analysis}

To evaluate the biotic index, a sampling location was selected from the 24 locations used for fishing and listed in Figure 1. The position number 6 was chosen due to the abundant quantity of data compared to the other sampling locations. All the samples collected from that location between the years 1994 and 2011 were used, producing a total of 19 samples.

Similar to the results of the FUZZY-WBQAI for water quality analysis, the behaviour of the FUZZY-WBQAI for biotic quality sub-indices followed the complete logic used in the formulation of the rules. For example, in sub-index $\mathrm{B}$, the combination of a low biomass percentage of non-native species with a high number of native Characiformes generated good biotic quality levels in the first samples. Also, a decrease in the number of native Characiformes and an increase of the biomass percentage produced a reduction in the quality value; as the Shannon index decreased and dominance increased, the value of sub-index $C$ decreased.

A comparison of the RRFAI (Terra and Araújo, 2011) and FUZZY-WBQAI (Figure 9) shows that both indices followed the same pattern of variation for the samples. The FUZZYWBQAI biotic quality index presents quality values that are slightly higher than those of the RRFAI.

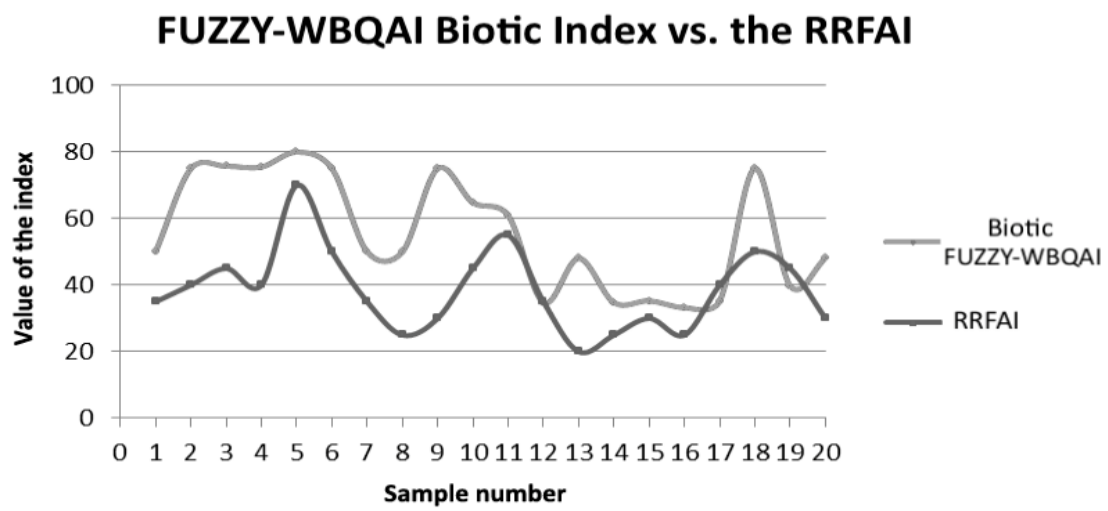

Figure 9. Results of the FUZZY-WBQAI Biotic Index vs. the RRFAI. 


\section{CONCLUSIONS}

FUZZY-WBQAI is a new evaluation model for environmental quality of a tropical reservoir, and a friendly computer tool to implement; it effectively represents advances in water quality evaluation on a numerical scale, in addition to considering the inherent subjectivity of the concept of quality. In the model, the oligo-mesotrophic conditions, morphometric features, long retention time, and stratification and mixture of the water column were considered the main forces acting on the Lajes Reservoir. The peculiar condition of an oligo-mesotrophic system used for domestic water supply was shown by the importance of maintaining chlorophyll- $a$ values below $5 \mu \mathrm{g} . \mathrm{L}^{-1}$ for better water quality. This condition complies with the environmental legislation.

Most variables included in previous limnological studies performed in this reservoir were included in the model, which was sensible to track water quality decrease in summer months (November to February) with higher temperature and pluviosity. Also, the mixing in winter was highlighted as decreasing water quality at sampling location 5 near the fish aquaculture. In this location, the accumulation of nutrients in the hypolimnion has been enhanced due to the longtime aquaculture activities.

The performance of the proposed model, FUZZY-WBQAI, was validated and found to be satisfactory when different quality indicators were combined in the formulation of the indices. The good performance was possible due to the ability of fuzzy logic to expand and easily combine quantitative data with qualitative information. Additionally, the model demonstrated efficiency equal to that of the RRFAI in characterizing biotic quality.

The computational tool developed possesses the following features: it can configure the defuzzification method of each FIS directly in the user interface without requiring additional configuration in the program; and it has a dynamic and user-friendly interface, with a configurable database that is uploaded into the application. Although the proposed model was specifically developed for tropical oligo-mesotrophic reservoirs, it can be adapted to reservoirs with different characteristics. Since this methodology considers the uncertainties involved in several steps of an integrated system, a robust collection of data and experts availability are of primary importance as well as limiting factors for practical use. Imprecise and heterogeneous data variations and expertise can be integrated more effectively using the fuzzy approach.

Given the wide variety of uses of Brazilian reservoirs, and considering that several reservoirs are being planned or constructed throughout the country, new and more efficient approaches to evaluate environmental quality are clearly welcome. This tool can be especially useful for energy production companies whose generating matrix is based on hydroelectric power plants with reservoirs.

\section{ACKNOWLEDGEMENTS}

The authors would like to thank the National Council for Scientific and Technological Development (Conselho Nacional de Desenvolvimento Científico e Tecnológico - CNPq), the Brazilian Federal Agency for the Support and Evaluation of Graduate Education (Coordenação de Aperfeiçoamento de Pessoal de Nível Superior - CAPES) and Light S.A. for their financial support.

\section{REFERENCES}

\section{AGÊNCIA NACIONAL DE ENERGIA ELÉTRICA (Brasil). Banco de Informação de Geração. $2020 . \quad$ Available at: https://www2.aneel.gov.br/aplicacoes/capacidadebrasil/capacidadebrasil.cfm}


ANDRADE, A. B. P. Modelo Inteligente de Avaliação da Qualidade de Água e da Qualidade Ambiental para um Reservatório Tropical Oligo-mesotrófico. 2013. Dissertation - Pontifical Catholic University, Rio de Janeiro, 2013.

ANGUlO, C.; CABESTANY, J.; RODRIGUEZ, P.; BATlle, M.; GONZÁleZ, A.; CAMPOS, S. Fuzzy expert system for the detection of episodes of poor water quality through constant measurement. Expert Systems with Applications, v. 39, p. 1011-1020, 2012. https://doi.org/10.1016/j.eswa.2011.07.102

APPELBERG, M.; BERGQUIST, B. C.; DEGERMAN, E. Using fish to assess environmental disturbance of Swedish lakes and streams - a preliminary approach. Verhandlungen der Internationalen Vereinigung fuer Limnologie, n. 27, p. 311-315, 2000. https://doi.org/10.1080/03680770.1998.11901244

BRANCO, C. W. C.; LEAL, J. J. F.; HUSZAR, V. L. M.; FARIAS, D. S.; SAINT'PIERRE, T. D.; SOUSA-FILHO, I. F.; KOZLOWSKY-SUZUKI, B. New lake in a changing world: The construction and filling of a small hydropower reservoir in the tropics (Rio de Janeiro. Brazil). Environmental Science and Pollution Research, n. 26, p. 36007-36022, 2019. https://doi.org/10.1007/s11356-019-06665-y

BRANCO, C. W. C.; KOZLOWSKY-SUZUKI, B.; SOUSA-FILHO, I.F.; GUARINO, A. W. S.; ROCHA, R. J. Impact of climate on the vertical water column structure of Lajes Reservoir (Brazil): A tropical reservoir case. Lakes Reservoirs Research Management, n. 4, p. 175-191, 2009. https://doi.org/10.1111/j.1440-1770.2009.00403.x

BRANDIMARTE, A. L.; ANAYA, M.; SHIMIZU, G. Y.; MEIRELLES, S. T.; CANEPPELE, D. Impact of damming the Mogi-Guaçu River Impact of damming the Mogi-Guaçu River (São Paulo State, Brazil) on reservoir limnological variables. Lakes Reservoirs Research Management, n. 13, p. 23-35, 2008. https://doi.org/10.1111/j.14401770.2007.00359.x

BROWN, R. M.; MCCLELLAND, N. I.; DEININGER, R. A.; TOZER, R. G. A Water Quality Index - Do We Dare? Water and Sewage Works, n. 117, p. 339-343, 1970.

BUSCH, W. D. N.; SLY, P. G. The Development of an Aquatic Habitat Classification System for Lakes. Boca Raton: CRC Press, 1992.

CARLSON, R. E. A Trophic State Index for Lakes. Limnology and Oceanography, n. 22, p. 361-369, 1977. https://doi.org/10.4319/lo.1977.22.2.0361

CETESB. Relatório 57 de Qualidade das Águas Interiores do Estado de São Paulo, 2004, 2005 and 2006. São Paulo, 2006.

CHANG, H. Spatial analysis of water quality trends in the Han River basin, South Korea. $\begin{array}{llllll}\text { Water } & \text { Research, } & \text { v. } & 42, & \text { p. }\end{array}$ https://doi.org/10.1016/j.watres.2008.04.006

CHEN, Q.; MYNETT, A. E. Integration of data mining techniques and heuristic knowledge in fuzzy logic modelling of eutrophication in Taihu Lake. Ecological Modelling, n. 162, p. 55-67, 2003. https://doi.org/10.1016/S0304-3800(02)00389-7 
CONAMA (Brasil). Resolução n 357 de 17 de março de 2005. Dispõe sobre a classificação dos corpos de água e diretrizes ambientais para o seu enquadramento, bem como estabelece as condições e padrões de lançamento de efluentes, e dá outras providências. Diário Oficial [da] União: seção 1, Brasília, DF, n. 053, p. 58-63, 18 mar. 2005.

CUNHA, D. G. F.; CALIJURI, M. C.; LAMPARELlI, M. C. A trophic state index for tropical/subtropical reservoirs (TSItsr). Ecological Engineering, n. 60, p. 126-134, 2013. https://doi.org/10.1016/j.ecoleng.2013.07.058

D'HEYGERE, T.; GOETHALS, P. L. M.; DE PAUW, N. Use of genetic algorithms to select input variables in decision tree models for the prediction of benthic macroinvertebrates. Ecological Modelling, n. 160, p. 291-300, 2003. https://doi.org/10.1016/S03043800(02)00260-0

DRAKE, M. T.; PEREIRA, D. L. Development of a fish-based index of biotic integrity for small inland lakes in central Minnesota. North American Journal of Fisheries Management, n. $22, \quad$ p. $1105-1123,2002$. https://doi.org/10.1577/15488675(2002)022\%3C1105:DOAFBI\%3E2.0.CO;2

FORIO, M. A. E.; MOUTON, A.; LOCK, K.; BOETS, P.; NGUYEN, T. H. T.; DAMANIK A.; MINAR, N.; MUSONGE, O. L. S.; DOMINGUEZ-GRANDA, L.; GOETHALS, P. L. M. Fuzzy modelling to identify key drivers of ecological water quality to support decision and policy making. Environmental Science \& Policy, n. 68, p. 58-68, 2017. https://doi.org/10.1016/j.envsci.2016.12.004

GARCIA, C. A. B.; SILVA, I. S.; MENDONÇA, M. C. S.; GARCIA, H. L. Evaluation of Water Quality Indices: Use, Evolution and Future Perspectives. Advances in Environmental Monitoring and Assessment, 2018. https://doi.org/10.5772/intechopen.79408

GHOLAMI, V.; KHALEGHI, M. R.; TAGHVAYE SALIMI, E. Groundwater quality modeling using self-organizing map (SOM) and geographic information system (GIS) on the Caspian southern coasts. Journal of Mountain Science, n. 17, p. 1724-1734, 2020. https://doi.org/10.1007/s11629-019-5483-y

GHOLAMI, V.; AGHAGOLI, H.; KALTECH, A.M. Modeling sanitary boundaries of drinking water wells on the Caspian Sea southern coasts, Iran. Environmental Earth Sciences, v. 74, n. 4, p. 2981-2990, 2015. https://doi.org/10.1007/s12665-015-4329-3

GHOLAMI, V.; KHALEGHI, M. R.; SEBGHATI, M. A method of groundwater quality assessment based on fuzzy network-CANFIS and geographic information system (GIS). Applied Water Science, n. 7, p. 3633-3647, 2017. https://doi.org/10.1007/s13201-0160508-y

GONÇALVES, L. B.; VELLASCO, M.; PACHECO, M. Inverted Hierarchical Neuro-Fuzzy BSP System: A Novel Neuro-Fuzzy Model for Pattern Classification and Rule Extraction in Databases, IEEE Trans. On Systems, Man, and Cybernetics - Part C: Applications and Reviews, v. 36, n. 2, 2006. https://dx.doi.org/10.1109/TSMCC.2004.843220

GUARINO, A. W. S.; BRANCO, C. W. C.; DINIZ, G. P.; ROCHA, R. Limnological Characteristics of an Old Tropical Reservoir (Ribeirão das Lajes Reservoir, RJ, Brazil). Acta Limnologica Brasiliensia, n. 17, p. 129-141, 2005.

HORTON, R. K. An index number system for rating water quality. Journal of Water Pollution Control Federation, n. 37, p. 300-306, 1965. 
ICAGA, Y. Fuzzy evaluation of water quality classification. Ecological Indicators, n. 7, p. 710-718, 2007. https://doi.org/10.1016/j.ecolind.2006.08.002

JANG, J. S. R.; SUN, C. T. Neuro-fuzzy modeling and control. Proceedings IEEE, v. 83, n. 3, p. 378-406, 1995. https://dx.doi.org/10.1109/5.364486

JENNINGS, M. J.; FORE, L.S.; KARR, J. R. Biological monitoring of fish assemblages in Tennessee Valley reservoirs. Regulated Rivers: Research \& Management, n. 11, p. 263-274, 1995. https://doi.org/10.1002/rrr.3450110303

JIN, Y. Fuzzy modeling of high-dimensional systems: complexity reduction and interpretability improvement. IEEE Transactions on Fuzzy Systems, v. 8, n. 2, p. 212-221, 2000. https://doi.org/10.1109/91.842154

KLIPPEL, G.; MACÊDO, R.L.; BRANCO, C. W. C. Comparison of different trophic state indices applied to tropical reservoirs. Lakes \& Reservoirs Research \& Management, v. 25, n. 2, p. 214-229, 2020. https://doi.org/10.1111/lre.12320

LEE, C. S.; CHANG, S. P. Interactive fuzzy optimization for an economic and environmental balance in a river system. Water Research, v. 39, p. 221-231, 2005. https://doi.org/10.1016/j.watres.2004.09.013

LERMONTOV, A.; YOKOYAMA, L.; LERMONTOV, M.; MACHADO, M. River quality analysis using fuzzy water quality index: Ribeira do Iguape River watershed. Ecological Indicators, n. 9, p. 1118-1197, 2009. https://doi.org/10.1016/j.ecolind.2009.02.006

LIOU, Y. T.; LO, S. L. A fuzzy index model for trophic status evaluation of reservoir waters. $\begin{array}{llllll}\text { Water Research, } & \text { n. 39, } 005 .\end{array}$ https://doi.org/10.1016/j.watres.2005.01.014

LU, R. S.; LO, S. L.; HU, J. Y. Analysis of reservoir water quality using fuzzy synthetic evaluation. Stochastic Environmental Research and Risk Assessment, n. 13, p. 327336, 1999. https://doi.org/10.1007/s004770050054

MOURHIR A.; RACHIDI T.; KARIM M. River water quality index for Morocco using a fuzzy inference system. Environmental Systems Research, n. 3, p. 1-12, 2014. https://doi.org/10.1186/s40068-014-0021-y

OCAMPO-DUQUE, W.; FERRÉ-HUGUET, N.; DOMINGO, J.L.; SCHUHMACHER, M. Assessing water quality in rivers with fuzzy inference systems: A case study.

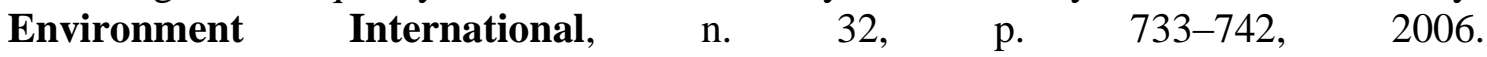
https://doi.org/10.1016/j.envint.2006.03.009

OCAMPO-DUQUE, W.; OSORIO, C.; PIAMBA, C.; SHUMAHMACHER, M.; DOMINGO, J. L. Water quality analysis in rivers with non-parametric probability distributions and fuzzy inference systems: Application to the Cauca River. Environment International, n. 52, p. 17-28, 2013. https://doi.org/10.1016/j.envint.2012.11.007

PINTO, V. G.; LIMA, R. N. S.; SANTOS, R. C. P.; RIBEIRO, C. B. M. Influência do número de classes na determinação da suscetibilidade morfométricas à inundação. Revista Ambiente \& Água, v. 11, n. 3, 2016. https://doi.org/10.4136/ambi-agua.1842 
RECKNAGEL, F.; BRANCO, C. W. C.; CAO, H.; HUSZAR, V. L. M.; SOUSA-FILHO, I. Modelling and forecasting the heterogeneous distribution of picocyanobacteria in the tropical Lajes Reservoir (Brazil) by evolutionary computation. Hydrobiologia, n. 749, n. 1, p. 53-67, 2015. https://doi.org/10.1007/s10750-014-2144-6

ROCHA, M. I. A.; RECKNAGEL, F.; MINOTI, R. T.; HUSZAR, V. L. M.; KOZLOWSKYSUZUKI, B.; CAO, H.; STARLING, F. L. R. M.; BRANCO, C. W. C. Assessing the effect of abiotic variables and zooplankton on picocyanobacterial dominance in two tropical mesotrophic reservoirs by means of evolutionary computation. Water Research, n. 149, p. 120-129, 2019. https://doi.org/10.1016/j.watres.2018.10.067

ROSET, N.; GRENOUILLET, G.; GOFFAUX, D.; PONT, D.; KESTEMONT, P. A review of existing fish assemblage indicators and methodologies. Fisheries Management and Ecology n.14, p.393-405, 2007. https://doi.org/10.1111/j.1365-2400.2007.00589.x

SALSKI, A. Fuzzy clustering of fuzzy ecological data. Ecological Informatics, n. 2, p. $262-$ 269, 2007. https://doi.org/10.1016/j.ecoinf.2007.07.002

SANTOS, A.R.; SILVA, R. C. F.; ASSIS, L. C.; MAUAD, F. F. Defining environmental conservation anthropic activity in the Uberaba River Basin protected area. Revista Ambiente \& Água, v. 14 n. 1, 2019. https://dx.doi.org/10.4136/ambi-agua.2279

SCARDI, M.; CATAUDELLA, S.; DIDATO, P.; FRESI, E.; TANCIONI, L. An expert system based on fish assemblages for evaluating the ecological quality of streams and rivers. $\begin{array}{lllllll}\text { Ecological Informatics, } & \text { n. } & 3, & \text { p. } & 55-63, & 2008 .\end{array}$ https://doi.org/10.1016/j.ecoinf.2007.10.001

SEMIROMI, F. B.; HASSANI, A. H.; TORABIAN, A.; KARBASSI, A. R.; HOSSEINZADEH, F. L. Water quality index development using fuzzy logic: A case study of the Karoon River of Iran. African Journal of Biotechnology, n. 10, p. 10125-10133, 2011. https://doi.org/10.5897/AJB11.1608

SILVA, L. H. S.; HUSZAR, V. L. M.; MARINHO, M. M.; RANGEL, L. M.; BRASIL, J.; DOMINGUES, C. D.; BRANCO, C. C.; ROLAND, F. Drivers of phytoplankton, bacterioplankton and zooplankton carbon biomass in tropical hydroelectric reservoirs. Limnologica, n. 48, p. 1-10, 2014. https://doi.org/10.1016/j.limno.2014.04.004

SILVERT, W. Fuzzy indices of environmental conditions. Ecological Modelling, n. 130, p. 111-119, 2000. https://doi.org/10.1016/S0304-3800(00)00204-0

SOARES, M. C. S.; MARINHO, M. M.; HUSZAR, V. L. M.; BRANCO, C. W. C.; AZEVEDO, S. M. F. O. The effects of water retention time and watershed features on the limnology of two tropical reservoirs in Brazil. Lakes Reservoirs Research Management, n. 13, p. 257-269, 2008. https://doi.org/10.1111/j.1440-1770.2008.00379.x

SOUZA, L. C.; BRANCO, C. W. C.; DOMINGOS, P.; BONECKER, S. L. C. Zooplankton of an urban coastal lagoon: composition and association with environmental factors and summer fish kill. Zoologia, n. 28, p. 357-364, 2011. https://doi.org/10.1590/S198446702011000300010

SOYUPAK, S.; CHEN, D. G. Fuzzy Logic Model to Estimate Seasonal Pseudo Steady State Chlorophyll-A Concentrations in Reservoirs. Environmental Modeling and $\begin{array}{llllll}\text { Assessment, } & \text { n. } & 9, & \text { p. } & \text { 51-59, }\end{array}$ https://doi.org/10.1023/B:ENMO.0000020890.57185.92 
TAHERIYOUN, M.; KARAMOUZ, M.; BAGHVAND, A. Development of an entropy- based fuzzy eutrophication index for reservoir water quality evaluation. Iranian Journal of Environmental Health Science \& Engineering, v. 7, n. 1, p. 1-14, 2010.

TERRA, B. D. F.; ARAÚJO, F. G. A preliminary fish assemblage index for a transitional riverreservoir system in southeastern Brazil. Ecological Indicators, n. 11, p. 874-881, 2011. https://doi.org/10.1016/j.ecolind.2010.11.006

THORTON, K. W. Perspectives on Reservoir Limnology. In: THORNTON, K. W.; KIMMEL, B. L.; PAYNE, F. E. (eds.). Reservoir limnology: ecological perspectives. New York: John Wiley \& Sons, 1990. p. 1-12.

VARGAS, R. R.; BARROS, M. S.; SAAD, A. R.; ARRUDA, R. O. M.; AZEVEDO, F. D. Assessment of the water quality and trophic state of the Ribeirão Guaraçau Watershed, Guarulhos (SP): a comparative analysis between rural and urban areas. Revista Ambiente \& Água, n. 13, p. 1-13, 2018. https://doi.org/10.4136/ambi-agua.2170 